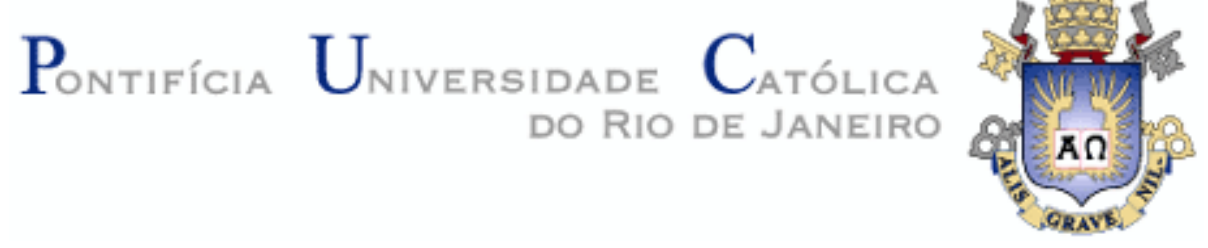

Francilaide de Queiroz Ronsi

\begin{abstract}
A mística cristã e o diálogo inter-religioso em Thomas Merton e em Raimon Panikkar Para uma maturidade cristã e uma mística inter-religiosa
\end{abstract}

Tese apresentada como requisito parcial para obtenção do grau de Doutor pelo Programa de Pós-graduação em Teologia Sistemática do Departamento de Teologia da PUCRio.

Orientadora: Profa. Maria Clara Lucchetti Bingemer

Volume I

Rio de Janeiro

Dezembro de 2014 
Francilaide de Queiroz Ronsi

\begin{abstract}
A mística cristã e o diálogo inter-religioso em Thomas Merton e em Raimon Panikkar Para uma maturidade cristã e uma mística inter-religiosa
\end{abstract}

Tese apresentada como requisito parcial para obtenção do grau de Doutor pelo Programa de Pós-graduação em Teologia do Departamento de Teologia do Centro de Teologia e Ciências Humanas da PUC-Rio. Aprovada pela Comissão Examinadora abaixo assinada.

Profa. Maria Clara Lucchetti Bingemer Orientadora Departamento de Teologia - PUC-Rio

Prof. Luís Corrêa Lima Departamento de Teologia - PUC-Rio

Profa. Lúcia Pedrosa de Pádua Departamento de Teologia - PUC-Rio

Prof. Gilbraz de Souza Aragão UNICAP

Prof. Sibélius Cefas Pereira

PUC-MG

Profa. Denise Berruezo Portinari Coordenadora Setorial de Pós-Graduação e Pesquisa do Centro de Teologia e Ciências Humanas - PUC-Rio.

Rio de Janeiro, 11 de dezembro de 2014 
Todos os direitos reservados. É proibida a reprodução total ou parcial do trabalho sem autorização da universidade, ou da autora e da orientadora.

\section{Francilaide de Queiroz Ronsi}

Graduou-se em Teologia Sistemática pela Universidade Católica de Pernambuco (UNICAP), em 2007. Desenvolveu pelo Programa de Iniciação Científica, uma pesquisa sobre a cultura e religiosidade afro-brasileira, utilizando-se da metodologia transdisciplinar. Aprimorou seu interesse científico pelo diálogo inter-religioso com o Mestrado em Teologia, pela Pontifícia Universidade do Rio de Janeiro (PUC-Rio), em 2009.

Ficha Catalográfica

Ronsi, Francilaide de Queiroz

A mística cristã e o diálogo inter-religioso em Thomas Merton e em Raimon Panikkar: para uma maturidade cristã e uma mística inter-religiosa / Francilaide de Queiroz Ronsi; orientadora: Maria Clara Lucchetti Bingemer. - 2014.

2 v. ; $30 \mathrm{~cm}$

Tese (doutorado)-Pontifícia Universidade Católica do Rio de Janeiro, Departamento de Teologia, 2014.

Inclui bibliografia

1. Teologia - Teses. 2. Pluralismo. 3. Diálogo inter-religioso. 4. Mística. 5. Experiência. 6. Religião. 7. Revelação. I. Bingemer, Maria Clara Lucchetti. II. Pontifícia Universidade Católica do Rio de Janeiro. Departamento de Teologia. III. Título. 


\section{Agradecimentos}

A Deus por seu cuidado sempre presente em todas as circunstâncias de minha vida, e por me conduzir à Sua presença nesta oportunidade de crescimento intelectual.

À minha orientadora Maria Clara Bingemer, que, com maestria, conduziu-me na realização desta tese.

Ao meu querido pai Francisco Ronsi Neto 'in memoriam' e a minha querida mãe Alaíde de Queiroz Ronsi, pelo carinho, paciência, confiança e estímulo.

Às minhas irmãs, ao meu irmão e sobrinhos por todo carinho e confiança.

Ao professor Gilbraz Aragão e aos demais professores da UNICAP por acreditarem em mim.

Aos professores e funcionários do Departamento de Teologia da PUC-Rio pelo apoio e acolhida fraterna.

Aos professores da Comissão examinadora que acompanharam pacientemente a realização desta tese com importantes colaborações.

À PROLIC e a PUC-Rio pelo auxílio financeiro durante este período de estudo.

Aos amigos e amigas conquistados no Rio de Janeiro e no Recife, os quais, pela presença fraterna e orações, me animaram nesta caminhada.

A todos da minha família pelo estímulo e confiança. 


\section{Resumo}

Ronsi, Francilaide de Queiroz; Bingemer, Maria Clara Lucchetti. A mística cristã e o diálogo inter-religioso em Thomas Merton e em Raimon Panikkar. Para uma maturidade cristã e uma mística interreligiosa. Rio de Janeiro, 2014. 343p. Tese de Doutorado. Departamento de Teologia, Pontifícia Universidade Católica do Rio de Janeiro.

$\mathrm{O}$ reconhecimento da realidade religiosa, ricamente plural em que nos encontramos, nos convida a buscar formas para que seja possibilitado o convívio harmonioso em nossa sociedade. Para o Cristianismo, em especial, lhe é proporcionado a busca por uma intensa experiência nas mais profundas raízes de sua origem religiosa e a compreensão do significado dessa pluralidade religiosa no projeto salvífico de Deus e sua relação com o mistério de Jesus Cristo. Por isso, acreditamos que, para o diálogo fecundo e acolhedor com as demais religiões, é de extrema importância a contribuição de um caminho espiritual enraizado na experiência de união com Deus, como possibilidade para que não se viva uma religiosidade muito epidérmica, recuperando a dimensão da experiência íntima do mistério de Deus e da experiência da unidade com ela. As experiências vividas por Thomas Merton e Raimon Panikkar, radicadas no cristianismo, de profunda intimidade com Deus, nos apresentam um caminho para um diálogo interreligioso realizado a partir de uma madura experiência religiosa. A experiência de Thomas Merton é profundamente inseparável do amor a Deus e à humanidade, em um seguimento aos ensinamentos de Jesus Cristo na dedicação ao seu ministério de sacerdote, monge e eremita, ricamente fortalecida pelo amor aos humanos. Em Raimon Panikkar, encontramos uma pessoa marcada por quatro identidades religiosas, sem que lhe fosse negada sua primeira origem, o cristianismo, caracterizada por uma profunda experiência de encontro com Deus. Para Raimon Panikkar este é o kairós do milênio que recém se abriu para todas as religiões e continuar com pequenas reformas não tem sentido. É necessária uma grande transformação, porém profunda, uma metanóia! Segundo Thomas Merton e Raimon Panikkar o diálogo entre as experiências religiosas não se resume a uma conversão vazia, mas que os interlocutores tenham de fato, penetrado com a máxima seriedade em sua própria tradição, assumindo a dimensão espiritual como o nível mais fecundo para a abertura e compreensão no diálogo inter-religioso. A 
partir destas experiências, sugerimos que o diálogo inter-religioso ultrapasse as fronteiras que separam as religiões em uma sincera e fecunda acolhida das mais diversas tradições, a partir de uma madura experiência religiosa. Através das contribuições de Juan Martin Velasco e de Andrés Torres Queiruga, confirma-se a importância que têm a dimensão espiritual e a experiência interior que possuem todas as religiões diante da autêntica necessidade do diálogo inter-religioso. Em todas as religiões existe a experiência mística unicamente graças ao convite de Deus, que deseja tornar-se conhecido e, acolhendo esta Presença, o ser humano tem a possibilidade de atingir sua autêntica realização. Sem fazer oposição à singularidade cristã na interpretação positiva das outras religiões e do pluralismo religioso, acreditamos que a maturidade da experiência religiosa do cristão contribui para aproximá-lo da realidade de ser imagem de Deus, que se dá na experiência mais profunda do ser religioso a partir de uma íntima relação com Deus.

\section{Palavras-chave}

Pluralismo; diálogo inter-religioso; mística; experiência; religião; revelação. 


\section{Abstract}

Ronsi, Francilaide de Queiroz; Bingemer, Maria Clara Lucchetti. The Christian mystical and interreligious dialogue in Thomas Merton and Raimon Panikkar. For a Christian maturity and an interreligious mystical. Rio de Janeiro, 2014. 343p. PhD thesis. Departamento de Teologia, Pontifícia Universidade Católica do Rio de Janeiro.

The recognition of religious reality, richly plural, invites us to seek ways to make possible the harmonious coexistence in our society. For Christianity, in particular, it is provided to search for an intense experience in the deepest roots of their religious background and understanding of the significance of religious plurality in the salvific plan of God and their relationship with the mystery of Jesus Christ. Therefore, we believe that for the fruitful and friendly dialogue with other religions, it is extremely important the contribution of a spiritual path rooted in the bonding experience with God, as a possibility for not living a very epidermic religiosity, recovering the dimension of an intimate experience of God's mystery and the unit experience with it. The experiences of Thomas Merton and Raimon Panikkar, rooted in Christianity, of deeper intimacy with God, show us the way to interreligious dialogue held from a mature religious experience. Thomas Merton's experience is deeply inseparable from the love for God and humanity, followed up to Jesus Christ's teachings in the dedication to his ministry as a priest, monk and hermit, richly strengthened by the love for human. In Raimon Panikkar, we find a person marked by four religious identities, without deny his first origin, Christianity, characterized by a deep experience of encountering God. For Raimon Panikkar this is the kairós of the millennium that has just opened to all religions and continue with small reforms is meaningless. It is required a great transformation, but a deep one, a metanoia! According to Thomas Merton and Raimon Panikkar the dialogue between religious experiences is not limited to an empty conversion, but the interlocutors have indeed penetrated with the utmost seriousness in your own tradition, assuming the spiritual dimension as the most fruitful level for an opening and understanding in the interreligious dialogue. Based on these experiences, we suggest that interreligious dialogue beyond the boundaries that separate religions in a sincere and fruitful reception of the most diverse traditions, from a mature religious experience. Through the contributions of Juan Martin Velasco and Andres Torres Queiruga, 
confirms the importance of the spiritual dimension and the inner experience that all religions have for the authentic necessity interreligious dialogue. In all religions there is a mystical experience exclusively thanks to God's call, who wants to become known and, by welcoming the Presence, the human being is able to reach an authentic realization. Without making opposition to Christian uniqueness in positive interpretation of other religions and religious pluralism, we believe that the maturity of the religious experience of the Christian contributes to alignment with the reality of being in God's image, which gives the deepest experience of being religious from an intimate relationship with God.

\section{Keywords}

Pluralism; interreligious dialogue; mystic; experience; religious; revelation. 


\section{Sumário}

Introdução.

I. Parte

A teologia e o contexto religioso......................................................21

1. O pluralismo religioso e a teologia das religiões ..............................21

1.1 Os desafios do pluralismo religioso............................................. 24

1.2 O pluralismo religioso: uma questão teológica................................28

1.3 Teologia das religiões e teologia do pluralismo religioso................... 29

$1.4 \mathrm{~A}$ teologia cristã das religiões....................................................... 33

1.5 A busca por um novo paradigma teológico.................................... 41

2. O fenômeno religioso e místico.......................................................... 46

2.1 Um desafio às religiões..................................................... 50

2.2 O ser humano chamado a viver a partir do seu interior.................... 53

2.3 A religião e sua reafirmação.................................................... 55

2.4 Fenomenologia mística.................................................... 59

2.5 A mística cristã............................................................. 67

2.6 A religião para além de si mesma.............................................75

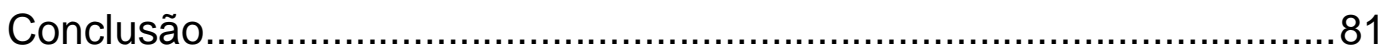

II. Parte

Um possível caminho............................................................ 82

1. A mística como paradigma................................................... 82

1.1 "Em todas as religiões existe experiência mística" ...........................83

1.20 ser humano, um ser com um mistério no coração..........................83

1.3 A mística e sua linguagem humana.........................................86

1.4 A presença originante.........................................................90

1.5 As características da experiência mística.....................................102

1.6 O núcleo originário da experiência mística...................................110

1.7 Mística, condição de existência para a religião..............................121

2. "Todas as religiões são verdadeiras"..............................................123

2.1 A Revelação como maiêutica histórica........................................125 
2.2 A hermenêutica do amor 132

2.3 A eleição e a universalidade de Deus.............................................134

$2.4 \mathrm{O}$ cristianismo e outras religiões.....................................................139

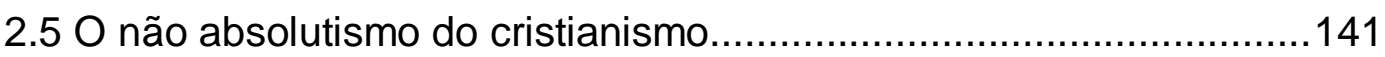

2.6 A necessidade de novas categorias...............................................142

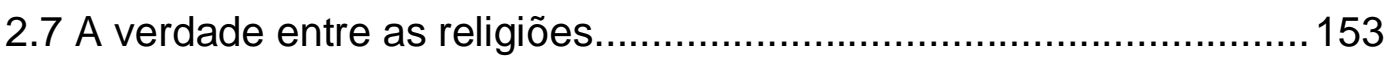

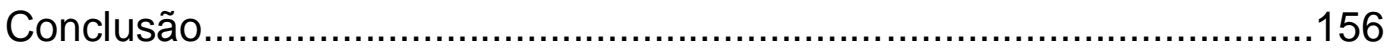

III. Parte

Experiência Cristã de Deus em Thomas Merton....................................158

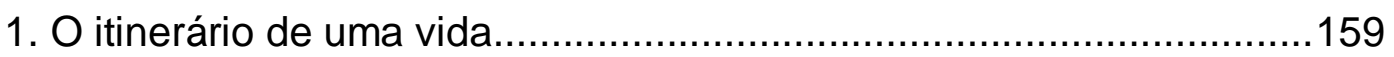

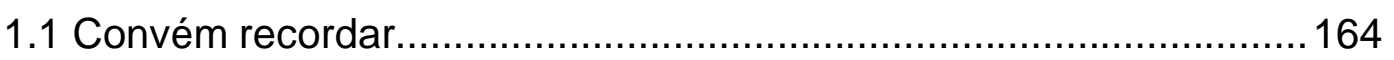

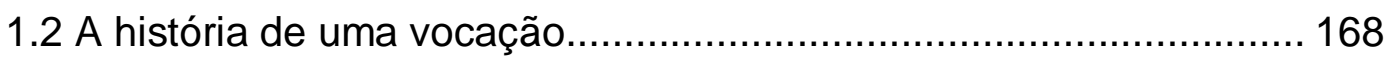

1.3 "Entre os quatro muros da minha nova liberdade".......................... 172

1.4 Um monge, escritor e poeta para o mundo...................................... 174

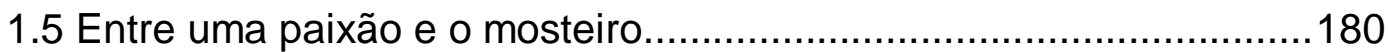

2. Cristão: "Filho de Deus" criado livre para o amor...............................181

2.1 Meu lugar no mundo: solidão e compaixão...................................... 188

2.2 "O eu interior: nossa realidade substancial"...................................... 192

2.3 "Para um contemplativo toda a vida é contemplação"....................... 196

2.4 A viagem ao Oriente: "...dela tirar proveito, aprender, mudar.".........206

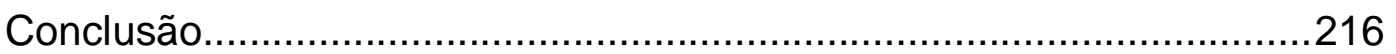

Cronologia da vida de Thomas Merton...............................................218

IV. Parte

Experiência Cristã de Deus em Raimon Panikkar..................................220

1. O itinerário de vida de Raimon Panikkar.............................................225

1.1 O encontro com a Índia e seu descobrimento como cristão, hindu e budista, período de 1954 até 196..........................................227

1.2 A volta para Catalunha e seu retorno à "sua casa"

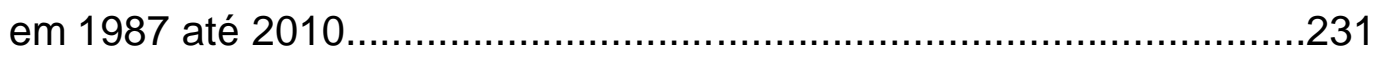

1.3 Igreja, "comunhão de Deus com todo o povo"................................ 233

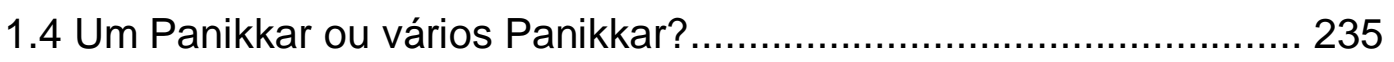

2. Buscar a unidade harmônica de toda a realidade..............................241 
2.1 Toda realidade é cosmoteândrica................................................ 249

2.2 O ser humano, uma realidade cosmoteândrica................................ 251

2.3 No ser humano, tudo é totalidade................................................. 254

$2.4 \mathrm{O}$ ser humano, um ser religioso e místico........................................ 256

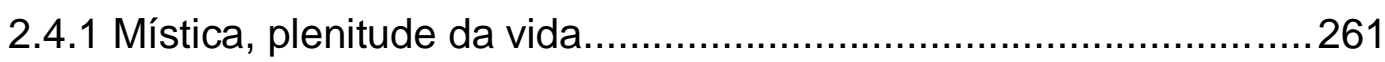

2.4.2 Mística e a experiência de Deus................................................. 264

2.5 Espiritualidade cosmoteândrica.................................................. 269

2.60 monge, arquétipo do ser humano.............................................272

2.7 "Toda realidade é uma cristofania"................................................ 274

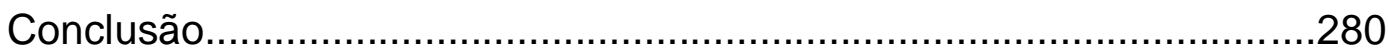

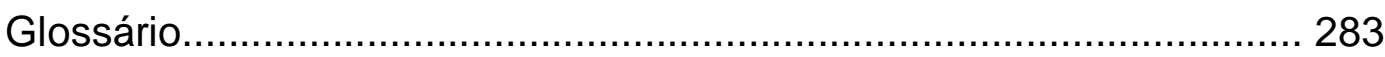

Cronologia da vida de Raimon Panikkar............................................. 285

V. Parte

A mística cristã na perspectiva do diálogo inter-religioso

em Thomas Merton e Raimon Panikkar................................................286

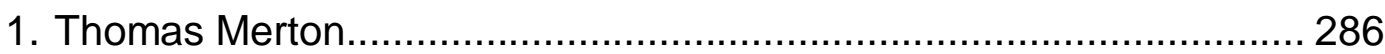

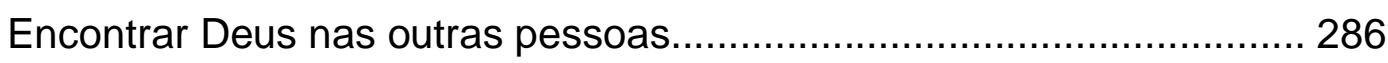

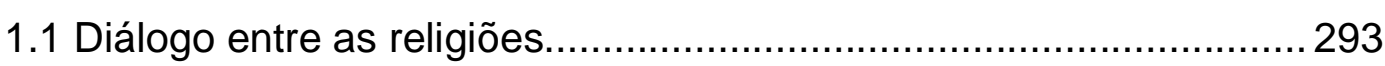

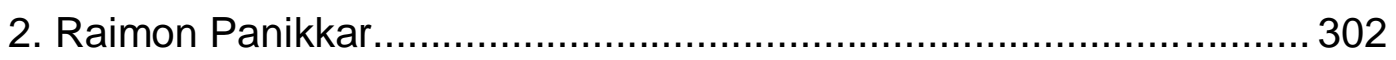

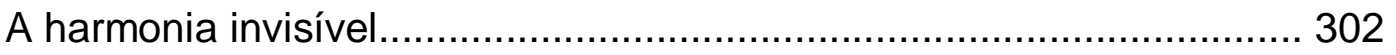

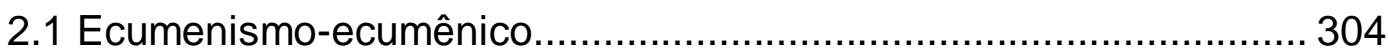

2.2 O diálogo, uma necessidade vital................................................. 306

2.3 Pluralismo não significa pluralidade .................................................. 314

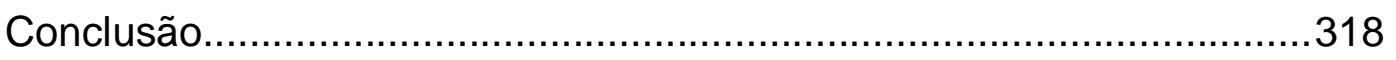

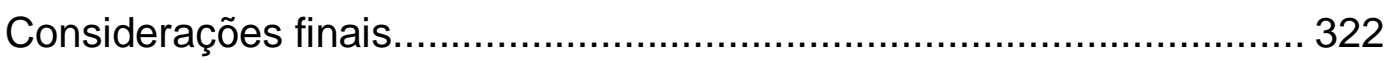

Perspectivas para uma maturidade cristã e uma mística

inter-religiosa - Caminhos apontados por Thomas Merton

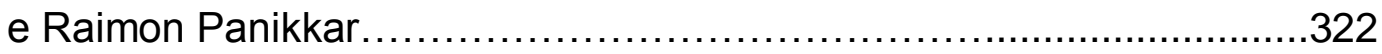

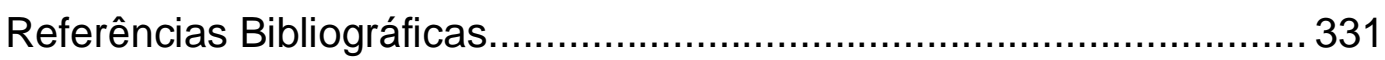




\section{Abreviações}

Documentos da Igreja

AG - $\quad$ Ad Gentes

DV - Dei Verbum

GS- Gaudium et Spes

LG- Lumen Gentium

NA- Nostra Aetate

RM- Redemptoris Missio

DH- Dignitatis Humanae

UR- Unitatis Redintegratio

DA- Diálogo e Anúncio

DM- Diálogo e Missão 
"É uma verdade incontornável que o Espírito de Deus está agindo em todas as religiões tradicionais. Dialogar é então uma viagem em companhia do Espírito para descobrir de onde vem e para onde vai sua graça. O que explica por que se trata de um ato espiritual e que só pode efetuar essa viagem estando aberto ao Espírito e sensivel à sua voz”.

FEDERAÇÃO das Conferências Episcopais da Ásia. O que o Espírito diz às Igrejas. Sedoc, v. 33, n. 281, julho/agosto de 2000, p. 46. 


\section{Introdução}

Esta tese visa produzir uma reflexão que possa aprofundar o fortalecimento da maturidade cristã, aproximando a pessoa religiosa cada vez mais da realidade de ser imagem de Deus. Deseja, assim, contribuir para desenvolver uma mística inter-religiosa que impulsione um pensar sério para além de uma simples troca de ideias, conhecimento conceitual ou formulações de verdades entre as religiões.

Diante da indiscutível realidade plural em que vivemos, procuraremos, no que diz respeito às religiões, e em especial ao Cristianismo, criar condições para uma apreciação positiva das demais religiões, através de um diálogo fecundo e acolhedor. Para isso, acreditamos que a realização de um caminho espiritual enraizado na experiência de união com Deus abre possibilidades para a maturidade da experiência cristã e uma mística inter-religiosa. Quando nos deparamos com as experiências de Thomas Merton e de Raimon Panikkar em seu diálogo com as religiões Orientais, nos damos conta de que o verdadeiro caminho trilhado por estes e por tantos outros/as cristãos/ãs no diálogo inter-religioso está aberto a todos que procuram manter com Deus uma relação de intimidade.

A teologia é chamada a refletir diante do atual contexto, as questões fundamentais que exigem dela mesma compreender o significado da pluralidade religiosa no projeto salvífico de Deus e sua relação com o mistério de Jesus Cristo e com o cristianismo. O que temos presenciado com o pluralismo religioso implica para as religiões o reconhecimento da dignidade e do valor do diferente de si. Exige o respeito ao direito de ser diverso e assume a acolhida como valor fundamental. Supõe compreensão nova da capacidade humana de captar a verdade, sempre parcial, provisória e sujeita a enriquecimento, revisão e ampliação.

Hoje essa situação é denunciada por homens e mulheres. Aqui é por Thomas Merton e Raimon Panikkar, os quais, ao viverem em profundidade sua fé e terem estado em contato com as religiões e espiritualidade oriental, chamam a atenção acerca da nova situação em que se encontra o cristianismo e, ao mesmo tempo, todas as religiões: desafiadas a dar um salto a um nível mais alto.

Sugere nova atitude diante da realidade de pluralismo: acolhimento e valorização da consciência da pluralidade, acompanhada de profunda atitude de 
diálogo real no qual todos aprendem. A partir de uma mudança que se dá por meio de uma transformação religiosa, através de uma profunda experiência de Deus. Porque a consciência religiosa, mais lúcida e desperta pede hoje uma transformação profunda em direção ao Mistério que a envolve e a sustenta.

Estudando Thomas Merton e Raimon Panikkar, os quais apresentam caminhos para uma mística inter-religiosa através de uma profunda experiência de Deus, poderemos apontar caminhos para que, no interior das religiões, a pessoa religiosa possa também realizar seu percurso de intimidade com Deus e, através desta, possa exercer a compaixão e acolhida às demais religiões.

Queremos propor que o diálogo entre as experiências religiosas não se resuma a uma conversão vazia, mas que os interlocutores tenham, de fato, penetrado com a máxima seriedade em sua própria tradição, em especial os cristãos. Apontamos ainda a dimensão espiritual como o nível mais fecundo para a abertura e compreensão no diálogo inter-religioso, encontrando meios que possam contribuir para que não se viva uma religiosidade epidérmica, recuperando a dimensão da experiência íntima do mistério de Deus e da experiência da unidade com ela.

Acreditamos que o mútuo reconhecimento da singularidade e das características próprias de cada tradição religiosa é condição indispensável à experiência de um diálogo inter-religioso que supera o simples reconhecimento conceitual. Além disso, cremos que a experiência mística dos fiéis das diferentes tradições religiosas fundamenta a abertura ao diálogo que supera as diferenças e remete à preocupação pela melhoria e pelo progresso da humanidade.

Desta forma, acreditamos que as experiências de pessoas como Thomas Merton e Raimon Panikkar podem colaborar para uma madura experiência cristã e uma mística inter-religiosa, pois ambos viveram o fecundo diálogo com as religiões do Oriente, profundamente ancorados em sua experiência cristã.

Estas experiências, através de um profundo encontro com Deus, indicarão possíveis caminhos para que, no interior do Cristianismo, a pessoa religiosa possa também realizar seu percurso de intimidade com Deus, e, através desta, possa exercer a humildade na acolhida às demais religiões, em uma rica e madura experiência cristã aproximando-se da imagem que é de Deus.

Estaremos também em constante diálogo com o filósofo da religião Juan Martin Velasco e o teólogo Andrés Torres Queiruga. Juan Martin Velasco nos 
apresenta a importância que está adquirindo no diálogo inter-religioso a dimensão espiritual e a experiência interior que comportam todas as religiões. Destacamos exatamente a experiência mística como importância decisiva no diálogo. Andrés Torres Queiruga nos afirma a autêntica necessidade de um encontro com as religiões, partindo da concepção de que todas as religiões como tematização da constitutiva relação salvífica do homem com Deus.

Esta confrontação nos permitirá reconhecer a plausibilidade de semelhanças entre os místicos de diferentes tradições religiosas, sem desconhecer ou relegar o que há de único e irrevogável em cada religião. E possibilitará o convívio com a diversidade, reconhecendo suas singularidades e características específicas, essenciais de cada uma em particular, bem como sua irredutível alteridade.

Procuraremos encontrar uma base para a reflexão teológica que possibilite à fé cristã o reconhecimento positivo, justo e respeitoso da pluralidade e da diversidade religiosas, sem abandonar a identidade cristã. Para isto, a nossa metodologia nos possibilitará uma compreensão complexa e não dualista das aparentes contradições nas tradições religiosas, para um encontro e diálogo entre as diferentes verdades existentes. No entanto, o mais importante de nossa reflexão pretende dar-se em outro nível, na experiência de Deus, na qual se acredita poder estabelecer uma ética capaz de corresponder aos anseios do ser humano, como condição insubstituível para sua liberdade e responsabilidade.

Para uma melhor realização do nosso objetivo, a tese será dividida em cinco partes. Na primeira parte, no primeiro capítulo, contrapondo-se ao crescimento secular imposto pelo avanço da chamada pós-modernidade, nos defrontaremos com o pluralismo religioso que nos convida a buscar formas de possibilitar o convívio harmonioso em nossa sociedade. Veremos que essa realidade para o cristianismo em particular, com sua atual configuração, o provoca mais do que em outra época a abrir-se para o reconhecimento das outras religiões. No que diz respeito ao diálogo inter-religioso, cria condições para uma apreciação positiva das mesmas em sua pluralidade e especificidade. Veremos que esta realidade é uma oportunidade para que ocorra uma atitude de respeito e amizade entre pessoas e comunidades distintas, em um conhecimento mútuo e um recíproco enriquecimento entre as religiões.

No segundo capítulo desta primeira parte, abordaremos o fenômeno religioso e místico. Nesse capítulo, sinalizaremos a necessidade que tem cada 
religião de avançar mais além das características externas, como o credo, os ritos etc. pelas quais é reconhecida e através das quais é transmitida, a ultrapassar as fronteiras de si mesma. Isto permitirá ao diálogo inter-religioso não se deter "nas diferenças, às vezes profundas, mas confiar-se com humildade em Deus, que é maior do que o nosso coração"1. Dentre os níveis de encontro com suas respectivas formas de diálogo que o cristianismo tem buscado concretizar, apontaremos a mística por alcançar o nível mais profundo, por uma "comunhão acima do nível das palavras"2. Neste nível, os homens e as mulheres são chamados a "compartilhar as suas experiências de oração, de contemplação, de fé e de compromisso, expressão e caminhos da busca do Absoluto"3. Nessa experiência do sagrado, o místico torna-se peregrino de seu próprio interior, descobre uma nova maneira de perceber o mundo: contempla-o com os olhos de Deus.

Procuraremos delinear uma concepção de mística a partir da experiência religiosa nas religiões, na tentativa de uma compreensão mais inclusiva da realidade plural religiosa de que o outro é condição de possibilidade de viver mais profunda e radicalmente a própria fé, sem perder sua essência. Para isto, despertar a necessidade de viver com intimidade uma relação com Deus, sem medo de abrir-se ao novo, e também de aprender com o que o outro é capaz de dar. Através desta experiência, poderemos encontrar os sinais para que uma religião possa chegar a ir além de si mesma, por assimilar um Mistério sempre maior e ser o ponto de partida para um fecundo diálogo inter-religioso, por se entender que as religiões são caminhos por onde as pessoas são conduzidas à sua origem, ao que "chamamos nosso ser mais profundo, o divino em nós e em tudo o que existe"

$\mathrm{Na}$ segunda parte, será a oportunidade para abordarmos as reflexões de Velasco e Queiruga. No primeiro momento teremos a reflexão de Velasco. Veremos que em meio a tantas experiências religiosas, esta é uma oportunidade para se desfazer de tudo que se tinha adquirido por 'se ouvir dizer' sobre Deus. Este é o momento para descobrir, pela própria experiência, as pegadas de sua Presença em nossa situação, aparentemente dominada pela incredulidade e tomar

\footnotetext{
${ }^{1}$ SECRETARIADO para os Não-Cristãos. A igreja e as outras religiões. São Paulo: Paulinas, 2001. (DM) 35.

${ }^{2}$ MERTON, Thomas. O diário da Ásia. Belo Horizonte: Vega, 1978. p. 248.

${ }^{3}$ DM 35.

${ }^{4}$ MELLONI, Javier. Las religiones, más allá de sí mismas. In: MELLONI, Javier (org.). El nolugar del encontro religioso. Ed. Trotta, Madri, 2008. p. 178.
} 
consciência de sua silenciosa, porém real, ativa e inconfundível presença no fundo do real, no âmago de cada ser humano. E assim, encontrar a autêntica fonte de existir da religião, nessa experiência de abertura a esta Presença, que expressandose segundo a época, cultura e educação, tem se dado de diferentes formas nas tradições religiosas.

Nessa experiência, o ser humano é provocado a um aprofundamento de si, e neste encontro consigo descobre-se no desapego que o impulsiona para o

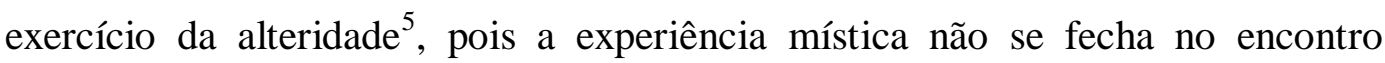
amoroso do fiel com Deus. Ao contrário, esta experiência tem como consequência um descentrar-se, um sair de si, para reconhecer o outro e, nesse reconhecimento, chegar ao Totalmente Outro.

No segundo momento, com a contribuição de Queiruga, entenderemos que a revelação de Deus ao homem implica um intenso encontro consigo mesmo, que se desdobra numa maior percepção sobre a vida e numa melhor contribuição na construção da história. E essa experiência se dá a partir da revelação acontecendo maieuticamente na história. Perceberemos que, a partir desta nova perspectiva da revelação, a experiência de Deus torna-se diferente, não mais acontecendo como um ditado divino, mas se apoiando na novidade da origem histórica e na livre iniciativa divina.

Para Queiruga, na revelação, "não se manifesta o que o homem é por si mesmo, e sim o que começa a ser por livre iniciativa divina. Não se trata de um desdobrar imanente de sua essência, mas de uma determinação realizada por Deus na história" 6 . O fiel, ao se deixar interpelar por esta Presença, apreende a profundidade de sua realidade, abre-se a uma experiência singular da revelação e se descobre no 'próprio-ser-apartir-Deus-no-mundo'. Essa é uma ação que parte sempre de Deus em direção ao homem, que, quando acolhe a presença reveladora de Deus, que estava desde sempre já aí, possibilita através desse seu ato uma abertura ao seu próprio crescimento, à sua realização humana.

E dentre os/as grandes personagens cristãos/ãs que percorreram ou que continuam a percorrer um caminho de profunda intimidade com Deus, optamos por dois místicos: Thomas Merton e Raimon Panikkar, os quais apresentaremos

\footnotetext{
${ }^{5}$ Cf. BINGEMER, M. Clara. Alteridade e vulnerabilidade. Experiência de Deus e pluralismo religioso no moderno em crise. São Paulo: Loyola, 1993. pp. 82-84.

${ }^{6}$ QUEIRUGA, A. Torres. A revelação de Deus na realização humana. São Paulo: Paulus, 1995. p. 115 .
} 
na terceira parte de nossa pesquisa. São homens que no seu itinerário espiritual desbravaram as fronteiras entre as religiões e mantiveram um diálogo aberto e acolhedor com outras tradições religiosas. Acreditamos que é possível enveredarmos por uma mística inter-religiosa quando nos deparamos com as tais experiências que revelam a manifestação do próprio Deus.

Mergulharemos na experiência de encontro com Deus que teve Thomas Merton, um monge contemplativo recolhido ao diálogo silencioso da oração e da meditação, que não se furtou ao diálogo com o mundo, abrindo sua alma e coração com rara franqueza e honestidade. Como mestre espiritual que foi, tornou-se uma referência incontornável nos estudos da espiritualidade cristã e da experiência religiosa num sentido mais geral. Pode-se mesmo afirmar que sua decisiva contribuição para o cristianismo contemporâneo foi promover uma renovação e redimensionamento da vida contemplativa.

Encontraremos em Thomas Merton uma experiência religiosa oriunda de dois inseparáveis amores: o amor a Deus e à humanidade. O seguimento de Jesus em Merton possui essa dupla abertura: paixão infinita por Deus, na dedicação incondicional como monge, sacerdote e eremita e no profundo amor aos humanos.

$\mathrm{Na}$ quarta parte de nosso texto, encontraremos em Raimon Panikkar alguém que ao longo de sua vida assumiu quatro identidades: o Cristianismo, religião em que nasceu e foi educado; o Hinduísmo que formava também parte de sua origem, porém foi descobrindo pouco a pouco, e assim ele mesmo diz: "há que deixá-lo emergir em mim"; o Budismo, que foi se desenvolvendo nele de forma natural como resultado do trabalho interior; e, por fim, sua identidade secular, como resultado do seu contato com o mundo ocidental.

As identidades encontradas em Raimon Panikkar nascem de uma personalidade fecundada pelas quatro tradições mencionadas, até o ponto de que não podemos compreendê-lo sem conhecer o que supõe para nosso autor o profundo diálogo interior que tem desejado e querido estabelecer.

Na penúltima parte de nossa pesquisa, apresentaremos o que para Thomas Merton e Raimon Panikkar significou o diálogo inter-religioso e o que cada um apontou como caminho para essa experiência. Veremos que estes místicos se transformaram em peregrinos na busca constante do encontro com Deus. Seguiram animados, inspirados e fortalecidos na sua busca no encontro com outras religiões, descobrindo-se cada vez mais cristãos. 
Por último, procuraremos concluir com uma reflexão que nos possibilite buscar na experiência cristã de encontro com Deus, uma maturidade capaz de romper fronteiras que ainda possam impedir o diálogo inter-religioso. 


\section{I - Parte}

\section{A teologia e o contexto religioso}

\section{O pluralismo religioso e a teologia das religiões}

As questões referentes à problemática do pluralismo religioso ocupam hoje nova relevância dentro de um novo contexto. No entanto, o pluralismo religioso, enquanto problema teológico, não é novo. Ainda com os Apóstolos, o cristianismo nascente teve de apresentar a sua mensagem. Primeiro, em relação ao Judaísmo e, depois, em relação às outras religiões que encontrou em seu caminho ${ }^{7}$. Segundo Jacques Dupuis, o que é "novo é a consciência aguda que o nosso mundo adquiriu do pluralismo das culturas e das tradições religiosas, bem como do direito à diferença que é própria de cada uma delas" 8 .

A teologia do pluralismo religioso surge então, nesse contexto, como um novo nome adotado para a teologia das religiões, cujo desenvolvimento começou na década de $60^{9}$. Sua reflexão se realiza a luz da fé sobre o pluralismo religioso, ou seja, sobre a pluralidade das religiões, sobre o fato de existir não apenas uma religião, mas, muitas.

Essa teologia possui o encanto da novidade, da abertura a horizontes desconhecidos, provocando assim proposições que, às vezes, no cristianismo, comovem as convicções mais profundas, pois o que seu estudo proporciona não é somente uma aquisição de novos conhecimentos, mas uma reconstrução do conhecimento religioso já adquirido, uma renovação de convicções religiosas básicas, possibilitando uma nova forma de viver a religião.

Surge, então, a necessidade de um novo paradigma, ou seja, uma nova forma global de articular e combinar os elementos da fé a partir de bases novas, de suposições gerais inéditas ${ }^{10}$, pois se percebe que "a marcha do mundo e de sua cultura, assim como o contato vivo entre as diversas religiões, têm-nos feito muito

\footnotetext{
${ }^{7}$ Cf. At 17,19-34 (Todas as passagens bíblicas serão tiradas da Bíblia de Jerusalém); Cf. DUPUIS, Jacques. $O$ cristianismo e as religiões. Do desencontro ao encontro. São Paulo: Loyola, 2004. p. 273. Referiremo-nos a este autor, no corpo do texto, apenas como Dupuis.

${ }^{8}$ Ibid., p. 273.

${ }^{9}$ VIGIL, J. Maria. Teologia do pluralismo religioso. Para uma releitura pluralista do cristianismo. São Paulo: Paulus, 2006. p. 13.

${ }^{10}$ Ibid., p. 14.
} 
conscientes de que a vivência religiosa encontra-se em uma situação nova; e, em aspectos importantes, radicalmente nova"11.

O pluralismo religioso não é um tema simplesmente teórico nascido das especulações de intelectuais que o estejam querendo transmitir à sociedade. Provém da própria realidade do mundo de hoje. É um fato que se aproxima cada vez mais em todos os âmbitos: na sociedade, na cidade, no trabalho, na comunicação e até mesmo na família, ninguém pode subtrair-se ao reconhecimento desta nova paisagem humana ${ }^{12}$.

Sem procurarmos expor os fatores que se encontram na origem desta nova realidade, sinalizamos apenas que se encontra vinculada ao amplo fenômeno da globalização, na medida em que proporciona uma aproximação virtual e real entre os diferentes povos. Essa aproximação, ocasionada pelo avanço dos meios de comunicação nas sociedades, vem realizando uma interação de conhecimentos mútuos, num processo que vem se acelerando exponencialmente ${ }^{13}$. Nesse processo, todos os elementos e dimensões das sociedades do planeta estão se inter-relacionando e fazendo-se mutuamente dependentes.

Esta interpretação das sociedades, com suas culturas e religiões, fazendo-se presentes umas nas outras, é um fenômeno novo ${ }^{14}$, o que acentua o fato de que as religiões e as culturas vejam-se obrigadas a conviver, pois muitas sociedades são pluriculturais, ou seja, compostas por grupos procedentes de vários países. Assim, "pelo contato efetivo das religiões"15, todas estão presentes umas nas outras, inevitavelmente.

As novas sociedades provocam uma transformação que supõe uma "verdadeira revolução na consciência religiosa da humanidade; estamos vivendo um momento da história no qual o acesso às diferentes religiões tem uma amplitude e uma profundidade sem precedentes" ${ }^{\prime 16}$.

Para Jean Claude Basset,

\footnotetext{
11 QUEIRUGA, A. Torres. El dialogo de las religiones en el mundo actual. El Vaticano III. Barcelona, Herber-El Ciervo, 2001. p. 69. Apud. VIGIL, J. Maria. Teologia do pluralismo religioso, p. 29.

${ }^{12}$ Cf. VIGIL, J. Maria. Teologia do pluralismo religioso, p. 27.

${ }^{13}$ Cf. MIRANDA, M. de França. O cristianismo em face das religiões. Religiões em diálogo. São Paulo: Loyola, 1998. p. 12 e p. 38.

${ }^{14}$ Cf. VIGIL, J. Maria. Teologia do pluralismo religioso, p. 31.

${ }^{15}$ QUEIRUGA, A. Torres. O diálogo das religiões. São Paulo: Paulus, 1997. p. 61.

${ }^{16}$ ARTHUR, Chris. Religious Pluralism. A metaphorical approach. The Davies group. Aurora, Colorado, 2000. p. 1. Apud. VIGIL, J. Maria. Teologia do pluralismo religioso, p. 29.
} 
a visão do mundo coerente e segura se encontra perturbada pelo contato com outras perspectivas, a escala de valores estabelecida sofre a competição de outros valores e outras normas. Não somente tem-se ampliado o campo dos conhecimentos, mas também põe-se em dúvida a própria noção de verdade. A filosofia ocidental se converte numa corrente de pensamento entre outras, como a mulçumana, a hindu, a chinesa, etc ${ }^{17}$.

No entanto, como vimos, mesmo que o processo de globalização gere uma cultura global e a homogeneização da cultura sob determinados aspectos, ela também cria um cenário favorável para o conhecimento e a manifestação das diferenças $^{18}$. A esses fatores acrescenta-se a mudança de consciência e de mentalidade na cultura ocidental, decorrente da conhecida crise da modernidade ${ }^{19}$. Esta nova situação nos coloca face a face com a pluralidade religiosa, pois se faz urgente uma posição em relação às outras religiões, não só no que diz respeito ao caráter teológico, mas também por questões de caráter sociocultural e político.

No que diz respeito ao caráter teológico, faz-se necessário partir de sua contextualização, ou seja, da teologia e do modelo a que esse princípio dá origem, chamado de teologia hermenêutica. Essa teologia se utiliza de um método indutivo que significa partir da realidade histórica e vivida, deixando-se questionar por ela e procurando lançar sobre ela a luz da Palavra revelada ${ }^{20}$.

Segundo C. Geffré, a teologia hermenêutica é "um novo ato de interpretação do evento Jesus Cristo com base numa correlação crítica entre a fundamental experiência cristã de que a tradição dá testemunho à experiência humana contemporânea" 21 .

Diante de uma realidade marcada pelo pluralismo religioso, não pode ser promissora, com efeito, uma reflexão teológica a partir de um discurso 'sobre os

\footnotetext{
${ }^{17}$ BASSET, Jean-Claude. El diálogo interreligioso. Desclée. Bilbao, 1999. p. 7.

${ }^{18}$ Cf. PACE, E. Religião e Globalização. In: ORO, A. P. - STEIL, C. A. (orgs.). Globalização e Religião. Petrópolis: Vozes, 1997. pp. 25-42; VELHO, O. Globalização: antropologia e religião. In: Ibid., pp. 43-61; PRANDI, R. A religião do planeta global. In: Ibid., pp. 63-70.

${ }^{19}$ Cf. LIBÂNIO, João B. As lógicas da cidade. O impacto sobre a fé e sob o impacto da fé. São Paulo: Loyola, 2001.

${ }^{20}$ Diferente do que tradicionalmente foi empregado pela teologia como método dogmático dedutivo. A partir do conteúdo doutrinal das enunciações dogmáticas da Igreja, fundamentadas em citações das escrituras construíam-se conclusões teológicas precisas que consistiam em partir de princípios gerais para chegar às suas aplicações concretas, aos problemas hodiernos. O perigo desse método estava no fato de que quanto mais deduções se faziam dos princípios abstratos tanto mais real era o risco de ficarem isoladas da realidade. No que tange à teologia das religiões, partindo-se do dado dogmático da salvação universal da humanidade em Jesus Cristo, deduzia-se com surpreendente facilidade a exclusão a priori de qualquer valor salvífico das outras tradições religiosas, a partir dos textos selecionados do Novo Testamento. Cf. DUPUIS, Jacques. $O$ cristianismo e as religiões, pp. 25-27.

${ }^{21}$ GEFFRÉ, C. Le christianisme au risque de l'interprétation. Cerf, Paris, 1983. p. 71. Apud. DUPUIS, Jacques. $O$ cristianismo e as religiões, p. 25.
} 
outros'. Pois se o princípio da contextualização e do método teológico interpretativo é aplicado seriamente à realidade religiosa do mundo, compreendese imediatamente que a teologia das religiões não pode ser vista simplesmente como um novo assunto ou sujeito sobre o qual se deve refletir teologicamente ${ }^{22}$.

Dupuis diz sobre a 'teologia das religiões' ou do 'pluralismo religioso' que, mais do que como um novo tema para a reflexão teológica, deve ser vista como um novo modo de fazer teologia numa situação de pluralismo religioso. Para ele, essa teologia hermenêutica 'inter-religiosa' é um convite a alargar o horizonte do discurso teológico e apresenta-se como "um novo método para fazer teologia". Segundo esse autor, se "conserva uma atitude dialógica em cada estágio da sua reflexão: é reflexão teológica sobre o diálogo e no diálogo. É teologia dialógica inter-religiosa ${ }^{, 23}$.

A teologia se vê, então, confrontada de uma maneira inédita em sua história com a tarefa da interpretação das religiões e do próprio fato do pluralismo religioso à luz da revelação cristã; e com uma re-interpretação da fé cristã dentro do horizonte hermenêutico fornecido pela realidade inter-religiosa atual. Procuraremos, então, situar os principais desafios do pluralismo religioso hoje à teologia, à fé e a práxis cristã, seguindo-se uma exposição sintética do percurso da teologia culminando, numa contextualização do debate atual.

\subsection{Os desafios do pluralismo religioso}

Diante do tema do pluralismo, é possível dizer que a sociedade hoje adquiriu, de alguma forma, certa noção de pluralismo e tolerância, ainda que superficialmente, visto que a história da qual viemos é de milênios de atitudes contrárias ao pluralismo ${ }^{24}$.

Segundo Schillebeeckx, o pluralismo passou a ser um pressuposto cognitivo da consciência individual, tornando-o constitutivo da estrutura interior da personalidade das pessoas ${ }^{25}$.

Nossa cultura contemporânea já nasceu plural. O pluralismo que foi gestado na modernidade ${ }^{26}$ chega na "pós-modernidade" ${ }^{27}$ ao seu auge. Nessa cultura,

\footnotetext{
${ }^{22}$ Cf. DUPUIS, Jacques. O cristianismo e as religiões, p. 29.

${ }^{23}$ Ibid., p. 29. (grifo do autor).

${ }^{24}$ Cf. VIGIL, J. Maria. Teologia do pluralismo religioso, p. 35.

${ }^{25}$ Para Schillebeeckx "o pluralismo se apoderou de nós como realidade cognitiva". Cf. SCHILLEBEECKX, E. História humana. Revelação de Deus. São Paulo: Paulus, 1994. p. 96.
} 
apresenta-se, do ponto de vista empírico, a pluralidade sob diferentes aspectos: pluralidade de confissão religiosa (pluralismo religioso), de valores (pluralismo axiológico), pluralidade de grupos sociais e culturais (pluralismo sociocultural) e de organizações políticas (pluralismo político) ${ }^{28}$.

Logo, é claro que a situação de pluralismo religioso, inédita na história humana, da forma como está acontecendo, com grande eloquência e facilidade de se fazer emergir uma nova expressão, torna-se uma característica desta sociedade contemporânea $^{29}$. Para Geffré, "o pluralismo religioso é um desafio mais amedrontador para a fé cristã do que o ateísmo moderno" $" 30$.

Nesta cultura, já não se admitem pretensões absolutistas, totalitárias e nenhuma forma de dogmatismo, seja em relação à religião ou a qualquer outro sistema que queira possuir o monopólio da verdade ${ }^{31}$. No entanto, exige-se passar da constatação factual da pluralidade religiosa para o pluralismo enquanto atitude de reconhecimento do valor, do significado e da riqueza das diferenças, superando tendências de dominação e desprezo e abrindo-se ao diálogo ${ }^{32}$.

No caso do cristianismo, deve "compreender-se e compreender: compreender-se a si mesmo a partir das demais religiões e compreender as demais religiões a partir da vivência e da interpretação da religião à qual se pertence" ${ }^{33}$.

Entretanto, nesse novo contexto em que se inserem todas as tradições religiosas, são suscitadas novas questões e a partir destas se abrem novas perspectivas e novas possibilidades de explicação sobre elementos presentes em cada religião e sua relação com as demais tradições. Mas é preciso ressaltar que

\footnotetext{
${ }^{26}$ Sobre a modernidade ver: AZEVEDO, Marcelo de C. Modernidade e cristianismo. São Paulo: Loyola, 1981.

${ }^{27}$ Cf. LIPOVETSKY, G. A era do vazio. Lisboa: Relógio d'água, 1989. Segundo este autor, vivemos na passagem de uma sociedade que se centralizou nas ideias, na razão, para uma sociedade que tem as imagens no seu centro.

${ }^{28}$ Cf. EICHER, Peter. Pluralismo. In: Dicionários de Conceptos teológicos. Vol. II. Barcelona: Herber, 1990. pp. 237-242; EICHER, Peter. Excelência da teologia em conflito com seu pluralismo. Concilium, v. 191, n.1, 1980. p.15; LIBÂNIO, J. B. As lógicas da cidade, pp. 113-143.

${ }^{29}$ Cf. MIRANDA, M. de França. Um homem perplexo. O cristão na atual sociedade. São Paulo: Loyola, 1989.

${ }^{30}$ GREFFRÉ, C. O lugar das religiões no plano da salvação. In: TEIXEIRA, Faustino (org.). $O$ diálogo inter-religioso como afirmação da vida. São Paulo: Paulinas, 1997. p. 112

${ }^{31}$ Cf. STIEL, C. A. O diálogo inter-religioso numa perspectiva antropológica. In: TEIXEIRA, Faustino (org.). Diálogo de pássaros. Nos caminhos do diálogo inter-religioso. São Paulo: Paulinas, 1993, pp. 25-26; Cf. SCHILLEBEECKX, E. Religião e violência. Concilium, 272. 1997. p. 168.

${ }^{32}$ Sobre a distinção entre pluralismo e pluralidade, cf. AZEVEDO, M., Prólogo de: TEIXEIRA, Faustino. Diálogo dos pássaros, p. 11.

${ }^{33}$ QUEIRUGA, A. Torres. O diálogo das religiões, p. 12.
} 
para compreender esse novo contexto dependerá do ângulo sob o qual seja contemplado, porque essa situação pode ser caracterizada como um problema ou como alternativa possível de sobrevivência da fé. Sobre as questões que são levantadas no caso do cristianismo, referem-se a elementos que lhe são fundamentais e dizem respeito à relação entre a revelação cristã e as outras religiões $^{34}$.

$\mathrm{Na}$ ordem sócio-política, o pluralismo religioso também apresenta algumas questões. Abordaremos apenas a questão da relação entre a violência e religião, como uma das principais preocupações no que diz respeito à convivência interreligiosa e à função das religiões na sociedade ${ }^{35}$.

Embora as religiões se caracterizem por sua função salvífica e humanizante, é conhecida pelo mundo afora a ocorrência de grandes conflitos justificados com motivações de ordem religiosa pelos mais diversos interesses ${ }^{36}$. No entanto, não se limita desta forma à violência religiosa; ela se apresenta, também, na forma mais sutil no cotidiano da convivência das pessoas presente na linguagem, no comportamento e em diferentes maneiras de ridicularização da religião alheia.

De certo, mesmo que a ligação entre a religião e a violência seja um fenômeno complexo, cuja compreensão global requer uma analise interdisciplinar $^{37}$, é sabido que existem obstáculos criados pelas próprias religiões para uma convivência inter-religiosa harmônica.

Essa realidade provoca um grande desafio para o diálogo inter-religioso, por pretender apontar a possibilidade de um horizonte de conversação alternativa; pois revela que a violência religiosa não faz parte da essência da religião, mas é um desvio ou traição do dinamismo mais profundo que anima a relação do ser humano com o Absoluto ${ }^{38}$.

No entanto, se as tradições religiosas têm contribuído para situações de violência, a História também tem dado amplo testemunho do papel positivo que podem desempenhar na sociedade. Quando essas assumem sua função

\footnotetext{
${ }^{34}$ Desenvolveremos essa questão quando aprofundarmos as reflexões de Andrés Torres Queiruga, no segundo capítulo da segunda parte de nossa pesquisa.

${ }^{35}$ Cf. BINGEMER, Maria C. (org.) Violência e religião. Cristianismo, islamismo, judaísmo. São Paulo: Loyola, 2002.

${ }^{36}$ Cf. AMALADOSS, M. Religiões: violência ou diálogo? Perspectiva teológica. v. 34, n. 93, 2002. pp. 179-196.

${ }^{37}$ Os estudos acima apontam neste sentido.

${ }^{38}$ Cf. TEIXEIRA, Faustino. Diálogo inter-religioso: o desafio da acolhida da diferença. In: Perspectiva teológica. v. 34, n. 93, 2002. p.155.
} 
humanizante e salvífica, "criando orientação, consolo, e uma ética de empatia" e constituem-se em "pontos de referência" de "redes de solidariedade, de ajuda mútua e de resistência" ${ }^{39}$, e em caminho de superação de situações injustas e de violência e de construção da paz $^{40}$. É certo que "a relação autêntica com o Absoluto como tal não é violenta sob nenhum aspecto, antes pelo contrário. Ela desperta a coragem inabalável para produzir mais humanidade em todos os setores da vida" $"$.

Identificamos, assim, que os principais desafios da relação entre as religiões estão relacionados à questão da convivência e do diálogo entre as mesmas e da comum responsabilidade na superação da violência, de situações de injustiça e na construção de uma cultura de paz ${ }^{42}$.

O cristianismo é provocado a realizar profundas mudanças, pois, mais do que em qualquer outra época de sua história, é desafiado a abrir-se para o reconhecimento das outras religiões em sua identidade e para o diálogo interreligioso. Estabelece-se uma oportunidade para uma 'comunicação recíproca', em 'atitude de respeito e amizade' como 'conjunto de relações inter-religiosas, positivas e construtivas, com pessoas e comunidades de outros credos para um conhecimento mútuo e um recíproco enriquecimento" ${ }^{43}$.

No entanto, para esta comunicação, é preciso o desenvolvimento de uma inteligibilidade das religiões e de sua autocompreensão, para que sejam superadas atitudes de discriminação e intolerância e, ao mesmo tempo, uma apreciação positiva das mesmas em sua pluralidade e especificidade, pois, em se tratando do cristianismo, "no diálogo inter-religioso, o cristão não deve ocultar a própria identidade ao mesmo tempo em que se cuida com todo respeito da identidade alheia" 44 .

Estando assim, cada tradição religiosa, enriquecida por sua autocompreensão, se descobre, como falou João Paulo II, que “o genuíno

\footnotetext{
${ }^{39}$ HÄRING, S. Superar a violência em nome da religião. Concilium. no . 272, 1997. 4, p. 683.

${ }^{40}$ Cf. HÜNG, H. Teologia a caminho. Fundamentação para o diálogo ecumênico. São Paulo: Paulinas, 1999. pp. 261-288.

${ }^{41}$ SCHILLEBEECK. E. Religião e violência. Concilium. nº. 272. 1997. 4, p. 171.

${ }^{42}$ Segundo Hans Küng: "não haverá paz no mundo sem uma paz entre as religiões". Cf. KÜNG, H. Projeto de ética mundial. Uma moral ecumênica em vista da sobrevivência humana. São Paulo: Paulinas, 1992, p. 108.

${ }^{43} \mathrm{DA}, 9$.

${ }^{44}$ QUEIRUGA, A. Torres. Autocompreensão cristã. Dialogo das religiões. São Paulo: Paulinas, 2007. p. 12.
} 
sentimento religioso conduz de fato a perceber o mistério de Deus, fonte da bondade, e isto constitui uma fonte de respeito e de harmonia entre os povos"

Entretanto, como veremos logo em seguida, o pluralismo religioso provoca a teologia em questões que lhe são essenciais e exige que a teologia compreenda o significado da pluralidade religiosa dentro do projeto salvífico de Deus e sua relação com o mistério de Jesus Cristo e com o cristianismo.

\subsection{0 pluralismo religioso: uma questão teológica}

O pluralismo religioso convoca a teologia a "se conscientizar da excelência do tema que lhe é próprio dentro da Igreja e diante da sociedade, isto é, da excelência da própria palavra de Deus que se fez história"46. Tal perspectiva exige também uma nova referência paradigmática.

Certamente, a mudança sociocultural provocada pelo pluralismo levou a teologia a uma profunda transformação, principalmente em relação ao cristianismo, que deve repensar sua atuação na sociedade, sem perder sua identidade singular - a revelação expressa pela encarnação de Jesus Cristo - e sua abertura ao diálogo com outras tradições religiosas, à "procura da unidade na diversidade" 47 . É preciso que procure ir além das fronteiras confessionais, pois todas as tradições religiosas aspiram "a uma Realidade Última, além dos limites dessa história e a aspiração a uma libertação ou a uma salvação em relação aos diversos males da condição humana" ${ }^{\text {48 }}$.

A atual diversidade religiosa e a autoafirmação das outras religiões como mediadoras da salvação constitui um fator de tensão que dificulta a aproximação e o diálogo. Logo, se percebe que do ponto de vista teológico, o desafio que se coloca é: como compreender e interpretar a vontade salvífica universal de Deus sem negar a mediação de Jesus Cristo?

A questão fundamental desta problemática teológica, que se encontra no centro das discussões a respeito das religiões, é a questão da unicidade de universalidade salvífica do evento Jesus Cristo. Muitos são os questionamentos já apresentados por muitos estudiosos desta temática. Por exemplo: Como se situa

\footnotetext{
${ }^{45}$ JOÃO PAULO II. Discorso di Giovanni Paolo II. Il Regno-Documeni. n. 3, 2002, p. 76. Apud. TEIXEIRA, Faustino. Diálogo inter-religioso, p. 155.

${ }^{46}$ EICHER, Peter. Pluralismo, p. 18.

${ }^{47}$ GEFFRÉ, C. O lugar das religiões no plano da salvação. In: TEIXEIRA, Faustino. $O$ diálogo inter-religioso, p. 115.

${ }^{48}$ Ibid., p. 116.
} 
esta afirmação cristã frente à diversidade de religiões? Como se situa Jesus Cristo no plano salvífico de Deus e que consequências essa sua posição tem para a interpretação das outras religiões? É possível à reflexão teológica cristã resolver este conflito sem renunciar à identidade cristã?

Para essas e tantas outras questões a esse respeito se faz necessária uma reinterpretação do cristianismo e de suas afirmações fundamentais em confronto com as questões suscitadas pelo pluralismo religioso. O problema principal a ser resolvido pela teologia cristã das religiões é a questão da singularidade e universalidade salvífica de Jesus Cristo em conexão com a vontade salvífica universal de Deus e sua correlação com a diversidade religiosa.

Estamos conscientes, no entanto, de que a busca de respostas à problemática cristológica suscitada pelo pluralismo religioso deva ser coerente com a fé cristã e aberta à questão do encontro e diálogo inter-religioso, "emoldurado em um regime de dom e gratuidade

Para isso, acreditamos que a possibilidade para uma resposta que seja coerente com a fé cristã se encontre na reinterpretação das afirmações centrais da fé cristã de uma maneira que preserve sua identidade e possibilite uma apreciação positiva das outras religiões. Nesse sentido, "o pluralismo interno da teologia moderna desafia a compreensão clássica de suas pretensões à verdade e introduz a necessidade da mais fundamental revisão em sua autocompreensão disciplinar" ${ }^{\circledR 50}$.

Como veremos a seguir, algumas reflexões teológicas recentes sobre este assunto apontam caminhos possíveis nesse sentido. O desafio principal que se impõe é encontrar uma base para a reflexão teológica que possibilite à fé cristã o reconhecimento positivo, justo e respeitoso da pluralidade e diversidade religiosa, porém, sem abandonar a identidade cristã.

\subsection{Teologia das religiões e teologia do pluralismo religioso}

Teologia das religiões é o ramo da teologia que faz das religiões o objeto de sua reflexão, que pensa sobre o significado das religiões, seu sentido no plano de Deus, sua validez salvífica, suas inter-relações e seus pontos em comum. ${ }^{51}$

\footnotetext{
${ }^{49}$ QUEIRUGA, A. Torres. Diálogo das religiões, p. 22. (grifo do autor).

${ }^{50}$ THEIL, John. Pluralismo na verdade teológica. Concilium. v. 256, n. 6, 1994. p. 77.

${ }^{51}$ Cf. VIGIL, J. Maria. Teologia do pluralismo religioso, p. 60.
} 
Durante vinte séculos, o cristianismo sempre se preocupou com o tema da presença da Salvação nas religiões não cristãs. No entanto, nunca houve um conjunto de doutrina como reflexão sistemática sobre as religiões, ou seja, uma verdadeira teologia das religiões. Essa teologia surgiu apenas na última metade do século XX, próximo ao Concílio Vaticano II $^{52}$. Segundo alguns autores, a primeira obra de teologia das religiões foi a de Heinz Robert Schlette, intitulada precisamente "As religiões como tema da teologia”, publicada em $1963^{53}$.

O surgimento dessa teologia se coloca na esteira de estudos das religiões já iniciados anteriormente por outras ciências da religião como a história das religiões, a psicologia da religião, a fenomenologia da religião, a filosofia da religião e a sociologia religiosa. Essa constatação indica que seu ponto de partida situa-se na renovação teológica dos anos pré-conciliares ${ }^{54}$.

Porém, se para o estudo das religiões o seu 'objeto material' é o mesmo das outras disciplinas, a teologia das religiões delas se distingue quanto ao seu 'objeto formal'. Assim como as outras ciências abordam as religiões a partir do ponto de vista que lhes é próprio, a teologia, por sua vez, interessa-se pelo seu aspecto histórico-salvífico, interpretando-as à luz da história salvífico-cristã, à luz da revelação cristã e, portanto, à luz da fé cristã ${ }^{55}$.

A teologia das religiões, a partir de sua especificidade, deixa claro que, necessariamente carregará consigo um caráter confessional. Para isso, mesmo que se pense na possibilidade de existir uma teologia universal ${ }^{56}$, é certo, no entanto,

\footnotetext{
${ }^{52}$ Cf. MIRANDA, M. de França. O cristianismo em face das religiões, p. 16.

${ }^{53}$ Cf. VIGIL, J. Maria. Teologia do pluralismo religioso, p. 61.

${ }^{54}$ Sobre a teologia das religiões antes do Concílio, cf. SARTORI, L. Teologia de las religiones no cristianas. In: Diccionario Teológico Interdisciplinar. v. 4, Salamanca: Sígueme, 1987. pp. 423428.

${ }^{55}$ Cf. BOUBLINK, V. Teologia delle religione. Roma: Studium, 1973. p. 41 Apud. DUPUIS, J. Rumo a uma teologia cristã do pluralismo religioso. São Paulo: Paulinas, 1999. p. 17. Esta é uma das mais importantes obras dentre as publicações sobre a teologia das religiões. Citaremos esta obra ao longo deste capítulo. Referiremo-nos a este autor como Dupuis;; TEIXEIRA, Faustino. Teologia das religiões: uma visão panorâmica. São Paulo: Paulinas, 1995. p. 12.

${ }^{56}$ Esta teologia universal pensada por alguns autores incluiria contribuições de todas as religiões e da fé em suas diferentes expressões religiosas, e, desta forma, se dirigiria não a uma religião específica, mas a todas as comunidades religiosas. Como podemos encontrar em José Maria Vigil, em seu esboço para uma teologia multireligiosa e pluralista da libertação. Segundo Vigil, "é possível pensar no nascimento de uma teologia nova, uma teologia pós-religiões que vá além não de uma religião, mas das religiões enquanto tal, enquanto configuração sócio-histórica humana congruente com o período 'agrário' da humanidade, período que já está perto do fim, progressivamente substituído pela 'sociedade do conhecimento'". Cf. VIGIL, José Maria. Por uma teologia planetária. São Paulo: Paulinas, 2011. Cf. DHAVAMONY, M. Teologia das religiões. In: LATOURELlE, R. - FISICHELLA, R. Dicionário de Teologia Fundamental. Petrópolis: Vozes; São Paulo: Santuário, 1994. p. 807; DUPUIS, Jacques. Rumo a uma teologia cristã, p. 18.
} 
que toda fé religiosa conta com um conteúdo que lhe é especifico e implica uma adesão total da pessoa, o que resulta inegavelmente numa diversidade de teologia. Então, necessariamente, toda teologia é 'confessional', atributo este que "indica a adesão da fé da pessoa ou da comunidade, que é o tema do próprio fazer teológico",57.

A constatação da diversidade teológica possibilita reconhecer a legitimidade de outras teologias confessionais das religiões e contribuir para que elas se desenvolvam, pois as tradições religiosas desenvolvem sua teologia "na medida em que seguidores destas diferentes religiões refletem sobre o encontro com as outras religiões do mundo, ou então, sobre a relação de sua religião específica com as demais religiões, à luz de sua fé" 58 .

A teologia do pluralismo religioso está se impondo porque os teólogos estão descobrindo que a realidade do pluralismo religioso, ou seja, a pluralidade de religiões - o fato de que sejam muitas e não uma - é o tema central hoje nesta teologia $^{59}$ e que, consequentemente, não é mais possível fazer teologia cristã sem dialogar com outras tradições. Logo, tendo em vista o diálogo inter-religioso, fazse necessário um empreendimento teológico que se orienta pela "sincera admissão da pluralidade e da diversidade de crenças, e da recíproca aceitação dos outros exatamente em sua alteridade" 60 .

Portanto, construir uma teologia cristã das religiões baseada na adesão pessoal da própria fé não significa fechamento e oposição à confissão de fé diferente, e sim, tomada de posição frente a elas, desde o próprio lugar religioso e teológico. Enfim, “a adesão pessoal à própria fé e a abertura à fé dos outros não precisam se excluir mutuamente. Deveriam, pelo contrário, crescer proporcionalmente uma em relação à outra" ${ }^{\prime 61}$.

A teologia das religiões se distingue da teologia da religião. Para o teólogo Dupuis, a teologia da religião busca compreender teologicamente o que é a religião, interpretar a experiência religiosa universal da humanidade e estudar as relações revelação-fé, fé-religião, fé-salvação, enquanto a teologia das religiões está voltada para a variedade de tradições religiosas, procurando compreender o

\footnotetext{
${ }^{57}$ DUPUIS, Jacques. Rumo a uma teologia cristã, p. 19.

${ }^{58}$ DHAVAMONY, M. Teologia das religiões, p. 807.

${ }^{59}$ Cf. VIGIL, J. Maria. Teologia do pluralismo religioso, p. 60.

${ }^{60}$ DUPUIS, Jacques. Op. cit., p. 20.

${ }^{61}$ Ibid., p. 20
} 
significado do pluralismo religioso dentro do plano salvífico de Deus para toda a humanidade e na sua relação com o mistério de Jesus Cristo e com a Igreja ${ }^{62}$.

Nessa perspectiva, a teologia das religiões se desdobra em dois momentos: uma teologia das várias religiões, que se volta para as tradições religiosas particulares $^{63}$, e uma teologia geral das religiões, que aborda as tradições religiosas em conjunto no seu significado dentro do plano salvífico de Deus. Essa teologia geral das religiões é anterior às teologias particulares na medida em que coloca as questões gerais relativas a todos os casos, que precedem as "questões especificas relativas ao diálogo cristão com tradições religiosas especificas"64.

Nos últimos anos, a expressão 'teologia das religiões' está sendo cada vez mais substituída ou ampliada pela expressão 'teologia do pluralismo religioso', apontando para uma mudança na perspectiva teológica. Isso porque a grande questão em debate, hoje em dia, passou a ser a pluralidade das religiões, o pluralismo religioso ${ }^{65}$. Como consequência, “em uma teologia das religiões, a pluralidade das religiões não pode deixar de ser, definitivamente, uma teologia do pluralismo religioso" $"$.

A reflexão teológica, que antes priorizava o problema da salvação, deslocase para o próprio fenômeno do pluralismo religioso, para, assim, compreender e valorizar positivamente a pluralidade religiosa à luz do mistério de Deus e o seu significado teológico. Essa nova reflexão provoca uma convergência das várias religiões, pautadas no reconhecimento e respeito pelas suas diferenças e no enriquecimento mútuo ${ }^{67}$.

Assim, o pluralismo religioso poderá ser mais que um desafio para a teologia; ele pode ser uma chance ${ }^{68}$ para que o cristianismo reveja suas posturas teológicas, eclesiológicas e pastorais. Desta forma, a teologia cristã, iluminada por sua raiz histórica e pelo contexto atual, pode renovar-se tendo em vista uma maior percepção da revelação de Deus, que deseja ser conhecido em máxima medida.

\footnotetext{
${ }^{62}$ Cf. DUPUIS, Jacques. Rumo a uma teologia cristã, p. 21.

${ }^{63} \mathrm{Cf}$. Ibid., p. 22ss. Ele apresenta como exemplo, a existência de uma teologia cristã do judaísmo e do encontro entre o Budismo e o Cristianismo.

${ }^{64}$ Ibid., p. $23 \mathrm{~s}$.

${ }^{65}$ Cf., Ibid., p. 19.

${ }^{66}$ Ibid., p. 271.

${ }^{67}$ Cf. Ibid., p. 26.

${ }^{68}$ Cf. MIRANDA, M. de França. O pluralismo religioso como desafio e chance. REB. v. 55, n. 218, 1995. p. 322.
} 
Abordaremos, no item seguinte, como se desenvolveu a teologia cristã das religiões. Veremos como a teologia cristã tem procurado relacionar-se com as demais tradições religiosas.

\subsection{A teologia cristã das religiões}

Desde seu surgimento, a teologia das religiões conheceu um significativo desenvolvimento, provocado, sobretudo, pelo aprofundamento do conhecimento das outras religiões, tanto no nível científico mediante estudos especializados sobre diversas religiões, quanto no nível experiencial mediante o contato, a comunicação e a convivência inter-religiosa ${ }^{69}$.

Foi o Concílio Vaticano II que, com ousadia, deu um grande salto com relação às outras religiões ${ }^{70}$. Seu ensino sobre as religiões se caracterizou por uma atitude positiva diante das outras religiões, possibilitando renovação teológica préconciliar $^{71}$. O Concílio afirmou respeitar e valorizar tudo de bom e santo que é suscitado pelo Espírito em outras tradições, declarando o caráter "verdadeiro e santo" das outras religiões, reconhecendo elementos positivos de vida e santidade presentes nas religiões não cristãs $^{72}$. Reconheceu que a salvação dos seres humanos vai muito além dos limites da Igreja. Por intermédio do Espírito Santo, Deus "opera de modo invisível" e oferece a todos a salvação ${ }^{73}$, admitindo e proclamando que Deus salva a humanidade "por caminhos só por ele conhecidos" ${ }^{\prime 74}$.

Esse Concílio marcou uma abertura sem precedentes nos posicionamentos oficiais da Igreja, determinando uma nova fase em sua relação com os nãocristãos $^{75}$. A partir dessa posição, estabelece-se uma oportunidade decisiva para o desenvolvimento da teologia das religiões nos anos pós-conciliares, pois nele se

\footnotetext{
${ }^{69}$ Cf. DUPUIS, Jacques. Rumo a uma teologia cristã, p. 26; MIRANDA, M. de França. Jesus Cristo, um obstáculo ao diálogo inter-religioso? REB. 57 (1997), p. 243-264; Id.,, O cristianismo em face das religiões;TEIXEIRA, Faustino (org.) Diálogo dos pássaros; Id., Teologia das religiões: uma visão panorâmica. São Paulo: Paulinas, 1995.

${ }^{70}$ Cf. VIGIL, J. Maria. Teologia do pluralismo religioso, p. 77.

${ }^{71}$ Cf. LG, 16 e 17; AG, 3, 9 e 11; Também NA; DV e DH apresentam importantes contribuições à questão.

${ }_{72}$ Cf. NA, 2; UR, 3; LG, 13 .

${ }^{73} \mathrm{Cf}$. GS, 22.

${ }^{74} \mathrm{GS}, 22$

${ }^{75}$ Sobre a teologia das religiões no Magistério da Igreja após o Concílio, Cf. DUPUIS, Jacques. Rumo a uma teologia cristã, p. 250ss. TEIXEIRA, Faustino. Teologia das Religiões, pp. 138-179.
} 
falou sobre as religiões não-cristãs de um modo mais positivo do que nenhum outro documento oficial da Igreja Católica havia feito antes ${ }^{76}$.

No entanto, o Concílio não teve tempo de ir mais além. Ele não questionou se era possível afirmar que as próprias religiões não cristãs são caminhos de salvação para seus membros por si mesmas, e não por uma participação sua no mistério de Cristo. Sua preocupação manteve-se em promover a compreensão, o diálogo, a acolhida e a cooperação entre o cristianismo e as religiões, suscitando, ao mesmo tempo, uma mudança de atitude por parte da Igreja e dos cristãos em relação às mesmas ${ }^{77}$.

O Concílio foi uma ocasião em que uma Igreja cristã tomou a sério e se pronunciou sobre as religiões não-cristãs de uma forma sem precedentes nem paralelos em toda a história. Suas afirmações significaram uma porta aberta aos teólogos, que se encontravam diante de um tema inédito, numa etapa nova de relação entre mais diversas tradições religiosas ${ }^{78}$. Embora tenha reconhecido o juízo teológico claro sobre o sentido salvífico das mesmas ${ }^{79}$ e sobre o significado do pluralismo religioso, deixou como tarefa para a reflexão teológica posterior examinar o alcance e tirar as consequências das afirmações desenvolvidas no mesmo.

Uma das mais famosas publicações de teologia das religiões, que reflete este espírito ainda em construção é: "Rumo a uma teologia cristã do pluralismo religioso" $" 80$. $\mathrm{O}$ adjetivo "cristã' que leva o título desta obra, permite entender que, em todas as religiões, há uma reflexão feita a partir da fé, uma fé que busca compreender e pensar mais ou menos sistematicamente. Num sentido legítimo, que a teologia das religiões não se dá apenas entre cristãos. Não há apenas uma teologia das religiões cristãs ${ }^{81}$. Podemos falar, então, de teologias das religiões feitas a partir de outras plataformas religiosas distintas do cristianismo.

\footnotetext{
${ }^{76}$ Cf. VIGIL, J. Maria. Teologia do pluralismo religioso, p. 81.

${ }^{77}$ Cf. DUPUIS, Jacques. Rumo a uma teologia cristã, p. 224.

${ }^{78}$ Cf. SULliVAN, Francis A.¿Hay salvación fuera de la Iglesia?. Desclée, Bilbao. 1999. Apud. VIGIL, J. Maria. Teologia do pluralismo religioso, p. 61.

${ }^{79}$ Cf. MIRANDA, M. de França. O cristianismo em face das religiões, p. 13.

${ }^{80}$ Esta obra, já citada anteriormente (ver nota 57), é a mais representativa de Jacques Dupuis e de grande importância para a teologia das religiões.

${ }^{81}$ Cf. VIGIL, J. Maria. Teologia do pluralismo religioso, p. 61.
} 
Esta realidade provoca, segundo uma diversidade de posicionamentos, as mais diversas classificações na tentativa de construir uma teologia das religiões ${ }^{82}$.

Propusemo-nos identificar os principais 'paradigmas' que dominaram a tentativa de construir uma teologia das religiões e do pluralismo religioso. Colocaremos, em primeiro plano, uma classificação tripartite universalmente aceita por sua clareza e simplicidade, ainda que alguns teólogos considerem esta classificação insuficiente ${ }^{83}$, tendo em vista que foi de um modo ou de outro, universalmente admitida. Dos modelos ou posições no âmbito da teologia das religiões, esta classificação distingue três perspectivas fundamentais: eclesiocêntrica, cristocêntrica e teocêntrica. A estas três perspectivas correspondem três posições básicas, respectivamente: exclusivismo, inclusivismo e pluralismo ${ }^{84}$. Essas distinções correspondem a uma dupla mudança de paradigma $^{85}$.

Procuraremos aqui, seguindo Dupuis, explicar as pressões que fizeram com que a teologia das religiões passasse por uma dupla mudança de paradigma, do eclesiocentrismo ao cristocentrismo, e do cristocentrismo ao teocentrismo, o que torna evidente que a questão cristológica, que originalmente se encontrava no centro de toda discussão da teologia das religiões, tende, na opinião de muitos com ou sem razão -, a uma progressiva marginalização. Será preciso "ir à procura de um modelo praticável para uma teologia sintética das religiões que seja ao mesmo tempo cristã e aberta" ${ }^{\natural 6}$.

Nessa classificação, o exclusivismo, como paradigma de teologia das religiões, é equivalente ao eclesiocentrismo: a Igreja se converte em centro da ação missionária ou mediação obrigatória da salvação. Essa foi a posição teológica hegemônica no cristianismo. Em uma "história tão dilatada no tempo e no espaço não é difícil encontrar pensadores e correntes eclesiais nos quais se

\footnotetext{
${ }^{82}$ Cf. VIGIL, J. Maria. Teologia do pluralismo religioso, p. 65; Cf. PANIKKAR, Raimon. Il dialogo intrareligioso. Assis: Cittadella, 2001. Apud. VIGIL, J. Maria. Teologia do pluralismo religioso, p. 61; TAMAYO, Juan José. Fundamentalismo y dialogo entre religiones. Madri: Trotta, 2005; KÜNG, H. Para uma teologia ecumênica das religiões. In: Concilium. nº. 161, 1986. pp. 124-131.

${ }_{83}$ Cf. Por exemplo: VIGIL, J. Maria. Teologia do pluralismo religioso, p. 62.

${ }^{84}$ Cf. DUPUIS, Jacques. Rumo a uma teologia cristã, pp. 257-264; MIRANDA, M. de França. $O$ cristianismo em face das religiões, pp. 16-19; TEIXEIRA, Faustino. Teologia das religiões, pp. 37-77.

${ }^{85}$ Cf. DUPUIS, Jacques. Rumo a uma teologia cristã, pp. 106-107.

${ }^{86}$ Ibid., p. 107.
} 
vislumbram traços de uma concepção mais ampla da salvação" ${ }^{\text {"87 }}$. No mundo católico, esse paradigma foi sustentado por vinte séculos e teve como expressão simbólica máxima a famosa sentença Extra ecclesium nulla salus (fora da Igreja não há salvação) $)^{88}$.

Se, na sua origem, este axioma, ao afirmar o papel da Igreja, não reivindicava sua exclusividade, ao longo da história, recebeu uma interpretação rígida, que resultou na negação da possibilidade de salvação fora da Igreja e num olhar pessimista com relação às outras religiões ${ }^{89}$.

No campo protestante, o exclusivismo adquire uma forma não eclesiocêntrica, porém centrada no tríplice princípio sola fide, sola gratia, sola scriptura (só a fé, só a graça, só a escritura). Para K. Barth, as religiões - todas, menos a religião bíblico-cristã - são, definitivamente, um esforço humano, uma tentativa de captar a benevolência de Deus. E a salvação vem unicamente pela entrega do ser humano - mediante a fé - à graça que o próprio Deus lhe oferece em Jesus Cristo. Para ele, somente a aceitação da graça de Deus vinda por Jesus Cristo pode salvar o ser humano ${ }^{90}$.

Esta posição foi oficialmente condenada pelo magistério da Igreja mediante a condenação do Santo Ofício da interpretação estreita da expressão 'fora da Igreja, não há salvação, ${ }^{91}$. Foi efetivamente descartada pelas afirmações do Vaticano II sobre a vontade salvífica universal de Deus e sobre os valores positivos presentes nas outras religiões, juntamente com a possibilidade de salvação fora da Igreja ${ }^{92}$. No entanto, permanece a questão da função salvífica de Jesus Cristo e a universalidade da vontade salvífica de Deus.

O Concílio Vaticano II marcou a mudança de paradigma quando rompeu com o exclusivismo do eclesiocentrismo. Nesse contexto, surge o inclusivismo assumindo o cristocentrismo, posição segundo a qual, ainda que a verdade e a

\footnotetext{
${ }^{87}$ VIGIL, J. Maria. Teologia do pluralismo religioso, p. 73.

${ }^{88}$ Cf. Ibid., p. 74.

${ }^{89}$ Sobre a história deste axioma Cf. DUPUIS, Jacques. Rumo a uma teologia cristã, pp. 123-155.

${ }^{90}$ Cf. BARTH, Karl. La revelación como abolición de la religión. Madri: Morova, 1973. Apud. VIGIL, J. Maria. Teologia do pluralismo religioso, p. 75. Karl Barth (1886-1968) foi um teólogo cristão-protestante, pastor da Igreja Reformada, e um dos líderes da teologia dialética e da neoortodoxia protestante. Em um momento de sua carreira teológica, migra da teologia puramente dialética e passa a utilizar a analogia da fé. Para ele, a analogia seria a única forma viável de se falar de Deus.

${ }^{91}$ Cf. MIRANDA, M. de França. O cristianismo em face das religiões, p. 157; TEIXEIRA, Faustino. Teologia das religiões, pp. 39-40.

${ }^{92}$ Cf. DUPUIS, Jacques. Rumo a uma teologia cristã, p. 159.
} 
salvação estejam plenamente presentes numa determinada religião, também se faz presente - de modo mais ou menos deficiente ou imperfeito - nas outras religiões, porém como participação na verdade e na salvação presentes na única religião verdadeira, reconhecendo, então, que a salvação pode se dar nas demais religiões, sem, no entanto, reconhecer nelas autonomia salvífica ${ }^{93}$.

O cristocentrismo coloca no centro da reflexão o mistério de Jesus Cristo, o que implica um 'des-centramento' da Igreja e um 're-centramento' em Jesus Cristo. "É este último, e não a Igreja, que está no centro do mistério cristão; a Igreja é, ao contrário, um mistério derivado, relativo, que encontra n'Ele sua razão de ser",94.

O cristocentrismo adquiriu os seguintes contornos: somente a religião cristã tem a verdade e a salvação; ainda que em outras religiões também haja elementos de Verdade. Participando, pois, da salvação também os não-cristãos, porém não por uma suposta validez de suas próprias religiões, e sim pelo poder de Cristo, que alcança a salvação para eles "de uma maneira somente conhecida de Deus" " Esta posição abriu um novo caminho no mundo teológico, em especial no campo católico, após o Concílio Vaticano II.

Entretanto, foram duas posições teológicas que prepararam o caminho até este Concílio e que ainda se desdobram no cristocentrismo: a teoria do cumprimento e a teoria da presença de Cristo nas religiões ${ }^{96}$.

A teoria do cumprimento sustentava que, para todas as religiões, o cristianismo vem a ser seu cumprimento, ou seja, sua consumação e, nesse sentido, seu acabamento, sua plenitude e, também sua superação. Esta teoria considerava que as religiões não-cristãs não têm capacidade salvífica por si mesmas, pois seriam religiões 'naturais', obra do ser humano que busca a Deus. E segundo Vigil, nesta corrente estão, com diferentes matizes, Jean Daniélou, Henri de Lubac e Hans Urs von Balthasar, teólogos do período pré-conciliar e conciliar $^{97}$.

A teoria da presença de Cristo nas religiões, que significa para Karl Rahner dizer que todos os que "aceitam livremente a oferta da auto-comunicação de Deus

\footnotetext{
${ }^{93}$ Cf. MIRANDA, M. de França. O cristianismo em face das religiões, p. 17.

${ }^{94}$ DUPUIS, Jacques. Rumo a uma teologia cristã, p. 259.

95 GS, 22.

${ }^{96} \mathrm{Cf}$. VIGIL, J. Maria. Teologia do pluralismo religioso, p. 77.

${ }^{97}$ Cf. Ibid., p. 78.
} 
mediante a fé, a esperança e o amor, entram na categoria de 'cristãos anônimos" $" 98$, ou seja, que toda a humanidade estava inserida na salvação de Cristo.

Foi o pensamento de K. Rahner ${ }^{99}$ que mais influiu no Concílio Vaticano II. Rahner afirmava que as religiões têm valores salvíficos positivos, já que, por elas, a graça de Cristo efetivamente alcança seus membros. Foi a primeira vez que, no cristianismo, se dizia de um momento tão explícito e fundamentado que a graça e o mistério de Cristo superavam inteiramente a Igreja. Era uma visão cheia de otimismo diante do pessimismo da visão exclusivista ${ }^{100}$. Os principais representantes desta teoria são, além de K. Rahner, Raimon Panikkar, Hans Küng e Gustavo Thils ${ }^{101}$.

No entanto, mesmo que provocando um grande salto qualitativo, esta posição, segundo alguns teólogos, permanece problemática. Isso se deve à noção de que, ao sustentar o caráter absoluto de Jesus Cristo, acaba afirmando a superioridade do Cristianismo com relação às outras tradições religiosas. Esta superioridade representa um obstáculo para o diálogo inter-religioso. Por isso, na busca de solução desta problemática, alguns autores começaram a defender uma nova e mais radical mudança de paradigma, propondo a superação do cristocentrismo com o teocentrismo ${ }^{102}$.

Surge o teocentrismo, uma posição pluralista $^{103}$, que, em relação ao exclusivismo no qual se afirma que só uma religião é verdadeira e todas são falsas, seria dito nesta nova posição necessariamente o contrário, ou seja, que todas as religiões são igualmente verdadeiras e equivalentes e estão todas equidistantes da verdade ${ }^{104}$. Ao seu redor estão todas as religiões que se relacionam com Deus diretamente, sem a mediação cristã.

\footnotetext{
${ }^{98}$ VIGIL, J. Maria. Teologia do pluralismo religioso, p. 79.

${ }^{99}$ Karl Rahner (1904-1984), um dos maiores teólogos do séc. XX. Rahner está entre os pensadores cristãos que procuraram estabelecer uma ponte entre o tomismo, (tradicionalmente cultivado pela intelectualidade católica) e a filosofia moderna (Kant, Hegel, Heidegger), filiando-se, assim, ao que se convencionou chamar de Tomismo Transcendental.

${ }^{100}$ Cf. VIGIL, J. Maria. Op. cit., pp. 78-79.

${ }^{101}$ Cf. DUPUIS, Jacques. Rumo a uma teologia cristã, pp. 219-221.

${ }^{102}$ Cf. Ibid., pp. 260-264; TEIXEIRA. Faustino. Teologia das religiões, pp. 58-74.

${ }^{103}$ Aqui pluralismo não significa pluralidade das religiões, e sim um paradigma de pensamento da teologia das religiões. Sobre a distinção entre pluralismo e pluralidade. Cf. JAYANTH, Mathew. De la pluralidad al pluralismo. In: Selecciones de Teologia. 163, 2002, pp. 163-176. Apud. VIGIL, J. Maria. Teologia do pluralismo religioso, p. 63.

${ }^{104}$ Cf. VIGIL, J. Maria. Teologia do pluralismo religioso, p. 88.
} 
Logo, esta mudança do cristocentrismo para o teocentrismo implica na rejeição da centralidade de Jesus Cristo. Com efeito, "para salvar um pluralismo salvífico era necessário romper o vínculo salvífico de Jesus Cristo com Deus como único e exclusivo, era preciso separar Cristo-logia de teo-logia”"105.

Pluralismo é a posição teológica segundo a qual todas as religiões participam da salvação de Deus. Nessa posição, sustenta-se que uma sincera busca cristã do diálogo com as outras religiões requer a renúncia a toda pretensão de unicidade salvífica para a pessoa e a obra de Jesus Cristo. Para esta posição teológica, somente Deus está no centro. Em todas as religiões, Deus sai ao encontro do ser humano, sem que haja apenas uma única religião verdadeira. Isto implica uma mudança radical no cristianismo ${ }^{106}$.

No entanto, todos esses paradigmas mostraram-se insuficientes para resolver o duplo desafio da relação do cristianismo com as outras religiões. Irão surgir outros modelos procurando salvaguardar a identidade cristã, os quais articulem os dois axiomas fundamentais da fé cristã - a vontade salvífica universal por parte de Deus e a necessária mediação de Cristo - sem, contudo, se fecharem à novidade proposta por outras tradições religiosas reconhecendo-as em sua alteridade.

Observamos que o exclusivismo, ao dar uma ênfase unilateral ao segundo axioma, entra em sérias contradições teológicas e não tem sustentação bíblica ${ }^{107}$. É descartada entre os teólogos católicos a posição exclusivista-eclesiocêntrica. Sobre o inclusivismo, Knitter questiona um dos seus pilares, que é o caráter único da pessoa de Jesus Cristo como critério para a salvação universal. Segundo ele, “Jesus realmente é a Palavra da Verdade de Deus, essencial para todos os povos, e não que Ele seja a única palavra de Verdade, essencial para todos os povos"108.

Os inclusivistas questionam as afirmações pluralistas, mesmo que acreditem nas suas importantes contribuições. Para esses, as afirmações pluralistas orientamse pelo axioma da vontade salvífica universal de Deus e deixam de lado a mediação de Jesus Cristo.

\footnotetext{
${ }^{105}$ MIRANDA, M. de França. O encontro das religiões. In: Perspectiva Teológica. 68, 1994. p. 20. ${ }^{106}$ Cf. VIGIL, J. Maria. Teologia do pluralismo religioso, pp. 63-64.

${ }^{107}$ Cf. DUPUIS, Jacques. Rumo a uma teologia cristã, p. 269.

${ }^{108}$ KNITTER, Paul. Diálogo inter-religioso e ação missionária: preparai os caminhos. São Paulo: CNBB: COMINA, 1994. p. 09. Paul F. Knitter é professor de Teologia, Religião e Cultura no Mundo União Theological Seminary na Cidade de Nova Iorque. Desde a publicação do seu livro, nenhum outro nome? (1985), Knitter foi amplamente conhecido por seu pluralismo religioso junto com seu amigo e colega, o filósofo da religião protestante John Hick.
} 
Entretanto, é certo que, embora a pretensão de unicidade e universalidade da salvação cristã apresente dificuldades para o diálogo inter-religioso, não pode, no entanto, uma teologia cristã das religiões desprezar as afirmações do Novo Testamento e de toda a tradição de experiências cristã sobre a revelação divina decisiva e definitiva em Jesus Cristo. Essa posição colocaria em jogo os aspectos fundamentais da fé cristã e separaria teologia e cristologia, o que é impossível numa teologia cristã ${ }^{109}$.

O pluralismo teocêntrico incorre numa interpretação nominalista das religiões, interpretando-as como diversas expressões de uma mesma realidade e numa interpretação essencialista das mesmas ao abordá-la sob o pressuposto de um denominador comum ${ }^{110}$.

No entanto, diante dessas questões teológicas, irão surgir outros modelos ligados ao paradigma teocêntrico. Emergem o 'reinocentrismo' e 'soteriocentrismo', perspectivas nas quais nem a Igreja, nem Jesus Cristo, nem Deus são centros. O centro é o objeto da pregação de Jesus Cristo: o Reino de Deus e a salvação. Em torno desse é que se devem centrar a reflexão e a prática das religiões ${ }^{111}$.

Ao colocar o Reino de Deus no centro, o reinocentrismo interpreta as religiões numa perspectiva escatológica, segundo a qual Deus e o Reino são a meta da história comum a todas as religiões. Possibilita, assim, uma interpretação fecunda, na medida em que reconhece que os membros de outras religiões, juntamente com os cristãos, “já são membros do Reino de Deus na história [...] dirigindo-se, todos juntos, para a plenitude escatológica de Deus" ${ }^{112}$. No entanto, o reinocentrismo continua se apoiando num conceito de Deus típico do monoteísmo, mas especificamente no conceito cristão, e coloca-se mais na linha do cristocentrismo.

Nesse contexto, outra tentativa foi superar o inclusivismo com o 'logocentrismo' e o 'pneumatocentrismo', que se baseiam na presença e na ação universal do Verbo e do Espírito de Deus, como dois modelos que poderiam

\footnotetext{
${ }^{109}$ Cf. DUPUIS, Jacques. Rumo a uma teologia cristã, p. 270; AMALADOSS, M. O pluralismo das religiões e significado de Cristo. In: TEIXEIRA, Faustino. Diálogo de pássaros, p. $91 \mathrm{~s}$.

${ }^{110}$ Cf. AMALADOSS, M. O pluralismo das religiões e significado de Cristo, p. 92.

${ }^{111}$ Cf. DUPUIS, J. O cristianismo e as religiões, pp.111-113; Id., Rumo a uma teologia cristã, pp. 270-272.

${ }_{112}$ Ibid., pp. 114-116; Id., Rumo a uma teologia Cristã, p. 272.
} 
substituir o cristocentrismo ${ }^{113}$. Entretanto, estão intrinsecamente vinculados com o cristocentrismo numa única economia e não podem representar uma importante contribuição para a teologia das religiões ${ }^{114}$.

Um novo modelo surge para ser o que podemos considerar o 'ponto de equilíbrio" entre o inclusivismo e o pluralismo: é o "inclusivismo aberto"115. Mesmo que desenvolvido para encontrar o "equilíbrio" "116, este novo modelo irá tender ao cristocentrismo ou ao teocentrismo. Há uma propensão em afirmar, nesse novo paradigma, a autonomia salvífica das religiões, ao mesmo tempo em que se assegura o caráter único e particular que Jesus Cristo exerce na História da Humanidade e, por consequência, na história da salvação, pois, "fora do mundo, não há salvação"117. O mundo aí é entendido como plenitude não fechada no cristianismo, mas de forma "relativa e aberta"118.

Chegar ao equilíbrio talvez seja difícil, mas reconhecemos o esforço demonstrado por todos esses paradigmas, procurando ser fiel à identidade cristã e à revelação de Deus, em querer fundamentar o diálogo inter-religioso e colaborar no crescimento de cada uma das tradições religiosas que se dispõem ao diálogo.

No entanto, o debate não para. As discussões e a procura por um paradigma que possa corresponder às necessidades, sem cair no absolutismo e nem no relativismo, são cada vez impulsionadas por uma inegável realidade, o pluralismo. Este deve ser levado a sério como lugar no desígnio de Deus para a salvação da humanidade.

\subsection{A busca por um novo paradigma teológico}

O debate persiste. Hoje, diante desta inegável realidade plural, em que "praticamente todas as religiões entraram em contato"119 e todas estão presentes umas às outras, inevitavelmente, surgem da teologia asiática novas abordagens

\footnotetext{
${ }^{113}$ Cf. DUPUIS, Jacques. Rumo a uma teologia cristã, pp. 173-277.

${ }^{114}$ Dupuis propõe a não-separação, mas a interligação entre esses paradigmas. Para ele, Jesus Cristo, Reino de Deus e Espírito Santo são realidades inseparáveis. Cf. DUPUIS, J. O debate cristológico no contexto do pluralismo religioso, p. 75ss; KNITTER, Paul. Diálogo inter-religioso e ação missionária; Id., A teologia católica das religiões numa encruzilhada. Concilium, v. 203, n. $1, \mathrm{p} .112$.

${ }_{115}$ Nomenclatura presente em: TEIXEIRA, Faustino. Teologia das religiões, p.78ss.

${ }^{116}$ AMALADOSS, M. O pluralismo das religiões e o significado de Cristo, p. 107.

${ }^{117}$ SCHILLEBEECK, E. História humana. Revelação de Deus. São Paulo: Paulus, 1994. p. 21.

${ }^{118}$ QUEIRUGA, A. Torres. O diálogo das religiões, p. 27.

${ }^{119}$ Ibid., p. 61.
} 
sobre a problemática inter-religiosa, provenientes da prática do diálogo, das experiências de encontro e da convivência com outras tradições religiosas ${ }^{120}$.

Dupuis cita A. Pieris que diz: "Eu me vi apropriando-me gradualmente de uma tendência da Ásia, que adota um paradigma em que as três supracitadas categorias [exclusivismo, inclusivismo e pluralismo] são desprovidas de sentido" ${ }^{\prime 21}$.

As novas abordagens, então, possibilitadas por esses e tantos outros testemunhos, caracterizam-se pelo esforço em descobrir e reconhecer a especificidade e singularidade das outras religiões e uma maior atenção ao fato do pluralismo religioso a partir da própria perspectiva de fé, pois, "o pluralismo religioso - sugere-se - mergulha suas raízes na profundidade do próprio Mistério divino e nas variadas formas com que as culturas humanas lhe responderam" ${ }^{122}$. Assim, Deus criador torna-se presente e ativo na pluralidade das religiões.

Dessa forma "se quisermos ter alguma esperança de construir uma teologia das religiões que não se funde em contradições e oposições recíprocas, mas em harmonia, convergência e unidade, a problemática ocidental deve ser abandonada" ${ }^{\prime 23}$. Nesse sentido, provocaria uma nova busca para a reflexão, procurando reconhecer a especificidade e singularidade de cada tradição religiosa.

Segundo a Declaração publicada pela XIII Reunião Anual da Associação Teológica Indiana, são criticadas as categorias em uso na teologia das religiões, por abordarem a religião dos outros de modo abstrato, acadêmico e especulativo e do ponto de vista de uma única cultura religiosa ${ }^{124}$. Elas [as categorias] traem "a aproximação teórica à fé de outras pessoas", que nascem “de uma sociedade caracterizada por uma só cultura religiosa e por um ponto de vista meramente acadêmico e especulativo" $" 125$.

Nesta nova perspectiva, vários teólogos ocidentais responderam positivamente, como D. Tracy e M. Barnes, por exemplo. Barnes sustenta a

${ }^{120}$ Cf. DUPUIS, Jacques. Rumo a uma teologia cristã, p. 278; Cf. AMALADOSS, M. Pela estrada da vida. Prática do diálogo inter-religioso. São Paulo: Paulinas, 1996. Nessa obra, o autor reúne vários artigos que têm como base a experiência de encontro e convivência entre pessoas de diferentes religiões.

${ }^{121}$ PIERIS, A. Na Asian Paradigm. Interreligious Dialogue and the Theology of Religions. In: The Month 26, 1993. 130. Apud. DUPUIS, Jacques. O cristianismo e as religiões, p. 117.

${ }^{122}$ DUPUIS, Jacques. $O$ cristianismo e as religiões, p. 117.

${ }^{123}$ Ibid., p. 117.

${ }^{124}$ Cf. Ibid., p.118.

${ }^{125}$ Declaração da XII reunião anual da associação de teólogos da Índia, em 28 a 31 de dezembro de 1989. n. 4. Apud. DUPUIS, Jacques. Rumo a uma teologia cristã, p. 118. 
necessidade de uma nova "rota de fuga da rígida esquematização do paradigma tripartite". De acordo com esse pensador, a resposta está "além do pluralismo"126, resultando numa pluralidade de iniciativas que situam a teologia das religiões numa nova perspectiva, em que o diálogo acontece no reconhecimento de cada membro da tradição religiosa em sua alteridade, e admitindo a legitimidade de sua fé $^{127}$. Para Tracy, deve ser empreendida uma 'teologia do diálogo' e não apenas uma 'teologia para o diálogo, 128 .

No entanto, surgem outros teólogos que convergem ao dizer que é necessário ir além da alternativa entre o inclusivismo e pluralismo, entre o cristocentrismo e teocentrismo. Segundo DiNoia, tanto o inclusivismo como o pluralismo acabam minimizando as diferenças dos outros, prejudicando o diálogo. Para esse autor, deve-se partir para uma "teologia em diálogo" 129 , em que não se deve "servir ao objetivo de abrir potencialidades afins ao cristianismo", mas "considerar essas doutrinas como ensinamentos alternativos autoconscientes a propósito daquilo sobre que deveria ser focalizada a vida humana"130.

Diante desta situação, outro autor, Fredericks apresenta uma nova proposta para a reflexão. Ele fala da necessidade de um "estudo comparativo das religiões" ${ }^{131}$. Para esse autor, os três paradigmas faliram em dois critérios, que validam a teologia cristã das religiões: na fidelidade à tradição cristã e na habilidade em impelir os cristãos a manter relações positivas e profícuas com os 'outros ${ }^{, 132}$. São muitas, no entanto, as vozes que se levantam apontando um novo caminho. Uma destas vozes é a de Dupuis, que apresenta para esta problemática uma cristologia trinitária ${ }^{133}$.

\footnotetext{
${ }^{126}$ Cf. BARNES, M. Theology of Religions in a Post-Moden World, in The Month 28, 1994. p. 270-274; 325-330. Apud. DUPUIS, Jacques. Rumo a uma teologia cristã, p. 118.

${ }^{127}$ Cf. BARNES, M. Theology of religions in a post-moderm world. The month 28 (1994), p. 273. Apud. DUPUIS, Jacques. Rumo a uma teologia cristã, p. 119.

${ }^{128}$ Cf. TRACY, D. Dialogue with the Other. The Interreligious Dialogue. Peeters Press, Louvain, 1990. Apud. DUPUIS, Jacques. Rumo a uma teologia cristã, p. 119.

${ }^{129}$ DINOIA, J. A. The diversity of religions. A chistian perspective. The catholic university of America press, Washington, 1992, 127.111. Apud. DUPUIS, Jacques. Rumo a uma teologia cristã, p. 119. ${ }^{130}$ Ibid., p. 119.

${ }^{131}$ FREDERICKS, J. L. Faith among faiths. Chistian theology and non-chistian religions, Paulist press, Nova York, 1999. Apud. DUPUIS, Jacques. Rumo a uma teologia cristã, p. 119.

${ }^{132}$ Cf. DUPUIS, Jacques. Rumo a uma teologia cristã, p. 120.

${ }^{133}$ Segundo Dupuis, por "cristologia trinitária se entende uma cristologia que, por um lado, faça sobressair as relações interpessoais entre Jesus Cristo e o Deus que Ele chama de Pai e, de outro, o Espírito que lhe impele e que ele, por sua vez, envia. Relações intrínsecas ao mistério da pessoa de Jesus e de sua obra". Cf. Ibid., pp. 259-531.
} 
Todavia, neste momento, na teologia cristã das religiões, que tem procurado superar suas muitas contradições, parece estar emergindo um consenso para evitar qualquer tipo de absolutismo ou relativismo. Isso se deve ao fato de se reconhecer que a grande questão em debate, hoje, passou a ser a pluralidade das religiões, o pluralismo religioso. Entende-se, então, que "uma teologia das religiões, não pode deixar de ser, definitivamente, uma teologia do pluralismo religioso" ${ }^{134}$. O que acaba sendo um novo nome adotado em nossos dias para a teologia das religiões, novo ramo da teologia.

Tal mudança terminológica demarca uma mudança na perspectiva teológica, que procura superar as categorias de inclusivismo e pluralismo por um 'novo paradigma teológico, ${ }^{135}$. Desloca-se, assim, a reflexão teológica, do problema da salvação mediante as outras religiões para o próprio fenômeno do pluralismo religioso.

Coloca-se, agora, a questão da origem do próprio pluralismo, "o seu significado no projeto de Deus para a humanidade, a possibilidade de uma convergência das várias tradições religiosas, com pleno respeito pelas suas diferenças, o seu mútuo enriquecimento e a sua recíproca fecundação" ${ }^{\text {136 }}$. Este novo enfoque procura compreender e valorizar positivamente a pluralidade religiosa confrontando-a, teologicamente, com o mistério de Deus.

Procura-se responder, com profundidade, se a pluralidade religiosa é simplesmente um fato da história, ou seja, se é um fenômeno de fato (pluralismo de fato), ou se é um fenômeno fundacional, algo que tem uma razão especifica de ser, algo querido por Deus e que exige uma contínua coexistência humana com o mesmo (pluralismo de princípio) ${ }^{137}$.

Reconhecer o 'pluralismo religioso de princípio' significa desocultar o significado positivo das diversas tradições religiosas na globalidade do único desígnio salvífico de Deus, o que atesta uma mudança significativa do olhar e afirma "a generosidade superabundante com que Deus se manifestou de muitos

\footnotetext{
${ }^{134}$ DUPUIS, Jacques. Rumo a uma teologia cristã, p. 271.

${ }^{135}$ Cf. Id,. Le pluralisme religieux dans le plan divin de salut. In: Revue Theologique de Louvain, 29 (4), 1998. p. 485.

${ }_{136}^{1}$ Id., Rumo a uma teologia cristã, p. 26.

${ }^{137}$ Cf. Ibid., p. 26.
} 
modos à humanidade e a resposta multiforme que os seres humanos deram à autorevelação divina nas várias culturas"138.

À margem desses intentos de interpretações da existência da pluralidade religiosa, que constituem as diferentes teologias das religiões, tem se desenvolvido um movimento cada vez mais intenso de encontros entre os membros das diferentes religiões.

A existência mesma do diálogo e a forma em que se está desenvolvendo supõem um desafio de uma transcendência insuspeita às tradições. Provavelmente a resposta das diferentes religiões a este desafio depende, em boa medida, do futuro da religião em nosso mundo ${ }^{139}$.

A experiência que supõe para o diálogo inter-religioso a existência de numerosos encontros inter-religiosos destaca a importância que está adquirindo o desenvolvimento do diálogo em que intervém a dimensão espiritual e a experiência interior que comporta todas as religiões. Aqui está a importância que reveste para o melhor desenvolvimento do diálogo entre as religiões a intervenção semelhante desses cultivadores eminentes da experiência religiosa que são os místicos. Isso demonstra a importância decisiva que pode ter a intervenção dos místicos para o diálogo inter-religioso.

Todavia, o que se busca em tais diálogos não é tanto a compreensão, mas a comunhão na contemplação: "O nível mais profundo da comunicação não é a comunicação, senão a comunhão. Nesse nível não tem palavras, está além das palavras e também além da linguagem e dos conceitos"140.

\section{Essas experiências}

mostram a possibilidade de encontros inter-religiosos mais além das ações, dos ritos, as instituições e as crenças, que desembocam no centro de toda experiência religiosa, em seu núcleo místico mais íntimo: o silêncio, a meditação, a oração, a experiência espiritual, o contato interior com a realidade última do que vivem todas as religiões ${ }^{141}$.

As razões que explicam a contribuição verdadeiramente única da mística ao diálogo inter-religioso e, dessa forma, ao desafio que supõe para as religiões consistem na capacidade de realizar a experiência dos serviços que podem prestar

\footnotetext{
${ }^{138}$ DUPUIS, Jacques. O cristianismo e as religiões, p. 526.

${ }^{139}$ Cf. VELASCO, J. Martin. El fenómeno místico. Estudio comparado. Madri: Trotta, 1999. p. 468.

${ }^{140}$ MERTON, Thomas. Vivir con sabeduria. Madri: PPC, 1997. p. 218.

${ }^{141}$ VELASCO, J. Martin. Op. cit., p. 470.
} 
e sua radical insuficiência para procurar uma união com Deus, ou com o Último, que se realiza na mais pura e desnuda fé amorosa, na mais absoluta confiança. Porque

o encontro mais profundo terá lugar na esfera da mística, no que vamos mais além das ideias, dos conceitos e das imagens, para um estado de amor silencioso. Aqui as pessoas permanecem em um estado de união sem palavras, aqui o espírito se encontra com o espírito ${ }^{142}$.

Assim, podemos entender que, no diálogo inter-religioso, em que se deve evitar o dogmatismo e o indiferentismo, a mística tem um lugar privilegiado, pois, é certo como veremos, no capítulo seguinte, que o místico encontra-se melhor preparado contra todos esses perigos. Contra o dogmatismo, por realizar uma radical relativização de todas as mediações que possui a religião, fazendo, pessoalmente, sua experiência. E além disso, por ter, na sua religião, a experiência do Mistério como centro, pode valorizar a vida religiosa, seja qual for o lugar em que ela floresça, superando a tentação de absolutista e exclusivista, bem como o perigo do indiferentismo.

Aprofundaremos, no próximo capítulo, o estado de crise em que se encontram todas as tradições religiosas, e seus desdobramentos nas religiões as quais são atingidas em todos os aspectos e níveis do complexo sistema em que cada uma delas se realiza.

Veremos que hoje, a proliferação de novos movimentos religiosos induz a pensar que a crise não se orienta tanto ao desaparecimento da religião, mas a sua radical transformação, a uma metamorfose ou uma mudança das formas em relação ao que até agora tinha se revestido.

\section{O fenômeno religioso e místico}

No contexto de pluralismo religioso em que vivemos, não nos é possível negar que, mesmo causando um 'mal estar religioso', são manifestações de um Deus que quer se tornar conhecido. E essa situação tanto pode ocultá-lo, como também pode, na medida em que for assumida e interpretada, tornar-se um lugar

${ }^{142}$ VELASCO, J. Martin. El fenómeno místico. p. 471. 
de escuta e de resposta ${ }^{143}$. Nesse contexto, nos chama atenção o fato de haver uma procura pela experiência direta com o mistério da Realidade Última, que parece acontecer em todas as religiões e confissões.

Isso comprova que a procura por essa experiência consiste na 'sede' que é comum a todos os seres humanos, e cada um busca saciá-la de uma maneira, ou de outra. Ninguém escapa da necessidade de sentido, da busca de respostas mais ou menos conscientes, da "procura por preencher o vazio provocado pelo abandono da religião herdada, em alguns casos, ou pelo descontentamento com suas formas estabelecidas, em outros" ${ }^{\prime 144}$.

Entretanto, cada um vive suas perguntas mais profundas na solidão. Todavia, sua busca não pertence ao campo da individualidade ensimesmada, ou melhor, de um individualismo narcisista ${ }^{145}$, porque toda experiência interior é transformante e modifica as relações da pessoa a partir de sua inclinação ao Mistério.

Tal processo provoca uma profunda mudança religiosa, advertida por religiosos e estudiosos. Porque para estes

trata-se de um passo a mais na evolução da consciência religiosa. Uma sorte da nova situação epocal religiosa, um novo 'tempo eixo', que alguns caracterizam como a fase inicial do passo da consciência mental, cognitiva, a consciência transpessoal, mística ${ }^{146}$.

Esta nova realidade, na experiência religiosa, é um fenômeno que responde a uma insatisfação generalizada ${ }^{147}$, que, provocada pela pós-modernidade, impulsiona o ser humano a viver o religioso explicitamente, possibilitando em muitos aspectos um ajustar-se a um novo reencantamento do mundo ou que se viva em estreita conivência com ele.

Para o cristianismo, esta é uma oportunidade para desfazer-se de toda falsa imagem de Deus ${ }^{148}$, que, mesmo trazendo a este contexto tantos questionamentos

\footnotetext{
${ }^{143}$ Cf. VELASCO, J. Martin. Experiência cristã de Deus. São Paulo, Paulinas, 2001. p. 16; Sobre o mal estar religioso conferir do mesmo autor: El malestar religioso de nuestra cultura. $2^{\mathrm{a}}$ Ed. Madrid, Paulinas, 1993.

${ }^{144}$ QUEIRUGA. A. Torres. O fim do cristianismo pré-moderno: desafios para um novo horizonte. São Paulo: Paulus. 2003. p. 108.

${ }^{145}$ Cf. WATT, Ninfa. La fuente de la cordialidad. In: RODRIGUEZ, Francisco J. S. (org.) Mística y sociedad en diálogo. Madri, Trotta, 2006. p. 81.

${ }_{146}$ MARDONES, J. Maria. Mística transreligiosa en una sociedade de incertidumbre. In: RODRIGUEZ, Francisco J. S. (org.). op. cit. p. 89.

${ }^{147}$ Cf. QUEIRUGA. A. Torres. O fim do cristianismo pré-moderno, p. 108.

${ }^{148}$ Cf. BLANK, Renold J. Deus na história: centros temáticos da revelação. São Paulo: Paulinas, 2007. Nesta obra o autor tem como ponto de partida as falsas imagens de Deus que prevalecem na
} 
da fé, possibilita o rompimento de tudo o que se tinha adquirido por 'se ouvir dizer', e como nos diz Velasco: "É um convite do Espírito a abrir os olhos e deixar-nos surpreender por esse Deus" ${ }^{\prime 149}$.

Como nos afirma Maria Clara Bingemer:

a mística cristã nos tempos atuais, portanto, como em outros tempos, está mais do que nunca desafiada a redescobrir seu lugar e seus caminhos, a olhar para o humano como via necessária para o divino ${ }^{150}$.

Isso se dá por meio de uma experiência que leve ao desvelamento desta Presença, comprovando uma deficiência "eu te conhecia só de ouvir. Agora, porém, os meus olhos te veem"151 e que pelas debilidades e pelas dificuldades culturais não permitiam reconhecer ${ }^{152}$. Uma deficiência provocada não apenas pela cultura, mas porque se vive 'fora' da realidade religiosa propriamente falando, por estar entretido com doutrinas, moral, leis, ritos, porém com pouco ou escassa densidade. Resulta isso em uma religiosidade muito epidérmica, muito externa e que não tem penetrado nas entranhas de cada realidade mesma a que se refere e que se vive ${ }^{153}$.

Esse estado de coisas leva, então, a uma experiência de nível místico em que hoje estaria pulsando a mudança religiosa mais fundamental. Por aí caminha a transformação não só do cristianismo, mas de toda religião, nesta época de globalização e de incertezas sócio-políticas ${ }^{154}$, reconhecendo que esta experiência se dá em diferentes formas que despontam como

inéditas de desvelamento de um Deus que não se deixa encerrar no terreno reservado pela religião e é maior que a consciência, a linguagem e os conceitos dos que o reconhecem com os meios precários que nossas tradições religiosas oferecem $^{155}$.

No entanto, mesmo reconhecendo essas novas formas de reconhecimento dessa Presença, não podemos esquecer que um dos aspectos importantes que dificultam vislumbrar a Presença em nossos dias é o que Martin Buber chamou de

\footnotetext{
linguagem e em muitas manifestações religiosas verificadas mesmo dentro da Igreja. Sua tese demonstra uma grande sensibilidade aos riscos de toda religiosidade que tende a se apegar mais às coisas da religião do que a Deus.

${ }^{149}$ VELASCO, J. Martin. Experiência cristã de Deus, p. 07.

${ }^{150}$ BINGEMER, Maria Clara. O mistério e o mundo. Paixão por Deus em tempos de descrença.

Rio de Janeiro: Rocco, 2013. p. 180.

151 Jó 42,5.

${ }^{152}$ Cf. VELASCO, J. Martin. El fenómeno místico, p. 06.

${ }^{153}$ Cf. MARDONES, J. Maria. Mística transreligiosa en una sociedade de incertidumbre, p. 91.

${ }^{154}$ Cf. Ibid. p. 89.

${ }^{155}$ VELASCO, J. Martin. Experiência cristã de Deus, p. 08.
} 
"eclipse de Deus"156. Trata-se de uma situação em que se dissiparam, na vida do homem, as pegadas de Deus.

A íntima relação disso com o pluralismo está na

característica-chave de todas as situações pluralistas, quaisquer que sejam os detalhes de seu pano de fundo histórico, isto é, que os ex-monopólios religiosos não podem mais contar com a submissão de suas populações ${ }^{157}$.

Ou seja, acontece a perda da plausibilidade da religião. E seguindo o pensamento de G. Vattimo, podemos pensar em um processo de conservação, distorção e esvaziamento da religião ${ }^{158}$ que provoca um "desencantamento que oculta as dimensões profundas, os lados inefáveis, os traços invisíveis nos quais o homem de outros tempos vislumbrava a presença da transcendência"159.

Hoje essas situações são denunciadas por homens e mulheres denominados 'mestres espirituais' que, predominamente, tem estado e estão em contato com as religiões e espiritualidade oriental ${ }^{160}$. Esses chamam a atenção acerca da nova situação em que se encontra o cristianismo e, ao mesmo tempo, todas as religiões: desafiadas a dar um salto a um nível mais alto.

Acreditamos ser este um tempo propício, o que podemos chamar de Kairós $^{161}$, para um despertar consciente da necessidade de ser redescoberta a verdadeira vocação das religiões. Aí a mística assume um lugar de destaque dentro da religião, eixo de transformação.

\footnotetext{
${ }^{156}$ BUBER, Martin. Eclipse de Dios. Buenos Aires, Galatea-Nueva Vision, 1970. p. 25.

${ }^{157}$ BERGER, Peter L. $O$ dossel sagrado: elementos para uma teoria sociológica da religião. São Paulo: Paulus, 1985. p. 149.

${ }^{158}$ Pensamento de Vattimo apud. MARTELLI, Stefano. A religião na sociedade pós-moderna. São Paulo: Paulinas, 1995. p. 444.

${ }^{159}$ VELASCO, J. Martin. Experiência cristã de Deus, p. 17.

${ }^{160}$ Como referências, temos autores como W. Jäger, monge beneditino, mestre zen desde 1981 da escola Sanbo-Kyodan do Japão. Guia espiritual da via zen e contemplativa. Cujas obras são: Adonde nos lleva nuestro anhelo. La mística en el siglo XXI. Desclée, Bilbao, 2004; suas obras anteriores: La oración contemplativa. Una introducción según san Juan de la Cruz. Obelisco, Barcelona, 1989; En busca de la verdad. Caminos - Esperanzas - Soluciones. Desclée, Bilbao, 1999; La ola es o mar. Desclée, Bilbao, 2002; W. Johnston, Jesuíta, diretor do Instituto de Religiões orientais da universidade de Sofia de Tókio, autor das seguintes obras: Mística para una nueva era. De la teologia dogmática a la conversión del corazón. Desclée, Bilbao, 2003; La musica callada. Paulinas, Madrid, 1985; El ojo interior del amor. Misticismo y religión. Paulinas, Madrid, 1994; Th. Keating, monge cisterciense, fundador do movimento 'Oração Centrante': Suas obras: Intimidad con Dios. Desclée, Bilbao, 1997; R. Rolheiser, En busca de Espiritualidad. Lineamientos para una espiritualidad Cristiana del siglo XXI. Lúmen, Buenos Aires, México, 2003.

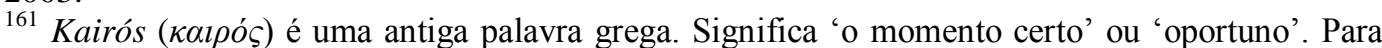
este povo antigo, duas palavras distinguiam seu tempo: chronos e kairos. A primeira refere-se ao tempo cronológico, ou sequencial, e a última é um momento indeterminado no tempo em que algo especial acontece. Na teologia é usada para descrever a forma qualitativa do tempo, o 'tempo de Deus', enquanto chronos é de natureza quantitativa, o 'tempo dos homens'.
} 


\subsection{Um desafio às religiões}

As religiões enfrentam, então, um grande desafio para que seja restabelecido o encantamento, pelo alcance de um tipo de experiência, que proporcione uma certeza que vai muito mais além da obtida pela via cognitiva. Trata-se, portanto, de uma mudança, ou melhor, de uma transformação que supõe um nível mais elevado de organização estrutural e de integração ${ }^{162}$.

Será preciso, nesta circunstância, uma experiência religiosa que permita descobrir as pegadas da presença de Deus em aspectos de nossa situação, em elementos de nossa cultura, aparentemente dominada pela incredulidade. Além disso é necessário tomar consciência do pressuposto radical de toda possível experiência de Deus: sua silenciosa, porém real, ativa e inconfundível presença no fundo do real, no centro do ser de cada ser humano ${ }^{163}$.

Em relação ao cristianismo, este só poderá ter uma reação positiva diante desse contexto se acolher o que nele há de genuíno e se mostrar

capaz de integrá-lo, dinamizá-lo e enriquecê-lo desde seu projeto específico. E cuja condição indispensável é deixar-se questionar, renovando o contato com suas raízes, mostrando-se aberto à mudança e à renovação: à conversão ${ }^{164}$.

Todo este contexto indica o suficiente para assinalar onde estão os lugares aniquilados e que necessitam de transformação: não se trata de 'arrumar pisos interiores', mas sim de novas formas de prática religiosa e, sobretudo, mais profundas, onde se viverá um novo nível da existência. O subtítulo da obra de W. Johnson sobre 'La mística para una nueva era' sugere por onde deve ocorrer a mudança: da teologia dogmática à conversão do coração ${ }^{165}$.

Para esse autor, trata-se de adquirir uma sabedoria distinta da teologia dogmática. "Vai mais além da argumentação e do pensamento, mais além da imaginação e da fantasia, mais além de um antes e de um depois para adentrar-se na realidade intemporal"166. Em outras partes do livro, indica que se trata, ao

\footnotetext{
${ }^{162}$ Cf. MARDONES, J. Maria. Mística transreligiosa en una sociedade de incertidumbre, pp. 8990.

${ }^{163}$ Cf. VELASCO, J. Martin. Experiência cristã de Deus, p. 20.

${ }^{164}$ QUEIRUGA. A. Torres. O fim do cristianismo pré-moderno, p. 117.

${ }^{165}$ Cf. JOHNSON, William. Mística para una nueva era. De la teologia dogmática a la conversión del corazón. Bilbao: Desclée de Brouwer, 2003; Sobre isto Queiruga nos fala da necessidade de resposta de conjunto, descendo as próprias raízes, ou seja, "não é mais a hora do remendo de pano novo sobre o pano velho, mas de odres novos para o vinho de um tempo novo". Para ele, desponta uma mudança de paradigma. Cf. QUEIRUGA. A. Torres. O fim do cristianismo pré-moderno, p. 120.

${ }^{166}$ JOHNSON, William. Mística para una nueva era, p. 70.
} 
menos no caso católico, de recuperar a dimensão da experiência íntima do mistério de Deus e da experiência da unidade com ela.

Mesmo diante de uma realidade caracterizada pela secularização da cultura, que eliminou a vigência social e cultural das respostas da religião às perguntas que o homem faz sobre si mesmo; esse passou a buscar uma resposta pessoal, possibilitando uma religião 'pós-moderna' em que dão testemunho alguns dos fenômenos agrupados sob o nome de novos movimentos religiosos ${ }^{167}$.

Essa atitude assinala que a religião não foi suprimida da dimensão antropológica e social na assim chamada pós-modernidade, pois, se era quase consenso afirmar a eliminação da religião, através de expressões como 'morte de Deus', 'era pós-cristã', hoje se percebe que o sagrado continua seduzindo ${ }^{168}$. Nesse sentido, 'reaparece' com uma fisionomia bastante diferente daquela da sociedade tradicional ${ }^{169}$, como resultado do próprio processo interno e estrutural da modernidade.

Apesar dos avanços científicos, as novas descobertas não ajudaram o ser humano a entender a causa, o motivo de sua existência. A ciência não conseguiu apagar o desejo de Deus do coração humano. Essa busca, agora, não é por uma religião, e sim por uma espiritualidade que ofereça um caminho para a experiência, algo que dê sentido à vida. Essa postura do homem pós-moderno provoca perplexidade e pasmo dentro das estruturas eclesiais. Pois, se por um lado, tal anseio pela experiência é um fato positivo por levar o crente a voltar-se para Deus e desenvolver uma fé mais convicta na vida e no cotidiano, essa experiência buscada e desejada é, na maior parte das vezes, desvinculada da norma moral, da verdade dogmática e da pertença institucional ${ }^{170}$.

Apesar de sua extraordinária ambiguidade, os novos movimentos religiosos expressam manifestações da insuficiência de uma civilização centrada na racionalidade objetiva, e reclamam uma nova forma de consciência aberta a alguma forma de transcendência ${ }^{171}$.

\footnotetext{
${ }^{167}$ Cf. BINGEMER, M. Clara. Alteridade e vulnerabilidade, pp.17-23. Conferir outro livro (mas recente) da mesma autora. O mistério e o mundo, pp. 11-28. Segundo Maria Clara, "se na modernidade parecia que tudo apontava para um mundo sem Deus e sem perspectiva de religiosidade, na pós-modernidade ocorre uma volta ao transcendente. Há uma ânsia cada vez maior de experiências e de práticas religiosas. Uma busca incessante pelo Sagrado, sem que com isso se tenha que escutar autoridades ou teólogos. Trata-se da busca por algo que atinja o coração humano e que o faça sentir-se querido e amado". Ibib., p. 19.

${ }^{168}$ Cf. Id., A sedução do Sagrado. In: CALIMAN, Cleto. (org.) A sedução do Sagrado: o fenômeno religioso na virada do milênio. Vozes: Petrópolis, 1998. p. 79.

${ }^{169}$ Sobre o 'reaparecimento' do sagrado, Cf. BINGEMER, M. Clara. O mistério e o mundo, pp. 29-91; MIRANDA, M. de França. Volta do sagrado: numa avaliação teológica. In: Perspectiva teológica, 21, 1989. pp. 71-83.

${ }^{170}$ BINGEMER, M. Clara. O mistério e o mundo, p. 20.

${ }^{171}$ Cf. VELASCO, J. Martin. El malestar religioso de nuestra cultura, pp. 53-79.
} 
Para a socióloga francesa Danièle Hervieu-Léger, não se trata simplesmente de um retorno do sagrado, mas de mudanças profundas no cenário religioso hodierno. A sociedade secularizada cria condições para a proliferação de novas crenças e práticas religiosas, pois uma vez desqualificados e enfraquecidos os grandes sistemas de explicação religiosa do mundo, nos quais homens e mulheres encontravam segurança e sentido existencial, paradoxalmente surgem e proliferam-se novas expressões e formas religiosas ${ }^{172}$.

E é a partir dessa mudança estrutural da sociedade que se torna possível compreender a emergência da multiplicidade de religiões nas sociedades modernas como fruto da própria dinâmica da modernidade que redefiniu a função da religião dentro do contexto social.

Por consequência, torna-se claro que, quando se procura explicar a necessidade de uma mudança, esclarece-se que não se trata de uma mera reforma, mas, sim, de uma transformação da maneira de se viver uma religião. "Não vale apenas uma reforma no interior das instituições" $" 173$.

Como insiste W. Jäger, encontramo-nos ante um salto na consciência religiosa. Deve-se cair na conta de que o que denominamos Deus ou a Realidade Última não é algo exterior à pessoa. Esta realidade não está fora, senão no seu próprio interior ${ }^{174}$. Mais ainda, pertence à própria vida. Na expressão de Jesus nos sinóticos “o Reino está dentro de vós” ou ‘tem chegado', está chegando, ou seja, é a profundidade do presente e o fundamento de sua elevação para o futuro ${ }^{175}$.

Toda essa mudança tem o impulso do desejo do ser humano de procurar o que está para além de si mesmo, do desejo do encontro com a Realidade Última de suas vidas. Para isto, o ser humano é também chamado a mergulhar no seu mais íntimo para que, encontrando-se consigo mesmo, assumindo sua condição de pessoa, e acolhendo esta Presença, possa receber o outro na sua vida em sua alteridade.

\footnotetext{
${ }^{172}$ Cf. HERVIEU-LÉGER, Danièle. O peregrino e o convertido: a religião em movimento. São Paulo: Vozes, 2008. p. 46 ss.

${ }^{173}$ MARDONES, J. Maria. Mística transreligiosa en una sociedade de incertidumbre, p. 91.

${ }^{174}$ Cf. JÄGER, W. Adonde nos lleva nuestro anhelo, p. 30.

${ }^{175}$ Cf. Mt 3,2; 4,17; Mc 1,4.15; Lc 3,3.
} 


\subsection{0 ser humano chamado a viver a partir do seu interior}

Não é estranho que surjam outras formas que remetem constantemente a certas experiências, identificadas em termos muito diferentes, como experiênciascume, sentimentos oceânicos, experiências do Absoluto, experiências-limite ou de fronteiras. E que consistem em abrir o horizonte da vida humana, dilatar a consciência, permitir uma ruptura de nível existencial e pôr a pessoa em comunicação com um novo nível de realidade, diferente daquela em que reinam os objetos que dominam a experiência cotidiana ${ }^{176}$.

Esses sinais constituem o princípio e fundamento sobre o qual descansa toda possível experiência de Deus, presença constitutiva no âmago da realidade e sua presença originária no centro da pessoa.

Entretanto, para uma verdadeira experiência, necessário se faz estar aberto a uma realidade nova e sempre presente. Será preciso, como nos diz S. João, com os símbolos da água viva, nascer de novo ${ }^{177}$ e reconhecer que o amor consiste em antes ter Deus nos amado primeiro ${ }^{178}$, pois é, segundo Santo Agostinho, "mais íntimo a nós que nossa própria intimidade".

Dessa forma, o ser humano assume sua condição de pessoa, exigência do Deus que se revela ao homem, que só é vivida na relação efetiva com as outras pessoas, no exercício da responsabilidade, no amor e no diálogo, condições para a revelação da verdade ${ }^{179}$. Afinal, o ser humano não vive só e a 'con-vivência' supõe 'vivência-com-os outros', vida compartilhada, experiência em companhia. Isso provoca a necessidade de diálogo, de encontros de tu a tu e de um compartilhar comunitário ${ }^{180}$.

Do duplo movimento - para-si, para-o-outro - a experiência mística tem propriamente seu lugar antropológico. Pode ser considerada como uma tensão fecunda entre ser e manifestação: entre o ser humano na sua finitude e nas condições da sua situação, e o dinamismo profundo ordenado ao Absoluto que move a sua automanifestação ${ }^{181}$.

Tudo isso exige uma abertura aos outros desde o interior, evitando viver apenas na superfície para viver desde dentro, a partir de um espaço no íntimo. O que chega de fora, transpassa a cerca do seu interior e recorre suas instâncias até

\footnotetext{
${ }^{176}$ Cf. VELASCO, J. Martin. Experiência cristã de Deus, p. 23. Cf. nota 5.

${ }^{177}$ Cf. Jo 3,6.

$1781 \mathrm{Jo} 4,10$

${ }^{179}$ Cf. VELASCO, J. Martin.Op. Cit. p. 30.

${ }^{180}$ Cf. WATT, Ninfa. La fuente de la cordialidad, p. 85.

${ }^{181}$ BINGEMER, Maria Clara. O mistério e o mundo, p. 25.
} 
chegar ao lugar da acolhida. Nesse intervalo, não submetido aos limites do espaço físico e ao tempo, se permite a resposta desde o melhor de si mesmo, desde o interior ${ }^{182}$, pois "o diálogo é sempre mais enriquecedor e possível, se produz uma aproximação até o interior e desde o interior" ${ }^{\prime 183}$.

Essa experiência acontece quando o ser humano, atento ao seu interior, se dá conta da existência de uma voz que arde em seu ser, anterior a qualquer outra. Pode-se dizer que ela surge da necessidade de que o homem sente de experimentar, o que havíamos sinalizado quando, no início deste capítulo, falávamos sobre a 'sede', de fazer seu um mais além de si mesmo que busca alcançar e com o qual não pode coincidir.

Esse mais além habitante do humano é o que torna as tendências do ser humano não serem apenas instintivas. Transforma-as em desejos e faz com que floresçam nesse desejo transcendido que é o amor, graças ao qual os sujeitos, na mútua entrega, se encontram participando de uma generosidade maior. Dessa mesma raiz, surge o milagre da liberdade, coração da dignidade da pessoa, que, antes de ser escolha e inclusive domínio de si, é aceitação da existência dada por uma generosidade anterior ${ }^{184}$.

Para os mestres espirituais, a ação de Deus na profundidade do ser humano, propicia um tipo de experiência religiosa que muda radicalmente em relação à predominante na religião institucional. Para esses, a religião já não é, fundamentalmente, um administrador do sagrado e menos um legislador de outras dimensões humanas. Ela é um sinalizador, em um nível de consciência que avista uma Realidade percorrendo toda a realidade.

Os fenomenólogos da religião não veem com estranheza esse 'giro místico' que propõem os mestres espirituais, porque a religião, a experiência do sagrado, leva em sua raiz, nos dirá M. Eliade, o intento de decifrar no temporal e historicamente concreto o desejo irresistível do homem de transcender o tempo e a história, de descobrir o fundamento das coisas, a Realidade Última ${ }^{185}$.

\footnotetext{
${ }^{182}$ Cf. WATT, Ninfa. La fuente de la cordialidad, p. 80.

183 Ibid., p. 82.

${ }^{184}$ Cf. VELASCO, J. Martin. Experiência cristã de Deus, p. 24.

${ }^{185}$ Cf. ELIADE, Mircea. Observaciones metodológicas sobre el estudio del simbolismo religioso. pp. 116-140. In: KITAGAWA, J. (Ed). Metodologia de la Historia de las religiones. Paidós, Barcelona, 1986. Apud. MARDONES, J. Maria. Mística transreligiosa en una sociedad de incertidumbre, p. 93.
} 
O homem, assim resumirá a filosofia cristã, em tudo o que conhece, conhece o ser, porque conhecer humanamente significa conhecer as coisas à luz do ser, captando nelas a realidade. E como o ser não é para essa filosofia mais que outro nome para Deus, em tudo o que conhece o homem conhece a Deus. A mente do homem não é outra coisa, portanto, senão 'uma espécie de participação da verdade primeira', isto é, de Deus ${ }^{186}$.

Nesse contexto, cabe enfatizar que o encontro com Deus, que se 'dá na alma no mais profundo centro', requer, como vimos, anteriormente do homem, uma reabilitação para o exercício de dimensões que na cultura pós-moderna, mesmo que ainda sinalize ser este lugar uma oportunidade para a mudança, não deixa de ser também um lugar de atrofia ${ }^{187}$. Entretanto, o encontro com Deus, no mais íntimo da pessoa, que se dá na acolhida de sua presença, é, sem dúvida, a raiz da experiência religiosa. E disto falam a fenomenologia e os místicos, os estudiosos do fenômeno religioso e o homem que se tem adentrado com seriedade na busca dessa Realidade, fundamento radical de tudo.

\subsection{A religião e sua reafirmação}

A sensibilidade que expressam os representantes da espiritualidade atual oferece uma perspectiva de mudança religiosa que não duvida em denominar transformação. Advertem um predomínio religioso do extremo, objetivo e institucional. E assinalam um giro para a interioridade que faça justiça à dimensão profunda da religião: a vivência da unidade com essa Realidade Última que nos envolve e que denominamos Deus ${ }^{188}$. Reconhecemos que:

A religião através da história humana sempre procurou organizar essa experiência da Transcendência e sistematizá-la em normas, rituais e conceituações doutrinais. Mas nada dessa organização poderia acontecer sem a experiência religiosa, fundamental em todas as grandes tradições religiosas, e que dá testemunho de que o ser humano é diferente de todos os seres criados, pois pode experimentar aquilo ao Aquele que o transcende e é maior do que ele ou do que se possa imaginar e conceber $^{189}$.

Religião, neste sentido, dirá W. Jäger, é nossa condição de seres humanos, é atuar a partir da experiência de unidade de nosso ser com esta Realidade Última. Este mesmo autor dirá que esta unidade do ser de Deus e a pessoa humana tem

\footnotetext{
${ }^{186}$ Cf. VELASCO, J. Martin. Experiência cristã de Deus, p. 25.

${ }^{187}$ Cf. Ibid., p. 31.

${ }^{188}$ Cf. MARDONES, J. Maria. Mística transreligiosa en una sociedad de incertidumbre, p. 93.

${ }^{189}$ BINGEMER, M. Clara. O mistério e o mundo, p. 214.
} 
que ser entendido, como uma imagem tomada do místico Rumí, "como o mar e a onda: o mar não é a onda; a onda não é o mar, porém ambos podem existir somente unidos. Desde este ponto de vista, a onda é, portanto, mar e o mar, onda" 190

No cristianismo, "a experiência humana é realmente total e plena somente quando se transcende em Deus, que é sempre maior do que tudo quando os seres humanos estão dispostos a experimentar" ${ }^{\text {191 }}$.

No entanto, não é fácil descrever os passos, as etapas e as modalidades do exercício dos preâmbulos de existências da experiência religiosa. Velasco destaca, por exemplo: a renúncia e o desprendimento, o recolhimento, a solidão e o silêncio. A renúncia e o desprendimento dos bens deste mundo não se confundem com sua negação pura e simples ou sua condenação e desqualificação como obstáculos para a realização humana, mas devem ser entendidos como superação do apego. O recolhimento distingue-se do 'ensimesmamento' do sujeito e de seu isolamento das pessoas e das realidades que compõem seu mundo ${ }^{192}$. Aqui o silêncio não é sinônimo de mudez nem de opacidade. É a condição para que a palavra de Deus ressoe no interior do homem, onde permanentemente mora e fala.

Todos esses passos constituem, então, a etapa purificadora do caminho até a experiência de Deus. No entanto, os esforços humanos são insuficientes. É a hora da intervenção purificadora do próprio Deus. A hora da 'noite passiva' em que o próprio Deus culmina a obra. Esta hora é indispensável para que o homem possa unir-se a ele, dilatar o coração, estender seu desejo na medida da realidade infinita de Deus. Desprendendo-se de qualquer apego que converta Deus em objeto à sua disposição, purificando seu amor para que se dirija a Deus por ele mesmo e não pelo que lhe possa outorgar ${ }^{193}$.

Esta busca pela unidade com a Realidade Última é o que alguns autores encontram como o denominador comum, o núcleo de todas as religiões. Alguns, segundo Mardones, como W. Jäger, o chamam, fazendo um jogo de linguagem com a expressão 'filosofia perene', a 'sabedoria perene'. Esse centro ou núcleo

\footnotetext{
${ }^{190}$ JÄGER, W. Adonde nos lleva nuestro anhelo, p. 93.

${ }^{191}$ BINGEMER, M. Clara. Op. cit., p. 214.

192 Cf. VELASCO, J. Martin. Experiência cristã de Deus, p. 33.

${ }^{193}$ Cf. Ibid., p. 34.
} 
religioso para o qual apontam todas as religiões. Nesse sentido, é uma religiosidade que sobrepassa ou transcende toda religião ou confissão ${ }^{194}$.

Por essa razão, como têm sugerido alguns filósofos e teólogos sensíveis ao diálogo inter-religioso, 'a verdade está na profundidade'. Esta frase de Paul Tillich, retomada hoje por Ricoeur ${ }^{195}$, impulsiona uma atitude de esperança de encontro com outra religião pela via do aprofundamento nesse Centro.

$\mathrm{Na}$ tradição cristã, o itinerário espiritual dispõe o homem para um novo olhar. E esse se distingue pela clareza, pela simplicidade, pela penetração, pela fruição que caracterizam a atitude contemplativa. Transforma o conhecimento em conhecimento interno, o saber em sabedoria. Desemboca numa espécie de conaturalidade da alma com Deus ${ }^{196}$.

É, então, da originalidade do interior do homem e da Presença que o habita que nasce a originalidade do itinerário do homem com ele. Aí, todo esforço do homem consiste em apenas tornar-se disponível, esvaziando o próprio interior, fazendo silêncio em torno de si mesmo e no próprio interior, para que ressoe a Palavra presente no coração ${ }^{197}$.

No reconhecimento desta presença originária, no consentimento ao seu chamado e na entrega despojada, se dá a experiência originária de Deus. A esta a fenomenologia da religião identifica como atitude religiosa fundamental, que as diferentes religiões realizam, em caminhos históricos determinados, sob formas distintas tais como: fé-esperança-caridade (cristianismo), obediência fiel (Judaísmo), islã, submissão incondicional (Islã); realização da identidade com o Brahman, 'tu és isso' (Bramanismo); bhakti, entrega confiante na divindade (outras formas de Hinduísmo); nirvana, extinção do sujeito no mais além absoluto (Budismo). Sem esse reconhecimento fundamental, não há experiência de unidade com a Realidade Última, com Deus ${ }^{198}$. No cristianismo tal experiência acontece

dentro da história de vida do próprio ser humano, e dela brota o seu encontro com o outro Absoluto. Experiência esta que "anula" a distância entre eles. A afirmação de que o místico não se encontra inserido em seu contexto (social, político, econômico, religioso) torna-se inconsistente. Assim, essa transformação envolve o ser completo daquele que a experimenta, modificando totalmente seu conhecer, querer, dentro da realidade em que vive, para que atue de modo a ultrapassar a

\footnotetext{
${ }^{194}$ Cf. MARDONES, J. Maria. Mística transreligiosa en una sociedad de incertidumbre, p. 94.

${ }^{195}$ Cf. RICOEUR, P. La pensée protestante aujourd'hui. Reforme 2.609 (1995), pp. 7-8 Apud. DUQUOC, Christian. El único Cristo. La sinfonia diferida. Sal da Térrea, Cantabria, 2005. p. 125.

${ }^{196}$ Cf. VELASCO, J. Martin. Experiência cristã de Deus, p. 35. ver notas 13 e 14.

${ }^{197}$ Cf. Ibid., p. 36.

${ }^{198}$ Cf. Ibid., p. 38.
} 
relatividade dos fatos e objetos que o cercam, chegando ao núcleo mais profundo da concepção de ser humano e de mundo ${ }^{199}$.

Além disso, examinando o contexto atual de um fervoroso pluralismo religioso, podemos nele destacar uma inegável insatisfação com a religiosidade predominante e institucionalizada, pois, mesmo que a religião ainda pulse no coração da existência humana, já não são mais as mesmas instituições religiosas que desempenham a função de transmissão de um código unificador de sentido social, nem tão pouco regulam a vida pessoal e coletiva dos indivíduos ${ }^{200}$.

Isso leva à instauração de uma busca mais pessoal e mais experimental do divino. Como já indicamos, aí está anunciada uma transformação ou uma decomposição do religioso, o que devemos reconhecer que é uma manifestação da consciência religiosa de nosso tempo. Porque a espiritualidade de nossa época não tem esperado a reforma das igrejas ou instituições religiosas para efetuar sua própria busca e são muitas as pessoas que já não associam a experiência religiosa imediata a uma afiliação religiosa ${ }^{201}$.

Isto se dá porque

a religião cessa de fornecer aos indivíduos e aos grupos o conjunto das referências, das normas, dos valores e dos símbolos que lhes permitem dar um sentido à sua vida e às suas experiências. Na modernidade, a tradição religiosa deixa de constituir um código de sentido que se impõe a todos ${ }^{202}$.

Todavia, diante deste contexto, Mardones acredita que a revolução interior mística se apresenta como solução ou defesa desta realidade ${ }^{203}$. Para ele, a religião, que desce à profundidade interior, descobre e vive a igualdade radical de todos os seres humanos, está em condições de resistir e fazer frente a esta epidemia de expulsão do outro ${ }^{204}$, contra o reducionismo da condição humana, pois, a atenção à intimidade, a profundidade de si, ao enfrentamento com nosso lado obscuro - o que C. G. Jung chamou a 'sombra' - devolve ao ser humano toda sua inteireza e suas polaridades. Não se esconde seu lado sombrio e perigoso que

\footnotetext{
${ }^{199}$ BINGEMER, Maria Clara. O mistério e o mundo, pp. 23-24.

${ }^{200}$ Cf. HERVIEU-LÉGER, Danièle. O peregrino e o convertido, p. 56ss.

${ }^{201}$ Cf. MARDONES, J. Maria. Mística transreligiosa en una sociedad de incertidumbre, p. 95. Ver notas 10 e 11.

${ }^{202}$ HERVIEU-LÉGER, Danièle. Op. cit. p. 38.

${ }^{203}$ Cf. MARDONES, J. Maria. Mística transreligiosa en una sociedad de incertidumbre, p. 96.

${ }^{204}$ Cf. Ibid., p. 103.
} 
pode delirar e conduzir para o pior, se o tem consciente da capacidade humana para enfrentá-lo e integrá-lo ${ }^{205}$.

A transformação religiosa via mística se constitui, assim, em um baluarte frente aos reducionismos antropológicos de nossa sociedade e cultura. Isso se faz em resposta à situação pluralista que, "ao acabar com o monopólio religioso, faz com que fique cada vez mais difícil manter ou construir novamente estruturas de plausibilidade viáveis para a religião"206.

No entanto, adverte-se após estas tendências místicas, a reação histórica do ser humano frente ao mal estar provocado por toda essa realidade, que solicita uma transformação da religião que passe da ênfase no exterior ao interior. Esse giro requer um salto na consciência religiosa. Mas, além das dificuldades inegáveis, arrisca-se um processo de mudança religiosa gigantesca que faz pensar em um 'novo tempo eixo'. Porque secularização, "é antes, perda da religião institucional e nunca perda da religião enquanto tal" 207 .

A consciência religiosa, mais lúcida e desperta, pede hoje uma transformação profunda até o Mistério que a envolve e a sustenta. Se todas as tradições religiosas têm seus dias contados em sua forma de domínio externo, aproxima-se um larguíssimo e frutífero caminho quando conduz seus fiéis a uma experiência que os levem ao mais íntimo de si, ao encontro com a Realidade Última.

No entanto, para uma melhor compreensão dessa experiência, que denominamos mística, se faz necessário uma abordagem fenomenológica do termo 'mística', pois, como veremos a seguir, trata-se de "um dos mais confusos termos que existe atualmente" 208 .

\subsection{Fenomenologia mística}

O termo 'mística' tem recebido, a partir da segunda metade do sec. XX, um especial interesse. Hoje, em plena época, como vimos, de secularização e de fundamentalismo religioso, de descrença e de indigência religiosa, em plena crise das instituições religiosas e sob o impacto de novas formas e manifestações da

\footnotetext{
${ }^{205}$ MARDONES, J. Maria. Mística transreligiosa en una sociedad de incertidumbre, p. 104.

${ }^{206}$ BERGER, Peter L. O dossel sagrado, p. 162.

${ }^{207}$ HERVIEU-LÉGER, Danièle. Representam os surtos emocionais contemporâneos o fim da secularização ou o fim da religião? In: Religião e Sociedade. 18/1, 1997. p. 31.

${ }^{208}$ TRESMONTANT, Claude. La mística cristiana y el porvenir del hombre. Barcelona: Ed. Herder, 1979. p. 7.
} 
religião, essa se apresenta, contra todo prognóstico, como uma das principais respostas ao fundamentalismo religioso e ao diálogo inter-religioso. Isso se dá através de dois campos: o dos estudos e pesquisas e o da experiência mística em todas as religiões ${ }^{209}$.

Visto que, então, este termo utilizado em vários contextos diferentes e em razão de sua complexidade em não ser um termo unívoco ${ }^{210}$, surgem as grandes dificuldades para sua compreensão. Defrontamo-nos, logo de início, com seu uso em toda a família dos novos movimentos. No terreno não religioso, apresenta-se, em virtude de uma analogia funcional, com o sentido de compromisso social de algo tomado por absoluto ${ }^{211}$.

No terreno religioso, no seu interior, utiliza-se este termo para fazer referência a zonas-limite da experiência humana. São encontrados testemunhos seculares, uniformes, e concordantes do fato místico nas tradições budista, hinduísta, muçulmana, judaica e cristã, entre outras ${ }^{212}$. Designa-se ao termo uma conotação completamente diferente do conhecimento ordinário, objetivo e científico. Por outro lado, ele deve ser interpretado em uma realidade que lhe negue qualquer trato racional ${ }^{213}$.

No entanto, nos mais recentes estudos interdisciplinares, as experiências religiosas profundas mostram que a mística acompanha, sem especial dificuldade, o intelecto e a afetividade, a razão e a sensibilidade, a experiência e a reflexão, a faculdade de pensar e a de amar, o que leva a filósofa Maria Zambrano a considerar a experiência mística como uma experiência antropológica fundamental ${ }^{214}$.

Ou seja, “a experiência mística não pode ser separada do dado antropológico, já que ambos estão em profunda unidade para desembocar na

\footnotetext{
${ }^{209} \mathrm{Cf}$. TAMAYO, Juan José. A mística como superacion del fundamentalismo. In: RODRIGUEZ, Francisco J. Sánchez (org.) Mística y sociedad en diálogo, p. 161.

${ }^{210}$ Cf. TRESMONTANT, Claude. La mística cristiana y el porvernir del hombre, p. 7.

${ }^{211}$ Sobre os novos movimentos, esses são os voltados para o esoterismo, ocultismo, o paranormal ou parapsiquismo. E no que diz respeito ao não religioso, com o sentindo de compromisso social, temos a mística de ação, a humanitária e a comunista. Cf. VELASCO. Juan Martin. El fenómeno místico, p. 18. Ver nota 05.

${ }^{212}$ Cf. ANCILLI, E. Mística non cristiana, p. 1631. In: ANCILLI, E. (org.). Dizionario Enciclopédico di Spiritualità. v. 02. Roma: Città Nuova Editrice, 1900; LÓPEZ-GAY. Místique. In: VILLE, M. et al. (Ed.). Dictionnaire de Spiritualitè. v. X. Paris: Beauchesne, 1980. p. 1893.

${ }^{213}$ Cf. VELASCO, J. Martin. El Fenómeno místico, pp. 17-18.

${ }^{214}$ Cf. TAMAYO, Juan José. A mística como superacion del fundamentalismo, p.162.
} 
diversidade de relações que envolve todo ser humano de acordo com o meio em que vive",215.

Se outrora se colocava o acento no caráter ahistórico, desencarnado, puramente celeste e angelical da mística, hoje se sublinha sua dimensão histórica. O místico, na compreensão cristã, é aquele quer realiza sua experiência de profunda intimidade com Deus e a vive em sua realidade procurando transformála, ou seja, "a riqueza e a profundidade interior segundo o cristianismo devem desembocar sempre, naturalmente, na ação",216.

$\mathrm{Na}$ verdade, pode-se pensar que a mística tem muito de fantasia e move-se no mundo da imaginação. No entanto, mesmo se assim for, a fantasia e a imaginação estão carregadas de utopia. A utopia 'forma parte da história' e situase no seu mais profundo, mas não para acomodar-se aos ritmos que impõe a ordem estabelecida, senão para subvertê-la desde seus alicerces, não para permanecer ao nível do chão, mas para ir à profundidade ${ }^{217}$.

\section{a) O termo 'mística'}

A origem do termo 'mística', na língua latina, vem da transcrição do termo grego mystikós, que significa os mistérios (ta mystika). Com o advérbio mystikós (secretamente), se tem uma família de termos derivados do verbo myein, que significa a ação de fechar aplicada à boca e aos olhos, possuindo em comum realidades secretas, ocultas e misteriosas. Essa terminologia vem dos cultos gregos, não cristãos ${ }^{218}$.

O surgimento desse termo no vocabulário cristão, que não aparece nem no Novo Testamento e nem nos Padres Apostólicos, dá-se a partir do século III pelos padres do oriente cristão, como adjetivo. Esse vocábulo presente no culto grego é reinterpretado em função do tema paulino como mistério de Cristo. Com a passagem do tempo, adquire três sentidos para nossos dias. Em primeiro lugar, o simbolismo religioso em geral, que se aplica ao significado típico ou alegórico da

\footnotetext{
${ }^{215}$ BINGEMER, Maria Clara. O mistério e o mundo, p. 26.

${ }^{216}$ Ibid., p. 23.

${ }^{217}$ Sobre a inserção do místico na sociedade, temos o testemunho de alguns cristãos como o de S. João da Cruz, Mestre Eckhart, Marguerite Porete e o sufí Ibn al'Arabí. Como também da carmelita descalça Cristiana Kauffmann, para quem a mística "é o dinamismo interno de toda atividade solidaria e criativa do cristianismo. Gera pessoas de incansável entrega aos demais, de capacidade de transformação das relações interpessoais". Sobre suas experiências que na maioria das vezes se tornaram incomodas para suas instituições, Cf. Ibid., pp. 163-164.

${ }^{218}$ Cf. VELASCO, J. Martin. El fenómeno místico, p. 20.
} 
Sagrada Escritura proporciona um sentido espiritual ou "místico", em contraposição ao sentido literal. Em segundo, remete ao culto cristão e a seus mais diferentes elementos, por ser próprio do uso litúrgico. Por último, seu sentido espiritual e teológico refere-se às verdades inefáveis e mais profundas, ocultas do cristianismo, objeto de um conhecimento mais íntimo.

No século V, Marcelo de Ancira fala de uma teologia inefável e mística, assegurando o conhecimento mais íntimo da natureza humana. Foi apenas no final deste mesmo século que o Pseudo-Dionísio, utilizando-se deste termo, elabora o primeiro tratado teológico sobre a mística, em oposição ao conhecimento dedutivo e puramente racional. Admite, como peculiar, o conhecimento religioso escondido, experimental e imediato, adquirido a partir da relação com Deus ${ }^{219}$.

No início do século XV, nos escritos de J. Gerson, o substantivo 'mística' aparece pela primeira vez e a teologia mística passou a desdobra-se em um aspecto prático, e outro especulativo, assegurando o exercício da mística como conhecimento de Deus por contemplação infusa, e uma reflexão doutrinal sobre a vida mística ${ }^{220}$.

No entanto, foi apenas na sua segunda metade do sec. XVII que se começou a usar o termo 'teologia mística' e a designar com o termo 'místico' pessoas que viviam uma experiência especial ou uma forma peculiar de conhecer a Deus, conhecido como conhecimento místico ${ }^{221}$.

Nesse momento, com a utilização deste substantivo estabelece-se algo específico. É delimitado um modo de experiência, um tipo de discurso, uma zona de conhecimento. Com isso, podem identificar-se os fatos isolados das ciências que abordaram seu estudo. A novidade, então, não está apenas na identificação da vida mística, mas no seu isolamento e sua objetivação diante dos olhares de quem começa a estudá-lo de fora, e o fato de que a palavra começa a designar um fenômeno, um fato em que intervêm vários fatores ${ }^{222}$.

Assim, sobre a palavra 'mística' devemos partir do princípio de que esta como a filosofia, a religião e outras, deve ser encarnada em uma cultura

\footnotetext{
${ }^{219}$ Cf. VELASCO, J. Martin. El fenómeno místico, p. 20. Ver notas 7 e 8.

${ }^{220}$ Cf. SUTTER, A. Mística. In: ANCILLI, E. (org.). Dizionario Enciclopedico di Spiritualità. p.1626.

${ }^{221}$ Cf. GUERRA, S. Mística. p. 904. In: PIKAZA, X., SILANES, N. El Dios cristiano. Diccionario Teologico. Salamanca: Secretariado Trinitario, 1992.

${ }^{222}$ Cf. VELASCO, J. Martin. Op. cit., p. 21. Ver nota 12.
} 
determinada, em uma realidade que se refere à palavra, e que só existe encarnada e diversificada culturalmente. E é nesse entendimento que o termo mística

não designa a essência de uma experiência humana única, que as diferentes místicas realizam de forma unívoca, de forma que a variedade e as diferenças se originam pelos esquemas expressivos e interpretativos com que os sujeitos as formulam ${ }^{223}$.

Diante da realidade plural a que se refere o termo 'mística', e do seu uso pelos estudiosos do fenômeno religioso, podemos perceber que não existe um significado preciso. Por isso, não se pode temer traduções diferentes vindas de várias tradições religiosas, quando se referir à experiência em outras culturas, pois o reconhecimento de uma realidade plural a que se refere a palavra mística se exigirá de quem pretende descrevê-los em toda a sua riqueza, em um diálogo que, sem cair no relativismo, intenta deixar-se conhecer pelo outro, aprender do outro e abrir-se a uma possível fecundação mútua.

Velasco sintetiza a palavra mística, dizendo que essa é utilizada para designar um tipo de experiência existente na tradição cristã,

tem sido convertida pelos estudiosos do fenômeno místico em 'categoria interpretativa' do conjunto de experiências, diferentes, diversas, ao mesmo tempo em que convergentes, presentes em outras tradições religiosas e à margem dessas tradições expressadas nelas como 'equivalentes homeofórmicos' e nas que intervêm, encarnadas nas várias culturas, as invariantes humanos que se manifestam nessas experiências ${ }^{224}$.

Por fim, em razão de toda a pluralidade de significados que carrega o termo 'mística', é compreensível, por causa da pluralidade de fenômenos a que se aplica, e a pluralidade do ponto de vista de vários campos de pesquisa, que não se pode determinar uma definição imposta pela própria religião, teologia ou filosofia.

No entanto, diante de todo conflito que possa existir em relação à definição do termo, existe entre os estudiosos do fenômeno religioso, um consenso de que a experiência que melhor e mais autenticamente expressa a vivência religiosa é a mística $^{225}$. E que a utilização de um método para seu estudo faz-se necessário para que melhor se consiga identificar o fenômeno místico e suas características.

b) Um método para o estudo do fenômeno místico

\footnotetext{
223 VELASCO, J. Martin. El fenómeno místico p. 21.

${ }^{224}$ Ibid., p. 48. O mesmo valor de "categoria interpretativa", Velasco atribui aos termos chaves da fenomenologia da religião, conferir outra obra sua: Introducion a la fenomenologia de la religión. Madri, Trotta, 2006. Sobre equivalentes homeofórmicos, conferir PANIKKAR, Raimon. La experiência filosófica de la Índia. Madri, Trotta, 1997.

${ }^{225}$ Cf. TAMAYO, Juan José. A mística como superacion del fundamentalismo, p.162.
} 
A procura por um modelo epistemológico para o estudo da mística vem se desdobrando desde as primeiras décadas do séc. XX, até que, nos anos sessenta, se apresentaram as propostas, designadas como 'essencialista', 'perenialista', e 'universalista' que têm se revestido de diferentes formulações. Uma das expressões deste modelo é a doutrina de Radhakrishnan sobre a verdade religiosa, resumida nestes termos: "Todas as religiões brotam do solo sagrado da mente humana e estão animadas pelo mesmo espírito. Os diferentes sistemas são intentos mais ou menos satisfatórios de ajuste da realidade espiritual" ${ }^{226}$.

Para Radhakrishnan, “o ser humano só pode conhecer a Deus se separa seus sentidos e sua mente do mundo da experiência externa e concentra suas energias na realidade interior" ${ }^{227}$, para que possa dar conta da sua verdadeira natureza no íntimo de sua própria identidade, pois, quando se possui o conhecimento de si mesmo, são destruídas as ataduras do coração e é transcendida a finitude. Assim, o valor da religião consiste em ser capaz de ativar no ser humano essas potencialidades.

No modelo "essencialista", colaboram a maior parte dos autores que se têm ocupado da mística a partir da ciência das religiões, na primeira metade do séc. XX. Esses estudiosos foram conduzidos por um princípio epistemológico comum, “o pressuposto de que todas as manifestações da mística são as expressões variadas de uma idêntica experiência ou, ao menos, de um reduzido número de experiências" ${ }^{228}$. As razões para esta afirmação estão nas semelhanças dos relatos das diferentes tradições místicas e de uma analise do fenômeno místico.

No entanto, diante das inúmeras críticas a este modelo, surge outro modelo de um novo paradigma epistemológico, o "construtivista". E essa nova postura diante da experiência mística tem como proposta principal compreender a experiência mística inserindo o místico em seu contexto considerado pluriforme, percebendo a relação entre o místico e sua meta, suas dificuldades e suas experiências cotidianas. Nesse modelo descarta-se a possibilidade de existirem experiências que não sejam mediadas, que sejam puras ${ }^{229}$. Descartam-se também

\footnotetext{
${ }^{226}$ RADAKRISHNAN, S. East and West in Religio, Allen and Unwin, London, 1933, p. 19. Apud. VELASCO, J. Martin. El fenómeno místico, pp. 36-37.

${ }^{227}$ RADAKRISHNAN, S. La religion y el futuro del hombre, Alianza, Madri, 1996, p. 133. Apud. VELASCO, J. Martin, Op. cit. p. 37.

${ }^{228}$ Ibid., p. 38. Ver nota n. 13.

${ }^{229}$ Cf. Ibid., p. 40.
} 
as críticas que dizem ser este modelo incapaz de explicar fatos de ruptura com a tradição e sua tendência ao reducionismo.

Destaca-se a intervenção da linguagem, a existência de experiências sensitivas e o possível condicionamento cultural que possa intervir na ação humana, no entanto, o problema parece situar-se em outro lugar, visto que "toda experiência é uma experiência interpretada e, em todo sentido depende da resposta do contexto e é estimulado por ele" ${ }^{230}$.

A experiência mística é configurada por conceitos que o místico já de antemão possui. Velasco cita Ricoeur, que diz: "toda experiência é uma síntese ativa de presença e de interpretação" ${ }^{\text {231 }}$. Afirma assim, que, na experiência mística, o sujeito se faz presente com seus esquemas de compreensão, hábitos etc. E que tudo isto configura quem é o sujeito na sua relação com o transcendente, "pois, o ser que somos não se esgota na forma histórica, certamente condicionada, de realizar esse ser" ${ }^{232}$.

Desta forma, abrem-se oportunidades que permitem perceber como se dão as experiências místicas nas diferentes tradições religiosas. Dentre os elementos que as configuram, estão presentes também as doutrinas de sua própria tradição, que não só se limitam a intermediá-la como também "afetam a substância mesma da experiência”,233.

Os limites do modelo construtivista estão nas críticas em que assinalam a existência de casos de experiências puras, fazendo referência às 'experiências sem conteúdo', 'acontecimentos de pura consciência', negando os fatores presentes em seu contexto cultural e em sua tradição ${ }^{234}$. No entanto, não existem "experiências puras", pois estas não poderiam dar-se, já que toda experiência humana comporta sua linguagem, história e cultura. Mesmo que estas não a esgotem por causa de determinada mediação ${ }^{235}$.

Está claro que a interpretação construtivista da experiência mística influencia também o pluralismo religioso em seu terreno cultural e religioso, bem

\footnotetext{
${ }^{230}$ VELASCO, J. Martin, El fenómeno místico, p. 42.

${ }^{231}$ Esta expressão de P. Ricouer foi citada por J. SERVAIS em "Faire I'expérience de Dieu?" In: Nouvelle Reveu Théologique. $\mathrm{n}^{\circ}$ 105, 1983, p. 413. Apud. VELASCO, J. Martin. A experiência cristã de Deus, p. 47.

${ }^{232}$ Ibid., p. 43.

${ }^{233}$ Id., El fenómeno místico, pp. 40-41.

${ }^{234}$ Cf. Ibid., p.42.

${ }^{235}$ Cf. Ibid., p. 43.
} 
como também nas conclusões da antropologia cultural sobre o "alcance noético" da cultura ${ }^{236}$.

E é justamente nessa relação da mística com a religião que os argumentos de muitos estudiosos contra o método construtivista estão baseados. Esses estão certos no entendimento de que a existência de semelhanças entre as diferentes tradições místicas permite identificar que todas são místicas, mesmo diante de diferentes contextos culturais. Assim, possibilitam estudos comparados entre religião e mística.

Isso se deve ao fato de que representantes de diferentes tradições religiosas encontrem-se para dialogar, e assumam em sua prática religiosa, experiências de outras tradições, assim, como fez Thomas Merton ${ }^{237}$. Para esse religioso, o monaquismo Oriental, a sabedoria do Oriente e seu pendor para valorizar o invisível, o Absoluto, cada vez mais o atraíam para um estudo aprofundado que traria para o cristianismo ocidental novas riquezas por vezes esquecidas ou postas de lado.

Thomas Merton, por ocasião de um convite que recebeu para participar de um Congresso Ecumênico, organizado pelos beneditinos em Bancoc, na Tailândia, assim escreveu em seu diário:

Vou com a mente de todo aberta. Sem ilusões especiais, espero. Minha esperança é simplesmente desfrutar da longa viagem, dela tirar proveito, aprender, mudar. Talvez encontrar alguma coisa ou alguém que me ajude a avançar em minha própria busca espiritual ${ }^{238}$.

Diante destas palavras, entendemos que a mística, bem como a religião, realiza-se na pluralidade cultural condicionada nas próprias tradições, porque existe

um conjunto de variantes humanas, só realizáveis historicamente. Portanto, na diversidade das tradições e das culturas, nenhum pensamento humano é capaz de perceber e descrever ahistoricamente, aculturalmente, uma noção que expresse uma essência intemporal, absoluta ${ }^{239}$.

Infelizmente, em algum momento, na teoria sobre a religião, tem-se esquecido de que as mais variadas formas religiosas são plurais, por pretender uma definição de religião que contenha a essência realizada em todas essas

\footnotetext{
${ }^{236}$ Cf. VELASCO, J. Martin. El fenómeno místico, p. 39.

${ }^{237}$ Cf. MERTON, Thomas. Merton na intimidade: sua vida em seus diários. Editores: Patrick Hart e Jonathan Montaldo. Rio de Janeiro: Fisus, 2001.

${ }^{238}$ Ibid., p. 380.

${ }^{239}$ Id., El fenómeno místico, p. 43.
} 
formas. No entanto, a tomada de consciência da pluralidade das formas não deve nos ocultar a existência do fato humano que todas elas constituem.

Nesse novo modelo, coloca-se em questão pressupostos que já eram comuns entre os estudiosos anteriores, quando se dizia que todas as experiências místicas são as mesmas ou similares. Procuram-se reconhecer nela suas diferenças, não valorizando uma em detrimento de outra. O que leva muitos estudiosos a proporem uma via média entre as posturas essencialista e a construtivista ${ }^{240}$, pois as manifestações religiosas e as não religiosas são todas formas que revelam as riquezas da experiência mística.

Assim, podemos dizer que a "mística é sempre religiosa e a religião é sempre mística" ${ }^{241}$. Porque, em toda experiência religiosa, encontram-se elementos místicos. E como vimos, no item anterior, apenas um método aplicado a partir do próprio contexto histórico é capaz de identificar um fenômeno místico.

Reconhecendo as diferenças existentes entre tantas experiências místicas, procuraremos, no item seguinte, descobrir se existe uma mística genuinamente cristã.

\subsection{A mística cristã}

Quando pretendemos descrever a mística no interior do cristianismo, deparamo-nos com algumas dificuldades. Primeiro, pela legitimidade do fenômeno místico na ação cristã. Existe mesmo uma mística que seja genuinamente cristã? E a segunda dificuldade encontra-se na enorme variedade de formas de que se tem revestido a mística na história do cristianismo oriental e ocidental.

Como temos visto, não poucos teólogos se inclinam por uma resposta negativa, quando se referem ao fato de existir na tradição cristã algo que possa ser atribuído ao fenômeno místico ${ }^{242}$. A razão para esta resposta encontra-se, como também já havíamos notado, no fato de que o termo 'mística' não está no Novo

\footnotetext{
${ }^{240}$ Cf. VELASCO, J. Martin, El fenómeno místico, p. 41.

${ }^{241}$ Esta afirmação de Hügel parte de um estudo apurado que o mesmo realizou sobre a vida mística de Sta. Catarina de Gênova. Cf. HÜGEL, Fr. von. The mystical element of religion, as studied in Saint Catherine of Genoa and friends. J.M. Dent, London, 1908, $2^{\circ}$ v. Apud. VELASCO, J. Martin. El fenómeno místico, p. 31.

${ }^{242}$ Conferir o capítulo anterior.
} 
Testamento e nem nos Padre Apostólicos, vindo a aparecer apenas na metade do século III.

Isso nos leva a perceber que todas essas razões contribuíram para que fossem excluídas da experiência mística as fontes cristãs, encontrando apenas a explicação para o misticismo nas influências da gnosis e no neoplatonismo. E assim, também se encontra na história da mística cristã, uma oposição entre a mística psicológica introspectiva e a mística objetiva ${ }^{243}$.

No entanto, a partir de uma compreensão ampla do significado da 'mística', é possível encontrar no Novo Testamento a peculiaridade própria da mística cristã, visto que toda experiência mística no cristianismo tem sua origem na vida e na experiência de Jesus Cristo e deve ter suas modalidades revestidas pela própria experiência de profunda intimidade que viveu o Mestre com o Pai, Ele se torna, assim, para o cristão, o paradigma da experiência mística.

A questão é se, à semelhança do que diz o Novo Testamento sobre a vida do cristão, a experiência sobre a qual descansam os escritos do Novo Testamento e o conhecimento de Deus que se propõe não permitem falar de uma dimensão mística no cristianismo ${ }^{244}$.

A possibilidade de resposta para essa questão encontra-se na própria experiência que designa uma realidade com raízes próprias, mas não exclusivas nos textos neotestamentárias, pois esta realidade se dá assumida no que se tem chamado tradicionalmente cognitio Dei experimentalis, ou seja, aquele profundo conhecimento experiencial de Deus de que os místicos cristãos têm sido testemunhos eminentes na história ${ }^{245}$.

A tradição pós-apostólica pode ser considerada como a memória coletiva daquelas experiências privilegiadas que constituíram a revelação fundacional, que alcançou seu clímax definitivo e insuperável com Jesus Cristo e a vinda do Espírito Santo ${ }^{246}$.

Quando procuramos pesquisar as características da mística cristã, percebemos que, na perspectiva de muitas teologias cristãs sobre a mística, tem-se destacado uma de suas características a referência constante da experiência do Mistério. Tal experiência apareceria mais claramente nas formas mais originarias

${ }^{243}$ Cf. GENIL, M. R. Del. Mística. In: BORRIELLO, L. et al., Dicionário de mística. São Paulo: Paulus: Edições Loyola, 2003. pp. 707-709.

${ }^{244} \mathrm{Cf}$. VELASCO, J. Martin. El fenómeno místico, p. 212.

${ }^{245} \mathrm{C}$. ELENA, Santiago del Cura. Mística Cristiana: su enraizamiento neotestamentario en perspectiva ecuménica. In: VELASCO, J. Martin (org.). La experiencia mística. Estudios interdisciplinar. Madri: Trotta. 2004. p. 130.

${ }^{246}$ BINGEMER, Maria Clara. O mistério e o mundo, 178. 
da mística cristã, as quais representam os textos neotestamentarios e os estudos dos Padres e que teriam sido eclipsadas pela influência do neoplatonismo ${ }^{247}$.

No entanto, essa presença do conteúdo sobre a vivência do místico é algo comum a todas as formas de mística religiosa autêntica, pois possuem como essência a condição

extática da experiência, que surge e vive da presença desse mais além do sujeito que só se faz presente descentrando-o em sua direção por meio da transcendência. O que na realidade constitui a originalidade da experiência mística cristã é a peculiaridade da configuração desse Mistério. Como todo o verdadeiramente nuclear, esta contém infinidade de aspectos que debulham essa verdadeira raiz da identidade da mística cristã ${ }^{248}$.

Para o cristão, o Mistério é, em primeiro lugar, o Deus pessoal de uma tradição monoteísta e profética. E, ao mesmo tempo, é o mistério do Deus encarnado: Jesus Cristo, em quem o cristão tem acesso ao Pai no Espírito. Em terceiro lugar, o Mistério que, em virtude da encarnação e em continuidade com a revelação veterotestamentária de Deus, desvela-se na história dos homens e a encaminha para si como seu fim escatológico. Por último, o Mistério que convoca os crentes à comunhão com a Igreja como gérmen do Reino de Deus ${ }^{249}$.

Os elementos do Mistério cristão consistem na adesão do crente a um Mistério que o dispõe à revelação, aspectos do Mistério que regulam a experiência cristã realizada pelos místicos de forma eminente. A relação da experiência mística com a fé não consiste em uma forma de conhecimento que supere o conhecimento de Deus pela fé ou o substitua.

Há uma dimensão mística inicial da fé e da caridade que é uma real experiência de Deus no nível da vida cristã fervorosa. A experiência propriamente dita se inscreverá então nessa vida cristã que, por comportar a experiência da fé, está já dotada de germens místicos e pode prosseguir e crescer até seu coroamente ${ }^{250}$.

A importância, nessa relação, move-se no interior mesmo da fé e essa nunca pode suplantá-la, pois a experiência mística realiza a mesma harmonia de aspectos aparentemente contrários que constituem a originalidade da fé cristã. Como a fé, a mística cristã está ligada ao Mistério, que surge de sua manifestação na obscuridade, nunca inteiramente dada. No entanto,

\footnotetext{
${ }^{247}$ Cf. VELASCO, J. Martin (org.). La experiencia mística. p. 217. Recentemente, a insistência na regulamentação da experiência pelo Mistério, tem como principais representantes, teólogos como H. de Lubac, H. Urs von Balthasar, L. Bouyer. Estes fazem frente ao perigo de psicologização da mística cristã que supõe uma interpretação fenomenológica, psicológica da experiência mística.

${ }^{248}$ VELASCO, J. Martin. El fenómeno místico, p. 217.

${ }^{249}$ Cf. Ibid., p. 218.

${ }^{250}$ BINGEMER, M. Clara. O mistério e o mundo, p. 297.
} 
esta experiência não se realiza na simples prolongação da interioridade abismal do sujeito, mas requer referência à revelação, à Palavra com a qual esse Mistério desperta a profundidade do homem e a remete ao mais além sempre inalcançável, na profundidade do sujeito e na palavra que o provoca $^{251}$.

Mística e Mistério, nos místicos cristãos, possuem uma configuração que é vivamente personalizada e de caráter eminentemente pessoal. O conteúdo dessa experiência que vem dada pela fé cristã e sua 'representação' é o mistério de Deus nos termos do Deus único, revelado no Novo Testamento, que como Pai, pela ação do Filho, nos comunica seu Espírito. Essa configuração trinitária do 'conteúdo' da experiência é o que a distingue das místicas do Absoluto da maior parte das tradições orientais e da mística 'apenas' monoteísta do islamismo, por mais parentesco que com elas possam ter as expressões de alguns místicos cristãos $^{252}$.

No entanto, não é raro encontrar descrições que apresentam como próprios da mística cristã características que se encontram nas místicas de outras religiões, porém formulados e entendidos em termos e modalidades outros que impõem a peculiaridade de cada uma delas.

É certo, todavia, que a originalidade que outorga à mística cristã sua referência a Jesus Cristo tem suas diferentes propriedades e lhe confere uma clara peculiaridade. E sem pretender que sejam características exclusivas do cristianismo, reconhece-se entre os estudiosos dois aspectos que afirmam a verdadeira originalidade da mística cristã.

O primeiro aspecto refere-se à sua dimensão eclesial, à qual frequentemente foi atribuído um individualismo derivado de sua insistência na interioridade, na subjetividade e na condição da relação com Deus. As religiões de orientação mística: hinduísmo, budismo, taoísmo, são caracterizadas, nas tipologias que insistem nesse aspecto, como religiões individualistas, frente à condição mais claramente comunitária das religiões de orientação profética ${ }^{253}$.

A mística cristã comporta uma dimensão eclesial, o que, no entanto, não significa que um místico cristão necessite como critério de autenticidade, o posicionamento da Igreja e a ortodoxia garantida pelo magistério. Essa dimensão deriva-se da natureza eclesial, em seu modo de realização, da fé vivida pelo

\footnotetext{
${ }^{251}$ VELASCO, J. Martin. El fenómeno místico, p. 219.

${ }^{252}$ Cf. Ibid., p. 221.

${ }^{253}$ Cf. Ibid., p. 231.
} 
místico e, em definitiva, do fato de que a união com Deus que procura ter lugar em Jesus Cristo, opera a incorporação do crente à sua morte e sua ressurreição.

E essa inserção 'crístico-eclesial' do crente cristão abre sua experiência de místico à atenção e ao cuidado dos outros e o dota de dinamismo evangelizador que está na raiz de boa parte de seus esforços por comunicar sua própria experiência. A união com Deus ocorre para eles, os místicos, em beneficio de outros e o amor de Deus que os inunda e corre através de suas vidas é de extraordinário valor para a humanidade.

O segundo aspecto se encontra quando nos deparamos com uma mística que se volta para a ética. Segundo Schweitzer, a mística de Paulo, como mística do ser em Cristo, mantém uma estreita relação com a ética. Isso porque a ética de Paulo não é outra coisa senão sua mística do ser em Cristo compreendida desde o ponto de vista do querer ${ }^{254}$.

Assim, a experiência mística para os místicos cristãos consiste, sobretudo, na união de semelhança que tem sua raiz na vida teologal e que se encarna na união da própria vontade com a de Deus e, mais concretamente no amor ao próximo, como expressão e meio de realização do amor de Deus ${ }^{255}$.

Essa experiência pode ser compreendida somente a partir do desapego, do vazio em todo o eu empírico, ou seja, em todo aquele complexo de volições, pensamentos e sentimentos que nos caracteriza em cada momento, mas que de forma nenhuma nos constitui naquilo que é essencial, mudando incessantemente. $\mathrm{O}$ parâmetro de tal vida envolvida nesta experiência será o seguimento de Jesus, atendendo ao chamado de "viver com Ele viveu" $" 56$.

Veremos a seguir que a mística cristã tem sua raiz única apresentada nos textos neotestamentário, na experiência de Jesus de Nazaré.

a) O enraizamento da mística cristã

O termo 'mística' refere-se a uma realidade que possui raízes próprias no texto neotestamentário e está presente no que se tem chamado cognitio Dei experimentalis. Este conhecimento refere-se ao "conhecimento de Deus não

\footnotetext{
${ }^{254}$ Cf. VELASCO, J. Martin. El fenómeno místico, p. 232. A. Schweitzer um grande estudioso da obra paulina é muito citado por Velasco quando este se refere a Paulo. A obra citada deste autor é: Mystik des Apostels Paulus. Mohr-Siebeck. Tübingen, 1981.

${ }^{255}$ Cf. Ibid., p. 233.

${ }^{256}$ BINGEMER, Maria Clara. O mistério e o mundo, p. 28.
} 
reduzido a dimensões intelectuais dos processos cognitivos, mas marcado decisivamente pelos aspectos vivenciais" 257 .

Privilegiar os termos 'vivência' ou 'experiência' significa expressar como a mística supera limites secamente intelectuais, racionais ou abstratos no conhecimento de Deus. Esta dimensão experiencial do 'conhecimento religioso' de Deus que abarca a totalidade do sujeito humano implica, no Novo Testamento, o reconhecimento crente de Jesus Cristo como revelação plena e definitiva de Deus. A experiência histórica de Jesus esteve animada do princípio ao fim pelo poder e o dinamismo do Espírito, tendo uma experiência muito profunda do mistério de Deus Pai.

O termo 'mística', que possui uma grande flexibilidade terminológica possibilita também muitas variações de significado e de conteúdo ${ }^{258}$. No entanto, a partir da compreensão dos elementos histórico-proféticos, fica claro que não se justificam os traços que antes apresentavam metodologicamente a questão, desde uma contraposição prévia e alternativa entre 'interioridade' e 'história'. Parece mais correto acolher o que o Novo Testamento tem a dizer sobre o cognitio Dei experimentalis como síntese, o que posteriormente se denominará como 'mística', pois é certo que a relação de Jesus de Nazaré, única e original, com Deus implica elementos fundamentais para toda experiência cristã de Deus ${ }^{259}$.

b) Elementos da mística cristã

A experiência religiosa, no cristianismo, baseia-se no acontecimento revelador do Novo Testamento, em que Deus Pai, por meio do Filho Jesus Cristo, nos outorga uma vida nova no Espírito Santo. Posteriormente se pôde dizer que isto se funda em um acontecimento 'Trinitário da salvação'. Esta é uma estrutura que marca o 'sentido espiritual' e a 'experiência mística' de Deus. E é justamente neste acontecimento e na realidade do Deus Trinitário que se encontra a peculiaridade dos traços místicos da tradição cristã.

A experiência cristã encontra na história de Jesus de Nazaré e no significado salvífico que encerra sua vida seu elemento mais decisivo. "Recentrar-se nele,

\footnotetext{
${ }^{257}$ VELASCO, J. Martin. El fenómeno místico, p. 132.

${ }^{258}$ Cf. Ibid., p. 133.

${ }^{259}$ Cf. ELENA, Santiago del Cura. Mística Cristiana, p. 133.
} 
constitui o primeiro critério de discernimento na relação entre a mística e cristianismo" 260 .

Um dos motivos da reserva protestante com a 'mística' encontra-se no que eles entendem por obscurecimento que esta causa à mediação salvadora de Jesus Cristo. Para uma corrente do protestantismo, a 'mística' implicaria uma tendência à autorredenção. Felizmente, hoje, se procura ir além destas contraposições meramente confessionais, quando os místicos cristãos, por meio de suas experiências, desmentem toda pretensão autossalvífica. No mesmo protestantismo, em outra corrente, pretendem por outro lado, superar as exclusões entre 'mística' e 'cristologia', entre o reconhecimento crente de Cristo 'por nós', entre o objetivismo e o subjetivismo salvífico ${ }^{261}$.

Isso possibilita uma grande abertura à mística neotestamentária, livre de preconceitos. Segundo o evangelho de João, para o cristão que aceita o convite de seguir a Jesus, essa aceitação significa não só reconhecer que este itinerário leva ao Pai, mas que também o introduz no mistério da presença recíproca que acontece entre ambos ${ }^{262}$. "Essa união tão estreita entre o Pai-Filho, que se abre aos discípulos de Jesus, pode chamar-se imanência mútua"263.

Aqui se inspira a convicção tão importante na experiência dos místicos cristãos de chamar-se em Cristo e de Cristo, ou seja, de uma ideia já tradicional de uma 'inabitação' ou de uma 'união mística'. Essa imanência não é estática e nem estéril, pois tem consequências no compromisso ético, no vigor missionário e na permanência do amor. $\mathrm{O}$ amor fraternal recíproco outorga à relação vertical DeusCristo-discípulos um componente horizontal decisivo e irrenunciável.

A mística joanina é cristológica. O Cristão vive sua própria existência 'em Cristo', que se dá entre ambos como uma reciprocidade de imanência. 'Viver em Cristo' é, ao mesmo tempo, uma vida 'no Espírito', pois essa presença implica simultaneamente a inabitação do Espírito de Deus neles ${ }^{264}$. A vida do cristão, enquanto seguimento de Cristo e permanência nele, equivale a viver no Espírito de Deus e a deixar levar-se por suas inspirações.

\footnotetext{
${ }^{260}$ ELENA, Santiago del Cura. Mística Cristiana, p. 144.

${ }^{261}$ Cf. Id., p. 145.

${ }^{262}$ Cf. Jo $14,9-12$.

${ }^{263}$ ELENA, Santiago del Cura. Op. cit., p. 150.

${ }^{264}$ Cf. Rm 8,1-11.
} 
“A vida cristã é uma vida 'espiritual' no sentido mais estreito do termo, ou seja, possibilitada, mantida e plenificada pelo poder e força do Espírito Santo" ${ }^{265}$. No entanto, nem sempre, na história do cristianismo ocidental, tem-se mantido uma consciência clara da vinculação estreita entre a realidade do Espírito (pneumatologia) e a vida 'no Espírito' (espiritualidade). Seu lamentado 'esquecimento' afetou tanto a tradição protestante como a católica. Em ambas, todavia, dá-se, desde alguns anos, um redescobrimento benéfico para a vida eclesial, para a reflexão teológica e para a vida espiritual.

É certo que o papel do Espírito na vida e no ministério de Jesus permite entender melhor a verdade radical de sua condição humana e torna possível apresentar a vida cristã como um caminho de seguimento depois dos sinais deixados por ele ${ }^{266}$. Essa é a força que permite viver, o que guia, anima, discerne e purifica. Tudo isso acontece de tal modo que eles 'no Espírito' gritam: Abba, Pai 267. O Espírito que habita 'nos' crentes e lhes outorga sua nova identidade é o Espírito de Deus e de Cristo. Precisamente por isso os crentes encontram-se 'em Cristo' e 'no Espírito' ${ }^{\text {268 }}$. Tomar, então, conhecimento experiencial de Deus (cognitio Dei experimentalis) como resumo da mística é algo que convém ter em conta que no conhecer a Deus, a fé desempenha um papel central, pois só quem ama a Deus é conhecido por ele e que este conhecimento-amor implica a pessoa inteira.

Enquanto na tradição católica tem-se posto ênfase em defender a possibilidade de um 'conhecimento natural' de Deus, grande parte da teologia protestante tem separado radicalmente, conhecimento de Deus e natureza, sobretudo por motivos teológicos.

No entanto, não se trata tanto de uma discussão epistemológica quanto de um tema que incide diretamente na existência cristã, pois é certo que as dimensões místicas do conhecer a Deus ajudariam a superar as contraposições unilaterais.

O conhecimento místico-religioso de Deus implica, no Novo Testamento, reconhecimento, adoração e ação de graças $^{269}$. Aqui nos defrontamos com uma experiência que se encontra muito longe de um tipo de conhecer alheio ao amor e

\footnotetext{
${ }^{265}$ ELENA, Santiago del Cura. Mística Cristiana, p. 160.

${ }^{266}$ Cf. Id., p. 162.

${ }^{267}$ Cf. Rm 8,15.

${ }^{268}$ Cf. ELENA, Santiago del Cura. Op. cit., p. 164.

${ }^{269}$ Cf. Rm 1,20-22.
} 
de um saber que se limita a tomar nota, de maneira ascética e neutra, de que existe um objeto chamado Deus. Esta experiência leva a pessoa que a vive ao encontro do outro, e como veremos a seguir, conduz a religião para ir além de si mesma.

\subsection{A religião para além de si mesma}

Neste item, procuraremos traçar um caminho que nos aponte a possibilidade de que as religiões podem ir mais além de si mesmas, a partir da compreensão de que para este percurso não seja necessário negar a irredutível especificidade de cada uma, pois seu caráter único significa sua razão de ser no encontro interreligioso, fazendo com que cada contribuição seja indispensável ${ }^{270}$. Na origem das religiões, como já constamos, está a existência da experiência mística, vivida em toda a sua radicalidade pelos fundadores e pelos seus primeiros seguidores.

Essa constatação confirma que cada religião está em um 'entre': entre Aquele que o precede e Aquele para o que conduz. E cada tradição recorre a este 'entre' de um modo diverso, proporcionando um acesso irrepetível à Realidade primeira e última. Cada uma delas é portadora de uma aurora única, inegociável e irredutível que recorda o Mistério de uma forma insubstituível.

O reaparecimento, o reemergir - mais do que a volta - do religioso, do Sagrado, a sede pelo Mistério e pela mística em distintas formas aparecendo após o banimento ensaiado pela secularização denota uma volta (ou uma permanência) da necessidade contemplativa, um aparentemente novo emergir de valores como a gratuidade, o desejo, o sentimento e a redescoberta, em nova dimensão, da natureza e da relação do homem com o planeta ${ }^{271}$.

E são os místicos nas religiões os primeiros a reconhecerem que a revelação de Deus tem se dado por muitas mediações, pois eles conseguem "ver na história e em todas as articulações da existência humana este fio condutor divino que tudo une, tudo ordena e tudo eleva" 272 .

Esses reafirmam que a autêntica fonte das religiões encontra-se na experiência mística, pois todas fazem a mesma experiência de ser, porém a

\footnotetext{
${ }^{270}$ Cf. MELLONI, Javier. Las religiones, más allá de sí mismas, p. 230.

${ }^{271}$ BINGEMER, Maria Clara. O mistério e o mundo, p. 159. No segundo capítulo deste livro, que tem como tema 'Cultura secular e crise da religião', Maria Clara nos apresenta, em meio a tantos desafios, a religião como grande força que atinge e afeta o desejo do ser humano e os seus desdobramentos em nossa sociedade. Cf. pp. 98-184.

${ }^{272}$ BOFF, Leonardo. Mestre Eckhart: mística de ser e de não ter. Petrópolis: Vozes, 1983. p. 15.
} 
expressam segundo a época, cultura, educação e religião que vivenciam ${ }^{273}$. Sem desaparecer as diferenças entre as tradições religiosas, nos diz Amaladoss que "elas vivenciam o mesmo Deus. Mas não têm a mesma experiência"274.

Nessa experiência, como nos afirma Thomas Merton, existe uma "real semelhança existencial", que permite uma "comunicação em profundidade",275, o que nos leva a afirmar com Bergson que a "mística constitui a essência da religião, a mais alta expressão possível da religiosidade" 276 e com Basset que esse é o nível mais profundo para o diálogo entre as religiões ${ }^{277}$.

Assim, os crentes de cada tradição, na medida em que assumem sua verdadeira identidade religiosa, são capazes de reconhecer e acolher o outro em sua diferença sem negar a sua própria experiência.

Diante dessa experiência, o psicólogo William James entende que a raiz e o centro da religião pessoal encontram-se nos estados de consciência mística. E assim, caracteriza a mística com quatro traços assumidos com unanimidade pelos estudos do fenômeno místico: inefabilidade, natureza do conhecimento, transitoriedade e passividade ${ }^{278}$.

No entanto, outros autores têm incorporado novas características, como: visão unificadora ou consciência de unidade do todo, sentido de superação do tempo, sentimento de felicidade e alegria, condição paradoxal, apreensão do Uno como a subjetividade interna de todas as coisas, sentido de objetividade ou realidade, integração dos diferentes elementos que intervêm na experiência mística $^{279}$.

${ }^{273}$ Cf. AGUILAR, Emilio Galindo. Musulmanes y cristianos conducidos por el Espíritu. In: MELLONI, Javier. El no-lugar del encontro religioso, p. 173.

${ }^{274}$ AMALADOSS, Michael. Pela estrada da vida. São Paulo: Paulinas, 1996. p. 88. A experiência realizada pela pessoa é única e específica em cada tradição. Pois, segundo Amaladoss: "Todas as comunidades religiosas são comunidades de fé, mas o objeto de sua fé não é apenas Deus em abstrato, mas Deus vivenciado numa tradição religiosa especifica". Ibid., p. 91.

${ }^{275}$ MERTON, Thomas. O diário da Ásia. Belo Horizonte, Vega, 1978. p. 248. Aqui segundo Merton, ocorre uma comunicação além de uma simples manifestação de conhecimento intelectual ou formulações, os interlocutores "se encontram além de suas próprias palavras e de seu próprio entendimento, no silêncio de uma experiência máxima, suprema, que possivelmente não poderia ocorrer se eles não se tivessem encontrado e falado".

${ }^{276}$ BERGSON, H. Las dos fuentes de la moral y de la religion. Madri, Tecnos, 1996. p. 280. Para Bergson "O misticismo é uma tomada de contato, e, por conseguinte, uma causalidade parcial, com o esforço criador que manifesta a vida. Esse esforço é de Deus, se não o próprio Deus. $\mathrm{O}$ grande místico seria uma individualidade que franquearia os limites consignados a espécie por sua materialidade, que continuaria e prolongaria, assim, a ação divina".

${ }^{277}$ Cf. BASSET, Jean-Claude. El diálogo interreligioso. Desclée: Bilbao, 1999. p. 354.

${ }^{278}$ Cf. JAMES, William. Las variedades de la vida religiosa. Península: Barcelona, 1996. pp. 285287.

${ }^{279}$ Cf. TAMAYO, Juan José. A mística como superacion del fundamentalismo, p. 170. 
Como veremos mais adiante, J. Martin Velasco descreve o fenômeno místico com estas características: caráter holístico, totalizador e englobante, passividade, imediatez, experiência fruitiva, simplicidade ou sinceridade, inefabilidade e experiência certa e obscura ${ }^{280}$. Velasco e Luce López-Baralt ressaltam a dimensão transformadora da experiência mística ${ }^{281}$.

Entretanto, das muitas características que possa ter a mística, ela possui elementos comuns em todas as religiões e pode ser um lugar de convergência das distintas experiências religiosas, pois todas elas se resumem na relação direta e no conhecimento direto do divino. A consciência mística é unitiva, não dual, integradora, não desagregadora; as pessoas místicas se sentem invadidas e transformadas pelo transcendente. Apesar da fugacidade da experiência mística, seus frutos perduram e seus resultados se deixam sentir nas atitudes de quem as vive: serenidade e equilíbrio, paz interior e paciência, alegria e compaixão, desinteresses e simplicidade, amabilidade e acolhida ${ }^{282}$.

Todas essas características reafirmam o que significa para Melloni a mística. Para ele, “a mística é a ou-topia, o 'não-lugar', das religiões e de todo diálogo, na medida em que aponta um campo de ação que está mais além de toda mediação e, ao mesmo tempo, é o lugar mais essencial e originário das diversas crenças e caminhos"283.

Sendo esta região o lugar do seu nascedouro, é também o lugar em que podem se encontrar para aprender a escutar-se e a respeitar-se, e assim, colaborarem juntas na transformação do humano, da sociedade.

Porque, segundo esse autor, toda religião está construída sobre dois polos:

o lugar conhecido por onde começam - sua história e seu universo conceitual e simbólico que configuram uma determinada experiência religiosa - e o não-lugar para o que se dirigem, essas regiões inacessíveis e inefáveis tanto para os símbolos como para os conceitos, cume que é muito mais que um lugar e também mais que um estado ${ }^{284}$.

Assim, cada religião é o veículo supremo em direção ao Absoluto. Não obstante, por detrás e mais além das características externas, como o credo, os

\footnotetext{
${ }^{280}$ Cf. VELASCO, J. Martin. El fenómeno místico, pp. 319-356. Na segunda parte de nossa pesquisa desenvolveremos estas características apresentadas por Velasco. Abordaremos o fenômeno místico a partir de sua reflexão.

${ }^{281}$ Cf. Ibid., p. 319. Cf., a obra de López-Baralt sobre este tema é: El sol a media noche. La experiencia mística: tradición y actualidad. Madri, Trotta, 1996.

${ }^{282}$ Cf. TAMAYO, Juan José. A mística como superacion del fundamentalismo, p. 179

${ }^{283}$ MELLONI, Javier. Las religiones, más allá de sí mismas, p. 09.

${ }^{284}$ Ibid.
} 
ritos, etc., pelas quais é reconhecida e através das quais é transmitida, contém em seu mesmo interior um chamado urgente aos seus seguidores a ir mais além de si mesma, na medida em que tem por essência ser um sinal do Absoluto ${ }^{285}$, o que proporcionará, no diálogo inter-religioso, não deter-se "nas diferenças, às vezes profundas, mas confiar-se com humildade e confiança a Deus, que é maior do que o nosso coração" 286 .

Nessa experiência, o ser humano é provocado a um aprofundamento de si, e nesse encontro consigo, descobre-se no desapego que o impulsiona para o exercício da alteridade ${ }^{287}$. Ou seja, para a descoberta do outro, pois a experiência mística não se fecha no encontro amoroso do fiel com Deus. Ao contrário, "Deus vem a ele e ele quer perder-se em Deus. E Deus sempre o reenvia ao outro homem”288. Deus não cessa de convidar o homem a descentralizar-se, a sair de si, a reconhecer o outro e, nesse reconhecimento, chegar ao Totalmente Outro ${ }^{289}$.

Esta é a razão de ser das religiões serem capazes de indicar caminhos para a $\operatorname{Vida}^{290}$. Por isso, todas incidem nas três dimensões que constituem o ser humano: sua afetividade, sua capacidade cognitiva e sua ação no mundo ${ }^{291}$. E nestes três campos, todos os seres humanos se acham, e, a partir deles, cada pessoa é configurada de um modo determinado.

As tradições religiosas oferecem um modo de trabalhar sobre estas três dimensões, de um jeito que se vá dando forma à transformação que tem que fazer continuamente. Essa experiência acontece a partir da purificação dos afetos e a iluminação da inteligência para que a ação de cada pessoa sobre o mundo seja o mais transparente, pura e desinteressada possível ${ }^{292}$.

Nos exercícios espirituais de Santo Inácio de Loyola, encontramos os mesmos elementos, quando, ao longo da segunda semana, se pede o

\footnotetext{
${ }^{285}$ Cf. SAUX, Henri Le. L'altra riba. Sannyasa o La crida al desert. Claret. Barcelona, 1980, p. 52 Apud. MELLONI, Javier. El no-lugar del encontro religioso, p. 229.

${ }^{286}$ DA, 35.

${ }^{287}$ Cf. BINGEMER, Maria Clara. Alteridade e vulnerabilidade, pp. 82-84. Maria Clara destaca: "Dificilmente se pode acusar - como se tentou tantas vezes - a mística e a contemplação de serem uma prática alienante e evasiva. Ao contrário, a verdadeira experiência iluminativa e espiritual abre a sensibilidade e a inteligência do contemplativo para a realidade cotidiana e o exercício da compaixão para com o próximo". Id., O mistério e o mundo, p. 206.

${ }^{288}$ CATTIN, Yves. A regra cristã da experiência mística, p. 30. In: Concilium, v. 254, n. 04, 1994.

${ }^{289}$ Sobre o reconhecimento do Outro, cf. CASTIÑEIRA, Angel. A experiência de Deus na pósmodernidade. Petrópolis: Vozes, 1997, p. 181.

${ }^{290}$ Cf. MELLONI, Javier. Las religiones, más allá de sí mismas, p. 239.

${ }^{291}$ Cf. PANIKKAR, Raimon. La Trindad. Una experiência humana primordial. Madri: Siruela, 1999. Este autor considera essa tríade uma manifestação da Trindade radical.

${ }^{292}$ Cf. MELLONI, Javier. Op. cit., p. 240.
} 
"conhecimento interno de Nosso Senhor que por mim se tem feito homem para que mais o ame e o siga" ${ }^{, 293}$. Nesta sequência, o conhecimento leva ao amor e o amor até a pessoa de Cristo. O cristão sai de si mesmo para o Outro e os outros. No budismo, fala-se de sabedoria (prajña) e de compaixão (karuna), desde as quais se realiza a ação adequada. Isso está desenvolvido no óctuplo caminho, de onde as três dimensões estão inseparavelmente implicadas ${ }^{294}$. Assim, também, na Torá judia e nos profetas está a conjunção inseparável entre ação, conhecimento e $\operatorname{amor}^{295}$.

Esta experiência provoca a transformação da vida, que, no lugar de estar centrada na angústia pela sobrevivência, torna-se gozo e oferenda, com a certeza de formar parte de uma totalidade infinita que é pura celebração. Isso acontece por permitir a quem vive perceber a presença do mistério em toda parte, pois "Deus conhece todas as línguas e compreende o suspiro silencioso exalado pelo coração de um amoroso" 296 .

Por conseguinte, todas as tradições entendem a Vida como via, como caminho, até essa progressiva abertura ao Absoluto. De diversos modos, contém uma progressão em três tempos que, no cristianismo, tomando-os do neoplatonismo, conhece-se como as vias purificativas, iluminativa e unitiva. A progressão no caminho é uma experiência humana universal ${ }^{297}$.

Melloni sugere a aplicação dessas três etapas ao encontro inter-religioso. Para ele, a etapa purificativa encontra-se na conversão que supõe reinterpretar as próprias crenças, ler os textos sagrados e praticar os próprios ritos de um modo que não seja exclusivista. A etapa iluminativa vai aparecendo quando vai-se passando do primeiro estranhamento e de uma informação superficial sobre o outro ao conhecimento e compreensão dessa alteridade, isto é, quando se começa a com-preender os textos alheios a partir deles mesmos, ou seja, captá-los com o coração, entendendo por coração a sede mais profunda e receptiva do ser humano.

Por último, a via unitiva do diálogo inter-religioso, é assintótica, pois se sustenta no paradoxo de uma união que celebra e venera a diferença. Esta união a-

${ }^{293}$ Exercícios Espirituais de Santo Inácio de Loyola, 104. Apud. MELLONI, Javier. Las religiones, más allá de sí mismas, p. 240.

${ }^{294}$ Cf. Ibid., p. 241.

${ }^{295} \mathrm{Cf}$. Is $58,7-12$.

${ }^{296}$ SCHIMMEL, Annemarie. L'incendie de l'âme: l'aventure spirituelle de Rûmî. Paris. Albin Michael, 1992. p. 201. Apud. TEIXEIRA, Faustino (org.). No limiar do mistério. Mística e religião. São Paulo: Paulinas, 2004. p. 28.

${ }^{297}$ Cf. MELLONI, Javier. Las religiones, más allá de sí mismas, p. 241. 
dual entre as religiões é a mesma que acontece no interior de cada caminho entre o Todo e a parte, entre Deus e a criatura, entre samsara e nirvana ${ }^{298}$. Esta união é o não-lugar comum das religiões na medida em que cada uma vai desprezando seu centro em favor do absoluto de Deus.

Aqui se encontram os sinais para que uma religião possa chegar a ir além de si mesma, assimilando um Mistério sempre maior, provocando o "enriquecimento recíproco e a cooperação fecunda na promoção e preservação dos valores e dos ideais espirituais mais altos do homem"299. Esse é o ponto de partida para o diálogo inter-religioso, no qual as religiões são caminhos por onde as pessoas deverão ser conduzidas à sua origem, ao que "chamamos nosso ser mais profundo, o divino em nós e em tudo o que existe" ${ }^{, 300}$.

Pois é certo que apenas um coração transformado pela experiência de Deus, e não cheio de doutrinas e ortodoxias, saberá dialogar e conviver com o diferente. Um coração assim, não falará de ouvido, nem com sábias palavras, porém vazias de experiências; falará desde o vivido, desde a experiência, raiz e meta de todo autêntico diálogo, colocando em comum suas experiências do divino ${ }^{301}$.

E sobre isso, diz o próprio Alcorão: “em direção a mim está o Devir”, ou seja, trata-se de obedecer a um princípio vital anterior e posterior ao meu e ao teu. Esse respeito e abertura ante a necessidade do Real é o que pode fazer hoje as religiões, no lugar de fartar-se com palavras sobre Deus, procurar retornar as palavras à sua Fonte para que se promova o acesso, e não a saturação da transcendência.

\footnotetext{
${ }^{298}$ Cf. MELLONI, Javier. Las religiones, más allá de sí mismas, p. 244.

299 DA, 35.

${ }^{300}$ MELLONI, Javier. Op. cit., p. 178.

${ }^{301}$ Cf. AGUILAR, Emilio Galindo. Musulmanes y cristianos conducidos por el espiritu. In: MELLONI, Javier. El no-lugar del encontro religioso, p. 190.
} 


\section{Conclusão}

Nesta primeira parte de nossa tese, vimos que o pluralismo religioso é fruto da própria realidade do mundo, que não é uma teoria, é um fato. A sociedade é plural, e esta pluralidade encontra-se presente em todos os seus âmbitos, atingindo o cotidiano da vida humana.

Entendemos que no que diz respeito às religiões, a teologia, por causa desta realidade plural, é provocada com a tarefa de interpretar as religiões à luz da revelação cristã, e surpreende-se por esta realidade significar mais que um desafio, por ser uma possibilidade para que o cristianismo reveja toda sua estrutura e renovando-se, adquira uma maior percepção da revelação de Deus, que se dá sem medida.

Constatamos que, diante do pluralismo religioso e da diversidade de posicionamentos, os encontros provocados por esta realidade com o intuito de conhecer as tradições religiosas se tem revelado uma oportunidade de rico crescimento mútuo entre os diversos membros das diversas religiões. E tem-se destacado a importância que está adquirindo para o diálogo inter-religioso a experiência espiritual em todas as religiões. Nesse contexto, pudemos destacar os místicos como excelentes cultivadores desta experiência religiosa.

O fenômeno místico e religioso adquirem, em nosso contexto ricamente plural, um privilegiado lugar de escuta e de resposta. De escuta porque diante de todos os desafios enfrentados pelas religiões, essas compreendem a necessidade de retornarem a sua essência, irem além da sua teologia dogmática, para atingir o coração e despertar a conversão. Isso significa conduzir seus fiéis à verdadeira experiência de Deus, visto que este é o desejo que move o coração do ser humano, que, indefeso, procura realizá-lo independente de qualquer tradição religiosa.

Quanto à questão das respostas, demos sinais de que estas se encontram na experiência de intimidade que o ser humano realiza com Deus e que acreditamos ser o 'não-lugar', quando cada uma das religiões a partir de seus fiéis se move para o absoluto de Deus, porque, nesse momento, todos estão voltados para um Mistério que sempre será para todos maior. As religiões, assim, realizam sua vocação: serem caminhos para que as pessoas possam ir à sua origem, a Deus. Diante do que constatamos, desejamos dar um salto em nosso estudo e ousaremos apresentar a mística como um paradigma para o diálogo inter-religioso. 


\section{Parte}

\section{Um possível caminho}

\section{A mística como paradigma}

Aqui ousaremos propor a mística como um paradigma para o diálogo interreligioso com a contribuição de dois grandes pensadores, um fenomenólogo da religião, Juan Martin Velasco, e um teólogo cristão, Andrés Torres Queiruga.

Velasco nos ajudará com seus estudos sobre o fenômeno místico. Ele acredita que, em todas as religiões, se encontram experiências místicas. Nesse sentido é possível que a mística seja um lugar em que todos podem se encontrar independentemente de sua origem religiosa.

Por reconhecermos que a experiência mística acontece porque primeiro Deus se apresenta e convida o ser humano ao seu encontro, acreditamos que muito nos pode ajudar Queiruga com seus estudos sobre a Revelação. Para ele, a Revelação adquire uma nova concepção, a do 'dar-se conta' da presença de Deus 'já aí', que, maieuticamente, revela-se ao homem independentemente de sua tradição e cultura.

Teremos, então, um fascinante percurso quando, vislumbrando as experiências místicas realizadas, nas mais diversas tradições, nos damos conta de que todas elas se realizam, porque Deus, o mesmo Deus, as provoca incessantemente.

\section{1 "Em todas as religiões existe experiência mística"}

Nesta parte de nossa pesquisa em que abordaremos as considerações de Juan Martin Velasco sobre a mística como experiência que constitui todas as religiões, procuraremos iniciar nossa reflexão por meio de uma das suas principais obras, segundo a qual não se pode conhecer a verdade de uma religião sem que se passe pelo conhecimento da mística ${ }^{302}$.

\footnotetext{
${ }^{302}$ Para este tema pesquisaremos as obras que Juan Martin Velasco apresenta suas reflexões sobre a mística e o fenômeno religioso. Destacaremos desse autor, as obras: El fenómeno místico. Estudio comparado. Madri: Trotta, 1999; Experiência cristã de Deus. São Paulo, Paulinas, 2001. Nesta segunda parte de nossa pesquisa, aprofundaremos a reflexão de Velasco sobre a mística, mesmo tendo-o já anteriormente citado várias vezes. Isto ocorrerá para que possamos confrontar com a reflexão sobre a revelação de Andrés Torres Queiruga.
} 
Ele realizará seu percurso a partir da fenomenologia da religião, referindo-se ao fenômeno místico em seu conjunto, tendo em conta suas inúmeras formas. No entanto, em nossa pesquisa, enfocaremos as experiências místicas vividas em um contexto religioso. Esse contexto é marcado por uma postura de acolhida em que se supõe que todas as experiências apresentam aspectos, riquezas e valores, mas que em nenhuma delas se esgota. Ele terá como base para descrição da estrutura do fenômeno místico as formas de experiência místicas presentes no cristianismo.

\subsection{0 ser humano, um ser com um mistério no coração}

A importância do místico se dá, porque, segundo o autor, o místico aparece no topo da história das religiões. Por sua causa, são organizados os diferentes elementos de cada sistema religioso. Ele "é alguém que vive pessoalmente a religião a que pertence, que realiza contato experiencial com a realidade última, o Mistério, Deus, o Divino"303.

Realiza com uma inigualável intensidade a experiência que se sobressai a todos os elementos que compõem uma religião. É apresentado como o sujeito que possui o 'conhecimento experimental do sagrado', de onde se originam as palavras, os ritos, e por último as instituições onde se cristalizam e que depois conhecemos como religião ${ }^{304}$.

O místico religioso é, então, alguém que nasce em uma tradição e não se contenta em apenas receber o conhecimento sobre o Mistério, mas decide fazer seu próprio caminho, em um processo originário, confessando como acontece nas várias tradições religiosas que "conhecia-te só de ouvido, mas agora viram-te meus olhos"305.

Daí que o "homem finito, falível por todos os seus flancos, contém em si a ideia de infinito - que não pode vir nem de si mesmo, nem do mundo - que só o

\footnotetext{
${ }^{303}$ VELASCO, J. Martin. El fenómeno místico, p. 253; Desta peculiar forma de experiência de Deus revelam-se as definições de mística que se adquiriu ao longo da história: Cognitio Dei experimentalis (Tomas de Aquino); "Uma experiência da presença de Deus no espírito pelo gozo interior que dela nos procura um sentimento intimo" (J. Tauler); uma "advertência amorosa de Deus" (S. João da Cruz). Hoje estudiosos falam de uma 'experiência fruitiva do Absoluto'; entende por mística 'a tomada de consciência de uma união ou unidade com ou em algo imensamente maior que o eu empírico'(R. C. Zaehner). Cf. Id., El fenómeno místico en la historia y en la actualidad. In: VELASCO, J. Martin (org). La experiencia mística, p. 17.

${ }^{304}$ Cf. Ibid., p. 10.

305 Jó $42,5$.
} 
infinito pôde pôr nele" ${ }^{306}$. Surge o desejo de experimentar e fazer seu um mais além de si mesmo que busca alcançar e com o que não pode coincidir. Que se dá no encontro com Deus, que só tem lugar "na alma no mais profundo centro"307.

Pois é da originalidade do interior do homem e da presença que o habita que nasce a originalidade do itinerário do homem em direção a ele, porque "o centro da alma é Deus" ${ }^{308}$. Assim, a experiência do centro, realizada pelo homem, consiste num movimento permanente de concentração e saída do centro, de entrada no mais interior de si mesmo e da saída irreprimível mais além de si mesmo ${ }^{309}$.

Esta experiência originária de Deus consiste, em primeiro lugar, na atitude de reconhecimento, no consentimento a seu chamado, e na entrega. Isto é o que a fenomenologia da religião identifica como atitude religiosa fundamental, que as diferentes religiões realizam, em caminhos históricos determinados e de distintas formas.

No entanto, essa "experiência de Deus não é outra coisa senão uma forma peculiar de experiência de fé, a encarnação desse reconhecimento de sua presença misteriosa nas diferentes faculdades da pessoa e nas diferentes situações da vida" 310 .

Essa atitude significa para Velasco "um convite do Espírito a abrir os olhos e deixar-nos surpreender por esse Deus" ${ }^{\text {"311 }}$, que não se deixa encerrar no terreno da religião por ser maior que a consciência, a linguagem e os conceitos precários que as várias tradições religiosas oferecem.

É fato que, embora a secularização da sociedade e da cultura tenha eliminado determinadas formas de presença da religião em nosso mundo, não conseguiu eliminar todas as pegadas da presença que a vida religiosa origina e que pulsam sob as formas mais variadas, até na vida secularizada.

É certo que, mesmo em uma cultura sem nenhuma referência ao religioso, a experiência religiosa funda-se de forma autônoma, e seu reconhecimento efetivo se dá no terreno da ética, na relação interpessoal aberta pelo rosto do outro, pela

\footnotetext{
${ }^{306}$ VELASCO, J. Martin. El fenómeno místico en la historia y en la actualidad, p. 25.

${ }^{307}$ CRUZ, S. João da. Obras Completas. Petrópolis: Vozes; Carmelo Descalço do Brasil, 1984. Poema: Chama de amor viva 1,12 (Todas as citações de S. João da Cruz serão desta obra); Cf. VELASCO, J. Martin. El fenómeno místico en la historia y en la actualidad, p. 31.

${ }^{308}$ S. João da Cruz. Poema: Chama de amor viva, 1,12.

${ }^{309}$ Cf. VELASCO, J. Martin. El fenómeno místico en la historia y en la actualidad, p. 36.

${ }^{310}$ Ibid., p. 38.

${ }^{311}$ Id., Experiência cristã de Deus, p. 7.
} 
experiência estética e na luta pela justiça. Tudo isso põe o homem moderno em contato com o Absoluto, e promove a tomada de consciência, mesmo que obscura, dessa presença ${ }^{312}$.

Assim, de uma compreensão do homem como subjetividade transcendental, constitutivamente aberto à transcendência, que leva a marca dessa abertura em todas as suas faculdades, provocado por experiências muito diferentes, poderá fazer a experiência da fé. Experiência humana mais significativa na vida de cada pessoa em relação à qual descobre e reconhece a presença 'doadora', gratuita, 'condescendente' e, portanto, reveladora desse Mistério que o origina ${ }^{313}$.

Para Velasco, está comprovado que todas as tentativas para compreender o Mistério divino e esclarecê-lo apontam para o

centro que cada vez se apresenta mais nitidamente com uma Presença, tão invisível como inconfundível, que o sujeito religioso, por meio de todos os elementos que configuram uma religião, trata de fazer sua, da qual trata de tomar consciência, de manter contato ${ }^{314}$.

O fenômeno místico é, então, a chave para que possam ser decifrados alguns dos problemas encontrados nas questões com o fenômeno religioso ${ }^{315}$. Por isso reconhece nas palavras de $\mathrm{K}$. Rahner que a mística assume um valor de extrema necessidade, quando este diz que o homem religioso do amanhã deverá ser místico para sobreviver a esta crise $^{316}$.

A mística, então, encontra-se na fronteira entre as questões do fenômeno religioso, que, por ser extraordinariamente complexo, deve ter todos os seus elementos levados em consideração quando se procura entender sua estrutura e seu sentido, visto que esses elementos que constituem esse fenômeno contribuem para a manifestação de seus traços significativos, quando a experiência do ser humano assume o lugar central ${ }^{317}$.

É por isso que as atenções de vários estudos das ciências das religiões têm se deslocado das estruturas institucionais e seus aspectos externos para as experiências do sujeito, por existir um estreito laço entre religião e mística,

\footnotetext{
${ }^{312}$ Cf. VELASCO, J. Martin. Experiência cristã de Deus, p. 22.

${ }^{313}$ Cf. Ibid., p. 49.

${ }^{314}$ Ibid., p. 9.

315 Sobre as questões que se referem ao fenômeno religioso, cf. Id., El malestar religioso de nuestra cultura, pp. 81-100.

${ }^{316}$ Cf. Id., El fenómeno místico, p. 11.

317 Cf. Ibid., pp. 9-10. Abordaremos ainda neste capítulo os elementos que para Velasco constituem o fenômeno místico.
} 
constatado pela presença de numerosos fatos místicos em muitas religiões. Além disso, observa-se que traços próprios da atitude religiosa são caracterizados como místicos.

Afinal, se tem entendido que é impossível conhecer de verdade a religião sem passar pelo conhecimento da mística, para que não seja ignorado o seu núcleo mais íntimo, sua verdade definitiva.

Isso leva Velasco a acreditar que a mística seja um caminho para avançar no conhecimento sobre a religião, porque, segundo ele, o estudo sobre a mística não vem apenas completar teoricamente o aprofundamento do fenômeno religioso, mas, sim, ser um caminho útil para avançar no conhecimento da religião e indispensável para ter um pouco de claridade na situação religiosa do homem de nossos dias, como também o conhecimento do próprio homem contemporâneo ${ }^{318}$.

O reconhecimento desta estreita relação é também proveniente do reconhecimento da mística como parte integrante da religião, apresentado por estudos de outras ciências como da psicologia e da filosofia. Mesmo que seja praticamente unânime o seu reconhecimento e a afirmação da presença da mística em todas as religiões, está muito distante a unanimidade na explicação da forma concreta da relação vigente entre os fatos e a forma precisa da presença da mística nas religiões justamente por não conseguirem esgotar o seu fenômeno ${ }^{319}$.

No entanto, Velasco reafirma as palavras de Von Hügel, o qual diz: "a

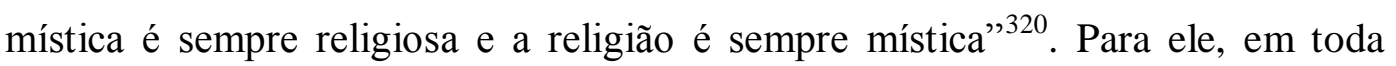
experiência religiosa, encontram-se elementos místicos e em todas as pessoas existe uma predisposição ontológica e psicológica para algo que a experiência mística assegura desenvolver em plenitude. E é, então, nesta abertura ao infinito, base do elemento místico em que se conserva a origem na presença ontológica de Deus no sujeito, que se dá o encontro pela fé.

\subsection{A mística e sua linguagem humana}

A mística é um fenômeno humano, porque se refere a uma experiência no mais íntimo da pessoa de uma realidade sobre-humana, indo além do seu contexto

\footnotetext{
${ }^{318}$ Cf. VELASCO, J. Martin. El fenómeno místico, p. 11.

${ }^{319}$ Cf. Ibid., p. 33.

${ }^{320}$ Ibid., p. 31.
} 
de vida ordinário. Esse fenômeno se torna presente no mundo por meio de várias manifestações que se convertem em um fato histórico, em grandeza humana.

A importância da linguagem no fenômeno místico adquire sua primeira expressão pelo fato de a palavra mística ter sido utilizada como adjetivo para referir-se ao sentido oculto dos textos, passando a ser designado como linguagem no séc. XVII, empregada como adjetivo para designar as pessoas que vivem ou padecem experiências místicas e como substantivo para referir-se ao fato, objeto da teologia mística ${ }^{321}$.

Nesse momento, a mística passa a se constituir essencialmente pelo corpo dos escritos em que os místicos formulam suas experiências. Nesses escritos religiosos, a linguagem mística apresenta-se com os mais variados gêneros literários. Nos menos sistemáticos ocorre um entrelaçamento entre os gêneros literários, ou seja, a presença em uma mesma página de vários gêneros. Esta linguagem distingue-se da liturgia, da pregação e da teologia ${ }^{322}$.

Nos textos de linguagem mística, as palavras nem sempre são apresentadas como se compõem na linguagem ordinária. Velasco cita J. Baruzi que diz: “A linguagem mística, propriamente dita, emana menos vocábulos novos que transmutações operadas no interior de vocábulos tomados da linguagem normal" ${ }^{323}$. No entanto, o místico, em muitos momentos, recorre a uma criação própria de palavras, na tentativa de melhor expressar algumas de suas experiências e, como veremos, possibilitará o surgimento de uma nova linguagem.

Esta linguagem é fragmento do momento originário da experiência, que não é apenas responsável por tornar a experiência comunicável, ou seja, por descrever a experiência que o provoca, mas em colaborar com o desvelamento da realidade no que consiste a verdade e seu conhecimento, que constitui o umbral do humano.

Isso leva Velasco a afirmar que

não existe uma experiência pura, anterior a toda linguagem. Sem a presença de algum tipo de linguagem, a experiência não seria experiência humana, se perderia no reino pré-humano do inconsciente. A experiência mística, como toda experiência humana, exige, para existir como tal, aflorar a consciência ${ }^{324}$.

\footnotetext{
${ }^{321}$ Quem faz esta observação é M. de Certeau. "Mystique au XVII siècle. Le problème mystique", en L' homme devant Dieu. Mélangues H. de Lubac II, Aubier, Paris, 1964, pp. 276-291. Apud. VELASCO, J. Martin. La experiencia mística, p. 17.

${ }^{322}$ Sobre os gêneros literários Cf. VELASCO, J. Martin. El fenómeno místico, p. 50.

${ }^{323}$ BARUZI, J. Introduction à des recherches sur Le langage mystique: Recherches philosophiques (1931-1932) In: Encyclopédie des mystiques I, Seghers, Paris, p. 39. Apud. VELASCO, J. Martin. El fenómeno místico, p. 51.

${ }^{324}$ Ibid., p. 59.
} 
A linguagem mística possui os mesmos traços que, em geral, caracterizam o fenômeno religioso. No entanto, a linguagem mística se distingue por sua condição de ser uma linguagem que tem a ver com sua 'proximidade', ou seja, pela experiência que se vive e se expressa graças a ela. "O místico não fala, como o teólogo, simplesmente de Deus. Fala do Deus que se tem dado como presente em uma experiência",325.

Assim, sua linguagem ordinária não comporta tal experiência. E por isso, é característica comum a todos os místicos e a todas as formas de linguagem mística a convicção da "insuficiência da linguagem"326.

Essa insuficiência não impede, no entanto, que ocorra a comunicação dos místicos. Ao contrário, libera forças criadoras que geram uma nova linguagem, despertando suas capacidades expressivas e que levam ao limite o poder significativo das palavras, pois o próprio da linguagem mística não é apresentar novos objetos nem novas verdades, mas, sim, produzir uma transmutação cuja origem está na "secreta mudança de quem recebe essas verdades" 327.

Essa capacidade de gerar uma nova linguagem resulta na categoria chamada de 'transgressividade' da linguagem mística, que procura não apenas levar o sentido primeiro dos vocábulos até o limite de sua capacidade significativa, mas também da sua utilização simbólica cujas expressões aparecem nas metáforas. Com a presença significativa dos símbolos na linguagem mística, lhe é conferida a grande proximidade com a linguagem poética.

O símbolo é a linguagem radical originária da experiência fundante, e precisamente, por seu uso, o místico pode tomar consciência da Presença não objetiva e originante que o habita como dimensão de sua última profundidade. Assim,

o símbolo seria, pois, a palavra fundamental da experiência mística em que se revela e realiza a relação com o ser que constitui o ser humano e que se expressa, segundo as tradições, como abismo sem nome, como absoluto, como pessoa, como $\operatorname{amor}^{328}$

No entanto, esta transgressividade própria da linguagem mística aflora em outras características, como a profusão de superlativos, que permite em alguns

\footnotetext{
${ }^{325}$ VELASCO, J. Martin. El fenómeno místico, p. 51.

${ }^{326}$ Id., El fenómeno místico en la historia y en la actualidad, p. 19.

${ }^{327}$ Id., Op. cit., p. 52.

${ }^{328}$ Ibid., p. 62.
} 
textos místicos um estilo hiperbólico, exagerado, o que se reafirma como seu recurso à metáfora, ao paradoxo e à antítese ${ }^{329}$.

Quando o místico toma consciência de sua experiência, sua linguagem assume um novo sentido e um novo significado e esta nova linguagem, por sua natureza 'transgressiva' e simbólica, atinge seus níveis mais originários ali onde aparecem os símbolos, com sua força e imediatez, onde aflora a ruptura analógica que suscita toda linguagem. O que descreve essa linguagem é essencialmente a experiência mística, ou seja, a experiência de fé vivida de uma forma peculiar, uma experiência intensa de união com Deus.

Para os místicos, o paradoxo em seus textos são expressões que vão contra a opinião vigente no mundo e na vida ordinária, de que a experiência mística vem subverter. Porque revela a insuficiência, vivida pelo místico, de sua linguagem para expressar a densidade de sua experiência e a eminência e profundidade da realidade a que chega ${ }^{330}$. O uso do paradoxo remete, então, à condição misteriosa da realidade dada na experiência, de seu conteúdo, do Deus que se faz presente nela.

Este recurso é tão característico da linguagem mística que aparece nos escritos místicos de todas as tradições religiosas. Também muito utilizado nos textos místicos, a antítese desempenha uma função parecida com o paradoxo, pois quer falar do que se refere

ao fundo da alma, a Deus, à sua ação sobre o homem ou à resposta desta presença, sua nova forma de expressar a incapacidade de referir-se, com os termos vigentes na experiência ordinária, à experiência singular que ele vive e, especialmente, o conteúdo da mesma ${ }^{331}$.

Velasco nos aponta outros recursos linguísticos, além desses já apresentados, em que os místicos procuram testemunhar ter alcançado o limite do humanamente compreensível. Ele se refere ao fato de que as informações que deveria o místico transmitir não conseguem fazê-lo em absoluto. E nesse caso, "a linguagem parece aproximar-se ao fenômeno verbal, porém já claramente

\footnotetext{
${ }^{329}$ Cf. VELASCO, J. Martin. El fenómeno místico, p. 54.

${ }^{330} \mathrm{Cf}$. Id., El fenómeno místico en la historia y en la actualidad, p. 21.

${ }^{331}$ Id., Op. cit., p. 55.
} 
extralinguístico, da glossolalia" ${ }^{332}$. E o limite desta linguagem é o silêncio, entendido como condição da própria linguagem mística, não como indiferença ${ }^{333}$.

Por ser expressão de uma experiência interior, a mística tem, segundo Velasco, como característica ser auto-implicativa e testemunhal, como toda linguagem de $\mathrm{fe}^{334}$. Por ser uma linguagem testemunhal, esta deve dar conta de algo que o sujeito tem vivido, que 'tem visto e ouvido', e por isso não pode calar $^{335}$.

Essa nova linguagem que surge a partir de uma experiência intensa da Presença originante terá seu estilo determinado por uma predisposição do sujeito lírica e psicológica, do uso do próprio material que o constitui, onde, a partir da tradição e de seu contexto, suas experiências serão verbalizadas.

\subsection{A presença originante}

A experiência mística depende de um 'outro'. Ou seja, de uma "natureza totalmente 'outra' em relação com as realidades mundanas e também com a própria realidade" ${ }^{336}$. Realidade Última, que se refere à categoria religiosa de "Mistério". É designada pela fenomenologia da religião como a realidade anterior e superior ao homem, em que cada religião se configura através de sua tradição e cultura, como também em um contexto não religioso. Uns identificam esta realidade como Deus, outros como o Uno, o Divino, o Brahman, o Tao, o Infinito, o Absoluto, ou como Transcendência ${ }^{337}$.

O Absoluto ultrapassa todos os sistemas religiosos e chega, assim, ao profano. E como realidade última, como 'Mistério', esta presença consta em toda a história religiosa da humanidade e talvez seja certo que determinadas formas de pensar esta realidade não são, na verdade, mais que outras formas de configurar a mesma realidade última, o mesmo Absoluto, cuja presença na história humana está seguramente atestada, e com toda certeza não se esgota nela mesma ${ }^{338}$.

\footnotetext{
${ }^{332}$ VELASCO, J. Martin. El fenómeno místico, p. 53.

${ }^{333}$ Sobre o silêncio e a palavra nos escritos místicos, Velasco faz referência ao artigo de J. Leclerq, Silence et parole dans l'experience spirituelle d'aujourd'hui. Collectanea Cisterciensia 45, 1983. pp. 185-198. Apud. Ibid., p. 56.

${ }^{334}$ Cf. Ibid., p. 57.

${ }^{335} \mathrm{Cf} . \mathrm{Hb} 4,20$.

${ }^{336}$ VELASCO, J. Martin. El fenómeno místico, p. 253.

${ }^{337} \mathrm{Cf}$. Id., El fenómeno místico en la historia y en la actualidad, p. 25.

${ }^{338}$ Cf. Id., El fenómeno místico, p. 254.
} 
Porque, assegura Velasco, todas as tentativas para compreender o Mistério divino e esclarecê-lo apontam para o "centro que cada vez mais se apresenta mais nitidamente com uma Presença, tão invisível como inconfundível"339.

Assim, em outro momento, ele vai dizer que, diante de todas as representações desta realidade última, existem dois traços comuns a todas elas:

a absoluta transcendência dessa realidade frente ao homem e a todas as realidades de seu mundo, sua condição de totalmente outro; e ao mesmo tempo, e precisamente por ser absolutamente transcendente, sua condição de realidade íntima imanente em toda a realidade mundana e no coração mesmo do homem ${ }^{340}$.

Essa Presença por sua condição transcendente-imanente em relação às realidades mundanas é o centro de toda a vida humana. E a religião, antes de ser explicação do mundo, teoria sobre Deus ou institucionalização social, consiste no próprio fato da religação, pois ela é em sua raiz, religação ao poder do real atualizado em toda pessoa humana ${ }^{341}$.

Toda pessoa humana encontra nesta Presença o seu centro como uma forma de resposta a ela. Pois, sem esta Presença, o homem não transcenderia ${ }^{342}$. Nem ao menos poderia conhecer, ou mesmo supor, que existisse uma realidade que, por definição, o ultrapasse absolutamente.

A religião, então, está sob esse fato originário, esse primeiro dado fundante da experiência humana que é a Presença originante que o constitui. Nesta Presença, repousa não só a religião, como também a própria experiência humana enquanto procura alcançar a sua verdadeira raiz.

Entendemos, então, que a Presença originante está em toda experiência humana de formas variadas, pois esta dimensão de transcendência que possibilita ao homem a Presença originante está "em todas as dimensões fundamentais em que a pessoa se realiza: na consciência, na tendência e no desejo, no sentimento, na liberdade",343.

Por conseguinte, é de grande importância a análise dessas dimensões para que se possa por em evidência essa Presença, mesmo assumindo a dificuldade para se fazer justiça a esta precedência absoluta do Mistério em relação com todo o real e com nós mesmos. Afinal, não nos é impossível, pela nossa condição

\footnotetext{
${ }^{339}$ VELASCO, J. Martin. Experiência cristã de Deus, p. 9.

${ }^{340}$ Id., El fenómeno místico, p. 254.

${ }^{341}$ Cf. Id., Experiência cristã de Deus, p. 27.

${ }^{342}$ Cf. Id., El fenómeno mistico, p. 254.

343 Ibid., p. 255.
} 
humana, referirmos-nos a ele, ao Mistério, a partir de uma realidade criada por nós. Enquanto, para descobrir sua origem e raiz, devemos referir-nos ao Mistério sem querer tê-lo por objeto.

Pois toda pergunta do homem sobre Deus é precedida por outra. Sua pergunta é eco à pergunta que Deus dirige a ele desde sempre. E quando procura responder à pergunta sobre Deus,

ele se dá conta de que só poderá respondê-la quando toma consciência de que esta pergunta tem sua origem em outra. E apenas quando se tem a consciência de que de antemão, já é questionado por Deus, se pode perguntar por Deus verdadeiramente ${ }^{344}$.

E é apenas quando o homem toma consciência da precedência absoluta de Deus, segundo Velasco, que a análise das dimensões fundamentais da sua existência se converte em lugares favoráveis para perceber essa Presença ${ }^{345}$.

Os místicos, que têm nesta Presença-ausência a origem de seu itinerário para Deus, por não conseguirem abarcá-lo e tê-lo para si, são impulsionados por um desejo sempre presente na constante busca de sua realização.

É este desejo uma das dimensões centrais no homem, chamado por S. Agostinho de o 'âmago do coração do homem' e que Spinoza disse ser: 'a essência mesma do homem'. E entre todas as necessidades e desejos, está, segundo S. João da Cruz, 'o que deseja o teu coração'. Velasco quer falar aqui, portanto, de um desejo que vai além da pessoa, por ser anterior a ela, e por inquietá-la constantemente, porque esse a constituiu ${ }^{346}$.

Diante dessa dimensão que constitui o homem, pode-se dizer que existe no ser humano um forte querer originário, que surge da necessidade de querer experimentar e fazer seu um mais além de si mesmo que busca alcançar e com o qual não pode coincidir. Dessa mesma raiz, surge o milagre da liberdade, coração da dignidade da pessoa, que, antes de ser escolha e inclusive domínio de si, é aceitação da existência dada por uma generosidade anterior ${ }^{347}$. Porque está no núcleo da existência humana sua condição de "síntese ativa de finitude e infinitude do temporal e do eterno, de liberdade e necessidade" ${ }^{348}$.

\footnotetext{
${ }^{344}$ VELASCO, J. Martin. El fenómeno místico, p. 256.

${ }^{345}$ Cf. Ibid., p. 180.

${ }^{346}$ Cf. Ibid., p. 257; Ver a notas: 8, 9, 10.

${ }^{347}$ Cf. Id., Experiência cristã de Deus, p. 24.

${ }^{348}$ Id., El fenómeno místico, p. 258. Cf. notas 14 e 15.
} 
Por isso, é para Velasco de muita importância para a realização e compreensão da mística reconhecer a antropologia que está por trás da experiência fundamental dos místicos. São várias as expressões que os místicos, por suas tão diferentes experiências, apresentam sobre a antropologia, no entanto, todas convergem na compreensão de que:

a presença no homem de um mais além de si mesmo, sua condição de estar habitado por um excessus que o inunda e o transborda; a definição de si mesmo como ser que se supera infinitamente; de ser fronteiriço entre o finito e o infinito, de ser constitutivamente religado ao poder do real, de ser 'ouvinte da Palavra' ${ }^{349}$.

A imagem do homem na mística hindu é um perfeito acordo com o sistema 'monista' de explicação do real em que se apresenta o sujeito como uma mesmidade no Absoluto. E no ateísmo religioso budista essa imagem se reflete na doutrina do não-sujeito.

No cristianismo, a compreensão do homem está pautada a partir da expressão bíblica de sua criação 'à imagem e semelhança' de Deus. Nessa imagem apoia-se a consciência da inigualável dignidade do homem, de sua condição de excelência da criação da referência de todo seu ser e toda sua vida até a comunhão com Deus, como fim ao qual Deus tem designado e orientado cada $\mathrm{um}^{350}$.

Os místicos da tradição cristã fazem sempre referência, por meio de suas experiências, ao mais íntimo do ser humano, como lugar último de relação, 'infinito santuário' de comunicação e de encontro com Deus ${ }^{351}$. Porque aqui, para esta tradição, todas as descrições dos sentidos e faculdades do homem são superadas pela experiência mística. Este lugar último de relação é um sinal da permanente Presença de Deus que impulsiona o homem para si. A fé o leva a abandonar-se e consentir a força desta Presença.

A partir das experiências místicas vividas nas várias tradições religiosas, Velasco constata que "a vida mística descansa sobre a Presença originante do Mistério na realidade e no centro do homem" ${ }^{\text {352 }}$. No entanto, os místicos são unânimes em afirmar que só a Presença não basta, pois esta experiência de

\footnotetext{
${ }^{349}$ VELASCO, J. Martin. El fenómeno místico, p. 260. Aspas colocadas pelo autor.

${ }^{350}$ Sobre este tema, Velasco não desenvolve o significado de cada termo da expressão 'imagem e semelhança' e sua relação com os Padres gregos e latinos da Igreja. Cf. Ibid., p. 261.

${ }^{351}$ Cf. Ibid., p. 261.

${ }^{352}$ Ibid., p. 271. Essa afirmação de Velasco é proveniente de um apurado estudo realizado sobre a mística nas grandes religiões orientais e nas grandes religiões proféticas. Cf. nesta mesma obra pp.131-244.
} 
encontro com a Presença que se dá no centro, no interior do homem, exige do sujeito o cumprimento de determinadas condições e só desta maneira se poderá entender o impulso que podemos chamar de místico, que pessoas e grupos de diferentes épocas e tradições têm para viver uma experiência mística.

A importância do reconhecimento da necessidade de serem cumpridas algumas condições dá-se pelo fato de que sempre ocorrem na história casos atestados de experiências ordinárias de superação da consciência e a entrada em 'outra condição' espécie de ruptura de nível na existência, que podem ser identificadas como experiências de transcendência ou fenômenos análogos ${ }^{353}$.

Entretanto, essas experiências, mesmo constatadas como fenômenos extraordinários, não é evidente que sejam um fenômeno místico. Porém, podem despertar um processo de verdadeira experiência mística quando o sujeito entra em contato com o Mistério consciente de que este contato o põe em relação com uma Presença que "já estava ali previamente",354 e o impulsiona a uma acolhida.

Essa 'Presença', que, no sentido mais rigoroso do termo, é uma realidade em ato de revelação e comunicação, é Presença que 'dá de si' à pessoa e que nunca deixa de insinuar-se. É uma existência dirigida pessoalmente, e que requer daqueles a quem se dirige a acolhida aceitação, o reconhecimento.

No entanto, o homem pode ignorar esta Presença evitando todos os sinais para que sua vida não seja importunada por acontecimentos os quais não seja capaz de dominar. Como pode também, além desta indiferença, simplesmente rejeitá-la.

Assim, a Presença não se deixa ouvir, por querer desligar-se do que o fundamenta - e a vida continua na superfície da realidade - alheio aos níveis de realidade e de consciência que estão ao seu alcance ${ }^{355}$.

É necessário, então, à experiência mística aceitar e acolher esta Presença que se oferece. O vocabulário cristão designa isto como atitude teologal, que pode ser resumida, como afirma Velasco, como 'atitude de fé', pois, para ele, "a mística realizar-se-á sempre no interior da fé" ${ }^{356}$. O sujeito supera a dupla tentação de desespero ao pretender realizar-se por si mesmo, por uma radical confiança, em

\footnotetext{
${ }^{353} \mathrm{Cf}$. VELASCO, J. Martin. El fenómeno místico en la historia y en la actualidad, pp. 23-25.

${ }^{354}$ Id., El fenómeno místico, p. 271.

${ }^{355}$ Sobre a indiferença religiosa, cf. VELASCO, J. Martin. El malestar religioso de nuestra, pp. 81-100.

${ }^{356}$ Id., El fenómeno místico, p. 275.
} 
que consiste a fé. Esta confiança provoca um deslocamento produzido pela aceitação de ser a partir de outro e não dispor da própria existência ${ }^{357}$.

A acolhida desta Presença, que gratuitamente se doa, também se dá fora do ambiente religioso, por não ser a religião a "única encarnação possível da atitude fundamental que a origina" ${ }^{\text {358 }}$. Velasco destaca a existência de uma estrutura semelhante entre as experiências místicas que acontecem fora do ambiente religioso, daquelas que acontecem no interior das religiões, pois o que está em seu núcleo, como atitude de acolhida e de conversão, está também, em termos diferentes, nas demais religiões.

Assim, essa acolhida apresenta-se no cristianismo na forma de atitude teologal, como fé-esperança-caridade. No judaísmo, descreve-se como obediência e fidelidade. Para os mulçumanos, essa atitude chama-se islã, submissão incondicional. O bramanismo hindu a descreve como 'realização' interior de unidade com o Brahman ou o Absoluto. O hinduísmo devocional resume a atitude religiosa em bhakti, entrega confiante de si mesmo à divindade. Para o taoísmo a atitude fundamental reduz-se a uma conformidade plena com a natureza última ou o principio que rege tudo o que existe. Para o budismo, é a extinção do sujeito no mais além absoluto, com o nirvana ${ }^{359}$.

Diante dos traços estruturais que todas as religiões apresentam no que diz respeito à acolhida da Presença, Velasco procura resumir suas semelhanças, destacando o reconhecimento da absoluta Transcendência-imanência em uma transformação radical de atitude e na aceitação radical de descentramento, em que deixa de ser sujeito da realidade transcendente para vivê-la como sujeito passivo $^{360}$.

Aqui, destaca-se também o aspecto da atitude religiosa movida por uma atitude de fé, em que se rompe a si mesmo no desejo de transcender. Essa é uma experiência assumida pelos verdadeiros crentes das mais variadas tradições religiosas, que consiste no "reconhecimento da Presença que nos origina e

\footnotetext{
${ }^{357}$ Cf. VELASCO, J. Martin. Experiência cristã de Deus, p. 43.

${ }^{358}$ Id., El fenómeno místico, p. 273. Das experiências místicas fora do ambiente religioso, Velasco lembra Plotino. Este quando descobriu o caminho para a contemplação e união com o Uno, indicou que o primeiro passo supõe uma conversão de olhar do exterior para o interior. Para ele a conversão é suscitada pela presença nela do Bem, que suscita o amor da alma. Seu processo consiste que alma atue no sentido do desejo que a oriente para o Bem, que tem como origem a opção por esse Bem, para perceber e acolher 'o amor que faz ver'. Cf. Ibid., p. 274.

${ }^{359}$ Cf. VELASCO, J. Martin. Experiência cristã de Deus, p. 38.

${ }^{360}$ Cf. Id., El fenómeno místico, p. 275; Cf. Id., A experiência cristã de Deus, pp. 62-69.
} 
coincide com o mais além de nós mesmos, que nos faz permanentemente ser, sendo, portanto, a entrada na única via para a realização de nós mesmos, no mais além de nós mesmos" ${ }^{, 361}$.

A mística sempre se realizará no interior da fé, pois, para ele, nas formas de mística religiosa, a experiência nunca deve tomar um caminho alheio ao da fé, ou alternativo a ela, o que significa uma característica que distingue as experiências místicas religiosas das não religiosas ${ }^{362}$. Conforme indica H. de Lubac: "A mística cristã, longe de escapar à ordem da fé, está na lógica da vida de fé. Nutre-se de outra coisa que não ela mesma. A experiência mística do cristianismo não é um aprofundamento de si mesmo; é aprofundamento da fé" 363 .

A importância da fé para uma melhor compreensão da mística e do seu processo de realização leva Velasco a deter-se na mística cristã, tendo-a como referência. Faz isso por perceber que a existência e a necessidade da atitude teologal tem orientado este fenômeno e que da estrutura do fenômeno místico, de suas principais manifestações, remete à experiência como seu elemento central. Desta forma, uma fenomenologia fiel da experiência mística, ao menos no caso das místicas de caráter religioso, descobre por debaixo dela a atitude teologal, ou seus homólogos em outras tradições ${ }^{364}$.

Teólogos e espiritualistas, pela leitura das experiências místicas à luz das Escrituras e da própria experiência, têm descoberto no homem a condição de imagem de Deus que o aproxima dessa Presença e o faz compartilhar de alguma maneira de sua natureza. Graças a essa presença prévia do amor de Deus na raiz e no centro da pessoa, o amor do homem a Deus consiste em sintonizar com o chamado que o constitui como ser humano, e esse amor lhe concede uma 'conaturalidade', uma 'familiaridade' com Deus, que torna possível o conhecimento imediato que comporta toda verdadeira experiência ${ }^{365}$.

Entretanto, faz-se necessário que o ser humano renuncie a interpor entre Deus e ele mesmo sua pretensão egocêntrica. Já que o amor vem de Deus, já que o

\footnotetext{
361 VELASCO, J. Martin. El fenómeno místico, p. 275.

${ }^{362}$ Cf. Id., El fenómeno místico en la historia y en la actualidad, p. 36.

${ }^{363}$ LUBAC, H. de, La mystique et les mystiques, Paris: DDB, 1964, p.2. Apud. Id., El fenómeno místico, p. 276.

${ }^{364}$ Cf. VELASCO, J. Martin. El fenómeno místico en la historia y en la actualidad, p. 35.

${ }^{365}$ Cf. Id., Experiência cristã de Deus, p. 63.
} 
amor é Deus mesmo dado ao homem, o amor do homem consiste só em consentir esse amor $^{366}$.

Assim, ocorrerá no sujeito uma 'conversão do olhar', que tem sua origem na conversão de toda a sua alma. Neste caminho, encontram-se os primeiros Padres quando desenvolvem o tema da imagem de Deus na alma, que a conduz para a semelhança, a assimilação e a divinização ${ }^{367}$.

No entanto, esta 'conversão do olhar' não esgota a riqueza da conversão que afeta toda a pessoa, pois a mudança de olhar é inseparável da reorientação do coração e aqui estaremos entrando em um novo aspecto que consiste na dimensão teologal. Aí vemos que esta mudança em relação ao coração acontece também na fé como descentramento e consentimento à Presença.

Isto significa dizer que:

Em verdade, aqui eu não sou 'sujeito', sou 'objeto'. Outro é o sujeito. Outro age fundamentalmente. A experiência religiosa - nós diríamos a fé - é o reconhecimento de que eu sou objeto de parte de Deus: aí eu já não sou consciência intencional, e sim, consciência convocada ${ }^{368}$.

Velasco cita S. Bernardo, que é quem melhor diz sobre o sentido desta experiência. Para ele, a fé é a 'conversão do coração a Deus'. Nessa conversão, o sujeito é o próprio coração, que é o centro unificador da pessoa, o centro da alma. Com essa reorientação do coração, o homem passa a aderir à imagem de Deus que está impressa em seu ser. E isto é uma atitude teologal em que o coração passa a ser simplificado e unificado, para, assim, poder contemplar o único e perfeitamente simples ${ }^{369}$. Assim, “a reorientação do coração em que consiste a fé comporta igualmente a reorientação do amor" ${ }^{370}$, afetando o próprio ser da pessoa.

A isso se referem às tradições religiosas quando dizem que o exercício da atitude religiosa supõe um novo nascimento e a conversão do coração. O novo ser vive de forma nova. A razão fiel, mais que explicar a realidade, deixa-se iluminar por sua luz; a vontade, mais que dominar, reconhece e consente.

\footnotetext{
${ }^{366}$ Sobre este amor disse Simone Weil que: "Só podemos consentir em perder nossos sentimentos próprios para dar passagem em nossa alma a este amor. Isto é negar-se a si mesmo. Somos criados só para esse consentimento, cf. WEIL, Simone. Attente de Deus, Paris, La Colombe, 1950. p.108. Apud. VELASCO, J. Martin. Experiência cristã de Deus, p. 63.

${ }^{367} \mathrm{Cf}$. Id., El fenómeno místico, p. 278. Aqui ocupa como eixo, a doutrina da encarnação.

${ }^{368}$ Id., Experiência cristã de Deus, p. 44.

${ }^{369}$ Cf. Id., El fenómeno místico, p. 279.

${ }^{370}$ Ibid., p. 280.
} 
Para outro aspecto de conversão na vida teologal, a esperança, Velasco refere-se a S. João da Cruz. Para ele, "para que a alma venha a unir-se a Deus em esperança, há que renunciar a toda posse de memória [...]; porque, quanto mais tem de posse (a memória), tanto menos tem de esperança"371.

A doutrina das virtudes teologais com sua correspondência às 'faculdades da alma' permite à vida espiritual do sujeito a possibilidade da mudança de orientação que imprime no sujeito a 'conversio cordis,372. Uma mudança que, segundo ele, dá origem a uma nova existência em que o homem assume a condição de imagem com que Deus o tem dotado, entregando-se ao querer ilimitado, ao 'desejo abissal' que o abre ao amor de Deus.

Essa nova forma de existência, que consiste em crer para se realizar efetivamente, necessita encarnar-se na totalidade de condições, aspectos e dimensões de cada sujeito; necessita ser 'vivenciada'. A opção fiel inicial e radical fraciona-se na multidão de facetas das diferentes pessoas e origina a incontável variedade de experiências religiosas concretas. Essa variedade é produzida no interior de cada uma das tradições religiosas e com frequência aparece ao longo da vida de uma mesma pessoa ${ }^{373}$.

Enfim, essas virtudes teologais destacam o caráter teologal da experiência mística e nos fazem perceber que o nascedouro dessa experiência é a fé. A mística, então, constitui uma forma peculiar e privilegiada de experiência que permite a realização efetiva da dimensão teologal: a fé-esperança-caridade ${ }^{374}$. Diante da afirmação de que a mística nasce da fé, a experiência de fé deve ser assumida e vivenciada pela pessoa em todas as dimensões do seu ser, na 'conversão do coração'.

De acordo com Velasco, se for ignorada nas tradições religiosas esta atitude, significa que se vive uma religião muito longe do que lhe é essencial ${ }^{375}$. Na teologia católica, ele explica que talvez tenha se dado a exclusão deste tema depois do Concílio de Trento, por causa do temor que essa experiência provocava

\footnotetext{
${ }^{371}$ S. João da Cruz. Poema: 3 Subida, II, 1;15,1;2. Apud. VELASCO, J. Martin. El fenómeno místico, p. 280.

${ }^{372}$ Cf. Ibid., p. 280.

${ }^{373}$ Cf. Id., Experiência cristã de Deus, pp. 51-53.

${ }^{374}$ Cf. VELASCO, J. Martin. El fenómeno místico, p. 281; S. João da Cruz reúne estas três virtudes teologais, pois para ele "a alma não se une com Deus nesta vida [...] senão só pela fé segundo o entendimento, e pela esperança segundo a memória e pelo amor segundo a vontade". 2 Subida 6,1 .

${ }^{375} \mathrm{Cf}$. Id., El fenómeno místico, p. 281.
} 
no desenvolvimento do subjetivismo religioso. O problema está na aparente contradição entre o significado ordinário da palavra 'experiência' em contextos culturais em que predomina a compreensão científica do conhecimento, com a forma de relação que impõe a atitude teologal à condição transcendente de seu termo.

Diante desta falta de esclarecimento, é indispensável esclarecer o significado da palavra 'experiência', visto que esta palavra é utilizada em diferentes contextos e com diferentes significados e que, ao longo da história do pensamento, adquiriu muitas interpretações e explicações diante dos fatos.

A partir de uma base comum de que a experiência trata de uma apreensão imediata pelo sujeito de algo que se oferece como dado, e que tem como oposição o conhecimento por experiência, Velasco nos apresenta três significados principais: 1. A apreensão sensível da realidade externa, que se destina à confirmação de hipóteses ou juízos sobre a realidade. 2. A apreensão por um sujeito de uma realidade externa, uma forma de ser. Essa forma de conhecimento distingue-se tanto do conhecimento sensível e do 'experimental' como do conhecimento obtido por abstração por meio de um conceito. 3. O aprendizado adquirido com a prática, possibilitando ao sujeito uma familiaridade, uma espécie de conaturalidade com a realidade ${ }^{376}$.

Essa expressão, 'experiência de fé', é muito utilizada em contextos religiosos e também nos diferentes teóricos sobre a religião. Por tratar-se da experiência que é a fé, só pode realizar-se como experiência.

Nas palavras de Paul Ricoeur, "toda experiência é uma síntese ativa de presença e interpretação" ${ }^{, 377}$. Assim, compreende-se que cada sujeito, ao realizar o reconhecimento em que consiste a experiência da fé, inscreve sua vida com o caudal de experiências comportadas numa tradição na qual existem já as palavras Deus, Brahman ou Alá etc., com as quais se identifica esse mais além do homem, interior a sua consciência e maior que seu coração ${ }^{378}$.

Tal experiência se dá convocada pela Presença originante, que, além de convocar, provoca a fé, realizando na pessoa uma tensão em suas 'faculdades',

\footnotetext{
${ }^{376}$ Cf. VELASCO, J. Martin. El fenómeno místico, p. 283.

${ }^{377}$ Expressão citada por J. Servais Apud. VELASCO, J. Martin. Experiência cristã de Deus, p. 47. Ver nota 9.

${ }^{378}$ Cf. Ibid., p. 48.
} 
conduzindo-a a um contato real em uma realidade absolutamente nova ${ }^{379}$. Essa fé é mais que afirmação de verdades, e vai além das crenças, já que realiza uma mudança profunda da alma, provocando uma reestruturação de todas as dimensões da pessoa em torno do novo centro da existência descoberta e reconhecida pela atitude teologal.

Pois toda experiência religiosa possui caráter responsorial; nela o sujeito é consciente de não ser a fonte da iniciativa, mas de ser iniciado e guiado desde seus primeiros passos. Cita Velasco, o autor da Imitação de Cristo: Tu enim prior excitasti me ut quaerem te ['tu me moveste primeiro para que te buscasse'], e Pascal que fala: "Não me buscarias se não me houvesses encontrado" ${ }^{380}$. Assim, em todos os atos humanos referidos a Deus, ao conhecimento de Deus, desejo de Deus, amor de Deus, esse, mais que objeto do ato em questão, é seu sujeito, de forma que esse ‘de Deus' não é genitivo objetivo, mas subjetivo.

A pessoa, dessa forma, assume uma nova forma de ser, de viver consciente e amorosamente a nova relação com Deus. O exercício da vida teologal desencadeia uma atitude em que a Presença acolhida transforma em seu amor a totalidade da pessoa e esta adquire a possibilidade de um crescimento permanente em reconhecimento de Deus e em contato amoroso com Ele ${ }^{381}$.

Porque 'experiência de fé' é uma experiência de Deus. Por ser uma atitude teologal tem em Deus seu fim, pois "a fé não termina nos enunciados, senão na realidade a que remete" ${ }^{382}$. De forma geral, pode-se dizer com razão que da expressão 'experiência de Deus', o homem nela só é sujeito ativo, porque previamente é sujeito passivo.

Velasco pergunta-se: como se converte uma experiência de fé em experiência mística? Sua resposta parte da experiência como primeiro traço comum a todos os fenômenos místicos. O que permitirá, segundo ele, a existência de vários graus de vivência dessa experiência. Com a inclusão da experiência na realização efetiva da fé e na compreensão da mística como forma peculiar dessa experiência de fé, ele chega a compreender que místicos são todos os que realizam a experiência de fé, e por acontecerem em diferentes formas e graus, só alguns,

\footnotetext{
${ }^{379}$ Cf. VELASCO, J. Martin. El fenómeno místico, p. 285.

${ }^{380} \mathrm{Cf}$. Id., Experiência cristã de Deus, p. 54.

${ }^{381}$ Cf. Id., El fenómeno místico, p. 286.

${ }^{382}$ Esta afirmação foi dita por S. Tomás. Cf. Ibid., p. 286. Ver nota 41.
} 
dependendo das suas características e do grau de intensidade, serão analisados se são místicos no sentido que atribui a esta palavra a história da espiritualidade ${ }^{383}$.

A experiência mística não consiste em atos isolados. Alguns podem ocorrer e ocorrerão normalmente, nas pessoas que progridem na realização de sua adesão e consentimento ao Mistério, como 'vivências'. A experiência mística, contudo, é mais propriamente o resultado do percurso, do itinerário percorrido pelo homem quando, consentindo em sua origem, encarna em sua vida esse consentimento e adquire, assim, a sintonia, a conaturalidade, a familiaridade do próprio ser a Deus e com Deus, que lhe permite descobri-lo em todas as realidades do mundo, em todos os acontecimentos da história e em todas as experiências da própria vida ${ }^{384}$.

Não são as repercussões sobre a consciência nem os estados de ânimo que proporcionam o definitivo critério para o discernimento das verdadeiras experiências, nem os fenômenos extraordinários. O critério decisivo é constituído pelo amor. A experiência não é mais que 'vivência', por meio de todas as faculdades, da opção radical que consiste nesse radical deslocamento que é a atitude teologal descrita como fé-esperança-amor. Daí que o sinal inequívoco da existência de uma experiência verdadeira seja a presença do amor ${ }^{385}$.

Sendo assim, a mística, como uma forma de realização da experiência da fé, chega, afirma Velasco, "ao umbral decisivo em relação com a vida religiosa no fato de haver ou não passado pela experiência da fé, e dentro dela, pela experiência do Mistério ao qual chega a fé" ${ }^{386}$.

Ir à outra margem, passar do umbral significa, para os místicos, uma passagem, como ruptura radical, a uma forma de vida que põe de manifesto o fundo da alma e faz possível o nascimento de Deus nela. Nessa experiência, supera-se a consciência ordinária, a divisão sujeito-objeto ${ }^{387}$.

\footnotetext{
${ }^{383}$ Cf. VELASCO, J. Martin. El fenómeno místico, p. 291.

${ }^{384}$ Cf. Id., Experiência cristã de Deus, p. 69.

${ }^{385}$ Cf. Ibid., p. 80.

${ }^{386}$ Id., El fenómeno místico, p. 291. Porém, segundo Velasco, essa não é a única forma de realizar essa experiência, porque pode dar-se por outro caminho, como no caso do amor efetivo e serviçal aos demais, ou no progresso das consequências 'éticas' de uma religião chamada pessoal. Cf. Ibid., pp. 446-466.

${ }^{387}$ Esta superação destaca Velasco, aparece nos relatos de experiências de "místicas da natureza". Em contexto profano: "até que 'a individualidade mesma pareceu dissolver-se e desvanecer no ser ilimitado'; 'até que 'Eu” parecia ser 'Isto', e "Isto' parecia ser 'Eu'; E no religioso: 'Eu sou Brahman, ’ é o Todo...”. Na mística ateísta nos graus extremos da contemplação e da união os místicos chegam à superação do sujeito e objeto. Cf. Ibid., p. 295.
} 
Quando Velasco fala da experiência como primeira característica do fenômeno místico, refere-se àqueles que, como Sta. Teresa, fazem uma experiência como conhecimento experiencial, em que se vive o contato com a realidade a que se refere. Ela insistia na experiência como caminho para conhecer a Deus. "Isto entendo eu e por experiência"; "do que eu tenho experiência posso dizer". A experiência de Sta. Teresa é um “conhecimento direto, saboroso em que se chega, a saber, de algo, não por notícia objetiva, senão por tê-la vivido ou padecido no próprio ser" ${ }^{388}$.

Logo, a característica comum entre todas as formas de mística, a partir desta experiência, é o místico ser alguém que, em relação com a Realidade Última a que remetem todos os elementos do fenômeno religioso, tem mantido em algum momento uma relação pessoal com o Mistério que o leva ou o tem levado a dizer como Jó: "Eu o tenho visto com os meus próprios olhos"389.

\subsection{As características da experiência mística}

A realização da experiência de fé é o centro do fenômeno místico, por ser uma resposta livre e pessoal do sujeito diante da presença do Mistério, em um encontro que se dá através da "alma no mais profundo centro" 390 , através de uma intensa acolhida ao Mistério como resposta à sua constante provocação.

O homem, sujeito no fenômeno místico, exerce, assim, sua condição de pessoa na sua forma mais plena. Desvela, na experiência mística, sua característica de "transformar a pessoa que opera"391. Logo, se para conhecer a religião, como já nos disse Velasco, é necessário ter a mística como referência, fica claro que não existe nenhuma experiência mística sem que se tenha a experiência de fé. Porque "toda fé viva tem algo de místico; como toda mística é um desenvolvimento peculiar da fé" ${ }^{392}$.

Assim, por se tornar difícil um limite entre as experiências não místicas e experiências místicas de fé, Velasco apresenta-nos, a partir das experiências mais eminentes da vida mística, alguns traços que possam caracterizar as experiências de fé identificáveis como místicas:

\footnotetext{
388 VELASCO, J. Martin. El fenómeno místico, p. 292.

389 Jó 42,5.

${ }^{390}$ VELASCO, J. Martin. Experiência cristã de Deus, p. 30.

${ }^{391}$ Id., El fenómeno místico, p. 324.

392 Ibid., p. 319.
} 
a) O caráter 'holístico', totalizador e englobante da experiência mística

Já constatado pelas chamadas 'místicas da natureza' em que o ápice da experiência aparece como sinal universal, está o permanente caráter global que a reveste. Nessa experiência, o mundo é visto como um todo, em total oposição à visão analítica da consciência ordinária e da experiência científica.

A experiência mística profana refere-se à natureza em seu conjunto, em que o sujeito integra-se e nesse todo se funde. Essa se vive como totalizadora, por viver a presença da natureza como um todo e pelo próprio sujeito sentir-se feito essa totalidade. Essa experiência encontra-se nas formas monistas, em que o sujeito experimenta, em sua consciência mais profunda, a mesmidade, Atman, e sua identificação com a raiz e o principio de tudo, Brahman ${ }^{393}$.

$\mathrm{Na}$ mística teísta, esse aspecto da experiência se revestirá de uma forma nova que radicaliza um aspecto já presente em toda experiência religiosa. Em qualquer experiência religiosa, o homem tem consciência de intervir com todas as suas dimensões e sente-se radical e inteiramente implicado.

É uma experiência mais além da diferenciação dos sentidos, desde o centro mesmo da pessoa. Para expressar essa radicalidade e totalidade da experiência, S. João da Cruz recorre ao sentido do tato como órgão da mesma e fala de um 'contato substancial da substância de Deus na substância da alma'394.

b) Passividade da experiência mística

Esta é uma das características mais importantes da experiência mística. E não deve ser entendida como sinônimo de inatividade, de ociosidade, de inércia, pois é vivida pelo sujeito no sentido de que seu fim, Deus, só pode ser conhecido na medida em que, anterior a si mesmo e já presente nele, se dê a conhecer. Como diz S. João da Cruz, "se a alma busca a Deus, muito mais a busca seu amado a ela"395.

Sua essência consiste, então, na superação do sujeito no conhecimento ordinário, a partir da sua adesão à ação de Deus sobre sua vida. Assim, acontece com o êxtase e a contemplação, que se caracterizam como ativos por causa de um fervoroso exercício que se requer do sujeito diante de algo que irrompe em sua

\footnotetext{
${ }^{393}$ Cf. VELASCO, J. Martin. El fenómeno místico, p. 322.

${ }^{394}$ Cf. Ibid., p. 323.

395 S. João da Cruz, poema: Chama viva B, 3,28.
} 
vida. É desta forma que se dá a passividade do sujeito na experiência, que acontece com mais unanimidade nos casos de experiências místicas religiosas ${ }^{396}$.

Toda experiência religiosa é vivida pelo sujeito de forma passiva por reconhecer que, no encontro, "Deus só pode ser conhecido na medida em que,

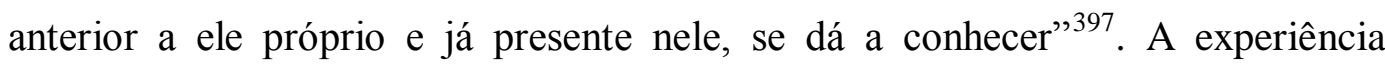
mística radicaliza este traço presente já em todo conhecimento humano e no conhecimento ordinário de Deus. Na experiência, o homem toma consciência de uma presença doada e a experimenta como tal.

c) Experiência imediata por contato com a realidade experimentada

Esta é uma característica considerada difícil de ser explicada e compreendida no fenômeno místico, porém toda experiência é um 'desvelamento'.

O conhecimento experiencial é o contato direto, imediato, sem qualquer tipo de mediação do sujeito com a realidade experimentada, provocando um 'desvelamento', ou seja, a queda dos obstáculos que impediam a visão, como superação da situação de engano, ilusão. Nas experiências místicas do hinduísmo e do budismo, essa característica é entendida como um despertar ou uma iluminação que põe em contato com a verdadeira realidade ${ }^{398}$.

Sobre a experiência teísta, recordemos num versículo do livro do Êxodo uma das grandes experiências místicas iniciada com a pergunta "Dize-me teu nome"399. Nas experiências místicas religiosas, este é o ponto de partida para sua realização, por existir no ser humano uma procura por algo ou alguém que, sem deixar-se perceber, já está presente, desencadeando, assim, uma busca constante pelo encontro, que se dará apenas quando realizada a experiência.

Dessa forma a "experiência mística, ao responder a esse desejo, a essa busca e súplica parece comportar a visão direta, o contato imediato com a realidade final de desejo" $" 400$. Faz isso por meio de uma experiência que significa uma forma de conhecimento diferente da percepção, conhecimento e amor, próprios da consciência ordinária.

\footnotetext{
396 Alguns autores qualificam estas experiências como experiências 'infusas'. Cf. VELASCO, J. Martin. El fenómeno místico, pp. 324-327.

397 Ibid., p. 325.

${ }^{398}$ Cf. Ibid., p. 328.

${ }^{399}$ Ex 3,13.

${ }^{400}$ VELASCO, J. Martin. El fenómeno místico, p. 329.
} 
Trata-se de contato imediato na medida em que nada alheio ao sujeito em seu centro mais pessoal se interpõe entre a presença divina e seu próprio ser. Porém, tal imediatez declara-se mediada, porque é sinal da ação de Deus na alma, convertida toda ela em meio de perceber a Deus, de onde tudo se reflete no homem como reflexo da Presença ${ }^{401}$.

Por isso, não deve a imediatez ser entendida como experiência empírica, porque a relação interpessoal na ordem humana é incompatível com a condição infinita e absoluta do 'tu' divino. S. João da Cruz fala sobre a imediatez em seus textos ao se referir aos 'contatos': "contato só da Divindade na alma, sem forma nem figura alguma intelectual nem imaginária"402.

Assim, o tipo de imediatez que corresponde à experiência mística não é uma visão direta em que o homem percebe diretamente a Deus como objeto, mas um conhecimento 'imediato', que produzirá melhor pelo contato amoroso de Deus com a alma, originando uma experiência in dono percepto o ex dono appropiato, no dom mesmo em que Deus une a alma com ele. Nele, o sujeito descobre por haver experimentado o "rosto do amado que leva em suas entranhas desenhado" 403 .

d) Experiência fruitiva

Esta característica refere-se nas experiências místicas a sentimentos inteiramente novos em relação aos que haviam sido experimentados em outros momentos. Esses são muitas vezes indescritíveis por meio de palavras, como, por exemplo, gozo, alegria, paz. E em muitas ocasiões se expressam através das lágrimas.

Ela revela a peculiaridade dos sentimentos descritos muitas vezes em expressões ambivalentes e paradoxais, aproximando-se dos elementos que R. Otto havia apresentado em sua clássica descrição da experiência do Mistério numinoso que surpreende o sujeito (mysterium tremendum) e ao mesmo tempo o cativa e fascina (Mysterium fascinans) ${ }^{404}$.

Toda a raiz dessa ambivalência e harmonia de contraste encontra-se na natureza da realidade divina, desfrutada apenas pelo ser humano no mais profundo

\footnotetext{
${ }^{401}$ Cf. VELASCO, J. Martin. El fenómeno místico en la historia y en la actualidad, p. 33.

${ }^{402}$ Id., El fenómeno místico, p. 330. Ver nota 42.

${ }^{403}$ Ibid., p. 331 . Ver nota 47.

${ }^{404}$ Cf. OTTO, Rudolf. O sagrado: os aspectos irracionais na noção do divino e sua relação com o racional. São Leopoldo, Sinodal/EST; Petrópolis: Vozes, 2007.
} 
do seu desejo. E esse desejo é um desejo de Deus, vivido, sentido com radicalidade, quando é o que deseja com toda a verdade de seu coração. É o resultado no homem da prévia presença de Deus nele, o sinal que imprime no homem, sob o olhar amoroso de Deus que faz o homem literalmente ser-para$\operatorname{Deus}^{405}$.

e) Simplicidade ou singeleza da experiência mística

Para esta característica, é importante destacar que a simplicidade não significa 'empobrecimento', 'redução' da pessoa que realiza essa experiência, mas se trata, nela, de uma concentração no unum necessarium, que não faz mais que intensificar a força da luz, como a concentração dos raios do sol enfocados em um ponto da superfície que iluminam, intensificam sua força para abrasar tudo quanto se encontra nele ${ }^{406}$. Velasco cita Panikkar como um dos autores que colocam a simplicidade no cume ou na essência da experiência mística ${ }^{407}$.

E para chegar a uma forma sumamente simples de relação com Deus é destacado um processo de purificação ascética que comporta a mais radical simplificação e redução à unidade e à simplicidade. E o desprendimento põe o homem em disposição de entrar na relação, de unir-se com o unum necessarium. O homem se desprende de tudo para coincidir com seu ser verdadeiro, "aceitar o ser próprio de Deus" ${ }^{\prime 408}$.

Assim, se o desprendimento opera a unidade, a simplicidade, sua radicalidade adquire a medida da unidade e simplicidade. Porque o desprendimento vivido em tamanha intensidade refere-se absolutamente a tudo. Ou seja, não se refere apenas às realidades exteriores ao sujeito, refere-se também às faculdades do homem e aos seus atos. Refere-se também ao homem mesmo e alcança o próprio desprendimento, porque o apego ao próprio desprendimento se coloca entre Deus e o homem, impedindo que a vontade de Deus se realize plenamente no homem.

\footnotetext{
${ }^{405}$ Cf. VELASCO, J. Martin. El fenómeno místico, p. 334.

${ }^{406}$ Cf. Ibid., p. 341.

${ }^{407}$ Cf. Ibid., p. 335. A obra de Panikkar a que Velasco se refere é: Elogio de la sencillez, Verbo Divino, Estella, 1993.

${ }^{408}$ Ibid., pp. 338-339.
} 
Isso significa, então, assumir sua condição humana na abertura do seu ser verdadeiro. Assumindo o nada para chegar ao todo, em um desprender-se totalmente para unir-se ao Absoluto.

f) Inefabilidade da experiência mística

Nesta característica, apresenta as observações de W. James que se referem à inefabilidade como a primeira das propriedades da experiência mística. Foi a partir de sua caracterização do misticismo, que se tornou raro o autor que não coloque a inefabilidade entre suas características ${ }^{409}$.

James chegou a esta afirmação a partir das experiências de mística da natureza, em representantes da mística afetiva ou esponsal, e, naturalmente, em representantes da mística essencial. Os testemunhos mais explícitos procedem dos místicos que fazem consistir essa experiência na 'realização' da unidade no Absoluto, no divino ou no Uno, mais além de todo ato de conhecimento que suponha a dualidade do sujeito que contempla o objeto contemplado. Nesta unidade, o sujeito supera o esquema sujeito-objeto, provocando a falta de uma estrutura conceitual que supõe a linguagem como sistema de significantes referidos aos significados ${ }^{410}$.

A inefabilidade, então, refere-se às interpretações dos místicos, como também dos estudiosos da mística quando tentam expressar em palavras o que é impossível, por tratar-se de uma experiência que os transcende. Isso a torna, quando entendida ao pé da letra, insignificante diante da razão.

Diante dessa constatação, Velasco apresenta-nos alguns passos que podem ajudar no entendimento do que for relativo à inefabilidade. Ele faz isso se referindo a P. Moore ${ }^{411}$, que, primeiro, distingue a inefabilidade em 'emocional', pela dificuldade de expressar com palavras o conteúdo de experiências emocionais, afetivas, e que abarca o vasto terreno de todas as vivências internas. Para esse autor, é impossível interpretar a experiência mística como tentativa de superar a razão. Para ele, esta experiência sempre terá como principal característica sua condição de inefável.

\footnotetext{
${ }^{409}$ Cf. VELASCO, J. Martin. El fenómeno místico, p. 341. A obra de W. James a qual se refere é: Las variedades de la experiencia religiosa. Penisula, Barcelona, 1988.

${ }^{410}$ Cf. Ibid., pp. 341-342.

${ }^{411}$ Cf. MOORE, P. Mystical Experience, mystical doutrine, mystical technique. En St. T. Katz (ed.), Mysticism and philosophical analysis, Seabury press, New York, 1978. Apud. VELASCO, J. Martin. El fenómeno místico, p. 345.
} 
Em outros casos, a inefabilidade é vista como 'causal' quando o sujeito sente-se incapaz de explicar sua experiência. E aqui estaríamos diante de uma inefabilidade de fato. No entanto, P. Moore alerta-nos para o fato de que não faltam casos em que os místicos referem-se de forma inequívoca à inefabilidade do que têm vivido. Para ele, esta atitude demonstraria uma inefabilidade 'descritiva', ou seja, uma forma própria da experiência mística, remetendo-a ao terreno do 'irracional'. Contribuiria para que o fenômeno místico seja inacessível à consideração, à análise e à interpretação de quem não tivesse acesso a essa experiência, tornando impossível a universalidade de suas conclusões ${ }^{412}$.

Percebemos aí a necessidade de evitar que o fenômeno místico seja reduzido à competência da razão. Para tal risco, alguns autores submetem as afirmações dos místicos a todo gênero de explicações, reduzindo-as a recursos retóricos para destacar a peculiaridade, a intensidade e o valor dos estados aos que se referem.

Entretanto, Velasco entende que seja necessário acolher a verdade última das expressões dos místicos sobre a inefabilidade de suas experiências, por acreditar que possa sua declaração estar fundamentada em uma concepção de linguagem deficiente. Para ele, o caminho deve ser feito a partir de uma atenção especial a alguns desenvolvimentos das teorias atuais sobre a linguagem e a experiência, a fim de que seja possível captar o núcleo de verdade das declarações dos místicos, sem deixá-las no terreno do irracional ${ }^{413}$.

Diante dos testemunhos de inúmeros místicos, tem-se a comprovação de que a inefabilidade não tem condenado os místicos à mudez. Mas, ao contrário, os tem conduzido a um lugar em tensão extrema de suas faculdades expressivas, levandoos a recorrer pessoalmente à recriação 'simbólica' de vários símbolos comuns a todos eles, recorrendo ao simbólico da noite, do vazio, do silêncio ou inventando uma nova linguagem. Assim,

tudo descansa sobre uma atividade simbólica em que o sujeito aflora sua consciência, expressa e comunica um mais além de si mesmo pelo que se sente habitado, de cuja presença não pode prescindir, pois, que tampouco pode captar diretamente como capta os objetos ${ }^{414}$.

\footnotetext{
${ }^{412}$ Cf. VELASCO, J. Martin. El fenómeno místico, p. 346.

${ }^{413}$ Cf. Ibid., p. 347.

${ }^{414}$ Ibid., p. 348.
} 
Diante do inefável da experiência mística, todo conhecimento objetivo da consciência ordinária se depara com sua ineficácia em expressá-la de forma direta em palavras que possam significar algo.

Dessa forma, os místicos, ao referirem-se a sua inefabilidade, sublinham não só a transcendência de seu conteúdo, mas a novidade de sua forma, pois se torna frequente que, diante da necessidade de expressá-la, recorra ao conhecimento de si mesmo como caminho imprescindível para a experiência de Deus, como mostra o chamado 'socratismo cristão', 'conhece-te a ti mesmo', e a experiência de amor, em que S. Gregório de Nissa disse: "pois o conhecimento se torna amor"

Entendemos que seja necessário esclarecer que o inefável desta experiência,

não se refere a um adicional de informações sobre a presença, do que o místico dispusera mais além do que sua linguagem é capaz de dizer. É a expressão da consciência na insuficiência da linguagem, a expressão da convivência do limite, que é a única forma dada neste estágio da vida humana de superá-lo ${ }^{416}$.

g) Experiência certa e obscura

Não nos é difícil encontrar nos relatos de experiências místicas a declaração que o sujeito faz de ter começado a ver Deus. Místicos das diferentes tradições religiosas confessam, depois de sua experiência, que tudo o que sabiam até esse momento sabiam como um saber de ouvido, em comparação como o novo saber, qualificadamente diferente, graças ao qual têm 'visto e ouvido'. Daí a certeza subjetiva que acompanha os estados místicos ${ }^{417}$.

Esta certeza se traduz na perfeita claridade de quem faz uma ideia clara e distinta do que conhece. Está baseada em uma luz que vem do mais além do próprio sujeito, e consubstancialmente obscura, tanto pelo tipo de experiência, como pelo meio de conhecimento, a fé, como pela realidade conhecida. A obscuridade nunca superada da experiência mística dá lugar à utilização por toda tradição mística do símbolo da noite que se refere a uma fase inevitável do processo, ou a um elemento consubstancial de sua estrutura ${ }^{418}$.

\footnotetext{
415 VELASCO, J. Martin. El fenómeno místico, p. 375.

416 Ibid., p. 349.

${ }^{417}$ Id., El fenómeno místico en la historia y en la actualidad, p. 28.

${ }^{418}$ A tradição mística do símbolo da noite tem sua origem em S. Gregório de Nisa, para quem o itinerário espiritual, tem na mais profunda obscuridade que supõe para o homem a condição misteriosa de Deus. Pertence também a Pseudo-Dionísio que introduz duas imagens que servirão de referência permanente na tradição apofática: a do 'raio de treva da divina supraessencia' e a da 'misteriosa escuridão do não saber'. Para J. Tauler este símbolo adquiriu um lugar central em sua
} 
E essa consciência de ter ido ao fundo, de uma manifestação evidente da verdadeira realidade acompanha em todos os casos esta certeza absoluta, que desafia toda dúvida em relação ao que acabam de viver.

No entanto, essa certeza não se refere a todas as etapas ou a todos os aspectos do complexo fenômeno místico. Ela se refere ao que é impresso na alma pela realidade mesma que se oferece. Como S. João da Cruz adverte "porque assim como (as notícias) são mais exteriores e corporais, assim também menos certas são de Deus" e também Sta. Teresa "Esta visão, ainda que imaginasse nunca a vi com olhos corporais, nem ninguém, senão com olhos da alma" ${ }^{419}$.

A certeza é o resultado do contato do sujeito com a realidade contemplada. E por não ser o resultado dos sentidos e nem da inteligência discursiva, esta não se vê ameaçada por sua fragilidade, nem submetida a sua limitação, desafiando todas as razões humanas.

Velasco nos faz lembrar de S. Gregório de Nissa. Para este, a "experiência de Deus, mesmo que seja uma experiência de uma presença obscura, é uma presença que se comunica como sentida e apreciada no amor, porque envolve a alma como numa noite divina" 420 . O homem é, assim, prova do mistério insondável que é Deus, pois, quanto mais se aproxima dele, mais experimenta sua obscuridade, seu mistério.

\subsection{0 núcleo originário da experiência mística}

Diante de todas essas propriedades da experiência mística, a fenomenologia do fenômeno místico se pergunta sobre o núcleo originário desta experiência, do qual se derivam suas propriedades tão peculiares.

Um estudo analítico das propriedades descritas permitiria descobrir referências semelhantes se baseadas na cumplicidade e comunicação entre as diferentes propriedades. Para Velasco, todas estas propriedades suscitam algo de realidade última: Presença originante que a provoca, e a atitude de

obra e experiência. Como também para S. João da Cruz, o místico da noite por excelência. A noite, para este santo, é um componente para toda experiência de Deus, "o fim para onde vai, que é Deus, o qual nem mais nem menos é noite escura para a alma nesta vida". Sobre S. João cf. VELASCO, J. Martin. Experiência cristã de Deus, pp. 201-294; Sobre a tradição do símbolo da noite, cf. Id., El fenómeno místico en la historia y en la actualidad, pp. 29-30.

${ }^{419}$ Id., El fenómeno místico, p. 352. Ver nota 103.

${ }^{420}$ Ibid., p. 354. Essa experiência diante da obscuridade da presença de Deus é a razão para teologia negativa. Para essa, a experiência mística não se encontra na dificuldade do homem em conhecer a Deus, mas na natureza mesma de Deus, por ser mistério insondável. 
reconhecimento pela fé, que é realizável em diferentes graus de intensidade, parece remeter a um termo que as focaliza, a um núcleo que as origina ${ }^{421}$.

Velasco, no intento de identificar esse núcleo pela fenomenologia da mística, desenvolverá esta tarefa através dos relatos e experiências místicas dos sujeitos que a viveram. Ele se surpreende com o fato de que, mesmo as experiências místicas possuindo uma grande variedade, por existirem em contextos religiosos e culturais diferentes, carregam algo de muito semelhante.

Essa variedade de experiências reflete também as variadas circunstâncias pessoais e psicológicas das pessoas. Pode-se falar de experiências sob a forma de relação pessoal com o Mistério representado em termos fortemente personalizados, como sucede no Judaísmo, de relação vivida como abismamento e extinção na absoluta Transcendência (Budismo theravada) ou como fusão das profundezas do sujeito como o Brahman ou o Absoluto (Hinduísmo brahmânico).

Cabe também referir-se à variedade originada pelo lugar em que se produzem as diferentes experiências - o cosmo, a consciência do sujeito, a história e seus acontecimentos, a totalidade do real - e à variedade que resulta da forma de se representar a realidade original da experiência como Deus único (monoteísmo), como Trindade (monoteísmo cristão), como totalidade indiferenciada que abrange o homem, o cosmo e o divino (panteísmo), como pluralidade de poderes e de formas que dirigem os diferentes aspectos da realidade e da vida (politeísmo) ou como vazio inominado do qual não cabe representação alguma e cuja única palavra é o silencio mais absoluto (Budismo) $)^{422}$.

Em suas palavras:

é admirável que pessoas de línguas, culturas, religiões e épocas históricas muito diferentes e muito distantes entre si coincidam no recurso a uma série limitada de imagens, símbolos, de alguma maneira arquétipos, que se repetem modulados pelas diferenças de tradições e de pessoas ${ }^{423}$.

Para ele, de modo muito especial, por ser este um dos pontos principais de sua pesquisa, "é sem dúvida a manifestação mais clara de que no fenômeno

\footnotetext{
${ }^{421}$ Cf. VELASCO, J. Martin. El fenómeno místico, p. 357.

${ }^{422}$ Id., Experiência cristã de Deus, pp. 53-54.

${ }^{423}$ Id., El fenómeno místico, p. 358.
} 
místico se faz presente um traço permanente e universal da condição humana, uma “invariável" da humanidade" 424 .

Para Velasco, no núcleo originário da experiência mística constam quatro expressões: a contemplação, o êxtase, a união e o estado teopático.

\section{a) A experiência mística como contemplação infusa}

A palavra contemplação, muito utilizada na tradição cristã, procede de um contexto anterior ao cristianismo, da Grécia, precisamente de Platão, que possibilitou aos primeiros pensadores cristãos os recursos para pensar a experiência de Deus, seu mistério, e que depois começou a ser identificado como teologia mística ${ }^{425}$.

Velasco não apresenta um estudo rigoroso sobre a contemplação platônica, mas faz uma breve descrição do tipo de conhecimento que designa a palavra 'contemplação', a partir dos filósofos, religiosos e místicos que do termo se utilizaram ao longo da história, para passar depois ao significado 'técnico' da palavra utilizada para expressar o núcleo do pensamento místico.

Ele parte de algumas interpretações do fenômeno descrito e dos problemas mais importantes que essas interpretações delineiam, o que permitirá para ele abordar nessa perspectiva o problema da 'essência' da experiência mística. E inicia, então, procurando destacar o sentido da palavra 'contemplação' em seu uso ordinário. Ou seja, essa palavra,

remete a uma forma determinada e superior de visão e conhecimento, que se exerce em diferentes ordens da vida e se refere a uma forma peculiar de aplicação da atividade cognoscitiva, sensível ou intelectual, em relação com a natureza, a atividade estética e a vida religiosa ${ }^{426}$.

Nessa experiência não se pode negar que aquele que está em contemplação tem, seu olhar em repouso na realidade contemplada. Isso revela certa passividade, onde o sujeito que a vive se deixa iluminar pela verdade da realidade contemplada. E atingindo toda a sua vida, esta se torna vida contemplativa, fazendo de quem a vive um contemplativo.

O termo 'contemplação' teve no terreno religioso, mais tarde visto como sua 'terra natal', suas propriedades realizada em grau eminente. Tudo começou partindo do entendimento da theoria - o termo grego para contemplação - que em

\footnotetext{
${ }^{424}$ VELASCO, J. Martin. El fenómeno místico, p.358.

${ }^{425}$ Cf. Ibid., p. 359.

${ }^{426}$ Ibid., p. 360.
} 
seus derivados e um significado religioso; o Pseudo-Plutarco pretendeu relacionar, ao parecer sem razão, a primeira parte theoria com theos (Deus); e os latinos atribuíram a contemplare um sentido religioso, pondo a palavra em relação com templum. 'Contemplar' é admirar esse grande templo que é a natureza, templum que consiste em um lugar aberto onde se pode estender o olhar. Depois essa noção foi aplicada ao conhecimento de Deus ${ }^{427}$.

Logo, para explicar o uso da categoria contemplação, faz-se indispensável introduzi-la no interior do contexto religioso e cultural a que pertence, como também, discernir seu significado em cada uma das religiões ${ }^{428}$. E Velasco o fará referindo-se expressamente ao significado de contemplação na tradição cristã.

Para o cristianismo, a contemplação supõe uma forma de conhecimento de Deus enraizado na fé, que não comporta nenhuma forma de captação ou percepção experimental de Deus. Para outros, baseando-se em alguns textos de místicos reconhecidos da tradição cristã, a contemplação, em seus últimos progressos à contemplação mística, comportaria "um conhecimento experimental e direto, uma percepção imediata de Deus"429.

O que está por baixo dessa discussão são duas formas de interpretar o fato da contemplação, fundadas em duas formulações tanto de autores espirituais como de teólogos e interpretes do fenômeno místico. Esses sublinham, por uma parte, a condição misteriosa do termo da contemplação e, por outra, a consciência de ter experimentado, de ter sido iluminado, de que dão testemunho os relatos místicos, o que possibilita a alguns intérpretes entender a contemplação como uma forma sublime de experiência direta, de percepção imediata de Deus ${ }^{430}$.

E é por causa das interpretações da experiência mística em termos de experiência direta e imediata de Deus, que Velasco desenvolverá um estudo a partir de diferentes posturas, de alguns teólogos, filósofos e fenomenólogos, para em seguida apresentar sua própria compreensão da natureza da experiência mística $^{431}$. Ele chega à conclusão de que a peculiaridade da experiência religiosa se radicalizada na contemplação, como forma suprema de sua realização e da tomada de consciência da mesma.

\footnotetext{
${ }^{427}$ Cf. VELASCO, J. Martin. El fenómeno místico, p. 361.

${ }^{428}$ Cf. Ibid., p. 362.

${ }^{429}$ Ibid., p. 366 . Ver nota n. 26 e 27.

${ }^{430}$ Cf. Ibid., p. 367.

${ }^{431}$ Cf. Ibid., pp. 368-385.
} 
b) O êxtase

Diferente de todos os outros estados da experiência mística, o êxtase é particularmente intenso e extremamente perceptível no sujeito. No entanto, como veremos, não é o momento culminante da experiência mística.

O êxtase é um fato frequente na vida mística, não só em suas manifestações religiosas, mas também nas formas profanas que põem de manifesto a repercussão de experiência humana muito intensa sobre o psiquismo e a corporalidade dos sujeitos que as sofrem. Para sua descrição, faz-se necessário distinguir dois elementos: O exterior, 'negativo', identificável como 'transe extático', que consiste em um estado somático anormal. Positivamente, o êxtase consiste em uma intensa concentração da mente, da imaginação ou da afetividade em um objeto único $^{432}$.

Percebe-se, nestas duas distinções, que essas se referem às definições usuais do termo, primeiro pela 'suspensão maior ou menor do uso dos sentidos' e depois por um 'estado da alma inteiramente preenchida pelo sentimento de admiração, alegria, etc.' ou, no caso do êxtase místico religioso, a um estado da alma caracterizado interiormente por certa união mística com Deus mediante a contemplação e o amor.

No entanto, podem ser também produzidos por experiências diferentes: em um primeiro momento, pode ser resultado de anomalias psíquicas ou vir acompanhadas delas, e ser provocadas por procedimentos ou técnicas apropriadas ou por ingestão de drogas.

Outros problemas que delineam esse fenômeno consistem na existência de místicos que apresentam sintomas patológicos na vivência de suas experiências. Esses não são considerados místicos por serem psicopatas. Sua condição de místico influenciou em sua neurologia ou psicopatologia. Os místicos de constituição normal ou curada apresentam desfalecimentos no 'funcionamento' de suas capacidades como consequência da intensidade das experiências que vivem $^{433}$.

Porém, é importante que sobre a experiência como tal em sua dimensão interior, espiritual, os místicos religiosos e, em alguns casos, também os não

\footnotetext{
${ }^{432}$ Cf. VELASCO, J. Martin. El fenómeno místico, p. 399.

${ }^{433}$ As ciências médicas, da psicologia e da antropologia passaram a estudar os fenômenos místicos, e o parentesco do êxtase com outras formas de estados extáticos vividos em contextos diferentes e com enfermidades somáticas ou psicológicas. Cf. Ibid., p. 405.
} 
religiosos afirmem que o que vivem é resultado de uma ação de Deus sobre eles. Chegam a falar da infusão de Deus em suas faculdades, no centro de sua pessoa do dinamismo e virtualidades que escapam a suas forças e seu controle. Por isso, ocorre, por parte dos místicos, aversão ao fato de que o êxtase possa ser provocado.

Isso parece ser uma característica de toda mística religiosa. Por exemplo:

O samadhi no hinduísmo, o satori no zen, que sem identificar-se com o êxtase contém em parte seus elementos, não é resultado do treinamento que comporta a yoga. Ocorre na vida como a iluminação do Buda, sem que o sujeito possa determinar o momento e o lugar de sua chegada ${ }^{434}$.

Esse fenômeno tem grande importância na mística cristã, pois "aparece em todas as manifestações da vida mística cristã e ocupa um lugar em quase todas as descrições e interpretações que dela se tem dado" ${ }^{435}$. Tem como a 'união mística' suas fontes na tradição bíblica e na religiosidade grega, na filosofia platônica e neoplatônica $^{436}$.

No entanto, esse fenômeno, mesmo diante de toda a sua importância para as experiências místicas, e mesmo na vida mística de Sta. Teresa, não é um elemento essencial nem integrante da contemplação infusa, nem a fortiori, seu momento culminante, pois existem místicos que dão mostra de ter chegado eminentemente à união sem ter padecido do êxtase ${ }^{437}$.

c) A união mística

Velasco, com apoio sobretudo dos textos dos místicos cristãos, mas também de místicos muçulmanos e judeus, acredita que o centro e resumo da experiência mística, consiste em que nela o sujeito vive na imediatez mediada do contato amoroso, a união mais intima com a realidade mesma de Deus presente no mais profundo do ser do sujeito ${ }^{438}$.

Por isso, torna tão significativo em sua investigação sobre o núcleo da experiência mística este tema da união. Por "expressar o grau último da relação

\footnotetext{
${ }^{434}$ VELASCO, J. Martin. El fenómeno místico, p. 406.

435 Ibid., p. 404.

${ }^{436}$ Sobre as fontes bíblicas, esse fenômeno encontra apoio nas diferenças veterotestamentária ao profetismo extático. No Novo Testamento, atribuem experiências extáticas a Jesus, a Paulo e a Estevam, e conta com os fatos e carismas das comunidades primitivas - como o acontecimento de Pentecostes e a glossolalia. E foram os padres que começaram a utilizar o léxico próprio do fenômeno extático com clara dependência da filosofia platônica. Cf. Ibid., p. 400.

${ }^{437}$ Cf. Ibid., p. 405.

${ }^{438}$ Cf. Id., La experiencia mística, p. 31.
} 
mística, a meta final do intermediário espiritual, a forma mais perfeita da experiência mística" ${ }^{\natural 39}$. Além disso, por confluir com outros muitos aspectos e fenômenos da experiência, tais como o rapto, o êxtase, o estado teopático, a transformação, que alguns autores se referem como cume de sua experiência.

Esta união é a resposta aos anseios que os místicos carregam pela força atrativa do amor que lhe vem do próprio Deus, meio privilegiado para a união. $\mathrm{O}$ encontro com Deus, por realizar-se 'na alma no mais profundo centro', tem lugar mais além dos atos próprios das faculdades humanas, porém nos dois, entendimento e vontade, redunda a união de Deus com o sujeito ${ }^{440}$.

O conhecimento que tal união procura distingue-se de todas as outras formas de conhecimento, cuja diferença se encontra "na experiência tanto objetiva como subjetivamente mais direta, às vezes inclusive imediata da presença divina" ${ }^{\text {"41 }}$.

Os escritos dos místicos são precisos quando revelam o que desejam: a união com Deus, a qual acontece de muitas maneiras e formas, de acordo com as diferentes imagens e símbolos. Em primeiro lugar, pelos contextos religiosos e culturais, pelos diferentes graus de intensidade que essa união pode alcançar; pelas diferenças que reveste a experiência devido às diferenças pessoais de quem a vive; e por último as diferentes formas de viver esta realidade ${ }^{442}$.

Certamente, a união introduz mudanças na consciência dos sujeitos. Esses podem chegar a uma espécie de suspensão da consciência, na interrupção do uso das faculdades humanas. Porém, essa suspensão não condena o sujeito à inconsciência, pois ele a vive com alguma forma de consciência que lhe permite depois recordar o vivido e descrevê-lo com notável precisão ${ }^{443}$.

Essas diferenças revelam-se nas experiências místicas dos Upanishads, do taoísmo e do budismo, em que "todas as formas de viver e representar a união se orientam para uma compreensão do termo que coincide em uma representação não pessoal" ${ }^{\text {444 }}$. Uma união que se converte em isolamento, identificação, fusão ou dissolução na realidade, origem e fim do processo.

\footnotetext{
${ }^{439}$ VELASCO, J. Martin. El fenómeno místico, p. 386; Id., El fenómeno místico en la historia y en la actualidad, p. 34.

${ }^{440}$ Cf. Id., El fenómeno místico en la historia y en la actualidad, p. 33.

${ }^{441}$ Ibid., p. 33. Ver nota 30.

${ }^{442}$ Cf. Ibid., p. 387.

${ }^{443}$ Cf. Ibid., p. 34.

${ }^{444}$ Id., El fenómeno místico, p. 388.
} 
Em outro extremo, situam-se as tradições cristãs e mulçumanas que representam o termo união na forma personalizada de um Deus que tem nome próprio e em algum caso, como no cristianismo, encarnado em uma vida humana, aqui nessa experiência não há fusão ou dissolução, a alteridade se mantém. Uma última diferença nas formas de viver e de representar a união consiste nos diferentes graus que essa pode realizar.

Isto se situa entre os graus mínimos, localizado na fronteira das manifestações não místicas da vida religiosa, e os últimos graus como matrimônio espiritual e a união transformante, em que a razão humana perde sustentação, as experiências inclusive simbólicas desfalecem e os místicos caem no silêncio e convidam seus interlocutores ou seus leitores ao silêncio ${ }^{445}$.

A união mística comporta uma modalidade nova de consciência, que Velasco chama de 'transconsciência', baseada na atuação de um nível mais profundo que o das faculdades e que produziria uma forma nova de conhecimento. E nela funcionaria como um 'consciente ser-com', mais que como um 'pensarsobre'. Aqui a consciência do homem passaria a transparecer o 'novo ser em Deus ${ }^{446}$.

Sobre os relatos dos místicos cristãos, no que se refere à união mística, vejamos as experiências e personagens dos textos bíblicos e as categorias do platonismo e do neoplatonismo, como possibilidades que os místicos encontraram para expressar sua experiência.

Isso permite identificar nos textos místicos cristãos algo a mais que os textos evangélicos, por terem eles estimulado doutrinas, termos, categorias nascidas em outras culturas e, especialmente, na filosofia e na religiosidade grega ${ }^{447}$.

No entanto, a

descrição da essência mesma da união esconde-se tanto como se revela através das imagens, e escapa à responsabilidade de uma descrição adequada. Para poder compreendê-la e expressá-la seria preciso que o homem pudesse dar conta da Divindade em que a união o transforma ${ }^{448}$.

\footnotetext{
${ }^{445}$ VELASCO, J. Martin. El fenómeno místico, p. 389.

${ }^{446}$ Cf. Id., El fenómeno místico en la historia y en la actualidad, p. 34.

${ }^{447}$ Cf. Id., Op. cit., pp. 391-392. Sobre a influência do platonismo, o neoplatonismo e de Plotino na experiência mística cristã, Velasco parte então, da relação com Deus evocada entre os filósofos platônicos, e, sobretudo neoplatônicos, pela utilização dos termos como "amizade", "semelhança" que faz a alma "deiforme". E que mais longe chegou Plotino com o termo de "união' (kenosis): "Já não são dois, senão um", que significa identificação com o Uno por meio do amor que une o Bem por um novo nascimento, pela inabitação divina.

${ }^{448}$ VELASCO, J. Martin. El fenómeno místico, p. 397.
} 
Porque é certo que quanto mais as pessoas se aproximam da Divindade, mais se veem abrasadas todas as suas potências e capacidades por ela.

\section{d) Estado Teopático}

Velasco utiliza-se desta categoria que tem sua raiz na tradição cristã, para designar o núcleo e o cume da experiência mística. E o faz a partir do sujeito que "mais que apreender Deus, mais que conhecê-lo, recebe-o, padece-o"449. O autor nomeia o que esta categoria produz no sujeito, como exerce sua condição e como se traduz na sua vida. E como se apresenta a vida de quem, na união transformante, tem recebido uma vida nova, que não é outra senão a vida de Deus $^{450}$.

H. Delacroix estudou essa expressão de forma rigorosa, no início do século passado. Esse termo 'estado' ressalta a situação a que o sujeito místico chega depois de um longo processo que constitui toda a experiência mística ${ }^{451}$. Para Delacroix, 'estado' não significa que a situação a que se chega consista em um repouso definitivo.

E que a experiência mística não é só um fenômeno dinâmico. É uma experiência que só é compreendida adequadamente como epéxtasis, tensão nunca liquidada, perfeição em progresso permanente, em movimento sem fim, pelo fato de que seu fim é Deus, a realidade infinita, cuius regni non erit finis, cuja natureza consiste em não ter fim ${ }^{452}$.

Esse termo epéxtasis foi utilizado por S. Gregório de Nissa para caracterizar a vida mística a partir do texto de Paulo, em que o Apóstolo descreve-se esquecendo o que deixou para trás "avançando para o que está adiante" ${ }^{453}$. Ele propõe como núcleo que a origina e a caracteriza, uma tensão permanente originada pelo desejo de Deus que desperta na alma sua condição de imagem, e que aumenta à medida que se aproxima de seu 'objeto'.

Assim, a condição de epéxtasis da experiência mística é dada pela transcendência infinita de Deus que possibilita que a mesma visão da glória não

\footnotetext{
${ }^{449}$ VELASCO, J. Martin. Experiência cristã de Deus, p. 53.

${ }^{450}$ Cf. Id., El fenómeno místico, 408.

${ }^{451}$ Cf. DELACROIX, H. Études d'historie et de psychologie Du mysticisme. Le grands mystiques chrétiens, Paris, 1908, p. 416; também pp. 417 e 368. Apud. VELASCO. El fenómeno místico, p. 409.

${ }^{452}$ Ibid., p. 407.

${ }^{453} \mathrm{Fl} \mathrm{3,13.}$
} 
seja descrita como um estado de fim, senão como o 'descobrimento permanentemente maravilhado das riquezas inesgotáveis da vida divina, ${ }^{454}$.

O termo 'teopático', por sua vez, tem sua origem na passividade. Velasco nos diz que o texto do Pseudo-Dionísio é o que melhor tem expressado como 'non tantum discens sed et patiens divina. Ou seja, uma passividade que não só apreende, mas patiens, quer dizer, experimenta o divino. Como também padece recebendo de Deus a luz e o impulso indispensável para entrar em contato com ele, e sofre com o deslumbramento de sua luz que cega, com o esvaziamento e a purificação indispensável em acolher sua Presença ${ }^{455}$.

Ele adota as características apresentadas por J. Baruzi ${ }^{456}$, para o qual o estado teopático é a expressão para designar o último estado de vida mística. As características são: a união com Deus, a transformação de amor nele, e por deixar na alma dois efeitos, apresentados por S. João, que são: “esquecimento e alienação de todas as coisas do mundo e mortificação de todos os apetites e gostos" ${ }^{457}$.

Esse 'esquecimento e alienação', no entanto, não priva a alma de sua relação com a realidade criada, não paralisa seus sentidos e potências para impedi-las de captar seu ser e sua beleza. O sujeito livre para acolher essa Presença é também livre para assumir, nessa experiência sua vida ordinária, pois tudo lhe é devolvido no estado teopático, transfigurado e embelezado por seu olhar, pelo olhar de Deus.

Velasco procura expressar o resultado do estado teopático, vendo-o como a 'inversão total de intencionalidade', que exige e comporta a fé e que a experiência mística leva a seu fim, inversão que, num primeiro momento, tem conseguido produzir a impressão 'perdida da realidade', pois tem conduzido o sujeito a ver a verdadeira trama das coisas que sua vista só natural o faz ver ao revés: “conhecer por Deus as criaturas e não pelas criaturas conhecer a Deus" ${ }^{\text {458 }}$.

Assim, essa inversão que intervém no amor de Deus faz com que esse consista fundamentalmente em deixar-se amar por ele, em aceitar ser amado, em acolher seu amor ou em corresponder a um amor prévio de Deus por nós que suscita nosso amor por ele.

\footnotetext{
${ }^{454}$ Cf. VELASCO, J. Martin. El fenómeno místico, p. 408. Ver nota n. 146.

${ }^{455}$ Cf. Ibid., p. 409.

${ }^{456}$ BARUZI, J. Saint Jean de la Croix et Le problème de l'expérience mystique, Alcan, Paris, 1931. Apud. VELASCO, J. Martin. El fenómeno místico, p. 410.

${ }^{457}$ S. João da Cruz, Poema: Cântico A, 17,1.

${ }^{458}$ VELASCO, J. Martin. Op. cit., p. 414. Ver nota n. 165.
} 
A isto corresponde o terreno do amor, não em amar a Deus pelo bem que procura, senão, libertada a vontade do apego que a escraviza aos bens mundanos, amar a Deus por Deus mesmo e, como consequência, amar a si mesmo e as criaturas com o amor mesmo de Deus, 'altamente com afeto divino, ${ }^{459}$.

Essa conversão supõe que Deus não seja mero objeto do homem, mas a raiz que o orienta, a partir de uma presença, que longe de girar em torno do homem, situa-o na órbita do divino, capacita-o para o possível chamado de Deus, dilata-lhe o coração para torná-lo capaz de recebê-lo.

Sobre o estado teopático, ele chega à conclusão de que seu arremate está na irrupção da vida pessoal, na penetração de todas as dimensões e níveis do ser que inicia a experiência mística enquanto experiência pessoal do consentimento da presença em que consiste a fé. Logo, o que resulta é poder enxergar a vida na sua realidade a partir do seu verdadeiro centro, e percebê-la como na verdade ela é ${ }^{460}$.

Velasco nos ajuda a entender que este estado está revestido pela "harmonia da pessoa e sua vida; na permanência ou não da consciência desse estado, e na natureza do gozo que a acompanha" ${ }^{461}$. Para ele, é evidente que essas formas nas diferenças em que se apresentam no fenômeno místico, em seu conjunto, refletem as formas de viver e permitem descrever o estado.

Até mesmo no interior de uma mesma tradição como a cristã, pode cada um viver sua própria experiência e manifestar as peculiaridades provenientes de suas características e circunstâncias pessoais.

O estado teopático não desloca o sujeito a um mundo recôndito de experiências extraordinárias, mas o devolve à vida diária que, recentrada pelo exercício da opção teologal, da experiência de fé, permite viver com novo valor, com novo sentido, com um novo olhar, o conjunto de sua vida cotidiana. Porque a “conversio cordis, a raiz teologal da experiência mística, não só exige, mas também possibilita a conversio morum, a mudança de conduta que comporta a moral" 462 .

Assim, esse último grau da experiência mística não retira o místico da sociedade e do mundo em que vive. Ao contrário, consuma-se em uma

\footnotetext{
${ }^{459}$ VELASCO, J. Martin. El fenómeno místico, p. 414.

${ }^{460}$ Cf. Ibid., p. 414.

${ }^{461}$ Ibid., p. 415.

${ }^{462}$ Ibid., p. 461.
} 
transformação do conjunto da vida: tomada a forma mística de uma mística na vida e da vida cotidiana ${ }^{463}$.

\subsection{Mística, condição de existência para a religião}

As experiências místicas têm seu centro na experiência humana peculiar, que faz menção a uma realidade que transcende à ordem da realidade com a qual o sujeito entra em contato no regime da consciência ordinária. Mesmo existindo em várias formas, essas têm seu fundamento no fato de compartilharem uma série de propriedades que lhes conferem uma semelhança funcional e estrutural e um ar de família surgido dessas propriedades comuns ${ }^{464}$.

Em todas as formas religiosas, a experiência que as origina recebe sua especificação de Mistério. Dessa especificação, segue-se a primeira peculiaridade da experiência mística em todas as suas formas, que consiste em ter sua origem em uma radical inversão de intencionalidade, permitindo que o sujeito humano seja um sujeito não ativo, senão passivo, vivendo como resposta ao Mistério.

No entanto, essas experiências são revestidas de vivências muito diferentes: “contida nas descrições dos últimos passos do processo do yoga: vivida como iluminação no budismo; experimentada como íntimo contato amoroso, em formas diferentes, pelos místicos muçulmanos e cristãos” ${ }^{\text {,65 }}$. São também interpretadas pelo sujeito místico em forma de símbolos pela tomada de consciência do seu ser mais profundo como "centro que origina todas suas faculdades e atos, centro ele mesmo originado; fundo, sobre o qual descansa toda a sua vida sem profundidade para um abismo que está constantemente surgindo" 466 .

Mesmo diante de todas as diferenças, é comum a todas elas o local de contato do sujeito com essa realidade transcendente, na certeza obscura e na confessada passividade do sujeito, etc. Acontecendo na consciência da identidade com o Absoluto (brahmanismo), na extinção de si mesmo (budismo), na conformidade com a lei que rege o devir do universo (taoísmo), na fé-confiança absoluta (cristianismo), na submissão incondicional (islã), etc ${ }^{467}$.

\footnotetext{
${ }^{463}$ Sobre a mística do cotidiano Cf. RAHNER. Karl. Experiencia de la gracia. In: Escritos de teologia, Madri:Taurus, 1961, v.3. pp. 103-107; e Experiência del espiritu, Madri: Narcea, 1977. pp. 50-53. Apud. VELASCO, J. Martin. Experiência cristã de Deus, p. 86.

${ }^{464} \mathrm{Cf}$. Id., El fenómeno místico, p. 424.

${ }^{465} \mathrm{Ibid}$., p. 431. Estas vivências foram formuladas por Plotino e citadas por Velasco.

${ }^{466}$ Ibid., p. 426.

${ }^{467}$ Cf. Ibid., p. 425.
} 
Esta experiência mística em suas diferentes formas religiosas nos tem aparecido como 'vivência', na tomada de consciência, na incorporação voluntária dessa atitude fundamental que está na base de todas as religiões e que no cristianismo se chama fé-esperança-caridade. Todos os traços muito numerosos que caracterizam a experiência mística: passividade, certeza-obscura, simplicidade, inefabilidade, etc., têm aqui sua origem e sua explicação.

Visto que o centro da experiência mística consiste na consciência-adesão à Transcendência-imanência de que a pessoa humana toma consciência de estar permanentemente surgindo, e se explicam os traços peculiares do núcleo da experiência mística: "presença incontestável, que precede ao sujeito e se impõe; que se faz presente na forma de ausência, só 'visível' no ato pelo qual o sujeito consciente vai mais além de si mesmo e aceita incondicionalmente o ato a que está se dispondo permanentemente na existência" ${ }^{468}$, chega-se, então, à conclusão de que a mística é parte integrante do fenômeno religioso e que, por isso, afirmase a sua existência em todas as religiões.

No entanto, convém lembrar que a descrição da experiência mística como forma peculiar de realização da atitude religiosa, e o fato de que a atitude religiosa comporta sempre alguma forma de experiência não têm levado a afirmar sua realização em grande parte dos membros de todas as religiões. Para ele, a questão adquire outra perspectiva que permite, por uma parte, precisar o lugar e a função do elemento místico no conjunto dos elementos que compõem cada sistema religioso, e, por outra, precisar a figura do místico no cristianismo atual ${ }^{469}$.

Sobre a escassez de experiências místicas, S. João da Cruz resume, com claridade, depois de ter afirmado em numerosos textos inequívocos, a universalidade do chamado de Deus à perfeição a todas as pessoas. Ele reconhece o caráter pessoal do chamado e afirma com toda decisão o respeito escrupuloso da liberdade humana:

E aqui nos convém notar a causa do por que ser então poucos os que chegam a tão alto estado de perfeição de união com Deus; no qual é de saber que não é porque Deus queria que houvesse poucos destes espíritos levantados, que antes queria que todos fossem perfeitos, senão que encontra poucos que queiram sofrer e chegar a tão alto $^{470}$.

\footnotetext{
${ }^{468}$ VELASCO, J. Martin. El fenómeno místico, p. 425.

${ }^{469}$ Cf. Ibid., p. 447.

${ }^{470}$ S. João da Cruz: Poema: Chama B, 2,27.
} 
Velasco, então, acredita que a razão fundamental do pequeno número dos que vivem a experiência mística seja a falta de ânimo, de fidelidade e de generosidade das pessoas ${ }^{471}$, visto que, segundo ele, mesmo que a importância da experiência mística esteja no seio da vida religiosa, essa não elimina o perigo de excluir da vocação, da aspiração à perfeição da maior parte dos crentes. Porque sua essência pode realizar-se de muitas maneiras e todo sujeito religioso está chamado a realizar a estreita união com Deus, como assim deseja o místico, pois cada pessoa pode responder a essa vocação de formas diferentes, de acordo com as múltiplas situações e circunstâncias pelas quais discorre sua vida. Poderão realizar, assim, o elemento que comporta o exercício da vida religiosa.

No entanto, não todos os elementos místicos encarnam-se na figura histórica que até agora tem revestido e até agora monopolizado o nome de 'místico'. Como dizia K. Rahner, 'os místicos não representam um grau mais alto que os crentes, senão um momento interno e essencial da fé', que se realiza de formas diferentes por diferentes crentes ${ }^{472}$.

Teremos então a oportunidade, no capítulo seguinte, de procurar compreender a revelação Divina como um acontecimento que se dá maieuticamente na história, e que por isso, todas as religiões podem, segundo Queiruga, ser consideradas verdadeiras. Assim, sem deixar de reafirmar a identidade cristã, esse autor promove um encontro verdadeiro com as demais tradições religiosas, que realizam de diferentes formas a experiência com esse Deus que se deixa encontrar independentemente de cultura e religião.

\section{2. "Todas as religiões são verdadeiras"}

Para essa afirmação, tema de um capítulo do livro de Queiruga, Autocompreensão cristã, ele chega a dizer que esse, mesmo tendo 'um certo ar provocativo', não 'renuncia ao sentido profundo que trazem suas palavras' ${ }^{473}$.

\footnotetext{
${ }^{471}$ Cf. VELASCO, J. Martin. El fenómeno místico, p. 448.

${ }^{472}$ Cf. Ibid., p. 452 . Ver nota 7.

${ }^{473}$ Cf. QUEIRUGA, A. Torres. Autocompreensão cristã, p. 138; Procuraremos desenvolver esse tema, reunindo aqui as reflexões de Andrés Torres Queiruga que foram apresentadas nestas obras: QUEIRUGA, A. Torres. A revelação de Deus na realização humana. São Paulo: Paulus, 1995. Id., $O$ diálogo das religiões. São Paulo: Paulus, 1997. Id., Autocompreensão cristã: diálogo das religiões. São Paulo: Paulus, 2007; Id., Cristianismo y religiones: 'inreligionación' y cristianismo assimétrico. Estúdios, Sal Térrea v. 84, n. 1 p. 3-19, 1997. Para este autor, "se Deus revela-se a
} 
Queiruga tem como base para sua afirmação uma nova concepção da revelação ${ }^{474}$. Esta deixa de adquirir um caráter de 'ditado divino' e forte sentido fundamentalista para assumir um novo entendimento, um 'dar-se conta' da presença de Deus 'sempre aí, que maieuticamente ${ }^{475}$, na história, revela-se ao homem, sem distinção de tradição cultural ou religiosa. Reafirma a identidade cristã ao mesmo tempo em que favorece novas perspectivas para o encontro real entre as várias tradições religiosas.

Como veremos, essa nova maneira de conceber a revelação possibilitou compreender a 'particularidade' como necessidade da realização histórica, abrindo um novo caminho e novas possibilidades, vislumbrados com a queda do exclusivismo, pela necessidade de rever a ideia da 'eleição" ${ }^{476}$ como privilégio divino. Permitida, assim, pela nova compreensão da revelação, com a constatação da universal presença reveladora e salvífica de Deus, pode-se eliminar toda ideia de favoritismo, e as religiões poderão ser apreciadas como verdadeiras pela medida com que cada uma capta a seu modo, em sua história e cultura, esta Presença.

O caminho, então, trilhado por Queiruga para chegar a esta afirmação foi obtido por causa da nova situação histórica, que exigia, diante dos novos problemas enfrentados pela teologia com avanço do pluralismo religioso, uma resposta capaz de possibilitar uma melhor abertura entre as tradições religiosas. Diante da ineficiência das categorias existentes, foi forçado a buscar novos meios, propondo três novas categorias.

todos, então, todas as religiões são reveladas e, portanto, nessa mesma medida, verdadeiras". Cf. Ibid., p. 05. Como veremos mais adiante, para Queiruga esses 'graus e verdade' não significam 'méritos', mas referem-se à tematização histórica das religiões ante o Absoluto. Referir-nos-emos a Andrés Torres Queiruga apenas como Queiruga.

${ }^{474}$ Essa nova concepção parte da relação entre Revelação e História. Queiruga atento a esta relação, procura compreendê-la a partir da dialética existente na experiência religiosa e na sua comunicação na história dos homens. A revelação que é a autocomunicação de Deus à humanidade, acontece na história do próprio homem. Em seu livro 'A revelação de Deus na realização humana', Queiruga magistralmente desenvolve sua reflexão, enriquecendo a teologia e possibilitando uma melhor abertura ao encontro e diálogo inter-religioso.

${ }^{475}$ Conceito da filosofia moderna, parte ativa da dialética de Sócrates. Cf. REALE, História da Filosofia Antiga. São Paulo: Paulus, 1990. v. 1. pp. 307-315. A maiêutica foi definida por Sócrates como a "arte de observar à psyche" (alma). E Queiruga se utilizará deste termo na teologia da revelação, como veremos mais adiante, realizando uma alteração, sem negar sua intuição primeira, pois o concede a qualificação de 'histórica', ressaltando a liberdade de Deus e a novidade da história humana. Sem, é claro, deixar de reforçar sua dimensão histórica.

${ }^{476}$ Como veremos mais adiante, Queiruga se utilizará da expressão 'estratégia de amor' ao termo 'eleição', para evitar que se entenda como 'favoritismo divino', ou se utiliza do termo usando-o entre aspas. 
'Universalismo assimétrico,477 é a primeira. Esse é adquirido como possibilidade, porque tem como pressuposto a afirmação da Presença universal da salvação, que torna possível o respeito ao valor intrínseco de todas as religiões e o reconhecimento de sua existência e desenvolvimento na história, pois é possível tanto em não ceder ao relativismo do 'tudo igual' diante do realismo histórico e antropológico, quanto ao achatamento na busca pela universalidade, como também na troca da 'lógica da concorrência' pela 'lógica da gratuidade', abrindose para a troca de experiências, por reconhecer que não lhe pertence como algo absoluto, mas que é para todos.

A segunda, exigindo uma revisão da cristologia, procura ser mais teocêntrica, partindo da própria relação de Jesus de Nazaré com Deus. Queiruga, assim, denomina esta categoria de 'teocentrismo jesuânico' ${ }^{478}$. Essa demanda um grande equilíbrio, pois enquanto procura acentuar a centralidade de Deus, não pode diminuir o papel único e irrenunciável de Jesus de Nazaré.

E como última de suas propostas como nova categoria, Queiruga apresentanos a 'irreligionação ${ }^{479}$. Nessa categoria, ele reafirma o avanço da 'inculturação' e propõe um passo a mais na tentativa de evitar suprimir a presença real de Deus no mundo, passando a respeitar a cultura e a experiência religiosa de cada tradição.

Assim, partindo da nova concepção da revelação que acontece maieuticamente na história, em que procura resguardar a liberdade de Deus sem perder a sua novidade na história humana, por estar 'já sempre aí', e da comprovação de que a revelação é a mais alta expressão do amor de Deus à humanidade e a possibilidade da mais autêntica realização humana, saberemos como essa descoberta provocou a mudança na relação com as demais tradições religiosas, chegando à afirmação de que 'todas as religiões são verdadeiras' .

\subsection{A Revelação como maiêutica histórica}

Queiruga nos fornece uma compreensão da estrutura da revelação que pode ser aplicada também às outras religiões e permite identificar, já do ponto de vista

\footnotetext{
${ }^{477}$ Cf. QUEIRUGA, A. Torres. Autocompreensão cristã, pp. 93-110.

${ }^{478}$ Cf. Ibid., pp.111-122.

${ }^{479}$ Cf. Ibid., pp. 167-193.
} 
fenomenológico, um dado prévio que dá suporte às diferenças e especificidades constitutivas das religiões, permitindo um esquema de interpretação para compreenderem-se as religiões em sua singularidade.

Isso porque a revelação faz parte da autoconsciência de todas as religiões, uma vez que essa venha a ser a tomada de consciência da presença do divino no indivíduo, na sociedade e no mundo. Essa afirmativa toca no constitutivo da autocompreensão do cristianismo, na convicção de que em Jesus Cristo se deu a plenitude da revelação, isto é, na pretensão de possuir a revelação absoluta.

No entanto, essa pretensão se choca com o fato de que outras religiões também se apresentam como religiões reveladas e com o fato do pluralismo religioso em si mesmo. As reflexões sobre essa questão se dão em duas direções: uma é aquela suscitada pela teoria de K. Barth, depois abandonada por ele, que negava qualquer possibilidade de revelação fora da revelação bíblica, não admitindo a religião como lugar da revelação de Deus ${ }^{480}$. Ao contrário, para ele a revelação era a supressão da religião. E a outra é a fenomenologia da religião, que em uma linha oposta rompe com esta visão restrita da revelação. Ali, por certo tempo, alguns estudos faziam uma distinção entre religião natural e religião revelada. Mas, na medida em que as ciências da religião foram demonstrando a existência de traços fundamentais comuns a todas as religiões, esta distinção foi se tornando irrelevante ${ }^{481}$.

O dado mais fundamental comum às diversas religiões é que todas compartilham da convicção de terem sua origem numa revelação divina, qualquer que seja o nome atribuído a esta realidade divina, de modo que "a revelação é um dado constitutivo da estrutura mesma da religião" ${ }^{482}$.

Diante dessa questão, Queiruga assume em sua reflexão o ponto de partida fornecido pela fenomenologia e enriquece-o com o dado antropológico da experiência humana da revelação. Para ele, o homem é um ser 'emergente', no qual se supõe toda uma evolução que alcança o seu extremo ${ }^{483}$. O ser humano,

${ }^{480}$ Cf. LATOURELlE, R. Revelação. In: Dicionário de Teologia Fundamental. Petrópolis: Vozes; São Paulo: Santuário, 1994, p. 816; QUEIRUGA, A. Torres. A revelação de Deus na realização humana, p. 20s.

${ }^{481}$ Cf. QUEIRUGA, A. Torres. A revelação de Deus na realização humana, p. 20.

${ }^{482}$ Ibid., p. 20.

${ }^{483}$ Cf. QUEIRUGA, A. Torres. A revelação de Deus na realização humana, p. 173. Um extremo ainda aberto e dinâmico, que continua, por outros caminhos, processos. Um extremo consciente, que se levanta sobre o horizonte do mundo, descobrindo, ao olhar para trás, o processo evolutivo que se perde na noite dos tempos, e se encontra adiante no 'aberto' (Rilke), movido por um 
diferente do animal, possui em si a pergunta que lhe arde, a pergunta sobre Deus. Diante dessa interrogação, existente independente de sua permissão, se tem a partir de sua acolhida um

significado fundamental da revelação como fundamento: essa receptividade radical na qual o homem acolhendo a presença salvadora de Deus, vai entrando em sua plena realização, enquanto determinado e entregue a si mesmo pelo Deus que a ele se comunica ${ }^{484}$.

A revelação de Deus ao homem implica para este em um intenso encontro consigo mesmo, em uma maior percepção sobre a vida e uma melhor contribuição na construção da história rica em significado para si e para a sociedade. E, para isso, ele nos apresenta a partir da revelação acontecendo maieuticamente na história, a possibilidade da realização do homem na revelação de Deus, pois, "na resposta à revelação, o homem está se realizando a si mesmo: está construindo, desde a última radicalidade, a história de seu ser" ${ }^{285}$.

E é a partir desta reflexão sobre a revelação de Deus à humanidade, que temos de Queiruga sua grande contribuição, com especial particularidade aquilo que o faz distinguir-se de outras reflexões teológicas. Contribuições essas que permitem abrir caminho para a comunicação entre as diferentes tradições religiosas e uma maior tematização da autocomunicação divina, porque ele acredita que Deus insiste em querer revelar-se a todos e de modos sempre novos, pois "Deus é livre para revelar-se quando e como quer" 486 .

Suas grandes contribuições que, no entanto, já acompanhavam a história humana, mas cuja tematização na teologia foi ele que proporcionou, foram a maiêutica histórica, como categoria mediadora e a hermenêutica do amor ${ }^{487}$.

Para podermos compreender a função desse método maiêutico na teologia, teremos que adentrar no campo da filosofia, precisamente em Sócrates que fazia uso desse método em sua dialética.

dinamismo infinito, intrinsecamente insatisfazível, aberto a uma plenitude que lhe chegue 'a partir de fora e a partir de cima' (Blondel), e até mesmo à 'escuta da palavra' que ilumine seu mistério (Rahner).

${ }^{484}$ QUEIRUGA, A. Torres. A revelação de Deus na realização humana, pp. 177-178.

${ }^{485}$ Ibid., p. 200. Tendo como título de seu livro "A revelação de Deus na realização humana" Queiruga, apresenta o ser humano como lugar próprio para a revelação de Deus, acontecendo maieuticamente na história.

${ }^{486}$ Id., ¿Qué significa afirmar que Dios habla? Selecciones de Teologia, v. 34, n. 134, pp. 102108, 1995. p. 102.

${ }^{487}$ Teremos a oportunidade no decorrer deste capítulo de aprofundarmos sobre essas tematizações apresentadas por Queiruga. 
Sócrates, que era filho de uma parteira, diz ter herdado o mesmo ofício de sua mãe, afirmando em um diálogo com Teeteto:

Ora, a minha arte de obstetra assemelha-se em todo o resto à das parteiras, mas difere delas no fato de agir sobre homens e não sobre mulheres, e cuidar das almas grávidas e não dos corpos. E o faz tanto pela verdade de que está grávido o homem como pela não verdade “... Se, depois, examinando as tuas respostas, eu encontrar que algumas são quimeras ou não verdades, arranco-as de ti e lanço-as fora, e não te zangues.... não é na verdade, por maldade que eu faço isso, mas só porque não considero lícito aceitar a falsidade ou obscurecer a verdade ${ }^{488}$.

Para ele, a maiêutica era a arte de obstetra da alma. Assim, como em um momento de dar à luz a uma criança, as mulheres sofriam a dor e a aflição, ele também ajudava os seus discípulos, em meio à dor e à aflição, a darem à luz as verdades presentes em seus espíritos, o que podia acontecer se já estivessem grávidos. Esse método "consiste em levar o interlocutor ao descobrimento da verdade mediante uma série de perguntas... e chega, por fim, a engendrar a verdade, descobrindo-a por si e em si mesmo" 489 .

Isso nos permite concluir que, para Sócrates, a maiêutica é 'a arte' de 'ajudar a gerar', a 'dar-à-luz' às novas ideias presentes nas almas de seus interlocutores. E até mesmo o parto do não verdadeiro é benéfico para a alma, pois essa se liberta de um conhecimento vão e dá lugar à verdade. Então, ajudando a gerar, a maiêutica socrática contribui apenas para que seu interlocutor descubra a verdade que traz em si mesmo e a externe ${ }^{490}$.

Queiruga, no entanto, fazendo uso desse termo, que se aproxima à primeira vista da revelação, o faz a partir de duas distinções bem precisas, sem se desfazer de sua intuição primeira: no uso da palavra externa do mediador e no envio do interlocutor à sua própria realidade. Para ele, "nós descobrimos a revelação, porque alguém no-la anuncia; mas a aceitamos, porque, despertados pelo anúncio, "vemos" por nós mesmos que essa é a nossa resposta certa" ${ }^{491}$. Aqui, a palavra do mediador contribui para que o interlocutor seja remetido para dentro de si mesmo, em um processo de reconhecimento e a-propriação.

Por descobrir uma nova realidade, que já estava presente e, ao mesmo tempo, desconhecida pela presença que já o acompanhava, e pela verdade vinda

\footnotetext{
${ }^{488}$ PLATÃO. Teeteto, 150b-15d. Apud. PANASIEWICZ, Roberlei. Diálogo e revelação: rumo ao encontro inter-religioso. Belo Horizonte: C/Arte, 1999. pp. 86-87.

${ }^{489}$ MORA, Ferrater. Mayéutica. Diccionário de Filosofia. Madrid: Alianza, 1981.

${ }^{490}$ Cf. PANASIEWICZ, Roberlei. Diálogo e revelação, p. 88.

${ }^{491}$ QUEIRUGA, A. Torres. Autocompreensão cristãa, p. 18. Grifo do autor.
} 
de Deus que já era e está sendo. E, assim desvendando, ou seja, permitindo o "nascer" de uma realidade nova, "o homem descobre a Deus que o está fazendo ser e determinando de uma maneira nova e inesperada" ${ }^{492}$.

Aqui, descobrimos que Queiruga procura ir mais além: primeiro, por apresentar a essa categoria socrática uma modificação em sua perspectiva gnoseológica, pois permite transparecer nessas suas distinções que o homem é sempre "homem-no-mundo de maneira que não pode haver desvelamento próprio sem desvelamento da situação, e que todo desvelamento da situação é também desvelamento do homem"493. Depois, a partir do que Schillebeeckx diz, "assim poderíamos definir o ser humano: um ser-com-Deus-neste-mundo-de-homens-ede-coisas"494. Para ele, o homem será um "ser-apartir-Deus-no-mundo",495, permitindo a esta categoria maiêutica sua inclusão no contexto atual.

Assim, é apresentada a maiêutica à revelação adentrando na teologia, lugar em que lhe será inserida a qualificação de "histórica", ressaltando a liberdade de Deus e a novidade da história humana: é a alteração de maneira radical do conceito socrático. Será a partir destas duas dimensões que Queiruga, por meio da Teologia da Revelação, irá reler a categoria socrática.

Sobre o método socrático, como pudemos observar a partir do que já nos foi apresentado, esse não gera nada de novo. A ele, como também às parteiras, não cabe criar nada. Apenas controlam o 'vir-à-luz' das verdades inerentes ao homem, pois esses a encontram e dão à luz por si mesmos. Esse método encerrase "na mais pura imanência"496, onde qualquer um pode dar à luz por si mesmo ao que já estava desde sempre presente.

Poderemos perceber com a perspectiva da revelação que o caminho se torna diferente, pois este se apoia na novidade da origem histórica e na livre iniciativa divina. Segundo Queiruga, na revelação "não se manifesta o que o homem é por si mesmo, e sim o que começa a ser por livre iniciativa divina. Não se trata de um

\footnotetext{
${ }^{492}$ QUEIRUGA, A. Torres. Autocompreensão cristã, p. 113.

${ }^{493}$ Ibid., p. 113-114.

${ }^{494}$ SCHILLEBEECKX, E. Intelligence de la foi er interprétation de soi. In: Théologie d'aujourd'hui et de demain. Paris, 1967. p. 125. Apud. QUEIRUGA, A. Torres. A revelação de Deus na realização humana, p. 114.

${ }^{495}$ QUEIRUGA, A. Torres. A revelação de Deus na realização humana, p. 114.

${ }^{496}$ Ibid., pp. 114-115.
} 
desdobrar imanente de sua essência, mas de uma determinação realizada por Deus na história" 497.

Isso a faz ser sempre experimentada de maneira nova e gratuita. Chega mesmo a ser entendida como "novo nascimento" ${ }^{498}$, como inovação essencial ${ }^{499}$, quando vivida em sua plena intensidade.

Aqui, a palavra passa a ser necessária para que a comunidade chegue à consciência da nova realidade. Queiruga não nega a intuição primeira de Sócrates do 'dar-à-luz', que permite ao seu interlocutor trazer à realidade um outro conhecimento de que, até então, não se havia dado conta, como também resguardar a importância do mediador $($ maieuta $=$ parteiro), para com a sua comunidade. Mas a sustenta nessa nova aplicação histórica. Para ele, “o mediador, com sua palavra e seu gesto, faz os demais descobrirem a realidade em que já estão colocados, a presença que já os estava acompanhando, a verdade que, vinda de Deus, já era ou está sendo"

Afirma ainda Queiruga que esse "não faz mais que iluminar, na consciência, a experiência transcendental da própria realidade já agraciada pelo Espírito" 501.

Assim é o que podemos ver em Moisés, um homem que vive e promove os acontecimentos a partir de uma profunda experiência religiosa, interpreta-os à luz dessa experiência, e consegue que, pouco a pouco, também outros a experimentem e a interpretem da mesma maneira. Ele é, assim, o mediador que possibilitou aos israelitas 'darem-à-luz' a presença atuante de Deus em seu meio. Deus que estava desde sempre presente $e^{502}$, de maneira oculta, embora real.

E assim, "Israel descobriu a Deus na história e, ao fazê-lo, foi-se descobrindo a si mesmo" ${ }^{, 503}$. Com essa tomada de consciência, os israelitas passam a servir como ponto referencial e possibilidade sempre nova de se 'aperceber' de algo de novo e de gratuito nessa revelação divina na História da Humanidade, pois a revelação, a partir dessa consciência, é 'patrimônio universal'

\footnotetext{
${ }^{497}$ QUEIRUGA, A. Torres. A revelação de Deus na realização humana, p. 115.

498 Jo 3,3-8.

499 cf. Rm 6, 2; 7,6; Gl 6,15; 2Cor 5,17; Ef 2,15; 4,24; Cl 3,10.

${ }^{500}$ QUEIRUGA, A. Torres. Op. cit., p. 113.

${ }^{501}$ Ibid., p. 1224 .

${ }^{502}$ Cf. Gn 1,1; Pr 8,22; Jr 1,5; Ex 3,18.

${ }^{503}$ QUEIRUGA, A. Torres. Revelação de Deus na realização humana, p. 103.
} 
e não consegue ser apenas para a experiência de alguns, mas, para todos, pois seu lugar é na comunidade ${ }^{504}$.

É o que nos afirma Queiruga quando diz que

O iniciador do processo vive sua experiência como dada por Deus, como iniciativa divina.... E ao mesmo tempo, essa revelação que vem de Deus reenvia à história: à circunstância concreta... e não se isola nunca em si mesma nem se considera propriedade privada do iniciador; ao contrário, dirige-se sempre aos demais: é para $\operatorname{todos}^{505}$.

Por isso, o ouvinte, ao se deixar interpelar pelo mediador, apreende a profundidade de sua realidade, abre-se a uma experiência singular da revelação e descobre-se no 'próprio-ser-apartir-Deus-no-mundo', sendo necessário apenas que reconheça e aceite a revelação. Nesta resposta à revelação, o homem está se realizando a si mesmo, e entra em construção em profundidade com a história de seu ser. Esse próprio-ser torna-se novo (ao contrário da 'preexistência' de Sócrates), pois, já o tendo reconhecido e aceito, 'já é idêntico' a ele, e o percebe como 'estando já aí'. É a articulação do 'novo' e do 'já aí' no próprio crente.

Diante desta relação do crente com a palavra, "ajudá-lo a descobri-lo constitui precisamente a tarefa da palavra inspirada, que, por isso, é para ele maiêutica" ${ }^{, 06}$. Assim recupera-se a maiêutica na História tornando-se necessária para a apreensão da autocomunicação de Deus.

Para concluirmos, como maiêutica histórica, a revelação "não consiste num estático sempre aí, senão num 'sempre aí' dinâmico, que se atualiza constantemente no novo de sua realização mediante a liberdade do homem e de sua história"507. Ela que tem seu aspecto maiêutico na função da palavra, que possibilita o novo, 'traz à luz'. Não leva para fora de si, nem fala de coisas estranhas, mas devolve o homem à sua mais radical autenticidade.

A palavra age, assim, com toda propriedade, como 'parteira' que traz à luz a consciência do novo ser, tornando clara sua nova situação, a 'nova criatura' que agora é. Seu aspecto histórico encontra-se no mediador, que surge na história e responde a uma missão, a uma livre iniciativa de Deus.

Ela é, assim, sempre um ato por parte de Deus, que se realiza na liberdade histórica do homem e torna-se realidade concreta tão-somente com sua acolhida.

\footnotetext{
${ }^{504}$ Cf. PANASIEWICA, Roberlei. Diálogo e revelação, p. 91.

${ }^{505}$ QUEIRUGA, A. Torres. A revelação de Deus na realização humana, p. 107.

${ }^{506}$ Ibid., p. 116.

${ }^{507}$ Ibid., p. 195.
} 
Esse processo de revelação acaba se identificando com a história do homem. Acentua Queiruga “que a realidade mesma é o 'gesto' de Deus que nela se expressa. Quanto mais densa essa realidade, melhor manifesta a intenção reveladora nela incorporada: quanto mais pleno o significante humano, mais plena a significação divina",508.

Assim, é inegável que somente na experiência humana, se encontre lugar para que Deus se revele ao homem.

\subsection{A hermenêutica do amor}

A partir do que nos foi apresentado sobre a revelação que se realiza maieuticamente na história, podemos, então, reafirmar que a mais alta expressão do amor de Deus à humanidade encontra-se no seu desejo de tornar-se conhecido. Como assim, nos diz Queiruga, "dado que à essência mesma da revelação pertence o ser ação atual e livre de Deus.... porque Deus quer manifestar-se"

Essa é uma ação que parte sempre de Deus em direção ao homem, "pressionando a consciência humana para que cada pessoa, em cada circunstância, possa descobri-lo" ${ }^{\prime 10}$. O homem quando acolhe a presença reveladora de Deus, que estava desde sempre já aí, possibilita, através deste seu ato uma abertura ao seu próprio crescimento, à sua realização humana. "Aí Deus vem a seu encontro para potencializá-lo e orientá-lo, de maneira que todo o restante fique finalizado nessa experiência, que o envolve como um todo" ${ }^{, 511}$.

Essa articulação entre Deus e o homem é então afirmada por Queiruga como "simultaneamente ação de Deus e realização do homem"512 pois,

descobrir-se desde Deus é maturar o próprio ser, ir dando e ele a substância de seu último e mais autêntico crescimento; ao mesmo tempo em que esse crescimento vai possibilitando, em dialética progressiva, novas capacidade de acolher a ação de Deus $^{513}$.

Essa articulação se dá por meio das liberdades humana e divina. Deus convida o homem à realização como ser humano e essa sua ação é um dar-se à liberdade humana. Uma ação livre de Deus a uma resposta humana no uso de sua plena liberdade.

\footnotetext{
${ }^{508}$ QUEIRUGA, A. Torres. A revelação de Deus na realização humana, p. 200.

${ }^{509}$ Ibid., p. 211.

${ }^{510}$ Ibid., p 197.

${ }^{511}$ Ibid., p. 211.

${ }^{512}$ Ibid., p. 202.

${ }^{513}$ Ibid., p. 202.
} 
É no 'face a face' do encontro, que Queiruga vai nos dizer que,

aperceber-se da presença de Deus não é descobrir um espaço neutro que o homem explora por sua iniciativa; ao contrário, é sentir-se chamado, interpelado, levado sempre mais além de si mesmo por caminhos nunca antes suspeitados, que o amor livre e gratuito vai traçando e assinalando ${ }^{514}$.

Assim, Deus entra na história dos homens por meio dessa liberdade humana. Para Queiruga, Deus “transforma o mundo não à base de milagres e intervencionismos, e sim mediante sua presença reveladora na liberdade do homem" ${ }^{, 515}$. Como exemplo, lembremos que muitos estavam no Egito, mas apenas Moisés acolheu a nova e libertadora presença de Deus com relação ao seu povo. Muitos viveram a crise do exílio babilônico, mas só pessoas como Jeremias, Ezequiel ou o Dêutero-Isaías vivenciaram e explicitaram as inéditas profundezas da intimidade divina que se abriram à nova circunstância.

Logo, esta é a experiência do profeta, aquele que se abre à novidade divina $\mathrm{e}$ acolhe a missão de voltar à realidade e despertar outras liberdades para Deus ${ }^{516}$. "O profeta capta a presença que está tentando chegar a todos e que no espírito de todos se insinua, mas que nem todos percebem, devido à obscuridade estrutural inerente à manifestação reveladora" ${ }^{, 517}$.

Queiruga entende que a 'obscuridade' existe, não por vontade divina, mas da própria condição de criatura inerente ao ser humano.

Retomando a função da maiêutica, podemos constatar que, diante deste limite humano, sua necessidade está no fazer 'vir-à-luz' essa presença do 'sempre aí' de Deus na história humana. Ou seja, ela permite elucidar a presença 'obscura e ambígua' de Deus perante a liberdade humana. A generosidade irrestrita de Deus, que é amor sempre em ato, e que se quer dar plenamente, tem seu limite não em si mesmo, mas na impossibilidade da criatura ${ }^{518}$.

Para Queiruga, Deus quer e deseja tornar-se conhecido por todos os homens de forma igual. Por isso, seu amor não cessa de procurar meios para

fazer-se sentir o mais rápido e intensamente possível pelo maior número de homens; que desejaria dar tudo numa luta amorosa para romper a incompreensão do homem e abrirem-se os olhos ao dom desde sempre disposto para ele ${ }^{519}$.

\footnotetext{
${ }^{514}$ QUEIRUGA, A. Torres. A revelação de Deus na realização humana, p. 211.

515 Ibid., p. 205.

${ }^{516}$ Cf. PANASIEWICZ, Roberlei. Diálogo e revelação, p. 93.

${ }^{517}$ QUEIRUGA, A. Torres. Op. cit., p. 210.

${ }^{518}$ Cf. Ibid., p. 286.

${ }^{519}$ Ibid., p. 288.
} 
Compreender, então, este amor de Deus somente é possível através de sua autocomunicação aos homens, já que sua presença é um 'já sempre aí' na história humana. Uma presença que quer simplesmente autocomunicar-se por condição de possibilidade de libertação e de construção da felicidade do homem.

Assim, o conceito de revelação encontra-se na hermenêutica do amor, e na maiêutica histórica, como possibilidade de tornar sempre atual a revelação, como "última e autêntica realização do homem"520. O que pode, então, dizer-nos Queiruga sobre a universalidade de Deus com a “eleição" de um povo?

\subsection{A eleição e a universalidade de Deus}

Queiruga continua a nos surpreender com sua maestria de pesquisador no campo do diálogo inter-religioso. Sua preocupação em contribuir para uma das questões que assombram a teologia tem possibilitado um pensar e um agir teológico complemente diferentes. Sua pesquisa tem apontado um novo caminho com ricas possibilidades de abertura para uma melhor compreensão e convivência com uma realidade religiosa que se constata cada vez mais plural.

Perceberemos, neste tópico, a partir da nova compreensão adquirida sobre a revelação como maiêutica histórica, que, para Queiruga, é possível afirmar que a revelação histórica particular tenha pretensão universal, desde que seja apresentada "sem exclusivismos elitistas ou estreitezas provinciais" ${ }^{521}$. Para ele, o problema encontra-se não na limitação que a revelação possa apresentar por se situar na história, mas se essa tem condições de se apresentar como universal ${ }^{522}$.

Como entender, então, a gratuidade do amor de Deus em sua universalidade, quando escolhe um povo em eleição histórica, em que biblicamente diz que para "amar Jacó tem que odiar Esaú",523?

Para essa questão, nosso autor se apoia absolutamente na revelação histórica e nessa 'eleição' não como restrição do amor, mas como sua máxima manifestação. O particular, para ele, não significa exclusivismo, mas generosa 'estratégia do amor' que deseja atingir a todos. “Deus revela-se sem reservas, com toda a força de sua sabedoria e de seu poder, e revela-se a todos na máxima

\footnotetext{
${ }^{520}$ QUEIRUGA, A. Torres. A revelação de Deus na realização humana, p. 220.

521 Ibid., p. 278.

${ }^{522}$ Cf. Ibid., p. 279.

523 Ibid., p. 280; Cf. Ml 1,2-3.
} 
medida possível" 524 . E mais uma vez afirma que "o limite, se aparece, deve vir de outro lugar: da incapacidade da criatura para captar com maior clareza sua revelação" 525 , pois, insistindo em querer amar, Deus "continua pressionando a consciência da humanidade, para emergir dela, fazendo sentir sua presença" 526 .

No entanto, encontram-se no homem, na "incomensurabilidade estrutural entre o Criador e a criatura" ${ }^{\natural 27}$ os limites para a revelação de Deus. E esses, impostos na relação entre Deus e o homem, enquanto impossibilitam a total revelação de Deus, demonstrando, assim, sua distância infinita, causam-nos espanto, pois, mesmo diante de tamanha impossibilidade, o homem ainda tem condições de aperceber-se dessa presença e trazê-la à palavra. O que acontece não por sua própria força, mas porque Deus desejaria dar tudo numa luta amorosa para romper a incompreensão do homem e abrir-lhe os olhos ao dom sempre disposto para ele.

Esse mistério que perpassa a relação entre Deus e a criatura, a qual, mesmo diante de tamanha fragilidade e ambiguidade que comporta o ser humano, ainda consegue deixar-se tocar pelo Criador e, indo além, consegue em limitadas palavras descrever sua experiência, encontra um caminho de explicação na 'teologia negativa'. Em toda teologia, essa questão torna-se mais provocante nas experiências místicas.

No entanto, Deus revela-se "a todos enquanto esteja ao seu alcance",528. A dificuldade, como já vimos, encontra-se na própria criatura. Ele ressalta que não poderia ser diferente, visto que é irrenunciável aceitar a historicidade do homem. Esta consiste em realizar-se na história mediante o exercício da própria liberdade, pois será no exercício de sua autonomia que o homem poderá estar aberto "à revelação real, que brota na liberdade e vai-se aproximando pelos caminhos da história" $" 529$.

A revelação, ao redor de seu mistério, tem então, na história própria do homem, na sua realização humana, o lugar de sua manifestação. Diferente do que se possa pensar, esse Deus é um Deus cujo amor é urgente, que busca por todos os

\footnotetext{
${ }_{524}$ QUEIRUGA, A. Torres. A revelação de Deus na realização humana, p. 280.

${ }^{525}$ Ibid., p. 283.

${ }^{526}$ Ibid., p. 288.

${ }^{527}$ Ibid., p. 280. Para Queiruga, a incomensurabilidade estrutural que o homem carrega, "indica sua condição historicamente insuperável e para situar nela o lugar radical das incomensurabilidades concretas, que se the acrescentam e a densificam".

${ }^{528}$ Ibid., p. 283.

${ }^{529}$ Ibid., p. 287.
} 
meios fazer-se sentir o mais rápida e intensamente possível pelo maior número de homens.

Queiruga não nos deixa passar despercebido que este desejo de Deus em querer tornar-se conhecido é pura gratuidade de seu amor, porque "se Deus não quisesse revelar-se, nada o homem poderia alcançar de sua intimidade....e que todo homem como tal, com todas as suas faculdades, é puro dom de Deus criador" ${ }^{230}$. Com essa gratuidade, Deus apresenta-se como amor total e universal, que quer atingir a todos os homens.

É a partir dessa compreensão da revelação, que representa toda a força do desejo de Deus em querer amar o ser humano, que Queiruga fala da “"eleição’ não como um 'favoritismo', pois é para todos nem como um mero 'acidente', porque Deus está total e pessoalmente em relação concreta com cada homem"531.

Assim, Deus encontra a possibilidade de ir potencializando um caminho rumo à manifestação total, quando a partir da realidade histórica do ser humano, acontecerá sua manifestação para a humanidade,

um grupo iniciará um tipo de peculiar experiência. Por diversas circunstâncias, entre as quais a providencial saída do Egito exerce um papel determinante, nesse grupo desenvolve-se uma especial sensibilidade para captar a "pressão" religiosa de Deus sobre a consciência da humanidade ${ }^{532}$.

O que não significa que Deus esteja preferindo este grupo e negando a outro, mas que

essa 'eleição' é também para os demais o caminho mais rápido do amor, que enquanto prossegue com eles, levando-os o mais adiante possível em sua própria circunstância, antecipa-lhes pelo atalho do oferecimento histórico o que o povo eleito alcançou por sua conta ${ }^{533}$.

Isso é o que Queiruga chama de 'estratégia do amor'. Esta 'estratégia' usada por Deus nesta particularidade da revelação bíblica permite transparecer desde suas entranhas a universalidade da revelação, pois "não cabe na história outra universalidade real". Ele elimina o pré-conceito de uma universalidade abstrata, que se apoia numa representação estática e isomórfica da realidade. Reconhecendo que a realidade do mundo e, sobretudo, a do homem é emergente,

\footnotetext{
${ }^{530}$ QUEIRUGA, A. Torres. A revelação de Deus na realização humana, p. 288.

${ }^{531}$ Ibid., p. 289.

${ }^{532}$ Ibid., p. 290.

${ }^{533}$ Ibid., p. 292.
} 
ou seja, histórica ${ }^{534}$, e que a revelação dá-se no próprio ir-se fazendo do homem, porque o que se quer universalizar tem de ser antes alcançado.

Afirma Queiruga, que "unicamente aquela revelação na qual se alcança a plenitude do homem pode ser, com justiça, universalizável, ou seja, apresentar-se como oferecimento a todos os homens" ${ }^{\text {535 }}$. E porque alcança em Jesus o limite insuperável, rompe-se toda particularidade ${ }^{536}$, Deus encontra em Jesus uma oportunidade para entregar-se totalmente a toda a humanidade.

No entanto, como é possível que esta particularidade cristã possa ser universal? Podemos afirmar que é apenas na "práxis do cristão que se pode verificar como universal a pretensão do cristianismo" ${ }^{\text {537. }}$. Porque a universalidade de Cristo encontra-se 'a partir de baixo', na sua kenósis, na única universalidade possível dentro da história: a do sofrimento ${ }^{538}$. O amor marca o dinamismo da revelação, tornando-a universal, na entrega que Deus faz do seu Filho.

Logo, a universalidade do cristianismo está na práxis do cristão, a partir de uma fé que se proclama universal e que o faz a partir da experiência da Cruz. Tem que buscar necessariamente o 'universal humano' através do esforço de uma maior justiça e de uma melhor vida para todos os homens ${ }^{539}$.

Essa universalidade consiste no próprio ato de Deus, por sua 'pressão' amorosa sobre a consciência da humanidade, no desejo de fazer sentir sua presença e em "acelerar o tempo pelo atalho de uma tradição particular, para fazer chegar o quanto antes a todos a oferta de amor que para todos foi pensada e posta em andamento desde o princípio nos caminhos da História" ${ }^{540}$.

Atingindo toda a sua plenitude em Jesus, torna o cristianismo uma religião portadora de uma experiência destinada a todos, porque parte da mesma experiência de todos, e nunca sai dela: o que faz é captar mais clara e intensamente o comum. E assim, "o cristianismo traduz, sem diferenciação nem distância, a gratuita paternidade divina horizontal e a irrestrita fraternidade humana"541.

\footnotetext{
${ }_{534}^{53}$ Cf. QUEIRUGA, A. Torres. A revelação de Deus na realização humana, p. 173.

${ }^{535}$ Ibid., p. 294.

${ }^{536}$ Cf. Ibid., Cap. VI. "A definitividade de Cristo como mediador comporta a definitividade da revelação".

${ }^{537}$ Ibid., p. 295.

${ }^{538}$ Cf. Ibid., pp. 295-296.

${ }^{539}$ Cf. Ibid., p. 296.

${ }^{540}$ Id., Cristianismo y religiones, p. 4.

${ }^{541}$ Ibid., p. 9.
} 
Queiruga destaca que a essência dessa experiência cristã consiste na consciência de que o que ela descobre não está separado do que descobrem as demais "pois sabe que o mesmo Deus que a salva é o que está trabalhando com sua graça a inteira massa da humanidade para trazê-la a idêntica salvação" 542 .

A partir dessa consciência, aberta à verdadeira universalidade de sua experiência, o cristianismo não tem como usar de sua particularidade histórica, "privilegiando o particular numa espécie de conquista" "543, em seu trabalho missionário, pois deve ser claro que ela chega sempre a uma casa já habitada por seu Senhor. E que assim, rompendo todo 'imperialismo' missionário, ação de quem impõe algo que lhe é externo, torna possível o diálogo entre as religiões em uma rica possibilidade de compreensão universal.

O diálogo torna-se então possível porque consiste em avançar no seio de uma mesma experiência. Não há imposição, porque se trata de ajudar a reconhecer a um Deus que é de todos: de nenhum modo mais próprio daquele que prega do que daquele que escuta ${ }^{544}$.

Essa apresentação não deve ser entendida como um nivelamento da experiência cristã com outras experiências. A revelação em Jesus é, pois, real, como progresso ontológico do que é o peculiar cristão, e de que é o último e derradeiro na realidade, que consiste na descoberta de uma relação viva e pessoal com Deus.

$\mathrm{O}$ que ele afirma longe de qualquer tentativa de etnocentrismo ou do 'imperialismo', por causa de Cristo, é que este

emerge solidariamente da comum e universal experiência religiosa humana, fazendo-a avançar em si mesma desde dentro até situá-la diante da gratuidade, misteriosa e total abertura pessoal de Deus: ao fazê-lo...o faz para todos, abrindo e expandindo para a frente a universalidade radical da qual partia ${ }^{545}$.

Queiruga ainda destaca que "a particularidade humana de Jesus, situada num país, num tempo e numa cultura, oferece-se a partir de então, na presença universal - sem limite algum de espaço e de tempo - do Ressuscitado" ${ }^{546}$, o que faz a universalidade cristã não impor nenhum particularismo cultural, mas estar

\footnotetext{
${ }^{542}$ QUEIRUGA, A. Torres. A revelação de Deus na realização humana, p. 300.

${ }^{543}$ Ibid., p. 297. Grifo do autor.

${ }^{544}$ Ibid., p. 300.

545 Ibid., p. 303.

${ }^{546}$ Ibid., p. 304.
} 
sempre disposta a encarnar-se em cada cultura, a 'inculturar-se ${ }^{, 547}$. Mais à frente, ele nos falará em 'inreligionar-se'.

\subsection{0 cristianismo e outras religiões}

No item anterior, abordamos a universalidade da revelação cristã, destacando que sua essência consiste na consciência de que o que ela descobre não está separado do que descobrem as demais. Agora teremos a oportunidade de analisá-la em ato, em sua extensão e contato efetivo com as demais religiões.

Para Queiruga, o tema 'cristianismo e religiões' é um tema de maior importância em toda a reflexão teológica. Tema que deixou de ser apenas teórico para fazer-se contato vivo, conhecimento imediato e diálogo inadiável, a partir da própria realidade, longe de quaisquer esquemas ou ideias prefixadas, com homens concretos em sua vida religiosa e sua relação ativa com Deus.

Queiruga tem duas ideias, já apresentadas no decorrer de nossa reflexão, como base para a mesma. Retomaremos, porque são essências para este item.

$\mathrm{Na}$ primeira, ele destaca "a presença real - salvadora e libertadora - de Deus no centro de toda a realidade e no coração mesmo de toda a história dos homens" ${ }^{548}$, já que esta presença realiza-se no processo da realização do homem. Deus só pode dizer-se a nós em nossa realidade, em nosso mundo. Porque "Deus se revela a todos os homens, e se revela a eles realmente, revela-se a eles, sobretudo, nas experiências mediadas por suas tradições religiosas" 549 .

Assim procura eliminar todo esquema subconsciente que mantém a relação cristianismo/religiões=revelação/não-revelação. Assim como também rompe o esquema de 'nós verdadeiros' e os 'outros falsos', quando na sua segunda ideia nos diz “que a 'eleição' é uma necessidade histórica que não consiste em privilegiar para separar, e sim em chamar uns para chegar melhor a todos" 550 . Para ele, está claro que "Deus está realmente presente em todos os homens; esses em sua experiência religiosa captam essa presença como revelação ativa e salvadora" 551 .

\footnotetext{
${ }^{547}$ Cf. QUEIRUGA, A. Torres. Inculturación de la fé. In: FLORISTAN, C. (org.). Conceptos fundamentales de pastoral. Madrid: Cristiandad. 1983. pp. 471-480.

${ }_{548}$ Id., Op. cit., p. 341.

${ }^{549}$ Ibid., p. 150.

${ }_{551}^{55}$ Id., A revelação de Deus na realização humana, p. 341; Id., O diálogo das religiões, p. 60.

${ }^{551}$ Id., A revelação de Deus na realização humana, p. 151.
} 
Assim entende-se que esse romper de esquemas é a única possibilidade para um autêntico diálogo entre as religiões. Afirmando com toda clareza que "todo homem está em constitutiva relação sobrenatural com Deus e, portanto, em contato vivo com ele, e que as religiões são justamente a tematização dessa relação e desse contato, todas as religiões são verdadeiras" ${ }^{352}$.

Essa afirmação tem como fundamental a compreensão que se tem do 'grau de verdade' de que cada religião utiliza-se pra captar esta presença amorosa de Deus. E para isso se utiliza de uma única dialética a de 'verdadeiro/mais verdadeiro', reconhecendo a limitação histórica de cada comunidade religiosa, sem assumir em nenhuma experiência o sentido de absoluto. Porque "não existe religião sem alguma verdade nem religião perfeita, pois nenhuma pode esgotar em sua tradução humana a riqueza infinita do mistério divino" 553 .

O que para ele "não se trata de aqui renunciar à experiência da revelação cristã como manifestação plena, definitiva e universal de Deus em Cristo" ${ }^{554}$, mas de deixá-la expandir-se conforme seu dinamismo, visto que "a experiência cristã não é posse dos cristãos; é dom que emerge na comunidade religiosa humana e que a toda ela está destinada" 555 .

Retomemos a 'estratégia de amor' para reafirmar que na experiência reveladora no cristianismo constitui um elemento na estratégia histórica do amor divino, que assim quer chegar mais rápida e eficazmente à humanidade inteira.

Isso permite ao cristianismo quando em missão, nunca visitar um lugar sem que este já esteja sob a presença de Deus. O que faz é aproximar de outro rosto de Deus presente em outra cultura e religião.

Esta ação impulsionada pela própria força da plenitude experimentada, como nos diz Queiruga, pelo cristianismo, permite-lhe tornar-se sensível às diversas deformações encontradas fora, porque "o rosto entrevisto desde a insuperável irradiação na vida de Jesus suscita o desejo irreprimível de fazê-lo brilhar também nas outras religiões" 556 .

Assim agindo, não faz nada mais do que assumir sua missão, pois não anuncia a si mesmo, não é dono da semente que lança, e nem mesmo é ele quem a

\footnotetext{
${ }^{552}$ QUEIRUGA, A. Torres. A revelação de Deus na realização humana, p. 341. Grifo do autor.

${ }_{553}^{5}$ Id., Um Dios para hoy. Santander, Sal Térrea, 1997. p. 22.

${ }_{554}^{5}$ Id., A revelação de Deus na realização humana, p. 341.

${ }_{555}^{55}$ Ibid., p. 342.

${ }^{556} \mathrm{Ibid}$.
} 
faz crescer $^{557}$. Dá gratuitamente o que de graça recebeu ${ }^{558}$, porque o Senhor não é de ninguém, e por isso é de todos.

\subsection{0 não absolutismo do cristianismo}

Assim como vimos, a fé cristã afirma sem cessar, ao longo de toda a história do cristianismo, que em Jesus se deu a salvação e a revelação definitiva de Deus. Entretanto, a reconstrução da confissão cristológica neotestamentária possibilitou à teologia "compreender irreversivelmente que a divindade de Jesus se realiza em sua autêntica humanidade" ${ }^{559}$. Logo toda a sua vida assume o coração da confissão neotestamentária, e toda a tradição existencialmente vivida que daí provém é a experiência salvífica vivida por algumas pessoas no encontro com Jesus, a qual graças ao seu testemunho, torna-se acessível a todas as pessoas.

$\mathrm{Na}$ reflexão de Queiruga, esta interpretação do cristianismo enquanto vinculada a uma experiência salvífica forma base tanto para a afirmação da unicidade e da singularidade cristã quanto para o reconhecimento de seu caráter contingente e limitado.

Com efeito, todas as afirmações neotestamentárias que apresentam Jesus como salvação e revelação divina definitiva e situam-no numa relação constitutiva e essencial com a vinda do Reino de Deus são afirmações que nascem da experiência de fé que, como tal, têm um caráter autoimplicativo, isto é, engajam existencialmente quem as emprega ${ }^{560}$. Trata-se de uma linguagem relacional, que articula uma dimensão subjetiva, na medida em que expressa algo do horizonte interpretativo e da atitude das pessoas que a usam, com uma dimensão objetiva, enquanto afirma algo de real a respeito de Jesus mesmo.

Entretanto, essas declarações neotestamentárias são afirmações portadoras de um caráter absoluto, que não pode ser ignorado quando se trata de interpretar o Novo Testamento. Trata-se de uma linguagem cuja fonte encontra-se numa experiência que mediatiza algo de mais profundo. Assim, a base da confissão de fé no Novo Testamento é o que se manifestou em Jesus de Nazaré. Por isso, o

\footnotetext{
${ }^{557}$ Cf. 1 Cor 3,6-7.

${ }^{558}$ Cf. Mt 10,8.

${ }^{559}$ QUEIRUGA, A. Torres. A revelação de Deus na realização humana, p. 71.

${ }^{560}$ Cf. Ibid., p. 70.
} 
fundamento último da unicidade de Jesus afirmada no Novo Testamento está na convicção de fé de que "N'Ele habita a plenitude de Deus",561.

De acordo com Queiruga, a afirmação cristã da unicidade e universalidade salvífica de Jesus Cristo é uma afirmação válida para nós que cremos em Jesus, dado que ela tem por base uma experiência de salvação de Deus.

No entanto, isso não implica que o acesso a Deus e à salvação não se possa dar através de outros caminhos de salvação, já que para ele, a universalidade cristã 'parte da mesma experiência de todos', procurando captar o que é comum no longo processo de tradição que Deus está tentando manifestar a todos. Porque acredita que "o centro último e decisivo para todos - como também sucedia para o mesmo Jesus - está em Deus" ${ }^{, 52}$.

E mesmo estando sob uma nova concepção da revelação, percebe-se a necessidade de novos meios que possibilitem uma melhor clareza diante das questões internas e externas que envolvem cada tradição religiosa no encontro e diálogo entre si. Veremos o que Queiruga nos propõe diante dessa questão no item seguinte.

\subsection{A necessidade de novas categorias}

Por toda compreensão adquirida com a nova concepção da revelação, e ainda que não se tenha condições de medir suas consequências, Queiruga ainda ousa, rompendo com velhos moldes, reconfigurar em um novo contexto a experiência de sempre, fazendo uso de novas categorias.

a) Universalismo assimétrico

A nova compreensão da revelação e da plenitude cristã encontra-se no dilema. Nosso autor reconhece que "o exclusivismo se torna evidentemente insustentável". Para ele, a saída poderia estar no inclusivismo, que apresenta grandes vantagens, entretanto, "não dá conta das exigências legítimas do pluralismo" ${ }^{~ 563}$. Surge, então, para não recorrer a categorias já superadas pela nova

\footnotetext{
${ }^{561} \mathrm{Cl} \mathrm{1,19.}$

${ }^{562}$ QUEIRUGA, A. Torres. Cristianismo y religiones, p. 18.

${ }^{563}$ Id., Autocompreensão cristã, p. 94.
} 
situação e pela busca de um possível equilíbrio, uma nova categoria, denominada 'universalismo assimétrico, 564 .

Para ele, trata-se de 'universalismo', porque tem como base todas as religiões desde seu nascimento e desenvolvimento histórico, que são em si mesmas caminhos reais de revelação e de salvação, porque expressam, da parte de Deus, sua presença universal e irrestrita, sem favoritismo, nem discriminação, posto que, desde a criação do mundo, Deus "quer que todos sejam salvos" 565 . E 'assimétrico', porque, para ele, está claro que é impossível ignorar o fato das diferenças reais nas conquistas das diferentes religiões.

Já que por parte do ser humano é inevitável a desigualdade, mais uma vez Queiruga destaca que as diferenças existem "não porque se trata de um 'desígnio' de Deus, que escolheria e privilegiaria algumas pessoas, culturas ou nações em detrimento de outras; mas porque isso é imposto pela constitutiva desigualdade de finitude criatural" $\$ 566$.

Queiruga continua afirmando que Deus age por gratuidade "enquanto amor irrestrito e 'sem acepção de pessoas', é forçosamente, de maneira e sem graus distintos, segundo o momento histórico, a circunstância cultural ou a decisão da liberdade" ${ }^{567}$. Isso se percebe quando, individualmente, procura-se amadurecer e aprofundar a relação com Deus, como também na história de cada religião. Pois, assim como o cristianismo diz que é uma 'religio semper reformanda', "não pode ser diferente no relacionamento das religiões entre elas; sendo todas verdadeiras, nem todas têm a mesma profundidade" ${ }^{\circ 68}$.

Com isto, torna-se intolerável "pretender açambarcar como privilégio próprio o que pertence a todos" $" 569$. Isso o leva, diante do caráter absoluto que se mantém no cristianismo, percebendo que se trata de uma grande pretensão renunciar à palavra absoluto, substituindo-a por plenitude.

Realizar esta confissão significa possibilitar a visibilidade do seu significado autêntico, rompendo com qualquer pretensão de domínio e de conquista porque no campo do religioso toda descoberta, mesmo que aconteça em um determinado

\footnotetext{
564 Cf. QUEIRUGA, A. Torres. A revelação de Deus na realização humana, p. 13; Id., Autocompreensão cristã, p. 95.

5651 Tm 2,4; Cf. Ibid., p. 95.

${ }^{566}$ Id., Autocompreensão cristã, p. 96.

${ }^{567}$ Ibid., p. 96; Cf. Rm 2,11.

${ }^{568}$ Id., Autocompreensão cristã, p. 97.

${ }^{569}$ Id., A revelação de Deus na realização humana, p. 99.
} 
lugar, tem um destino universal. É “dom que busca realizar-se identicamente na acolhida própria e no oferecimento aos demais", que deixando de ser possessão passa a ser percebida como "responsabilidade e encargo". Partilhada não como bem particular, mas como herança comum na promessa de um futuro pleno ${ }^{570}$.

Queiruga explica o significado da palavra plenitude neste novo contexto. Para ele, não pode significar nada semelhante à 'onicompreensão', como se uma religião determinada, por mais elevada que fosse, pudesse abarcar o Mistério. Como também, não pode significar um 'fechamento', que contribua para “que paralise a história e acabe com o futuro". Ao contrário, "remete a uma Plenitude dinâmica, em que todo o processo anterior chega realmente a si mesmo e abre-se às máximas possibilidades de sua vivência" ${ }^{, 571}$.

No entanto, nada pode impedir aos cristãos que confessem a 'plenitude' e definitividade da revelação em Jesus Cristo, o que exige um longo e difícil caminho para novas categorias que melhor ajudem sua compreensão. Para tal desafio, ele acredita no seguinte: “deve-se elaborar uma dialética, que por um lado evidencie a imprescindibilidade de Jesus de Nazaré como pessoa histórica, e por outro, reconheça que no fim das contas, o centro último é sempre Deus" ${ }^{, 572}$. Surge assim, como proposta sua a categoria 'teocentrismo jesuânico'.

b) Teocentrismo jesuânico

A importância desta categoria parte de uma questão crucial: a particularidade, que no caso de Jesus é confessada como definitiva, atingindo precisamente o seu cume: o cristocentrismo, quando mal-interpretado é um obstáculo insuperável para o diálogo com outras religiões ${ }^{573}$. A cristologia deve ter como tarefa fundamental "mostrar como na vida terrena de Jesus, deixa-se transparecer o mistério único de sua filiação divina"574. Logo, deve-se ter uma atenção cuidadosa à nova visão crítica do processo da revelação na Bíblia, unida a uma consideração realista do diálogo atual entre as religiões.

Queiruga, fazendo uma reflexão sem se aprofundar nas soluções que se apoiam no recurso ao 'Cristo Cósmico' ou ao 'Logos Universal', e sem negar sua legitimidade na reflexão teológica, mesmo podendo tornar menos traumática a

${ }^{570}$ Cf. QUEIRUGA, A. Torres. A revelação de Deus na realização humana, p. 100.

${ }^{571} I d$., Autocompreensão cristã, p. 101.

${ }^{572}$ Ibid., p. 102.

${ }^{573}$ Cf. Ibid.,p. 103.

${ }^{574}$ Id., Confesar hoy a Jesús como el Cristo. Santander: Sal Terrea, 1994. p. 31. 
passagem para um paradigma, nos diz que "não fazem justiça à densidade histórica e à transcendência ontológica do corrido em Jesus de Nazaré, nem preservam o universal caráter absoluto de Deus, tal como o vivia o próprio Jesus" $" 575$.

Ele, assim, procurando tornar claro o caráter 'teocêntrico' da nova categoria, começa acentuando a importância decisiva da pessoa histórica de Jesus. Porque para ele

embora não se faça de Jesus o centro absoluto, o teocentrismo está tão intimamente unido a ele que para a confissão cristã não há lugar para uma possível separação, nem para uma realização equivalentemente paralela em nenhum outro indivíduo passado, presente ou futuro - da humanidade ${ }^{576}$.

Diante do fenômeno do pluralismo religioso, que muito provoca a uma melhor compreensão de toda essa nova situação, se faz importante esclarecer o sentido desse 'jesuanismo' para que não haja má interpretação em seu entendimento, mesmo que sua compreensão não possa privar-se da densidade histórica de Jesus.

Aqui se encontra a contribuição dessa nova categoria: "trata-se de uma nova manifestação do problema da particularidade" ${ }^{977}$. Esclarecendo que não se trata de um favoritismo, ou mesmo de privilégio divino, mas de uma resposta a uma necessidade estrutural, visto que não pode existir outra possibilidade para sua realização na história.

Assim, esclarece também que a revelação de Cristo não se situa à margem das demais revelações. Por causa da emergência e de sua intensificação, procede ao lugar comum que é a presença reveladora de Deus em todas as religiões, o que significa dizer que "a referência é Deus mesmo, e Ele está diante de todas as religiões" ${ }^{, 578}$.

Partindo sempre da experiência religiosa e nunca de fora dela, realiza, então, de modo específico sua captação levando-a à sua culminação. Por isso, "Jesus se conecta - e só assim ele próprio é historicamente possível - com a tradição de

\footnotetext{
${ }^{575}$ QUEIRUGA, A. Torres. Autocompreensão cristãa, p.104. Queiruga apresenta, em nota, para uma melhor exposição dos diversos posicionamentos as obras: MIRANDA, M. de França. $O$ cristianismo em face das religiões, pp. 26-30; 46-51 e DUPUIS, J. Rumo a uma teologia cristã do pluralismo religioso, pp. 251-294;

${ }_{5776}^{57 b i d .,}$ p. 104.

${ }^{577}$ Ibid., p. 105.

${ }^{578}$ Id., Cristianismo y religions, p. 19.
} 
Israel e, através dela, com a de toda a humanidade" ${ }^{\text {579 }}$. Logo, na missão cristã, deve-se reconhecer que o que ela faz é oferecer seu modo, novo e pleno, de compreender o Deus único, comum a todos.

A particularidade, por causa da intrínseca historicidade do humano, só pode realizar-se numa única pessoa. Isso acaba por afetar a raiz mais profunda do humano, sua realização última, como assim se faz no descobrimento de sua relação viva com Deus. E sua realização última equivale a realizá-la na abertura da própria existência, que consiste em tomar consciência da mesma ${ }^{580}$.

Mário de França Miranda adverte para o perigo de reduzir a revelação a uma simples 'manifestação' da 'salvação, ${ }^{581}$. Isso o leva a insistir na identidade ontológica da revelação ${ }^{582}$.

Para Queiruga, não cabe aqui a categoria de 'representação', porque o problema está no descobrimento originário, pois

tratando-se da ultimidade humana, não há lugar para descobrimento - nem, por isso mesmo, de símbolo - sem realização, pois, no processo de chegar ao extremo de si mesmo a partir da relação com Deus, o ser humano só pode ver aquilo que vive ${ }^{583}$.

Encontra, então, na realização a única possibilidade para avançar realmente no descobrimento e na comunhão, único modo possível de ser, depois, representação. Diante dessa questão interessa-lhe reforçar o realismo da aposta e sua necessidade histórica, que não se encontra 'na lógica do privilégio', mas em uma 'estratégia de amor'. O desejo de Deus em querer entregar-se à humanidade dá-se no concreto da história, que a torna real e não aparência . E deve ser vista como dom para todos e que a todos é oferecida como sua possível realização.

Assim dito, Queiruga confessa:

minha convicção é de que em Cristo a relação viva com Deus atingiu o intransponível e o insuperável, de tal modo que nele se tornam patentes para mim as chaves definitivas da atitude de Deus em relação ao mundo e da consequente conduta de nossa parte ${ }^{584}$.

E mais adiante conclui: "para mim, não existe um teocentrismo pleno que não inclua aquilo que foi revelado em Jesus de Nazaré, isto é, que não seja

\footnotetext{
${ }^{579}$ QUEIRUGA, A. Torres. Autocompreensão cristã, p. 106.

${ }^{580}$ Cf. Ibid., p. 106.

${ }^{581}$ Cf. MIRANDA, M. de França. O cristianismo em face das religiões, pp. 49-51 e 60-62 apud. QUEIRUGA, A. Torres. Autocompreensão cristã, p. 107.

${ }^{582}$ Cf. Id., A revelação de Deus na realização humana. Nessa obra, também descarta a categoria de 'representação' quando de fala da revelação.

${ }_{583}$ QUEIRUGA, A. Torres. Op. cit., pp. 107-108.

${ }^{584}$ Ibid., p. 108. Grifo do autor.
} 
também jesuânico", e assim, "reconhecer a verdade presente em outros 'teocentrismo' e inclusive de aprender deles determinados aspectos que enriquecem o meu particular teocentrismo" $" 585$.

Sua confissão consiste em duas condições: primeiro, porque deixar tudo o que $\operatorname{possui}^{586}$ e até a própria vida, "requer respeito por todos aqueles que acreditam ter feito, em sua religião, uma descoberta igual ou semelhante"; segundo, "pela mesma razão, a convicção de que cada um precisa ser apresentado com uma proposta aberta ao diálogo, ao contraste e à verificação" ${ }^{, 587}$.

Enquanto dom, a experiência vivida não pode ter outro interesse, senão o de favorecer o seu possível destinatário, o que acontecerá se ele a perceber capaz de plenificar sua visão e abrir-lhe um novo horizonte de definitividade. Assumidas essas condições, Queiruga não nega que lhe seja exigido uma atitude complexa e cheia de matizes. Considerando como certo "por um lado, uma clara e confiável afirmação da própria identidade.... e por outro, a humildade de quem não se remete a si mesmo nem sequer insiste demasiadamente no modo de compreender a verdade descoberta" ${ }^{258}$. Isso implica em que deve estar aberto para possíveis correções e aperfeiçoamentos. Como novas nuances, sem impor limites a questionamentos externos.

O específico nesta categoria está na preeminência do teocentrismo, que se encontra profundamente presente em Jesus de Nazaré. Logo nos remeterá a toda a sua problematicidade histórica. No entanto, para o diálogo, a ênfase prioritária deve estar não em sua figura individual, mas em sua proposta reveladora e salvífica.

É em vista desta proposta apresentada por Jesus a partir de uma experiência de Deus, como Abbá, que os cristãos apoiam sua convicção e a têm como proposta cristã. Confiando em sua própria força de convicção a proposta cristã, sem imposição arbitrária, nem soberba, assumindo-se como fruto do que propõe, sente-se autorizada a abrigar a humilde esperança de que possa produzir o mesmo efeito nos demais.

\footnotetext{
${ }^{585}$ QUEIRUGA, A. Torres. Autocompreensão cristã, p. 109. Queiruga, em seu livro, "O diálogo das religiões", sobre o cristocentrismo diz que "é o sentido primeiro e facilmente acessível; com a mesma razão, há também um 'budacentrismo' e um 'maomecentrismo'... Mas Jesus - como Buda e Maomé - não pregou a si mesmo; ele remeteu sempre ao Pai, a Deus. Jesus foi, sem dúvidas, 'teocêntrico"'. p. 68.

${ }^{586}$ Cf. Mt 13,44-46.

${ }_{587}^{587}$ QUEIRUGA, A. Torres. Op. cit., p. 110.

${ }^{588}$ Ibid., pp. 110-111.
} 
Pois, continua Queiruga:

aquele que através de Jesus, descobriu que "Deus é amor" (1Jo4,8.16), isto é, que consiste em amar e em suscitar amor, tem motivos para pensar que, mesmo dentro dos limites da sua apresentação histórica, oferece algo no qual todos podem encontrar uma plenificação - não necessariamente uma refutação - de sua busca religiosa $^{589}$.

A partir desse encontro com Deus, que por amor procura se achegar a todos e a todas sem distinção, inclusive dos maus e dos injustos ${ }^{590}$, que perdoa sem condições e sem impor penas ${ }^{591}$, que é incapaz de julgar e condenar ${ }^{592}$, que ama e perdoa $^{593}$; diante de um Deus que só sabe amar, e o faz de forma gratuita, que suscita entre todos este amor, em que toda sua ação e intenção é salvífica ${ }^{594}$; resta apenas confessá-lo e fazer o possível para que o mundo seja invadido e transformado por seu amor.

No entanto, diante do que nos foi apresentado "evidencia por si mesmo que já não se pode falar, sem matizes ou reservas de simples 'cristocentrismo"”,595. Frases como 'não existe conhecimento de Deus a não ser em Jesus Cristo' são para Queiruga entendidas apenas como uma linguagem interna de natureza 'confessional', que não deve ter pretensão de ser uma definição objetiva. Para ele, a linguagem deve ser a do amor, pois "o centro último e decisivo para todos como de resto, acontecia com o próximo Jesus - radica-se em Deus, o único absoluto" $" 596$.

Entretanto, diante desta nova perspectiva, não se pode esquecer-se de outra questão: 'a plenitude da revelação em Cristo', que, de uma forma mais sutil, atinge o diálogo. E para tal questão, Queiruga pede-nos para lembrarmos "que esta revelação remete-nos a Cristo também na qualidade de Ressuscitado, isto é, além de sua particularidade histórica" ${ }^{997}$, pois ao destino pleno de Jesus e sua revelação pertencem também sua morte e sua ressurreição.

\footnotetext{
${ }^{589}$ QUEIRUGA, A. Torres. Autocompreensão cristã, p. 112.

${ }^{590}$ Cf. Mt 5,45.

${ }^{591}$ Cf. Lc 15,22-24.

${ }^{592}$ Cf. Rm 8,31-34.

${ }^{593}$ Cf. 1 Jo 3,20.

${ }^{594}$ Cf. Mt 7,12; Lc10, 27-28.

${ }^{595}$ QUEIRUGA, A. Torres. Op. cit., p. 113.

${ }^{596}$ Ibid., p. 114.

597 Ibid., p. 115.
} 
Esta afirmação pertence às afirmações teológicas de segunda ordem, que não entram no primeiro momento do diálogo, e se forem introduzidas devem estar abertas à reinterpretação.

Reinterpretação que, mesmo sendo profunda, não significa reduzir à pura 'metáfora' o mistério da encarnação ${ }^{598}$, mas em ir ao encontro da essência do cristianismo para torná-lo melhor. Atitude provocada pelo diálogo com outras religiões, que obriga a revisar com absoluta seriedade o cristocentrismo ${ }^{599}$.

Esse, com toda certeza, levará ao "teocentrismo" e adquirirá uma nova dimensão. Pois,

no modo concreto, historicamente único, da proposta cristã induz uma certa bipolaridade, não porque nega a primazia absoluta de Deus, mas porque para o cristão essa primazia apresenta-se mediada de maneira indissolúvel pela pessoa de Jesus de Nazaré6 ${ }^{600}$.

Por isso, é fortemente significativo para Queiruga, diante dessa bipolaridade, falar de um 'teocentrismo jesuânico'. Assim, ele mesmo diz: 'Parece-me na realidade que essa expressão aponta melhor tanto para o mistério do Pai, enquanto origem ultimamente fundante, quanto para sua - em relação a nós - irrenunciável mediação no Evangelho de Jesus de Nazaré"601.

Para ele, em relação aos outros, isto não prejudica em princípio seu direito de falar, se assim o creem, de um teocentrismo diferentemente qualificado, porque está certo de que "a expressão remete com certa clareza à misteriosa estrutura à qual se faz alusão, ao mesmo tempo em que é uma resposta à necessidade de nosso tempo em transição e em busca de novas categorias" ${ }^{602}$.

E é aqui que está o ponto delicado para o diálogo, pois requer aceitar a união da pessoa de Jesus de Nazaré com Deus apenas no presente momento, numa cultura que atribui valor constitutivo à história. O que torna possível pensar, então, que o fato de Jesus de Nazaré ter alcançado essa visão objetivante insuperável de

\footnotetext{
${ }^{598}$ Cf. Queiruga cita John Hick como o que mais tem buscado este caminho. HICK, John. The Myth of God Incarnate. London/Philadelphia, 1997; principalmente God Hás Many Names, pp. 8;19;27-28;58;74;125. Para ele, mais equilibrada e sugestiva é a apresentação de HAIGHT, R. Jesus, símbolo de Deus. São Paulo, Paulinas, 2005.

${ }^{599}$ Em nota, Queiruga destaca este lugar como o ponto crítico da questão. E faz referência à obra de DUPUIS, J. Rumo a uma teologia do pluralismo religioso, pp. 251-294. Cf. QUEIRUGA, A. Torres. Autocompreensão cristã, p. 115.

${ }^{600}$ Ibid., p. 116.

${ }^{601}$ Ibid.

${ }^{602}$ Ibid., p. 117.
} 
Deus, signifique também de direito, o indício que permite reconhecer a unicidade de sua relação com Ele.

E já que a fé cristã teve sua origem numa experiência salvífica dentro de um contexto determinado, onde o encontro com Jesus de Nazaré constituiu-se em resposta à necessidade concreta de salvação, em que o testemunho dos primeiros cristãos adquiriu seu significado. Podemos dizer que o significado da mensagem evangélica para nós, hoje, como o sentido de todo o discurso sobre Deus, só pode se manifestar em referência à situação atual concreta, em conexão com as interrogações vitais que nos colocamos.

Logo, nossas experiências atuais devem oferecer ocasião para falar de Deus de modo humano e sensato; caso contrário, nos limitaríamos à mera repetição de esquemas tradicionais, perdendo a relevância para a vida cotidiana. Assim, veremos que Queiruga vai além, quando propõe junto à 'inculturação' a 'inreligionação'.

\section{c) A inreligionação}

Acentuando a importância da "inculturação" na colaboração com o diálogo entre as religiões, Queiruga questiona suas respostas diante dos desafios apontados com os avanços das reflexões atuais, pois reconhece a difícil tarefa que persiste na atualidade em permanecer com a distinção entre cultura e religião ${ }^{603}$.

Para ele, "o perigo principal aponta, no fundo, para uma deficiência hermenêutica, pois continua trabalhando com o pressuposto de um dualismo excessivo entre as religiões e a cultura, de modo que ambas acabariam sendo claramente separáveis $" 604$.

O que se pode perceber nesta prática é a existência das consequências de um paradigma anterior, sobretudo na compreensão acerca da revelação. Esse fato é uma oportunidade para avançar, pois, reconhece que toda religião possui por necessidade intrínseca, a interpretação de uma experiência originária, que, para tornar-se compreensível e poder ser vivida, deve encarnar-se nos "elementos culturais" das pessoas e comunidades. Queiruga se pergunta: "Por que não deveria

\footnotetext{
${ }^{603}$ QUEIRUGA, A. Torres. Autocompreensão cristã, p. 174.

${ }^{604}$ Cf. Ibid., p. 175.
} 
acontecer o mesmo com os "elementos especificamente religiosos'?" ${ }^{605}$. Assim, ele propõe, indo além da 'inculturação', a 'inreligionação'.

Isso fazendo, tem clara a consequência da impossibilidade de distinguir entre o cultural e o religioso em um mesmo fenômeno, pois a revelação sempre se dá a partir de um conjunto de pressupostos, expectativas e ideologias geralmente aceitas e disponíveis no contexto histórico e sociocultural de uma época, que nunca se dá 'em estado puro'. Logo, é certo que a revelação será sempre interpretada, o que significa afirmar que "não cabe religião a não ser inculturada" ${ }^{\circ 06}$.

Pelo fato desse contexto mediar a revelação, será sempre por ela transformado. Assim, como o foi com a fé cristã que teve sua origem numa experiência salvífica dentro de um contexto determinado, onde o encontro com Jesus de Nazaré se constituiu em resposta à necessidade concreta de salvação, naquele contexto, o testemunho dos primeiros cristãos adquiriu o seu significado. Como nos disse João Paulo II: “uma fé que não se faz cultura é uma fé que não foi plenamente recebida, nem inteiramente pensada, nem inteiramente vivida"607.

E com um avanço teórico-significativo da inculturação, temos consequências importantíssimas para o diálogo inter-religioso. Que além de sua aceitação entre os teólogos, recebeu-a também do magistério da Igreja:

Por meio da inculturação, a Igreja encarna o Evangelho nas diversas culturas e, ao mesmo tempo, introduz os povos com suas culturas em sua própria comunidade; transmite às mesmas seus próprios valores, assumindo o que há de bom nelas e renovando-se a partir de dentro ${ }^{608}$.

No entanto, não deixou de receber críticas. Queiruga destaca duas como principais: a) que pode levar ao imperialismo de uma cultura e b) que pressupõe uma ideia de universalismo. E ele sintetiza estas críticas fazendo um alerta para o seu perigo, indicando que a força semântica dessa palavra pode sugerir que o encontro deve respeitar a cultura, mas suprimir (ou ignorar) a religião. Pois é conhecido que nos encontros entre as religiões, quando foi possível respeitar sua

\footnotetext{
${ }^{605}$ QUEIRUGA, A. Torres. Autocompreensão cristã, p. 176.

${ }^{606}$ Id., Repensar o pluralismo: da inculturação à inreligionação. In: Concilium. Petrópolis: Vozes, n. 319, 2007. p. 114.

${ }^{607}$ Id., Repensar o pluralismo, p. 115. Citação de João Paulo II, 1982.

${ }^{608} \mathrm{RM}, 52$.
} 
cultura, foi desconhecido seu valor religioso, favorecendo consequências arrasadoras: perseguições, destruições e o desejo de acabar com toda tradição ${ }^{609}$.

Mesmo diante dos riscos apresentados, a inculturação não deve ser substituída. No entanto, ele não descarta a necessidade de que ela seja corrigida e completada, pois,

reconhecendo revelação real em qualquer religião, torna-se evidente que não se pode tratar de suprimi-la: significaria suprimir ou negar a presença real de Deus". Para ele, é certo que o encontro entre as religiões só é "legítimo para dar e/ou receber uma melhora: oferecer aquilo que julgamos que pode ajudar o outro (e/ou receber do outro o que possa ajudar-nos ${ }^{610}$.

É o outro que, para acolher a oferta de quem chega, vai julgar se é possível aceitá-la. Assim, como na inculturação, isso não deve acontecer negando sua própria cultura, na religião, acontece algo semelhante, pois quem ouve é uma pessoa religiosa e que vai fazer uso de sua experiência religiosa para também acolher ou descartar o que se lhe anuncia.

É isso que a 'inreligionação' quer insinuar. Ela promove tanto uma acolhida como um oferecimento. Acolhida que não significa recusar a própria religião, mas aceitar a partir dela, tendo-a como base para a compreensão, a acolhida ou a recusa do que lhe é anunciado. Ou seja, manter a própria unidade religiosocultural - 'inculturar e inreligionar' - a partir dela tudo o que pode melhorá-la.

E sobre o oferecimento, evitando todo tipo de discriminação e superioridade sobre a outra religião, assumindo a presença de Deus em todas as religiões, e assim, adquirindo uma atitude de que "minha religião é verdadeira, mas também a tua; e, sendo Deus sempre maior do que a nossa compreensão, devemos complementar-nos", e Queiruga termina afirmando que "contra rotinas excludentes e intolerantes, convém aprender de novo a grande verdade do amor: tudo é de todos, já que de todos quer ser o mesmo e único Deus"611.

Toda experiência religiosa genuína é resposta à universal e viva presença de Deus, e que nessa mesma medida é revelada e verdadeira, constituindo um caminho real de salvação.

Não pode, no entanto, ficar fora da reflexão sobre o diálogo inter-religioso a relação entre fé e cultura, e separar essa compreensão da história do ser humano.

\footnotetext{
${ }^{609}$ Cf. QUEIRUGA, A. Torres. Repensar o pluralismo, p. 115; Id., Autocompreensão cristã, p.175.

${ }^{610}$ Id., Repensar o pluralismo, p. 116.

${ }^{611}$ Ibid., p. 117.
} 
Porque a revelação, como já vimos, em relação a Deus é a sua "autocomunicação aos homens" ${ }^{\prime \prime 12}$, e em relação aos homens "é a autoconsciência de toda a religião", como "tomada de consciência da presença do divino no indivíduo, na sociedade e no mundo" $" 613$.

\subsection{A verdade entre as religiões}

Para Queiruga, o comportamento linguístico adquire aqui grande importância, pois se, a partir da contraposição entre religião verdadeira e religiões falsas, será difícil que ocorra o diálogo autêntico, para ele, "se partirmos da afirmação de que todas as religiões - enquanto modos específicos de acolhida e configuração comunitária da universal presença salvífica de Deus - são verdadeiras, o diálogo brota por si mesmo"614.

Para isso, é necessário entender que "tudo se resume ao modo e à intensidade da verdade que cada religião alcança na difícil e sempre insatisfatória luta para captar e expressar em palavras, condutas e instituições a irradiação amorosa do Mistério"

Porque reconhecendo que a recepção humana é sempre frágil, desigual, a dialética autêntica jamais é o 'zero e o infinito', mas o 'mais e o menos', ou como o 'bom e o melhor'. Se, na história, nenhuma realização é perfeita, todas as religiões devem fazer a experiência dessa dialética em seu interior, em diálogo consigo mesmas, para encontrar o que é melhor, em um processo de conversão contínua.

Isso leva Queiruga a dizer que 'o diálogo entre as religiões é, por isso mesmo, decidida e sinceramente real', porque 'conecta-se com essa busca que cada uma delas realiza a partir de seu interior' ${ }^{616}$.

É dessa experiência que cada religião faz do Mistério impulsionando-a ao oferecimento gratuito, que se encontra a justa atitude religiosa diante de um Deus sempre maior e perenemente presente, que Queiruga avança em sua reflexão “qualificando de 'intrínseca' a verdade das religiões, no sentido de que seria

\footnotetext{
${ }^{612}$ RAHNER, K. Curso fundamental da fé: introdução ao conceito de cristianismo. São Paulo: Paulinas, 1989. p. 145.

${ }^{613}$ QUEIRUGA, A. Torres. A revelação de Deus na realização humana, p. 100.

${ }^{614}$ Id., Autocompreensão cristã, p. 139.

${ }^{615}$ Ibid., p. 140.

${ }^{616}$ Cf. Ibid., p. 141. Grifo do autor.
} 
incorreto concebê-las com simples mediação em vista de uma verdade superior". Para ele, "elas possuem valor em si mesmas"

As religiões, por tratarem do destino definitivo de seus membros, são 'absolutas ${ }^{\prime 618}$. Entendendo que na

perspectiva cristã nós vemos sua abertura num momento posterior, ou seja, no fato de serem intimamente chamadas, também elas, à completude com aqueles aspectos que não estão presentes nelas e que de acordo com a nossa confissão estão presentes na plenitude aberta por Cristo ${ }^{619}$.

A autocompreensão cristã, assumindo esta atitude, deixa uma prática baseada em uma 'lógica de concorrência', na qual as 'minhas razões e a minha religião são lançadas contra a religião dos outros', para assumir uma 'lógica da gratuidade', adquirindo a

consciência de estar apoiada numa transcendência que tudo fundamenta e que, por isso mesmo, busca incansavelmente, desde sempre e em todos os lugares, dar-se a conhecer e entregar-se a todo homem e a toda mulher. Porque quer ser dom para todos, não pode ser possessão de ninguém ${ }^{620}$.

A própria fenomenologia da religião diz-nos que toda experiência religiosa por causa de seu próprio dinamismo, tende a compartilhar, mesmo que ameaçada por atitudes particularistas, sua orientação intrínseca sem fronteiras; no limite, rumo à universalidade.

Porque a verdade que uma religião descobre, ela acredita que não é só para si, por exclusividade, mas para que pertença a todos os outros. A verdade religiosa acaba sendo um "reflexo da plenitude de Deus no espírito humano, plenitude à qual, de nossa parte, só podemos responder com a busca conjunta, fraternal e compartilhada. Todos recolhendo os fragmentos de uma verdade que, refletida na finitude, é destinada a todos"621.

Logo, o diálogo entre as religiões (diálogo inter-religioso) é uma condição intrínseca da verdade, pois está claro que ambos nunca foram fatos isolados, mas constituem um tecido denso de contatos e influências. O diálogo inter-religioso veio à tona através de um grande salto qualitativo nos meios de comunicação, na constituição da 'aldeia global'.

${ }^{617}$ QUEIRUGA, A. Torres. Autocompreensão cristã, p. 142. Grifo do autor.

${ }^{618}$ Cf. Ibid., p. 145.

${ }^{619}$ Ibid., p. 146.

${ }^{620}$ Ibid., p. 147.

${ }^{621}$ Ibid., pp.148-149. 
Esta realidade, no entanto, não obriga em nada a que os cristãos renunciem a sua verdadeira experiência na revelação em Cristo. Porque não sendo esta experiência propriedade dos cristãos, deve ser assumida como "dom de Deus comum, que foi emergindo e se configurando num ponto da comunidade religiosa humana"622. Logo, negar sua experiência é privar outros de uma possível riqueza à qual têm direito.

Ou seja,

a missão cristã não sai nunca para o deserto da pura ausência, mas para o encontro com outros rostos do Senhor, que impulsionados pela experiência da plenitude encontrada em Cristo, desejam fazer brilhar também para os outros o rosto que se entreviu a partir da insuperável irradiação da vida de Jesus ${ }^{623}$.

Desta forma permite ao cristão corrigir seus próprios defeitos e descobrir novas riquezas no encontro com Deus nas outras religiões. Queiruga propõe a consciência dos limites de toda autocompreensão, reconhecendo que este é o melhor caminho para ir elaborando todos juntos e de passos bem marcados, uma compreensão mais decididamente universal.

Para isso, prefere utiliza-se da palavra 'encontro' no lugar da palavra 'diálogo', pois entende que o diálogo "pode implicar a conotação de uma verdade que já se possui plenamente e que vai ser 'negociada' com o outro, que também já tem a sua", e que 'encontro', "pelo contrário, sugere muito mais um sair de si, unindo-se ao outro para ir em busca daquilo que está diante de todos"624.

Esta sua resistência em fazer uso da palavra 'diálogo' também se reflete ao falar de 'inclusivismo', pois, para ele, “o que a palavra sugere é que toda a verdade dos outros já está ‘dentro’ (incluída) da nossa”. Isto justifica também para ele a postura 'pluralista', mesmo não cedendo "às conotações de nivelamento igualitário ou de relativismo indiferenciado" $" 625$.

Mesmo utilizando-se de uma nova linguagem, não se está livre de ser mal interpretado, devendo-se evitar todo reducionismo, afirmar algo como verdade implica excluir a verdade do outro. Está claro que se deve sempre ter como pressuposto que:

o que foi revelado em Cristo há muito que é também patrimônio de outras religiões... e que inclusive, em diferente medida, tem sido trazido por estas, mas, além disso, que essas religiões têm aspectos e perspectivas ausentes no cristianismo

\footnotetext{
${ }^{622}$ QUEIRUGA, A. Torres. Autocompreensão cristã, p. 150.

${ }^{623}$ Ibid., p. 151.

${ }^{624}$ Ibid., p. 153-154.

${ }^{625}$ Ibid., p. 154.
} 
e que podem ajudá-lo e completá-los, em seu esforço em vista de uma melhor e mais completa realização histórica ${ }^{626}$.

Sobre as demais religiões, o cristianismo deve entender que todas convergem cada vez mais entre si, pois estão habitadas pela presença do mesmo Senhor e todas chamadas à máxima plenitude possível.

Queiruga tem claro que considerar que essa plenitude alcançou em Cristo sua máxima realização histórica, não significa que se pretenda ver 'nossa' religião como realização perfeita e acabada em todos os aspectos. Para ele, todas as religiões apresentam-se em sua essência mais íntima, necessitadas de um melhor conhecimento de si e de descentralização, para poder melhor refletir o Mistério que as envolve, e que é comum a todos.

Por fim, concluímos que, assim, reafirma-se a convicção de que 'todas as religiões são verdadeiras', na medida em que acolhem a presença salvífica de um mesmo Deus. Uma vez que estejam abertas a esta presença, todas são convocadas a somarem os seus reflexos, pois dando e recebendo tendem a crescer e a fortalecer a união com as demais. "O que está em jogo não é o 'em si' da comunicação de Deus, mas o precário e relativo 'para nós' da recepção",627.

E de tal modo o cristianismo, em relação a outras religiões, deve reconhecer que tem muito que aprender e que nele não se encontra a comunicação plena de Deus, pois "existem aspectos que só a partir de fora de sua configuração concreta podem chegar-lhe e que justamente pela fidelidade ao Deus seu e de todos, deve estar disposta a acolher" ${ }^{\prime 28}$.

\section{Conclusão}

Nesta parte de nossa tese, pudemos aprofundar um pouco mais sobre a mística e a revelação. A mística como realização de todas as religiões e caminho para conhecê-las, como também para o conhecimento do próprio homem. E sobre a revelação, que reinterpretada no cristianismo, deixa de ser concebida como um 'ditado divino', para ser vislumbrada como um 'dar-se conta' da presença de Deus, que maieuticamente se revela na história.

\footnotetext{
${ }^{626}$ QUEIRUGA, A. Torres. Autocompreensão cristã, p. 155.

${ }^{627}$ Ibid., p. 156.

${ }^{628}$ Ibid., p. 157. Grifo do autor.
} 
Constatamos que a experiência mística acontece porque Deus assim tem procurado o ser humano incessantemente. E esta experiência reafirma a identidade do religioso ao mesmo tempo em que o conduz ao encontro real com as demais tradições religiosas, pois o leva a ter um contato com Deus no mais intimo de si, na descoberta de si mesmo, e o conduz ao outro que, por vezes negado, é aceito em sua alteridade.

Neste momento, concluímos, então, reafirmando que mesmo que o diálogo inter-religioso tenha se chocado permanentemente com o dogmatismo e com o relativismo indiferente, o cultivo da dimensão mística pode eficazmente ajudar a evitar esses obstáculos, pois o exercício da experiência mística permite captar o íntimo parentesco de todas as religiões ao pôr em contato quem a vive com a raiz de onde todas elas procedem.

Podemos dizer que a mística assume o melhor lugar para o encontro e diálogo inter-religioso. No cristianismo a experiência mística, que conduz o religioso ao mais profundo mergulho em seu interior e lá encontrar Deus, descobre que o mais intimo de sua humanidade é sua capacidade de amar que imprime nele a imagem e a semelhança de Deus. Para isso, tomaremos nas partes seguintes de nossa tese duas experiências oriundas do cristianismo de místicos como Thomas Merton e Raimon Panikkar que ousaram, a partir de sua experiência de encontro com Deus, ir ao encontro de outros crentes de diferentes tradições religiosas e com eles redescobrirem a sua própria fé como força dinamizadora para um profundo e fecundo diálogo inter-religioso.

Em Thomas Merton, encontraremos um místico consciente do valor da solidão para seu crescimento espiritual e da necessidade de comunicar-se com as outras pessoas. À medida que crescia sua experiência de Deus, sentia uma maior responsabilidade pelo bem do outro e de toda sociedade.

Em Raimon Panikkar, reconheceremos um homem que na profundidade de sua experiência de Deus, longe de um mosteiro, acredita que toda caminhada espiritual em que o homem procura com todo o seu ser o encontro com Deus, a Realidade Última, se encontra um monge desconhecido. Para este a experiência de Deus "não só é possível, como também necessária para que todo ser humano chegue à consciência de sua própria identidade" ${ }^{629}$.

${ }^{629}$ PANIKKAR, Raimon. Iconos del mistério. La experiencia de Dio. Barcelona: Penísula, 1998. 


\section{III - parte}

\section{Experiência Cristã de Deus em Thomas Merton}

Nos ocuparemos, nesta parte de nossa pesquisa, da experiência de Deus vivida por Thomas Merton $^{630}$. Encontraremos um jovem ansioso, inquieto, que percorreu um caminho gradual de ascensão à Verdade. Boa parte de sua jornada transcorreu em caminhos indiretos, às vezes às escuras, vislumbrando ao longe uma centelha de luz.

Vivendo em um contexto de grande crise mundial, eclesial e social, pôde dar através de sua fé, de sua teimosa esperança, e de seu inflamado amor, contribuições importantíssimas aos desafios de sua época. Veremos que foi de dentro do seu mosteiro que os enfrentou, à luz da contemplação cristã, autêntica e incompatível com qualquer espécie de alienação.

Até vinte e seis anos de idade, Merton vive numa íntima confluência com o mundo, pois tudo o que acontecia "lhe dizia respeito". Ele se engaja resolutamente na experiência do viver, procurando para si, e para os nãoconformistas, uma postura dialética que harmonize ação e contemplação e que, como tal, seja capaz de tornar menos aflitivo o mysterium tremendum da condição humana.

Em sua experiência de vida, testemunhada em seus escritos, encontramos um homem na busca constante por corresponder à vontade de Deus, sem afastarse da realidade dos seres humanos. Encontraremos um homem que, mesmo isolado no seu mosteiro, transformou-se em uma das vozes mais atuantes do seu tempo, nenhum dos dilemas da humanidade escapou à sua atenção.

Três anos: este foi o tempo que decorreu entre o batizado de Merton e sua entrada em Gethsemani. Um período conturbado, cheio de indecisões que o preparariam duramente para o ingresso no claustro.

Nosso percurso se dará em um primeiro momento por sua autobiografia, $A$ montanha dos sete patamares ${ }^{631}$, desvendando o itinerário de sua vida, as mudanças, as descobertas, as ilusões, a história de uma vocação, suas atividades

\footnotetext{
${ }^{630}$ No decorrer de nossa pesquisa nos referiremos a Thomas Merton apenas como Merton.

${ }^{631}$ MERTON, Thomas. A montanha dos sete patamares. Petrópolis: Vozes. 2005. Biografia escrita no mosteiro de Gethsemani, em que ele conta a história de sua vida, desde o seu nascimento até o início de sua vida como monge. Título original: The seven story mountain, publicado em 1948.
} 
desenvolvidas em prol dos direitos humanos e contra a guerra e a experiência de um grande amor.

Para aprofundarmos e ampliarmos sua experiência de Deus, enveredaremos, principalmente, por alguns de seus livros: A experiência interior ${ }^{632}$, Novas sementes de contemplação ${ }^{633}$ e seu diário $O$ signo de Jonas ${ }^{634}$, em que reconheceremos em Merton o testemunho de alguém que não se cansou, em sua peregrinação, ao encontro de Deus, encontrando-O no íntimo de si mesmo.

Em algumas das páginas de outro diário, Diário da Ásia ${ }^{635}$, encontraremos passagens da sua extraordinária caminhada traduzidas em seus desafios, confrontos e interações com as tradições do Ocidente e do Oriente e o fim de uma peregrinação.

Na experiência de Merton, reconhecemos muito claramente sua adesão ao verdadeiro humanismo, do primado do homem sobre a tecnologia, da compaixão sobre a violência. Por isso mesmo é que, no seu testamento espiritual, a chave da liberdade interior que a vida monástica pode e deve trazer ao mundo é a libertação de cada ser humano em face de sua crescente opressão pelas estruturas. Sem elas, não há vida social possível. Uma vida interior profunda é a base de toda a vida exterior fecunda.

\section{O itinerário de uma vida}

Filho de um casal de artistas. Seu pai era pintor e sua mãe bailarina. Merton, cujo verdadeiro nome é Tom Faverel Merton, nasceu em uma pequena cidade, Prades, na França, no dia 31 de janeiro de 1915. Pouco mais de um ano depois, fugindo da guerra, a família muda-se para os Estados Unidos. Foram morar perto

\footnotetext{
${ }^{632}$ MERTON, Thomas. A experiência interior: notas sobre a contemplação. São Paulo: Martins Fontes, 2007. Foi publicado em 2003; título original: The inner experience. Notes on contemplation. Esse livro é uma revisão que Merton fez do livro $O$ que é contemplação?, publicado em 1948.

${ }^{633}$ Id., Novas sementes de contemplação. Rio de Janeiro: Fisus, 1999. Título original: New seeds of contemplation, publicado em 1962.

${ }^{634}$ Diário em que Merton narra os cinco primeiros anos de sua vida no mosterio de Gethsemani. Título original: The sign of Jonas, publicado em 1953

${ }^{635}$ Id., O diário da Ásia. Belo Horizonte: Ed. Vega, 1978. Nesse diário constam os registros a partir do dia 15 de outubro até o dia 08 de dezembro de 1968. Período de sua viagem à Ásia. Título original: The Asian Journal of Thomas Merton, publicado em 1973.
} 
dos seus avós maternos, em Flushing. Neste período, nasceu seu irmão, John Paul Merton $^{636}$, em $1918^{637}$.

Merton, filho de artistas, herdou de seu pai a sensibilidade para a beleza da natureza em todas as suas formas e mistérios. O impulso de perfeição e insatisfação que o leva a chegar ao mais profundo das coisas e de si mesmo talvez tenha vindo da mãe. Possivelmente foi herança, também de sua mãe, o costume de escrever diários. Desde criança, sua mãe escrevia um minucioso registro de acompanhamento, anotando as etapas e descobertas do seu desenvolvimento ${ }^{638}$.

Por causa dos registros de sua mãe, sabemos os fatos de sua infância, e depois o próprio daria continuidade ao escrever seus diários, crônicas de sua vida exterior e interior, nos quais nos comunicou as reflexões mais profundas de seu cotidiano. Isto nos permite seguir seu itinerário humano e espiritual, revelandonos a diversidade de facetas que integram sua personalidade. Ele confessa em seu diário, O signo de Jonas:

Estou contente de que estas páginas me mostrem como sou: inquieto, cheio de murmúrio de meus defeitos e paixões, e com as feridas abertas deixadas por meus pecados. Sinto-me cheio de meu próprio vazio. E, contudo, ainda que minha casa esteja em ruínas, $\mathrm{Tu}$ vives nela! ${ }^{639}$

A partir da liberdade que possui para escrever, torna-se difícil ler sua obra sem encontrar o próprio Merton. O material que tem em suas mãos para aprender o humano e o divino é sua própria vida. Nesse percurso, é possível descobrir alguns aspectos e atitudes da pessoa que ele se tornara. Como, por exemplo, segundo Maria Laguna, seu desenvolvimento como pessoa e a descoberta do mais profundo eu ${ }^{640}$.

Merton foi educado pelo método progressista. Era desejo de sua mãe que ele fosse independente, original, individual, que tivesse um caráter definido e ideais

\footnotetext{
${ }^{636}$ John Paul Merton era o único irmão de Merton. John Paul Merton ingressou na Real Força Aérea Canadense (RCAF) em 1941, com a intenção de se envolver na Segunda Guerra Mundial. Em 16 de abril de 1943, ele embarcou em um bombardeiro sobre Canal Inglês. Por razões desconhecidas o avião perdeu altitude e caiu. Ele morreu no dia 17, sábado da Semana Santa. Merton soube da morte de seu irmão na terça-feira de Páscoa e compôs um poema para meu irmão intitulado: "Missing in Action de 1943", que conclui o seu diário A Montanha dos Sete Patamares, p. 365-366.

${ }^{637}$ Cf. MERTON, Thomas. A montanha dos sete patamares, p. 10-13.

${ }^{638}$ LÓPEZ, María Luisa Laguna. Thomas Merton: uma vida com horizontes. Aparecida, SP: Editora Santuário, 2010. p. 59.

${ }_{639}$ MERTON, Thomas. O signo de Jonas, p. 59.

${ }^{640}$ Cf. LÓPEZ, María Luisa Laguna. Thomas Merton: uma vida com horizontes. p. 78.
} 
próprios $^{641}$. Porém, posteriormente, desde sua mais profunda consciência de monge, confessa: "de alguma maneira, tenho que buscar minha identidade não só em Deus, senão também nos outros. Jamais poderei encontrar a mim mesmo se me isolo do resto da humanidade como se pertencesse a uma espécie diferente" ${ }^{642}$.

Quando tinha seis anos, sua mãe morreu. Com seu pai, iniciou uma série de mudanças de residências que o fizeram em muito pouco tempo conhecer experiências educativas diferentes na França e na Inglaterra. Até que não pôde mais continuar instável, por causa dos estudos ${ }^{643}$.

Depois do regresso do seu pai, partiram para o país em que nascera ${ }^{644}$. No novo colégio, começa a escrever seus primeiros romances junto com um grupo de amigos. Teve, naquele colégio, a oportunidade de participar de algumas celebrações protestantes. No entanto, não foram momentos que lhe deixaram algum ensinamento. Entre estes estão mais os que, com simplicidade de vida e conversas informais, tivera com seu pai ${ }^{645}$.

Aos dezesseis anos, ficou órfão ao morrer seu pai, em Londres. A notícia da morte do pai deixou-o triste por vários meses. Passada a dor, assume sua vida com uma liberdade própria do século $\mathrm{XX}^{646}$. Estava destinado a viver como um autêntico cidadão do seu século.

De férias, quando estudava na Escola Secundária de Oakham, decidiu ser comunista mesmo não sabendo o que isso significava ${ }^{647}$. Na volta à escola participou de manifestos comunistas e se sentiu um grande rebelde. Em seguida, depois de se graduar e ter sido aprovado com êxito nos exames para aluno bolsista da Universidade de Cambridge, ganhou de seu tio, seu tutor, como presente de aniversário, uma viagem pela Europa ${ }^{648}$.

Merton já havia estado anteriormente em Roma e quer descobrir algo novo e diferente do que já havia visitado. Impressionam-lhe muito as ruínas e os restos históricos. Visitou várias igrejas e museus, ficou fascinado pelos mosaicos bizantinos e se converteu em um peregrino que buscava a instrução através daqueles altares, mosaicos e santuários. Até que passou a visitar esses lugares não

${ }^{641}$ Cf. MERTON, Thomas. A montanha dos sete patamares, p. 16.

${ }^{642}$ MERTON, Thomas. Novas sementes de contemplação, p. 58.

${ }^{643} \mathrm{Cf}$. Id., A montanha dos sete patamares, pp. 20-21.

${ }^{644}$ Cf. Ibid., pp. 32-33.

${ }^{645}$ Cf. Ibid., pp. 41-42.

${ }^{646}$ Cf. Ibid., p. 81.

${ }^{647}$ Cf. Ibid., p. 87.

${ }^{648}$ Cf. Ibid., p. 95 . 
só pela sua arte, mas pela paz que o ambiente lhe dava e pela descoberta de Cristo $^{649}$.

Ele confessa em seu diário:

E pela primeira vez na vida comecei a descobrir alguma coisa daquela Pessoa que muitos chamavam de Cristo. Foi um conhecimento obscuro, mas verdadeiro, e em certo sentido, mais verdadeiro do que supus e mais verdadeiro do que eu admitiria. Foi em Roma que se formou minha concepção de Cristo ${ }^{650}$.

O que poderia ter sido uma conversão, ficou enterrado sob as cinzas da vida que leva em seu primeiro ano em Cambridge. Os amigos que o acompanharam desde Oakham dizem que Merton parecia outra pessoa completamente diferente da que conheceram na escola. Logo se separa deles, segue outro caminho conforme indica: "depois de haver conhecido umas duzentas pessoas diferentes, lancei-me na multidão que gravitava no polo oposto da vida de Cambridge" ${ }^{651}$.

Merton foi obrigado por seu tutor a voltar para morar com seus avós maternos nos Estados Unidos. No final do ano de 1934, abandonou a Europa ${ }^{652}$. Em 1935, nos Estados Unidos, estudando na Universidade de Columbia, colaborou em diversas publicações internas e escreveu sua dissertação, requerida para alcançar seu título de mestre, sobre a arte e a natureza em William Blake ${ }^{653}$.

Em 1938, começando seus estudos para o doutorado, interessando-se pela obra do poeta Gerard Manley Hopinks, SJ. Por própria decisão, depois de um período juvenil inquieto, foi batizado na Igreja Católica ${ }^{654}$.

Por mais de um decênio após aquela noite romana, ao sair da adolescência, a experiência da mocidade, desvanecedora de todas as ilusões com o mundo moderno, bem como o seu pouco tempo no comunismo, pensou Merton em entrar para os franciscanos ${ }^{655}$. Mas ainda achou pouco. Alma de extremos como era, buscou uma solução mais radical. A mais exigente quanto à renúncia ao mundo: a Trapa, o silêncio e o isolamento. Entrou, em 1941, no mosteiro de Gethsemani, Kentucky, querendo para sempre virar as costas ao mundo ${ }^{656}$. Não era esse, como veremos, o apelo misterioso que recebera na própria Roma.

\footnotetext{
${ }^{649}$ Cf. MERTON, Thomas. A montanha dos sete patamares, p. 101.

${ }^{650}$ Ibid., p. 102.

${ }^{651}$ Ibid., pp.110-111.

${ }^{652}$ Ibid., p. 117.

${ }^{653}$ Cf. Ibid., pp. 138 e 173.

${ }^{654}$ Cf. Ibid., pp. 202-204.

${ }^{655}$ Cf. Ibid., p. 264.

${ }^{656}$ Cf. Ibid., pp. 337-338.
} 
Seu período monástico compreende várias etapas notadamente diferenciadas: noviciado (1942-1944), primeiros votos até a ordenação sacerdotal (1944-1949), mestre de escolásticos (1951-1955), mestre de noviços (1955-1966) e finalmente sua etapa de ermitão (1966-1968) e de monaquismo universal (1968). Dez anos depois de seu ingresso na abadia, adota a cidadania norte-americana.

Pouco depois de concluir seu período de formação monástica, começou a escrever. Primeiro, sobre temas de espiritualidade monástica e contemplativa. É sua primeira etapa, em que se desenvolve o sentido da vida contemplativa e monástica, expressa por uma linguagem nova e marcante, sincera e, em alguns momentos, crítica.

Em uma segunda etapa, vive o paradoxo na busca maior pela solidão, sentese mais comprometido com os problemas mundiais: a paz, a violência, a guerra, os direitos humanos, a descrença, a contribuição do oriente às formas de vida ocidentais, o papel da ciência e da tecnologia no mundo contemporâneo.

Em uma etapa mais adiante, alarga os seus horizontes a outras culturas e religiões. O livro mais significativo de sua viagem ao oriente, e até ao seu próprio interior cristão e universal, foi seu último livro que não viu publicado: Diário da Ásia.

Em 1965 lhe é concedida a permissão, longamente esperada, para viver como ermitão, nas proximidades da abadia ${ }^{657}$. Três anos mais tarde, em 1968, é convidado para viajar em busca de novos lugares para futuros eremitérios e viaja para o Novo México, Califórnia e Alaska, antes de viajar por vários lugares da Ásia por causa de encontros de monges beneditinos e cistercienses em Bancoc ${ }^{658}$. Ali morre de forma acidental eletrocutado por um ventilador.

Não nos é possível pensar no místico Merton separando-o de sua produção escrita. Há uma tensão contínua entre sua lealdade ao papel de monge e o de escritor que reflete os conflitos durante boa parte de sua vida, até assumir por completo que seus escritos constituem uma forma lícita de oração, um modo muito íntimo de comunicação pessoal e de comunhão universal, uma opção livre, embora uma expressão rigorosa de obediência.

\footnotetext{
${ }^{657}$ HART, Patrick; MONTALDO, Jonathan. Merton na intimidade: sua vida em seus diários. Rio de Janeiro: Fisus, 2001. p. 269. Um livro que reúne memórias em forma de diário, composta por passagens selecionadas de seu diário (uma obra de 7 volumes). Traduzido por Leonardo Fróes (monge trapista).

${ }^{658}$ Cf. MERTON, Thomas. O diário da Ásia, p. XXVIII.
} 


\subsection{Convém recordar}

O jovem Merton recordando seus passos, na busca por querer recuperar algo de bom que tenha vivido, não se dá conta do verdadeiro caminho que esteve percorrendo:

Há muitas coisas boas para rever, no entanto, porque antes do meu primeiro ano em Cambridge, apesar de sempre possuído por um orgulho insano, mesmo assim eu amava Deus e rezava e não estava repleto de pecados. Houve, pois, dias bons em Oakham - e em Estrasburgo e em Roma e, antes disso, na França e em Londres nas férias escolares. Mas penso que, mesmo quando criança, eu já estava muito cheio de egoísmo e ira para querer agora recuperar minha infância! ${ }^{659}$

Todavia, era certo que precisava não mais procurar recuperar o que tinha vivido ou tido, mas sim procurar viver o presente. As experiências no decorrer de sua vida vão definindo sua identidade e indicando um caminho.

Uma experiência marcou profundamente Merton. Ele estava na cidade Romana, durante uma viagem feita aos 16 anos. Ele confessa em seu diário que sentiu bruscamente, como S. Paulo, em sua alma "completamente morta", a revelação pessoal e os primeiros indícios de seu invencível chamado, ao qual, aliás, só muito mais tarde iria responder ${ }^{660}$.

Eu estava em meu quarto. Era noite. A luz estava acesa. De repente pareceu-me que papai - morto há mais de um ano - estava ali comigo. A sensação de sua presença foi tão viva, real e chocante como se tivesse tocado meu braço ou falado comigo. Tudo aconteceu num piscar de olhos. Mas neste piscar de olhos fui dominado por uma visão repentina e profunda da miséria e corrupção de minha alma e fui transpassado por uma luz que me fez compreender um pouco da condição em que me encontrava. Fiquei horrorizado com o que vi e todo o meu ser revoltou-se contra o que estava dentro de mim; minha alma queria escapar e libertar-se de tudo isso com uma intensidade e urgência que jamais eu tinha conhecido antes. E nesse instante, acho eu que, pela primeira vez na vida, comecei realmente a rezar - não com meus lábios, intelecto e imaginação, mas a partir das verdadeiras raízes de minha vida e de meu ser; comecei a rezar a Deus que nunca conheci: que viesse a mim saindo de sua treva, que me ajudasse a ficar livre de milhares de coisas terríveis que mantinham escrava minha vontade ${ }^{661}$.

Ainda em Roma, quando estava de partida, passando perto de um mosteiro trapista de Tre Fontane, desce do bonde e, acometido por um impetuoso movimento, entra em uma igreja. Assim escreveu em seu diário: “[...] Fiquei então andando de cá para lá na silenciosa tarde, crescia em mim o pensamento: Quero ser monge trapista". Essas experiências não passaram, "de um devaneio - e

\footnotetext{
${ }^{659}$ HART, Patrick; MONTALDO, Jonathan. Merton na intimidade, p. 6.

${ }^{660}$ Cf. MERTON, Thomas. Montanha dos sete patamares, p.103.

${ }^{661}$ Ibid., pp.103-104.
} 
suponho ser um sonho que sobrevém a muitos homens, mesmo não acreditando em nada" 662 .

$\mathrm{Na}$ faculdade, todos estranhavam o seu grande entusiasmo pela vida, um desejo de viver tudo intensamente. Em um momento, suas leituras o fizeram refletir sobre sua vida, até mesmo perceber sua infelicidade. Passou a ler os livros de Freud, Jung e Adler ${ }^{663}$.

Ele se sente envolvido pelo ar corrompido e putrefato da sociedade, sobretudo das classes altas, que, partindo da Inglaterra, parecia estender-se por toda a Europa e enraizar tudo no vício, nos anos que precederam a Segunda Guerra Mundial. Terminado o ano, ele começa uma nova etapa, matriculando-se na Universidade de Columbia ${ }^{664}$. Ele confessa:

Não tive de fazer muita reflexão sobre o ano que havia passado em Cambridge para que ela me mostrasse que todos os meus sonhos de fantásticos prazeres e deleites eram loucos e absurdos e que tudo o que havia alcançado se havia reduzido a cinzas em minhas mãos, e que eu mesmo, além disso, me tornara uma espécie de pessoa muito desagradável... fútil, egocêntrica, dissoluta, fraca, indecisa, indisciplinada, sensual, obscena e orgulhosa. Eu era uma confusão... Considerava a pessoa que era agora a pessoa que havia estado em Cambridge, o que eu havia feito de mim mesmo e via bem claramente que era produto de meus tempos, de minha sociedade e de minha classe. Eu era algo assim como um produto de egoísmo e irresponsabilidade do pensamento materialista em que vivia ${ }^{665}$.

É por causa do vazio que sente e pela repulsa que Merton tem da sociedade que ele filia-se à Liga dos Jovens Comunistas, acreditando, por pouco tempo, que no comunismo estavam as bases da reforma de que o mundo necessitava, e, sobretudo, que era um movimento pacifista e contra a guerra. Ele sempre foi contra toda classe de guerra, foi um pacifista determinado ${ }^{666}$.

Diante de todas as experiências vividas até esse momento, inconsciente ou não, procura uma espécie de anestésico para sua extraordinária lucidez. O intelecto é a única - e insatisfatória - arma que ele possui para defender-se do mundo e preencher seu crescente vazio interior. Ele decidiu lutar pelas causas sociais, contra todas as injustiças e sedes do capitalismo. Estava pronta sua nova religião, prática e fácil em que todo o mal do mundo vinha do capitalismo. Assim, procurava reparar seu egoísmo com uma espécie de consciência social política ${ }^{667}$.

\footnotetext{
${ }^{662}$ Cf. MERTON, Thomas. A montanha dos sete patamares, p. 106.

${ }^{663}$ Cf. Ibid., p. 115.

${ }^{664}$ Cf. LÓPEZ, María Luisa Laguna. Thomas Merton: uma vida com horizontes, p. 40.

${ }^{665}$ MERTON, Thomas. Op. cit., pp. 122- 123.

${ }^{666}$ Cf. Ibid., pp. 130-133.

${ }^{667}$ Cf. Ibid., pp. 122-124.
} 
$\mathrm{Na}$ Universidade de Columbia se inscreve em um curso sobre literatura francesa medieval, e teve a oportunidade de ler $O$ espírito da filosofia medieval, de E. Gilson, sem saber que se tratava de um livro católico. Isto lhe causa muita raiva, "fiquei com vontade de jogá-lo pela janela". Por mais que pudesse admirar a cultura católica, sempre houve grande recusa à Igreja Católica. Foi através das páginas deste livro que Merton revolucionou sua concepção sobre Deus, assim ele confessa:

Foi um alívio para mim descobrir não só que nenhuma de nossas ideias, muito menos nossas imagens, podiam representar adequadamente Deus, mas também que não nos seria permitido satisfazer-nos com nenhum conhecimento dele ${ }^{668}$.

A partir deste momento, teve um respeito pela filosofia e pela fé católica, pois reconhecia que os cristãos católicos acreditavam em alguém realmente e que a fé não era um sonho. Passou então a sentir vontade de ir à Igreja, e agora à procura de ajuda para satisfazer a necessidade de fé que lhe brotava da alma ${ }^{669}$.

Um momento decisivo na vida de Merton foi seu encontro com Mark Van Doren, jovem professor de Columbia. Ele ensinava literatura inglesa no primeiro semestre em que Merton começava sua nova experiência universitária. Se a vida de Columbia em contraste com Cambridge conseguiu frutificar de uma maneira tão rica e positiva, se deu, em grande parte, graças a esse encontro que se prolongou em amizade irrevogável durante toda a sua vida ${ }^{670}$. Sobre o curso de literatura diz: "Foi o melhor curso que tive na Universidade. Ele me fez um bem enorme sob diversos pontos de vista" ${ }^{671}$.

Por indicação de outro amigo, Bob Lax, leu o livro Ends and Means, de Aldous Huxley. Neste livro, o autor trata sobre mística como algo real e muito sério, e que é acessível através da oração, fé, abnegação e amor. Esta leitura despertou nele um interesse pela mística oriental ${ }^{672}$.

Nessa universidade, ele conclui seu curso de bacharelado em Arte e resolve fazer uma especialização em literatura inglesa do séc. XVIII. Sua pesquisa para dissertação era examinar nos poemas de William Blake os aspectos de sua ideia religiosa. Sem perceber, estava enveredando por um caminho totalmente desconhecido, permitindo-se conhecer a si mesmo.

\footnotetext{
${ }^{668}$ MERTON, Thomas. A montanha dos sete patamares, p. 157

${ }^{669}$ Cf. Ibid., p. 158.

${ }^{670}$ Cf. Ibid., p. 128

${ }^{671}$ Ibid., p. 164.

${ }^{672}$ Cf. Ibid., p. 168.
} 
Foi algo especial viver em contato com o gênio e a santidade de William Blake naquele ano, naquele verão, escrevendo a dissertação.... à medida que Blake ia penetrando em meu sistema, eu me tornava sempre consciente da necessidade de uma fé vital e da completa irrealidade e insubstancialidade do racionalismo sem vida e egoísta que vinha congelando minha mente e minha vontade nos últimos sete anos. Quando terminou o verão, eu estava prestes a tomar consciência do fato de que a única maneira de viver era viver num mundo cheio da presença e realidade de Deus. ${ }^{673}$.

Entretanto, ainda não chegara o momento de uma conversão vinda das raízes de sua vontade. Merton estava vivendo uma realização em nível intelectual.

A vida da alma não é o conhecimento; é o amor, uma vez que o amor é o ato da faculdade suprema, a vontade, pela qual o ser humano é unido formalmente à última instância de todos os seus esforços - pela qual o ser humano se torna um com Deus ${ }^{674}$.

Outra amizade muito importante que faz nessa época é com o monge hindu Bramachari, que lhe é apresentado por seu amigo Seymour Freedgood. Bramachari o impressiona de imediato, não só por demonstrar uma grande paz interior, mas por recomendar-lhe, não a leitura dos Upanishadas, mas das Confissões de Santo Agostinho e da Imitação de Cristo. Estas sugestões surpreendem Merton, mas ele as aceita e começa, através do cristianismo, a penetrar no misticismo oriental, a cujo estudo se dedicaria com afinco e paixão até o fim da vida. As influências de Bramachari e do Aldous Huxley de Ends and Means foram mais fortes do que ele supunha ${ }^{675}$.

É impressionante perceber que enquanto volta sua atenção para os estudos sobre o Oriente, seu coração encontra profundidade no aprofundamento sobre a tradição mística Ocidental.

Escrevendo sua tese, tem contato com um livro de Maritain, que o leva a aprofundar o mundo da escolástica ${ }^{676}$. Junto com Blake, faz novas descobertas que o marcaram profundamente:

$\mathrm{Eu}$, que sempre fora um antinaturalista na arte, havia sido um puro naturalista na ordem moral. Não era de admirar que minha alma estivesse doente e arrasada; mas agora a ferida aberta fora fechada pela noção da virtude cristã, determinada pela união da alma com Deus ${ }^{677}$.

\footnotetext{
${ }^{673}$ MERTON, Thomas. A montanha dos sete patamares, pp. 173-174.

${ }^{674}$ Ibid., p.174.

${ }^{675}$ Cf. Ibid., p. 180.

${ }^{676}$ Cf. Ibid., p. 186. Título do livro de Maritain: Art et scolastique. Paris. Rouart, 1920.

${ }^{677}$ Ibid., p. 185.
} 
Assim, sem dar-se conta, quando escreve sua tese, seu coração vai se abrindo. Começa a querer dedicar sua vida a Deus. E assim, a experiência universitária de Merton realça as sombras e luzes da sua vida, de um jovem totalmente comprometido e enraizado em seu tempo. Com seu afã de viver e provar tudo, com suas ilusões e fracassos, suas ansiedades e aborrecimentos, encontra em seu esforço um bem sem saber encontrá-lo. Como veremos a seguir, um novo caminho se abre para Merton.

\subsection{A história de uma vocação}

Neste momento, ele não só tinha o conhecimento intelectual sobre Deus, como também passara a desejá-lo. Precisava, no entanto, reconhecer que o intelecto é independente do seu desejo, pois todas as suas contradições estavam sendo resolvidas no nível do conhecimento. Sem deixar-se envolver por inteiro, estava preso em si mesmo. "A única resposta ao problema é a graça, só a graça, a docilidade à graça. Eu ainda estava na precária posição de ser meu próprio guia e meu próprio intérprete da graça. É de admirar que tenha chegado ao porto!" ${ }^{678}$.

Diante de toda a luta que travava sua alma, ele responde ao seu impulso e vai pela primeira vez participar de uma missa. "A primeira vez na vida! Era verdade... Não esquecerei facilmente o que senti naquele dia" ${ }^{679}$. Tudo foi muito novo e surpreendente. No sermão ouviu falar sobre a humanidade e divindade de Jesus, "era tudo o que eu precisava ouvir" ${ }^{680}$. Ele sabia que não poderia acreditar no mistério da encarnação de Jesus por um simples ato de querer, se não recebesse de Deus uma luz verdadeira, um impulso de fé. E tomado por um desejo tão forte de ser batizado, saiu à procura de um padre e disse: "Quero tornar-me católico" 681 .

Foi então orientado pelo padre, por dois meses, nos estudos sobre a doutrina católica. E é desejando que se realize logo seu batismo, que surgiu o pensamento de ser sacerdote ${ }^{682}$.

Após seu batismo, não consegue viver o que tanto lhe animara e colocando o desejo de ser padre de lado, segue sua vida rotineira. O que estava acontecendo

\footnotetext{
${ }^{678}$ MERTON, Thomas. A montanha dos sete patamares, p. 187.

${ }^{679}$ Ibid., p. 188.

${ }^{680}$ Ibid., p. 191.

${ }^{681}$ Ibid., p. 196.

${ }^{682}$ Cf. Ibid., pp. 200-201.
} 
era que se julgava convertido a partir de seu intelecto. Acreditava em Deus e nos ensinamentos da Igreja e até se achava um cristão zeloso.

Eu ia à missa não só aos domingos, mas às vezes durante a semana. Nunca fiquei longe dos sacramentos; eu me confessava e comungava se não toda semana, pelo menos a cada quinze dias. Lia muitas coisas que podiam ser chamadas "espirituais", mas não lia espiritualmente ${ }^{683}$.

Precisava reconhecer que a conversão do intelecto não bastava, enquanto sua vontade não fosse totalmente de Deus. O solo que agora pisava depois de seu batismo requeria dele uma mudança interior e não apenas o cumprimento de obrigações católicas. Mas ele seguia sua vida sem perceber o convite que recebera na pia batismal. "Era estranho que eu não tenha percebido logo o quanto isso significava e chegado a compreender que era somente para Deus que eu devia viver. Deus devia ser o centro de minha vida e de tudo o que eu fazia",684.

Anos depois, de forma surpreendente, confessa: "Vou ser sacerdote!" 685 . Foi claro e preciso, ficou certo o que realmente queria, e estava em suas mãos a possibilidade desse desejo tornar-se realidade. Ele procura os franciscanos e como não havia nenhum impedimento, fica decidido que sua entrada no noviciado seria no ano seguinte ${ }^{686}$.

Ele não esperava que fosse rejeitado pela Ordem dos Franciscanos e isso aconteceu $^{687}$. E então começa a duvidar de sua vocação para a vida religiosa. "A única coisa que sabia, além da enorme aflição em que estava mergulhado, era que não devia mais pensar que tinha vocação para o claustro" ${ }^{688}$. Mesmo assim, a ideia de despedir-se do mundo secular não o abandona. Conforma-se provisoriamente com o emprego de professor na Universidade Franciscana de São Boaventura, em Olean, uma cidade localizada a sudoeste de Nova York ${ }^{689}$. Data desta época o diário que publicaria mais tarde com o título Diário Secular ${ }^{690}$.

No ano de 1941, na semana santa, resolve fazer retiro em um mosteiro trapista. Sem compreender e deixando-se envolver, sentiu: "meu coração

\footnotetext{
${ }^{683}$ MERTON, Thomas. A montanha dos sete patamares, p. 210.

${ }^{684}$ Ibid., p. 211.

${ }^{685}$ Ibid., p. 229.

${ }^{686}$ Cf. Ibid., p. 240.

${ }^{687}$ Cf. Ibid., p. 269.

${ }^{688}$ Ibid., p. 270.

${ }^{689}$ Cf. Ibid., p. 272.

${ }^{690}$ Título original: The secular journal of Thomas Merton. Publicado em 1959.
} 
expandiu-se em alegria antecipada" ${ }^{, 691}$, apenas em saber que seria possível ser aceito o seu pedido.

Aproximava-se a semana do seu retiro no mosteiro trapista. E antes de ir faz uma pesquisa sobre os trapistas e descobre que são cistercienses ${ }^{692}$. Tudo que lê move seu coração, "o pensamento desses mosteiros, daqueles coros remotos, daquelas celas, eremitérios e claustros, daqueles homens com seus capuzes, dos pobres monges, daqueles homens que voluntariamente se fizeram nada, tudo isso abalou meu coração"693.

Seu coração foi invadido por um ardente desejo pela vida monástica, mas ali estava sempre sua razão lembrando-o de que não tinha vocação. E envolto pelo desejo de ser monge e pelo medo de não ter vocação, parte para o mosteiro de Gethsemani.

Quando chega, um irmão lhe abre a porta: "eu entrei e a porta fechou silenciosa atrás de mim. Eu estava fora do mundo" ${ }^{694}$. Uma pergunta do monge deixou-o apavorado: "Veio para ficar?". Meio sem jeito respondeu que não ${ }^{695}$. Seu coração ficou mergulhado no silêncio e na paz que envolvia a casa. "O silêncio era um abraço! Eu acabara de entrar na solidão de fortaleza inexpugnável. E o silêncio que me envolvia também me falava, e falava mais alto e mais eloquente do que outra voz qualquer" ${ }^{696}$.

Durante o retiro em Gethsemani, Merton se impressiona com a prática da vida contemplativa: observa-a nos mínimos detalhes, lê tudo o que é possível sobre a Ordem e, à medida que passam os dias, aumenta a certeza de que a Trapa é o seu destino ${ }^{697}$. Anos mais tarde, ele escreveria em A montanha dos sete patamares:

A lógica da vida cisterciense era o oposto da lógica do mundo, onde os homens dão sempre um passo à frente, de maneira que no mundo o mais excelente vem a ser o que emerge, predomina, torna-se eminente sobre os demais, o que atrai a atenção.

691 MERTON, Thomas. A montanha dos sete patamares, p. 281.

${ }^{692}$ Cf. Vida monástica no seguimento de Cristo segundo as regras de São Bento, fundada em 1098. No séc. XI com a abertura de um mosteiro em Cister (Borganha, França) passaram a se chamar Cistercienses. A partir do séc. XII, ocorreu um afastamento dos ideais das origens, e foi iniciada a reforma, o abade Francês Dom Jean Armand, realiza em sua comunidade de La Trappe, um programa de reforma, enfatizando a separação com o mundo. Passando em seguida a novas fundações com a forma de vida La Trappe. Constituindo-se juridicamente uma nova ordem cisterciense da estrita observância (Trapistas). Cf. www.mosteirotrapista.org.br/história.htm.

${ }^{693}$ MERTON, Thomas. A montanha dos sete patamares, p. 287.

${ }^{694}$ Ibid., p. 290.

${ }^{695}$ Cf. Ibid., p. 290.

${ }^{696}$ Ibid., p. 291.

${ }^{697}$ Cf. Ibid., pp. 291-300. 
Qual era a resposta para esse paradoxo? Simplesmente que o monge, ao esconderse do mundo, não se torna menos ele próprio, menos pessoal, mas sim mais ele próprio com mais perfeição, porque sua personalidade e sua individualidade se aperfeiçoam em sua legítima categoria, a espiritual, endógena, da união com Deus, que é o princípio de toda perfeição. A lógica do êxito mundano se apóia numa falácia, no estranho equívoco de que a nossa perfeição depende dos pensamentos, opiniões e aplausos dos outros homens! Uma vida brilhante precisa sempre ser refletida na imaginação de mais alguém, como se aí fosse o único lugar em que uma pessoa possa se tornar real ${ }^{698}$.

De volta para São Boaventura, entrega-se à leitura das vidas de Joana D'Arc, São João Bosco, São Bento e dos sermões de São João da Cruz. Merton identificase cada vez mais com a posição espiritual deste último. A qualidade das poesias de São João da Cruz fascinou Merton. Não é difícil, por isso, imaginarmos sua alegria ao encontrar uma "alma irmã" como a do santo espanhol. Principalmente porque, sendo também um rebelde, um inconformista (chegou a ser preso), ele acreditava no primado da beleza e no da purificação da vida monástica como a única via legítima para chegar a Deus ${ }^{699}$.

Não tem mais dúvida: quer ser um monge trapista, quer despir-se o mais rápido possível do mundo e mergulhar naquele majestoso silêncio. É então que surge em São Boaventura alguém que seria uma das pessoas mais importantes da sua vida: Catarina Doherty, a baronesa de Hueck, uma refugiada russa que se dedica integralmente a ajudar os favelados do Harlem e que para tal fundara a "Friendship House"700.

A ideia de trabalhar no Harlem entusiasma Merton e ele não perde tempo: faz uma visita à "Friendship House" e a ela volta muitas vezes. Escreve muitas cartas à baronesa, chegando mesmo a sentir-se tentado a morar naquela comunidade. $^{701}$ As questões relacionadas à discriminação racial, despertadas pela baronesa, acompanhariam Merton até o fim da vida.

No entanto, depois de terminada a leitura de um pequeno livro sobre a vida cisterciense que trouxera de Gethsemani, conversa longamente com frei Philoteus que lhe pergunta: "Por que fazer-se trapista? Merton o fixa nos olhos com firmeza e diz: "Porque quero dar tudo a Deus!"702.

\footnotetext{
${ }^{698}$ MERTON, Thomas. A montanha dos sete patamares, p. 286.

${ }^{699}$ Cf. LÓPEZ, María Luisa Laguna. Thomas Merton: uma vida com horizontes, pp. 119-132.

${ }^{700}$ Cf. MERTON, Thomas. Op. cit., p. 307.

${ }^{701}$ Cf. Ibid., p. 313.

${ }^{702}$ SOUZA, Maria Emmanuel e Silva. Thomas Merton: um homem feliz. Petrópolis:Vozes, 2003. pp. 31-32
} 


\section{3 "Entre os quatro muros da minha nova liberdade".}

Merton escreve ao abade de Gethsemani e prepara-se para ingressar no mosteiro. Chega o dia da sua viagem e a alegria o acompanha em todo o trajeto. Quando chega, o irmão lhe abre a porta e pergunta: "Desta vez veio para ficar? E agora, tomado por uma alegre certeza, responde: sim" ${ }^{703}$. Quando ele entra no mosteiro diz: "O Irmão Matthew fechou a porta atrás de mim e me encontrei fechado entre os quatro muros de minha nova liberdade"704.

Ele sente que a longa peregrinação terminara e que é chegado o momento da união mística com sua casa. Era 10 de dezembro de 1941. Era o tempo do Advento. Ele era postulante e se preparava para o noviciado. Adquiriu um novo nome: Frei Louis.

O que ele fala ao entrar no mosteiro revela o que para ele já se apresentava como significado para a liberdade. Ele escreveu muitas vezes sobre esse tema. No livro Homem algum é uma ilha, publicado em 1955, ele diz que "sendo mais livres, também somos mais felizes. Não somente teremos mais do que tínhamos, mas seremos mais do que éramos. É no aprofundamento da nossa união com a vontade de Deus, que nos vem esse haver e esse ser" ${ }^{\text {,705 }}$. Merton lembra que a “consciência é a alma da liberdade"706, e que sem ela a liberdade não saberá o que fazer de si mesma.

Ele havia encontrado sua 'casa', estava feliz com o caminho percorrido e por descobrir qual era o seu lugar no mundo. Segundo ele, "somos chamados por Deus para participar da Sua vida e do Seu reino. Cada um é chamado a ocupar no reino um lugar especial; se encontramos esse lugar, seremos felizes"707. Sem, no entanto, descuidar de que a vocação do ser humano não consiste em apenas ser, e sim em trabalhar em união com Deus na criação de sua própria vida, sua identidade, seu destino.

Ou seja, "somos seres livres e filhos de Deus. Quer isso dizer que não temos de existir passivamente, mas devemos participar ativamente da liberdade criadora

\footnotetext{
${ }^{703}$ Cf. MERTON, Thomas. A montanha dos sete patamares, p. 336.

${ }^{704}$ Ibid., p. 337.

${ }^{705}$ Id., Homem algum é uma ilha. Campinas, SP: Verus Editora, 2003. p, 40. Publicado em 1955; tema original: No man is an island.

${ }^{706}$ Ibid., p. 38.

707 Ibid., p. 120.
} 
de Deus em nossa vida e na vida dos outros, escolhendo a verdade"708. Ele continua: "falando com maior nitidez, diremos que somos até chamados a participar da ação criadora de Deus, criando a verdade de nossa identidade" ${ }^{\text {709 }}$.

O lugar em que Merton se encontra o convida a sair de si para encontrar quem ele procura, pois "se somos chamados a um lugar em que Deus deseja fazernos o maior bem, somos chamados onde melhor podemos deixar-nos para achá10,710 .

Ele vai descobrindo que as experiências vividas tinham sido sinais da presença de Deus em sua vida. Ele descobre não ser possível se recordar de Deus, e sim que Ele pode ser descoberto, pois é certo que "Conhecemo-1O porque Ele nos conhece. Conhecemo-1O quando descobrimos que nos conhece. Nosso conhecimento de Deus é o efeito do Seu conhecimento de nós. É sempre a experiência de uma nova maravilha, que Ele se lembre de nós"711.

O que Merton procurava era uma proporção harmônica entre ação e contemplação. Sua entrada em Gethsemani não deve ser vista como uma ruptura drástica com o mundo exterior, nem como um ódio a este mundo e muito menos como uma fuga.

A minha alma não se descobre senão quando age. Ela deve, pois, agir. A estagnação e a inatividade trazem a morte espiritual. Mas a minha alma não deve projetar-se inteiramente nos efeitos externos da sua atividade. Não preciso ver-me a mim mesmo, eu só preciso ser quem sou ${ }^{712}$.

Para ele não existia primazia da contemplação sobre a ação e nem desta sobre aquela: sua vida mostra isso de maneira clara e irrefutável. Para Merton, a vida contemplativa pode significar tudo, menos alienação. Para melhor contemplar o mundo, ele se afastou dele, como se sua nitidez só fosse obtida a distância.

$\mathrm{Na}$ manhã do dia em que professou seus votos solenes, reconheceu que não lhe importava saber o que era ser contemplativo, o que era sua vocação e nem o que era a vocação cisterciense. Assim, ele escreveu:

Naquela manhã, quando estava estirado com o rosto no chão no meio da Igreja, com o reverendo Abade rezando sobre minha cabeça, comecei a rir com boca no pó, porque sem saber como e por que eu havia feito a coisa certa e mesmo uma

\footnotetext{
${ }^{708}$ MERTON, Thomas. Novas sementes de contemplação, p. 40.

${ }^{709}$ Ibid., p. 40.

${ }^{710}$ Id., Homem algum é uma ilha, p. 126.

${ }^{711}$ Ibid., p. 194.

${ }^{712}$ Ibid., p. 110.
} 
coisa surpreendente. Mas o surpreendente não era o meu trabalho, mas o trabalho que Vós realizastes em mim $^{713}$.

A gratidão de Merton a Deus, por seu cuidado com sua vida, está também refletida no que para ele significa sua ordenação: "ninguém é ordenado sacerdote exclusivamente para si, meu sacerdócio me faz pertencer não somente a Deus, mas a todos os homens" $" 714$.

Merton havia, enfim, encontrado seu lugar, aprendera a esperar e a dar tudo a Deus. Tinha reconhecido que o caminho percorrido por vezes tão longo e doloroso o conduziu, a ele, artista, diletante delicado, poeta, homem do mundo, para os Tabernáculos da Contemplação, do silêncio e da solidão em Deus; e para sua surpresa, para o mundo também.

\subsection{Um monge, escritor e poeta para o mundo}

Merton refletiu e meditou profundamente sobre o sentido da própria identidade pessoal durante sua vida, o que para ele significava uma realidade existencial profunda que só poderia ser entendida plenamente através da experiência pessoal do amor. Como vimos, para Merton, a liberdade é uma necessidade básica e irrenunciável. Em todas as fases da sua vida, uma qualidade sempre presente foi a sua liberdade interior, seu ser livre sem barreiras nem fronteiras. Assim, em sua vida monástica, soube integrar a mais estrita observância com o exercício de sua liberdade, à qual jamais renunciou.

A liberdade, portanto, é um talento que Deus nos dá, um instrumento com o qual devemos trabalhar. É o material com que construímos nossas próprias vidas, nossa própria felicidade. Nossa verdadeira liberdade é algo que jamais devemos sacrificar, pois, se sacrificássemos, estaríamos, em realidade, renunciando a Deus. Nossa liberdade é que faz de nós Pessoas, criadas à semelhança da imagem divina $^{715}$

Em um dos seus diários, ele havia escrito que desejava a total solidão, queria o anonimato. No entanto, seu Abade lhe pediu para que escrevesse livros que ajudassem a levar as pessoas ao amor de Deus e à contemplação ${ }^{716}$.

$\mathrm{Na}$ primeira etapa de sua vida, como escritor no mosteiro, ele escreve sobre a vida espiritual e seus temas fundamentais, sobre mística e contemplação e sobre

\footnotetext{
${ }^{713}$ MERTON, Thomas. A montanha dos sete patamares, p. 379.

${ }^{714}$ Id., O signo de Jonas, p. 209.

${ }^{715}$ Id., Novas Sementes da Contemplação, p. 200.

${ }^{716}$ Cf. Id., O signo de Jonas, p. 46.
} 
diversos aspectos da vida monástica, de um modo novo e perfeitamente acessível aos seus leitores, cada vez mais numerosos ${ }^{717}$.

Dentre os últimos diários que escreveu em Gethsemani, dois foram publicados: O signo de Jonas, que abrange os anos de 1942 a 1952, e Reflexões de um espectador culpado, que vai de 1956 a 1965. No primeiro, Merton se detém longamente naquilo que podemos chamar de "seu lugar na solidão". Ele é escrito justamente na época em que estuda a vida dos grandes contemplativos da Igreja, como Santa Lutgarda de Aywères e São Bernado de Claraval, tendo escrito e publicado suas biografias $^{718}$.

Ele, que sofrera tanto com a sua identidade de escritor e poeta, e que desejava uma vida de contemplação precisou de muita fé e generosidade para ser obediente. Não que lhe fosse difícil escrever, mas seu desejo era a solidão. Merton foi aprendendo que

em todos os acontecimentos, meu único desejo e minha alegria devem ser: aqui está o que Deus quis para mim. Nisso é que encontro o seu amor, e aceitando o que ele me envia é que posso dar-lhe de volta esse amor e a mim mesmo, inteiramente. Pois ao dar-me a ele encontrá-lo-ei e ele é vida eterna ${ }^{719}$.

Teve que romper os fortes muros de seu coração e cortar os nós de seu egoísmo que o atavam; teve que atravessar a mera temporalidade e a inautenticidade para empreender este caminho. O caminho de todo aquele que quer ser monge é ser verdadeiramente humano. Ele chegou à conclusão de que para pertencer a Deus deve pertencer a si mesmo e para isto tem que estar "só", ao menos internamente. Não podia pertencer a nada senão a Deus, e se sentia livre.

Tenho que aprender a "largar-me" para poder me encontrar, entregando-me ao amor de Deus. Se eu estivesse à procura de Deus, cada acontecimento e cada momento haveriam de plantar em minha vontade sementes de sua vida que um dia dariam maravilhosa colheita ${ }^{720}$.

O que acontecia sem saber era que precisava mais uma vez se colocar sob a vontade de Deus e deixar-se conduzir por Ele, pois estava entrando em mais uma nova etapa de sua vida que já havia sido iniciada quando quis 'dar tudo a Deus'. Segundo Merton, “em todas as situações da vida a "vontade de Deus" chega a nós,

\footnotetext{
${ }^{717}$ Cf. MERTON, Thomas. O signo de Jonas, p. 46.

${ }^{718}$ Cf. Ibid., p. 58.

${ }^{719}$ Ibid., p. 26.

${ }^{720}$ Id., Novas Sementes da Contemplação, p. 25.
} 
não apenas como um ditame impessoal de uma lei externa, mas, sobretudo, como um convite interior e pessoal de amor" 721 .

Obteve do Abade a permissão para tratar, em seus livros e em vários artigos, de assuntos mais candentes do mundo contemporâneo. Foi um formador de opinião, não só escrevendo, mas também quando realizava conferências. Denunciou como obscena e imoral a fabricação e o uso de armas atômicas e inspirou os maiores grupos promotores da paz e da justiça. Para ele seria uma blasfêmia falar sobre Deus e silenciar diante da guerra do Vietnã ${ }^{722}$.

Foi um dos poucos padres que se manifestou contra a guerra. Quando escreveu um artigo "Loucura da Guerra" ${ }^{723}$, causou grandes controvérsias no ambiente católico, levando-o a fazer uma reflexão contra as estruturas da Igreja que se revelavam através das Ordens Religiosas:

De certo modo penso que a posição da Ordem é de fato irrealista e absurda. Que numa época como esta ninguém na Ordem deva parecer estar preocupado com as realidades da situação mundial de um modo prático - que os monges em geral, inclusive os beneditinos que podem falar abertamente, estejam imersos em questiúnculas de erudição sobre escritores e textos medievais de importância menor até para eruditos, isso durante a maior crise moral da história humana: isso me soa incompreensível $^{724}$.

Suas afirmações sobre quem é o monge e a vida monástica, a autêntica solidão e contemplação, o que deve ser a "experiência interna" de um cristão, e sua visão de mundo, explicam que tenha chegado a ser um dos autores mais apreciados por fiéis cristãos de diferentes denominações e inclusive por inúmeros seguidores de outras religiões.

Para Merton a relação com Deus acontece a partir da realidade humana. Seu diálogo com outras religiões e principalmente com as místicas judaica, budista, hinduísta e com o islã, realizando pontes entre elas, se dava, dentre outros motivos, por entender que Deus nos fala através dos acontecimentos no mundo e que os sinais de crise devem ser interpretados pelos homens de religião.

No começo dos anos sessenta, começa a trabalhar na tradução de textos do místico e escritor taoísta chinês Chuang-tzu, que, com os maiores místicos budistas, elegera a via da compaixão como a única e verdadeira senda pela qual podemos nos entregar ao nosso próximo e dele receber uma contribuição positiva

\footnotetext{
${ }^{721}$ MERTON, Thomas. Novas Sementes da Contemplação, p. 23.

${ }^{722}$ Cf. HART, Patrick; MONTALDO, Jonathan. Merton na intimidade, p. 214.

${ }^{723}$ Cf. Ibid., p. 213.

${ }^{724}$ Ibid., p. 214.
} 
para o nosso crescimento interior ${ }^{725}$. Os budistas chamam de Karuna a compaixão, síntese de uma espécie de código moral que regula o relacionamento entre as pessoas. Uma das consequências da iluminação (satóri) é desrepresar a compaixão, deixando-se inundar por ela e fazendo-a inundar o mundo à volta de quem atinge tal estado ${ }^{726}$.

Fascinavam Merton no misticismo oriental os conceitos sobre a renúncia e sobre a compaixão. Tinham sido esses "sinais" que o guiaram até Gethsemani e, por conseguinte, à vida contemplativa. Ele vê que o Evangelho e Chuang-tzu dizem a mesma coisa: a perda da vida é a única maneira de salvá-la e procurar salvá-la por motivos pessoais significa perdê-la ${ }^{727}$.

Sua abertura às correntes islâmicas, em especial o sufismo, pouco a pouco o fez de tanto ler sobre o assunto, um especialista ocidental em zen-budismo. Sobre o sufismo disse:

Não se pode questionar que se trata de uma verdade viva e convincente, uma profunda experiência do mistério de Deus nosso Criador, Quem nos observa em todo momento com graça e amor infinitos. Estou comovido no mais profundo do meu coração pela intensidade da piedade muçulmana, por Seus Nomes e a reverência com que Ele é invocado como 'o Compassivo e o Misericordioso, ${ }^{728}$.

E confessou a Abdul Asiz, especialista no sufismo:

Profunda simpatia pelo sufismo. É altamente prático, realista, profundamente religioso e situado na correta perspectiva de relação direta com Deus. Nossa conduta está baseada nesta relação com Ele, não em meros sistemas éticos e ideais $^{729}$.

Seu desejo de unidade, embora se aproximasse das decisões tomadas pelo Concílio Vaticano II, revela-se, porém, mais profundo que as regras de atualização e reforma originárias de Roma. Para ele, "as diferenças doutrinárias devem ser conservadas, mas elas não invalidam uma qualidade muito real de semelhança existencial" ${ }^{730}$. As diferenças doutrinárias possibilitam as semelhanças na esfera da experiência religiosa, em um diálogo que não significa ‘fusão nem confusão', mas cooperação, no aprofundamento do próprio compromisso de fé.

\footnotetext{
${ }^{725}$ Cf. HART, Patrick; MONTALDO, Jonathan. Merton na intimidade, p. 195.

${ }^{726}$ Cf. MERTON, Thomas. A experiência interior, pp. 14-15.

${ }^{727}$ Cf. Ibid., pp.17-18.

${ }^{728}$ Id., Reflexiones sobre Oriente. Barcelona: Ediciones Oniro, 1997. pp. 84-85

${ }^{729}$ Ibid., p. 85

${ }^{730}$ Id., O diário da Ásia, p. 245.
} 
A partir deste diálogo em profundidade com as tradições religiosas orientais, se confirma em Merton 'uma oportunidade maravilhosa' de aprofundamento das potencialidades e virtualidades existentes nestas tradições ${ }^{731}$, possibilitando uma ampliação de seus horizontes.

Desde a época em que conheceu o monge hindu Bramachari (1935), seu interesse pelas religiões do oriente não parou de crescer. Hinduísmo, budismo (tibetano principalmente), taoísmo e zen-budismo constituíram objeto de estudo, interpretação e reflexão tão intensas, como o próprio cristianismo. A correspondência com Daisetz T. Suzuki ${ }^{732}$ contribuiu para que ele se familiarizasse cada vez mais com a vida dos grandes místicos e com o misticismo oriental.

Em 1965, depois de dedicar-se a um árduo estudo de textos de Chuang-tzu, Merton publica-os com o título de $A$ via de Chuang $T z u^{733}$, enriquecendo-os com um primoroso prefácio, no qual diz entre outras coisas:

\begin{abstract}
Uma vida contemplativa e interior que fizesse com que o indivíduo se conhecesse mais a si mesmo e que lhe permitisse tornar-se obcecado pelo seu próprio progresso interior seria, para Chuang Tzu, uma ilusão não menos significativa do que a da vida do homem 'benevolente' que tentasse, por seus próprios esforços, impor a sua ideia de bem a todos os que pudessem se opor a essa ideia e assim, tornar-se-iam aos seus olhos, 'inimigos do bem ${ }^{134}$.
\end{abstract}

Torna-se colaborador assíduo de diversas publicações dedicadas à divulgação do zen-budismo no ocidente. Muitos desses artigos foram publicados no livro Místicos e mestres zen ${ }^{735}$. Escritos com clara preocupação didática, numa linguagem fluente e despojada, sintetizam a história do zen no oriente, bem como sua propagação no ocidente.

Outro livro indispensável para se conhecer a orientalização do pensamento de Merton é Zen e as aves de rapina ${ }^{736}$, constituído por uma reunião de ensaios publicados em revistas e prefácios a livros de outros autores. Nele, faz o elogio ao zen e mostra que a experiência cristã, como a de Mestre Eckhart, muito se

${ }^{731}$ Cf. MERTON, Thomas. O diário da Ásia, p. 267.

${ }^{732}$ Daisetsu Teitaro Suzuki foi um famoso autor japonês de livros sobre o Budismo, o Zen e Jodo Shinshua. Ele foi o responsável, em grande parte, pela introdução destas filosofias no ocidente. Suzuki também foi um prolífico tradutor de literatura chinesa, japonesa e sânscrita.

${ }^{733}$ MERTON, Thomas. Via de Chuang Tzu. Petrópolis: Vozes, 2003. Título original: The way of chuang Tzu. N. York: Straus Abbey of Gethsemani, 1965.

${ }^{734}$ Ibid., p 45.

${ }^{735}$ Id., Místicos e mestres Zen. São Paulo: Martins Fontes, 2006. Título original: Mystics and Zen masters. N. York: Straus Abbey of Gethsemani, 1967.

${ }^{736}$ Id., Zen e as aves de rapina. Rio de Janeiro: Civilização brasileira, 1970.Título original: Zen and birds os appetite. N. York: Straus Abbey of Gethsemani, 1968. 
aproxima dessa escola do budismo e conta como foi seu primeiro encontro com Suzuki.

Toda a viagem de Merton à Ásia foi registrada em seu último diário Diário da Ásia. Começa com uma anotação feita em 15 de outubro e termina com outra lançada em 08 de dezembro, dois dias antes de sua morte. Coube a um amigo e secretário de Merton, Irmão Patrick Hart, a missão de organizar o Diário e, também em um post-scriptum, contar os tristes acontecimentos da volta de Merton ao lugar que escolhera para sua morada ${ }^{737}$.

Nos últimos anos de sua vida, trabalhou arduamente por abrir seu coração e suas inquietudes a todos os horizontes da espiritualidade humana em suas distintas manifestações religiosas. Isto não se tratou de uma mera curiosidade religiosa, mas sim de ir além, na urgência em encontrar-se consigo mesmo e compartilhar com os demais a unidade espiritual que emana de todos os homens.

Teve sempre muito clara a consciência de que, sem pessoas unificadas, não haveria nem mundo, nem religião, nem unidade. A divisão interna que as pessoas experimentam é um fato que podemos constatar em nosso próprio viver, e as divisões religiosas, sociais e políticas constituem um dado estatístico inegável: por um lado, guerras e violências; por outro, intentos de unidade e desejos de paz.

Segundo Merton, "se eu não tiver em mim unidade, como poderei pensar e menos ainda falar em unidade entre cristãos? No entanto, é evidente: procurando a unidade para todos os cristãos, encontro em mim, também, a unidade"738.

Ele ainda destaca:

Só há uma fuga verdadeira do mundo; não se trata de fugir do conflito, da angústia e do sofrimento, mas sim de fugir da desunião e da separação, para dentro da união e da paz pelo amor aos outros homens. [...] Pois fugir do mundo nada mais é do que fugir à preocupação do nosso próprio eu. E quem se tranca a sós com seu egoísmo se coloca numa posição em que o mal que nele existe dele se há de apoderar como um demônio ou então fá-lo-á perder a cabeça ${ }^{739}$.

Não se pode negar em Merton uma subjetividade aberta, por ver o outro e ser visto humanamente, falar ao outro e escutá-lo, em ajudar e por último em assumir unicamente que somos humanos com os outros e junto a eles ${ }^{740}$.

\footnotetext{
${ }^{737}$ Cf. MERTON, Thomas. Diário da Ásia, p. XXV.

${ }^{738}$ Id., Reflexões de um espectador culpado. Petrópolis, RJ: Vozes, 1970. p. 166. Título original: Conjectures of a guilty bystander, publicado em 1966.

${ }^{739}$ Id., Novas sementes da contemplação, p. 82.

${ }^{740}$ Cf. GARCIA RUBIO, A. Unidade na pluralidade: o ser humano à luz da fé e da reflexão cristã. São Paulo: Paulus, 2001. pp. 452-454.
} 
Merton foi um monge, escritor e poeta que não apenas conseguiu traduzir em linguagem moderna os temas fundamentais da vida monástica e da vida espiritual cristã, como também soube integrar sua vida com o mundo através de pessoas representativas no âmbito da arte, letras e da cultura em geral.

Em meio a uma vida cheia de desejo em corresponder à vontade de Deus, Merton, vive uma forte paixão. A importância deste fato, que o mesmo ressalta em seu diário, está em assumir seus próprios sentimentos.

\subsection{Entre uma paixão e o mosteiro}

Era março de 1966, quando teve de ser submetido a uma cirurgia, enquanto estava em recuperação no hospital, conhece uma enfermeira que tinha sido designada para ocupar-se de seus curativos. No seu diário escreveu: "Neste dia me mandaram, como enfermeira, ainda estudante, para cuidar especialmente de mim, mudar as compressas na minha coxa, ... em uma semana estávamos apaixonados" ${ }^{741}$. Ele amou e permitiu-se ser profundamente amado pela enfermeira Margie Smith.

Logo que saiu do hospital, escreveu um poema sobre o que estava vivendo. Releu o que havia escrito sobre solidão em seu livro, liberdade e solidão, reconheceu que o havia melhorado, por tudo de novo e surpreendente que estava acontecendo, e neste momento percebeu que:

Nada conta a não ser o amor, e uma solidão que não seja simplesmente a total abertura da liberdade e do amor não é nada. Amor e solidão é o solo da verdadeira maturidade e liberdade. A solidão que é apenas solidão e nada mais (i.e., que exclui tudo que não é solidão) não tem valor. A verdadeira solidão abarca tudo, pois é a plenitude do amor que não rejeita nada e ninguém, que se abre para Todos em Tudo $^{742}$.

Merton pôde experimentar em sua liberdade o sentimento de amor por uma mulher, arriscou-se amá-la sem medo! Em nenhum momento negou a si mesmo. Estava nesta relação por inteiro e, por isso, pôde, com mesma liberdade com que amou, dizer a si mesmo que não poderia viver sem o eremitério, sem ser fiel ao voto de castidade e a tudo que prometera a Deus.

Em Merton percebemos que a mais repressiva ascese não consegue apagar as poderosas correntes subterrâneas de nosso psiquismo. As paixões não conhecem a linguagem da repressão, mas da integração.

\footnotetext{
${ }^{741}$ HART, Patrick; MONTALDO, Jonathan. Merton na intimidade, p. 351.

${ }^{742}$ Ibid., p. 315.
} 
Ele confessa em seu diário:

Não posso considerar isso como 'apenas um episódio'. É um fato entranhado em minha vida e que há de ter penetrado em meu coração a fundo para alterar e transformar todo o meu clima de pensamento e experiência. Nela, como agora percebo, encontrei alguma coisa, alguém, que eu andei procurando a vida inteira. Sei que ela também sente o mesmo a meu respeito. Não importa o que aconteceu, creio que ambos sempre sentiremos que isso foi e é uma coisa muito profunda e real para ser mudada na essência. $O$ que encontramos um no outro não ficará perdido: mas também não será verdadeiramente possuído ${ }^{743}$.

Ele reconheceu que tudo o que vivia não era apenas desejo seu, mas que a “solidão é a vontade de Deus pra mim - não é apenas que eu 'obedeça' às autoridades e às leis da Igreja. É mais do que isso. É aqui que estão minhas raízes" 744.

E em junho do mesmo ano, não negando em nenhum momento para si mesmo a experiência amorosa que viveu, ele rompe seu relacionamento voltando ao primeiro amor, lembrando-se de seus votos de entrega incondicional a Deus. Para Merton suas escolhas e decisões, bem como sua compreensão sobre as experiências religiosas, são agora iluminadas por seu profundo desejo de corresponder à vontade de Deus, que se refletia na sua constante busca de uma melhor relação com o mundo, com as pessoas e com Deus. No que o constituía um homem totalmente integrado consigo mesmo em todas as suas dimensões.

\section{Cristão: "Filho de Deus" criado livre para o amor}

A experiência religiosa vivida por Merton lhe dava a clareza sobre a existência do ser humano. Para ele, o ser humano foi criado como "filho de Deus", porque sua vida, desde o princípio, compartilha o Espírito de Deus. Isto significa que estava destinado a viver e respirar em harmonia com Deus, a ver as coisas como ele as via, a amá-las como ele as amava. Assim, ele afirma: "Deus nos disse não somente que somos chamados a ser seres humanos e a governar nossa terra, mas que temos uma vocação mais elevada que essa: somos seus filhos" ${ }^{745}$.

\footnotetext{
${ }^{743}$ HART, Patrick; MONTALDO, Jonathan. Merton na intimidade, p. 336.

${ }^{744}$ MERTON, Thomas. A montanha dos sete patamares, p. 348.

${ }^{745}$ Cf. MERTON, Thomas. Humanismo cristiano. Cuestones disputadas. Barcelona: Editorial Kairós, 2000. Cf. p, 44, Jo 10,35; Sl 81,6; Título original: Disputed questions. The Abbey of Our Lady of Gethsemani, 1953.
} 
O ser humano pode entrar no interior de seu ser e permanecer diante de Deus, seu Pai. O auge da vida interior é a contemplação, que é a perfeição do amor e do conhecimento de Deus.

Precisamos do dom de Deus pelo qual nos tornamos capazes de encontrar em nós mesmos, não somente a nós mesmos, mas a Deus: então nossa nulidade se torna Sua plenitude, o que não é possível sem a libertação efetuada pela comunhão e pela humildade. Para tanto, não exige talento, nem a mera intuição, mas arrependimento, entregar-se em amor e confiança ${ }^{746}$.

Deus criou o ser humano com uma natureza ordenada a uma vida sobrenatural, e esta vocação de ser filhos de Deus significa que o ser humano deve aprender a amar como Deus o ama, pois Deus é amor. "O amor é, pois, não só nossa própria salvação e a chave do sentido de nossa existência, senão também a chave do sentido de toda a criação de Deus" ${ }^{\text {747 }}$. Neste amor, o ser humano é chamado a transformar e redimir o mundo e a edificar o Reino de Deus na terra.

A perfeita imagem de Deus, nosso "eu" mais profundo, quando desperta, encontrase na presença daquele de quem é imagem; e, por um paradoxo que ultrapassa toda expressão humana, Deus e a alma possuem um único "Eu". São (pela graça divina) como uma só pessoa. Respiram, vivem e agem como um. "Nenhum" dos "dois" é visto como um objeto ${ }^{748}$.

Deus quis que o ser humano, seu filho, fosse verdadeiramente divino, para que participasse de sua própria sabedoria, poder, justiça e realeza. E tudo isto dependia de uma coisa: o amor, o único pelo qual a humanidade poderia participar da vida de seu Pai ${ }^{749}$, ou seja, "a maior dignidade do homem, sua faculdade mais essencial e peculiar, o mais íntimo de sua humanidade, é sua capacidade de amar. Esta faculdade da profundidade do ser humano, imprime nele a imagem e a semelhança de Deus" ${ }^{\text {"750. }}$.

Para Merton, o ser humano exercendo sua capacidade de amar torna-se capaz de encontrar Deus nos outros seres humanos, de ver o que está por baixo da superfície e pressentir a presença do eu interior e inocente, que é sua imagem de Deus ${ }^{751}$. Todavia, "quando procuramos afirmar nossa unidade negando haver qualquer relação seja com quem for, rejeitando a todos no universo até chegarmos

\footnotetext{
${ }^{746}$ MERTON, Thomas. A experiência interior, p. 76.

${ }^{747}$ Id., Humanismo Cristiano, p. 45.

${ }^{748}$ Ibid., p. 28.

${ }^{749}$ Cf. Ibid., p. 47.

${ }^{750}$ Ibid., p. 44.

${ }^{751}$ Cf. Id., Op. cit., p. 78.
} 
a nós mesmos, que resta para ser afirmado?" ${ }^{, 752}$. O verdadeiro caminho é justamente o oposto: "quanto mais sou capaz de afirmar os outros, dizer-lhes "sim" em mim mesmo, descobrindo-os em mim mesmo e a mim mesmo neles, tanto mais real eu sou. Sou plenamente real se meu coração diz sim a todos"753.

No entanto, esse amor é o sentido da existência do ser humano, de sua salvação e de toda a criação. $\mathrm{O}$ amor natural permite perpetuar a humanidade no tempo, enquanto que a função do amor espiritual é de um alcance maior: dar à pessoa a posse da eternidade, edificar o Reino de Deus, um reino espiritual de unidade e de paz, que faz do ser humano o beneficiário da criação. "A realidade do amor é julgada por sua capacidade de ajudar o ser humano a ir mais além de si mesmo, para que se renove transcendendo suas limitações" ${ }^{\text {754 }}$. Portanto, o amor verdadeiro leva o homem a sua máxima realização, que se alcança transcendendo a si mesmo.

O amor, pois, é a ligação entre o ser humano e a realidade mais profunda de sua vida. Sem ele está isolado, alienado de si mesmo, alienado dos outros, separado de Deus, da verdade, da sabedoria e da fortaleza. Pelo amor, homens e mulheres entram em contato com sua essência mais profunda ${ }^{755}$.

Ou seja, o amor verdadeiro é a morte e ressurreição em Cristo, que implica que todos os membros se deem uns aos outros e à Igreja; que nos percamos na vontade de Cristo e no bem aos outros, e morramos em nossos próprios interesses para ressuscitar com outros Cristos ${ }^{756}$. Em Cristo Deus se fez homem. Nele, Deus e o homem não estão mais separados. O que é divino tornou-se conatural a nós no amor de Cristo. Tornamo-nos filhos de Deus por adoção na medida em que nos assemelhamos ao Cristo e somos irmãos seus ${ }^{757}$.

No entanto, é o Espírito de Deus quem deve ensinar quem é Cristo ao ser humano; ele é quem tem de formar Cristo nas pessoas e transformá-los em outros Cristos. Ser Cristo significa penetrar na vida do Cristo total, o corpo Místico formado da Cabeça e dos membros; Cristo e todos os que, pelo Espírito, estão nele incorporados ${ }^{758}$.

\footnotetext{
${ }_{752}^{753}$ MERTON, Thomas. Reflexões de um espectador culpado, p. 166.

${ }^{753}$ Ibid., p. 166.

${ }^{754}$ Ibid., p. 45.

${ }^{755}$ Ibid., p. 45.

${ }^{756}$ Cf. Id., Humanismo cristiano, p. 46.

${ }^{757}$ Cf. Id., Novas sementes de contemplação, p. 151.

${ }^{758}$ Cf. Ibid., p. 157.
} 
"O ser humano não pode viver sem amor"759. Sem amor, o ser humano está isolado, separado dos outros e de Deus, da verdadeira sabedoria e fortaleza, enquanto que pelo amor o ser humano entra em contato com sua essência mais profunda, com seu próprio eu, com seus irmãos, e com a sabedoria e o poder de Deus $^{760}$. É o amor que se faz humano através de Deus, que leva o ser humano à sua plenitude, tornando-o filho de Deus. O ser humano foi criado para viver em sociedade, pois o amor dos outros dá vida, e amor ao próximo o leva a sua realização; por meio dele, Deus estende seu amor sobre o mundo.

\section{Para Merton,}

todo verdadeiro amor está estreitamente associado com três atividades fundamentalmente humanas: o trabalho criador, o sacrifício e a contemplação. Se as três estão presentes, estamos diante de uma prova segura de vida espiritual, mesmo que de forma rudimentar. E a mais importante das três é o sacrifício ${ }^{761}$.

Porém o amor tem que buscar a realidade, se não frustra a pessoa que se ama em seu ser mais profundo. A realidade do amor está determinada pela relação que estabelece entre as pessoas enquanto pessoas. Há que amar as pessoas não como objetos, mas amá-las como a si mesmo ${ }^{762}$.

É para isso que viemos ao mundo - para essa comunhão e essa transcendência de si. Não nos tornamos plenamente humanos até nos darmos um ao outro no amor. E isso não deve se confinar apenas à realização sexual: abrange tudo na pessoa humana - a capacidade de entrega de si, de partilha, de criatividade, de cuidado mútuo, de preocupação especial ${ }^{763}$.

No entanto, a subjetividade essencial para amar não diminui a realidade objetiva, mas a incrementa. $\mathrm{O}$ amor compromete o ser humano diante da relação com uma realidade objetivamente existente, porém precisamente por ser amor, é capaz de salvar o abismo entre sujeito e objeto e entrar em comunhão com a subjetividade do ser amado ${ }^{764}$. "Só o amor pode realizar este tipo de união e proporcionar esta forma de conhecimento por identidade com o ser amado"765.

Para amar o próximo como pessoa há que começar por outorgar-lhe sua própria autonomia e identidade, pois "a vida consiste em aprender a viver de

\footnotetext{
${ }^{759}$ Cf. MERTON, Thomas. Humanisno cristiano, p. 50.

${ }^{760}$ Cf. Ibid., p. 47.

${ }^{761}$ Ibid., p. 46.

${ }^{762}$ Cf. Ibid., p. 48.

763 Id., Amor e vida. São Paulo: Martins Fontes, 2004. p. 28. Título original: Love and living. New York, Farrar, Straus and Giroux, 1979.

${ }^{764}$ Cf. Id., Humanisno cristiano, p. 48.

${ }^{765}$ Ibid., p. 49
} 
maneira autônoma, espontânea e livremente: para isso é preciso reconhecer-se a si mesmo - estar familiarizado e à vontade consigo mesmo"766.

Esta é também a base da relação filial com Deus: a relação sujeito-objeto tem que estar completamente excluída. Só é possível conhecer a Deus quando o ser humano o encontra, escondido pelo amor, dentro de si mesmo. Paradoxalmente a isto, só o alcançará se sair para fora de si mesmo por meio do sacrifício $^{767}$.

Nossa atitude em relação à vida também será, de um jeito ou de outro, uma atitude em relação ao amor. Nossa concepção de nós mesmos será profundamente afetada por nossa concepção - e nossa experiência - de amor. E nosso amor, ou nossa falta de amor, nossa disposição de correr o risco, ou nossa determinação de evitá-lo será, no final, uma expressão de nós mesmos: de quem pensamos que somos, do que queremos ser, do que pensamos sobre estar aqui ${ }^{768}$.

Só a partir do amor, que esvazia a sua vontade, o ser humano é capaz de encontrar a Cristo no lugar antes ocupado por sua individualidade. Isso ocorre porque a realidade interior da história do ser humano é o ser humano, o ser humano filho e imagem de Deus. Essa realidade não é apenas humana, mas divina, pois Deus uniu o homem a si, em Cristo ${ }^{769}$.

No amor experimentamos por assim dizer em nossos próprios corações o segredo íntimo, pessoal do Amado. E Cristo nos deu sua amizade para que lhe fosse possível dessa maneira penetrar em nossos corações e neles permanecer como em sua morada, como uma presença pessoal, não como um objeto, não como um "quê" , mas como um "Quem". Assim, Aquele que é está sempre presente nas profundezas de nosso ser como nosso Amigo e como outro eu. É esse o mistério do Verbo vivendo em nós em virtude de sua Encarnação, e de nossa incorporação em seu corpo Místico, a Igreja ${ }^{770}$.

Entretanto, o ser humano foi criado livre para eleger seu destino, porém só é autenticamente livre quando ele realiza o bem por amor; como todo bem, perfeição e felicidade se encontram na vontade de Deus, que é infinitamente boa.

A liberdade só pode acontecer a partir da união perfeita à vontade de Deus.

O mundo, portanto, é mais real na proporção em que as pessoas nele são capazes de ser mais plenamente e mais humanamente vivas: isto é, mais capazes de fazer uso consciente e lúcido de sua liberdade. Basicamente, essa liberdade deve consistir, antes de tudo, na capacidade de escolherem suas próprias vidas, de se encontrarem no nível mais profundo possível ${ }^{771}$.

\footnotetext{
${ }^{766}$ MERTON, Thomas. Amor e vida, p. 3.

${ }^{767}$ Cf. Id., Humanisno cristiano, pp. 49-50.

${ }^{768}$ Id., Amor e vida, p. 29.

${ }^{769}$ Id., A experiência Interior, p. 217.

${ }^{770}$ Id., Sementes de contemplação, p. 154.

${ }^{771}$ Id., Amor e vida, p. 4.
} 
O livre arbítrio é a mera capacidade de eleger entre o bem e o mal. No entanto,

a simples capacidade de escolha entre o bem e o mal é o nível mais baixo da liberdade e o único elemento de liberdade que há nisso é o fato de podermos sempre escolher o bem. Na medida em que somos livres para escolher o mal, deixamos de ser livres. Uma escolha má destrói a liberdade ${ }^{772}$.

Logo, a perfeita liberdade é a incapacidade total de fazer uma má eleição. Só a eleição que aspira ao bem e também a alcança, faz com que o ser humano sinta-se feliz, por torná-lo livre.

Pois a liberdade não consiste em um equilíbrio entre boas e más ações, senão em amar e aceitar perfeitamente o que é realmente bom e odiar e rejeitar o que é mau, e quem rejeita todo mal porque é incapaz de desejá-lo, é livre. Toda liberdade verdadeira é um dom sobrenatural de Deus, uma participação em sua liberdade, pelo amor que infunde em nossas almas que nos une a ele, primeiro em um consentimento perfeito e depois em uma união transformadora de vontades ${ }^{773}$.

A liberdade é um dom dado por Deus, um instrumento com o qual o ser humano constrói sua vida e sua felicidade. É o elemento mais precioso do seu ser; se renunciar a ela renunciará a Deus. A liberdade torna o ser humano a imagem de Deus.

$\mathrm{Na}$ ordem espiritual, é escravo o ser humano cujas eleições têm destruído toda espontaneidade e o tem entregado às suas compulsões e ilusões. Não pode defender-se de si mesmo até que não tome decisões espirituais. Para isto, tem que resistir à cega compulsão da paixão. "A mais simples definição da liberdade, portanto, é a seguinte: a aptidão para fazer a vontade de Deus. Ser capaz de resistir à vontade divina é não ser livre" 774 . Se vamos viver como homens livres na ordem sobrenatural, temos que assumir opções livres sobrenaturais, e isto é obedecer a Deus por amor.

Não se trata de submeter a vontade do ser humano à autoridade de Deus; é a livre união de sua vontade com a vontade de Deus por amor, é a livre opção que os torna filhos de Deus. Não podem fazer-se filhos de Deus por uma obediência que só seja uma renúncia cega a sua autonomia; a liberdade espiritual consagra nossa autonomia a Cristo, e em Cristo ao Pai.

\footnotetext{
${ }_{772}^{773}$ MERTON, Thomas. Novas sementes de contemplação, p. 197.

${ }^{773}$ Cf. Ibid., p. 198.

${ }^{774}$ Ibid., p. 198.
} 
A liberdade é uma coisa espiritual, uma realidade sagrada e religiosa, cujas raízes estão em Deus e não no homem, pois a liberdade do homem, que faz deste uma imagem de Deus, é uma participação na liberdade de Deus. O homem é livre na medida em que é semelhante a Deus ${ }^{775}$.

O temperamento não predestina uma pessoa à santidade ou à reprovação. Todos os temperamentos podem servir para a salvação ou para a ruína. O temperamento é um dom de Deus, um talento com o qual temos que viver, não importa o difícil ou problemático que seja.

Se desejar o que é mau, seu gênio tornar-se-á uma arma malfazeja dirigida contra os outros, até contra sua própria alma. Deseja-se o que é bom, pode seu gênio tornar-se um instrumento controlador, destinado a combater o mal que nele existe, e a auxiliar os outros a vencer os obstáculos que encontram no mundo. Permanece, portanto, livre podendo desejar o bem ou o $\mathrm{mal}^{776}$.

Podemos perceber que a liberdade humana não atua em um vazio moral, porém a coerção de fora, as fortes inclinações temperamentais e as paixões dentro do ser humano, em nada afetam a essência de sua liberdade, simplesmente definem sua ação impondo certos limites, e isto revela um caráter peculiar que lhe é próprio.

Todavia, o ser humano ainda é um intermediário entre Deus e a criação, um sacerdote que oferece a Deus todas as coisas sem destruí-la nem danificá-las, chamado a cuidar e trabalhar no jardim do Éden e a contribuir por meio de seu trabalho na criação de Deus, no mundo ${ }^{777}$.

O mundo foi criado como um templo, um paraíso, ao qual o próprio Deus haveria de descer e conviver familiarmente com os espíritos por ele ali colocados para cuidar desse jardim. Deus criou o homem e confiou-lhe a tarefa de partilhar com ele do cuidado das coisas criadas. Criou o homem à sua imagem e semelhança, como um artista, um trabalhador, homo faber, como o jardineiro do paraíso. Deixou ao homem a liberdade de decidir ele próprio de que maneira haveria de interpretar as coisas criadas como compreendê-las e utilizá-las ${ }^{778}$.

Para o cristianismo o ser humano assume, então, uma parceria com o Criador, ele é seu intermediário. Sobre as verdades do catolicismo, afirma Merton: "Serei melhor católico, se puder afirmar a verdade que existe no catolicismo e ir ainda além, e não se refutar todos os matizes que existem no protestantismo" "779 . E indo além, em direção a outras religiões, ele continua:

\footnotetext{
775 MERTON, Thomas. Experiência interior, p. 221.

776 Id., Liberdade e solidão, p. 21.

${ }^{777}$ Cf. Id., Novas sementes de contemplação, p. 286.

778 Ibid., p. 284.

${ }^{779}$ Id., Reflexões de Espectador culpado, p. 166
} 
Assim também em relação aos muçulmanos, os hindus, os budistas, etc. Isso não significa sincretismo, indiferentismo, camaradagem vazia e despreocupada que tudo aceita sem sobre nada refletir. Há muita coisa que não se pode "afirmar" e "aceitar". No entanto, é preciso, em primeiro lugar, dizer, "sim" quando realmente isso é possível ${ }^{780}$.

E para finalizar, como imagem e semelhança de Deus, seu filho, diz Merton:

Se eu me afirmo como católico simplesmente negando tudo que é muçulmano, judeu, protestante, hindu, budista, etc., no fim descobrirei que, em mim, não resta muita coisa com que possa afirmar-me como católico: e certamente nenhum sopro do Espírito com o qual possa afirmá-lo ${ }^{781}$.

Ou seja, o ser humano procura a unidade porque ele é a imagem do Deus Uno. "Viver em comunhão, em autêntico diálogo com outros, é absolutamente necessário para que o ser humano permaneça humano" ${ }^{782}$.

Quem está obcecado com sua unidade interior não é capaz de perceber sua desunião com Deus e com o próximo. Ao passo que, em união com os demais é possível estabelecer de modo fácil e natural nossa unidade interior. Preocupar-se por mudar primeiro sua unidade interior, e não amar os demais é seguir uma lógica de ruptura que é contrária à vida ${ }^{783}$.

\subsection{Meu lugar no mundo: solidão e compaixão}

Antes de entrar no mosteiro, Merton se perguntava qual era o seu lugar no mundo. ${ }^{784}$ No mosteiro, encontra como resposta a solidão. No entanto, agora outra pergunta é feita: Qual é o meu lugar na solidão? A resposta a esta pergunta é buscada, de maneira sofrida, durante seus primeiros anos no mosteiro. Merton demora a encontrá-la, como podemos ler em um relato despojado de suas crises naquele período.

Hoje creio ter a certeza de que a solidão é na verdade o que Deus deseja para mim, e que é realmente Deus quem está me chamando para o deserto. Mas tal deserto não é necessariamente, um deserto geográfico. É uma solidão de coração na qual as alegrias criadas são destruídas e voltam a nascer em Deus ${ }^{785}$.

A sua vida começou a tomar um novo rumo, logo dois anos depois de sua ordenação, quando assume a formação de noviços e se dedica à felicidade destes

\footnotetext{
${ }^{780}$ MERTON, Thomas. Reflexões de Espectador culpado, p. 166.

${ }^{781}$ Ibid.

${ }^{782}$ Id., Liberdade e solidão, p. 62.

${ }^{783}$ Id., Novas sementes de contemplação, p. 195.

${ }^{784}$ Id., Signo de Jonas, p. 364.

${ }^{785}$ Ibid., p. 64.
} 
jovens $^{786}$. Foram anos fecundos. Nascia a sua compaixão pelo ser humano e o desejo de partilhar com o mundo tudo que recebia de Deus. "Morro de amor por ti, compaixão, tomo-te como mulher, igual a Francisco que se casou com a pobreza, caso contigo, rainha dos ermitões e mãe dos pobres" ${ }^{\text {} 787}$.

Quando analisou sua vida, compreendeu que a autêntica solidão não é estar isolado, senão que em sua solidão conhecia mais a seus alunos e estava mais unido a eles. Ele aprendera que

quando Deus chama alguém para a solidão, qualquer coisa que toque contribuirá para aumentar sua solidão. Tudo que afeta a pessoa serve para construir uma ermida em torno dessa pessoa até o ponto em que ela não insista em querer fazer seu próprio trabalho, em construir sua própria espécie de ermida ${ }^{788}$.

É interessante lembrar que o estado de solidão "evolui" continuamente na vida de Merton, desde o simples estar só dos outros até o estar só da própria solidão, este último dentro dos ensinamentos zen-budistas, dos quais ele foi um fervoroso admirador. Ele descobriu que o seu deserto chamava-se compaixão. Segundo ele "não há solidão tão terrível e tão bela, tão árida e tão frutífera como o ermo da compaixão. É o único deserto que realmente florescerá como o lírio" ${ }^{789}$.

Merton tem uma nova experiência de conversão. Uma conversão do mosteiro ao mundo ${ }^{790}$. Ele percebeu, depois de viver 17 anos como monge, que não existe oposição entre o sagrado e o profano, natural e sobrenatural. A sua experiência de "conversão à compaixão" trata-se de uma epifania, uma revelação e uma profecia sobre sua própria vida e sobre a realidade do ser humano no mundo, que aconteceu na cidade de Louisville, Kentucky. Na esquina das ruas Fourth com Walnut, no movimentado centro comercial, ele nos conta que: "aconteceu, como se eu visse a secreta beleza de seus corações, a profundeza de seus corações onde nem o pecado, nem o desejo, nem o autoconhecimento podem penetrar. Isto é, o cerne da realidade de cada um, da pessoa de cada um aos olhos de Deus"791.

Merton usa a expressão le point-vierge para falar sobre essa experiência. Segundo ele, no cerne da realidade de cada pessoa, no centro do ser humano, existe um ponto, intocado pelo pecado e pela ilusão, lugar da "pura glória de Deus

\footnotetext{
${ }^{786}$ Cf. MERTON, Thomas. Signo de Jonas, p. 35

${ }^{787}$ Ibid., p. 377.

${ }^{788}$ Ibid., p. 376.

${ }^{789}$ Ibid., pp. 376-377.

${ }^{790}$ Id., Reflexões de um espectador culpado, p. 181.

${ }^{791}$ Ibid., p.183.
} 
em nós".

Essa experiência retira o véu da ilusão que ainda poderia estar em Merton. Ele toma consciência da necessidade de abrir-se a algo novo e importante: ver e amar a Deus no mundo inteiro, em toda sociedade ${ }^{792}$. Libertando-se de uma diferença ilusória, alegra-se por pertencer à raça humana, em ser homem como os outros homens. Mergulhado nessa experiência ele declara:

Sinto uma imensa alegria em ser homem, membro de uma raça na qual o próprio Deus se encarnou. Como se as dores e a estupidez da condição humana pudessem submergir-me, agora que tenho consciência daquilo que todos nós somos. E se ao menos todos pudessem ter disso consciência! Porém não pode ser explicado. Não há nenhum meio de dizer às pessoas que elas estão todas brilhando como sóis ${ }^{793}$.

No entanto, esta descoberta não foi repentina, estava presente como algo conatural. No seu diário O Signo de Jonas, escrito dez anos antes dessa experiência ele diz:

De fato eu vim ao mosteiro para descobrir o lugar que me corresponde no mundo e, se não consigo encontrar este meu posto no mundo, estarei perdendo o tempo aqui.[...] A vinda ao mosteiro representou para mim o isolamento verdadeiro. Deume perspectiva. Ensinou-me a viver. E agora devo a todos os demais habitantes do mundo viver esta vida. Meu primeiro dever consiste em iniciar pela primeira vez uma vida como membro da raça humana, que não é mais (nem menos) ridícula que eu mesmo. E meu primeiro ato humano há de ser reconhecer o muito que devo aos demais (03 de março de 1951) ${ }^{794}$.

Esta experiência em Louisville marcou a passagem entre seus primeiros livros e sua vida monástica silenciosa, a um intenso contato com o mundo nos seus últimos anos de vida.

Merton se via atraído à solidão e também ao compromisso com as pessoas fora do mosteiro. Sua experiência não lhe sugeria abandonar sua vida monástica, senão que a solidão verdadeira é talvez não presença e assistência, não participação e compromisso, encobrimento e hospitalidade, desaparecimento e chegada. Então começou a criar novos caminhos de contato e diálogo com pessoas fora do mosteiro.

A pedido seu, foi autorizado, antecipando o movimento ecumênico do Papa João XXIII, a manter durante cinco anos encontros quinzenais com pastores e estudantes protestantes e também com estudiosos judeus ${ }^{795}$. Foi o precursor do

\footnotetext{
${ }^{792}$ BERTELLI, Getúlio Antônio. Mística e compaixão: a teologia do seguimento de Jesus em Thomas Merton. São Paulo: Paulinas, 2008. p. 46.

${ }^{793}$ MERTON, Thomas. Reflexões de espectador culpado, p. 182.

${ }^{794}$ Id., O Signo de Jonas, p. 282.

795 SOUZA, Maria Emmanuel e Silva. Thomas Merton: um homem feliz, p. 36-37.
} 
ecumenismo e do macroecumenismo. E de coisas que o Concílio Vaticano II iria explicitar.

Todas as suas atividades já estavam dificultando seu cotidiano no mosteiro. Sempre motivado pelo desejo de silêncio e solidão, em 1965, teve do Abade e do Capitulo Geral da Ordem a licença para ter uma vida de eremita. Passa a morar perto do mosteiro onde todos os dias vai celebrar a missa. Tem uma vida simples e austera ${ }^{796}$.

O eremitério foi, para Merton, mais um lugar para que pudesse melhor conhecer-se e assumir-se com plena consciência. Segundo ele,

a vida solitária, agora eu me confronto com ela, é assustadora, assombrosa, e constato não dispor de resistências em mim para enfrentá-la. Profunda impressão de minha própria pobreza e, acima de tudo, consciência dos erros que permite em mim mesmo, junto com esse desejo positivo. Tudo isso é bom ${ }^{797}$.

O eremitério oferece, então, ao monge, algo de que uma pessoa madura necessita: a oportunidade de explorar um terreno desconhecido para descobri a si mesmo.

o segredo da minha identidade plena está escondido Nele. Só Ele pode tornar-me quem sou, ou melhor, quem serei quando, por fim, começar a ser plenamente. Mas essa obra jamais será realizada se eu não desejar essa identidade e trabalhar para encontrá-la com Ele e Nele ${ }^{798}$.

Passava seu dia meditando, escrevendo, trabalhando no jardim e lendo correspondências que recebia do mundo inteiro. E foi do eremitério, do seu silêncio que ele manteve com o mundo uma frutuosa relação. Estava atento a tudo que acontecia. Sua contemplação e ação são inspiradas no relato bíblico sobre Marta e Maria e no lema beneditino ora et labora, por meio do qual compartilhava com o mundo os seus frutos.

Nenhum dos grandes problemas do mundo deixou de ser abordado por Merton. Ele viveu o grande paradoxo. Liberto do mundo, ele volta a ser seu prisioneiro, no exercício supremo de uma liberdade duramente conquistada. Ele escreve contra as guerras, contra as ditaduras da América Latina e chama a atenção do mundo para as miseráveis condições de vida dos pobres dos países

\footnotetext{
${ }^{796}$ Cf. HART, Patrick; MONTALDO, Jonathan. Merton na intimidade, p. 293.

797 Ibid., p. 290.

${ }^{798}$ MERTON, Thomas. Novas sementes de contemplação, p. 40.
} 
subdesenvolvidos $^{799}$. Em seu eremitério, sua vida contemplativa é mais atuante do que nunca.

O paradoxo vivido por Merton, durante o período no eremitério foi que por um lado era plenamente consciente do valor da solidão para seu crescimento espiritual, mas, por outro, sentia a necessidade de comunicar-se com as outras pessoas. Na medida em que crescia sua experiência de Deus, sentia uma maior responsabilidade pelo bem do outro e de toda a sociedade.

Escrever era a maneira que tinha para poder se comunicar. Foi uma verdadeira missão e vocação que cresceram de sua experiência de Deus. O que o ajudou muito nesta relação com a sociedade foi seu temperamento aberto às novas experiências, sempre atento ao mundo, pois reconhecia ser dom de Deus ${ }^{800}$.

\section{2 "O eu interior: nossa realidade substancial"}

Diante do contexto de sociedade vivido por Merton, ele ressalta que um dos problemas em que vive o ser humano é que ele não está unificado, vive dividido entre numerosos compartimentos distintos, pensamentos, desejos, vontades. Ele diz que antes de se pensar em contemplação "a primeira coisa que se deve fazer é tentar recuperar sua unidade natural fundamental, reintegrar seu ser fragmentado com um todo simples e aprender a viver como uma pessoa humana unificada" ${ }^{801}$. Para que, reunindo os fragmentos de sua existência possa, quando disser "eu", existir alguém perfeitamente definido que responda a esse pronome pessoal.

Encontra-se no ser humano dois "eus" distintos: o "eu exterior", que manipula os objetos para possuir os outros, a Deus e a si mesmo; e o "eu interior", que é uma espontaneidade livre que não se pode enganar, nem manipular, que só aparece quando o homem se encontra com calma e em silêncio. "O eu interior não pode ser seduzido por nada nem ninguém, pois responde somente à atração divina" ${ }^{\prime 802}$.

Merton, então define o que é o "eu interior":

$\mathrm{O}$ eu interior não é parte de nosso ser, é nossa própria realidade substancial em sua totalidade e em seu nível mais pessoal e existencial. É como nossa vida e, de fato, é

\footnotetext{
${ }^{799}$ Cf. HART, Patrick; MONTALDO, Jonathan. Op. cit., p. 246.

${ }^{800}$ MERTON, Thomas. Na liberdade da solidão. Petrópolis. Rio de Janeiro: Vozes, 2001. p. 20.

Título original: Thoughts in solitude, publicado em 1958.

${ }^{801}$ Ibid., p. 7.

${ }^{802}$ Ibid., p. 9.
} 
vida: é nossa vida espiritual em seu máximo, a vida pela qual tudo mais em nós é vivo e se move ${ }^{803}$.

Está claro que o "eu interior" não é algo que devemos temer, é algo que somos, é uma qualidade indefinível do nosso ser, é tão secreto quanto Deus e, como Ele, escapa a todo conceito que pretenda captá-lo completa e totalmente.

Em cada experiência espiritual, seja religiosa, moral ou artística, existe a presença do eu interior, para que se possa alcançar certa profundidade. É somente do eu interior que qualquer experiência espiritual pode adquirir profundidade, realidade e uma certa incomunicabilidade.

Tudo que podemos fazer, por meio de qualquer disciplina espiritual, é produzir em nós mesmos algo do silêncio, da humildade, do desapego, da pureza de coração e impassibilidade, que são elementos necessários para que o eu interior nos dê uma tímida e imprevisível manifestação de sua presença ${ }^{804}$.

O "eu interior" é uma fonte de conhecimento de Deus. O ser humano é imagem de Deus e em seu eu mais interior, como em um espelho, Deus se reflete a si mesmo. Se o ser humano entra no mais profundo de si, primeiro se encontra com seu próprio eu. Quando transcende esse eu, seu verdadeiro eu se encontra com o "eu sou" do Onipotente. O conhecimento de Deus provém dessa experiência. É uma participação sobrenatural em que Deus se revela a si mesmo. Só quando o eu interior desperta, o ser humano torna-se consciente da presença de Deus dentro dele ${ }^{805}$.

Faz-se necessário para a experiência cristã não apenas uma consciência do eu interior, mas também, pela intensificação sobrenatural da fé, uma apreensão exterior de Deus, na medida em que Ele se faz presente em nosso eu interior. Ainda segundo a tradição cristã não é possível encontrar o centro interior e lá conhecer a Deus enquanto se está envolvido com as preocupações e desejos do eu exterior.

É indispensável, para penetrar nas profundezas do ser, a libertação das influências do "eu exterior", de seus impulsos inconscientes das paixões desordenadas. "A liberdade para adentrar o santuário interior de nosso ser é negada àqueles que se detêm pela dependência de autogratificação e satisfação dos sentidos" $"$,

\footnotetext{
${ }^{803}$ MERTON, Thomas. A experiência interior $\mathrm{p} .12$.

${ }^{804}$ Ibid., p. 12.

${ }^{805}$ Cf. Ibid., pp. 19-20.

${ }^{806}$ Ibid., p. 24
} 
Merton cita São João da Cruz, que inclui na "fé" a liberdade para entrar no templo interior. De acordo com São João da Cruz, a fé é a "noite escura" em que encontramos Deus, servindo como meio para a divina união nesta e na outra vida, e como intermediário para o conhecimento de Deus. Indo além da concordância às verdades dogmáticas oriundas da autoridade da revelação divina, a fé é uma aceitação direta e pessoal de Deus ${ }^{807}$.

No final desta jornada de fé e amor, que nos conduz às profundezas de nosso próprio ser e nos libera para que possamos ir além de nós mesmos em direção a Deus, a vida mística culmina em uma experiência de Deus que transcende toda descrição e somente é possível porque a alma foi completamente "transformada em Deus", de modo que se torne, por assim dizer, "um só espírito" com Ele ${ }^{808}$.

É importante para Merton reafirmar que a identidade interior não é recuperada simplesmente por meio do isolamento e da introversão. Embora sejam necessários esses elementos que possibilitarão as condições para o despertar do que é mais interior no ser humano, o eu interior não é um mero vazio ou inconsciência. Tampouco chega o homem ao seu eu interior pela autoafirmação pessoal. Nada pode levá-lo a uma autorrealização pessoal se não é consciente de pertencer a uma coletividade, se não tem consciência de ser um "eu" enfrentando um "tu", que complete e preenche seu próprio $\operatorname{ser}^{809}$.

Ou seja,

o cristão não está simplesmente "só com o Só", no sentido neoplatônico, mas é Um com todos seus "irmãos em Cristo". Seu eu interior é inseparável de Cristo, sendo, portanto, de um modo misterioso e único, inseparável de todos outros "Eus" que vivem em Cristo, de tal forma que todos eles juntos formam uma só "Pessoa Mística", que é Cristo ${ }^{810}$.

O cristão não está só com Deus, senão que é “um” com todos os cristãos em Cristo. Seu eu interior é inseparável de Cristo. Paradoxalmente, o eu interior, o santuário da solidão mais pessoal e individual do ser humano, é o que está mais unido ao "tu" que o ser humano enfrenta, e ao que é mais capaz de compreender desde seu próprio conhecimento, pelo amor no Espírito ${ }^{811}$.

O eu mais profundo, Cristo morando em nós, não pode existir se não existir o "outro" a quem amar. O eu mais profundo não só ama a Deus, mas também aos irmãos, no amor guiado pelo Espírito de Cristo, que busca mais o interesse da

${ }^{807}$ Cf. MERTON, Thomas. A experiência interior, p. 25.

${ }^{808}$ Ibid., p. 27.

${ }^{809}$ Cf. Ibid., pp. 30 e 33.

${ }^{810}$ Ibid., p. 33.

${ }^{811}$ Cf. Ibid., p. 34. 
comunidade do que o interesse da pessoa ou seus prazeres transitórios. A contemplação consegue o despertar de Cristo no ser humano, e instaura o Reino de Deus em seu eu mais íntimo; isto é o despertar do eu interior ${ }^{812}$.

Previne Merton sobre o que chama de o "eu exterior profundo", os níveis mais profundos do "eu" exterior atado ao mundo exterior, que não tem nada a ver com o homem interior, em total liberdade espiritual.

Em vez de mergulharmos nas profundezas de nossa verdadeira liberdade e espiritualidade, simplesmente nos recolhemos aos níveis subterrâneos mais obscuros do eu exterior, o qual permanece alienado e submetido aos poderes pertencentes à ordem exterior ${ }^{813}$.

Também nos previne da barbárie moderna que reduz o indivíduo, em nome da modernidade e da tecnologia, a um sujeito totalmente alienado, que pode chegar a um estado de êxtase político arrastado pelo ódio, o medo e as cruas aspirações políticas, ou pelas falsas religiões. Fatos que podem ser constatados nas pseudorreligiões, considerados por ele como um dos "traços mais perigosos do nosso barbarismo moderno: a invasão da sociedade por uma barbárie que vem de dentro da sociedade e de dentro do próprio homem" ${ }^{\text {,14. }}$.

Ainda sobre as religiões: todas as suas formas sérias e espirituais aspiram a um despertar contemplativo de seus membros. O simbolismo é importante para despertar o eu interior, o culto tem que estabelecer uma conexão entre o rito exterior e o eu interior das pessoas. Porém, hoje parece que os ritos têm perdido sua força, e só são capazes de despertar as emoções inconscientes do eu exterior.

As formas de religião e adoração litúrgica que perderam o impulso inicial do fervor tendem a esquecer cada vez mais seu propósito contemplativo, passando a dar importância exclusiva aos ritos e às formas cerimoniais por si mesmos ou pelo efeito que se espera que causem no Ser adorado ${ }^{815}$.

Essa forma de religião e seus ritos já tinham sido denunciados pelos profetas do Antigo Testamento, e por Jesus contra os fariseus. Para a revivificação do fervor religioso, deve-se cuidar para que seja restaurada a orientação profundamente interior da atividade religiosa, almejando a renovação e a purificação da vida interior suscitada pelos ritos simbólicos, mistérios e preces.

\footnotetext{
${ }^{812}$ Cf. MERTON, Thomas. A experiência interior, p. 36.

${ }^{813}$ Ibid., p. 37 e 39 ,

${ }^{814}$ Ibid., p. 39.

${ }^{815}$ Ibid., p. 38
} 
Ou seja, "é uma questão de livrar-se do formalismo mecânico e compulsivo e de acordar o fervor interior e espontâneo do "coração" ",816.

Não é possível deixar de perceber que, diante da clareza sobre a sua experiência na busca por encontrar o seu "eu interior", Merton tenha se colocado em algum momento distante da tradição cristã, pois, mais uma vez, ele retoma destacando que a contemplação

é a afirmação mais criativa e dinâmica de sua filiação divina. É a confrontação do homem com Deus, do Filho com seu Pai. É o despertar do Cristo dentro de nós, o estabelecimento do Reino de Deus em nossa própria alma, o triunfo da Verdade e da Divina Liberdade no "Eu" mais profundo, no qual o Pai é um com o Filho na unidade do Espírito que é dado ao crente ${ }^{817}$.

Se o cristão não está unificado não poderá falar de unidade entre os cristãos e entre todos os homens. Unidade que não consiste em refutar todos os matizes do protestantismo ou das outras religiões, senão em afirmar a verdade que existe nelas e seguir adiante ${ }^{818}$.

\section{3 "Para um contemplativo toda a vida é contemplação"}

Merton, marcado pela sociedade do seu tempo, afirma que o ser humano vive uma ilusão de onipotência, uma ilusão que a coletividade se apressa em compartilhar, um sistema que provoca o ser humano a desejar o que a sociedade impõe. No entanto, a verdadeira necessidade é “termos que estar só, e sermos nós mesmos, e recordar aos outros a verdade que existe neles" ${ }^{\text {} 819}$.

O reconhecimento do valor da vida contemplativa para o ser humano moderno tem sua importância no que diz respeito ao seu ideal mais valioso, que segundo Merton, parte da necessidade que o mesmo tem de encontrar sua emancipação e liberdade. Para ele,

Hoje, mais do que nunca, o homem busca sua emancipação e liberdade.[...] Porém a liberdade é algo espiritual. É uma realidade sagrada e religiosa. Suas raízes não se fundam no homem, senão em Deus. Porque a liberdade do homem, que o torna imagem de Deus, é uma participação na liberdade de Deus. O homem é livre à medida que se assemelha a Deus. Sua luta pela liberdade implica, pois, em uma luta por renunciar uma autonomia falsa e enganosa, a fim de fazer-se livre para

\footnotetext{
${ }^{816}$ MERTON, Thomas. A experiência interior, p. 41. Em geral, o coração é usado como um símbolo mais ou menos adequado do eu interior, embora o Antigo Testamento se utilize de outros órgãos físicos com a mesma finalidade, como as vísceras e os rins.

${ }^{817}$ Ibid., p. 50

${ }^{818}$ Cf. Id., Reflexões de um espectador culpado, p. 166.

${ }^{819}$ Id., Incursiones en lo Indecible, Sal da Terrae: Santander, 2004. pp. 25 e 31.
} 
além e de si mesmo ${ }^{820}$.

Ou seja, para que o ser humano seja livre, deve estar livre de si mesmo. Quem é escravo dos seus próprios desejos, necessariamente, explora o seu próximo, a fim de render tributos ao tirano que habita em seu interior, por ser escravo dos seus desejos. O ser humano deve aprender a encontrar o caminho para a liberdade em seu interior ${ }^{821}$.

O percurso desenvolvido por Merton para encontrar esse caminho segue em direção à busca do silêncio, chegando à contemplação. E foi durante muito tempo de sua vida adulta, procurando viver esse silêncio, que ele desejou entender o que significava contemplação. Um dos seus primeiros livros teve como título: $O$ que é contemplação ${ }^{822}$. Onze anos depois, ainda se sentido incomodado com essa questão, reescreve esse livro, agora como um novo título: A experiência interior. Em sua revisão deixa claro o que, para ele, depois de uma década, significava contemplação. “Como eu estava enganado ao fazer da contemplação uma simples parte da vida humana. Para um contemplativo, toda sua vida é contemplação" ${ }^{~} 823$.

A contemplação não é um mero compartimento da existência, mas sim a via por excelência para que a pessoa possa integrar os diversos aspectos de sua vida de modo que faça desta um todo coerente.

A clareza que Merton tem sobre a contemplação definirá sua experiência interior. Esta reedição apresenta, segundo o autor, "uma visão mais ampla e mais profunda sobre a mesma coisa, a contemplação, com mais referências às ideias orientais. Para mim, isso é tudo que importa, mas todas as coisas aí estão contidas" $\$ 24$. Ele denuncia o perigo de viver dividido, em compartimentos diferentes. E acredita que "as tradições orientais têm a vantagem de dispor o homem mais naturalmente para a contemplação" "825.

Para Merton o que pode escravizar o "eu" são o autoengano e o apego apaixonado pelas coisas. Em vários dos seus escritos falou sobre esse tema. Ele

\footnotetext{
${ }^{820}$ MERTON, Thomas. La experiencia interna. Notas sobre la contemplación, em Cistercium 212 (1998), p. 97.

${ }^{821}$ Cf. Ibid., p. 970.

${ }^{822}$ Cf. Ibid., p. VII.

${ }^{823}$ Ibid., p. 223.

${ }^{824}$ Ibid., p. X

${ }^{825}$ Ibid., p. 7.
} 
afirma que, "para experimentar a si mesmo, não tem que suprimir a consciência de sua contingência, sua irrealidade, sua situação de carência radical" ${ }^{\prime 26}$.

Existe uma sutil, porém inevitável conexão entre a atitude "sagrada" e a aceitação de nosso eu mais íntimo. O movimento de reconhecimento que aceita nosso próprio eu obscuro e desconhecido, produz a sensação de uma presença “numinosa" em nosso interior. Este temor sagrado é a verdadeira expressão de uma libertação de energia espiritual que é o melhor testemunho de nossa união e reconciliação interna com o mais profundo de nosso ser, através do eu interno, com o poder transcendente e invisível de Deus. Isto supõe humildade ou a plena aceitação de tudo que tendíamos a rejeitar e ignorar em nós mesmos ${ }^{827}$.

A necessidade de reintegrar o eu interior, realidade substancial em sua totalidade do ser humano, em seu nível mais pessoal e existencial, consiste em reconhecer que o verdadeiro "eu" é simplesmente o que realmente somos e nada mais. Para usar termos cristãos, é o nosso eu tal como é visto por Deus, é o eu em toda a sua unicidade, dignidade, simplicidade e inefável grandeza: a grandeza que recebemos de Deus nosso Pai, que temos em comum com Ele justamente porque Ele é nosso Pai, e "nele vivemos, nos movemos e existimos" (Atos 17,28) ${ }^{828}$.

Segundo a tradição da mística cristã, para encontrar o próprio centro interior e lá conhecer a Deus, faz-se necessário afastar-se das preocupações e desejos do eu exterior. Sendo nosso "eu" mais profundo a perfeita imagem de Deus, quando desperta, encontra-se na presença daquele de quem é imagem. Para despertar o eu interior, é preciso aprender o quão inteiramente novo é o relacionamento e como ele nos dá uma visão completamente diferente das coisas ${ }^{829}$.

A descoberta do eu interior, como vimos, é bastante familiar na mística cristã. Merton lembra, no entanto, que no zen parece não haver esforços para ir além do eu interior, enquanto no cristianismo, o eu interior é apenas um degrau para alcançar a consciência de Deus. "O homem é a imagem de Deus e o eu interior é uma espécie de espelho no qual se vê refletido e ao qual se revela" ${ }^{\# 30}$. Ou seja, nosso interior comunica-se diretamente com o ser de Deus, que está em nós.

\footnotetext{
${ }_{826}^{827}$ MERTON, Thomas. Incursiones en lo Indecible, pp. 25 e 31.

${ }^{827}$ Cf. Id., A experiência interior, p.75.

${ }^{828}$ Cf. Id., p. 19.

${ }^{829}$ Cf. Ibid., pp. 24-30.

${ }^{830}$ Cf. Ibid., p. 19.
} 
As especulações de Santo Agostinho revelam um clima experiencial bastante diferente do que foi apresentado no zen. É difícil encaixar nessa experiência o "eu" mais profundo apresentado por Santo Agostinho.

Há sempre a possibilidade de um oriental, ao descrever o "Eu", estar descrevendo o que o místico ocidental descreve como Deus, pois a união mística da alma com Deus os torna (ainda que metafisicamente distintos) "indivisos" na experiência espiritual. E o fato de o místico oriental, não condicionado por séculos de debates teológicos, não estar inclinado a refletir analiticamente em sutilezas de distinção metafísica, não significa necessariamente ele não tenha experimentado a presença de Deus ao falar do seu conhecimento do Eu mais Profundo ${ }^{831}$.

Na experiência de contemplação que pode viver, o cristão descobre que não existe uma "coisa" nem um "quê", mas um puro "QUEM", Deus. Ele é o "TU" diante do qual o mais íntimo de nosso "eu" desperta e é movido a uma tomada de consciência. Ele é o "EU SOU” diante do qual nós, com nossa própria e inalienável voz pessoal, lhe fazemos eco: "eu sou"

Mas o que significa para Merton a contemplação? Primeiro, ele nos chama a atenção para o fato de não ser mencionada no Novo Testamento a palavra contemplação e deixa claro que a sua existência está nos "ensinamentos de Cristo que é essencialmente "contemplativo", no sentido mais elevado, mais prático e menos esotérico que o de Platão" ${ }^{\text {833. }}$.

E a partir da experiência e dos ensinamentos de Jesus Cristo, contemplação na tradição cristã

é simplesmente a "experiência" (ou melhor, o conhecimento quase-experiencial) de Deus em uma treva luminosa que é a perfeição da fé iluminando nosso eu mais profundo. É o "encontro" do espírito com Deus em uma comunhão de amor e entendimento que é um dom do Espírito Santo e uma penetração no mistério de Cristo $^{834}$.

Ele continua reafirmando que:

De fato, a contemplação é a atividade espiritual mais elevada e mais essencial ao homem. É a afirmação mais criativa e dinâmica de sua filiação divina. Não é simplesmente o suave e repousante abraço do "ser" em um contentamento difuso e obscuro: é a faísca do relâmpago divino rompendo as trevas do nada e do pecado. Não é algo geral e abstrato; ao contrário, é o mais concreto, particular e "existencial" que é possível. É a confrontação do homem com Deus, do Filho com seu Pai. É o despertar do Cristo dentro de nós, o estabelecimento do Reino de Deus em nossa própria alma, o triunfo da Verdade e da Divina Liberdade no "Eu" mais

\footnotetext{
831 MERTON, Thomas. Experiência interior, pp. 21-22.

${ }^{832}$ Cf. Id., Novas sementes de contemplação, p. 21.

${ }^{833}$ Id., Experiência interior, p. 49.

${ }^{834}$ Id., Novas sementes de contemplação, p. 50.
} 
profundo, no qual o Pai é um com o Filho na unidade do Espírito que é dado ao crente $^{835}$.

A palavra contemplação pode nos sugerir repouso, intemporalidade, ou mesmo uma espécie de passividade. Esses elementos podem ser encontrados nessa experiência. No entanto, o mais importante é a consciência, a vida, a criatividade e a liberdade, tornando essa experiência, como já foi dito, a mais importante e essencial atividade espiritual do ser humano.

A experiência contemplativa que viveu Merton, no mergulho profundo nas fontes do cristianismo, afirma em poucas palavras que "a contemplação é a consciência e a compreensão, e mesmo, em certo sentido, a experiência daquilo que cada cristão crê obscuramente: "Agora não sou mais eu quem vive; é Cristo quem vive em mim" ${ }^{836}$. Segundo São Paulo, o eu mais íntimo de nosso ser é nosso "espírito" ou "pneuma", ou em outras palavras, o Espírito de Cristo, até mesmo Cristo morando em nós. E através do reconhecimento espiritual de Cristo em nosso irmão, nos fazemos um em Cristo, mediante o Espírito Santo.

Merton sentiu-se interrogado sobre a relação que tem a ressurreição de Jesus com a contemplação. Segundo ele:

a ressurreição e ascensão de Cristo, Novo Adão, restituíram completamente à natureza humana sua condição espiritual, tornando possível a divinização de todo homem que vem a este mundo. Isso quer dizer que, em cada um de nós, o eu interior tornou-se agora capaz de ser despertado e transformado pela ação do Espírito Santo, sendo que esse despertar não apenas nos permite descobrir nossa verdadeira identidade "em Cristo", como também torna vivamente presente em nós o Salvador ressuscitado. Daí a importância da divindade de Cristo - pois é como Deus-Homem que Ele ressurgiu dos mortos e é como Deus-Homem que ele é capaz de viver e agir em todos nós por Seu Espírito, de modo que, n’Ele, somos não apenas nosso verdadeiro eu, mas também uma só Pessoa Mística, um só Cristo. Cada um de nós é capaz de, em certo sentido, ser completamente transformado à semelhança de Cristo e de se tornar, com Ele, divinamente humano, participando assim de Sua autoridade espiritual e de Seu poder carismático neste mundo ${ }^{837}$.

No entanto, a contemplação está além das verdades abstratas sobre Deus, e da meditação das coisas em que cremos. A contemplação é um despertar, uma iluminação e apreensão espantosa, com que o amor se certifica da intervenção criadora e dinâmica de Deus em nossa vida cotidiana.

Segundo Merton, “a percepção de que a revelação do mistério de Deus e Homem no Cristo, Corpo Místico, não é algo que devemos esperar passivamente,

\footnotetext{
${ }^{835}$ MERTON, Thomas. A experiência interior, p. 50.

${ }^{836}$ Ibid., p. 12.

${ }^{837}$ Ibid., p. 55.
} 
mas algo que somos chamados a produzir pela ação de nossa liberdade criativa" ${ }^{838}$.

Fica cada vez mais claro que a autorrealização cristã não pode ser apenas uma mera afirmação individualista da própria personalidade. O "eu" interior é o santuário de nossa solidão mais pessoal e individual, no entanto, paradoxalmente, o que é mais solitário em nós se une ao "Tu" frente ao "nós"

Não é possível negar que a experiência de descoberta de Cristo, em seu mais profundo interior, tenha marcado toda vida de contemplativo de Merton, ou melhor, dizendo, sua experiência de contemplação parte do princípio de que

o Cristianismo é a vida e a sabedoria em Cristo. É um retorno ao Pai em Cristo. É um retorno ao abismo infinito de pura realidade em que nosso próprio ser está fundado, e no qual existimos; um retorno à fonte de todo sentido e de toda verdade; um retorno ao manancial interior de vida e felicidade. É a redescoberta do paraíso em nosso próprio espírito por meio do abandono de si mesmo. E, por causa de nossa unidade com Cristo, é o reconhecimento de nós mesmos como filhos do Pai; é, ainda, nosso reconhecimento de nós mesmos como outros Cristos; e é o reconhecimento da força e do amor a nós comunicados pelo Indizível, pelo Oculto, a quem chamamos Espírito Santo ${ }^{840}$.

Se a natureza humana é assumida em Cristo e passa a pertencer à pessoa do Verbo de Deus, então tudo que é humano em Cristo, torna-se divino. O ser humano, que vive e age segundo a graça de Cristo que nele habita, age, nesse caso, como outro Cristo, como um filho de Deus, prolongando, assim, os efeitos e o milagre da encarnação.

Ou seja, em Jesus Cristo estava de forma inseparável sua existência humana e divina. A ordem natural não foi simplesmente imposta de fora à natureza criada. A própria natureza criada foi, no ser humano, transformada e sobrenaturalizada de modo que, o abismo que separa o homem de Deus foi transposto pela encarnação e, no ser humano, esse mesmo abismo é transposto pela presença invisível do Espírito Santo ${ }^{841}$. Cristo está realmente presente no ser humano, tornando-os "outros Cristos"

No entanto, essa vida divina permanece oculta no ser humano, até que seja desenvolvida por uma experiência de ascetismo e caridade, no nível mais profundo, de contemplação. Lembremos que, para a contemplação, é necessário o

\footnotetext{
${ }^{838}$ MERTON, Thomas. A experiência interior, p. 215.

${ }^{839}$ Cf. Ibid., p. 34.

${ }^{840}$ Ibid., p. 53.

${ }^{841}$ Ibid., p. 57

${ }^{842}$ Ibid., p. 59.
} 
homem interior despertar para a vida ao entrar em contato espiritual com Deus pela fé. Em uma profunda participação na vida de Cristo ${ }^{843}$.

Sobre a contemplação, Merton é bastante enfático quando afirma: "Tenho repetido que a contemplação é real. Tenho, além disso, insistido em sua simplicidade, sobriedade e humildade, bem como em sua integração em uma vida cristã normal" ${ }^{, 844}$.

Como cristão, o contemplativo deverá estar atento às necessidades dos outros, o que não significará uma complacência moral. Para Merton, que esteve sempre atento aos desafios e necessidades de um tempo, marcado pela indiferença, abandono e guerras, está claro que:

De que nos serve celebrar seminários sobre a doutrina do corpo místico e a sagrada liturgia, se não nos preocupamos em absoluto com o sofrimento, a indigência, a enfermidade e até a morte de milhões de potenciais membros de Cristo? Podemos imaginar que toda pobreza e sofrimento estão alheios ao nosso país; porém se conhecêssemos e entendêssemos nossas obrigações com respeito à África, ao Sul da América e Ásia, não seríamos tão complacentes. E, todavia, não temos que olhar além de nossa fronteira para descobrirmos enormes doses de miséria humana nos subúrbios de nossas grandes cidades e nas zonas rurais menos privilegiadas. $\mathrm{O}$ que fazemos a respeito? Não basta colocar as mãos nos bolsos e tirar algumas moedas. $\mathrm{O}$ que temos que dar aos nossos irmãos não são unicamente nossos bens, senão a nós mesmos. Enquanto não recuperarmos o profundo sentido da caridade, não poderemos compreender toda profundidade da perfeição cristã ${ }^{845}$.

Significa que um autêntico cristão deve estar sempre atento às necessidades do ser humano, em qualquer parte do mundo. Todos estão obrigados a tomar parte ativa na solução de problemas urgentes que afetam globalmente sua sociedade e o seu mundo. A clareza de Merton quanto à atitude de um contemplativo não deixa dúvidas: "a contemplação não vira as costas para a realidade nem foge desta, mas vê através do ser superficial e vai além deste. Isso implica uma plena aceitação das coisas como elas são, além de uma sã avaliação destas" ${ }^{\text {} 846}$.

Ou seja, o verdadeiro contemplativo não está menos interessado na vida normal do que os outros, não está menos atento ao que acontece no mundo. Está, ao contrário, mais interessado, mais atento. $\mathrm{O}$ fato de ser um contemplativo o torna capaz de um interesse maior e de uma atenção mais profunda. É capaz de

\footnotetext{
${ }^{843}$ Cf. MERTON, Thomas. A experiência interior, p. 63.

${ }^{844}$ Ibid., p. 166.

${ }^{845}$ Id., Vida y santidad. Sal Terrae: Santander, 2006. pp. 60-61.

${ }^{846} I d$., A experiência interior, p. 160.
} 
enxergar mais claramente e entrar mais diretamente na pura realidade da vida humana ${ }^{847}$.

Diante das ilusões que muitos sustentam sobre a contemplação, Merton faz um alerta para que ninguém se iluda com as aspirações contemplativas se não está determinado a assumir os labores e as obrigações comuns da vida normal.

Pode haver muita desolação e sofrimento no espírito do contemplativo, mas há sempre mais alegria que tristeza, mais segurança que dúvida, mais paz que desolação. O contemplativo é aquele que encontrou aquilo que todos os homens buscam de um modo ou de outro ${ }^{848}$.

Sobre a extensão da vocação contemplativa, permanece o fato de que há algo comum em todas as religiões, chamadas por ele de superiores. Segundo ele, em toda parte, seja no cristianismo ou no budismo, no hinduísmo ou no islã, encontramos exemplos de vida contemplativa, ao menos no sentido amplo.

Em toda parte, encontramos ao menos uma aspiração natural pela união interior e comunhão intuitiva com o Absoluto. Além disso, em todo lugar, encontramos expressões de alguma espécie de experiência espiritual, geralmente natural, às vezes sobrenatural. A experiência mística sobrenatural é, ao menos teoricamente, possível em qualquer lugar sob o sol, para qualquer homem de boa consciência que busque a verdade e corresponda às inspirações da graça divina ${ }^{849}$.

A vida contemplativa é uma vida de unidade. O contemplativo pode transcender a divisão e alcançar a unidade, recolhendo-se em si mesmo para encontrar o centro interior de atividade espiritual. E, em um sentido estrito, a contemplação é a intuição imediata e, em certo sentido, passiva da realidade interior, de nosso eu espiritual e de Deus presente dentro do ser humano. Ele nos apresenta alguns tipos de contemplação, como veremos em seguida:

1. Contemplação ativa ou imediata se realiza com a cooperação da pessoa: In nobis et non sine nobis. Ela se nutre da meditação, da leitura, da vida sacramental e da liturgia da Igreja ${ }^{850}$.

2. A união com Deus na atividade diz respeito a muitos cristãos que, apesar de nunca entrarem na vida contemplativa, não são estranhos às graças oriundas da contemplação. Embora sejam trabalhadores ativos, são também contemplativos ocultos. Uma espécie de contemplação "disfarçada" 851 .

${ }^{847}$ MERTON, Thomas. A experiência interior, p. 213.

${ }^{848}$ Ibid., p. 168.

${ }^{849}$ Ibid., p. 167.

${ }^{850}$ Cf. Ibid., pp. 82 e 84.

${ }^{851}$ Cf. Ibid., p. 92. 
3. Contemplação infusa refere-se a uma realidade que não é direta ou empiricamente verificável, mas é um dado da revelação ${ }^{852}$.

4. Contemplação natural e teologia mística. Merton presume a existência de uma intuição suprassensorial do divino, dom da graça para o qual se pode preparar-se com seus próprios esforços. Ele se baseia em uma distinção feita pelos padres gregos: a distinção entre contemplação natural (theoría physiké) e teologia (theología) ou contemplação de Deus ${ }^{853}$.

O contemplativo deve aceitar com humildade, sem inferir coisa alguma e sem estabelecer nenhuma comparação com outras experiências. Apenas caminhar na presença de Deus. Quando aceita de maneira correta, a experiência contemplativa tem seu efeito próprio: torna mais intenso e mais simples o amor a Deus e ao próximo ${ }^{854}$. Merton destaca a união com Deus diante das atividades cotidianas. Ou seja, apesar de não estarem na vida contemplativa, não estão longe das graças da contemplação. Sendo trabalhadores ativos, são também contemplativos ocultos.

O que para Merton pode sinalizar que houve uma contemplação? Para ele, é necessário que haja alguma percepção da contemplação. E se não há nenhuma percepção, então não há contemplação ${ }^{855}$.

Da experiência contemplativa em seus diversos graus, podemos ver que todas as formas de contemplação autêntica têm algo em comum. Associadas ou não ao nosso próprio esforço, todas as formas de contemplação convergem para um contato experimental e misterioso com Deus, além dos sentidos e, de algum modo, além dos conceitos ${ }^{856}$.

Merton, assim, resume os elementos essenciais da contemplação:

1. É uma intuição que, em seus graus mais baixos, já transcende os sentidos; e, em seus graus mais elevados, transcende a própria inteligência.

2. É caracterizada por uma qualidade de luz nas trevas, um saber no não-saber. Está além do sentimento e até mesmo dos conceitos.

3. A contemplação é obra do amor e o contemplativo prova seu amor ao abandonar todas as coisas, mesmo as mais espirituais, por Deus, no

\footnotetext{
${ }^{852}$ Cf. MERTON, Thomas. A experiência interior, p. 81.

${ }^{853}$ Cf. Ibid., p. 96.

${ }^{854}$ Cf. Ibid., p. 85.

${ }^{855}$ Cf. Ibid., p. 92.

${ }^{856}$ Cf. Ibid., pp.102-103.
} 
aniquilamento, no desapego e na "noite". O fator decisivo na contemplação é a livre e imprevisível ação de Deus.

4. A contemplação é um amor e um conhecimento sobrenatural de Deus. Simples e obscuro, infundido por ele no ápice da alma, dando a esta um contato direto e experimental com ele.

5. A experiência da oração contemplativa e os sucessivos estados de contemplação pelos quais se passa são fenômenos modificados pelo fato de a alma ser passiva, ou parcialmente passiva, sob a orientação de Deus.

6. A contemplação é a luz de Deus, lançando-se diretamente sobre a alma. Toda alma, entretanto, está enfraquecida e ofuscada pelo apego às coisas criadas, as quais ama desordenadamente, por causa do pecado original.

7. A contemplação infusa é, cedo ou tarde, acompanhada por uma terrível revolução interior. A alma é tentada a pensar que tudo acabou e que, em punição por suas infidelidades, toda vida espiritual chegou ao fim.

8. Pode-se dizer, sem dúvida alguma, que as inspirações do Espírito Santo estão muitas vezes em completo desacordo com as normas tradicionais e salutares das sociedades religiosas ${ }^{857}$.

Diante dos elementos essenciais da contemplação apresentados, Merton ainda destaca que, embora a essência de Deus não possa ser adequadamente apreendida, podemos alcançá-lo diretamente pelo amor, pelo amor, nós "o alcançamos e dele nos aproximamos. E quando o amor o alcança, estamos satisfeitos. O conhecimento de nada importa, pois o conhecemos pelo amor" ${ }^{, 858}$. Para o Mestre Eckhart, segundo Merton, existe uma centelha mística, ou centro da alma, ponto de contato com Deus, algo vivo e dinâmico que faz Deus viver na alma e a alma em Deus. É o nosso eu mais profundo, a vida espiritual da alma em Deus $^{859}$.

Não é possível imaginação nem metáfora capaz de transmitir o que significa experiência contemplativa na alma de alguém.

A contemplação tem, definitivamente, um elemento positivo, dinâmico, vivente, criativo e transformador. É uma espécie de revolução interior que inexplicavelmente tira a alma de sua rotina normal de pensamento e desejo,

\footnotetext{
${ }^{857}$ Cf. MERTON, Thomas. A experiência interior, pp. 104-111.

${ }^{858}$ Ibid., p. 121.

${ }^{859}$ Cf. Ibid., p. 122.
} 
fazendo-a buscar o que não pode ser pensado e alcançar o que está além de todo $\operatorname{desejo}^{860}$.

Merton faz alguns alertas sobre a contemplação. Sobre a heresia do quietismo, ele nos diz que ela fecha o homem em si mesmo, em uma solidão completamente egoísta, que exclui tanto os outros homens quanto o próprio Deus. O quietismo, embora guarde certa semelhança superficial com a contemplação cristã, é, na verdade, sua mais completa contradição. Enquanto a contemplação cristã é a perfeição do amor, o quietismo é exclusão de todo amor e a quintessência do egoísmo ${ }^{861}$. Sobre o inspiracionismo vai nos dizer que na contemplação o que importa não é o que se sente, mas o que acontece além do plano do sentido ou da experiência. Ou seja,

a experiência, a visão, a intuição são apenas um sinal e além disso, passíveis de ser dissociadas de qualquer realidade, tornando-se meras figuras vazias. O inspiracionista é aquele que se apega ao sinal, à experiência, sem consideração pela substância invisível de um contato que transcende toda experiência ${ }^{862}$.

No entanto,

Isso não quer dizer que uma experiência produzida pelo uso de uma droga não possa ser associada a algo de sobrenatural. Deus é o senhor de Seus dons e os pode conceder como lhe aprouver. O ponto, porém, é que o perigo de engano é, nesse caso, muito grande. Por isso, estou inclinado a dizer, como opinião pessoal, que o perigo mais grave enfrentado pelo contemplativo hoje é essa enganadora tentação do inspiracionismo. Só posso encarar com maior receio a falsificação e corrupção da religião mística que podem surgir do abuso de tais métodos perigosos ${ }^{863}$.

A vida contemplativa é fundamentalmente uma vida de unidade, solidão, verdade e comunhão. O contemplativo é aquele que transcende as divisões para alcançar uma unidade por cima de qualquer divisão.

\subsection{A viagem ao Oriente: “...dela tirar proveito, aprender, mudar”.}

Persistia em Merton, mesmo vivendo em seu eremitério, o desejo do silêncio e da contemplação. As muitas preocupações o incomodavam e, assim, desabafou no seu diário: "Na realidade não estou vivendo como eremita. Vejo

\footnotetext{
${ }^{860}$ MERTON, Thomas. A experiência interior, p. 124.

${ }^{861}$ Cf. Ibid., pp. 147-146.

${ }^{862}$ Ibid., p. 157.

${ }^{863}$ Ibid.
} 
gente demais, tenho muito trabalho ativo a fazer, o lugar é por demais barulhento e acessível" ${ }^{864}$.

Toda sua angústia o fazia procurar nas leituras sobre a mística oriental uma nova maneira de reencontrar seu caminho, porque nela muito o impressionava a busca da contemplação e a ideia de solidão como parte da clarificação que inclui viver para os outros, a dissolução do ego ao 'pertencer a todos' por considerar como seus os sofrimentos alheios ${ }^{865}$.

Quando leu um livro sobre o budismo que falava da meditação, fez o seguinte comentário:

Um dos livros mais belos que já li. Dá-me uma visão toda nova (velha) de minha própria vida. Tudo se afina à perfeição com meu tom. Profundamente comovedor em todos os sentidos. Raras vezes encontrei um livro ao qual eu reagisse tão totalmente $\operatorname{assim}^{866}$.

Esta não foi sua primeira leitura sobre o budismo ou sobre as místicas orientais. Nutria ele um grande interesse por estas leituras desde sua juventude. E os reflexos destas estavam em sua busca pela essência da contemplação e solidão. "Vejo a importância e real seriedade do que se refere à disciplina meditativa e aprofundamento - não apenas silêncio e privacidade (que nem sempre, aliás, eu tenho)" 867.

O monaquismo oriental, a sabedoria, o oriente e seu pendor para valorizar o invisível, o absoluto, cada vez mais o atraíam para um estudo aprofundado que traria para o cristianismo ocidental novas riquezas por vezes esquecidas ou postas de lado.

Merton quis encontrar-se com a solidão e deixar que tudo acontecesse de maneira silenciosa e invisível. Em um convite que recebeu par a participar de um Congresso Ecumênico, organizado pelos beneditinos em Bancoc, na Tailândia, percebeu que era a sua chance de estabelecer contatos com monges e dirigentes budistas. Era também a oportunidade para reencontrar seu caminho, e assim escreveu em seu diário:

Vou com a mente de todo aberta. Sem ilusões especiais, espero. Minha esperança é simplesmente desfrutar da longa viagem, dela tirar proveito, aprender, mudar. Talvez encontrar alguma coisa ou alguém que me ajude a avançar em minha própria busca espiritual... Não estou partindo com um plano concreto de nunca

\footnotetext{
${ }^{864}$ HART, Patrick e MONTALDO, Jonathan. Merton na intimidade, p. 370.

${ }^{865}$ Cf. Ibid., pp. 382-383.

866 Ibid., p. 380.

${ }^{867}$ Ibid., p. 381.
} 
retornar, nem com a absoluta determinação de retornar a todo custo. Sinto que aqui não há muito pra mim no momento e que preciso me abrir para o monte de novas possibilidades. Como fazê-lo! Mas continuo a ser monge de Gethsemani. Se terminarei ou não aqui meus dias, não sei. Talvez isso não seja tão importante. A grande coisa é corresponder perfeitamente à Vontade de Deus nessa ocasião providencial, seja o que for que ele traga ${ }^{868}$.

Com a aprovação deste convite, recebe mais outros de diversos mosteiros de sua ordem, na Indonésia, para pregar retiros. Sua viagem para a Ásia é preparada com grande ânimo. Ele inclui visitas a mosteiros budistas e conversas com líderes $\operatorname{religiosos}^{869}$.

Antes de partir em viagem, Merton escreve uma carta aos amigos, em setembro de 1968. Nessa carta, ele explica que não poderá receber suas correspondências e que não sabe por quanto tempo ficará ausente, assim ele escreve:

Considerando a importância crucial dos tempos, a necessidade da renovação monástica, o isolamento de nossos mosteiros na Ásia e seus constantes apelos, sinto-me no dever de corresponder. E espero que isso me permita entrar em contato com a vida monacal budista e conhecer em primeira mão alguma coisa sobre ela ${ }^{870}$.

Mesmo sendo seu maior interesse o contato com asiáticos, ele também aproveitará sua viagem para encontrar um lugar para um melhor isolamento. $\mathrm{O}$ seu Abade lhe havia sugerido procurar um lugar mais isolado para viver depois que voltasse de sua viagem. Havia a possibilidade de utilizar tal lugar, também para outros monges de Gethsemani ${ }^{871}$.

No entanto, em seu diário, no final de dezembro, revelou sua determinação em permanecer monge de Gethsemani:

Não creio que me deva separar completamente de Gethsemani, mesmo que só mantenha lá a minha residência oficial, legalmente. Creio que devo acabar os meus dias lá. Sinto falta dali de muitas maneiras. Não existe o problema de eu querer sair de Gethsemani; é o meu mosteiro e o fato de estar longe dele ajudou-me a vê-lo em perspectiva e amá-lo ainda mais ${ }^{872}$.

Em outra carta, escrita no dia 09 de novembro aos seus amigos, contandolhes suas experiências na viagem, deixa transparecer sua alegria por causa dos

\footnotetext{
${ }^{868}$ HART, Patrick e MONTALDO, Jonathan. Merton na intimidade, p. 386.

${ }^{869}$ Cf. MERTON, Thomas. Diário da Ásia, p. XXVI.

${ }^{870}$ Carta circular aos amigos, em setembro de 1968. In. MERTON, Thomas. Diário da Ásia, pp. 231.

${ }_{871}$ Cf. Ibid., p. XXIX.

${ }^{872}$ Ibid., pp. 114-115.
} 
novos contatos e por estar, a partir das experiências na Ásia, mergulhando na sua própria fé.

Espero poder levar para o meu mosteiro alguma coisa da sabedoria asiática, com a qual tenho a sorte de estar em contato - mas coisa muito difícil de expressar em palavras. Desejo a todos a paz e alegria no Senhor e um crescimento na fé; pois nos meus contatos com estes novos amigos também eu sinto consolação na minha própria fé em Cristo e na Sua presença que me envolve ${ }^{873}$.

Merton vai desenvolvendo a certeza de que deveria permanecer no seu mosteiro, no entanto, a procura por um maior isolamento foi, sem dúvida, um tema recorrente em seus diários. Sua procura o fez descobrir que o cerne desta questão se encontrava em um nível mais profundo:

Nossa verdadeira viagem na vida é interior; é uma questão de crescimento, de aprofundamento e de entrega sempre maior à ação criadora do amor e da graça em nossos corações. Nunca foi tão necessário para nós correspondermos a essa ação ${ }^{874}$.

No momento da decolagem, indo para o oriente, ele revelou em seu diário:

Eu com mantras cristãos e profundo sentido de destino, de estar enfim no meu verdadeiro caminho depois de anos de espera, inquirição e perambular. Que eu não volte sem resolver a grande questão. E sem ter encontrado também mahakaruna, a grande compaixão ${ }^{875}$.

Sua peregrinação à Ásia foi também uma peregrinação para dentro de si, na constante busca por aprofundar seu compromisso religioso e monástico. Sua primeira parada na Ásia é em Calcutá, onde deverá falar para monges de várias ordens católicas. Em seu discurso, ele escreveu, deixando claro o motivo de sua viagem:

Falo como um monge do ocidente que está interessado eminentemente em sua própria vocação e dedicação monástica. Deixei meu mosteiro e vim até aqui não só na qualidade de um estudioso pesquisador, ou mesmo como escritor (que também me acontece ser); venho como um peregrino que está ansioso para obter não só informações, não somente fatos sobre outras tradições monásticas, mas para beber em antigas fontes de visão e de experiência monásticas. Não só procuro aprender mais (quantitativamente), sobre religião e vida monástica, mas também me tornar um monge melhor e mais iluminado (qualitativamente) ${ }^{876}$.

Em sua palestra sobre Vida Monacal, pronunciada informalmente ${ }^{877}$ ele fala sobre a crise que enfrenta o monasticismo, no ocidente. E convida os monges do oriente a se manterem fiéis às suas antigas tradições, a não terem receio dessa

\footnotetext{
${ }^{873}$ MERTON, Thomas. Diário da Ásia, p. 254.

${ }^{874}$ Ibid., p. 232.

${ }^{875}$ Ibid., p. 3.

${ }^{876}$ Ibid., p. 246.

${ }^{877}$ Merton havia preparado um texpo para essa palestra, no entanto preferiu fazê-la informalmente. Cf. Ibid., pp. 243-249.
} 
fidelidade. Ele gosta muito da ideia de que outros encontros como esses serão possíveis de fazer, no entanto, "deixando claro que esses deverão ser no nível da experiência. E que não sejam apenas entre instituições monásticas, mas entre pessoas que estão buscando. A condição básica disso é que cada qual permaneça fiel à sua própria busca”. E continua, finalizando sua palestra:

E entre essas pessoas, - se elas são fiéis ao seu chamado, à sua própria vocação, à mensagem que lhes vem de Deus, - a comunicação é possível em nível mais profundo. E o nível mais profundo de comunicação não é comunicação, é comunhão. Sem palavras. Além das palavras. Além do poder da palavra, além do conceito. Não se descobre uma nova unidade; descobre-se uma unidade antiga. Caros irmãos, nós já somos um; apenas, imaginamos não o ser. O que nos é preciso é recuperar a nossa unidade original. Temos de ser o que já somos ${ }^{878}$.

Lembra aos participantes que "em todas as grandes religiões do mundo há alguns indivíduos e comunidades que se consagram de maneira especial a levar até o fim todas as consequências e implicações de sua fé" ${ }^{879}$. Ele destaca as várias formas de vida monástica, sua disciplina e distinção entre os tipos de consagração. Segundo ele,

há uma real possibilidade de contato em nível profundo entre essa tradição monástica contemplativa ocidental e as várias tradições contemplativas do oriente, inclusive Sufis, muçulmanos, sociedades leigo-contemplativas da Indonésia, etc., do mesmo modo que com os mais conhecidos grupos monásticos do Hinduísmo e do Budismo ${ }^{880}$

Sobre a possível unidade entre as religiões, ele ressalta:

Mesmo havendo irreconciliáveis diferenças de doutrina e de crença formulada, há grandes semelhanças e analogias ao nível da experiência religiosa. [...] As diferenças culturais e doutrinárias devem ser conservadas, mas elas não invalidam uma qualidade muito real de semelhança existencial. E que nesse nível de experiência existencial e de maturidade espiritual é possível fazer contatos reais e significativos e, talvez, muito mais do que isso ${ }^{881}$.

Merton está convencido de que a "comunicação em profundidade não somente é possível agora e desejável como é da maior importância para o destino do Homem do Século XX"882. Para terminar, reafirma a importância da comunicação, chegando à comunhão entre contemplativos de tradições diferentes, de diferentes disciplinas e religiões. Para ele,

\footnotetext{
${ }^{878}$ MERTON, Thomas. Diário da Ásia, p. 242.

${ }^{879}$ Ibid., p. 243.

${ }^{880}$ Ibid., pp. 244-245.

${ }^{881}$ Ibid., pp. 245-246.

${ }^{882}$ Ibid., p. 246.
} 
a comunicação verdadeira no nível mais profundo é mais do que uma simples troca de ideias, de conhecimento conceitual ou de formulações da verdade. A espécie de comunicação necessária neste nível profundo deve ser também "comunhão" acima do nível das palavras - uma comunhão na experiência autêntica, partilhada não só em nível "preverbal", mas também em um nível "postverbal"883.

O nível "preverbal" é da preparação, predisposição da mente e do coração, necessárias a toda e qualquer experiência monástica. O monge deve ser mais do que um meticuloso praticante de tradições exteriores. Deve estar completamente aberto à vida e à nova experiência por ter utilizado integralmente sua própria tradição e a ter ultrapassado. Enquanto o nível "postverbal" é aquele em que ambos se encontram além de suas próprias palavras e de seu próprio entendimento, no silêncio de uma experiência ${ }^{884}$.

Ele visita vários países. Na China, conversou com Phara Khantipalo (autor de livros sobre o budismo) sobre meditação. Já com o abade budista Chao Khun, conversou sobre os objetivos do budismo theravada ${ }^{885}$. Todas estas conversas possibilitaram uma melhor compreensão das experiências religiosas vividas nas religiões orientais, de sua disciplina e dedicação.

Teve também encontros com o Dalai Lama, que lhe causou forte impressão, no seu diário registrou; "é ativo e forte, mais alto do que eu esperava. Um homem sólido, cheio de energia, generoso e cordial" ${ }^{886}$. Conversou bastante com ele, foram três encontros. As conversas foram sobre religião, filosofia e particularmente sobre meditação e seus métodos ${ }^{887}$.

Um dos conselhos que recebeu do Dalai Lama sobre a meditação foi que precisava "ter uma boa base de filosofia Madhyamika (nagarjuna e outra fontes hindus autênticas) e a que consultasse mestres tibetanos qualificados, unindo o estudo à prática" ${ }^{988}$.

No segundo encontro conversaram sobre epistemologia e mente. Merton the falou que: "Era importante que os monges no mundo fossem exemplos vivos da libertação e transformação da consciência que a meditação pode dar" ${ }^{889}$. E o

\footnotetext{
${ }^{883}$ MERTON, Thomas. Diário da Ásia, p. 248.

${ }^{884}$ Cf. Ibid., p. 248.

${ }^{885}$ Theravada ( Pali: thera "anciãos" + vada "palavra, doutrina" ), a "Doutrina dos Anciãos", é o nome da escola de Budismo que tem suas escrituras no Cânone em Pali ou Tipitaka, que os acadêmicos em geral aceitam como sendo o registro mais antigo dos ensinamentos do Buda.

${ }^{886}$ HART, Patrick; MONTALDO, Jonathan. Merton na intimidade, p. 399.

${ }^{887}$ Cf. MERTON, Thomas. Diário da Ásia, p. 75.

${ }^{888}$ Ibid., p. 75.

${ }^{889}$ Ibid., p. 402.
} 
Dalai Lama lhe falou sobre $s a m a d h i^{890}$, no sentido de concentração controlada, referindo-se à mente como "aquilo no que alguém se concentra", insistindo no “desapego, numa vida não-mundana, como caminho para o perfeito entendimento e participação nos problemas da vida e da sociedade" 891 .

O que seria importante para esta atitude, colaborando com o que Merton acreditava ser necessário criar uma nova consciência de tempo, temps vierge, para a vida contemplativa. Um espaço em que o monge possa usufruir suas próprias potencialidades. O tempo da pessoa que não fosse dominado pelo ego e suas exigências. Para que fosse aberto para o outro, um tempo compassivo ${ }^{892}$.

Dalai Lama também se interessou pela vida monástica ocidental, perguntou sobre os votos, a regra do silêncio, o caminho ascético e tudo mais sobre como vive um monge. Dos momentos que teve com o Dalai Lama, assim, escreveu em seu diário: "Senti que nos tornáramos muito bons amigos, estando bem próximo, de algum modo, um do outro. Tenho um grande respeito e afeição por ele como pessoa, crendo, além disso, que entre nós há um verdadeiro vínculo espiritual" ${ }^{893}$.

Outro momento importante que teve foi quando conversou com um eremita Chatral Rinpoche, sobre a meditação Nyingmap ${ }^{894}$. Fizeram comparações entre alguns pontos da doutrina cristã e o budismo. Que contribuiu para que fossem esclarecidas as diferenças bem como, o que poderia haver de semelhantes.

Desta partilha resultou:

A mensagem da conversa, não expressa ou expressada pela metade, foi o nosso mútuo e completo entendimento como pessoas que estavam de alguma forma à beira da grande percepção do real, que sabiam disso e tentavam desse ou daquele modo sair e perder-se nele e que nosso encontro havia sido uma graça para os dois $^{895}$.

Logo após este encontro, já perto de sua partida, teve uma experiência única quando andava por uma trilha e se deparou com grandes imagens do Buda esculpidas em pedras:

\footnotetext{
${ }^{890}$ Pode ser traduzido por "meditação completa". É a última etapa do sistema ioga, quando se atinge a compreensão da existência e a comunhão com o universo.

Significa concentração correta na meditação.

${ }^{891}$ Cf. MERTON, Thomas. Diário da Ásia, p. 85.

${ }^{892}$ Cf. HART, Patrick e MONTALDO, Jonathan. Merton na intimidade, p. 403.

${ }^{893}$ Ibid., p. 95.

${ }^{894}$ Meditação de uma das linhagens do budismo (nyígma). Que se formou a partir das primeiras tradições budistas introduzidas no Tibete. Suas práticas introspectivas promovem calma e clareza interiores. O sentar-se silencioso, o caminhar meditativo e o canto de mantras estão entre as ricas práticas meditativas oferecidas.

${ }^{895}$ HART, Patrick e MONTALDO, Jonathan. Op. cit., pp. 407-408.
} 
O silêncio de suas extraordinárias faces. Os sorrisos largos. Imensos, porém sutis". E contemplando nelas a busca e o encontro que Buda teve com o nada, e ao mesmo tempo tudo. "Olhando-as fui bruscamente e quase à força arrancado para ficar livre do modo habitual de ver as coisas, já em si algo exausto, e uma clareza interior, uma nitidez que parecia explodir das pedras, tornou-se manifesta e óbvia.... a grande questão, sobre isso tudo, é que não há enigma, não há problema, não há 'mistério'. Todos os problemas já estão resolvidos e tudo está muito claro, simplesmente porque o que importa está claro. A pedra, toda a matéria, toda a vida, está imantada de dharmakaya - tudo é vazio e tudo é compaixão. Não sei quando em minha vida tive tal senso de beleza e vitalidade espiritual a fluir juntas numa mesma iluminação estética.... Quero dizer que eu sei e vi aquilo de que andava obscuramente à procura. $\mathrm{O}$ que resta, não sei, mas agora já vi, penetrei pela superfície adentro e fui além da sombra e do disfarce. ${ }^{896}$

Esta experiência que viveu Merton provocou um mergulho em si mesmo. Como ele mesmo disse: "Somente quando não resta mais nenhum vestígio do eu como 'lugar' no qual Deus age, somente quando Deus age puramente em si mesmo, nós, enfim, recobramos nosso 'verdadeiro eu', (que nos termos Zen, é não-eu, não-ser)" ${ }^{897}$. Todo o caminho percorrido, até mesmo antes de sua viagem, as conversas e escutas de tantas pessoas nestas terras (no oriente), estranhas ao seu corpo, mas tão familiares ao seu desejo, lhe possibilitaram de uma forma inimaginável este desvelamento.

Para Merton, de tudo o que havia vivido nesta viagem, estava claro que:

Encontrar-me com o Dalai Lama e os vários tibetanos, lamas ou leigos 'iluminados', foi o que houve de mais significativo, particularmente pelo modo como fomos capazes de nos comunicar uns com os outros e compartilhar uma experiência essencialmente espiritual do 'budismo' que está em harmonia, de alguma forma, com o cristianismo ${ }^{898}$.

Estava próximo o dia da realização do Congresso, em que ele iria falar para cristãos e budistas. Partiu, então, para Tailândia, e em sua conferência intitulada 'Marxismo e perspectivas monásticas', ele inicia sugerindo mudança no título, para ele poderia ser "Teoria marxista e teoria monacal". Ele estava muito mais interessado no pensamento e na espécie de mística do marxismo do que no seu pensamento ortodoxo. Para fundamentar sua discussão ele utilizará a obra de Herbert Marcuse, muito influente entres os grupos neo-marxistas estudantis ${ }^{899}$.

Para o monge

será preciso haver uma dialética entre a recusa e a aceitação do mundo. A recusa feita pelo monge encerra também a possibilidade de aceitar um mundo aberto à

\footnotetext{
${ }^{896}$ HART, Patrick e MONTALDO, Jonathan. Merton na intimidade, pp. 416-417.

${ }^{897}$ MERTON, Thomas. Zen e as aves de rapina, p. 15.

${ }^{898}$ HART, Patrick e MONTALDO, Jonathan. Op. cit., p. 409.

${ }^{899}$ Cf. MERTON, Thomas. Diário da Ásia, p. 256.
} 
mudança. Por outras palavras: o monge não aceita o mundo porque deseja vê-lo mudado. Isso coloca o monge no mesmo plano que o marxista, porque o marxista conduz uma crítica dialética às estruturas sociais na direção de uma mudança revolucionária. $\mathrm{E}$ a diferença entre o monge e o marxista é fundamental no ponto em que o marxista reivindica uma mudança de subestruturas, subestruturas econômicas, ao passo que o monge procura mudar a consciência do homem ${ }^{900}$.

Sobre o monasticismo asiático, o cristão deve buscar um melhor aprofundamento, procurando romper o superficial da experiência asiática.

Para um cristão - tanto quanto para um budista, parece-me - existe uma orientação essencial que transcende esta ou aquela sociedade, esta ou aquela cultura e mesmo esta ou aquela religião. Portanto, estando abertos aos valores culturais asiáticos e usando-os, creio que também devemos ter em mente o fato de que Cristianismo e Budismo, em sua pureza original, conduzem para além das divisões entre isto e aquilo $^{901}$.

Ele continua dizendo:

Respeite-se, portanto, a pluralidade dessas culturas sem fazer delas um fim em si. Respeitemos tudo isso ultrapassando-o dialeticamente. O que estou dizendo é que no Cristianismo dispomos de uma abordagem dialética dessas realidades - e no Budismo existe uma dialética essencial chamada Madhyamika, que é a base do Zen, e assim por diante. Todas essas abordagens dialéticas (e também o marxismo é dialético) ultrapassam tese e antítese, isto e aquilo, preto e branco, oriente e ocidente. Aceitamos a divisão, trabalhamos com a divisão, e ultrapassamos a divisão ${ }^{902}$.

Diante de vários líderes monásticos da Ásia, Merton concluiu suas observações com uma apreciação sincera dos valores monásticos do oriente como complemento para o monacato ocidental cristão:

Acredito que a abertura ao Budismo, ao Hinduísmo e a essas grandes tradições asiáticas nos traz uma oportunidade maravilhosa para aprender mais sobre a potencialidade das nossas próprias tradições porque eles penetram, do ponto de vista natural, muito mais profundamente nisso do que nós. A combinação das técnicas naturais, graça e outros fatores manifestados na Ásia com a liberdade cristã do Evangelho deveria levar-nos todos por fim, a essa liberdade plena e transcendente situada além das meras diferenças culturais, das meras exterioridades e meros isto ou aquilo ${ }^{903}$.

Para ele, na experiência religiosa, há uma real 'semelhança existencial', em que possibilita 'uma comunicação em profundidade'. E em consequência do aprendizado, na disciplina e experiência dos budistas e hindus se tem não só o aperfeiçoamento, mas também a qualificação da vida monástica cristã. Sua experiência, então, no diálogo com estas religiões, não diminuiu ou causou

\footnotetext{
${ }^{900}$ MERTON, Thomas. Diário da Ásia, p. 259.

${ }^{901}$ Ibid., p. 266.

${ }^{902}$ Ibid., p. 266.

${ }^{903}$ Ibid., p. 267.
} 
difusão pela influência que obteve, mas contribuiu para que pudesse encontrar no cristianismo dimensões que não conseguiria perceber sem a ajuda destas.

"And now I will disappear" 904 . Com estas palavras, Merton termina a conferência. O calor é sufocante e ele deseja voltar logo para o hotel, tomar um banho e descansar. Um fio exposto cala para sempre uma das vozes mais perturbadoras do século vinte. Uma voz que foi buscar no silêncio e na solidão a força necessária para ser ouvida e respeitada. Uma voz, serena como a de um cúmplice e irada como a de quem vê no conformismo a maior tragédia da humanidade.

Após esta conferência, Merton se recolheu e, em seu quarto, acidentalmente, morre eletrocutado por um ventilador defeituoso. Estava com 53 anos.

$\mathrm{Na}$ conferência em Bancoc, tendo ela ocorrida no próprio dia de sua morte, encontramos a chave de sua mensagem, ao mesmo tempo mística e pragmática, da vida monástica, como presença no mundo e não como ausência do mundo.

Existem muitas especulações de que sua morte nada foi acidental. Por causa do momento de crise em que estava o mundo - era tempo de guerra do Vietnã esta palestra não ficaria impune. Merton sempre demonstrou ser contrário e havia contribuído para a criação de vários movimentos contra todo ato violento e era contra a obrigatoriedade ao serviço militar na guerra do Vietnã.

Um jornalista chamado Robert Grip foi quem mais escreveu a respeito. Ele solicitou a abertura dos arquivos do FBI e da CIA, e estes revelaram que Merton era uma pessoa visada por órgãos de segurança. Um grupo de católicos ultranacionalistas enviou ao FBI uma carta sugerindo que os passos de Merton fossem vigiados, por se tratar de uma pessoa perigosa e ter sido comunista na juventude. Estes foram os seus grandes inimigos, chegaram a queimar publicamente suas obras, chamando-o de ateu e antipatriota, por se opor à guerra do Vietnã ${ }^{905}$.

O fato é que Merton em meio a tropeções e quedas percorreu seu caminho, deixou marcas de uma personalidade forte e terna por onde passou. E, enfim, conhece agora quem tanto amou e ouve com clareza sua voz. Seu amor proclamado quando escreveu rezando, anunciava mais uma vez seu desejo de abandono, de entrega total e da certeza que tinha de ser amado:

\footnotetext{
${ }^{904}$ Cf. MERTON, Thomas. Diário da Ásia, pp. 256-267. O texto completo da conferência.

${ }^{905}$ Cf. BERTELLI, Getúlio Antônio. Mística e compaixão, p. 144.
} 
Pai, eu te amo, a ti que não conheço, e te abraço sem ver-te, abandono-me a ti a quem ofendi porque me amas em teu unigênito. Vês ele em mim, abraças a ele em mim porque ele quis identificar-se completamente comigo por aquele amor que o levou à morte, por mim, na cruz ${ }^{906}$.

\section{Conclusão}

Merton foi um homem que desfrutou de uma vida intelectual brilhante, desde sua juventude, quando percorria um caminho de desilusão e conflitos, até que, encontrando-se consigo mesmo em Deus, assumiu-se como um escritor apaixonado, em seu diário anotou que escrever "é pensar e viver - e até rezar", "escrever é amar". E desta forma, além de suas conferências, manteve-se em contato com o mundo, consigo mesmo e com Deus.

Destacamos diante de tudo o que nos foi apresentado, que sua trajetória, sua espiritualidade e mística profundamente enraizadas no Evangelho são um convite a uma experiência sadia com Deus, deixando a sedução do que aliena pela sedução do Absoluto.

Sua contribuição para os dias de hoje, tempo que nos clama por uma mudança de paradigma, está em sua espiritualidade encarnada com a realidade, uma espiritualidade da libertação, que se traduz em uma abertura ao outro, ao diferente; seu diálogo frutuoso com as diversas religiões orientais, que não diminui ou causa confusão, contribui para que se possa encontrar no cristianismo dimensões que não conseguiria perceber sem a ajuda destes e por uma visão integral do ser humano.

No mosteiro, sua angústia era encontrar um equilíbrio entre ação, temporalidade e eternidade. Ele se preocupa muito, nos primeiros anos de sua vida monástica, em encontrar soluções para estes dilemas; porém se dá conta de que tem que assumir sua própria identidade no palco da temporalidade - são os anos mais conflitivos de sua existência, anos em que retoma sua própria raíz humana e social e tem contato com muitas pessoas.

Ele descobre que, em relação à temporalidade, faz-se necessário um olhar universalizante, ecumênico e interconfessional no religioso, e um olhar misericordioso e compassivo sobre um mundo esquecido pelas guerras e violência, necessitando de uma reconciliação pacífica para a paz mundial.

\footnotetext{
${ }^{906}$ MERTON, Thomas. Na liberdade da solidão, p. 58.
} 
O interesse de Merton pelos horizontes espirituais do homem tem sua origem na profundidade de sua fé; a segurança interior levou-o a explorar, a experimentar e a interpretar as afinidades e as diferenças entre as religiões, à luz de sua própria religião: o Cristianismo, que representava para ele o supremo fato histórico e a perfeita revelação.

Merton procurou a totalidade do ser humano e sua visão abrangedora não lhe permitia negar qualquer escritura autêntica ou qualquer ser humano de fé. $\mathrm{O}$ silêncio da meditação e a oração que em toda a vida buscou, encontrou-os não só em sua experiência monástica como também em seu último entusiasmo pelo Tibete. Acreditando no ecumenismo, adiantou-se e explorou novos caminhos de compreensão entre diferentes credos, encorajado pelo espírito do Vaticano II.

Foram quase 27 anos, de 31 janeiro de 1915 a 10 de dezembro de 1941, quando entrou no Mosteiro Trapista. A partir de seu ingresso na Ordem até sua morte, em 10 de dezembro de 1968, transcorreram também 27 anos, justamente no aniversário da sua entrada no Mosteiro de Nossa Senhora do Gethsemani.

Conciliar ação e contemplação era e sempre foi seu destino. Um destino perseguido com paixão e sofrimento, alegria e desespero. Não havia, para Merton, um tempo para agir e um tempo para meditar. A fronteira entre eles era quase inexistente e ele levaria muito tempo para descobrir que tanto um gesto como o outro só são autênticos se permanecem indissociáveis.

Na próxima parte de nossa tese, nos deteremos na experiência de encontro com Deus a qual viveu Raimon Panikkar. Encontraremos um homem de personalidade ricamente vivaz. Sua experiência de Deus tem raiz no cristianismo, sem esquecer-se de outras dimensões religiosas, místicas e teológicas, em especial o pensamento hindu e budista. Indo além dos limites cristãos, sua experiência nasce de um diálogo intrarreligioso ${ }^{907}$ com outras tradições religiosas, superando o diálogo inter-religioso, em um estreito ecumenismo.

\footnotetext{
907 O termo "diálogo intrarreligioso" é inspirado na linguagem teológica que fala das relações Trinitárias ad intra e ad extra. Em que a relação ad intra é a relação que se dá no seio da Trindade entre o Pai, o Filho e o Espírito. E a relação ad extra é a relação da Trindade com o mundo. Para Panikkar o diálogo inter-religioso, ao qual dedicou tanto tempo e tantos escritos, no fundo é algo que parte da experiência interna. Ou seja, o diálogo inter-religioso só pode funcionar se estiver acompanhado por uma dimensão "interior", ad intra, intrarreligioso. Antes do diálogo interreligioso, os dialogantes devem realizar um diálogo consigo mesmo para por em questão suas próprias convicções e verificar a posteriori as afirmações que se davam por supostas a priori sobre a unicidade e absolutismo de sua experiência religiosa. Aprofundaremos logo em seguida esse termo. Cf. PANIKKAR, Raimon. Il diálogo intrareligioso. Cittadella: Assisi, 1988.
} 


\section{Cronologia da vida de Thomas Merton}

1915 - 31 de janeiro: nasce em Prades. Seus pais chamavam-se Owen Merton e Ruth Jenkins.

1916 - A família Merton muda-se para os Estados Unidos, e vivem em Douglaston, com os pais de Ruth, Samuel e Martha Jenkins.

1917 - A família Merton se instala em uma casa de sua propriedade em New York.

1918 - 02 de novembro: nasce John Paul, seu irmão.

1921 - Ruth Jenkins morre de câncer.

1922 - 1923 - Viagens com o pai.

1925 - Com seu pai passa a morar na cidade francesa St. Antonin.

1926 - Ingressa no Instituto de Montauban, França.

1929 - Ingressa em Oakham School.

1931 - Depois de uma longa enfermidade, seu pai morre por causa de um tumor celebral.

1933 - 01 de fevereiro: finalizado os seus estudos em Oakham, Thomas Merton viaja para Itália. Em outubro volta para Inglaterra para começar seus estudos universitários no Clare College, Cambridge University.

1935 - Ingressa em Columbia University.

1938 - É graduado em Columbia. Em 16 de novembro é batizado por Fr. Joseph C. Moore.

1939 - É Crismado pelo bispo Stephen J. Donahue e recebe nome de James.

1940 - Leciona durante um semestre na Columbia Extension School.

Verão: manifesta certos escrúpulos sobre seu passado ao Superior dos Franciscanos, que lhe sugere que retire seu pedido de ingresso.

Setembro: aceita ser professor em St. Bonaventure College.

1941 - Está profundamente animado para passar a Semana Santa em Gethsemani. Solicita seu ingresso na Abadia em que ingressa no dia 10 de dezembro.

1942 - 21 de fevereiro: é recebido no noviciado e recebe um novo nome religioso: Irmão Louis.

John Paul Merton é batizado na Igreja paroquial de New Haven, Kentucky, e recebe a primeira comunhão na Abadia de Gethsemani.

1943 - Abril: John Paul morre em uma ação de guerra. 
1944 - Faz sua profissão de votos temporais.

1947-19 de março: faz seus votos solenes. Profissão monástica por toda vida na Ordem Cisterciense.

1949 - 25 de maio: Ordenação sacerdotal.

Novembro: começa a lecionar no Noviciado da Abadia.

1951 - Junho: é nomeado mestre de jovens professos.

26 de junho: é concedida sua cidadania norte-americana.

1953 - Recebe a permissão para morar em um eremitério no bosque da Abadia.

1955 - É nomeado mestre de noviços.

1960 - Novembro: é construída a casa de retiros que será seu eremitério.

1964 - Junho: visita D. T. Suzuki, em New York.

Novembro: Encontro em Gethsemani com líderes de movimentos pacifistas.

1965 - Agosto: faz-se ermitão, vivendo nas terras da Abadia.

1966 - Abril: é internado no hospital de Louisville para um procedimento cirúrgico. Tem início sua relação amorosa com a enfermeira.

1967 - Dezembro: encontro em Gethsemani com representantes de Ordens Contemplativas feminina.

1968 - Outubro: viaja ao Alaska, Califórnia e Ásia.

Dezembro: morre por acidente em Bancoc. 


\section{Parte}

\section{Experiência Cristã de Deus em Raimon Panikkar}

Como veremos, Raimon Panikkar ${ }^{908}$ sempre buscou a integração do conjunto de toda a realidade em todas as suas dimensões. Concebe a Realidade como totalmente relacional; uma relação que não é nem dualista, nem monistapanteísta, senão advaita ${ }^{909}$ em que estão integrados o Cosmos, o ser Humano e Deus. É o que Panikkar chamou de Intuição Cosmoteândrica ${ }^{910}$. Segundo nosso autor: "Nada é negligenciado, nada se deixa de lado, tudo está integrado, assumido, transfigurado... Pensar em todos os fragmentos de nosso mundo atual para reuni-los em um conjunto harmônico" ${ }^{911}$. Ele procura a interlocução de todos com tudo frente ao reducionismo, por uma harmonia entre as diversas dimensões da Realidade.

A partir do homem como realidade cosmoteândrica, a mística assume a forma de sua antropologia de fé, de esperança e de caridade, da imanência e da transcendência humana, que, sem negar o tempo e o espaço, os assume e os ultrapassa. Como veremos, para Panikkar, "a mística é a experiência plena de Vida"912.

Ele ousou aproximar-se de outras tradições religiosas acreditando que as mesmas enriqueciam a sua experiência cristã. Surge o termo "diálogo

\footnotetext{
${ }^{908}$ Em princípio o seu nome era Raimundo Paniker Alemany, porém este mudou pouco a pouco. Era chamado por "Raimundo", "Raymond" e, finalmente, como "Raimon". Seu sobrenome ficou definitivamente Panikkar, depois de sua estadia na Índia (ele descobriu que este é um nome da nobreza malabar), e que essa é sua transcrição mais precisa. No final dos anos 60, estando em Harvard e Califórnia, foi apresentado como Raimon Panikkar. Cf., PINGEM, Jordi. El pensament de Raimon Panikkar: Interdependència, pluralisme, interculturalitat. Barcelona: Institut d'Estudis Catalans, 2007. p. 18. Referiremo-nos ao Raimon Panikkar apenas como Panikkar no decorrer do nosso texto.

${ }^{909}$ Significa $a$-dual - riquíssimo conceito hinduísta, também presente no budismo, no taoismo e no sufismo. Panikkar assumindo este pensamento não-dualista faz alusão, em vários momentos, desse conceito contrapondo-o tanto ao monismo como ao dualismo.

${ }^{910}$ Aprofundaremos seu significado e importância para o pensamento de Panikkar, a partir do seu livro La intuición cosmoteándrica. Las tres dimensiones de la realidad. Madrid: Editora Trotta, 1999. Titulo original: The cosmotheandric experience (1993). Esta é a fundamental intuição para entender o pensamento de Panikkar. Falaremos sobre este tema mais adiante. Por ora, uma breve ideia: "Finalmente o que tenho chamado de Intuição cosmoteândrica ou teantropocentrismo em que a realidade é não dual e cada coisa tem três dimensões constituintes: a cósmica, a humana e a divina, ou em outra palavras: a material (espaço-temporal) , a intelectual (consciente) e a mistérica (infinita)". PANIKKAR, Raimon. Autobiografía intelectual. La filosofía como estilo de vida". Anthropos, pp. 53-54 (1985): p. 15.

${ }_{911}^{11}$ Id., La intuición cosmoteándrica, p. 19.

${ }^{912}$ Id., De la mística. Experiencia plena de la Vida. Barcelona: Editorial Herber, 2005. p. 25.
} 
intrarreligioso", que significa diálogo no interior de si mesmo, um mergulho na religiosidade pessoal, quando se está diante de outra experiência religiosa em um nível muito íntimo. Em outras palavras, se o diálogo inter-religioso deve ser um verdadeiro diálogo, este deve ser acompanhado de um diálogo intrarreligioso. Este diálogo começa com o questionamento sobre si mesmo e da relatividade de suas crenças (o que não significa em seu relativismo), aceitando o risco de uma mudança, uma conversão de uma reviravolta dos meus modelos tradicionais. $\mathrm{Ou}$ seja, não se pode entrar na arena de um diálogo religioso autêntico, sem uma atitude de autocrítica. O diálogo inter-religioso é uma preparação para o diálogo intrarreligioso, em que a fé viva exige constantemente uma renovação total, ou em termos cristãos - uma verdadeira metanoia, pessoal, constantemente renovado $^{913}$.

Panikkar sempre considerou esta relação indispensável para o fazer teológico e filosófico. Para ele, a teologia, igualmente em sua capacidade intelectual e espiritual interna, deve sempre estar atenta à inter[intra]-culturalidade e a inter[intra]-religiosidade. Ele nos situa diante deste importante diálogo interior.

Quisera ser fiel à intuição budista, não me afastando da experiência cristã e não me desconectando do mundo cultural contemporâneo... Sigo sendo cristão e hindu, embora eu perceba que aqui não acaba a minha peregrinação... Porque levantar muralhas e manter zelosamente as separações? O fato de acentuar uma tradição humana e religiosa não significa menosprezar as demais. A síntese de todas elas é improvável e talvez nem sequer seja possível, porém isso não quer dizer que a única alternativa esteja no exclusivismo ou no ecletismo ${ }^{914}$.

Ele reafirma, negando qualquer esquizofrenia ou irracionalidade, que se sente com uma quádrupla identidade, profundamente incrustada em sua vida: a tradição cristã, a hinduísta, a budista e o pensamento secular do século XX. Esta identidade está presente em seu pensamento até o ponto de que não podemos compreendê-lo se não conhecemos o que supõe o diálogo interior.

Um diálogo interno dentro do próprio eu, um encontro no profundo da religiosidade própria e pessoal do eu; quando este esbarra com outra experiência religiosa nesse nível íntimo... Um diálogo intrarreligioso que tenho que começar eu mesmo, perguntando-me sobre mim mesmo, sobre a relatividade de minhas crenças (que não é o mesmo que relativismo) e aceitando o desafio de uma mudança, de

\footnotetext{
${ }^{913}$ Cf. PANIKKAR, Raimon. Il dialogo intrareligioso, pp. 114-116.

${ }^{914}$ Id., El silencio del Buddha. Una introducción al ateísmo religioso. Madrid: Siruela, 1996. p. 27 e 16.
} 
uma conversão e o risco de romper minhas abordagens tradicionais ${ }^{915}$.

A partir de sua experiência existencial, procura conscientemente o que ele chama de harmonia invisível, que, para ele, deve existir entre todas as religiões e cultura. Segundo ele, devemos nos abrir aos demais e crer, confiar na experiência humana em seu conjunto, na harmonia dos seres humanos e do cosmos. A harmonia invisível está intimamente relacionada com o que Ele mesmo denominou efeito pars pro toto: a visão que tenho da realidade (totum), a realizo, necessariamente através de minha particular janela cultural e religiosa (pars). Isto significa que cada um de nós pode ser consciente do todo, porém sob uma

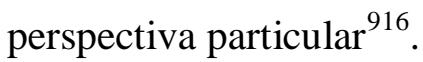

Em seus escritos, destaca-se uma forma de ser apaixonada, porém não avassaladora. Erudição e simplicidade se conjugam de tal maneira que revelam uma sabedoria impactante. Seu pensamento, como veremos mais adiante, está fincado no religioso, porque, para ele, é impossível fazer uma leitura da realidade se não for através da religião.

Reconhecemos em Panikkar, segundo V. Pérez Prieto, uma pessoa que

desconcerta, perturba e, contudo, é um homem que seduz, mesmo quando não se está totalmente de acordo com o que ele diz. Seduz por seu verbo criativo e sua escrita brilhante, porém, sobretudo por seu agudo e rico pensamento que abre a concepções habitualmente diferentes do comum. É um homem que quer viver e pensar com liberdade de espírito, como os velhos profetas, porém também com rigor intelectual. Quer fazer uma teologia com liberdade e rigor, partindo da experiência pessoal e recebida da tradição ${ }^{917}$.

Seu pensamento tem origem em sua própria experiência de vida. Suas ideias são resultados de suas reflexões feitas sobre as diversas experiências culturais, religiosas e acadêmicas que se iniciam, inclusive, no seio familiar. Como ele mesmo falou, escrever é resultado de seu próprio itinerário existencial:

O risco existencial é de uma vida que se enraíza em mais de uma cultura e religião [...] Minhas circunstâncias pessoais (biológicas, históricas e biográficas) me tem tornado possível aceitar o risco de uma conversão sem alienação, sem ter em repúdio, a síntese e a simbioses sem cair em um sincretismo ou ecletismo. A doutrina indiana do próprio karma resultou para mim um símbolo vivo. Não trata de me confirmar voluntariamente, ao mesmo tempo, indiano e europeu, ou que me

915 PANIKKAR, Raimon. El dialogo interno: la insuficiencia de la llamada 'époché' fenomenologica en el encontro religioso. Salmanticensis, XXII/2 , 1975, pp. 349-350.

${ }^{916}$ Id., Sobre el diálogo intercultural. Salamanca: San Esteban, 1990. p. 135. Abordaremos, mais adiante, com mais detalhes o que significam os conceitos: harmonia invisível e efeito pars pro toto.

${ }^{917}$ PRIETO, Victorino Pérez, Más allá de la fragmentación de la teología, el saber y la vida: Raimon Panikkar. Valencia: Tirant lo Blanch, 2008. p.165. 
finja homem religioso e ao mesmo tempo secular. E antes que, por nascimento, educação, iniciação e vida real sou uma pessoa que vive das experiências originais da tradição ocidental tanto cristã como secular, e da tradição indiana, tanto hindu como budista [...] Sou consciente do risco que isto implica. Porém o desafio permanece. A compreensão mútua e a fecundação entre as distintas tradições podem realizar-se pelo sacrifício da própria vida, submetendo-se primeiro a sustentar as tensões existentes sem cair na esquizofrenia e a manter as polaridades sem uma paranoia pessoal ou cultural ${ }^{918}$.

Em outro momento ele afirma:

A aventura da minha vida nunca é planejada conscientemente. Por isso, em sua quintessência, considero típica de nossa época... Basta mudar os nomes genéricos do hinduísmo, cristianismo, budismo e ateísmo por outros mais concretos... Se o chamo típico não é porque é um modelo a imitar, senão porque com toda sua parte de imperfeição, e inclusive de erros, parecem ser paradigmáticos de nossa geração e talvez de algumas gerações futuras ${ }^{919}$.

Panikkar não busca verdades universais e imutáveis, para ele tal pretensão não é sustentável. Seu pensamento está atravessado por três olhos que ele mesmo reconhece em uma entrevista que fez com R. Forner-Betancourt:

O conhecimento integral que não separa o amor do conhecimento; um saber de sabedoria que é provisório e constitutivamente itinerante, e que por isso não se formula com nenhuma pretensão de universalidade nem de validade perene, e, em terceiro lugar, o caráter essencialmente dialógico do pensar [...] A partir dessa harmonia, proponho uma filosofia onde se tem superado duas grandes armadilhas: primeiro, a dicotomia teoria-práxis, e, segundo a dicotomia sujeito-objeto ${ }^{920}$.

O itinerário pessoal e intelectual de Panikkar é bastante rico, seja por ter sido longo e intenso - foram 91 anos como por uma ampla produção intelectual -, seja por todas as relações afetivas estabelecidas entre as diversas culturas e religiões, o que torna difícil falar sobre a vida pessoal sem destacar seu trabalho intelectual. O mesmo diz que:

Escrevo não sobre mim mesmo, senão que escrevo para mim mesmo... eu mesmo sou aquele que escreve e escrevo como alguém que fala... Cada parágrafo que escrevo, cada frase, deveria refletir, na medida do possível, toda minha vida e ser expressão do meu ser. Deveria reconhecer minha vida inteira em uma só frase. Escrever é, para mim, meditação, isto é, remédio e, simultaneamente, ordem para o mundo. Escrever é, para mim, vida intelectual, e esta é, por sua vez, existência espiritual... participação na vida do universo, fazer parte da sinfonia cósmica e divina, a que também os mortais são convidados... É por isso que escrever é, para mim, um ato religioso... Escrever me permite aprofundar o mistério da realidade e me obriga a fazê-1o ${ }^{921}$.

\footnotetext{
${ }^{918}$ PANIKKAR, Raimon. Autobiografía intelectual. pp.13-14.

${ }^{919}$ Id., El silencio del Buddha, pp. 35-36.

${ }^{920}$ Fornet-Betancourt, Raúl. La mística del diálogo. Jahrbuch für kontextuelle Theologien 93. Frankfurt: IKO, 1994. pp.19-37. pp. 36-37.

${ }_{921}$ PANIKKAR, Raimon. Invitación a la sabiduría, Espasa: Madrid, 1999, p. 104.
} 
Ele reitera em outra obra sua um tempo depois:

Escrevo para aprofundar a fé que me foi dada, submetendo minhas intuições ao exame crítico do intelecto e da sabedoria da tradição. E estou não por interesse próprio, senão para desenvolver nessa corrente vital que flui pelas artérias profundas do corpo místico da realidade. A primeira tarefa de toda criatura é a de completar, conduzir a sua perfeição, o ícone do real que todos nós somos ${ }^{922}$.

M. Siguan, em uma homenagem aos seus 70 anos, escreveu o que podemos considerar uma sinopse de sua vida:

Uma existência caleidoscópica e progressivamente acelerada que resultaria absurda se não fosse por um fio condutor claríssimo: a pretensão de assumir tudo, de levar tudo até sua última raiz, até sua total plenitude, a vontade de absoluto. Uma vocação que se limitasse a ordem intelectual poderia classificar-se de científica ou de filosófica, porém, porque aspira a uma plenitude existencial é inevitavelmente religiosa. Itinerário religioso que parte de uma herança cristã lucidamente assumida e do esforço por superar suas contradições tal como se apresentavam a um jovem de Barcelona nos dias de sua juventude: Como ser talvez profundamente cristão e plenamente moderno? Tensão que talvez fosse decomposta em múltiplas faces, tensão entre crença religiosa e conhecimento científico, entre localidade e universalismo [...] E sob estas tensões debatidas em praças públicas, outras mais profundas entre teologia positiva e teologia negativa, ou se preferir, entre dogma e mística e mais radicalmente, todavia, entre conhecimento e amor como formas básicas de aproximar-se da realidade e de dar sentido a existência ${ }^{923}$.

Tal "existência caleidoscópica" e "acelerada", como veremos, está caracterizada por uma rica produção intelectual, proveniente de seu itinerário existencial.

Como veremos, é possível destacar quatro etapas que claramente se apresentam na vida de Panikkar. A primeira, que vai do seu nascimento até sua relação com a Opus Dei, no período de 1918 até 1954; a segunda, seu encontro com a Índia, onde se descobre cristão, hindu e budista, período que vai de 1954 até 1966; a terceira, quando se encontra nos Estados Unidos, anos que vão de 1966 até 1987; e a quarta, a sua "volta a casa" em que se estabelece em Taverte de 1987 até agosto de 2010, o último ano de sua vida entre nós.

\footnotetext{
922 PANIKKAR, Raimon. La plenitud del hombre. Una cristofanía. Madrid: Siruela, 1999. Prólogo, p.14.

${ }^{923}$ SIGUAN, Miquel, Philosophia pacis. Homenaje a Raimon Panikkar. Madrid: Símbolo, 1989. pp. 9-11.
} 


\section{O itinerário de vida de Raimon Panikkar}

Panikkar nasceu em 3 de novembro de 1918 na antiga vila de Sarriá, hoje um bairro de Barcelona. Sua mãe, Carmem Alemany, era catalã, filha mais nova de uma grande família burguesa católica, gostava muito de música e das artes, era profundamente católica e de mentalidade muito aberta. Seu pai, Ramun Panikkar era indiano de origem aristocrata com passaporte britânico. Realizou seus estudos primeiro em Madrás e logo na Inglaterra, onde conseguiu os títulos de Mestre em Artes e Mestre em Ciências. Porém, ao chegar a Guerra, teve que fugir para Espanha, indo morar na Catalunha. Carmem e Ramun se conheceram em Catalunha, namoraram e, apesar da oposição da família, se casaram na Igreja e tiveram além de Panikkar, mais três filhos: Josep-Maria, Mercé e Salvador. Foi com seu pai que recebeu os ensinamentos sobre a tolerância, o sentido de relativização e profunda espiritualidade. Seu pai veio a falecer em 1954 e em 1975 ele fica órfão, também de mãe ${ }^{924}$.

Panikkar sempre foi muito grato por sua família. Ele relata: "Havia uma harmonia profunda entre meu pai e minha mãe, sendo os dois de tradições diferentes" $" 925$. Tem falado desta experiência familiar, dizendo que desde o começo de sua existência começou a descobrir "aquelas dimensões da fé cristã que me permitiam viver em paz com a outra parte de meu ser: a discreta influencia do meu pai, que cantava e explicava o Bhagavad Gita, que me dava os fundamentos do sânscrito e me envolvia em uma não confessional atmosfera hindu"926. E que se via fortalecido pelas convicções de sua mãe, profundamente católica e, no entanto não sectária.

Foi neste ambiente familiar em que foi se desenvolvendo em Panikkar sua singularidade e a profunda tendência religiosa metafísica. Sempre lhe chamou atenção o problema religioso, marcando sua trajetória de vida e intelectual, tornando-o um grande expoente nos estudos das relações inter-religiosas e

\footnotetext{
${ }^{224}$ Cf. PRIETO, Pérez V., Raimon Panikkar. El pensamiento cristiano es trinitario, simbólico e relacional. Encontros con R. Panikkar, Iglesia Viva 223, 2005, p. 64.

${ }^{925}$ M. Abumalham, em "Samâdhânam. Homenaje a R. Panikkar". 'Ilu. Ciencias de las Religiones, Madrid, 2001, p. 21. Apud. PRIETO, Victorino Pérez, Más allá de la fragmentación de la teología, p. 41.

${ }^{926}$ Confesión de R. P. en el libro-diálogo, Pinchas Lapide-Raimon Panikkar, Meinen wir denselben Gott? Ein Streitgesprächa, Kösel, München, 1994, p. 116. Apud. PRIETO, Victorino Pérez, Más allá de la fragmentación de la teología, p. 41.
} 
interculturais. Segundo ele, "não me considero meio espanhol e meio indiano, meio católico e meio hindu, senão totalmente ocidental e totalmente oriental"927.

Estudou em um Colégio Jesuíta, San Ignacio de Sarriá, onde cursou o Bacharelado em Ciências e Letras com "Prêmio Extraordinário", em 1935. No período universitário, com a Guerra Civil, muda-se para Alemanha onde estudou física, matemática, filosofia e teologia. Um homem pacifista como Panikkar sofrera profundamente por causa da terrível Guerra. Esse triste período contribuiu para que se acentuasse nele a vocação sacerdotal, uma porta por onde podia se aproximar do sagrado.

Volta para Espanha em 1939, por causa da Segunda Guerra Mundial. Termina seus estudos na Espanha, onde obteve a Licenciatura em Ciências na Universidade de Barcelona, em 1941 e em Letras na Universidade de Madri, em $1942^{928}$.

No final do ano de 1939, Panikkar conheceu José María Escrivá de Balaguer com quem manteve uma estreita amizade. Depois de um longo tempo de amizade, em 1945, foi o próprio José Maria Escrivá que lhe propôs o sacerdócio. Ele volta para Madri para sua preparação sacerdotal e em 1946 é ordenado com mais cincos companheiros. Foi capelão em um Colégio Maior de Mancloa, onde viveu uma intensa atividade com sacerdotes e leigos. Sobre o seu ministério sacerdotal, disse anos mais tarde:

Eu fui ordenado segundo a ordem de Melquisedeque, que não era judeu, nem circunciso, nem acreditava em Yahveh, e me ordenou com referência a Abel [...] Porém não nego minha vinculação com Abraão, nem muito menos com Cristo, nunca me ocorreu que recebia uma iniciação para algo menor que ter uma função no corpo místico de toda a realidade ${ }^{929}$.

Fez seu doutorado em filosofia e letras na Universidade de Madri, em 1946. O título de sua tese foi: Filosofia Cristiana. El concepto de naturaleza, que se converteria em seu primeiro livro com o título: El concepto de naturaleza. Análisis histórico y metafísico de un concepto. Já se fazia presente a intuição que permaneceu durante toda sua vida: a filosofia com sabedoria do amor e a crítica ao predomínio da razão.

Em Madri, onde vive até 1959, torna-se amigo de reconhecidos professores

927 CASTAgnARO, M. Passaggio in Asia, entrevista, Jesus, Roma, 4 (2001). Apud. PRIETO, Pérez Victorino. Más allá de la fragmentación de la teología, p. 43.

${ }^{928}$ Cf. PRIETO, Pérez Victorino. Más allá de la fragmentación de la teologia, p. 44

${ }^{929}$ PANIKKAR, Raimon, El conflicto de eclesiologías: hacia un concilio de Jerusalén II, Tiempo de Hablar, pp. 56-57 (1993). pp. 33-47. 
de filosofia, como Laín Entralgo, García Morente e Xavier Zubiri. Nesse período, exerce a docência como professor de filosofia da história, culturas comparadas e sociologia religiosa em várias universidades. Escreve alguns livros: A Índia. Gente, cultura e crenças, em 1960; Patriotismo e cristandade, em 1961 e Humanismo e cruz, em 1963. Também escreve assiduamente para as revistas da Opus Dei. Por ter escrito o prólogo do livro A Virgem Maria ${ }^{930}$, de J. Guiton, foi enviado a Roma para estudar a "verdadeira" teologia, em 1953. Este fato o marcou profundamente, como o mesmo manifestou:

[A Obra] iniciou como um pequeno grupo mais ou menos carismático com um ideal evangélico muito puro e elementar que lentamente, a raiz das circunstâncias por uma parte, e do que estava latente no espírito do fundador, foi se convertendo no que sociologicamente se chama seita [...] Pouco a pouco, o jurídico, a prudência de espírito ou da carne, a necessidade de pensar em si mesmo para sobreviver como grupo diferenciado, e a ideologia [...] Fez com que a Obra se convertesse em modelo absoluto para julgar sobre toda atividade pessoal ou coletiva ${ }^{931}$.

Quando chega a Roma reside nas colinas. Anos depois escreverá Panikkar: "Tive que voltar a estudar teologia em Roma, porque a Opus Dei me exigiu o selo da ortodoxia romana para neutralizar os meus poucos comentários \$,932.

\subsection{O encontro com a Índia e seu descobrimento como cristão, hindu e budista, período de 1954 até 1966}

No final de 1954, terminados os seus estudos em Roma, foi enviado à Índia em missão apostólica. Depois de um ano no sul deste país, se estabelece em Varanasi, por ser a cidade Santa do Hinduísmo. Essa experiência o marcou profundamente e inicia uma etapa crucial em sua vida. Ele tem 36 anos, quase a metade de sua vida, quando vai à terra de sua origem paterna, como ele mesmo reconheceu: "Parece necessário falar uma última vez de mim para cancelar um

\footnotetext{
${ }^{930}$ Moncada relata esse fato: "O conflito ocorreu quando Panikkar publicou o prólogo do livro de Jean Guitton sobre a Virgem Maria. O cardeal Segura ficou muito irritado com o tratamento teológico apresentado sobre Maria e escreveu uma carta pastoral, de oitentas páginas, muito negativas, condenando o livro [...] E o mandaram a Roma para estudar a boa doutrina. Era a primeira metade da década de cinquenta e aí começa seu afastamento da Espanha e sua desvinculação com o apostolado da Obra". Moncada, op. cit. p. 81. Ainda segundo Moncada, esse prólogo seria reconhecido mais adiante junto com outro trabalho de Panikkar, em um livro sobre o mesmo tema, em que ele recolhe a teologia mariana, em Dimensioni mariane della vita, Vicenza: La Locusta, 1972.

${ }^{931}$ MONCADA, Alberto. Historia oral del Opus Dei, Plaza \& Janés: Barcelona, 1987. p. 131.

${ }^{932}$ Nachword von Raimon Panikkar, In P. Lapide-R.Panikkar, Op. cit, p. 117. Apud. PRIETO, Pérez Victorino. Más allá de la fragmentación de la teología, p. 51. Em um ano faz a licenciatura em Teologia.
} 
período de minha vida, que quase com toda certeza abarca mais da metade de minha cronológica existência terrestre [...] Posso dizer que começa um novo período em minha vida $[\ldots]]^{933}$.

Ainda quando se preparava para viagem, ele já intuía que essa experiência teria um efeito transcendental em sua vida, como refletia em uma de suas confissões pessoais: "Estas palavras foram escritas apressadamente quando, empacotando todos os meus equipamentos, juntamente com toda minha vida, em 20 kilos de bagagem, para transladar-me para o Oriente, quis deixar uma nota introdutória como para uma obra póstuma"934. Um tempo depois, ele escreve, reconhecendo o momento em que vive:

Posso dizer que começa um período novo em minha vida, com a morte real de minhas ilusões e ideais tidos até agora... Aqui minha vida muda no mais interno do meu ser, pois que ... (trata-se) de que abandone a ilusão de mergulhar na cultura... Em sinfonia a Criação tem compassos sonoros e também ritmos de silêncio. Parece-me que tenho que por música em minha existência e agora me dizem que meu trabalho é o silêncio ${ }^{935}$.

E em outro momento revela o que sente em forma de oração:

Teus caminhos, Senhor, são os meus e teus desejos são os meus... Quando já me havia provocado o ânimo por estabelecer-me para servir-te com minhas forças no mundo cultural cristão no Ocidente, quando já havia quase abandonado aquele mundo abismático do Oriente que seguia latente em meus cromossomos; é aqui que me chamas a ele e me encarregas de conhecê-lo mais profundo... Não me proponho a ir com ar de suficiência, nem com missão docente alguma, senão com exclusiva missão de serviço ${ }^{936}$.

Panikkar deixa claro que suas ideias, aquelas que começaram a provocar um mal estar, apresentado pela Opus Dei, na "saudável ordotoxia", estavam presentes antes de sua viagem à Índia: "acaso logo se dirá que muitas de minhas ideias são de origem hindu e de sabor pagã oriental [...] Quisera deixar claro que tudo o que depois eu diga, já o penso e digo antes de ter pisado em solo indiano"937.

Ele passa a trabalhar como pesquisador nas Universidades de Varanasi, Mysore e Benarés, aprofundando seus estudos nas religiões do hinduísmo e do budismo, o que provoca o reconhecimento de suas próprias raízes. Sua experiência de profundo encontro com o budismo e o hinduísmo não o fez

\footnotetext{
${ }^{933}$ PANIKKAR, Raimon. Cometas. Fragmentos de un diario espiritual de la postguerra. Madrid: Suramérica, 1972. p. 98.

${ }^{934}$ Ibid., 26.

${ }^{935}$ Id., Mi testamento. In. Cometas, pp. 95, 98, e 99.

${ }_{936}^{93}$ Id., Mi último cometa de Occidente. In. Cometas, p. 194.

${ }^{937}$ Ibid., p. 196.
} 
abandonar o cristianismo, todavia o levou a realizar um profundo mergulho, também, em sua raiz cristã. Mais tarde dirá do que ocorreu em si mesmo: "Saí cristão, descobri a mim mesmo como hindu e volto budista, sem ter deixado de ser cristão" ${ }^{938}$, reflexão que revela o peregrinar de sua própria vida, à qual, também, agregou a identidade secular ${ }^{939}$.

Anos depois descreverá seu encontro com o hinduísmo e o budismo, dizendo que

foi à Índia como aluno, como aquele que busca, como alguém que se senta sem dificuldades aos pés de um mestre", confessando que "queria identificar-se com sua identidade hindu [...] Sua identidade budista se desenvolveu como resultado do trabalho interior, feito com paciência e humildade ao estilo do Buda ${ }^{940}$.

Dentre os encontros que teve durante esse período, foi muito importante para Panikkar, o que ocorreu com dois cléricos franceses pioneiros do diálogo inter-religioso: o sacerdote Jules Monchanin (1895-1957), o monge beneditino Henri le Saux (1910-1973) e com o beneditino inglês Bed Griffiths (1906-1993). Os três buscaram encarnar-se na realidade hindu, compromentendo-se com sua cultura e religião, até chegarem a declarar-se cristãos e hindus ${ }^{941}$. Panikkar percebeu, depois desse encontro, que continuava um peregrino, um buscador de si mesmo e de Deus, ele assim escreveu: "chegarei a ser mais cristão, tornando-me mais hindu" ${ }^{942}$.

Durante esse período, predomina em seus livros sua reflexão sobre a possibilidade do encontro e o diálogo entre as civilizações e as religiões, contemplando suas vivências sobre a espiritualidade hindu.

Seu encontro com o hinduísmo o remete a sua realidade familiar:

Somente vendo as raízes destas duas grandes tradições e estudando-as, não só pelo que dizem, senão por ser capaz de experimentá-las de forma vivencial, não me

\footnotetext{
${ }^{938}$ PANIKKAR, Raimon. Il diálogo intrareligioso. p. 42.

939 Além de sentir-se triplamente religioso, Panikkar também se considera um homem secular. Quando escreve em 1979 o prefácio para a nova edição do livro O Cristo escondido do Hinduísmo, afirma encontrar-se na confluência (sangam) de quatro grandes rios: as tradições cristã, hindú, budista e secular. Cf., Id., El Cristo desconocido del hinduismo. Madrid: Grupo Libro 88, 1994. p. XVI.

${ }^{940}$ Lapide y Panikkar, Meinen wir denselben Gott? Ein Streitgespräsh, pp.117-120. Apud. RUEDA, José Luiz Meza. La antrolología de Raimon Panikkar e su contribuición a la antropología teológica cristiana. Pontifícia Universidad Javeriana, Bogotá, Colombia, 2009. p. 52. ${ }_{941}$ PRIETO, Pérez Victorino. Más allá de la fragmentación de la teología, p. 56. Não foram estes os únicos cristãos que buscaram uma simbiose com o hinduísmo. Religiosos tão diferentes como o jesuíta Henri Heras (+1955), o carmelita Lambert de la Mère de Dieu (+1968) que chegou a ser também recebido como sannyasi, o trapense Francis Mathieu... e algumas religiosas. Cf. Ibid., p. 58.

${ }_{942}$ PANIKKAR, Raimon. Presentación de La montée au fond du coeur, OEIL, Paris, 1986, p. I.
} 
sinto dividido [...] tendo convivido como o amor de meus pais, que sendo de culturas e temperamentos distintos, não recordo nunca uma falta de amor $\mathrm{e}$ consideração ${ }^{943}$.

Nesta época, volta repentinamente à Europa e viaja por outros países. Obtém o doutorado em Ciências na Universidade de Madri (1958), com a tese Alguns problemas limítrofes entre ciência e filosofia. Sobre o sentido da ciência natural, que logo seria publicado como livro, com o título Ontonomía de la ciencia. Sobre el sentido de la ciencia y sus relaciones con la filosofía (1961). Na tese desse livro, ele contrapõe o conceito de ontonomía ao de heterônoma e autonomia. Tais conceitos, segundo a sua análise, devem ser superados. Além disso, faz uma forte crítica à ciência e à tecnologia, preocupações que estiveram presentes em toda sua vida.

Três anos depois, obteve o Doutorado em Teologia na Universidade Lateranense, em 1961 com seu trabalho El Cristo desconocido del Hinduismo, que se constituiria um de seus livros mais publicados em várias línguas sob o mesmo nome. Em 1964, regressa à Índia e renuncia canonicamente a seus compromissos com a Opus Dei. Deixa de pertencer juridicamente à Obra e incardina-se na diocese de Varanasi. Foi membro da Opus Dei de 1940 até 1964. Anos mais tarde ele dirá sobre seu ingresso à Obra:

[...] Eu a entendi em seu núcleo sacramental mais profundo, como entendo a Igreja. Eu não entrei em nenhum clube [...] Por pertencer à Obra, estrutura sacramental da Igreja, considerei minha entrada como uma iniciação. E toda iniciação é um ponto de partida, uma porta e não uma meta ${ }^{944}$.

Ele continua com suas pesquisas sobre a filosofia hindu. Neste momento, ele escreve: Os deuses e o Senhor, em 1967; Religião e religiões, em 1964; Mistério e revelação: Hinduísmo e Cristianismo, encontro entre duas culturas, em 1966; e vários artigos publicados em muitas partes do mundo ${ }^{945}$.

Panikkar pensava em viver para sempre na Índia, quando recebe o convite para partir para os Estados Unidos, assim ele confessa:

Pensava permanecer ali toda a minha vida. Vivia ali alegre e feliz, na simplicidade [...] Uma vez por mês iria à casa do Bispo de Varanasi [...] Porém tive a péssima ideia de escrever um artigo que descobriu um professor de Harvard; ele gostou a tal ponto de convidar-me para essa universidade na qualidade de professor visitante

\footnotetext{
943 ABUMALHAM, Montserrat. Conversación con Raimon Panikkar. In. Revista de Ciencias de las Religiones. Samâdhânam. Anejo VI (2001): pp.7-26. p. 21.

${ }_{944}^{94}$ MONCADA, Alberto. Historia oral del Opus Dei, p. 130.

${ }^{945}$ Cf. PRIETO, Pérez Victorino. Más allá de la fragmentación de la teología, p. 60.
} 
[...] O bispo me aconselhou aceitar, e quase me obrigou a fazê-lo ${ }^{946}$.

Quando chega aos Estados Unidos, não deixa sua relação com a Índia. Durante mais de vinte anos, de 1966 até 1987, divide seu tempo entre a Índia e os Estados Unidos. Trabalha como professor nas universidades de Harvard e Califórnia, e logo como catedrático na Universidade de Santa Bárbara (Califórnia), onde se instala de maneira quase permanente entre 1971 e 1987, trabalho acadêmico que fez em paralelo com suas atividades em universidades e instituições de outras partes do mundo (Union Theological Seminary de New York, Universidades de Cambridge y Montreal, y United Theological College de Bangalore). Esta etapa foi de uma enorme produção intelectual ${ }^{947}$.

\subsection{A volta para Catalunha e seu retorno à "sua casa" em 1987 até 2010}

Depois de vinte anos de trabalho na Universidade de Califórnia, em 1987, volta para a Catalunha. Desde esse momento até o último dia de sua vida, viveu em Tavertet, um pequeno povoado pré-Pirineu espanhol. Não foi uma etapa de sua vida em absoluto ociosa, continuou com o seu trabalho acadêmico e ministerial, porém em um ritmo diferente por causa da sua idade e estado de saúde. Foram anos de grandes produções bibliográficas, em que escreveu novos livros e atualizou outros tantos ${ }^{948}$.

\footnotetext{
${ }^{946}$ PANIKKAR, Entre Dieu et le cosmos. Entrevista com Gwendoline Jarczyk, Albin Michel: Paris, 1998. Uma longa entrevista entre Panikkar e esta pensadora especialista em Hegel e Eckhart. Edição em catalão, 2006. p. 21.

${ }_{947}$ Os livros publicados nessa época foram: Kerygma und Indien (1967), Técnica y tiempo. La tecnocronía (1967), L'homme qui devient Dieu. La foi, dimension constitutive de l'homme (1969), El silencio de Dios (1970) que anos mais tarde sairia atualizada como El silencio del Buddha (1996), The Trinity and World Religions (1970), obra revisada e aumentada em The Trinity and The Religious Experience of Man. Icon, Person, Mystery (1973) y en La Trinidad. Una experiencia humana primordial (1989), Dimensioni mariane della vita (1972), Worship and Secular Man (1979), Salvation in Christ (1972), Spiritualità indù (1975), The Vedic Experience (1977), The Intra-religious Dialogue (1978), Myth, Faith and Hermeneutics (1979), Blessed Simplicity. The Monk as Universal Archetype (1982).

${ }_{948}$ Nesta etapa publicou novos livros e outros que atualizaram abordagens feitas anos atrás: $L a$ torre di Babele. Pace e pluralismo (1990), Der Weisheit eine Wohnung bereiten (1991), La nueva inocencia (1993), The Cosmotheandric Experience. Emerging Religious Consciousness (1993), Ecosofia: la nuova saggezza. Per una spiritualità della terra (1993), Paz y desarme cultural (1993); La experiencia de Dios (1994); Meinen wir denselben Gott? Ein Streitgespräsh (1994), La experiencia filosófica de la India (1997), Il "daimôn" della politica (1995), Invisible Harmony. Essays on Contemplation Responsibility (1995), Entre Dieu et le cosmos (1998), La pienezza dell'uomo. Una cristofania (1999); El mundanal silencio (1999), El diálogo indispensable. Paz entre las religiones (2003), De la mística. Experiencia plena de vida (2005), Lo spirito della parola (2007), entre outros. Ele nos deixou uma grande obra publicada que está sendo recolhida
} 
Como ele mesmo dizia: "Escrevo para aprofundar a fé que me foi dada, submetendo minhas intuições ao exame crítico do intelecto e da sabedoria da tradição" 949 .

Por isso, é possível encontrar em toda sua obra o propósito de colligite fragmenta, buscar a união dentro de uma "harmonia invisível": "Sou daqueles que creem que não tem que voltar a andar para trás. Cada novo esforço intelectual é um lançar-se para adiante [...] O que tento, justamente, é superar a fragmentação do saber e a fragmentação da vida humana" ${ }^{950}$.

Desta maneira podemos entender, segundo A. Rossi ${ }^{951}$, por que seu desejo de compreender a realidade. Sua obra vai além dos desafios da filosofia, da ciência, da história das religiões e do desenvolvimento tecnológico, apresenta-se como um projeto coerente de construir uma espiritualidade a altura do homem contemporâneo. O pensamento de Panikkar está marcado por sua experiência religiosa. Para ele, é impossível fazer uma leitura da realidade se não for através da religião ${ }^{952}$.

Embora tenhamos falado da quádrupla identidade de Panikkar como cristão, hindu, budista e secular, foi a primeira que mais marcou sua vida e seu pensamento. Ele afirma:

Eu me confesso cristão porque reconheço minha pertença a uma tradição histórica humana chamada cristã [...] Minha crença está ligada ao núcleo da crença cristã e me reconheço em comunhão com a Igreja cristã. Porém, comunhão não significa para mim obedecer a um partido, nem um seguimento cego, nem estar de acordo acriticamente com as políticas de uma igreja oficial particular $[\ldots]^{953}$.

Panikkar manteve durante toda sua a vida uma profunda identidade sacerdotal, "Eu sou sacerdote in aeternum, secundum ordinem Melchisedech". Vale lembrar que como sacerdote foi, em Madri, capelão dos universitários em um Colégio Maior e professor no Seminário (1946-1950). Em Salamanca, foi capelão dos estudantes (1950-1953). Em Varanasi (1954-1960/1964-1970) e em Roma (1960-1963), atuou como capelão para estudantes universitários. Nos

\footnotetext{
pela editora Jaca Book (Itália), em que estão previstos 18 volumes.

${ }_{949}^{9}$ PANIKKAR, Raimon. La plenitud del hombre, p. 14.

${ }^{950} I d$., Reflexiones autobiográficas, p. 22.

${ }^{5} 1$ Cf. ROSSI, A. Pluralismo e armonía. Introduzione al pensiero di Raimon Panikkar. Roma: L'altrapagina, 1990. p. 5.

${ }^{952}$ Cf. PANIKKAR, Raimon. Cometas, p. 13.

${ }^{953}$ Id., A Self-Critical Dialogue. En The intercultural Challenge of Raimon Panikkar editado por Joseph Prabhu, 227-291. Maryknoll, NY: Orbis, 1996. p. 263
} 
Estados Unidos, colaborou na paróquia de Santa Bárbara ${ }^{954}$.

Em Tavertet, seguiu exercendo seu ministério pastoral em retiros, palestras e acompanhamento individual. No dia 26 de agosto de 2010, aos 91 anos, Panikkar retorna a "sua casa", na harmonia que sempre buscou com a Realidade. Como uma gota de água caída no mar e encontra-se definitivamente no Todo.

\subsection{Igreja, "comunhão de Deus com todo o povo"}

Para Panikkar, a Igreja católica era "a comunidade constituída pela assembleia de todos os que buscam a verdade com retidão... reúne todos os que não se excluem da salvação, embora estejam fora da Igreja institucional" ${ }^{955}$.

Ou seja, para ele a Igreja é "comunhão de Deus com todo o mundo",

Se a Igreja não é comunhão, o que é? Não é este o mistério de Cristo que por amor ao mundo estabelece esta comunhão, a mais íntima que se pode ter, que é a encarnação, que é a comunhão total? A essência da Igreja é esta comunhão, tanto no horizontal, entre os homens, quanto no vertical, com o divino. A Igreja é Sacramentum mundi... mysterium tou kosmo, o mistério do cosmos ${ }^{956}$.

Sua relação com a Igreja se dá a partir de sua fé no "mistério cósmico da Igreja", uma Igreja que ele defende como "lugar universal de salvação" e "sem limites definidos". Sua dimensão cósmica e mistérica não nega sua dimensão histórica, social e jurídica, porque, mesmo encarnada na história, não se reduz às coordenadas espaço-tempo, por ter sua origem e sua fonte no mistério trinitário divino.

Acredito agora e sempre no 'mistério cósmico da Igreja'... a Igreja não possui limites definidos... Acredito na validade deste adágio, pela simples razão de que a Igreja em que creio definiu-se mais que o lugar da salvação. O lugar da salvação se encontra em uma praia ou em uma religião, em tal edifício ou no seio de uma família, ou bem seguindo fielmente uma Igreja, então, aí estará a Igreja ${ }^{957}$.

De acordo com Panikkar, a "ordem de Melquisedeque" significa muito mais que uma liturgia. Manifesta a dimensão do sacerdócio e particularmente do sacerdócio cristão:

Sua missão é definitiva e histórica, sair ao encontro de Abraão e restabelecer o vínculo que o unia ao sacerdócio universal da humanidade desde o princípio do mundo [...] Significa, em uma palavra, que Cristo, o Alfa e Ômega, o Princípio e o

\footnotetext{
${ }^{954}$ Cf. PRIETO, Victorino Pérez. Más allá de la fragmentación de la teología, p. 86.

${ }_{955}$ PANIKKAR, Raimon. Entre Dieu et el cosmos, p. 49.

${ }^{956}$ Diálogo com Raimon Panikkar, em 1995. www. Il-margine.it/archivio/1995/c6 apud. PRIETO, Victorino Pérez, Más allá de la fragmentación de la teología, p. 80.

${ }^{957}$ PANIKKAR, Raimon. Entre Dieu et el cosmos, p. 47.
} 
Fim em quem todas as coisas subsistem e por cujo meio tudo existe, já estava antes de Abraão. Existe um só sacerdote na nova Aliança, porque existe um só sacerdote ao final dos tempos, o Redentor. Melquisedeque é o sacerdote cósmico de uma nova natureza caída que, contudo espera com ansiedade; essa é precisamente a linha de Cristo, que vem redimir o Homem em seu ser ${ }^{958}$.

O sacerdócio é "uma constituição do seu ser", "O sacerdócio não é uma ocupação, nem um ofício, senão uma constituição mesma de meu ser”. E reafirma sua dimensão comunitária: “o sacerdote é incompreensível sem uma comunidade, não tem razão de ser sem o povo, sem o povo fiel para o qual e do qual é um pessoa sagrada" ${ }^{959}$. Sua essência está na mediação:

Compreendo o sacerdócio como uma mediação. O sacerdote é um mediador, não um intermediário... Não é um burocrata ou um funcionário de Deus... Favorecer a mediação quer dizer, frequentemente, fazer a obra de paz... Também no campo da liturgia... como o que nos deve ajudar a superar... a dimensão puramente biológica da vida do homem ${ }^{960}$.

E ainda que: "O sacerdócio não é somente da Igreja, do Deus judeu ou do Deus cristão; é uma figura religiosa primordial. É a iniciação que nos abre ao reino do Sagrado, aquela dimensão mistérica, sacramental, da realidade" ${ }^{\$ 961}$.

Nesta compreensão sobre o sacerdócio, ele decidiu romper com a lei do celibato por entender que esta disciplina não estava unida à identidade do sacerdócio católico e contraiu matrimônio com María González Haba, espanhola, da região de Andaluzia, e doutora em filosofia. Ele já estava com mais de 60 anos. Os dois adotaram duas crianças da Índia. E permaneceu sempre como sacerdote da Igreja Católica. Esta decisão ocorreu, segundo Panikkar, depois de um "longo colóquio com as autoridades competentes" que durou três anos, indo e vindo da Índia e passando por Roma; até que por fim "compreenderam" sua posição ${ }^{962}$. Ele continuou pertencendo à diocese de Varanasi, celebrando a eucaristia com a comunidade de Vivarium.

Sobre sua fidelidade à Igreja ele afirma categoricamente: "Uma coisa é certa, minha fidelidade à Igreja, minha obediência à Hierarquia, minha entrega ao

\footnotetext{
${ }^{958}$ PANIKKAR, Raimon. Meditación sobre Melquisedec, Nuetro Tiempo, 102 (1962) pp. 675695, p. 693. Apud PRIETO, Victorino Pérez, Más allá de la fragmentación de la teología. p. 88.

${ }^{959}$ PANIKKAR, Raimon. Cometas, p. 269.

${ }^{960}$ Id., Entre Dieu et le cosmos, pp. 57, 59 e 61.

${ }^{961} I d$., Uno no es feliz hasta que no se encuentra a sí mismo, entrevista de Nuria Oriol, Missión Abierta, p. 7 (1996) 6. Apud. PRIETO, Victorino Pérez, Más allá de la fragmentación de la teología, p. 90.

${ }^{962}$ Cf. PRIETO, Victorino Pérez, Más allá de la fragmentación de la teología. p. 87.
} 
Corpo Místico... Uma coisa quero deixar claro: Minha fidelidade à Igreja e minha continuidade com a tradição"963.

\subsection{Um Panikkar ou vários Panikkar?}

Segundo J. D. Soriano Escobar ${ }^{964}$, em sua tese sobre Panikkar, é possível encontrar três mentalidades associadas a três períodos de sua vida: $\mathrm{O}$ 'primeiro Panikkar' é marcado por seus estudos de física, química e filosofia, que se desenvolvem entre 1930 e 1960. Ele mesmo diz que:

comecei com o estudo da matéria. Durante sete anos foram a física e a química minhas ocupações intelectuais mais sérias. Depois comecei ao mesmo tempo os estudos de filosofia, porém não porque me sentisse desenganado de meu trabalho científico. Em vez disso, se deu por causa da continuidade dos meus interesses; meu pathos filosófico existia desde o princípio. Necessitava somente paciência até que fui capaz de dedicar-me a ele profundamente e de modo sistemático. Seguiram longos anos de rigoroso estudo filosófico e de atualidade intelectual ${ }^{965}$.

Neste primeiro momento, Panikkar é um cientista e um filósofo profundamente religioso que se move dentro da teologia católica. É um bom conhecedor de Santo Tomás de Aquino e com clara adesão ao Magistério da Igreja. Sua preocupação é mostrar uma visão teológica da ciência, que ele denomina Teo-física, segundo ele: “A expressão deve compreender-se. Não se trata de uma física de Deus, senão do Deus da Física, isto é, do Deus criador do mundo, ou, com outras palavras, do mundo, não como ser autônomo, isto é, independente e desconectado de Deus, senão constitutivo e ontonômicamente religado a Ele" 966 .

O 'segundo Panikkar' resulta do período em que esteve na Índia entre 1954 e 1966. Este será um período de sua vida que será determinante para o desenvolvimento do seu pensamento. Para Escobar, o seu interesse intelectual mudará totalmente. Ele se torna um promotor do diálogo entre as religiões, em especial, o Hinduísmo e o Budismo com o cristianismo. E promoverá o encontro

\footnotetext{
963 PANIKKAR, Raimon. Cometas, p. 60.

964 ESCOBAR, J.D. Soriano, Revelación, cristianismo y religiones en la obra de Raimundo Panikkar. Universidad Pontificia de Salamanca, 1996. Nesta parte de nosso estudo desenvolveremos o tema a partir da tese de Escobar.

${ }^{965}$ PANIKKAR, Raimon. Autobiografía intelectual, 13.

${ }^{966}$ Id., Ontonomía de la ciencia. Sobre el sentido de la ciencia e sus relaciones con la filosofia, Gredos: Madris, 1961. p. 205.
} 
com as culturas orientais e ocidentais ${ }^{967}$. Quando lhe é perguntado sobre o que significou em sua vida e pensamento a experiência na Índia, ele responde:

é para mim é muito difícil responder a esta pergunta, porque em todo desenvolvimento existe uma mudança não sei se consciente [...]. Acredito evidentemente que tem ocorrido uma evolução em mim. Havia algo que me faltava. Eu vejo agora. Por exemplo: havia sido educado em duas religiões de uma forma harmoniosa. Minha formação teológica estava mais inclinada no sentido do cristianismo, e precisamente porque era filho do seu tempo, estava orientado na direção pós-tridentina, antes do Vaticano II, ouvindo que o cristianismo era a religião dominadora de tudo, superior a tudo, quase exclusivista. Eu não acreditava totalmente, porém não posso negar que tenha sido uma grande parte da minha formação teológica recente. Vou à Índia, falo com teólogos indianos e me dou conta que as coisas não são tão simples. Então se inicia um esforço de integração e me dou conta que a teologia não é uma coisa que se aprende de memória, senão que surge de uma experiência pessoal em que se integram todas as informações. Por tanto, o que aconteceu foi que comecei a ser mais eu mesmo, que comecei a ser cristão pelo fato de ser mais hindu ${ }^{968}$.

Panikkar acredita que sua experiência na Índia o ajudou a ter um cristianismo mais profundo, universal e flexível. A obra que marcará este período é sua tese doutoral em teologia: El Cristo desconocido del Hinduismo, em 1970. Neste livro, Panikkar trata de colocar os filósofos indianos ao alcance do pensamento cristão. E seguindo São Paulo, afirma que Cristo não está consumado, está presente, inclusive sofrendo, fazendo-se o Cristo total em toda a humanidade. Então, o cristianismo e hinduísmo se encontram em Cristo:

Cristo é seu ponto de coincidência. O verdadeiro abraço somente pode ter lugar em Cristo, porque somente em Cristo podem coincidir. Não podemos 'provar' esta declaração de modo racional. Podemos somente tentar demonstrar que não pode coincidir em nenhum outro lugar e que, tendo em conta o que ambas representam, só podem coincidir em Cristo, se é que de alguma maneira se encontram ${ }^{969}$.

Para Panikkar, esse encontro do cristianismo e hinduísmo não se dá na esfera doutrinal, senão em um nível profundo, que é denominado por ele: ônticointencional ${ }^{970}$. Ou seja, aprofundar o "nível existencial" que tem as duas religiões. Para ele é necessário descobrir Cristo no hinduísmo e a atitude cristã não deve ser de mando, senão de serviço. Cristo morreu e ressuscitou para todos os homens antes e depois dele, sua redenção é universal e única. Além do mais é portador da revelação definitiva. Para Panikkar, a revelação significa desvelamento,

967 ESCOBAR, J. D. Soriano, Revelación, cristianismo y religiones en la obra de Raimundo Panikkar. p. 19.

${ }^{968}$ PANIKKAR, Raimon. La vocación humana es fundamentalmente religiosa. Anthropos, pp. 5354 (1985): pp.16-25. p. 20.

${ }_{969}$ Id., El Cristo desconocido del Hinduísmo, p. 33

${ }^{970}$ Cf. Ibid., p. 31. 
descobrimento da realidade, que nos permite descobrir o verdadeiro rosto de Deus $^{971}$.

O 'terceiro Panikkar' é o Panikkar que está preocupado com a sociedade ocidental e quer ajudar a encontrar uma solução para os seus grandes problemas: falta de sentido, individualismo, intolerância, ausência de paz, etc. Este resume sua vida filosófica sob dois prismas: "risco existencial" e "responsabilidade intelectual" ${ }^{\prime 972}$.

O risco existencial é o de uma vida que se enraíza em mais de uma cultura e religião, de uma existência entregue à "ortopraxis" mais que uma "ortodoxia". Suas circunstancias pessoais (biológicas), o tem feito possível aceitar o "risco" de uma conversão sem alienação, e repúdio, a síntese ou simbiose que ele pretende realizar sem cair no sincretismo ${ }^{973}$.

A responsabilidade intelectual não é mais leve do que o risco existencial. Para ele consiste em ter que expressar suas experiências fundamentais de uma maneira compreensível. Para isso, sua obra Ontonomia (nómos tou óntos) referido ao nomos interno e constitutivo de cada coisa, contribui, acredita ele, ao mútuo entendimento e fecundação dos distintos campos da atividade humana e a esfera do ser, permitindo o crescimento sem romper a harmonia. Para Panikkar o Símbolo ${ }^{974}$, introduz as diferenças simbólicas e irredutíveis, como a ontologia e a teologia. Esta diferença simboliza a estrutura de toda a realidade, simbólica dela mesma que transcende a dicotomia entre sujeito-objeto, tanto no campo epistêmico como no ontológico. Pistema ${ }^{975}$, necessário para compreender o último fenômeno humano, isto é o fato religioso. O diálogo dialógico ${ }^{976}$ indispensável

\footnotetext{
${ }^{971}$ Cf. PANIKKAR, Raimon. El Cristo desconocido del Hinduísmo p. 79.

972 ESCOBAR, J. D. Soriano. Revelación, cristianismo y religiones en la obra de Raimundo Panikkar. p. 24.

${ }^{973}$ Cf. PANIKKAR, Raimon. Autobiografía intelectual, pp. 12-15.

${ }^{974}$ Nosso autor nos diz: "O símbolo é tão somente quando simboliza e então é quando transcende o hiato entre objeto-sujeito. O símbolo não se encontra nem ao lado do sujeito, nem ao lado do objeto, senão na relação existente entre os dois. Reconhecer o ser como símbolo, abre, segundo penso, um novo capítulo no encontro com as culturas e concepções do mundo". Cf. Ibid., p. 15.

975 Ou seja,"se a pura fenomenologia nos tem permitido compreender os mais díspares estados de consciência usando uma apropriada epoché para compreender e alcançar o noema intelectual e inteligível, o pistema necessita para compreender o último dos fenômenos humanos, isto é o fato religioso [...]. Assim para compreender o que o homem é, necessito conhecer o que crê o homem de si mesmo; ou seja, necessito compreender até certo ponto suas próprias crenças". Ibid., p. 15.

976 Segundo Panikkar, "o diálogo dialogal é radicalmente diferente do diálogo dialético: não pretende convencer o outro, ou seja, vencer dialeticamente o interlocutor [...] O diálogo dialogal, pressupõe uma confiança recíproca em um aventura comum ao desconhecido [...], nos leva a conhecer na medida que somos conhecidos e vice versa [...], desce ao diálogo com culturas concretas [...] O diálogo dialogal implica portanto, todo nosso ser e requer tanto um coração puro
} 
para atravessar o logos e assim alcançar o significado do mito. O caráter tempiterno ${ }^{977}$ da realidade faz alusão ao aspecto temporal da mesma globalmente considerada; este caráter é somente um aspecto parcial da natureza tempiterna de cada coisa. A realidade não se esgota em sua temporalidade, não é agora temporal e depois eterna, senão "tempiterna". Intuição "cosmoteândrica ou teantropocentrismo" responde ao fato de que a realidade é não dual e cada coisa tem "três" dimensões constituintes: a cósmica, a humana e a divina, ou em outras palavras: a material (espaço-temporal), a intelectual (consciente e a mistérica) ${ }^{978}$.

Em síntese, este terceiro Panikkar é um intelectual que pensa, medita, pesquisa, fala e propõe um novo método de análise filosófico e teológico para um Ocidente que tem perdido, segundo ele, seu conteúdo noético, ético e estético.

Segundo Escobar, todo o enfoque acerca da verdade e da realidade que Panikkar nos apresenta nesta etapa, parte de uma hipótese prévia que aparece como inquestionável: existe a plenitude, a regra ideal, a realidade última, ou seja, existe quem finaliza nosso destino e caminho. E é onde surge a realidade religiosa e especificamente Cristo como fundamento de todo seu pensamento. Esta convicção tem implicações na maneira de conceber o ser humano, as sociedades, a cultura, a política e a espiritualidade. Isto se vê refletido em sua preocupação pela paz, e o diálogo intercultural, a resistência aos atropelos da modernidade e da mística como experiência vital. Neste ponto está a conexão dos três Panikkar ${ }^{979}$. Sobre essa consideração dos três Panikkar, o mesmo falou:

Existe um processo de crescimento e desenvolvimento em todo intelectual, então eu não posso negar a priori que possa haver três Panikkar, existe, contudo, uma unidade não-dualista em meu pensamento que poderia dar a impressão de multiplicidade quando se trata somente do polifacetismo que tenho chamado relatividade (diferença do relativismo que repudio) ${ }^{980}$.

Diferente de Escobar, Victorino Pérez reconhece que existe uma evidente evolução em nosso autor, desde uma concepção tradicionalmente católica -

como uma mente aberta". Cf. PANIKKAR, Raimon. Paz e interculturalidad. Una reflexión filosófica. Barcelona: Herder, 2006. pp. 52-57.

${ }_{977}$ Panikkar destaca que: "se experimenta a tempiternidade quando se vive a "vida eterna" nos mesmos momentos temporais de nossa existência. Não é uma vida nem depois do tempo nem fora do espaço, porém não se esgotam nela os parâmetros espaços-temporais. Quando estes momentos temporais se revelam 'eternos' se começa a viver a vida eterna que é a vida ressuscitada". Cf. Id., De la mística, p. 254.

${ }_{978}$ Cf. Id., Culto y secularización. Madrid: Marova, 1979.

${ }^{979}$ Cf. ESCOBAR, J. D. Soriano. Revelación, cristianismo y religiones en la obra de Raimundo Panikkar. p. 27.

980 PANIKKAR, Raimon. Carta personal, 6. 1989. Apud. ESCOBAR, J. D. Soriano. Revelación, cristianismo y religiones en la obra de Raimundo Panikkar. pp. 27-28. 
inclusive apologética - com um pensamento neotomista, até a amplíssima aproximação universal que o leva a um diálogo não somente inter-religioso, senão intrarreligioso. Porém não parece tão clara essa separação, quiçá não tão radical a diferença do jovem Panikkar e o maduro Panikkar como pode parecer. Apesar das profundas mudanças que teve em sua vida, e da impressão que estas tiveram na evolução de seu pensamento, cremos que existe uma continuidade e que encontramos como um filum, um fio condutor constante dos primeiros escritos: a pretensão de assumir tudo e levá-lo até sua última raiz, até sua plenitude em uma constante busca pela harmonia ${ }^{981}$.

É o que se confirma quando comparamos os primeiros escritos de Panikkar com os mais novos, a sua evidente evolução, presente na busca da síntese e harmonia total. E isto responde a uma experiência humana comum: somos homo viator, somos seres em processo, como em alguma ocasião ele bem recordou. Ele mesmo resume a evolução de sua concepção de Deus em três passos fundamentais que se implicam um no outro: "Do Deus imóvel ao Deus relação". É a evolução de um Deus distinto do mundo, pessoal, infinito e eterno frente a um mundo finito e criado $^{982}$ e o Deus em íntima relação com o mundo da intuição cosmoteândrica $^{983}$.

Sobre a primeira parte de sua vida temos um livro de caráter mais ou menos autobiográfico, Cometas. Fragmentos de um diário espiritual do pós-guerra, publicado anos depois, em 1972. Em uma Carta-Prefácio fala de sua atividade: aulas, exercícios, negociações, etc, porém também fala sobre "orar, meditar, sofrer e desfrutar", participando "na teândrica situação de nossa existência". Ali expõe nosso autor como assume sua evolução: "Quem nega o passado torna mais dependente dele que quem o considera como tal, sem ressentimentos nem repressões" 984 .

Três décadas depois, Panikkar escreve em outro livro: "por pertencer à Opus Dei a estrutura sacramental da Igreja, considerei minhas entrada na Obra como uma iniciação. E toda iniciação é um ponto de partida, uma porta e não uma

\footnotetext{
${ }^{981}$ PRIETO, Victorino Pérez. Más allá de la fragmentación de la teología, p. 66.

${ }^{982}$ PANIKKAR, Raimon. El concepto de natureza. Análisis histórico y metafísico de un concepto, CSIC, Madri, 1972, pp. 13-14.

${ }_{983} \mathrm{Cf} . \mathrm{Id}$., La intuição cosmoteândrica.

${ }^{984}$ Id., Cometas, p. 18.
} 
meta" 985 .

Panikkar superou clara e expressamente o conceito de cristandade por outro, a "cristofania", que quer manifestar uma mutação na autocompreensão da consciência e a identidade cristã para uma religiosidade mais pessoal: "Cristofania é a forma de viver o cristianismo no terceiro milênio, superando o segundo milênio, que foi de um cristianismo mais ou menos enxertado de cristandade"986.

Encontramos diferenças importantes na maneira de Panikkar entender e defender o velho dogma católico "Extra Ecclesiam nulla salus" e em sua visão radicalmente ecumênica posterior, em que todas as religiões podem ser verdadeiros caminhos de encontro salvífico com Deus. $\mathrm{O}$ artigo dos anos 50 afirma em suas primeiras páginas: “Aqui se afirma que a exclusividade moral, senão ontológica... fora da Igreja não existe cultura, sociedade, mundo de consistência durável" ${ }^{987}$.

Anos depois, o faz já na perspectiva claramente ecumênica, falando da salvação cristã mais além da perspectiva exclusivista e da perspectiva inclusiva. Para a primeira, a salvação "é um privilégio"; para a segunda, "preserva a identidade incluindo os outros que não são do próprio grupo: cristãos anônimos, batismo de desejo" 988 . E inclusive, mais além de certa ideia de Igreja que tenta superar a tensão entre algo histórico concreto para chegar a uma concepção em que a Igreja se pode encarnar em qualquer realidade cultural e inclusive existencial: "Trata-se da tensão entre a Igreja considerada uma organização social visível ou um corpo místico" $" 989$.

A partir de sua concepção de fé e de pertença à Igreja que não quer ser sectária, Panikkar confessa: "Minha fé em Cristo não é algo que me separa dos outros homens e de todas as coisas, senão exatamente o contrário... Minha crença no Cristo me faz mais homem, mais material e também mais divino" 990 .

Em uma de suas entrevistas, manifesta que "a máxima formulação da autoidentidade da Igreja... por definição, é o lugar de salvação: Onde há salvação,

\footnotetext{
${ }^{985}$ MONCADA, Alberto. Historia oral del Opus Dei, p. 130.

986 PANIKKAR, Raimon. Reflexiones sobre religión y Europa, Alandar, Madrid, 1997, p. 14. Aprofundaremos esse tema mais adiante.

${ }^{987}$ Id., Humanismo e cruz, Rialp, Madrid, 1963, pp. 163-177.

${ }^{988}$ Id., Salvation in Christ: Concreteness anda Universalitty, The Supername, Tantur, Jerusalem, 1972, pp. 6-7.

989 Ibid., p. 8.

${ }^{990}$ Id., La vision cosmoteandrica: El sentido religioso emergente del tercer milênio, Qüestions de vida cristiana, 156, 1990. pp. 79-80.
} 
ali existe Igreja...". Se bem, que isto "é no sentido simbólico que temos perdido, não no conceitual"991.

Encontramos também uma mudança quando ele fala de missões. Em um texto publicado em Humanismo e cruz, em $1947^{992}$, ele defendia a missão como necessidade de expansão católica. E já em um trabalho publicado trinta anos depois fala da missão em diálogo, um encontro em profundidade entre as diferentes religiões ${ }^{993}$.

Acreditamos que Panikkar tenha passado por um processo de grande evolução em seu pensamento, a partir de sua constante busca espiritual. Ele mesmo declara: "minha grande inspiração era e é abarcar, ou melhor, tornar a ser (a viver) a realidade em toda a sua plenitude" ${ }^{\text {"994 }}$. Encontramos em nosso autor uma vocação que não é limitada apenas ao campo científico filosófico, mas por aspirar a uma plenitude existencial apresenta-se, indubitavelmente, como uma vocação religiosa. Seu itinerário religioso parte de uma herança ricamente cristã que ele assumiu e no esforço por superar suas próprias contradições.

\section{Buscar a unidade harmônica de toda a realidade}

Panikkar já demonstrava, desde a sua formação religiosa e intelectual ${ }^{995}$, seu desejo de integração de toda a realidade. Em um de seus artigos, declara sobre a filosofia que:

A filosofia é para mim sabedoria do amor, mais que amor a sabedoria... A filosofia é uma área especialíssima do amor... Não é simplesmente eros ou ágape ou bahkti ou prema. É a sophia (jñana) contida no amor primordial... E a sabedoria emerge quando o amor do conhecimento e o conhecimento do amor se unem ${ }^{996}$.

Apoiando-se em textos escolásticos e místicos,

a essência da natureza é o amor. O amor é o vínculo unificador de todo o universo e a força interna que o anima. $\mathrm{O}$ amor é juntamente com a inteligência o reflexo mais perfeito da Divindade [...] O último fim de todos os seres é Deus, e de Ele têm recebido a força e o impulso para amá-lo... O fim de toda criatura é o amor, já que amar é unir-se com o amado em união mais perfeita que o conhecimento ${ }^{997}$.

Outro elemento importantíssimo para sua filosofia, apontada também no seu itinerário vital e intelectual é a interculturalidade. Considerado por ele como um

\footnotetext{
${ }^{991}$ FORCANO, Benjamin. Entrevista a Raimon Panikkar, Exodo, 65 (2002) pp.10-17. p. 13.

${ }^{992}$ Cf. PANIKKAR, Raimon. Humanismo y cruz. Madrid: Rialp, 1963. pp. 153-162.

${ }_{993}$ Cf. Id., La transformación de la misión cristiana en diálogo, Madrid, 1992.

${ }^{994}$ Id., Autobiografia intelectual, p. 13.
} 
profundo problema existencial. Segundo ele, o pluralismo é um problema humano existencial. É uma questão prática que tem sua raiz na coexistência humana de quem habita este mundo com todas as nossas diferenças peculiares próprias ${ }^{998}$.

E mais ainda, a interculturalidade se vê como um fato cotidiano que traz consigo um pressuposto e um exigência. Quando ao pressuposto, temos um imperativo cultural: uma só cultura não é possível encontrar saída para a complexidade do mundo contemporâneo ${ }^{999}$. Sobre a exigência: é necessário o reconhecimento do outro como um legítimo outro ${ }^{1000}$.

O que é imprescindível, para Panikkar, é levar em conta as várias culturas para chegar a um verdadeiro conhecimento da realidade. "As diferenças culturais são, portanto, diferenças humanas e não podemos, por isso, ignorá-las nem eliminá-las ao tratar dos problemas humanos. Assim, como se deve respeitar a personalidade de cada um para que a rede de relações humanas não se rompa" ${ }^{1001}$.

A interculturalidade é hoje muito mais do que uma discussão acadêmica: é uma necessidade vital para a sobrevivência humana.

Possivelmente nenhuma cultura pode ensinar nada às demais, porém toda cultura pode aprender muito com as outras. E me atreveria a dizer que somente sobreviveriam aquelas que sabem aprender com as outras, o qual não é sinônimo de deixar-se ensinar, nem menos ainda colonizar. 'Aprender' quer dizer assimilar sem perder a identidade ${ }^{1002}$.

A interculturalidade é um caminho para conhecer-se a si mesmo. "É um convite para descobrir o universal na profundidade do concreto" ${ }^{\text {"1003. }}$.

Segundo Panikkar, a ciência e a filosofia não conseguem captar toda a realidade, ou seja: “A realidade não é totalmente acessível ao pensar científico”. E a teologia completa os pontos de vista da Ciência e a Filosofia com uma

\footnotetext{
${ }^{995}$ Como já vimos em sua trajetória religiosa e intelectual, no primeiro capítulo desta IV parte de nossa tese.

${ }_{996}$ PANIKKAR, Raimon. Autobiografia intelectual, p. 12.

${ }^{997}$ Id., El concepto de naturaleza. Análisis histórico y metafísico de un concepto. Madrid: CSIC, 1951. pp. 257 e 259.

${ }^{998}$ Cf. Id., Sobre el diálogo intercultural. Salamanca: San Esteban, 1990. p. 20.

${ }^{999}$ Cf. Ibid., p. 24.

${ }^{1000}$ Cf. Id., Paz e interculturalidade, p. 147.

${ }^{1001}$ Ibid., p. 16.

${ }^{1002}$ Id., Pensamiento científico y pensamiento cristiano. Maliaño-Madrid: Sal Terrae-Fe y secularidad, 1994. p. 30

${ }^{1003}$ Id., Paz e interculturalidade, p. 91.
} 
perspectiva diferente, com a vantagem de que pretende dar respostas à pergunta final sobre o fim do homem ${ }^{1004}$.

Em seu livro Humanismo e Cruz, dirá:

O que interessa não é a Filosofia, nem a Teologia, nem a Ciência enquanto tais. Interessa a solução harmônica de todos os problemas da vida do homem sobre a terra e sua complexidade apresentam... fundir a síntese pessoal [a unidade do fazer do homem] com a síntese objetiva [estabelecer a ordem cósmica] ${ }^{1005}$.

Ainda buscando a plena comunhão com a Realidade, doutora-se em teologia na Universidade Lateranense de Roma. Com a tese El Cristo desconocido del Hinduismo, ele estuda o encontro entre o cristianismo e o hinduísmo, procurando mostrar que existe uma presença viva de Cristo nesta tradição. Ele parte da ideia comum da vinda de Cristo no fim dos tempos e que todas as religiões podem convergir para Ele, "isto não deve obscurecer a verdade complementar e prévia de que Cristo se acha não somente no fim, mas também no princípio. Não poderia ser o ômega de todas as coisas, se não for também o alfa"1006

Porque "Cristo não é somente a meta ontológica do hinduísmo, senão também sua verdadeira inspiração, e sua graça é a força motriz, embora oculta, que o impulsiona para sua plena manifestação" ${ }^{\text {1007. }}$.

O encontro entre o cristianismo e o hinduísmo deverá acontecer a partir da experiência religiosa, a partir da fé no único Deus manifestado de distintas maneiras. Um encontro em um nível "ôntico-intencional”, baseado na aspiração de oferecer a salvação que tem todas as religiões; todas apontam a mesma meta ôntica: buscar a plenitude e perfeição do ser humano: "união com Cristo", diria um cristão, "união total com o Absoluto", diria um hinduísta, "isolamento puro", diria um yoga, ou "nirvana, diria um budista" 1008 .

Este estudo não é, portanto, uma cristologia hindu, senão um livro que pretende apresentar "um Cristo com sentido para o hinduísmo". A cristologia de Panikkar está presente em sua obra muito posterior La plenitud del hombre. Una cristofanía $^{1009}$.

\footnotetext{
${ }^{1004}$ Cf. PANIKKAR, Raimon. La Trinidad. Una experiencia humana primordial. Siruela, Madrid, 1998.

${ }^{1005}$ Id., Humanismo e cruz, p. 25.

${ }^{1006}$ Id., El Cristo desconocido del hinduismo, p. 15.

${ }^{1007}$ Ibid., p. 16.

${ }^{1008}$ Cf. PRIETO, Victorino Pérez. Más allá de la fragmentación de la teología, p. 110.

${ }^{1009}$ Aprofundaremos este tema mais adiante.
} 
A profundidade do pensamento de Panikkar nasce não apenas de sua capacidade intelectual e espiritual, mas também da interculturalidade e do mundo inter-religioso em que moveu toda sua vida, na busca por "conseguir uma visão cristã do mundo, alcançar uma concepção integral das coisas, ter uma visão cristocêntrica do universo".

Ele testemunha:

Desde meus primeiros anos de mocidade... tenho tido não só uma preocupação religiosa constante, senão um ideal humano, intelectual, único: conseguir uma visão cristã do mundo, alcançar uma concepção integral das coisas, ter uma visão cristocêntrica do universo... era uma preocupação de estar na verdade, santificarme na verdade... Resumindo e compreendendo em toda a plenitude de seu sentido, chamaria isto de minha vocação teológica... Possivelmente minhas expressões sejam chocantes, inoportunas e mesmo inexatas ou inclusive falsas... porém o que vejo, o que sinto, o que quero dizer, expressar, significar... é o que visualizo das almas conscientes do mistério na sinfonia do universo, no caminho do Reino de Deus para a plenitude... Minha visão mística é um anel invisível que reforçam, corrigindo inclusive, outros que vêm depois e cuja missão será coram facie Ecclesiae $^{1010}$.

O pensamento de Panikkar quer harmonizar o logos e o pneuma, o racional e o simbólico, teologia, filosofia, ciência e mística. Para ele deveria voltar a integrar-se no ocidente, de maneira complementar, a religião, a filosofia e a teologia. Segundo V. Pérez Prieto,

é a possibilidade de restaurar o conceito de filosofia e da teologia, mas sem negar a legitimidade da existência de uma ciência racional puramente filosófica. Trata-se de voltar a um conhecimento e uma sabedoria integral da realidade, uma visão completa dos problemas últimos de uma resposta espiritual do ser humano ao problema da existência. Por isso, se trata de um pensamento de claro caráter sapiencial, que requer não só agilidade, senão também virtude moral e reflexiva ${ }^{1011}$.

Ou seja, filosofia e teologia devem caminhar juntas, em união inseparável, sendo esta não-dualista, advaita.

O pressuposto desta síntese consiste, evidentemente, em mostrar que o Deus da razão não é outro que o Deus da religião... Não poder haver dois 'Deuses', o da fé e o da razão... Paulatinamente, a teologia vai convertendo em filosofia e Deus vai sendo absorvido na ontologia: o verdadeiro teólogo é o filósofo e o contemplativo... Toda uma espiritualidade cristã, hindu e muçulmana se fundamenta nesta premissa: o conhecimento da verdade significa plenitude religiosa... É a função salvífica do conhecimento, porque descobre a verdade, alcançada a Realidade: Gnosis, jñâna, alhikmat, salvar ${ }^{1012}$.

Esse pensamento começa a ficar claro quando, ainda preocupado pelo todo, por uma harmonia entre as diversas realidades particulares e as distintas

${ }^{1010}$ PANIKKAR, Raimon. Cometas, pp. 96,97 e 99.

1011 PRIETO, Victorino Pérez. Más allá de la fragmentación de la teología, p. 177.

1012 PANIKKAR, El silencio del Buddha, pp. 201-203. 
concepções culturais do ocidente moderno e do oriente, na autêntica "visão do todo", ele nos fala sobre o particularismo e o universalismo.

Não podemos viver por mais tempo em compartimentos estanques e narcisisticamente satisfeitos no isolamento que deixam de ser esplêndidos para converter-se em miseráveis... Trata-se da interconexão de tudo com tudo, como destaca praticamente todas as místicas ${ }^{1013}$.

Não se pode chegar a alcançar a realidade total se não é desde o particular. Não se pode ser verdadeiramente universal sem ser radicalmente particular. O particular nos faz concretos, nos enraíza em uma cultura e em um lugar concreto para não viver isolados. Só se pode ser verdadeiramente universal desde a própria singularidade maduramente assumida: para ser genuinamente universal é necessário ser radicalmente concreto ${ }^{1014}$.

Seu pensamento está em consonância com o pensamento hindu, ele insiste na relatividade de todas as partes, frente ao absolutismo predominante de uma delas. "O dilema não é o relativismo ou absolutismo, senão o reconhecimento da relatividade radical de toda a Realidade"1015.

Panikkar insiste no que chama de relatividade radical, afirmando que não é o relativismo. Este conceito, que tem um equivalente no hinduísmo pratiyasamutpãda, deve aplicar-se à nossa relação humana, à nossa relação com o mundo, à relação com Deus, com esse mundo, e inclusive à mesma realidade divina:

Deus é relatividade radical ou reciprocidade total. Com isso se quer destacar o caráter de relação constitutiva de tudo com tudo, algo muito distinto de um puro e simples relativismo, que defendo que não existem afirmações válidas negando sua mesma pretensão de validade. O relativismo é pessimista e destrói qualquer critério de verdade, porém sem absolutizá-los ${ }^{1016}$.

Panikkar converte esta relatividade radical, reciprocidade total ou relação em algo constitutivo de toda realidade, incluindo a mesma Divindade. Este é o fundamento de sua concepção da Trindade, que quer ser profundamente cristã.

A relatividade radical nos diz que as coisas somente podem ser constitutivamente relações mutuas se existe uma relação sempre mais profunda que permita transcender a dualidade.

Um simples olhar para o mundo nos faz descobrir que a relação entre os seres não é

1013 PANIKKAR, Raimon. Mistica comparada?, em VV AA, La mistica en el siglo XXI. Trota: Madrid, 2002, p. 228.

1014 Cf. PRIETO, Victorino Pérez. Más allá de la fragmentação da teologia, p. 183

1015 PANIKKAR, Raimon. La Trindad, p. 18

${ }^{1016}$ Id., El silencio del Buddha, p. 234. 
poliédrica, senão radical, de tal maneira que nenhum 'ser' é totalmente explicado por um número limitado de relação. Sempre está em 'espaço aberto' acima de qualquer dualidade. A relatividade radical é a abertura constitutiva de todo o universo em todas as suas relações ${ }^{1017}$.

O que nos leva a compreender a razão pela qual Panikkar apresenta o neologismo, a intuição cosmoteândrica, que expressa aquela "visão da realidade que compreende o divino, o humano e o cósmico, como três constitutivos da realidade sem subordinação alguma entre eles"1018. A Realidade é trinitária e, portanto, tem uma dimensão divina, uma dimensão humana e uma dimensão material. Ele ilustra sua visão cosmoteândrica com a mandala ou círculo:

Possivelmente uma mandala - o círculo - ajudaria a simbolizar esta intuição. Não existe círculo sem um centro e sem uma circunferência. Estas três coisas não são as mesmas e, apesar disso, não são de modo algum separáveis. A circunferência não é o centro, porém sem centro não haveria circunferência. $\mathrm{O}$ círculo, invisível em si, não é nem a circunferência nem o ponto central, e, todavia é circunscrito por uma e implica o outro. $\mathrm{O}$ centro não depende nem do círculo nem da circunferência, já que é um ponto sem dimensões, e, não obstante, não seria o centro - não seria absolutamente nada neste contexto- sem os outros. O círculo, visível somente desde a circunferência, é matéria, energia, é o mundo. E isso é assim porque a circunferência, o homem, a consciência, o envolvem. E estas duas são o que são, porque existe um Deus. Que podemos dizer de uma mandala completa? Temos que distinguir o divino, o humano e o cósmico: o centro não tem que confundi-lo com a circunferência, e esta não devemos mesclar com o círculo, porém não podemos permitir separá-los. Finalmente, depois, a circunferência é o centro "alargado", o círculo é a circunferência "recheada", e o centro mesmo atua como verdadeira "semente" dos outros dois. Existe uma circuminsessio, uma perichôrêsis dos três ${ }^{1019}$.

Esta mandala nos ajuda a entender porque não existem três 'realidades': Deus, o Homem ${ }^{1020}$ e o Mundo; porém tampouco existe uma, ou Deus, ou Homem

${ }^{1017}$ PANIKKAR, El silencio del Buddha, p. 238.

${ }^{1018}$ Id., El mundanal silencio. Barcelona: Martínez Roca, 1999. p. 26.

${ }^{1019}$ Cf. Id., La intuición cosmoteándrica, p. 98.

1020 Sobre o uso do termo homem em seus escritos ele vai nos dizer, que: "Em meus escritos, quanto escrevo 'homem' me refiro ao purusa, anthrôpos, homo, Mensch e não permito que o varão monopolize a palavra. Sou muito sensível a origem depreciativa e até o sentido de denegrir, às vezes, as palavra usuais para designar as "women", "mulieres", etc. A maioria das línguas, diferente do inglês, não confundem o gênero com o sexo. Utilizar a diferença sexual como o mais importante no homem trai uma ideologia particular como a que trairia se disséssemos "ricos e 
ou Mundo. A realidade é cosmoteândrica.

Suas 'realidades' podem diferenciar-se, porém não se separar. Não existe nem monismo, nem dualismo, trata-se de uma relação a-dual (advaita). Isto é o característico do princípio cosmoteândrico.

Não existem três realidades: Deus, o Homem e o Mundo; porém tampouco existe uma, ou Deus, ou Homem ou Mundo. A realidade, para fazer avançar a história, para continuar a criação... Existe um dinamismo e um crescimento em que os cristãos chamam o Corpo místico de Cristo e os budistas dharamakãya. Deus, Homem e Mundo estão comprometidos em uma única aventura e este compromisso constitui a verdadeira Realidade ${ }^{1021}$.

O que esta intuição sublinha é que as três dimensões da realidade não são, nem três modos de uma realidade monolítica indiferenciada, nem três elementos de um sistema pluralista. Existe uma relação, porém intrinsecamente tríplice, que manifesta a constituição última da realidade [...] A visão cosmoteândrica supera a dialética, porque descobre a estrutura trinitária de tudo, e essa terceira dimensão, o divino, não é uma "terceira" oposição, senão precisamente o mysterium coniunctions $^{1022}$.

Para Panikkar, o melhor termo para compreender a realidade cosmoteândrica é a Trindade Radical. "A noção de Trindade Radical é fruto do que temos chamado uma experiência teoantropocósmica, que por razões de respeito à tradição e por ser menos cacofânico temos denominado cosmoteândrica" ${ }^{\prime 1023}$.

E ainda que: "a Trindade não é um monopólio cristão: praticamente todas as religiões têm uma estrutura trinitária" 1024 e "a Trindade não é um monopólio de

pobres", "brancos e negros" para abarcar a raça humana. Não devemos fragmentar nossa personalidade desnecessariamente. Tampouco convém utilizar expressões que nos convertem em simples membros de uma classe, como "humanos" e "ser humano", eliminando com isso nossa dignidade única e não classificável. Em rigor, nem homem nem Deus teriam que ser do gênero masculino, porém permanece o fato de que este último tenha monopolizado tanto o humano como o divino. A palavra "humanidade" nos resulta demais abstrata, e a expressão "gênero humano" implica um ideologia darwinista (como se o homem fosse uma espécie) que nos parece inaceitável. Dizer "homem/mulher" ou "ele/ela" não seria mais que acentuar a divisão na cultura moderna. Por tudo isso, e na espera de um utrum, de um novo gênero que inclua o masculino e o feminino sem ser neutro (neutrum: nem um nem outro), uso a palavra "homem" para referir-me ao anthrôpos. A palavra homem não é um monopólio de varão; acaso deveria ser do gênero epiceno (غ̇лıкoıvós)". Id., El silencio del Buddha, 24. Procurando ser fiel ao autor, permitiremos no texto o uso desse termo, quando por ele utilizado.

${ }^{1021}$ PANIKKAR, Raimon. La Trindad, p. 90.

${ }^{1022}$ Cf. Id., La intuición cosmoteándrica, p. 82.

${ }^{1023}$ Id., La Trindad, p. 90.

${ }^{1024}$ Panikkar afirma que a divisão da realidade em três (sejam espaciais, temporais, metafísicos ou cosmológicos) são comum a todas as culturas humanas. Trata-se de um invariante cultural. Id., The Cosmoteandric Experience. Maryknoll, NY: Orbis, 1993. p. 55. 
Deus. É a última estrutura da realidade. A Trindade é essa visão que considera a realidade constitutivamente relacional entre três polos distintos, porém inseparáveis" $" 1025$.

A interdependência entre Deus-Homem-Mundo implica em si mesma a aventura trinitária que não se trata de três aventuras individuais, a de Deus, a do Homem e a do Mundo. A realidade última é trinitária: ela é divina, humana e cósmica [...] Existem três dimensões do real: uma dimensão de infinito e de liberdade que chamamos divina; uma dimensão de consciência, que chamamos humana; e uma dimensão corporal ou material, que chamamos o cosmos. Todos nós participamos dessa aventura da realidade ${ }^{1026}$.

Sua visão da realidade não se opõe à sua fé cristã:

Se a mensagem cristã significa algo, é esta experiência da realidade cosmoteândrica de todo ser, da qual Jesus Cristo, verdadeiro Deus e verdadeiro Homem é o paradigma. Em Cristo não está a Matéria por sua própria conta, o Homem por sua parte e Deus por outra; nenhuma destas dimensões intrinsecamente unidas leva vantagem sobre a outra, de modo que não tenha sentido afirmar que Cristo é mais divino que humano, mais mundano que celeste, ou vice versa. $\mathrm{O}$ véu da separação foi rasgado e a integração da realidade começa com a redenção do homem $^{1027}$.

E ainda:

$\mathrm{Na}$ intuição trinitária convergem as visões mais profundas das religiões transcendendo o acervo particular de uma cultura determinada. Na experiência trinitária se encontram em profundidade e mútua fecundação as diferentes atitudes espirituais, sem forçar nem violentar as particularidades fundamentais das distintas tradições religiosas ${ }^{1028}$.

Nas possibilidades trinitárias das religiões, na procura por realizar a síntese destas atitudes espirituais, é onde o diálogo das religiões encontra sua mais profunda inspiração e sua mais segura esperança. E como resultado da mútua fecundação das religiões e das experiências que as sustentam, teremos na consciência religiosa da humanidade uma maior integração da experiência do mistério e da vida da Trindade, e com isso uma reintegração do Homem na realização do papel que lhe corresponde na aventura da Realidade ${ }^{1029}$.

Panikkar faz uso de outro conceito o pars pro toto, sobretudo para fundamentar um autêntico diálogo intra-religioso. Significa que a visão que eu tenho do todo da realidade (totum), a realizo, necessária e legitimamente em um

\footnotetext{
${ }^{1025}$ PANIKKAR, Raimon. El silencio del Buddha, Ecosofía. Para una espiritualidad de la tierra. Madrid: San Pablo, 1994. p. 28.

${ }^{1026}$ Id., Entre Dieu et le Cosmos, p. 135.

${ }^{1027}$ Id., Culto y secularización, p. 94.

${ }^{1028}$ Id., La Trindad, p. 66.

${ }^{1029}$ Cf. Ibid., p. 76.
} 
tempo, através de minha particular janela cultural e religiosa $(\text { pars })^{1030}$.

Temos que ser conscientes de que vemos o totum per partem, o todo através da parte. Temos que conceder ao outro, o não cristão, por exemplo, ter uma experiência similar e que diga que o cristão toma a pars pro toto, já desde fora não só vê a parte e não $o$ totum; a janela, não é o panorama ${ }^{1031}$.

O efeito pars pro toto se relaciona de maneira direta com o que ele chama de harmonia invisível, harmonia que deve existir entre todas as religiões e culturas, a mesma que existe em toda a realidade.

A harmonia a que me refiro se manifesta no modo criativo e espontâneo com que trato uma religião particular, porque realmente me encontro como em minha casa e, desta forma, sou capaz de simplificar e de relacionar as coisas dispares, ou unificar práticas. Estou falando de certas identificações com essa religião, que não excluem, por suposto, opiniões críticas nem juízos rigorosos, porém que em qualquer caso, sempre estão formulados desde dentro ${ }^{1032}$.

Ou seja, "quando nossa relação com uma corrente religiosa é neste nível, devemos falar ex abundantia cordis et mentis. Qualquer diálogo religioso autêntico dissipa as péssimas interpretações e proporciona outras novas" ${ }^{\text {"1033. }}$.

\subsection{Toda realidade é cosmoteândrica}

Para Panikkar toda a realidade é cosmoteândrica, e se o ser humano faz parte dessa realidade, ele é uma realidade cosmoteândrica. O princípio cosmoteândrico nos ajuda a reconhecer que o divino, o humano e o terreno são as três dimensões irredutíveis que constituem o real ${ }^{1034}$. A visão cosmoteândrica supera a dialética porque descobre a estrutura trinitária de tudo:

Não existem três realidades: Deus, o Homem e o Mundo; porém tampouco existe uma, ou Deus, ou Homem ou Mundo. A realidade é cosmoteândrica. É nossa forma de olhar para o que faz com que a realidade nos pareça às vezes sob um aspecto e às vezes sob outro. Deus, Homem e Mundo estão por assim dizer, em uma íntima e constitutiva colaboração para construir a realidade, para fazer avançar a história, para continuar a criação. Não se trata de que o Homem esteja trabalhando duramente aqui embaixo, enquanto Deus o supervisiona das alturas com vista a recompensá-lo ou a castigá-lo e que o Mundo permaneça impassível às elucubrações da mente humana ${ }^{1035}$.

A intuição cosmoteândrica não é uma ideia ou um exercício intelectual, é

\footnotetext{
${ }^{1030}$ Cf. PANIKKAR, Raimon. Paz e interculturalidade, p. 134.

1031 Ibid., pp. 134-135.

1032 Ibid., p. 133.

1033 Ibid.

${ }^{1034}$ Id., La intuición cosmoteândrica, p. 82.

${ }^{1035}$ Id., La Trindad, p. 93.
} 
uma experiência (uma experiência mística). Não é uma compreensão analítica. É uma intuição que aparece na consciência humana, uma vez tenha vislumbrado a relação intrínseca entre o cognoscente, conhecido e conhecimento. Em tal dinâmica intervém os "três olhos", o da carne, o do intelecto e o da fé ${ }^{1036}$.

Os três olhos nos permitem "ver" como a realidade mostra sua tríplice dimensão: metafísica (transcendente ou apofática), noética (consciente ou pensante) e empírica (físico ou material). "A intuição cosmoteândrica não é uma divisão tripartida entre os seres, senão um olhar para o centro tridimensional de tudo o que é, enquanto é"1037.

Em outras palavras, o divino, o humano e o cósmico são três dimensões de toda a realidade; Deus, Homem e Mundo são suas "partes" constitutivas. Descreveremos, brevemente, estas três dimensões:

a) dimensão 'divina' da Realidade: Todo ser possui uma dimensão abissal, tanto transcendente como imanente. Todo ser transcende tudo, inclusive, mais precisamente, a 'si mesmo', na verdade, não tem limites. [...] Esta dimensão divina não é uma superestrutura sobreposta aos seres nem um mero fundamento extrínseco a eles, senão o princípio constitutivo de todos os seres ${ }^{1038}$. "Deus não é somente o Deus do Homem, senão também o Deus do Mundo"1039. Deus permite que o Mundo e o Homem sejam por Ele transformados, restaurados em sua essência divina.

b) dimensão 'humana' da Realidade é a consciência presente. Está relacionado com o conhecimento humano. O campo inteiro da realidade vive humanizado nele. O caráter transparente da consciência pertence não só ao homem que conhece, senão também ao objeto conhecido. Isto pode ser chamado de uma

\footnotetext{
${ }^{1036}$ Panikkar afirmou que: “[...] embora em rigor os três olhos não possam separar-se. O que ocorre é que se dá prioridade a experiência sensível, a intelectual ou a espiritual e se interpela a realidade sob o prisma de um olho, com atrofia dos outros dois". Id., De la mística, p.168. E na mesma obra diz "A euforia moderna do racionalismo (não digo da razão) tem provocado a atrofia do terceiro olho, que é o da fé (quando esta não se tem reduzido à crença). "Fides enim est vita animae"( "A fé, pois, é a vida da alma"), escreveu Tomás de Aquino. É esta fé que nos permite gozar a Vida - "vita [...] id in quo maxime delectatur"("da vida [...] aquilo em que temos o máximo gozo"), diz o mesmo mestre". Ibid., La Trindad, p. 24.

${ }_{1037}$ Id., La nueva inocencia. Pamplona: Verbo Divino, 1999. p. 55. Panikkar em algumas ocasiões recorda São Victor, fazendo menção dos três olhos que participam nas três formas de conhecimento: o olho da carne, o olho da mente e o olho do espírito (carnis, mentis et fidei). Cf., Id., De la mística, p. 183. Ricardo de São Victor e Juan de Findenza (conhecido como são Boaventura, franciscanos do século XIII) falaram pela primeira vez dos "três olhos" como forma de ter acesso ao conhecimento.

1038 PANIKKAR, Raimon. La intuición cosmoteándrica, p. 82.

${ }^{1039}$ Ibid., p. 97.
} 
dimensão da consciência, porém pode ser também dimensão humana, pois a consciência se manifesta no homem e através dele ${ }^{1040}$.

c) dimensão 'material' da Realidade. Todo ser se encontra no Mundo e compartilha de sua secularidade. Nada existe que, ao entrar na consciência humana, não entre ao mesmo tempo em relação com o Mundo. E esta relação não é meramente externa e acidental: qualquer coisa existente tem uma relação constitutiva com o Mundo de matéria/energia e do espaço/tempo ${ }^{1041}$. A grandeza e a miséria do Homem também são a grandeza e a miséria do Mundo. Assim como Deus e o Homem guardam uma relação de interdependência, também Deus e o Mundo $^{1042}$.

Para Panikkar,

a intuição cosmoteândrica não se contenta em detectar a 'presença' trinitária na 'criação' e a 'imagem' no homem, senão que considera a Realidade em sua totalidade como sendo a Trindade completa que consta de uma dimensão divina, outra humana e outra cósmica ${ }^{1043}$.

As dimensões da Realidade: Deus, Homem e Mundo coexistem estão interrelacionados e podem ser hierarquicamente integrados, no entanto não podem ser isolados, isto os aniquilaria ${ }^{1044}$. De acordo com o próprio Panikkar, sua intuição cosmoteândrica "representa a consciência religiosa que está aflorando em nosso tempo" ${ }^{\text {"1045. }}$. Pois se percebem sinais de ressurreição na raiz da sensibilidade ecológica, nela existe uma veia mística; na imagem que o homem projeta de si mesmo existe uma necessidade de infinito. E no mesmo coração do divino existe um impulso para o tempo, o espaço e o homem.

\subsection{0 ser humano, uma realidade cosmoteândrica}

O ser humano é uma realidade cosmoteândrica por participar de sua natureza, enquanto ser da realidade: a) possui uma dimensão abissal, talvez transcendente e imanente. Ao ter uma dimensão divina, participa de uma infinita inesgotabilidade, de caráter aberto, é um mistério, é liberdade. b) possui uma

\footnotetext{
1040 PANIKKAR, Raimon. La intuición cosmoteándrica, p. 83.

1041 Ibid., p. 85.

${ }^{1042}$ Cf. Ibid., p. 95.

${ }^{1043}$ Id., La Trindad, p. 14.

${ }^{1044}$ Cf. Id., Op. cit., p. 98.

1045 Id., La Trindad, p. 99.
} 
dimensão da consciência, propriamente "humana", aquela que permite estar no Mundo, compartilhar sua secularidade, mover-se nas coordenadas do espaço e tempo, não de forma acidental, senão de forma constitutiva. Por isso, o homem é espírito, alma e corpo. As três dimensões do ser humano (realidade ad intra) não são outra coisa que o reflexo da perichôrêsis entre Deus-Homem-Mundo

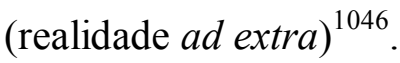

A integração da aventura trinitária a toda a Realidade não diminui nem a transcendência divina nem a diferença entre Deus e o Mundo, de maneira análoga a unidade trinitária não elimina a diferença entre as pessoas divinas ${ }^{1047}$.

Panikkar se utiliza do termo clássico 'Teandrismo' para designar a unidade íntima e plena entre o divino e o humano que se realiza em Cristo. Este termo indica os dois elementos de toda espiritualidade: o elemento humano que serve de ponto de partida e o que o vivifica desde o seu interior, ou seja, sua consequência transcendente. Sendo esta palavra cristã, ela não é exclusiva desta sua tradição. Pelo contrário "está presente como o fim para o que tende a consciência religiosa da humanidade e também como a interpretação mais adequada da experiência mística" ${ }^{\prime 1048}$.

O ser do Homem não pode ser reduzido a uma 'pura natureza' teórica. Sua vocação desde o princípio é ser Filho de Deus, uno com o Filho único. Considerar o Homem como um simples 'animal racional' é negar-lhe o direito a seu verdadeiro fim e privá-lo da esperança de alcançá-lo, pois, "Deus é o fim, o limite do Homem",1049.

$\mathrm{Na}$ esfera antropológica o significado da espiritualidade teândrica é claro. Representa uma síntese harmoniosa, na maior medida possível entre as tensões da vida: entre o corpo e a alma, o espírito e a matéria, o masculino e o feminino, a ação e a contemplação, o sagrado e o profano, o vertical e o horizonta ${ }^{1050}$.

Ou seja,

o ser humano experimenta a profundidade de seu próprio ser, descobre e sente que em seu ser existe algo mais, um plus que está por construir, que pertence a seu ser privado e ao mesmo tempo o transcende. Descobre outra dimensão que não pode manipular. Sempre existe algo mais do que os olhos podem ver, do que a mente pode encontrar ou do que pode comover ao coração. Este mais - mas do que pode perceber, entender e sentir - representa a dimensão divina ${ }^{1051}$.

\footnotetext{
${ }^{1046}$ Cf. PANIKKAR, Raimon. La intuición cosmoteándrica, pp. 82-85.

1047 Id., La Trindad, p. 90.

1048 Ibid., p. 91

${ }^{1049}$ Ibid., p. 92

${ }^{1050}$ Ibid., p. 91

${ }^{1051}$ Ibid., p. 96.
} 
Recordemos a mandala do círculo do qual aproveita Panikkar para ilustrar o 'lugar' que ocupa o Homem dentro da trindade radical e, o mais importante, a reciprocidade que existem entre elas.

Esta mandala nos ajuda a visualizar o centro, que não é sempre fácil. Este centro, imanente e transcendente, às vezes, é o verdadeiro núcleo das três dimensões constitutivas da realidade, cada um das quais está presente e atua no processo de todo o real: o Kosmos (ou matéria e energia), o anthrôpos (ou consciência e vontade), o etheos (ou liberdade, indeterminação absoluta) e o amor, se me permite usar esta palavra de que se tem abusado tanto ${ }^{3052}$.

Panikkar persiste em dizer que o "homem não é um ser isolado e seu vínculo com o corporal e o divino lhe é constitutivo". Afirma ainda que "não existe Homem sem Mundo e sem Deus, nem Deus sem Mundo, nem Mundo sem Deus e sem Homem"1053. Mesmo que se possa pensá-los separadamente, será uma abstração da realidade, não será real. Segundo ele, o ser humano é o mediador entre o céu e a terra.

O homem é um ser entre o céu e a terra. Com os pés toca a terra, porém ao dar-se conta deste toque, observa que tem uma cabeça que pode tocar também o céu com sua visão. Ao dar-se conta de que toca a terra percebe também que toca o céu com um toque distinto do sensível. O que sejam o céu e a terra não sabe, porém é consciente de sua posição de mediador ${ }^{1054}$.

Ele recupera a natureza mediadora do ser humano, "aquilo que nós somos, nosso ser, é precisamente mediação" ${ }^{1055}$. Esta ideia permite estabelecer outra de maior profundidade que aprofunda suas raízes no cristianismo primitivo: o ser humano é um sacerdote cósmico. "O homem é um sacerdote do universo, é um mediador entre o céu e a terra" 1056 .

Como já tínhamos dito a relação Deus-Homem-Mundo é a-dual. A ruptura da harmonia entre Deus-Homem-Mundo não é somente de tipo epistemológico, é existencial: Quando o ser humano rompe sua relação com a terra, querendo bastarse a si mesmo, torna-se um monstro; querendo dominá-la, se destrói a si mesmo. Quando rompe sua relação com os céus, querendo conduzir-se a si mesmo, se

\footnotetext{
${ }^{1052}$ PANIKKAR, Raimon. Elogio de la sencillez. Navarra: Verbo Divino, 2000. p. 166.

${ }^{1053}$ Id., De la mistica, pp. 264-265.

1054 Ibid., p. 86.

1055 Id., Experiencia de Dios. Madrid: PPC, 1994. p. 36.

${ }^{1056}$ Id., Der Mensch ein trinitarisches Mysterium. En Die Verantwortung des Menschen für eine bewohnbare Welt im Christentum, Hinduismus und Buddhismus escrito por Panikkar y W. Strolz, pp. 147-190. Freiburg: Herder, 1985. p. 177. Apud. RUEDA, José Luis Meza. La antropología de Raimon Panikkar. p. 106.
} 
converte em uma automotriz que destrói os demais ${ }^{1057}$. Nesse sentido, o homem, o divino e o cosmos coexistem, permanecem inter-relacionados e podem estar constituídos ou coordenados hierarquicamente ${ }^{1058}$.

O ser humano é um nó de relações que se estende até os limites alcançáveis de sua alma. Para a tradição indiana, um santo é um mahãtma, uma alma grande; para as tradições abraãmicas é aquele que tem conseguido dilatar a própria alma e amar o próximo como a si mesmo; tudo está em relação com tudo, proclamam tanto o budismo como o hinduísmo e também o cristianismo quando fala do corpo místico $^{1059}$.

Tudo está relacionado com o todo, cada parte deste todo é diferente. Cada um é um nó único em rede de relações que constitui a realidade. Quando este nó rompe os fios que os une a outros nós, não permitindo a liberdade constitutiva da inter-in-dependência entre os nós, em última instância, com a realidade, nasce o individualismo que perturba a harmonia e leva a morte da pessoa fazendo-a perder sua identidade que é somente relacional ${ }^{1060}$.

Panikkar insiste:

Não só na natureza humana forma uma única rede, também a realidade constitui um todo relacional de elementos relativamente interdependentes que encontramos descritos com a variedade de expressões, desde o sarvam sarvātmakam (tudo relacionado com tudo) do trika do śivaismo do Kashmir a perichôrêsis (interpretação dinâmica da realidade) patrística, ao budista pratītyasamutpāda (interdependência de tudo), ou ao quodlibet in quolibet (tudo em tudo) do Cusano, etc,. ${ }^{1061}$,

\subsection{No ser humano, tudo é totalidade}

O ser humano como realidade teantropocósmica é corpo, é alma e é espírito, em uma unidade irredutível, diferenciada e inseparável. Portanto, não tem um corpo, uma alma e um espírito como se tratasse de três partes justapostas e organizadas hierarquicamente.

O anthrôpos do qual falamos não é somente o ponto de encontro entre o divino e o cósmico, é ao mesmo tempo essa unidade complexa que consiste em corpo, alma e espírito, que abarcam o universo inteiro. Sem estes três elementos não existe o

\footnotetext{
${ }^{1057}$ PANIKKAR, Raimon. Paz y desarme cultural. Santander: Sal Terrae, 1993. p. 49.

${ }^{1058}$ Cf. Id., La nueva inocencia, pp. 51-52.

${ }^{1059}$ Cf. Id., Paz y interculturalidad, p. 15.

${ }^{1060}$ Cf. Ibid., p. 16.

${ }^{1061}$ Cf. Ibid., p. 72.
} 
homem $^{1062}$.

Ou seja, tudo é uma totalidade. Recuperar a consciência desta unidade é essencial. Esta recuperação não pode fazer-se por adição, nem por eleição facultativa, senão que deve sair de uma nova consciência. Panikkar relaciona esta nova consciência à mística, como forma de integrar o ser humano.

[A mística] é aquela experiência que integra o corpo e o amor sensível na vida plena do homem, sem perder por isso o equilíbrio hierárquico entre as três

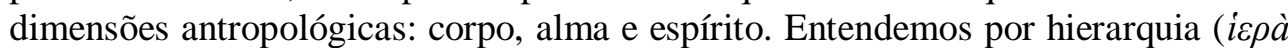
$\dot{\alpha} \rho \chi \dot{\eta}$, hiera archê), a "ordem sacra" que mantém a harmonia da realidade e no domínio de uma parte sobre a outra ${ }^{1063}$.

Estes elementos não se veem em 'partes' senão como dimensões constitutivas da natureza humana. O mistério do ser humano se revela através do mistério de Cristo e em Cristo também se manifesta plenamente a trindade radical. Nele se apresenta a unidade não-dualista entre o divino, o humano e o cósmico (o mistério teândrico da teologia oriental, ou melhor, cosmoteândrico). Daí o ser humano "é também uma unidade não-dualista entre corpo e espírito: nele se dá também, portanto, a corporeidade própria das coisas materiais. Os "três" (divino, humano e material) vão juntos sem confusão nem separação"1064.

As tensões se resolvem no humanum como um símbolo de perfeição que assume o que realmente somos: seres terrenais e espirituais.

O humanum são é somente invisível, senão também não realizado aqui na terra. Necessita uma existência transcendente, seja no tempo (futuro), no espaço (paraíso) ou ambas coisas e mais além (nirvāna, Brahman, Deus). A realização do humanum é uma tarefa escatológica. Tem que descobrir, seja na esperança ou com uma intuição (anubhāva) que transcende tempo e espaço, comprovando se 'já' está ali" 1065

A este respeito, Panikkar reconhece que o modelo do humanum para os cristãos é Cristo, Deus Homem verdadeiro, que ilumina o homem para ser o que deve ser $^{1066}$. O humanum revela a imanência e a transcendência do homem. Ele dirá que

somos seres limitados - e todavia, seres com um inato desejo de elevarmos sempre mais alto, mais além dos confins extremos, como está magistralmente representado em algumas cartografias antigas nas quais o homem aparece com a metade de seu corpo para descobrir que existe mais além do seu mundo e quer ir plus ultra ${ }^{1067}$.

\footnotetext{
1062 PANIKKAR, Raimon. El mundanal silencio, p. 71.

${ }^{1063}$ Id., De la mística. p.114.

${ }^{1064}$ Id., La plenitud del hombre, p. 222.

${ }^{1065}$ Id., Elogio de la sencillez, p. 203.

${ }^{1066}$ Cf. Id., Raimon. Humanismo y cruz, p. 206.

${ }^{1067}$ Id., Paz e interculturalidad, p. 28.
} 
No entanto, se retomamos o próprio da in-finitude do homem, estamos admitindo que "existe algo nele que deve evoluir e afirmar também a capacidade de levar a cabo tal evolução. A abertura da fé é a capacidade do homem de avançar para sua plenitude" 1068 .

Pela fé o homem reconhece que não é perfeito, que tem a necessidade de ser completo; todavia, tem a necessidade de uma ajuda para alcançar a meta.

Graças à fé o homem descobre sua indigência [...] A fé expressa também a grandeza do homem e sua suprema dignidade, porque sua abertura existencial não é somente sinal de uma necessidade, senão que indica ao mesmo tempo uma iluminada capacidade de crescimento ${ }^{1069}$.

A fé não se desliga da esperança e do amor que o levam a ser mais e a fazer mais em um "aqui e agora" não se esquecendo de "um além e um depois". Desta forma, se entende porque Panikkar afirma que a experiência de transcendência somente pode se feita a partir da imanência. Imanência e transcendência são duas noções que apontam aquela realidade que não é nem uma nem duas. Quando se compreende isso, se alcança, pela fé, a experiência mística que é uma experiência que não faz separação entre o material e o espiritual, por isso, ela mesma é advaitica e tem implicações em um e outro sentido, pois é indivisa ${ }^{1070}$.

A partir desta perspectiva, a relação advaitica entre imanência e transcendência, não se concentra somente nos valores do espírito e se separa do resto do homem. A espiritualidade se faz integral e não deixa de lado nenhum aspecto da realidade ${ }^{1071}$.

\subsection{0 ser humano, um ser religioso e místico}

Para Panikkar o ser humano é um ser religioso. Para ele a religião (de religare) liga o ser humano ao seu fundamento, e a fé o liberta de uma mera existência. Desta experiência de abertura nasce a liberdade que o coloca no coração da relação pessoal trinitária ${ }^{1072}$.

\footnotetext{
${ }^{1068}$ PANIKKAR, Raimon. Mito, fe y hermenéutica. Barcelona: Herder, 2007. p. 224.

1069 Ibid.

${ }^{1070}$ Id., De la mística, pp. 69-70.

${ }_{1071}$ Id., El Cristo desconocido del Hinduismo, p. 58.

${ }^{1072}$ Cf. Id., Mito, fe y hermenéutica. P. 203.
} 
A religião é, antes de tudo, uma dimensão constitutiva do ser humano, por isso a experiência religiosa sustenta o ser humano, apesar da dificuldade que as instituições possam impor-lhes ${ }^{1073}$.

Pode a fé também libertar a religião. Isto significa que a fé é a garantia das relações humana.

[A fé] pode servir para libertar a religião de seus aspectos exclusivistas, de seu caráter, com frequência, sectário e de um unilateralismo arcaico incompatível com o processo de universalização no que a humanidade está comprometida. O reconhecimento da fé como dimensão antropológica situa o encontro entre os povos em um plano plenamente humano e não isola a religião do diálogo ${ }^{1074}$.

Segundo ele,

na fé e mediante a fé, o crente se comunica e se confraterniza com a pessoa que se autodefine não crente. Separado deste profundo nível da fé, a fraternidade humana se converte em uma comunicação subumana de ordem biológica, se não inclusive em um contato artificial ${ }^{1075}$.

Essa afirmativa se fundamenta no fato de que a fé não é somente necessária para compreender, mas também para alcançar a plena humanidade. Em outras palavras, a fé é uma dimensão humana constitutiva. É uma dimensão antropológica do ser humano. Panikkar resumidamente diz: "crer para poder ser" ${ }^{\prime 1076}$. Ou seja, pela fé o ser humano mantém uma relação ontológica com o Absoluto que o caracteriza como humano, distinguindo-o de todos os demais seres $^{1077}$.

A fé está assentada no coração, como a palavra "credo" indica; o mesmo ocorre em sânscrito com a palavra sharaddhâ (dar o coração). A fé é esta capacidade, faculdade, possibilidade de mais - seria a palavra mais plena -, de transcendência seria a palavra mais filosófica - , de Deus - seria a palavra mais teológica. Capax Dei chamavam os escolásticos a essa capacidade do infinito, do que não tem fronteiras ${ }^{1078}$.

Lembrando-se do "terceiro olho" que a tradição cristã tem chamado o oculus fidei, o olho da fé. A fé "é uma experiência, por isso, não está nas proposições, como disse Santo Tomás: Fides non est de enuntiabilibus" ${ }^{\text {"1079 }}$. A fé é um dom de Deus, e nada o impede de ser um "dom universal" esquecendo, que:

\footnotetext{
${ }^{1073}$ PANIKKAR, Raimon. Experiência de Deus, p.64.

${ }^{1074}$ Cf. Id., Mito, fe y hermenéutica, p. 204.

${ }^{1075}$ Ibid., p. 205.

${ }^{1076}$ Ibid., p. 202.

${ }^{1077}$ Cf. Ibid., pp. 202-203.

${ }^{1078}$ Id., Experiência de Deus, p. 62.

${ }^{1079}$ Id., De la mística, p. 86.

${ }^{1080}$ Id., Mito, fe y hermenéutica, p. 220.
} 
O dom da fé é um convite à uma resposta, um chamado provocador, uma porta aberta. Implica a liberdade e a possibilidade de recusa, porque um dom não é um dom se não é aceito, se não existe uma resposta positiva. A fé é essa dimensão asubstancial do homem que o permite não parar na metade do caminho, ou ficar paralisado no tempo, fechado no passado. A fé é fundamentalmente dinâmica, funcional $^{1081}$.

Ela se inscreve na discreta ação da providência que "inspira" a humanidade ${ }^{1082}$; e não fundamentalmente é um ato do intelecto - porém possui uma dimensão intelectiva - senão de toda a pessoa humana ${ }^{1083}$.

No entanto, não pode ser confundido o ato de fé com crença, ou seja, ato de fé põe o ser humano em movimento. É o ato que surge do coração e pelo qual o leva a transcender, a alcançar sua plenitude. Não é um ato automático: é um ato livre e não alienante. Por outra parte, a crença é a formulação, a articulação doutrinal, geralmente feita por um coletivo. É a expressão simbólica mais ou menos coerente da fé, que muitas vezes se formula em termos conceituais ${ }^{1084}$.

Panikkar defende que as virtudes teologais se unam à dimensão antropológica da fé. Segundo ele, "a fé é a abertura existencial, o vazio que existe no homem e que o torna capaz sempre de um mais, de um sempre mais além" Nesta perspectiva antropológica, a esperança é a antecipação da fé, sair do vazio para algo que possa preencher tal carência, tendendo para o infinito, o inefável, para o Absoluto.

Se o ato de fé é a resposta intelectual ao fato de se descobrir como um ser aberto, como uma entidade inesgotável, como uma pessoa, todavia não realizada, a esperança é o ato "logicamente" precedente de sair de si mesmo para ir para a meta infinita e indefinida. Ou seja, não haveria esperança se não houvesse fé ${ }^{1086}$.

E por último o amor, é ele que 'salva', porque obriga o homem a sair de seus limites, em definitivo de sua própria finitude. Se a esperança é o impulso, o amor é a união, a fruição efetiva.

Todavia, a fé não se expressa de uma única maneira. Panikkar sugere três formas típicas de identificação da fé e simpatiza radicalmente com a terceira: a ortodoxia, a ortopoesis e a ortopráxis.

A primeira é baseada na primícia de uma concepção essencialista da

\footnotetext{
${ }^{1081}$ PANIKKAR, Raimon. Mito, fe y hermenéutica, p. 220.

${ }^{1082}$ Id., El Cristo desconocido del Hinduismo, p. 185.

${ }^{1083}$ Id., Mito, fe y hermenéutica, p. 229.

${ }^{1084}$ Cf. Id., Experiência de Deus, p. 63.

1085 Id., Mito, fe y hermenéutica, p. 221.

1086 Ibid., p. 222.
} 
Verdade, que nos leva a identificar a fé com a ortodoxia, ou seja, com a correta doutrina. A segunda insiste no caráter moral do ato religioso, baseado na supremacia do Bem, e em consequência nos leva a identificar a fé com a ortopoieses. Se na primeira ocorre o risco de 'dogmatismo', a segunda pode aproximar-se do 'moralismo', integrando-se a essas duas interpretações, que não parecem falsas senão unicamente unilaterais.

Panikkar propõe o conceito de fé como ortopráxis, vejamos:

a) A fé como ortodoxia ${ }^{1087}$ - parte do pressuposto de que o homem é, sobretudo um 'animal racional'. A fé assume uma dimensão quase exclusivamente intelectual; considera a verdadeira fé como sinônimo de ortodoxia. Disso derivase que, em princípio, seja possível ter distintas formulações da fé. A formulação é, em certo sentido, intrínseca à fé mesma. Não se pode ter fé se não se adere a uma determinada doutrina.

b) A fé como ortopoiesis ${ }^{1088}$ - contêm elementos práticos e voluntários, seu fim não é simplesmente a verdade, senão também o bem. $O$ valor positivo da ortopoieses reside na acentuação da fé como amor, como oferta pessoal, como decisão de vida, como liberdade humana livremente assumida. O ser humano torna-se o artífice de sua vida.

c) A fé como ortopraxis ${ }^{1089}$ - parte do pressuposto de que o homem possui inteligência e vontade, que se lança para frente atraído para a verdade e o bem. Porém não se esgota aqui, estas atividades brotam de uma fonte, todavia, mais profunda: seu mesmo ser, seu ser como ato; sua atividade não é simples poiesis, mas, sobretudo práxis. O efeito da práxis é parte do ser mesmo do homem: é a atividade salvífica por excelência, em que o ser humano atinge seu objetivo e sua plenitude.

Em resumo,

As religiões não pretendem como primeira coisa, ensinar uma doutrina ou proporcionar uma técnica. Aspiram salvar o homem, ou seja, a libertá-lo ou, em outras palavras, abrir-se à vida para a plenitude de seu ser, seja qual seja esta plenitude. Quando esse fim é interpretado como visão intelectual, emerge o aspecto doutrinal. Se em troca é visto como a recompensa pela vida, e por uma conduta moral, prevalecem os valores práticos. Porém, em ambos os casos, se pressupõe que a plenitude humana consista em adquirir esse valor que está no centro da finalidade humana ${ }^{1090}$.

${ }^{1087}$ Cf. PANIKKAR, Raimon. Mito, fe y hermenêutica, pp. 209-213.

${ }^{1088}$ Cf. Ibid., pp. 213-214.

1089 Cf. Ibid., pp. 215-217.

1090 Ibid., p. 215. 
A fé, insiste Panikkar, "deve ser algo comum a todos os homens, independente de suas crenças religiosas. Negar isto equivale a dizer que a enorme maioria dos seres humanos não alcançam a salvação e está condenada"1091. Desta maneira, compreendemos a razão pela qual "a fé é uma abertura existencial para a transcendência", uma "abertura ao Ser" para ser "preenchida".

A abertura da fé é uma abertura constitutiva. Não pode ser fechada; é infinita, não limitada nem limitável. A fé é como uma cavidade no ser humano que jamais pode ser preenchida, nem menos ainda transformada em uma espécie de substancialidade que representaria a máxima blasfêmia religiosa e excluiria o homem de toda relação com o infinito. Através desta cavidade ele alcança o infinito $^{1092}$.

Além do mais, "o homem é in-finito", ou seja, "não-acabado". O ser humano não é completo porque é itinerante, não definido 'não finito', não acabado, incompleto. A abertura existencial da fé representa a capacidade do homem de entrar em sua não-plenitude, ou seja, a sua in-finitude. Não considera a si mesmo como finito, como acabado, como alguém que tenha esgotado as possibilidades de chegar a ser. A abertura da qual falamos é constitutiva do ser humano, a outra face disso chamamos contingência. Esta última aparece quando olhamos para trás, para nossa origem, descobrindo que não temos em nós mesmos e por nós mesmos a base de nossa existência. A primeira, ou seja, a abertura primordial aparece quando olhamos para adiante, para a meta, o fim, o transcendente, etc., e descobrimos que não estamos completos ${ }^{1093}$.

Reconhecer essa abertura no ser humano é admitir que ele não é Deus, que precisa evoluir. E que esta abertura da fé é a capacidade que possui para avançar para a plenitude.

E é graças a esta dimensão da fé, que o homem descobre sua indigência. A fé é o suporte que aponta a precariedade humana e, ao mesmo tempo, a sua grandeza e sua suprema dignidade. Representa um fundamento muito mais sólido que a autonomia ou a autossuficiência humana, expressando a máxima riqueza ôntica possível. Reconhecemos, assim, que nenhum valor 'humano' ou limitado, poderá jamais preenchê-1o ${ }^{1094}$.

Por fim,

\footnotetext{
${ }^{1091}$ PANIKKAR, Raimon. Mito, fe y hermenêutica p. 219.

1092 Ibid., p. 226.

1093 Ibid., p. 224.

${ }^{1094}$ Cf. Ibid., p. 225.
} 
O homem é religioso não primeiramente porque descobre ou aceita esta relação com Deus, qualquer que seja o conteúdo que se queira dar a este conceito, senão em virtude da realidade ou do fundamento sobre o que se faz possível um o conhecimento deste tipo, ou seja, porque o homem, realmente e de fato, se encontra 'intimamente unido' com Deus. Isto quer dizer que o primeiro elemento da religião não é a consciência, senão o ser, o existir, a contingência. A dependência do ser humano com respeito a Deus tem algo de comum com a dos animais, das palavras e da terra: é um vínculo cósmico com a Causa, com o Princípio e com a fonte deste mesmo cosmos ${ }^{1095}$.

\subsubsection{Mística, plenitude da vida}

Quando Panikkar nos fala sobre mística, é nítida sua intenção de não fragmentar o ser humano em suas dimensões e relações constitutivas. Trata-se, segundo ele, "de integrar a mística no ser do homem: no homem, espírito místico tanto quanto animal racional e ser corporal" ${ }^{1096}$. Em outras palavras, a mística é uma dimensão antropológica. No entanto, a mística não pode separar-se do problema teológico do que seja Deus nem do problema cosmológico do que seja o mundo ${ }^{1097}$.

A mística não é um privilégio de uns enquanto escolhidos, senão característica humana por excelência, "o homem é essencialmente um místico", consequência evidente da maneira como ele entende a fé.

O homem é essencialmente místico ou, se o considera como animal (um ser 'movido' por um anima, um animal místico - embora, a animalidade (embora seja racional) não define o homem [...] O homem é antes um espírito encarnado do que um vivente racional, um animal espiritual poderia dizer se anima for interpretado segundo sua etimologia indo-europeia (aniti, o respirar; anilah, o sopro). Anima incluirá então também o espírito ${ }^{1098}$.

Em seu livro De la mística, Panikkar, com clareza, afirma que a mística é "a experiência da Vida". Para poder compreender o que nosso autor quer dizer, teremos que nos deter em suas noções de "experiência" e "Vida", em sua relação com a "experiência de Deus" e no que significa para o ser humano a "experiência mística".

Por uma parte, nosso autor reconhece a polissemia e a ambiguidade da palavra "experiência", por isso a depura de uma perspectiva psicológica e a inscreve em uma ontológica. Para ele, a experiência é "aquilo" que "transforma

\footnotetext{
${ }^{1095}$ PANIKKAR, Raimon. Mistério y revelación, p. 44.

${ }^{1096}$ Id., De la mistica, p. 20.

${ }^{1097}$ Cf. Ibid. p. 55.

${ }^{1098}$ Ibid., p. 19.
} 
nosso ser mais profundo, é o sentir-se aprisionado por uma realidade mais forte que nos penetra e nos transforma" ${ }^{, 1099}$.

Trata-se de um contato imediato [...] indica mais que simples imediatez; indica com-penetração, ter penetrado no mesmo interior de algo 'experienciado' [...] A experiência se reconhece nesse 'interior intimo meo' (mais interior que o meu mais íntimo) de santo Agostinho ${ }^{1100}$.

Ou seja, experiência se interpenetra no 'experienciado'. É experiência de união, relacionalidade, interpenetração, porém também é conhecimento, amor e ação $^{1101}$.

Imagino que é por isso que a sabedoria de praticamente todos os povos nos ensinam que a abertura para a experiência de Deus pode surgir: a) através do conhecimento (jñana): pelo esforço da inteligência em transcender a si mesmo; b) pelo amor (bhakti): pelo anseio do coração em buscar algo que lhe preencha; c) através das obras (karma): pela criatividade da criatura que quer imitar o criador criando, isto é fazendo ${ }^{1102}$.

Esse pensamento vai de encontro com a noção cristã que considera a mística como cognitio Dei experimentalis ("conhecimento experimental de Deus") ${ }^{1103}$. Ou seja, "trata-se de uma experiência e não de uma interpretação, embora nossa consciência dela seja concomitante [...] Trata-se de uma experiência completa e não fragmentaria" ${ }^{1104}$.

Sobre a palavra 'Vida', Panikkar a usa com letra maiúscula como o desejo de não excluir a priori que a vida pode ter outras dimensões, além dos aspectos fisiológicos e psíquicos. Ele quer lembrar-se de sua dimensão espiritual, por entender a mística como uma experiência integral da Vida. Assim, ele usa a palavra Vida no lugar da realidade.

Usamos a palavra 'vida' no lugar de 'realidade' por encontrá-la mais próximo da experiência. [...] A 'vida' é algo que experimentamos diretamente; somos seres vivos, participamos da Vida [...] ainda que a reflexão logo nos diga que somos seres (viventes) que participamos no Ser. Nossa experiência é a Vida ${ }^{1105}$.

Quando ele fala desta experiência de Vida, significa participar da Vida de Deus.

Quando digo experiência da Vida não digo experiência de minha vida senão da Vida, aquela vida que não é minha embora esteja em mim; aquela vida que, como

\footnotetext{
${ }^{1099}$ PANIKKAR, Raimon. La plenitude del hombre, p. 45.

${ }^{1100}$ Id., De la mistica, p. 76.

${ }^{1101}$ Ibid., p. 164.

${ }^{1102}$ Id., Experiencia de Dios, p. 93.

${ }^{1103}$ Id., Diccionario de la mistica, p. 737.

${ }^{1104}$ Id., La mistica, p. 19.

${ }^{1105}$ Ibid., pp. 22-23.
} 
dizem os Vedas, não morre, é infinita, que alguns chamariam divina: Vida, contudo, que se "sente" palpita, ou melhor, dito simplesmente vive em nós. Suas interpretações, naturalmente, variam deste o chamado sentimento oceânico até a sensação biológica de viver, passando pela experiência de Deus, Cristo, do Amor ou inclusive do Ser. A experiência da Vida (zôê), diz São Justino no século II, é a experiência do doador da vida - posto que a vida, a alma, não vive por si mesma, senão que participa da Vida ${ }^{1106}$.

A vida é comunhão entre Deus, os homens e a natureza, é integração entre imanência e transcendência, e é confluência entre temporalidade e eternidade. A experiência de vida não é a consciência do ritmo do tempo. O que se 'experiência' é o instante da tempiternidade. Esta experiência integral da vida

é a vivência completa tanto do corpo, que se sente viver com palpitações de prazer e dor, como da alma, com suas intuições de verdade e seus riscos de erros, adicionadas às fulgurações do espírito que vibra com o amor e repulsão ${ }^{1107}$.

Ou seja, é uma experiência corporal, intelectual e espiritual ao mesmo tempo. Igualmente é material, humana e divina - é uma experiência da realidade cosmoteândrica $^{1108}$. Sentir-se vivo é, desta forma, sentir a Vida em sua plenitude dentro de nossas limitações concretas.

Panikkar insiste em dizer que é preciso cultivar a harmonia, fazer participar o corpo na felicidade do espírito e associar o espírito ao prazer do corpo. A beatitudo (beatitude) ou ãnanda (bem-aventurança divina) é uma experiência cosmoteândrica $^{1109}$. A experiência da Vida é a conjunção mais ou menos harmônica dos três olhos ${ }^{1110}$, ou se preferir, das três consciências (sensível, intelectual e espiritual).

A experiência mística abraça tanto a consciência sensível como a intelectual e espiritual em uma não-dualidade harmônica, embora em distintos graus. A experiência mística não pertence a uma ordem 'superior' senão que está na base da mesma constituição do ser humano ${ }^{1111}$.

De acordo com Panikkar, a estrutura da experiência não é nem uma nem tríplice. Os 'tres' olhos estão imbricados um no outro, como na perichôrêsis trinitária. Não se pode reduzir as três dimensões a uma só, posto que são

\footnotetext{
${ }^{1106}$ PANIKKAR, Raimon. De la mistica p. 24.

1107 Ibid., p. 26.

${ }^{1108}$ Cf., Ibid., p. 27.

${ }^{1109}$ Cf. Ibid., p. 179.

1110 Já mencionados na nota 130 desta parte de nosso texto.

${ }^{1111}$ PANIKKAR, Raimon. La mistica, p. 181. "A dificuldade se apresenta se as isolar. A mística, sem intelecto e sem os sentidos, é falsa. Voltar a simbiose é uma obrigação urgente da autêntica filosofia contemporânea. Uma dessas tarefas seria o de situar o problema do divino sem romper do homem o problema do cosmos: é o problema da infinitude e da liberdade, que está em tudo". Id., Ecosofía, p. 41.
} 
$\operatorname{distintas}^{1112}$. Caso contrário,

se por experiência mística se entende somente a experiência que nos abre o terceiro olho tem que recorrer então a uma cosmologia dualista de dois níveis: o nível da razão ou da natureza e o nível do sobrenatural ou da graça, em que a razão representa aufgehoben, no sentido hegeliano (negado, superado, aceito e mantido). Neste caso a experiência mística representaria um estágio superior que somente pode chegar pela 'graça' especial - que se dá a muitos poucos segundo o destino ou beneplácito divino ${ }^{1113}$.

Ele insiste nessa não dualidade, retornando a fala sobre as três dimensões:

sensorial, intelectual e mística, como dimensão, também, da realidade.

A consciência sensorial nos relaciona, por meio de nossos órgãos dos sentidos, com o que podemos chamar a parte material da realidade. A Consciência intelectual nos abre o mundo inteligível, a essa rede de relações que sustentam o mundo intelectual e que não podemos equiparar à mera matéria. A consciência mística nos põe em contato com o que é invisível aos sentidos e ao intelecto [...] Estas três ordens de consciência são, em essência, não janelas independentes senão três dimensões, três formas distintas (sensorial, intelectual e mística) da mesma consciência primordial [...] Estas três dimensões da consciência são também dimensões da realidade: a primeira é a condição para atuar, a segunda permite compreender e a terceira $\operatorname{ser}^{1114}$.

A experiência plena da Vida poderá corrigir a concepção reducionista do homem, por entendê-la como cosmoteândrica ${ }^{1115}$. No ser humano, se integram todas as dimensões da realidade.

Logo, a mística não é uma especialidade de alguns seres humanos, senão sua dimensão essencial. Mesmo que essa dimensão se encontre hoje um tanto atrofiada, [...] o Espírito, em troca, não é individual nem tampouco individualizante: não é nossa propriedade privada nem teremos domínio sobre ele. O Espírito sopra onde, quando e como quer, e nos faz entrar em conexão com um novo grau de realidade que em nós se manifesta na consciência - precisamente na consciência mística.

\subsubsection{Mística e a experiência de Deus.}

Como vimos, na tradição cristã a mística é uma experiência de Deus ${ }^{116}$, pois 'Ele era a vida'. E é uma experiência de Vida, experiência sensível, intelectual e espiritual. Ou seja, é uma experiência humana, em sua plenitude, que

\footnotetext{
1112 Cf. PANIKKAR, Raimon. La mistica, p. 171.

1113 Ibid., p. 172.

${ }^{1114}$ Id., Mito, fe y hermenéutica, p. 312

${ }^{1115}$ Id., De la mistica, p. 34.

${ }^{1116}$ Cf. Id., La mistica, p. 64.
} 
supera toda alienação sem cair no solipsismo ${ }^{1117}$.

Nenhuma religião nem mesmo qualquer sistema de pensamento pode monopolizar a experiência de Deus. E enquanto "experiência última, é uma experiência não só possível, mas também é necessária para que todo ser humano chegue à consciência de sua própria identidade" ${ }^{1118}$.

A experiência de Deus que subjaz a toda experiência e pela qual nos fazemos seres humanos nos faz conscientes de nossa contingência, torna-nos humildes capazes de compreender. Por essa experiência nos damos conta de que estamos dentro de algo que abarca tudo e somos conscientes de uma dupla dimensão de ausência e presença, conscientes de que participamos de um mais no qual, de uma maneira ou outra, podemos confiar. Alguns a chamarão de a experiência do Ser que se atualiza no amor não-egoísta aos entes. Em outras ocasiões a chamei de confiança cosmoteândrica ${ }^{1119}$.

A experiência de Deus é a raiz de toda experiência. É a experiência em profundidade de todas e em cada uma das experiências humanas: do amigo, da palavra, da conversa. É a experiência subjacente a toda experiência humana: dor, beleza, prazer, bondade, angústia, frio... subjacente a toda experiência no tanto que nos descobre uma dimensão de infinito, não-infinito, in-acabado ${ }^{1120}$.

Como fundamento da mística, a experiência de Deus não se contrapõe com a liberdade, nem com a responsabilidade. Ou seja,

a mística, bem entendida, é o reino da liberdade: libera o homem tanto de suas condições transcendentais como imanentes sem deixar-se fazer, por outra parte, em libertinagem anárquico, posto que abre o caminho para realizar sua identidade ${ }^{1121}$.

Panikkar apresenta como requisito indispensável para acolher a experiência de Deus, a integração do interior humano. Para ele, o ser humano deve estar em harmonia consigo mesmo e com o universo, base de toda experiência humana ${ }^{1122}$.

A experiência mística é uma experiência da profundidade. O ser humano descobre em si mesmo e nos outros seres a dimensão de profundidade, de infinito que existe em tudo. Esta experiência concede humildade, por um lado e liberdade por outro $^{1123}$.

É a beata solitudo, na qual sou verdadeiramente eu, porque Deus não é o ser que me esquadrinha, mas o que me permite ser eu mesmo ao máximo. Dito de outra

\footnotetext{
1117 Cf. PANIKKAR, Raimon. La mistica, p. 185

${ }^{1118}$ Id., Experiencia de Deus, p. 76. Ou seja, "o ser humano chega a ser plenamente humano quando faz a experiência do seu último "fundamento", do que realmente é".

1119 Ibid., p. 79.

${ }^{1120}$ Cf. Ibid., pp. $77-78$

${ }^{1121}$ Ibid., p.42.

1122 Ibid., pp. 80-81.

${ }^{1123}$ Ibid., p. 82 .
} 
maneira: quando eu estou verdadeiramente só, encontro a Deus, não como objeto, mas - dizendo com santo Agostinho - interior intimo meo, como o mais íntimo de mim, o que me é mais interior, o que mais realmente sou que é então, precisamente, o que me abre aos demais ${ }^{1124}$.

A experiência mística é inefável, no entanto não se consegue evitar a palavra, pois "silêncio e palavra se complementam, digo silêncio e palavra, e não mudez e verborreia. Toda palavra que não surge do silêncio não é autêntica, e

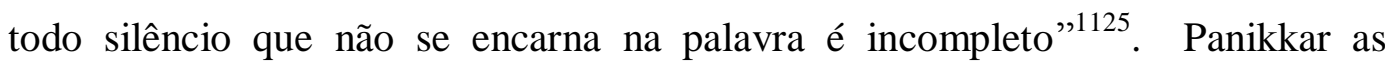
imagina em uma relação advaitica e cria a expressão: Palavra de Silêncio, que "não significa Palavra sobre o Silêncio (genitivo objetivo), senão o Silêncio que existe em toda Palavra (genitivo subjetivo). Não significa a palavra silenciosa, senão a palavra do silêncio, o silêncio que existe em toda palavra feita de silêncio ${ }^{1126}$. Ele afirma que "qualquer palavra que não comporta o pão, isto é, que não conduz à práxis, não é verdadeira" $" 1127$.

A mística integra o temporal e o eterno. Portanto, "não nos distrai do cotidiano, senão que o conecta com o tempiterno [...] O místico descobre a eternidade no instante e continua com paixão o jogo da Vida"1128. A contemplação é a respiração da vida "a pessoa contemplativa simplesmente 'se sente', simplesmente 'é ', vive" ${ }^{\text {1129 }}$. O contemplativo experimenta a realidade, adquire um caráter de mediação:

quem se entrega à contemplação experimenta a realidade, Deus, o céu, brahman, moksa, nirvāna, satori, clarividência, a verdade, o ser ou o nada..., aqui embaixo, já desde agora, no ato mesmo que se está realizando, na situação mesma que se está vivendo ${ }^{1130}$.

E faz a experiência da tempiternidade, assim como o místico. "Os contemplativos não necessitam céu algum nas alturas, porque para eles tudo é sagrado: tratam as coisas 'sagradas' como se fosse profanas e as 'profanas' como se fossem sagradas" $" 1131$.

\footnotetext{
${ }^{1124}$ PANIKKAR, Raimon. De la mistica, p. 84.

${ }^{1125}$ Ibid., p. 183

${ }^{1126}$ Id., Mito, fe y hermenéutica, p. 286.

${ }^{1127}$ Id., De la mistica, p. 183.

${ }^{1128}$ Ibid., pp. 37-38. Em outro texto ele vai dizer que: "É uma consciência que substitui ou, melhor ainda, que alcança a plenitude do tempo, posto que os três tempos são experimentados de maneira simultânea [...] E este paradoxo: quanto mais sou eu mesmo, mais desaparece meu ego. Eu sou, então, todos e tudo, porém desde um ângulo único, por dizê-lo assim". Id., La intuición cosmoteándrica, p.162.

${ }^{1129}$ Id., La nueva inocencia, p. 64.

${ }^{1130}$ Ibid., p. 65.

${ }^{1131}$ Ibid., p. 67
} 
"O tempo tem sido redimido, superado ou negado" ${ }^{1132}$. Esta é a experiência da tempiternidade, que não é nem temporalidade nem eternidade:

Não é nem uma temporalidade mais ou menos perfeita, nem uma eternidade impermeável ao temporal, senão a integração perfeita e, portanto hierárquica do que em aparência parecem ser dois fatores, 'tempo e eternidade', em um tempiternidade integral. A salvação moksa, nirvāna, e outras expressões do fim último da vida humana não se projetam em um futuro que tenha sido de alguma forma purificado ou aperfeiçoado, senão que se descobre em uma plenitude que somos capazes de experimentar 'no' tempo e no 'mais tarde'. Esta consciência descobre, no e através do temporal, o núcleo tempiterno da plenitude de nosso ser, ou como queremos chamar, da realidade ${ }^{1133}$.

A tempiternidade não é somente a busca pela eternidade. Na tempiternidade se vive a experiência do presente em toda sua profundidade, um presente que abraça o tempo e a eternidade, o finito e o infinito. O presente tempiterno é irredutível, isto é, um presente em que se realiza uma ação autêntica e pura. É aquele tempo pelo qual vale a pena ter vivido; é o tempo cujos atos encerram uma vivência tempiterna ${ }^{1134}$.

Todos os tempos coexistem na tempiternidade, o que tem sido é tão real como o que será. "O destino temporal do homem está intrinsecamente ligado a seu destino eterno e a sua situação eterna"1135. Desta forma, tempo e eternidade formam uma relação advaitica. "A eternidade não existe fora do tempo, como tampouco nele admitindo o valor metafórico das duas proposições. Porém tampouco existe o tempo fora da eternidade ou nela. A tempiternidade é o símbolo mesmo da realidade" $" 1136$.

Em outro momento ele vai afirmar que

a felicidade, que a beatitudo da tradição cristã, ou ānanda da Índia, não é meramente uma bem aventurança que tem que experimentar na vida próxima. É antes uma felicidade tempiterna, que não se esgota na temporalidade, porém que tampouco se situa fora dela. A vida eterna se reflete na temporalidade. A existência real e concreta da vida humana é uma existência tempiterna ${ }^{1137}$.

Logo, a experiência integral é transcendente e imanente. Panikkar insiste em repetir que a mística é uma experiência não-dualista - advaita. E que é uma

\footnotetext{
${ }^{1132}$ PANIKKAR, Raimon. La nueva inocencia, pp. 68-70.

${ }^{1133}$ Id., Elogio de la sencillez, p. 106.

${ }^{1134}$ Id., Presente eterno. In Diccionario interdisciplinar de hermenéutica editado por Andrés OrtízOsés y Patxi Lanceros, pp. 650-655. Bilbao: Universidad de Deusto, 1998. p. 653.

${ }^{1135}$ Id., El mundanal silencio, p. 34.

${ }^{1136}$ Id., Presente eterno, p. 655.

${ }^{1137}$ Cf. Id., Paz y desarme cultural, p. 102.
} 
experiência da realidade, não de suas partes ${ }^{1138}$. Ela não separa ação e contemplação.

A mística de nosso tempo, como visão plena da realidade, é agudamente sensível à dor do mundo, em especial ao sofrimento devido às mãos do homem e às injustiças humanas. Isto não faz do místico um 'ativista político' no sentido atual da palavra. Combinam as três dimensões da realidade e não perde a paz nem a equanimidade, porém sabe sujar as mãos se for preciso ${ }^{1139}$.

A presença de Deus impulsiona a participar consciente e livremente na exploração da Vida que representa a mesma aventura cosmoteândrica da Realidade $^{1140}$. O místico não espera passivamente. "Espera" tomando parte no advento de um mundo mais justo, o mundo que para os cristãos é denominado "Reino de Deus". Panikkar ainda afirma em outro texto:

somente quando o pensar transforma nosso fazer e o fazer nosso pensar em um círculo não vicioso, senão vital, é quando nos encontramos em boa direção. Se a ação não é contemplativa, não é na realidade ação; se a contemplação não é ativa, não é realmente contemplação. Tudo mais: a dicotomia deve ser superada no nível da antropologia e da metafísica. Optar por um eternalismo paralisador das atividades humanas é tão infecundo e errôneo como limitar-se a mera temporalidade da ação humana ${ }^{1141}$.

A experiência mística desta forma desfaz todo estigma de uma mística perdida nas alturas, desencarnada e alheia às dores do mundo, sem por isso esgotá-la na pura terrenalidade ou sufocá-la em um ativismo, posto que “experimenta a realidade da condição humana em sua totalidade e, portanto, não perde a serenidade nem a paz e elimina o medo de participar no esforço em prol da justiça" 1142 .

Este movimento é provocado pela experiência, pois a mística precisa do conhecimento e do amor. De acordo com Panikkar, o "amor é o companheiro natural do conhecimento [...] Quando a mística fala do conhecimento, é um conhecimento amoroso e quando canta o amor, é um amor cognoscente" ${ }^{, 143}$.

Evidencia que "um conhecimento exclusivamente intelectual não é conhecimento completo; um amor exclusivamente sentimental não é amor do qual falamos [...] o amor pode conhecer-se e o conhecimento pode amar-se" ${ }^{\not 144}$.

Panikkar insiste em dizer que "não só não conhece a realidade se não a ama,

${ }^{1138}$ Cf. PANIKKAR, Raimon. Paz y desarme cultural, p. 70.

1139 Ibid., p. 188.

1140 Id., La Trindad, p. 18.

1141 Id., Presente eterno, p. 654.

${ }^{1142}$ Id., De la mística, p. 203

${ }^{1143}$ Ibid., p. 92.

${ }^{1144}$ Ibid., p. 116. 
senão que não a ama se não a conhece. É então quando se descobre o núcleo amoroso de todo real"1145.

É importante lembrar o que diz respeito ao próprio ser humano: “conhecer de verdade é chegar a ser algo conhecido sem deixar de ser o que é. Chegar a ser não é somente mudança, não é um movimento do que somos ao que deveríamos ser. Chegar a ser é o verdadeiro crescimento do ser-sendo. O verdadeiro ritmo da realidade" ${ }^{\prime 146}$.

O conhecimento e o amor têm estreita relação com a sabedoria, a verdade e a beleza:

poderíamos afirmar que o homem está habitado, como tenho preferido dizer, por uma dupla força, por um dinamismo centrífugo que o impulsiona para o exterior atraído pela Beleza que brilha desde fora, e por um dinamismo centrípeto que o impulsiona para o interior aspirado pela Verdade que tem de descobrir em si mesmo. Deixar-se levar somente pelo primeiro impulso é frivolidade, quando não concupiscência, e somente pelo segundo é egoísmo, quando não soberba. A sabedoria é a harmonia entre a atração da Beleza e a aspiração à Verdade. No centro se encontra o Bem que é belo e verdadeira ao mesmo tempo ${ }^{1147}$.

A experiência mística não separa o amor a Deus do amor ao próximo. O Evangelho é uma mensagem de serviço e amor ao próximo (Mt 10,40) e o amor a Deus e o amor ao próximo são um só amor (1Jo 3,16). Panikkar também reconhece esta condição em outras religiões:

a este respeito [sobre o amor a Deus e ao próximo] o hinduísmo não fica para trás (Manu II, 161; Mahâbhârata XII, 3880). Tampouco o budismo [...] A misericordia e a compaixão são dois aspectos fundamentais da espiritualidade budista (Dîgha Nikâya II,196; III,220). Não se pode ser feliz isoladamente. A felicidade é comunitária $^{1148}$.

\subsection{Espiritualidade cosmoteândrica}

De acordo com Panikkar, o problema da "tecnocracia não é um problema tecnológico (não pode ser resolvido por uma tecnologia melhor ou mais nova); é um problema humano-antropológico, lê-se religioso". Aqui se situa seu desafio. Ele está convicto de que "no mundo atual somente os místicos sobreviveriam"1149. É claro para ele que sem uma compreensão da "terceira dimensão da realidade

\footnotetext{
${ }^{1145}$ PANIKKAR, Raimon. De la mística, p. 119.

${ }^{1146}$ Cf. Id., El toque contemplativo. En El árbol de la vida editado por Chantal Maillard et al., pp. 45-48. Barcelona: Kairós, 2001. p. 47.

${ }^{1147}$ Id., De la mística, p. 121.

${ }^{1148}$ Id., El silencio del Buddha, p. 275.

${ }^{1149}$ Id., El espíritu de la política. Homo politicus. Barcelona: Península, 1999. p.129.
} 
com a qual o místico nos põe em contato e que sustenta as dimensões do sensível e do inteligível, o real não seria mais que uma pura abstração - sensível ou inteligível" ${ }^{\prime 150}$.

Neste sentido, Panikkar faz uma proposta audaciosa apresentando uma espiritualidade secular ou mística cosmoteândrica. Sobre o termo espiritualidade ele nos diz que:

Quisera utilizar a palavra 'espiritualidade' de maneira válida para todas as diferentes vias que conduzem o homem ao seu destino [...] A espiritualidade deve ser integral e não pode deixar de lado nenhum aspecto da realidade. Tudo tem que ser 'purificado pelo fogo', tudo deve ser transformado: é a apokatastasis que nos fala são Pedro $(1 \mathrm{pd} \mathrm{3,11).} \mathrm{Temos} \mathrm{que} \mathrm{fazer} \mathrm{uma} \mathrm{síntese} \mathrm{entre} \mathrm{interioridade} \mathrm{e}$ exterioridade ${ }^{1151}$.

Quando ele se refere à espiritualidade secular insiste em uma experiência integral:

pois representa um novum que corresponde a emergência da consciência da 'sacra secularidade'. A experiência mística não é idêntica ao que alguns têm chamado 'experiência cume' [...] A experiência mística é mais, ou mesmo, que um estado de consciência - é uma abertura (consciente) à realidade total ${ }^{1152}$.

Entendemos, diante das suas reflexões que a mística é uma "experiência da Vida", a espiritualidade como "a atitude básica do homem com respeito ao seu fim último"1153 e a contemplação como "mediação cosmoteândrica" "1154, falam da mesma realidade. Trata-se de uma coerente reflexão apresentadas de formas diferentes.

O ser humano que vive esta experiência é sensível às relações constitutivas da Realidade ${ }^{1155}$. A mística cosmoteândrica não fica apenas na relação DeusHomem; inclui o mundo nesta comunhão, posto que Deus, Homem e Mundo formam uma relação não-dualista e "tolerante" ${ }^{1156}$. Quem realiza esta experiência está

aberto ao mundo exterior como ao interior, ao cultivo da política como ao cultivo do espírito, a preocupação pelo demais como por si mesmo [...] A visão mística inclui tanto o Outro (alter) como a mim Mesmo, tanto a Humanidade e a Terra como o Divino. É a experiência cosmoteândrica. O resto são reducionismos ${ }^{1157}$.

\footnotetext{
${ }^{1150}$ PANIKKAR, Raimon. El espíritu de la política. Homo politicus. p.129.

${ }^{1151}$ Id., La nueva inocencia, pp. 314-317.

${ }^{1152}$ Id., De la mística, 180.

${ }^{1153}$ Id., La Trindad, p. 37.

${ }^{1154}$ Id., La nueva inocencia, p. 65.

1155 Cf. Id., Humanismo y cruz, p. 43.

${ }^{1156}$ Cf.. Id., Mito, fe y hermenéutica, p. 49.

${ }^{1157}$ Id., De la mistica, p. 186.
} 
Assim, a espiritualidade cosmoteândrica realiza a síntese harmônica das três dimensões da vida: Deus, Homem e Mundo. Nela existe a contemplação, que é algo mais que pensamento; ação, que não limita seu horizonte à construção da cidade terrena. Deus, que não é unicamente um juiz ou um olho contador. Amor, que sobrepassa todo sentimentalismo. Oração que não se limita à petição, nem sequer a louvores, senão é também silêncio, sem cair na indiferença. Apofatismo, que não para no niilismo. Graça, que não é antinatural. Espaço e tempo, que não são passageiros senão que são dinamismos criadores. E, sobretudo, inteligência, que nos permite falar conscientes e responsavelmente de tudo isso ${ }^{1158}$.

Ou seja, uma madura espiritualidade humana não será um jogo dialético entre as três formas de vida ou a especialização reducionista, mas uma síntese harmônica entre as três dimensões constitutivas da Realidade.

Uma espiritualidade cuja mais simples expressão seria: o Homem é algo mais que 'homem': é um mistério cosmoteândrico. Deus, o Homem e o Mundo estão comprometidos, embora diferentemente, em uma mesma aventura ${ }^{1159}$.

No entanto não significa, nesta relação, evitar as diferenças, mas perceber as inter-relações e conscientizar-se da interdependência existente entre Deus, o Homem e o Mundo. Em síntese ${ }^{1160}$ :

a) esta intuição cosmoteândrica deve emergir espontaneamente, o que requer uma nova consciência. A espiritualidade tem que germinar livremente nas profundidades do ser;

b)tal espontaneidade supõe que esta espiritualidade se mantenha independente de hipóteses científicas e filosóficas;

c)a terra não é nem inferior, nem superior ao ser humano. O ser humano não é o líder deste Mundo, nem simplesmente uma criatura. O ser humano e o cosmos, são realidades supremas, e por isso irredutíveis um ao outro os dois a uma entidade superior;

d) a relação do ser humano com a terra é parte de sua autocompreensão. É uma relação constitutiva;

e) com esta espiritualidade a ideologia panmonetária é superada. Uma pessoa não vive somente para se alimentar, como não trabalha apenas para ganhar dinheiro. A espiritualidade cosmoteândrica vê a realização não tanto no tempo futuro como

\footnotetext{
${ }^{1158}$ Cf. PANIKKAR, Raimon. La Trindad, p. 99.

1159 Ibid., p. 99.

${ }^{1160}$ Cf. Id., La intuición cosmoteándrica, pp. 179-180.
} 
em um espaço mais amplo que incorpora os 'três tempos';

f) esta espiritualidade supera a dicotomia entre o chamado misticismo natural como a forma inferior de união com o Mundo, e o misticismo teísta, como forma, supostamente, superior de união com Deus.

Esta espiritualidade curaria a ferida aberta do ser humano moderno: o abismo entre o material e o espiritual e, com isso, entre o secular e o sagrado, o inferior e o exterior, o temporal e o eterno ${ }^{1161}$.

\subsection{0 monge, arquétipo do ser humano}

Panikkar nos apresenta o 'monge' como o 'ideal' do homem místico, contemplativo e sábio. Este pensamento ele desenvolve amplamente em seu livro Elogio de la sencillez. Nele nos basearemos para explorar o que ele quer dizer quando elege o monge como o arquétipo humano. Ele inicia seu livro procurando explicar o uso deste termo.

Fazendo uso da ambiguidade da frase 'arquétipo monástico' nos dirigimos não a descrever o monge como arquétipo, ou seja, o monge como um paradígma de vida humana, senão a explorar o arquétipo do monge, ou seja, a forma de vida do monge como uma possibilidade de arquétipo humano ${ }^{1162}$.

Arquétipo aqui, não significa modelo. Ele é mutável e dinâmico ${ }^{1163}$. O monge é a expressão de um arquétipo que constitui uma dimensão constitutiva da vida humana: o monástico ${ }^{1164}$. Ou seja, o arquétipo do qual o monge é uma expressão, corresponde a uma dimensão do humanum, de modo que "todo ser humano tem potencialmente a possibilidade de realizar esta dimensão. O monástico é um dimensão que tem que ser integrada a outras dimensões da vida humana para conseguir o humanum. Não somente de pão vive o homem"1165. O "humanum é multidimensional, e nenhuma de suas dimensões pode por si somente abraçar a complexidade da vida humana"1166.

Panikkar concebe o monge, como aquela pessoa que aspira alcançar o fim último da vida com todo seu ser, renunciando a tudo o que não é necessário para isso, ou seja, concentrando-se neste único e singular objetivo.

\footnotetext{
${ }^{1161}$ PANIKKAR, Raimon. La intuición cosmoteándrica, p. 180.

${ }^{1162}$ Id., Elogio de la sencillez, p. 16.

${ }^{1163}$ Cf. Ibid., p. 16.

${ }^{1164}$ Cf. Ibid., p. 24.

1165 Ibid., p. 29.

1166 Ibid., p. 30.
} 
O monge se encontra no mínimo mumukşūtva, o desejo de ser libertado, e está tão concentrado nisso que renuncia aos frutos de sua ação (ihāmutrārthaphala bhogavirāgah) distinguindo o real do que não é (nityānitya-vastuviveka), e por isso está disposto a seguir a práxis necessária (sādhana $)^{1167}$.

Assim o monge assume com radicalidade a missão de alcançar o fim último da vida, como aspiração propriamente humana. Neste empenho evita distrair-se com aquilo que não se converte em meio para alcançá-lo ou desviar-se por caminho que não o conduzem para a meta desejada. Igualmente, também necessita da experiência (de fé) como condição de possibilidade da dimensão monacal. A dimensão monástica do homem é uma dimensão constitutiva do ser humano que, igualmente à mística,

não é o monopólio de uns poucos, senão que é uma riqueza humana canalizada em diferentes graus de pureza e consciência por distintas pessoas. Porém esta riqueza também pode ser frustrada. Cada ser humano tem uma dimensão monástica, e cada um deve realizar-se de forma distinta ${ }^{1168}$.

Diante das críticas que Panikkar apresentou sobre a modernidade com respeito a tecnologia, o mercado consumista e o individualismo excessivo. Ele no apresenta a simplicidade como contraponto a essa realidade.

Uma chamada a bendita simplicidade é necessariamente urgente. Se não o fazem monges antigos, surgiram novos monges para exercer esta função de recordar ao mundo, com seu exemplo, que somente necessitam poucas coisas para uma vida humana plena e feliz; e, todavia menos para alcançar a 'vida eterna', que não é necessário, é claro, deixar para o futuro ${ }^{1169}$.

A simplicidade recorda ao ser humano o ascetismo monacal e o atualiza para torná-lo presente em sua vida. Recorda a primeira e primordial tarefa: estarmos ocupados com a plenitude (ou na salvação, a libertação, a perfeição...) deste aspecto da realidade que é o ser humano. Estarmos comprometidos na perfeição de si mesmo neste sentido não é egoísmo, senão a mais plena realização do ser humano ${ }^{1170}$.

Somos parte de uma realidade superior e mais ampla em que não existem apenas outros (Deus, Homens e Mundo) que compartilham e que influenciam nosso destino, senão que existem outras dimensões da realidade (divina, humana e cósmica) que estão bem comprometidas na mesma aventura última. A ascética nos permite reconhecer a interdependência da Realidade, e bem integrada no ser

\footnotetext{
${ }^{1167}$ PANIKKAR, Raimon. Elogio de la sencillez, p. 24.

${ }^{1168}$ Ibid., p. 31.

${ }^{1169}$ Ibid., p. 195.

${ }^{1170}$ Cf. Ibid., p. 205.
} 
humano, trabalha para a melhora do mundo e pela transformação das estruturas externas da realidade ${ }^{1171}$.

Certo é que o monaquismo representa uma dimensão constitutiva do cristão, porém, também o é de todo ser humano.

O monaquismo não é um caminho, senão uma dimensão do humano caminhar sobre a terra, quando este peregrinar não é um arrastar os pés tristemente e sem esperança; representa a dimensão escatológica da existência, o elemento transcendente da vida humana, o contato tempiterno com o Absoluto, ou como quiser caracterizá-lo ${ }^{1172}$.

Desta maneira compreendemos ainda melhor porque a vida monástica não é nem um estado nem uma vocação particular própria de alguns, senão uma dimensão da vida humana e um elemento da vocação de todo homem. "Cada homem tem um pouco de monge. Bem-aventurados os monges, disse Cristo segundo o evangelho copto de Tomás"1173.

Por fim, Panikkar apresenta um monaquismo além das fronteiras do cristianismo. Essa experiência não se esgota em um grupo, mas a de todo ser humano. "O monge, como monge, não é um testemunho direto e imediato de Cristo, senão do Absoluto; não é um fenômeno eclesial, senão é uma manifestação universal da religiosidade constitutiva do homem"1174.

\section{7 "Toda realidade é uma cristofania"}

Cristo é a plenitude da vida. Esta plenitude, que tem tantos nomes, na tradição cristã é chamada Jesus, o Cristo, símbolo real da 'divinização', isto é, a plenitude do ser humano ${ }^{1175}$. Panikkar, em seu livro La plenitud del hombre, desenvolve diretamente sua proposta da cristofania. Ele lembra de que se trata de um "palavra cristã" aberta à problemática universal de um modo concreto e $\operatorname{limitado}^{1176}$.

Segundo ele, a cristofania apresenta "a epifania da condição humana à luz tanto de nossa situação atual como dessa luz que parece ter sua fonte mais além do homem, luz que tem acompanhado o homo sapiens desde o princípio de sua

\footnotetext{
${ }^{1171}$ Cf. PANIKKAR, Raimon. Elogio de la sencillez, p. 197.

1172 Ibid., p. 197.

1173 Ibid., p. 203.

1174 Ibid., p. 197.

${ }^{1175}$ Id., La plenitud del hombre, p. 15.

${ }^{1176}$ Cf. Ibid., p. 128.
} 
existência [...] Cristofania equivale à manifestação de Cristo na consciência humana e inclui uma experiência do Cristo e um reflexão crítica da mesma" ${ }^{\text {1177. }}$. Em relação com cristianismo primitivo existe "um Cristo escondido, cujo monopólio não têm os cristãos, e que pode ou poderia ser símbolo de uma unidade muito mais unificadora, como o tem sido o símbolo de Deus na história"1178.

A cristofania não é somente uma cristologia que tenta interpretar os fatos históricos de Jesus de Nazaré. Pretende, antes de tudo, acolher criticamente "o mistério aparecido, manifestado, revelado" $" 1179$ com todos os meios de conhecimento dos que pode dispor o homem. Este mistério estava já desde o princípio "no seio do Pai"1180 e, portanto não é histórico nem temporal, como foi uma afirmação temporal de Jesus ao dizer que ele era "antes de Abraão",1181.

Panikkar esclarece que a cristofania não pretende fazer desaparecer o Jesus histórico em um gnosticismo não cristão, ainda que em certas teologias se possa encontrar uma historiolatria. "A cristofania não rejeita em absoluto a historicidade de Jesus, senão afirma que a história não é a única dimensão do real e que a realidade de Cristo não se esgota, portanto, com a historicidade de Jesus" ${ }^{1182}$.

A encarnação é um ato trinitário, porque Cristo remete ao Pai e ao Espírito. A este respeito nosso autor, em Ícones do mistério, interpreta três textos evangélicos que representam a experiência trinitária de Jesus de Nazaré ${ }^{1183}$.

a) "Eu e o Pai somos um" (Jo 10,30). Esta frase se entende como uma "confissão não-dualista entre o Pai e o Filho". Existe uma distinção (“Eu e o Pai”), porém existe comunhão interna que manifesta a inseparabilidade de ambos ("somos um”). As relações intratrinitárias são relações dinâmicas e o Espírito é a expressão permanente desse dinamismo. E é precisamente nesse dinamismo intratrinitário, que o ser humano é chamado a participar ${ }^{1184}$.

b) "Quem me tem visto, vê o Pai" (Jo 14,9). "Este ver o Pai em Jesus significa - e há de significar em nós também - que a verdadeira essência de Jesus é a

\footnotetext{
1177 PANIKKAR, Raimon. La plenitud del hombre, pp. 31-32.

1178 Ibid., p. 67.

${ }^{1179} \mathrm{Rm} \mathrm{16,26.}$

1180 Jo 1,18 .

${ }^{1181}$ Cf., Id., Jesús en el diálogo interreligioso. En Diez palabras clave sobre Jesús de Nazareth, compilado por Juan José Tamayo, 453-488. Navarra: Verbo Divino, p. 481. Cf. Jo 8,58

1182 Ibid., p. 465.

${ }^{1183}$ Cf. Id., Icones do místério. A experiência de Deus. São Paulo: Paulinas, 2007. pp. 142-149.

Título original: Iconos del misterio: la experiencia de Dios (1998).

${ }^{1184}$ Cf. Id., Icones do místério. pp. 142-143.
} 
transparência" ${ }^{1185}$. Cristo transparece nos outros. Por isso nossa experiência de Cristo não pode ser outra senão nossa experiência crística dos outros; uma experiência de abertura, de entrega, de doação, de encontro ${ }^{1186}$. Nos outros descobrimos a Cristo: "Todo ser é uma cristofania"1187.

c) "Convém que eu vá; porque, se eu não for o Espírito não virá até vós" (Jo 16,7). Neste texto, revela-se a presença direta do Espírito Santo. Este Espírito integra o ser humano na vida trinitária de uma maneira corporal, pessoal, contingente. Esta é a experiência de Deus, a experiência de plenitude do ser humano no Ser. Incorporados na perichôrêsis ou circumincessio trinitária de toda realidade $^{1188}$.

Deste modo, a Cristofania não remove nada da Cristologia, porém se manifesta mais claramente aberta à realidade do Espírito sem separação entre logos e pneuma. Sem uma visão mística, a cristofania não adquire seu verdadeiro significado $^{1189}$. A cristofania apresentada é eminentemente Trinitária. Todavia, como esta implica uma consciência transhistórica, resulta necessário explicar a compreensão que tem nosso autor acerca do Jesus histórico e o Cristo da fé. Em primeiro plano, Panikkar não nega a história, tampouco nega que o Jesus histórico seja Cristo, no entanto, para ele, Cristo não se esgota em Jesus histórico:

Jesus é o Cristo, e quem confessa que Jesus é o Cristo define a identidade cristã. Porém Cristo não esgota Jesus. Jesus é idêntico a Cristo, não existe nada em Jesus que não seja Cristo, porém Cristo era anterior a Abraão e Jesus não era antes de Abraão [...] Cristo está em todo irmão que sofre, e Jesus de Nazaré não está aî ${ }^{1190}$.

E como os cristãos acreditam que Cristo ressuscitou ${ }^{191}$ transcendem o tempo e o espaço, é possível ter um encontro pessoal com Ele "aqui e agora". Portanto, o mistério de Cristo transborda da manifestação que tem lugar em Jesus e, também, na experiência mesma que os cristãos têm de Cristo ${ }^{1192}$.

Está claro que "Jesus para o cristianismo é a experiência de Jesus ressuscitado, isto é, do Cristo vivo, hic et nunc, ontem, hoje e sempre, para dizer com São Paulo. Não é uma experiência histórica, mas transhistórica, pessoal e

\footnotetext{
1185 Cf. PANIKKAR, Raimon. Icones do mistério, p. 144.

${ }^{1186}$ Cf. Ibid., p. 145.

1187 Ibid., p. 91.

${ }^{1188}$ Cf. Id., Icones do místério. Ibid., p. 149.

${ }^{1189}$ Cf. Ibid., p. 148.

${ }^{1190}$ Id., Ecosofia, p. 64.

${ }^{1191}$ Cf. 1 Cor 15,14 .

${ }^{1192}$ Cf. PANIKKAR, Raimon. Jesús en le diálogo interreligioso, p. 456.
} 
intransferível"1193.

A experiência com o Cristo vivo, o ressuscitado, conduz a um descobrimento de sua identidade. Panikkar considera que podemos estabelecer a identificação de Jesus histórico, porém, se queremos falar ao menos um traço de sua identidade, esta resulta do encontro com Jesus ressuscitado ${ }^{1194}$.

No entanto, ele distingue as duas realidades, mas não as separa, ainda que seja enfático em assinalar que o mistério Cristo excede o fato histórico Jesus. Diante disto, afirma que "Cristo é o símbolo de toda a realidade" ${ }^{1195}$. Em relação ao que ele entende por símbolo, o mesmo nos diz que: "o símbolo de uma coisa não é nem outra coisa nem a coisa em si, senão a coisa mesma tal com se manifesta, como é no mundo dos seres, na epifania do ser [...] é a coisa realmente como aparece, como realmente é, no reino dos seres"1196. Um símbolo não necessita ser interpretado, ou seja,

não apreendemos os símbolos; no entanto, nos abrimos a eles, nos encontramos a nós mesmos neles, de modo que participando neles é como têm sentido e nos conduzem à compreensão do que simbolizam. Um símbolo é um mediador, não um intermediário $^{1197}$.

\section{Em Cristo}

estão contidos não somente 'todos os tesouros da divindade', senão também que estão escondidos 'todos os mistérios do homem' e toda a espessura do universo [...] Ele é o símbolo da realidade mesma, o símbolo cosmoteândrico por excelência ${ }^{1198}$.

A autocompreensão cristã de Cristo é completa: Ele é o alfa e o ômega, é antes que Abraão, o começo e o fim. O Cristo é a figura histórica, porém é também o Cristo cósmico; é o ômega de Teilhard, porém também o alfa de Orígenes, e o símbolo para os cristãos daquilo que representa a plenitude da humanidade, a plenitude da divindade, a plenitude da corporeidade e a matéria. Cristo é o símbolo daquilo que nós chamamos com certa linguagem o absoluto: o símbolo da realidade [...] Cristo é o ícone de toda a realidade ${ }^{1199}$.

Cristo é o centro da mandala cósmica, do que emerge a realidade inteira e a que caminha tudo. Se poderia dizer que tudo surge dele em uma cristofania. O universo está ordenado organicamente e centrado. Este centro é, por definição, Cristo ${ }^{1200}$.

\footnotetext{
${ }^{1193}$ Cf. PANIKKAR, Raimon. Ícone do mistério, p. 127.

${ }^{1194}$ Ibid., pp. 125-126.

1195 Id., Ecosofía, p. 63.

${ }^{1196}$ Id., Mito, fe y hermenéutica, p. 319.

${ }_{1197}$ Id., Culto y secularización, p. 30.

${ }^{1198}$ Id., La plenitud del hombre, p. 180.

${ }^{1199}$ Cf. Id., Ecosofía, p. 63.

${ }^{1200}$ Id., Salvation in Christ, pp. 41-42.
} 
Cristo tem de cada ser uma cristofania porque "os seres são geração $\gamma \varepsilon \dot{v} v \varepsilon \sigma l \varsigma$ de Cristo, de onde este gênesis significa certo devir. Todos os seres são em Cristo, por Cristo e com Cristo" ${ }^{1201}$. Em todas as relações Cristo se faz presente, em nenhuma comunicação humana ele está ausente.

Panikkar propõe um Cristo trinitário, cosmoteândrico:

A tradição cristã não separa a compreensão de Cristo da compreensão da criação, por um lado, e da Trindade, por outro. Cristo não somente é o salvador, é também o criador. Cristo não é um meteorito divino, é um da Trindade. A cristofania tem sentido somente no interior de uma visão trinitária. Em Cristo temos a plena manifestação da Trindade ${ }^{1202}$.

Ou seja, "Cristo resulta incompreensível sem a Trindade. Um Deus nãotrinitário não poderia encarnar-se. Um Cristo não-trinitário não poderia ser totalmente humano e totalmente divino" ${ }^{1203}$. Ele considera que a encarnação não é histórica, mas é um acontecimento na história com serias implicações para a cosmovisão cristã. E se a encarnação é um ato divino histórico, pela mesma razão,

o Cristo protológico é o mesmo Cristo histórico, e o Cristo histórico não é separável do Cristo eucarístico e ressuscitado. Analogamente, o Cristo escatológico, a última vinda de Cristo, a parusia de Cristo, não é separável do Cristo eucarístico e ressuscitado ${ }^{1204}$.

De acordo com Panikkar, “a Encarnação não é somente a divinização de um homem (e com ele todo homem) senão também a humanização de Deus (e com ele todo o divino). Não se poderia ver esta perichôrêsis se não tivesse descoberto a Trindade" 1205 , pois é ela que permite dizer coerentemente que Cristo é plenamente Homem e plenamente Deus. Na linguagem cristã, se diz que Cristo é também corpo, e que nós somos templos do Espírito Santo participando do seu mistério crístico ${ }^{1206}$.

Em Jesus se encontra toda a Corporeidade, Humanidade e Divindade em sua forma mais concreta e plena. Esta frase não teria sentido se não tivesse descoberto seu caráter divino que transcende o espaço e o tempo. Jesus Cristo é divino. Porém, analogamente, não poderíamos conhecer com aquele 'conhecimento que é a vida eterna' se não participássemos da mesma humanidade. Jesus Cristo é humano. Tudo se reduziria ao simples intelecto abstrato se não tratasse de uma Corporeidade que é também a nossa e que está representada na Encarnação - e na Eucaristia ${ }^{1207}$.

\footnotetext{
${ }^{1201}$ PANIKKAR, Raimon. Misterio y revelación, p. 90.

${ }^{1202}$ Id., La plenitud del hombre, p. 206.

${ }^{1203}$ Id., El Cristo desconocido, p. 27.

${ }^{1204}$ Id., La plenitud del hombre, p. 206.

${ }^{1205}$ Id., De la mística, p. 247.

1206 Ibid., p. 260.

1207 Ibid., p. 261.
} 
Por isso, está certo que: "Jesus Cristo é o símbolo (concreto) de toda a realidade - o símbolo da experiência cosmoteândrica. Toda realidade é uma cristofania" ${ }^{1208}$.

Sobre a ressurreição ele vai nos dizer que:

Não se trata evidentemente de uma causalidade física, senão de uma perichôrêsis, de uma correlação constitutiva de toda realidade. Sem dúvida é um sacrifício, em seu sentido real e tradicional, morrendo ressuscitou e ressuscitando restaurou a qualidade de vida - transformou a vida biológica em uma vida mais plenamente humana, isto é, divina (sem deixar por isso de ser humana). Existe uma perichôrêsis tanto humana como cósmica - não somente 'intra-trinitária' ${ }^{1209}$.

Logo, quando o ser humano vive a ressurreição de Cristo em si mesmo, ele está rompendo sua finitude. Trata-se de uma experiência tempiterna. A reflexão que faz Panikkar sobre a realidade de Cristo como símbolo pleno da realidade cosmoteândrica torna-o universal.

Segundo Panikkar, a Jesus Cristo não se pode conhecer sem amá-lo. Se conheceria então só uma ideia. Não se pode amar sem aquele conhecimento unitivo. Seria então só uma projeção psicológica. Ele enfatiza que,

faz falta a experiência (mística) que integra conhecimento e amor e os transcendem. Descobre-se então o Cristo vivo de 'hoje, ontem e sempre'. Somente se ele vive em mim e eu nele [...], somente se temos corressuscitado com ele, podemos participar da experiência. Por algo se dizia a autêntica teologia requer a experiência de fé - e acrescentaria a esperança e o amor ${ }^{1210}$.

Em Jesus Cristo a união hipostática é claramente presente; no homem, no entanto, a circumincessio trinitária é uma realidade ainda não alcançada plenamente:

Jesus Cristo é o filho de Deus, porém também o somos nós - e toda a criação é uma aventura trinitária -. Em Cristo a humanidade e a divindade não podem separar-se. Em nós tampouco, porém não tem chegado a interpretação. Isto é a perichôrêsis e isto é a realização ${ }^{1211}$.

Jesus Cristo é a transparência, o caminho. Ele é o protótipo de toda a humanidade, o totus homo, o homem pleno. Todo aquele que descobre a Jesus Cristo experimenta a vida eterna, ou seja, a ressurreição da carne e, portanto, a realidade da matéria, do cosmos. Jesus Cristo é o símbolo vivente da divindade, da humanidade e do cosmos (o universo material) ${ }^{1212}$.

\footnotetext{
${ }^{1208}$ PANIKKAR, Raimon. De la mística, p. 261.

${ }^{1209}$ Ibid., p. 252.

${ }^{1210}$ Ibid., p. 262.

${ }^{1211}$ Id., La plenitud del hombre, p. 213.

${ }^{1212}$ Cf. Ibid., p. 220.
} 
Além disso, Cristo é o mediador.

Este último [o intermediário] relaciona duas entidades desde o exterior, por assim dizer, ou encontra uma síntese superior que o abarca. A mediação, em troca, é uma relação interna e constitutiva entre dois polos - enquanto polos. [...] Os "dois" polos formam precisamente uma polaridade a-dual. A mediação não une duas entidades, senão que é a mesma união, união que não significa unidade nem unificação senão polaridade constitutiva. A mediação nos faz ver que não se trata de duas entidades que $\log$ o se relacionam senão que a relação é fundamental [...] não permite a reductio ad unum; isto é, ver ambos os polos. Não é que Jesus Cristo, como um exemplo cristão, seja um homem que nos une a Deus ou um Deus que verifica os homens, senão que é tanto e plenamente Deus e homem - não Deus e metade homem: é mediador e não intermediário ${ }^{1213}$.

Somente quando o homem estiver completamente vazio de si mesmo, morará Cristo plenamente nele, ou seja, quando estiver em um estado de kenosis, realizará Cristo sua encarnação nele ${ }^{1214}$. Isso porque também é para o ser humano esse esvaziamento, essa experiência de kenosis lhe permitirá alcançar até onde seja possível, a plenitude, o humanum.

Para Panikkar,

todos somos kenóticos, vazios da divindade que reluz escondida em cada um de nós; todos estamos despojados, por assim dizê-lo, de nossa vestidura mais autêntica; todos nós, mesmo tendo uma origem divino e sendo templos da divindade, aparecemos, não somente frente aos demais senão frente a nós mesmos, como meros indivíduos de uma espécie submetida ao sofrimento e a morte. Ele não o escondeu. Somente uma pessoa divina pode manifestar tanta humanidade ${ }^{1215}$.

\section{Conclusão}

Em Panikkar, encontramos um homem que viveu sua experiência de Deus, descobrindo-se um constante peregrino, aprendiz do seu amor. Desde o seio familiar, por ser filho de mãe católica e de pai hindu, surgiu a busca pela harmonia entre as religiões e culturas, que se tornará cada vez mais clara e determinante para ele a partir de sua experiência de Deus em que procurou integrar toda a realidade em todas as suas dimensões. Como vimos, todo o seu peregrinar se deu a partir de sua experiência existencial.

O desenvolvimento de seu pensamento e as suas descobertas tiveram origem em sua própria experiência de vida, a partir do encontro com outras tradições

${ }^{1213}$ PANIKKAR, Raimon. De la mística,. 79.

${ }_{1214}^{121}$ Id., El Cristo desconocido del Hinduismo, p. 58.

${ }^{1215}$ Id., La plenitud del hombre, p. 167. 
religiosas e culturais e na sua fecunda formação intelectual. A partir dessas experiências, ele inicia uma busca incansável pela harmonia entre as diversas dimensões da Realidade contra todo tipo de reducionismos, dando início ao que ele chamou de intuição cosmoteândrica.

Quando Panikkar foi enviado em missão à Índia ele se redescobriu, como hindu e budista, sem deixar de ser cristão. Também se identificou com uma identidade secular. Em seus escritos, ele procurou deixar sempre claro que nunca deixou de ser um sacerdote cristão, pois esta consagração fazia parte do seu ser. Podemos dizer que sua experiência de Deus o levou a ultrapassar os limites impostos pela instituição, abrindo-se a uma profunda experiência de encontro consigo mesmo, em um profundo mergulho em suas raízes internas, descobrindose, assim, uma pessoa com quatro identidades.

Todo o seu pensamento é marcado por sua experiência religiosa. Não era possível para ele realizar uma leitura da realidade se não fosse através da religião. Encontramos em Panikkar uma vocação que aspirou a uma plenitude existencial. Quando desenvolve sua intuição cosmoteândrica, revelando que o divino, o humano e o terreno são as três dimensões irredutíveis que constituem a Realidade, ele supera a dialética. Essas dimensões coexistem, estão inter-relacionadas. Essa sua intuição representa a consciência religiosa, que segundo ele, diz está surgindo em nosso tempo, quando o ser humano deseja integração da realidade.

Acompanhando o seu pensamento, reconhecemos mais uma vez o seu desejo de não fragmentação do ser humano em sua experiência mística. Para ele, essa experiência adquire uma dimensão antropológica. Ela integra as dimensões e relações constitutivas do ser humano, tendo a experiência de Deus como raiz de toda experiência em profundidade.

Panikkar nos apresentou o monge como o arquétipo do ser humano, por causa do seu esforço por caminhar na simplicidade, buscar uma nova inocência, e por aspirar alcançar o fim último da vida com todo o seu ser, ou simplesmente para ser. E que a vocação monástica precede o fato de ser cristão, budista, hindu, "inclusive ateu", e por isso, é um arquétipo universal.

Da mesma forma, sua experiência religiosa revelou que Cristo e seus ensinamentos não são monopólios ou propriedades exclusivas do cristianismo. Pelo contrário, Cristo é o símbolo universal da unidade divino-humana, a face humana de Deus. O cristianismo se aproxima de Cristo de uma forma particular e 
única, informado pela sua própria história e evolução espiritual. Mas Cristo transcende amplamente o cristianismo. Essa experiência foi crucial para Panikkar, porque longe de diluir ou, de alguma forma, enfraquecer as crenças e práticas cristãs centrais, esse diálogo, além de ter promovido o entendimento e a harmonia inter-religiosa, ofereceu um meio indispensável para o aprofundamento da sua fé cristã.

Foram 91 anos de vida na busca da não fragmentação do ser humano e da Realidade em que vivemos. Uma vida dedicada não a verdades universais, mas ao conhecimento integral que não separa o amor do conhecimento, cumprindo a tarefa, como ele mesmo dizia, de toda criatura: completar, conduzir a sua perfeição, o ícone do real que todos nós somos.

Na próxima parte de nossa tese, procuraremos, a partir da experiência de profundo encontro com Deus vivida por Merton e Panikkar, destacar os passos que os mesmos trilharam no diálogo inter-religioso e a possibilidade de uma mística inter-religiosa. 


\section{Glossário}

advaita (sâns.) não-dualidade. Expressão metafísica da irredutibilidade da realidade a pura unidade (monismo) ou a mera dualidade, elaborada filosoficamente por muitas religiões do Oriente.

advaitin (sâns.) adepto da advaita, o que professa a não-dualidade ātman-

\section{Brahman}

aliud (lat.) o outro, neutro.

alius (lat.) o outro (outro eu).

ätman (sâns.) o si-mesmo de um ser e da realidade. Uns o traduzem por "si", outros por"eu". Núcleo ontológico no hinduísmo e meramente inconstante no budismo.

Bhagavad-gītā (sâns.) canto do Bem-aventurado. O mais conhecido dos livros sagrados da Índia.

bhakti-mārga (sâns.) atitude mística de devoção, de amor ao Senhor. Um dos caminhos para a salvação mediante a união com a Divindade.

Brahman (sâns.) designação da Realidade absoluta, uno e idêntico ao ätman fundamento de tudo; alma e essência do mundo.

capax Dei (lat.) capacidade da alma de perceber e receber a Deus.

circumincessio (lat.) compenetração das três pessoas da Trindade. Equivale ao grego perichôrêsis.

cit (sâns.) consciência, inteligência, espírito, intelecto.

coesse (lat.) ser conjuntamente, existir juntos; co-existir.

humanum (lat.) característica fundamental do humano; o específico da

humanidade.

jñāna-mārga (sâns.) conhecimento experiencial da Realidade. Um dos caminhos de libertação ou perfeição centrado no conhecimento por experiência, por uma intuição direta da Realidade.

karma/karman (sâns.) obra, ação. Originalmente, a ação sagrada, o sacrifício, posteriormente também o ato moral. O resultado de todas as ações e obras de acordo com a lei do karma que governa as ações e seus resultados no universo.

mokșa (sâns.) libertação final do samsāra, do ciclo do nascimento e morte, do karma, da ignorância, da limitação: salvação.

mysterium coniunctionis (lat.) mistério de unificação, reintegração da unidade das 
partes; a reunificação dos opostos em unidade primordial.

nirvāṇa (sâns.) extinção. A libertação de toda limitação; a meta última para o budismo e o jainismo.

noumenon (grego.) o que está oculto por trás da aparência (phainomenon), o que está mais além da experiência sensível.

perichôrêsis (grego.) noção da doutrina trinitária da igreja primitiva que designa a interpretação das pessoas divinas. Equivale ao termo latino circumincessio.

pisteuma (grego.) do grego pisteuō (crer); o que o crente crer, o mistério intencional dos fenômenos religiosos.

plērōma (grego.) plenitude, cheio, completo.

pratîtyasamutpâda (sâns.) doutrina budista do surgimento condicionado ou dependente, que afirma que nada é por si mesmo e que nada conduz em si mesmo as condições de sua existência, senão que tudo está relacionado.

sarvam-sarvātmakam (sâns.) tudo está relacionado com tudo.

satori (jap.) do verbo saturo, designa a "iluminação" que se procura no budismo zen. Significa literalmente "compreensão". É análogo ao conceito de criatividade, no sentido que reconcilia oposições aparente.

Upanișad (sâns.) ensinamento sagrado fundamental sob forma de textos que constituem o final dos Veda; parte da revelação (śruti) e base do pensamento hindu posterior.

Veda (sâns.) conjunto de "sagradas escrituras" do hinduísmo.

Bhakti (sâns) atitude mística de devoção, de amor para Deus; participação no divino por amor, devoção, abandono. Significa tanto "separação" (bañj), como "dependência" (bhj). Por extensão é a religião do amor. O bhakta é o adepto da bhakti.

Mandala (sâns) "círculo", esquema cosmogênico. 


\section{Cronologia da vida de Raimon Panikkar}

1918 - 03 de novembro: Nasce em Barcelona, Raimon Panikkar. Filho de pai hindu Ramun Panikkar e de mãe catalã católica, Carmem Alemany.

1935 - Bacharelado em Ciência e Letras.

1940 - Ingressa na Opus Dei.

1941 - Licenciatura em Ciências, em Barcelona.

1942 - Licenciatura em Letras, em Madri.

1946 - Ordenação sacerdotal na Opus Dei. Doutorado em Filosofia e Letras, em Madri.

1954 - Licenciatura em Teologia, em Roma.

1954 - Missão apostólica na Índia.

1958 - Doutorado em Ciências, em Madri.

1961 - Doutorado em Teologia, em Roma.

1962-1963 - Participa do Sínodo de Roma e em atividades do Concílio Vaticano II.

1964 - Regressa à Índia. É dispensado canonicamente da Opus Dei e incardina-se na diocese de Varanasi.

1996-1987 - Leciona em universidades dos Estados Unidos.

1987 - Volta para Tavertet, Catalunha.

2010 - Completa o seu ciclo de vida. Morre em Tavertet no dia 26 de agosto aos 91 anos. 


\section{V - Parte}

\section{A mística cristã na perspectiva do diálogo inter-religioso em Thomas Merton e Raimon Panikkar}

Nesta parte de nossa tese, daremos continuidade à reflexão sobre a experiência vivida por Thomas Merton e Raimon Panikkar ${ }^{1216}$, destacando o que significou o diálogo inter-religioso e o que cada um apontou como caminho para essa experiência. Diante da indiscutível realidade plural em que vivemos, reconhecemos no que diz respeito às religiões, e em especial ao Cristianismo, que se devem criar condições para uma apreciação positiva das demais religiões através de um diálogo fecundo e acolhedor. Para isso, acreditamos que, a exemplo das experiências de místicos como Merton e Panikkar, a realização de um caminho espiritual enraizado na profunda experiência de Deus abre possibilidades para uma mística inter-religiosa.

\section{Thomas Merton Encontrar Deus nas outras pessoas}

Como pudemos ver na III parte de nossa tese, Merton, no decorrer de sua busca interior, nos revelou que a contemplação é sinal de maturidade cristã que se inicia com o despertar do eu interior para a vida ao entrar em contato espiritual com Deus a partir da fé.

A contemplação é sinal de vida cristã perfeitamente madura. Faz com que o crente não seja mais escravo ou servo de um Mestre Divino, não esteja mais possuído de temor na observância de uma lei difícil, e mesmo não seja mais um filho submisso e obediente, demasiadamente jovem ainda para participar das decisões de seu Pai. A contemplação é aquela sabedoria que faz do homem um amigo de Deus ${ }^{1217}$.

Pois ele está de convicto que a maturidade cristã alcançada pela contemplação permite ao crente alcançar a comunhão com o Deus vivo.

O místico, isto é, o contemplativo, não só vê e toca o que é real, mas, além da superfície de tudo que é atual, alcança a comunhão com a liberdade, fonte de toda realidade. Essa realidade, essa liberdade, não é um conceito, uma coisa, não é um objeto, nem mesmo um objeto de conhecimento. É o Deus vivo, o Santo, Aquele ao qual ousamos aplicar um Nome unicamente porque Ele próprio revelou-nos um Nome, mas que está situado para além de todos os Nomes como supera todo Ser,

1216 Continuaremos a nos referir ao Thomas Merton como Merton e ao Raimon Panikkar como Panikkar, no decorrer do nosso texto.

${ }^{1217}$ MERTON, Thomas. O homem novo, p. 20. Sobre o Evangelho ver o texto: Jo, 15,15-16; 5,7. 
todo conhecimento, todo amor. É Ele o infinitamente "Outro", o Transcendente, do qual não temos nem podemos ter nenhuma ideia unívoca ${ }^{1218}$.

A pessoa é colocada diante de uma realidade em que se apresenta uma renovação mais profunda da vida, de acordo com uma autêntica experiência de Cristo, causada por nossa semelhança, nossa filiação, pelo dom do Espírito divino que faz Cristo 'habitar em nosso coração' ou em nosso eu mais profundo ${ }^{1219}$.

Ou seja,

Assim como um homem conhece a si mesmo pelo testemunho de seu eu mais profundo, de seu espírito, também Deus revela a Si mesmo no amor de seu Espírito. E o Espírito de Deus, que habita em nós, que é dado a nós para ser como que nosso próprio espírito, permite-nos conhecer e experimentar, de modo misterioso, a realidade e a presença da misericórdia divina em nós. Assim, o Espírito Santo está intimamente unido ao nosso eu mais profundo e sua presença em nós faz de nosso "eu" o "Eu" de Cristo e de Deus ${ }^{1220}$.

Em Cristo, o abismo que separa o ser humano de Deus foi transposto pela encarnação, e no próprio ser humano esse abismo é transposto pela presença do Espírito Santo. Ele se faz presente em todo ser humano, nele 'nos tornamos outros Cristos'. E está gravada nas raízes do próprio ser humano a imagem de Deus, recordando-o sempre quem é e para que foi criado.

Embora não exista uma ponte "natural" entre a ordem sobrenatural e a natural, a situação concreta em que se encontra o homem, como natureza criada para um fim sobrenatural, torna essa angústia inevitável. Não pode o homem descansar se não repousa em Deus. Não o Deus, meramente, da natureza, e sim o Deus Vivo. Não um Deus que possa ser objetivado por algumas noções abstratas, e sim o Deus que está acima de qualquer conceito. Não o Deus de uma união apenas racional ou moral, mas o Deus que se faz Um com nossa alma, no Espírito! É essa a única realidade para a qual fomos criados. Somente aqui, por fim "nos encontramos" não em nosso ser natural, mas fora de nós mesmos, em Deus. Pois nosso destino é sermos infinitamente maiores do que nosso pobre eu. A angústia espiritual do homem só tem um remédio: o misticismo ${ }^{1221}$.

Merton nos lembra que as sementes dessa vida sublime são plantadas em toda alma cristã pelo batismo e que milhares de cristãos não sabem nada sobre essa presença em seus corpos, "são filhos de Deus e não percebem sua própria identidade" ${ }^{, 222}$.

As sementes da contemplação e da santidade plantadas nessas almas permanecem simplesmente dormentes. Não germinam, não crescem. Em outras palavras, a graça santificante preenche a substância da alma desses indivíduos, mas nunca extravasa

\footnotetext{
${ }^{1218}$ MERTON, Thomas. O homem novo, p. 18.

${ }^{1219}$ Cf. Id., Experiência interior, p. 61.

1220 Ibid., pp. 65-66.

${ }^{1221}$ Id., O homem novo, p. 92.

${ }^{1222}$ Id., Experiência interior, p. 69.
} 
para inflamar, irrigar e tomar posse das faculdades deles, de seu intelecto e de sua vontade. A presença de Deus nunca se torna uma realidade íntima. Deus não se manifesta a essas almas porque elas não $\mathrm{O}$ buscam com real desejo ${ }^{1223}$.

São pessoas divididas entre Deus e o mundo. Estão alheias ao que é mais profundo em seu interior, por nunca buscarem ou mesmo por nunca desejarem essa dimensão. Seus pensamentos e desejos estão longe de Deus.

É bem normal, quando entra alguém em contato íntimo com Deus, sentir-se inteiramente transformado por dentro. Nosso espírito passa por uma metanoia, uma conversão que dá nova orientação a todo nosso ser após o haver elevado a um novo nível, parecendo mesmo transformar completamente nossa natureza. Então, a "autorrealização" torna-se uma conscientização do fato de sermos bem diverso do nosso ser normal empírico [...] Vemos que somos, em verdade, mais humanos quando elevados ao nível do divino. Transcendemo-nos, vemo-nos numa luz nova, perdendo-nos de vista, e não mais nos consideramos, mas só a Deus. Assim, num ato único, realizamos o duplo movimento de entrar em nós mesmos e de sair de nós mesmos, que nos leva ao estado paradisíaco para o qual fomos originariamente criados $^{1224}$.

É necessário recobrar o domínio do verdadeiro eu pela libertação da angústia, do medo e do desejo desordenado. Assim, conquistado o domínio de sua alma, deve-se aprender a 'sair' de si mesmo para ir ao encontro de Deus e dos outros por meio da caridade.

Uma vez que fomos criados à imagem e semelhança de Deus, não há outro meio de descobrirmos quem somos senão descobrindo em nós a imagem divina. Ora, essa imagem, presente, pela natureza, em cada um de nós pode, de fato, ser conhecida por inferência racional. No entanto, isso não basta para nos dar uma experiência autêntica de nossa identidade ${ }^{1225}$.

Para reconhecer essa imagem no próprio ser, não basta entrar em si mesmo.

Não basta estar consciente de que a espiritualidade de sua natureza o torna, potencialmente, semelhante a Deus. Essa potencialidade tem de ser atualizada.

Como? Pelo conhecimento e o amor. Ou, mais precisamente, por um conhecimento de Deus inseparável de uma experiência de amor ${ }^{1226}$.

A recuperação da imagem divina em nossa alma, na medida em que é experimentada por todos nós, é a experiência de um modo de ser inteiramente novo. Tornamo-nos "homens novos" em Cristo. E podemos verificar o fato pela mudança em relação ao objeto do nosso conhecimento e nossa maneira de conhecer. Sim, quando Deus é conhecido desta maneira, não é conhecido como "objeto", uma vez que não está encerrado num conceito. Pelo contrário, o conhecimento místico de Deus refletido no espelho de sua imagem dentro de nós: "Conhecerei", diz São Paulo "como fui conhecido" (I Cor 13,12). Nós o

\footnotetext{
1223 MERTON, Thomas Experiência interior p. 69.

${ }^{1224}$ Id., O homem novo, pp. 100-101.

1225 Ibid., p. 97.

${ }^{1226}$ Cf. Ibid., p. 98. Como diz Santo Tomás: “A imagem de Deus está na alma conforme o conhecimento que concebe de Deus e conforme o amor que flui desse conhecimento".
} 
apreendemos pelo amor que se identifica, dentro de nós, com o amor que Ele tem por nós. Aquilo que, na visão beatífica, será plenamente realizado, realiza-se de modo incoativo, na contemplação, desde já na vida presente ${ }^{1227}$.

Está claro que, para se preparar para receber o Espírito Santo e o seu amor, a pessoa deve direcionar o seu desejo para essa experiência, retirando seus desejos de todas as satisfações externas e ambiciosas e dos interesses temporais.

O desejo, entretanto, é a coisa mais importante na vida contemplativa. Sem desejo nunca vamos receber os grandes dons de Deus. Não pode haver desejo onde não há um mínimo de conhecimento. Não podemos desejar a união com Deus a não ser que tenhamos conhecimento da existência desta, bem como alguma ideia daquilo em que ela consiste ${ }^{1228}$.

"Spiritualia videri non possunt nisi quis vacet a terrenis" (não se podem ver

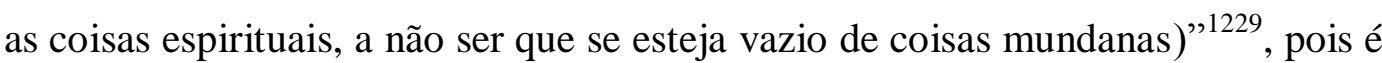
certo que:

A vida, então, não é apenas objeto de conhecimento, é vivida. É vivida e experimentada em sua inteireza, isto é, em todas as ramificações de sua atividade espiritual. Todas as capacidades da alma se desenvolvem no sentido da liberdade, do conhecimento e do amor. E todas convergem e se reúnem num só ato supremo que irradia paz. A realidade concreta dessa experiência é, no mais alto sentido, existencial. Ainda mais, é comunhão - um percepção de nossa própria realidade imersa, e, em certo sentido, unida à suprema Realidade, o Ato Infinito de Existir que denominamos Deus. E, enfim, comunhão ao Cristo Verbo Encarnado. Trata-se, não apenas de uma união pessoal das almas com Ele, e sim de comunhão ao grande e único ato no qual Ele venceu a morte, uma vez por todas, pela sua própria Morte e Ressurreição ${ }^{1230}$.

No entanto, para o homem alienado, assim como para o cristão inteiramente ocupado com atividades externas e interesses temporais, o único meio de descobrir algo sobre as alegrias da contemplação é pela experiência ${ }^{1231}$.

A experiência da contemplação é a experiência da vida e presença de Deus em nós, não como objeto mais como fonte transcendente de nossa própria subjetividade. A contemplação é um mistério no qual Deus se revela a nós como o próprio centro de nosso ser mais íntimo, intimior intimo meo, na expressão de Santo Agostinho. Quando, num relance, tomamos consciência de Sua presença em nós, nosso próprio ser desaparece nEle e atravessamos misticamente o Mar Vermelho de separação para nos perdermos (e assim encontrar nosso ser verdadeiro) $\mathrm{nEle}^{1232}$.

Merton nos apresenta a diferença entre uma visão secular e uma visão sagrada da vida. O adjetivo "secular" é proveniente do latim saeculum, que

${ }^{1227}$ MERTON, Thomas $O$ homem novo, p. 99.

${ }^{1228}$ Id., Experiência interior, p. 71.

${ }^{1229}$ Ibid., p. 70. Segundo TM: "Mundanas - aqueles que amam as coisas transitórias e sem importância deste mundo".

${ }^{1230} I$ Id., O homem novo, p. 22.

${ }^{1231}$ Cf. Id., Experiência interior, p. 71.

${ }^{1232}$ Id., Op. cit., p. 21. 
significa tanto "mundo" quanto "século" e que talvez esteja relacionado ao Grego kuklon, "roda", do qual se tira "ciclo". Originariamente, o "secular" era o que percorre, interminavelmente, ciclos sempre recorrentes. Isto é o que faz "a sociedade mundana", cujos horizontes são de uma sempre repetida mesmidade ${ }^{1233}$.

Ora toda a nossa existência nesta vida está submetida à mudança cíclica. Só isso por si não a faz secular. A vida se torna secularizada quando se compromete inteiramente com os "ciclos" do que parece se novo, mas de fato é a mesma coisa de sempre. A vida secular é uma vida de vãs esperanças, aprisionada à ilusão de novidade e mudança, uma ilusão que nos faz voltar sempre ao mesmo ponto, a contemplação de nossa própria nulidade. A vida secular é uma vida desesperadamente dedicada à fuga, pela novidade e variedade, de nosso temor de morte ${ }^{1234}$.

Assim, o secular e o sagrado refletem duas espécies de dependências. Primeiro o mundo secular depende da criação e multiplicação de necessidades artificiais e de tudo mais para fugir de sua nulidade. $O$ mundo secular pretensamente exalta a liberdade humana, pois "escraviza-o pelas coisas de que depende para satisfazer as suas sempre crescentes necessidades, sua intranquilidade, insatisfação, ansiedade e seus temores, mas, acima de tudo, à culpa que o reprova por ser infiel à verdade que leva dentro de si”" ${ }^{235}$. No mundo sagrado, o ser humano tem como seu mestre Deus, não admitindo nenhuma dependência interior ou mesmo exterior.

Somente quando Deus é nosso mestre somos livres, pois Deus está dentro e acima de nós. Ele nos rege libertando-nos e nos elevando à união com Ele dentro de nós mesmos. Ao fazê-lo, liberta-nos de nossa dependência das coisas criadas que estão fora de nós. Nós as usamos e dominamos, de tal modo que estas existem para nós, e não o contrário ${ }^{1236}$.

A atitude sagrada diante da vida não é uma fuga do sentido de nulidade, mas um movimento que penetra as trevas dessa nulidade, percebendo que a misericórdia divina a transformou em seu templo e que em suas trevas se oculta a própria luz divina.

A autorrealização, no sentido religioso verdadeiro de que falamos, é não tanto estarmos conscientes de nós mesmos, mas sim estarmos conscientes de Deus, ao qual somos atraídos nas profundezas de nosso ser. Tornamo-nos reais e experimentamos nossa realidade, não quando paramos para refletir sobre nós próprios como entidade individual isolada, mas, antes, quando transcendendo-nos e ultrapassando a reflexão, polarizamos nossa alma inteiramente em Deus, que é nossa vida. Quer isso dizer que nós nos 'realizamos' plenamente quando cessamos

\footnotetext{
${ }^{1233}$ Cf. MERTON, Thomas. Experiência interior, p. 72.

${ }^{1234}$ Ibid., p. 73.

${ }^{1235}$ Id., Experiência interior, p. 74.

${ }^{1236}$ Ibid., p. 75.
} 
de estar conscientes de nós mesmos 'em separado', e nada mais conhecendo senão o Deus que está acima de todo conhecimento ${ }^{1237}$.

Logo, "a atitude sagrada não se afasta da vacuidade interior da pessoa, mas entra nesta com espanto, reverência e consciência do mistério" ${ }^{1238}$. É essencialmente contemplativa a atitude sagrada da vida, enquanto que a atitude secular é fundamentalmente ativa, voltada para o exterior. No entanto, não significa que não possa haver uma atividade secular que seja sagrada (baseada no amor). Mas para Merton "essa atividade, entretanto, só é sagrada na medida em que tende para a contemplação" 1239 .

O homem dotado da visão "sagrada" das coisas é justamente aquele que não tem necessidade de odiar-se, e nunca sente vergonha nem temor diante da perspectiva de permanecer em sua própria solidão, pois nela está em paz e, por meio dela, pode chegar à presença de Deus ${ }^{1240}$.

Nessa presença pode ir mais além,

ele é capaz de, a partir de sua própria solidão, encontrar Deus nos outros homens. Isso quer dizer que, em seus contatos com os outros, não está obrigado a identificálos com seus pecados e condená-los por suas ações, pois é capaz de ver, também neles, o que está por baixo da superfície e pressentir a presença do eu interior e inocente, que é imagem de Deus. Tal homem pode ajudar outros homens a encontrar Deus em si mesmos, educando-os com base na confiança, pelo respeito que consegue sentir por ele ${ }^{1241}$.

Assim, uma atitude sagrada é uma vida de reverência, espanto e silêncio diante do mistério que começa a tomar lugar no ser humano consciente do seu eu mais profundo. O ser humano de fé então se abandona à vontade divina.

Em silêncio, esperança, expectativa e ignorância, o homem de fé abandona-se à vontade divina: não como a um poder mágico e arbitrário, cujos decretos são pronunciados em fórmulas crípticas, mas à corrente da realidade e da própria vida. A atitude sagrada é, assim, uma atitude de profundo e fundamental respeito por todo o real, em qualquer nova forma que este possa se apresentar ${ }^{1242}$.

Nesta atitude sagrada, quem é o homem de fé? O homem de fé está idealmente livre de preconceitos. Ela fala de um 'idealmente' para excluir aqueles cuja fé não é pura, mas somente outra forma de preconceito, mais que uma viva sensibilidade ao logos de cada nova situação.

\footnotetext{
${ }^{1237}$ MERTON, Thomas $O$ homem novo, p. 98.

${ }^{1238}$ Id., Experiência interior, p. 76.

${ }^{1239}$ Id., O homem novo, p. 77.

${ }^{1240}$ Ibid., p. 78.

${ }^{1241}$ Id., Op. cit., p. 78. Grifo nosso.

${ }^{1242}$ Ibid., p. 79.
} 
Existe uma espécie de fé religiosa "dura" e rígida, que não é realmente viva ou espiritual, mas reside inteiramente no eu exterior e é produto do convencionalismo e do preconceito sistemático. Ao falar da obediência e da docilidade do homem de fé, Cristo deixou claro que a união com a vontade de Deus na ação é um passo necessário para uma percepção contemplativa de Deus (Jo 14, 15-16.21) ${ }^{1243}$.

Como podemos perceber em Merton, a total e incondicional docilidade à vontade de Deus concede ao ser humano o gosto pelas coisas espirituais. Esse delicado gesto de ceder ao mais leve movimento do amor de Deus é o que torna a pessoa um contemplativo. Ou seja,

a realidade de Deus torna-se para nós, na contemplação, objeto de conhecimento de um modo inteiramente novo. Quando apreendemos a Deus por meio de conceito, vemo-lo como um objeto separado de nós, como um ser do qual estamos alienados, ainda que creiamos em seu amor por nós e em nosso amor por Ele. Na contemplação, essa divisão desaparece, pois a contemplação ultrapassa os conceitos e apreende a Deus, não como objeto separado, mas a Realidade dentro de nossa própria realidade, o Ser dentro de nosso ser, a vida de nossa vida ${ }^{1244}$.

Descobre-se a presença de Deus na profundidade do ser da pessoa que marca a mudança de uma vida exterior para uma vida interior. A expressão "vida interior" é a descrição válida para qualquer espécie de busca pela prece e autodisciplina. Ou seja, a vida interior desperta a consciência espiritual e interior e enquanto não há esse despertar, o "homem interior" permanece morto ou ao menos adormecido ${ }^{1245}$.

Na medida em que a vida espiritual é feita de pensamentos, desejos, ações, devoções e projetos do eu exterior, ela participa do não-ser e da falsidade deste. É claro, não existe uma espiritualidade puramente exterior. Não importa quão exterior nossa vida espiritual possa ser, se ela tem uma raiz de sinceridade, é fundamentada no homem interior e tem, portanto, valor e realidade aos olhos de Deus. O propósito de nossa vida, entretanto, é conduzirmos todos os esforços e desejos ao santuário do eu interior, entregando-os todos ao comando de uma consciência interior e inspirada por Deus. Esta é a obra da graça ${ }^{1246}$.

Merton analisa um texto do livro do Gênesis, que narra a luta entre Jacó e o anjo $^{1247}$ para explicar a batalha que ocorre entre o eu exterior e o eu interior. A

\footnotetext{
${ }^{1243}$ MERTON, Thomas. Experiência interior, p. 79.

${ }^{1244}$ Id., O homem novo, p. 21.

${ }^{1245}$ Cf. Id., Experiência interior, p. 130.

1246 Ibid., p. 133.

${ }^{1247}$ Eis o texto: "E Jacó ficou só. E alguém lutou com ele até surgir a aurora. Vendo que não o dominava, tocou-lhe na articulação da coxa, e a coxa de Jacó se deslocou enquanto lutava com ele. Ele disse: "Deixa-me ir, pois já rompeu o dia". Mas Jacó respondeu: "Eu não te deixarei se não me abençoares! Ele lhe perguntou: "Qual é o teu nome?" "Jacó", respondeu ele. Ele retomou: "Não te chamarás mais Jacó, mas Israel, porque foste forte contra Deus e contra os homens, e tu prevaleceste". Jacó fez essa pergunta: "Revela-me teu nome, por favor". Mas ele respondeu: "Por que perguntas pelo meu nome?"E ali mesmo o abençoou”. Gn 32, 25-30.
} 
batalha que ocorre entre Jacó e o anjo é a da força baseada no eu exterior, contra a força de Deus, vida e realidade de nosso eu interior.

Temos, sobre o nosso antagonismo, um certo poder, pois, ainda que não possamos vencê-lo, podemos impedi-lo de ir embora até que nos abençoe. Esse poder é mais que a nossa própria força; é o poder do amor, o qual procede secretamente de dentro, vem do próprio antagonismo. É com seu próprio poder que este deseja ser detido por nós. É o poder pelo qual ele é "alcançado e se mantém próximo" [...] Ele permite que "lutemos fortemente com Deus" e conquistemos para nós um novo nome, Israel, que significa "o que vê a Deus". É esse nome que faz de nós contemplativos - é o novo ser e uma nova capacidade de percepção. Contudo, quando perguntamos seu nome, não o podemos conhecer, pois mesmo nosso eu mais profundo nos é desconhecido, assim como Deus nos é desconhecido ${ }^{1248}$.

A contemplação aqui apresentada não se refere a um misticismo puro e simples, mas como uma intuição direta da realidade a simplex intuitus veritatis. Ou seja, “à pura percepção que é e deve ser o fundamento não só da especulação metafísica genuína, como também da experiência religiosa madura e sapiencial" ${ }^{\prime 249}$.

\subsection{Diálogo entre as religiões}

Assim, "um dos aspectos mais importantes do diálogo entre as religiões tem sido, até agora, um dos menos discutidos: é a contribuição especial que a vida contemplativa pode trazer ao diálogo"1250. A contemplação é um "dom" (uma graça) e uma "arte". Pode-se admitir que seja quase "uma arte perdida" ${ }^{1251}$. Sobre o cristianismo ele vai nos dizer que:

É uma religião de amor. O moralismo cristão é um moralismo de amor. Não pode haver amor sem a obediência que une a vontade do que ama com a vontade do Amado. Mas o amor é destruído por uma união das vontades mais forçadas que espontâneas. Quem obedece a Deus por estar compelido a isso não o ama de verdade. Deus não quer um culto de obrigação. Quer um culto livre, espontâneo, sincero, "em espírito e verdade". É certo que deverá sempre haver um limite em que a pobreza humana será protegida contra si mesma por um mandamento formal: "Não farás!" Não pode haver amor de Deus que ignore tais mandamentos. Todavia, um amor verdadeiro e maduro obedece, não porque é mandado, e sim porque $\mathrm{ama}^{1252}$.

\footnotetext{
${ }^{1248}$ MERTON, Thomas. Experiência interior, pp.134-135.

${ }^{1249}$ Id., Místicos e mestres zen, p. 236.

${ }^{1250}$ Ibid., p. 235.

${ }^{1251}$ Cf. Id., O homem novo, p. 140.

${ }^{1252}$ Ibid., pp. 139-140.
} 
No entanto, a nostalgia não faz do ser humano um contemplativo. Para voltar-se à contemplação, faz-se necessário mergulhar em um cristianismo em que o discipulado se realiza em Cristo.

O cristianismo não é a religião de uma lei; é a religião de uma pessoa. $\mathrm{O}$ cristão não é meramente o que observa as regras que lhe são impostas pela Igreja. É um discípulo do Cristo. É verdade que ele observa os mandamentos de Deus e as leis da Igreja. No entanto, a razão por que o faz não deve ser procurada em nenhum poder de decretos legais. Encontra-se no Cristo [...] Jesus vivendo em nós pelo seu Espírito é a nossa Regra de Vida. Seu amor é a nossa lei e é coisa absoluta. A obediência à lei de Jesus nos torna conformes a Ele como pessoa. Assim, aperfeiçoa em nós a imagem divina. Faz-nos semelhantes a Deus. Enche-nos com a vida e a liberdade que Ele nos ensinou a procurar. Esse é o valor que determina todos os atos do cristão. Essa é a base ao mesmo tempo do humanismo e do misticismo cristãos. O cristão vive de amor e, portanto, de liberdade ${ }^{1253}$.

O contemplativo não é simplesmente uma pessoa que vive enclausurada.

Pelo contrário, o contemplativo possui certa abertura para o mundo e uma participação genuína em sua angústia. E assim, diante do diálogo inter-religioso, Merton dirá que

um diálogo genuinamente produtivo não pode se contentar com um interesse diplomático cortês por outras religiões e suas crenças. Procura um nível mais profundo, no qual as tradições religiosas sempre afirmaram testemunhar um conhecimento mais elevado e mais pessoal de Deus daquele que é simplesmente expresso no culto exterior e na doutrina formulada ${ }^{1254}$.

É profundamente claro que,

em todas as religiões, encontramos não só a reivindicação de uma forma de revelação (divina), mas também o registro de experiências especiais nas quais a validade absoluta e final dessa revelação é, de alguma forma, atestada. Além disso, em todas as religiões se reconhece, mais ou menos geralmente, que essa experiência "sapiencial" profunda, chamem-na de gnose, contemplação, "misticismo" "profecia", ou do que quiserem, representa o fruto mais profundo e mais autêntico da própria religião. Todas as religiões, então, buscam um "ápice" de santidade, de experiência, de transformação interior ao qual seus fiéis - ou uma elite de fiéis - aspiram porque têm esperança, por assim dizer, de encarnar em suas próprias vidas os valores mais elevados nos quais creem. Em palavras grosseiramente simplificadas, todas as religiões aspiram, de um jeito ou de outro, a uma "união com Deus" e, em todas, essa união é descrita em termos que têm claras analogias com as experiências místicas e contemplativas da tradição cristã, particularmente da católica ${ }^{1255}$.

Por muito tempo, os cristãos consideraram as experiências religiosas não cristãs com suspeita e acreditavam não valer a pena nem mesmo estudá-las.

${ }^{1253}$ MERTON, Thomas. Místicos e mestres zen, p. 236.

${ }^{1254}$ Id., p. 236.

${ }^{1255}$ Ibid., p. 237. 
O diálogo conduzido por teólogos e bispos quanto à doutrina e ao ajuste prático jamais poderá ter qualquer sentido sério se, no fundo, persistir uma profunda conviç̧ão de que as religiões não cristãs são todas corrompidas em seu âmago, e o que reivindicam com suas mais altas perfeições e sua suprema realização não passa, de fato, de uma diabólica ilusão. Todavia, não acredito que os estudiosos e os teólogos façam hoje essa generalização indiscriminada ${ }^{1256}$.

O Concílio Vaticano II reconheceu a legitimidade do "profundo sentido religioso" que capacitou os homens de todas as raças e povos a reconhecerem Deus, a "contemplarem o mistério divino e a expressá-los", e a buscarem libertação da angústia da condição humana. Segundo o Concílio, “a Igreja não rejeita nada do que há de verdadeiro e santo nessas religiões" ${ }^{1257}$, e acrescenta que o propósito do diálogo deveria ser combinar "o testemunho sincero da fé cristã com a compreensão e até a promoção dos bens morais e espirituais que se encontram nessas culturas" 1258 .

Entretanto, a Igreja de forma alguma abandona sua intenção de anunciar a mensagem definitiva de salvação para o homem em Cristo; o diálogo, tal como o Concílio o concebe, não se baseia apenas na suposição de que todas as verdades religiosas são igualmente e indiferentemente boas. Não obstante, a contemplação sobrenatural é certamente admitida como possível em todas as religiões ${ }^{1259}$.

Merton nos apresenta o primeiro problema que surge no diálogo. Faz-se necessário ser claros sobre a solidez das intuições metafísicas, das intuições prédialéticas e diretas do "ser" (descrito no hinduísmo como Brama ou atmã, no budismo como "o vácuo" ou sunyata) que formam a base das religiões orientais. Em que sentido as religiões da Ásia se dizem "místicas" ou "sobrenaturais"? Existe uma variedade de opiniões. Segundo uma grande autoridade do zenbudismo - Daisetz T. Suzuki - o zen "não é misticismo". O jesuíta autor de uma história clássica do zen, o padre H. Dumoulin, procura mostrar que o zen pode, em certo sentido, ser chamado de misticismo ${ }^{1260}$.

No entanto, deve-se admitir que Deus não é limitado em seus dons.

\footnotetext{
${ }^{1256}$ MERTON, Thomas. Místicos e mestres zen, p. 238.

${ }^{1257} \mathrm{NA}, 2$.

1258 NA, 2.

${ }^{1259}$ MERTON, Thomas. Místicos e mestres zen, pp. 238-239.

${ }^{1260}$ Heinrich Dumoulin, SJ, teólogo que amplamente escreveu sobre o zen budismo. Foi fundador do Instituto de Religiões Orientais e primeiro diretor do Instituto Nanzan para Religião e Cultura. Suas principais obras sobre o zen são: The Development of Chinese Zen After the Sixth Patriarch in the Light of the Mumonkan, 1953; A History of Zen Buddhism, 1963; Christianity Meets Buddhism, 1974; Buddhism in the Modern World, 1976; Zen Enlightenment: Origins and Meaning, 1979; Zen Buddhism in the Twentieth Century, 1992; Zen Buddhism: A History; Volume 1 India and China, 2005; Zen Buddhism: A History; Volume 2 Japan, 2005. Cf. MERTON, Thomas. Místicos e mestres zen, p. 239.
} 
não há motivo para pensar que Ele não possa conceber Sua luz a outros homens sem primeiro nos consultar, não pode haver, de forma alguma, motivos sólidos para negar a possibilidade de revelação sobrenatural (privada) e de graças místicas sobrenaturais a indivíduos, não importa onde estejam ou quais sejam suas tradições religiosas, desde que busquem sinceramente a Deus e a Sua verdade. Nem há nenhuma base a priori para negar que as grandes figuras proféticas e religiosas do islã, do hinduísmo, do budismo, etc., pudessem ser místicas no sentido verdadeiro, sobrenatural da palavra ${ }^{1261}$.

Em seguida nos alerta:

Por outro lado, todos estão conscientes da tendência oposta, a um sincretismo vago e irresponsável que, baseado em semelhanças puramente superficiais e sem um estudo sério das diferenças qualitativas, passa a identificar todas as religiões e todas as experiências religiosas umas às outras, afirmando serem todas igualmente verdadeiras e sobrenaturais e diferirem apenas nos detalhes da expressão cultural. Adotar essa visão como axiomática seria garantir, logo de saída, que o diálogo inter-religioso acabaria em confusão ${ }^{1262}$.

As duas visões, a priori extremas, uma que nega qualquer reivindicação de validade às experiências religiosas não católicas, e a outra que afirma que todas as tradições religiosas são igualmente verdadeiras e sobrenaturais, procedem ambas de uma consideração superficial dos dados. E se permanecer apenas entre pesquisadores e nos estudos de documentos ficará privado de sua dimensão mais essencial. Aqui se vê a necessidade do contemplativo cristão e do contemplativo não cristão entrarem modestamente na discussão.

A questão dos contatos e da comunicação efetiva entre os contemplativos das várias tradições não apresenta mais obstáculo. Uma pequena experiência de diálogo desse tipo mostra de imediato, que este é precisamente o nível mais frutuoso e mais compensador da troca [...] É realmente esclarecedor e chega a ser maravilhoso conversar com um zen-budista do Japão e descobrir que se tem muito mais em comum com ele do que com muitos dos próprios compatriotas que estão pouco preocupados com a religião, ou estão interessados apenas em sua prática externa $^{1263}$.

Em todas as raças e tradições religiosas encontra-se a capacidade para a experiência contemplativa, presente nas grandes tradições religiosas asiáticas ou europeias. Merton nos lembra que o clima espiritual da Idade Média cristã e do período patrístico era essencialmente 'sapiencial' e não científico, em que se cultivava especialmente a contemplação favorecendo uma visão intelectual e espiritual semelhante às culturas tradicionais do Oriente. Por isso, nos mosteiros contemplativos católicos, por preservarem essa experiência, estariam os monges

\footnotetext{
${ }^{1261}$ MERTON, Thomas. Místicos e mestres zen, p. 240.

1262 Ibid

${ }^{1263}$ Ibid., p. 242.
} 
"predispostos a apreciar e a entender os que vêm a eles com experiências em tradições análogas".

Quando entramos em contato com nosso ser mais profundo, com um bem ordenado amor de nós mesmos, inseparável do amor de Deus e de sua verdade, descobrimos que toda sorte de bem cresce de dentro de nós, surgindo das profundezas ocultas de nosso ser em consonância com as normas concretas e existenciais determinadas pelo Espírito que nos é dado por Deus. Essa espontaneidade mística (que se inicia com a livre opção da fé e aumenta com nosso crescimento na caridade) dá o tom a toda nossa vida moral. É a promulgação interior da nova lei de Deus em nossos corações: a caridade ${ }^{1264}$.

Lembremos que na III parte de nossa tese, quando aprofundávamos a experiência mística de Merton, o mesmo afirmou não ser essa experiência cristã de forma alguma redutível a uma experiência de afastamento e recolhimento, uma negação da matéria e dos sentidos, um simples dobrar-se sobre a misteriosa presença interior de Deus, na "oração de silêncio", na "oração de união", no "noivado espiritual" e no "matrimônio espiritual"1265. É uma experiência de reconhecimento de sua realidade interior no profundo de si mesmo para reencontrar no seu íntimo sua imagem e semelhança de Deus.

Sem este despertar interior que brota da compreensão do amor misericordioso de Deus por nós, a imagem permanece uma semelhança meramente potencial, enterrada e obscurecida. Não apreciada, porque está oculta. A imagem brota para a vida quando tocada pela inefável misericórdia de Deus, começa a recuperar a semelhança perdida, identificando-se com Aquele que é Amor. A presença de Deus em nós é a presença de sua semelhança em nosso espírito - semelhança que é mais que uma representação: é o próprio Verbo de Deus, unido à nossa alma pela atuação do Espírito Santo. A sensação de ser "conduzido" e "atraído" pelo amor para dentro do espaço infinito de uma liberdade sublime e incompreensível é a expressão de nossa união espiritual com o Pai, no Filho, pelo Espírito Santo que nos constitui em nossa verdadeira identidade de filhos de Deus ${ }^{1266}$.

É preciso se lembrar de todas as dimensões litúrgicas, bíblicas e patrísticas do misticismo cristão. Ademais, que entenda que a theoria cristã é uma resposta à manifestação de Deus de Si mesmo em Sua Palavra. É uma compreensão contemplativa de toda a criação à luz da Ressurreição, da nova criação, ou ainda de um 'novo ciclo'. Indo além, é uma consciência espiritual do mistério de Deus em ação na história e na Igreja como pleroma de Cristo (Ef 1,18-23). Para o cristão, a contemplação está centrada na cruz de Cristo, que é o mistério da kenosis.

\footnotetext{
${ }^{1264}$ MERTON, Thomas. O homem novo, p. 179.

1265 Cf. Id., Místicos e mestres zen, pp. 244-245.

1266 Id., O homem novo, p. 100.
} 
Nesse mistério encontramos a plena expressão da dialética da plenitude e do vazio, tudo e nada, vácuo e infinitude, que aparece no centro de todas as grandes formas tradicionais de sabedoria contemplativa. Aqui também encontramos paradoxalmente na "palavra da cruz" o esvaziamento de todas as sabedorias humanas (1Cor 1,18-25) a fim de que o homem possa encontrar diretamente a luz e o poder de Deus [...] Portanto, toda a ideia da contemplação cristã é uma theoria que une e funde vigorosamente o cristianismo "encarnado" e o "escatológico" e depois se abre para o domínio da iluminação divina, a theologia, na qual o mistério mais elevado, a trindade de pessoas em uma única natureza, não é contemplada como "objeto", mas celebrada no hino do Espírito, "Abba, Pai!", o qual, no entanto, não é dado à língua do homem pronunciar em fala humana inteligível (Rm $8,14-18$; II Cor 12,4$)^{1267}$.

A contemplação torna-se necessária para o diálogo ecumênico. Sendo esta verdadeira e não um narcisismo consagrado, deve ser capaz de mostrar-se repleta do alimento oferecido pela palavra de Deus e que, "fortalecido em poder pelo seu Espírito no homem interior", pode "conhecer o amor de Cristo que excede a todo conhecimento para ser plenificado com toda a plenitude de Deus" (Ef 3,17-19). E que esta não é meramente uma técnica esotérica e mágica. E mais ainda que:

Realizamo-nos plenamente quando toda a nossa atenção consciente está voltada para um outro. Aquele que é inefavelmente "Outro" que todos os seres, porque é infinitamente superior a todos. A imagem de Deus toma a vida em nós, quando nos liberta, rompendo através da mortalha e do sepulcro no qual a atenção a nós mesmos o manteve prisioneiro e se perde numa total tomada de consciência daquele que é Santo. Esse é um dos principais caminhos nos quais "quem quer salvar sua vida perdê-la-á" $(\operatorname{Lc} 9,14)^{1268}$.

Assim, para o diálogo inter-religioso com o contemplativo asiático, por exemplo, deve-se revelar que é consciente das dimensões religiosas da pessoa e do mistério do ser; que o contemplativo cristão "não confunde pessoa com indivíduo e que não considera sua relação com o âmago do ser uma relação puramente sujeito-objeto - que não está confinado ao individualismo exagerado e materialista das preocupações puramente éticas e práticas" ${ }^{1269}$.

O papel que o contemplativo pode desempenhar seria então, idealmente falando, muito importante. Se as ordens contemplativas estão hoje à altura dessa tarefa é outra questão. A renovação da vida contemplativa, exigida no esquema sobre os religiosos propostos pelo Concílio, certamente requer algo mais do que o cumprimento das disciplinas da clausura, do silêncio e da regularidade da oração canônica. Mas, ao mesmo tempo, as ordens contemplativas devem tomar um cuidado especial para evitar uma acomodação superficial que, em nome de uma aggiornamento mal compreendido, acabaria por privá-las das riquezas autênticas de sua tradição mística e profética ${ }^{1270}$.

\footnotetext{
${ }^{1267}$ MERTON, Thomas. Místicos e mestres zen , p. 246.

${ }^{1268}$ Id., O homem novo, pp. 98-99.

${ }^{1269}$ Id., Místicos e mestres zen, pp. 246-247.

${ }^{1270}$ Ibid., p. 247.
} 
No entanto, todos podem desejar a contemplação desde que sejam sinceros, prudentes e permaneçam abertos à verdade. Os grandes obstáculos para a mesma são a rigidez e o preconceito. Por isso, ninguém deve se iludir com as aspirações contemplativas se não está determinado a assumir, em primeiro lugar, os labores e as obrigações comuns da vida normal.

A contemplação não é uma espécie mágica, um atalho fácil para a felicidade e a perfeição. No entanto, ao nos conduzir a um contato com Deus em um relacionamento pessoal e direto de amizade misteriosamente experimentada, a contemplação traz, necessariamente, aquela paz que Cristo prometeu e que "o mundo não pode dar". Pode haver muita desolação e sofrimento no espírito do contemplativo, mas há sempre mais alegria que tristeza, mais segurança que dúvida, mais paz que desolação. O contemplativo é aquele que encontrou aquilo que todos os homens buscam de um modo ou de outro ${ }^{1271}$.

Um dos paradoxos da vida mística é que não pode alguém penetrar no mais íntimo de seu ser, chegando a Deus, se não for capaz de sair inteiramente de si mesmo, esvaziando-se de si mesmo e dando-se aos outros na pureza de um amor que não se busca a si próprio.

Essa unidade é algo que não podemos compreender e saborear a não ser na treva da fé. Mesmo aqui, porém, quanto mais formos Um com Deus, tanto mais estaremos unidos uns com os outros; e o silêncio da contemplação é sociedade profunda, rica, incessante, não só com Deus, mas com os homens. O contemplativo não está isolado em si mesmo; está liberto de seu eu externo, egoísta, pela humildade e a pureza de coração - não há mais, portanto, obstáculo algum ao amor simples e humilde para com os outros ${ }^{1272}$.

No entanto, vivemos em um tempo em que o ser humano se encontra fortemente determinado por estruturas sociais e por processos de socialização e globalização e, por outro lado, deseja encontrar espaço de solidão e silêncio para ter contato com sua própria interioridade. Merton, que sempre viveu esse dilema, faz a seguinte reflexão:

Visto que todas as coisas têm seu momento, existe um tempo de gestação. Em efeito, temos de começar em um ventre social. Porém existe também um tempo para nascer. O que tem nascido espiritualmente com identidade madura está liberto do ventre em torno do mito e do preconceito. Aprende a pensar por si mesmo, já não é guiado pelos ditames da necessidade de sistemas e processos e caminhos para a criação de necessidades artificiais e em seguida, "satisfazê-las"1273.

Ele nos apresenta duas formas para essa emancipação:

Essa emancipação pode adotar duas formas: primeiro, a vida ativa, que liberta da escravidão da necessidade de considerar e atender as necessidades dos demais sem

${ }^{1271}$ MERTON, Thomas. Experiência interior, p. 168.

1272 Ibid., pp. 70-71.

${ }^{1273}$ Id., Incursiones en lo Indecible, p. 26. 
pensar em interesses pessoais ou compensações. E segundo, a vida contemplativa, que não tem de construir-se como uma fuga do tempo e da matéria, e da responsabilidade social e da vida dos sentidos, senão como um avanço para a solidão e o deserto. [...] No coração da angústia se encontram os dons da paz e compreensão: não simplesmente na iluminação e a libertação pessoal, senão no compromisso e a compreensão, pois o contemplativo deve assumir a angústia universal e a situação inevitável do homem mortal. O solitário, longe de fechar-se em si mesmo, é de todos os homens. Mora na solidão, na pobreza, na indigência de todos os homens ${ }^{1274}$.

Merton sugere ainda que a vida contemplativa tenha um espaço para a liberdade e silêncio para que possam vir à tona novas escolhas, além das habituais. Deve-se criar uma nova consciência de tempo, um temps vierge. Não seria um espaço vazio para preencher, mas um lugar para que se possa desfrutar das próprias potencialidades e anseios e da presença de si mesmo. "O tempo da pessoa. Não, porém ocupado pelo próprio ego com suas exigências, mas aberto aos outros - um tempo compassivo, tendo ao fundo a consciência da ilusão comum e a crítica desta" $" 1275$.

Este tempo, como um tempo compassivo, pode significar um espaço em que deve ocorrer o diálogo entre as tradições religiosas, em um nível para além da comunicação, na comunhão ${ }^{1276}$.

Sem afirmar que se dê a unidade plena de todas as religiões no "topo", ou seja, no nível místico ou transcendente, e sem afirmar que tampouco elas partem de diferentes posições dogmáticas para encontrar-se logo no "cume", é perfeitamente correto dizer que, mesmo tendo entre elas diferenças um tanto irrenunciáveis, tanto em nível doutrinários como no da formulação de crenças, existe também grandes semelhanças e analogias ao nível da experiência religiosa. [...] As diferenças culturais e doutrinárias devem ser mantidas, porém não invalidam uma qualidade muito real de semelhança existencial ${ }^{1277}$.

Para essa experiência, é preciso lembrar da capacidade do ser humano de ser mais plena e humanamente vivo, ou seja, a fazer uso consciente de sua liberdade de escolher sua própria vida e de ir ao mais profundo de si mesmo. Vivendo uma liberdade superficial, sem destino que experimenta isto ou aquilo. E assim, pretendendo ser uma liberdade de escolha se esquiva de descobrir quem é que

\footnotetext{
${ }^{1274}$ MERTON, Thomas. Incursiones en lo Indecible, p. 27.

${ }^{1275}$ Id., O Diário da Ásia, p.89 e 136. Sobre esse tema já tínhamos apresentado na III parte de nossa tese, no segundo capítulo, item 2.1.

${ }^{1276}$ Cf. Ibid., p. 249.

${ }^{1277}$ Ibid., p. 245.
} 
escolhe. Não se torna livre por ser incapaz de enfrentar o risco da autodescoberta $^{1278}$.

No entanto, quem alcança sua identidade mais profunda se identifica, em certo sentido, com todos - ou na linguagem do Novo Testamento, ele é 'tudo para todos'. Atingiu a liberdade mais profunda e íntima - a liberdade do Espírito. Ela é conduzida, não apenas pela vontade e a razão, mas por um "proceder dinâmico sujeito a uma visão dinâmica"1279.

O ser humano que alcança a integração do seu ser, não mais se encontra limitado pela cultura em que está inserido. Este aceita não somente sua própria comunidade, sua sociedade, seus amigos e sua cultura, mas a humanidade toda; não permanece atado a um único padrão de valores limitados de maneira tal que a elas se oponha com agressividade ou na defensiva com os outros. Ou seja, para Merton,

O ser humano plenamente integrado é plenamente 'católico' no melhor sentido da palavra; tem uma visão e uma experiência unificadas da verdade única que refulge em todas as suas manifestações, mais nítidas umas do que outras, mais definidas e mais certas umas que outras. Para ele não se trata de estabelecer uma oposição entre essas visões parciais contrapondo uma à outra, mas de unificá-las numa dialética ou uma visão interior de complementaridade. Com esta visão da vida pode ele injetar na vida de outros perspectiva, liberdade e espontaneidade. O homem finalmente integrado é um artífice da paz, por isso é que há uma necessidade tão premente de que nossos líderes se tornem homens de visão ${ }^{1280}$.

No mais profundo do coração de Merton, pulsava o sincero desejo de amar a tudo e todos; uma paixão pela unidade e a paz entre os homens, um sentimento fortemente enraizado de levar adiante ocupações que contribuem para a unidade e harmonia de todos os seres humanos, quais forem suas crenças, sua condição social, sua origem e cultura.

Por essas razões, porque estava convencido no mais profundo de seu coração e porque havia percorrido em profundidade os caminhos de sua própria tradição, acolhe com entusiasmo a possibilidade que logo se tornaria realidade, sua viagem à Ásia que preparou conscientemente e que cristalizaria anos de interesses por outras religiões e expressões místicas. Nesta viagem ele afirma que:

Acredito que mediante a abertura ao budismo, ao hinduísmo, e a essas grandes tradições asiáticas nos traz uma oportunidade maravilhosa para aprender mais sobre a potencialidade das nossas próprias tradições. [...] A combinação das

${ }^{1278}$ Cf. MERTON, Thomas. Amor e Vida, p. 4

${ }_{1279}$ Cf. Id., Contemplação num mundo de ação, p. 202.

${ }^{1280}$ Ibid., p. 203. 
técnicas naturais, graça e outros fatores manifestados na Ásia com a liberdade cristã do Evangelho, deveria levar-nos todos, por fim, a essa liberdade plena e transcendente situada além das meras diferenças culturais das meras exterioridades e meros isto ou aquilo ${ }^{1281}$.

A experiência de profundidade que viveu Merton em sua fé e - como veremos no capítulo seguinte - também Panikkar, em que respectivamente estiveram em contato com as religiões e a mística oriental, nos chamam a atenção acerca da nova situação em que se encontra o cristianismo, de colaborar para que seus crentes realizem uma experiência de mergulho em sua fé e se reconheçam como imagem e semelhança de Deus. Para que não se viva uma religiosidade epidérmica, recuperando a dimensão da experiência íntima do mistério de Deus e da experiência da unidade com ela.

\section{Raimon Panikkar A harmonia invisível}

Percebemos que Panikkar, em sua imensa produção literária, nos revela sua busca pela harmonia, a qual ele mesmo denominou 'harmonia invisível' de todas as religiões, por constituírem um todo harmônico. Segundo ele, somente dessa harmonia se pode chegar à verdade total, que não possui nenhuma religião em particular. Ou seja, a Verdade somente pode ser possuída parcialmente, como verdades limitadas.

Assim, para as religiões como para as culturas, a harmonia invisível pode ser uma resposta para as tentativas de uma religião universal bem como de uma cultura universal. Seu pensamento é contrário diante da tentativa de elaborar uma teoria universal da religião. Para Panikkar a busca de uma "teoria universal" fomenta o diálogo, porém corre o perigo de impor sua própria linguagem e a "supremacia do $\operatorname{logos}$ frente ao pneuma", a razão frente ao espírito ${ }^{1282}$.

$\mathrm{Na}$ contramão da busca de uma teoria universal, Panikkar defende que é preciso abrir-se aos demais, acreditar e confiar na experiência humana, na harmonia dos seres humanos e do cosmos. A harmonia invisível apresentada está relacionada com o que o mesmo denominou o "efecto pars pro toto": A visão que se tem de toda realidade (totum), é de uma particular janela cultural e religiosa

\footnotetext{
${ }^{1281}$ MERTON, Thomas. Diário de Ásia, p. 267.

1282 Cf. PANIKKAR, Raimon. Sobre el diálogo intercultural, p. 103
} 
(pars). Isto significa que cada um pode ser consciente do todo, porém sob uma perspectiva particular, ou seja: "Não existe universalidade nem objetiva nem subjetiva. Vemos quanto podemos ver, porém somente tudo o que nós podemos ver, nosso totum... conhecemos o totum somente em parte e per partem. Vemos tudo através de nossa janela" ${ }^{1283}$.

O verdadeiro ecumenismo não é a redução a um denominador comum. A autêntica tolerância não requer destruir os pontos de vista inaceitáveis. Não faz falta diluir as próprias convicções religiosas para poder aceitar as de outros. Cada tradição reclama o todo (totum) e o busca de maneira incondicional... porém vê o totum in parte et per partem, em suas próprias categorias e desde sua perspectiva ${ }^{1284}$.

A Realidade para Panikkar é relacional, não é nem dualista, nem monistapanteísta, mas advaitica (a-dual), em que estão presentes o Cosmos, o ser Humano e Deus. É o que ele chamou de Perspectiva Cosmoteândrica ou Trindade Radical. Com o intuito de superar toda fragmentação do saber, para chegar à verdade por meio da inter-relação que ele chamou ôntica, de todos os conhecimentos, ele nos apresenta o ecumenismo-ecumênico religioso cultural.

E ainda, para compreendermos esta harmonia entre as partes e o todo que pretende Panikkar - em conformidade com o pensamento hindu -, encontramos sua persistência na relatividade de todas as partes, frente ao absolutismo predominante de uma delas. Ele vai nos dizer que relatividade não é o mesmo que relativismo, cada parte do todo tem seu valor particular. Segundo ele: "O dilema não é relativismo ou absolutismo, senão o reconhecimento da relatividade radical de toda a Realidade" $" 1285$.

Este conceito de relatividade radical deve aplicar-se nas relações humanas, na relação com o mundo, e na realidade divina. Esta relatividade radical é constitutiva de toda realidade: "Tudo está relacionado com tudo". Ele chega à conclusão de que também Deus é pura relação, não é uma substância: relação genitiva constitutiva da realidade, o genitivo constitutivo e gerador de todas as coisas. É o alicerce de sua concepção trinitária, que quer ser profundamente cristã chamada por ele de Trindade radical: "Deus não é um em si mesmo, uma vez que é um eu, um tu e um ele, que se converte na perichôrêsis trinitária”"1286.

\footnotetext{
${ }^{1283}$ PANIKKAR, Raimon. Sobre el diálogo intercultural, p. 135.

${ }^{1284}$ Id., Invitación a la sabiduría. Madrid: Espasa, 1999. p. 128.

${ }^{1285}$ Id., La Trindad. p. 18.

${ }^{1286}$ Id., El silencio del Buddha, p. 235.
} 
A Trindade radical elaborada por Panikkar é uma perspectiva cosmoteândrica da realidade, em que o Cosmos, o ser Humano e Deus estão intima e indissoluvelmente relacionados. "É a intuição, totalmente integrada, do tecido sem costuras da realidade inteira" ${ }^{2287}$. A intuição cosmoteândrica é o conhecimento indiviso da totalidade que pode levar à comunhão harmônica com o todo. A realidade não é monolítica. Por isso não pode reduzi-la a um sistema único de crenças, tornando-se unilateral. Faz-se então necessária uma interpretação recíproca de todas as culturas e religiões.

As diferenças culturais são diferenças humanas e não se pode ignorá-las nem eliminá-las ao tratar os problemas humanos. Assim como se deve respeitar a personalidade de cada um para que a rede de relações humanas não se rompa, há que manter flexível tudo o que seja necessário para que não prejudique a humanidade ${ }^{1288}$.

Para Panikkar, o caminho é abrir o terceiro olho contemplativo, místico, que nos leva mais além da ciência e da razão. Ele nos chama a atenção para a oração, que não é apenas petição, é também silêncio e encontro com quem somos. E assim, afirma:

Oramos na medida em que somos. (Daí a total importância do homem sobre a oração: não podemos orar além do que somos, e não podemos ser além do que oramos. Por outra parte, somos na medida em que oramos. (Daí a importância da alma que ora: podemos fazer tudo e ser tudo na medida em que nossa oração é e que nosso ser $e^{1289}$.

\subsection{Ecumenismo-ecumênico}

O diálogo ecumênico é uma constante em Panikkar. No entanto, na intuição desde o diálogo ecumênico, Panikkar trata de ir mais além do ecumenismo interconfessional, limitado às confissões cristãs, para chegar a um ecumenismo inter-religioso, um ecumenismo-ecumênico, como ele mesmo denominou. Nosso autor procura uma relação mutuamente fecundante entre as distintas religiões da oikumene, desde o Ocidente ao Oriente. Para ele:

O ecumenismo-ecumênico não comporta uniformidade de opiniões, senão que significa harmonia de corações despertos... O objetivo é uma melhor compreensão, uma crítica corretiva e uma melhor fecundação entre as tradições religiosas do

\footnotetext{
${ }^{1287}$ PANIKKAR, Raimon. La intuición cosmoteándrica, p. 19.

${ }^{1288}$ Id., Paz e interculturalidad, p. 127.

${ }^{1289}$ Id., La nueva inocência, p. 189.
} 
mundo sem diluir suas respectivas heranças ou prejudicar suas eventuais diferenças irredutíveis ${ }^{1290}$.

E assim, desejando ir mais além de um mero diálogo, fala de um diálogo aberto a um mútuo enriquecimento. E como já pudemos conhecer um pouco sobre nosso autor na parte anterior de nossa pesquisa, sabemos que seu pensamento e seu caminho existencial colaboraram na busca por um diálogo ecumênico que supõe aproximar-se dos outros buscando abrir-se a eles sem temer perder as suas supostas certezas, e, inclusive, com a convicção de que estas serão enriquecidas com as contribuições dos outros. Trata-se de superar o nível de dialética das ideias para chegar a um diálogo aberto e acolhedor em que se reconheça a alteridade de comunhão.

E ainda em relação aos paradigmas (exclusivismo, inclusivismo e paralelismo), ele afirma que interdependência não supõe perder a própria identidade:

Se nos damos conta de que a religiosidade de nosso vizinho não representa somente um desafio, senão que pode também enriquecer a nossa; e que, afinal de contas, a diferença que as separa se situa potencialmente no interior de nossas convicções; começamos a aceitar a ideia de que a outra religião pode ser complementar à nossa; chegamos inclusive a admitir que, em casos particulares, a outra religião pode suprir a nossa crença, a condição de que nossa religiosidade mantém conjuntamente indivisível ${ }^{1291}$.

A relação entre as várias religiões deve ter como inspiração a imagem da perichôrêsis trinitária divina.

As religiões não existem mais que em relação de uma com a outra... Em outra palavra, a relação entre as religiões não pode derivar do exclusivismo (a minha é suficiente), nem o inclusivismo (a minha abraça e inclui a todas as outras), nem do paralelismo (ainda de um modo independente, tendemos todas para o mesmo fim). A relação entre as religiões deriva de uma perichôrêsis sui generis ou circumincessio; isto é, de uma interpretação recíproca que nos questiona a particularidade própria de cada religião ${ }^{1292}$.

A insistência de Panikkar avança para além do diálogo inter-religioso. Segundo ele, faz-se necessário um diálogo intrarreligioso. O ecumenismoecumênico propõe um diálogo no interior da vida religiosa da pessoa. Por isso, como veremos, é um caminho fundamentalmente espiritual: um diálogo que cada crente deve realizar no interior de sua própria experiência e de sua própria vida para abrir-se profundamente à experiência dos outros. Não se perde a própria

\footnotetext{
${ }^{1290}$ PANIKKAR, Raimon. La nueva inocência, p. 325.

${ }^{1291}$ Id., Il diálogo intrareligioso. Cittadella: Assisi, 1988. p. 35.

${ }^{1292}$ Ibid., p. 36.
} 
experiência espiritual específica e pessoal, senão que se enriquece com a dos outros irmãos.

Ele nos apresenta o ecumenismo-ecumênico como um caminho para o encontro, em que ocorre um enriquecimento religioso e teológico, ou seja, uma “inter-relação serena e uma interpenetração dialogal de todos os caminhos que a pessoa acredita levar à plenitude o destino final de sua vida"1293. Esse ecumenismo não significa igualdade de todas as crenças, ou um "relativismo agnóstico e insustentável”. Trata-se de uma busca comum da Verdade desde um autêntico diálogo dialógico, no dialeto consciente de que a verdade é sempre relacional. O que não significa deixar de lado suas próprias convicções, senão que requer

uma confrontação mútua de tudo o que somos, cremos e cremos ser, com o objeto de estabelecer a mais profunda compenetração humana sem prejudicar os resultados, sem excluir nem sequer qualquer possível transformação de nossa religiosidade pessoal ${ }^{1294}$.

Surge o diálogo a partir da fé, com esperança de um entendimento mútuo e com amor, compreendendo, assim, o outro. Diante do pluralismo, deve-se ir além da mera coexistência de uma pluralidade de religiões e visões do mundo, para se chegar ao esforço na busca pela compreensão do outro, cuja visão do mundo e de Deus enriquecem quem a vive. Este pluralismo se converte, assim, em 'supremo imperativo humano e religioso'.

Uma vez tendo começado o diálogo interno, uma vez empreendida a tarefa da busca intrarreligiosa genuína, estamos em condições de enfrentar o que eu chamo de método imparativo - ou seja, o esforço de aprender dos outros, e permitir que nossas convicções sejam fecundadas pelas visões dos outros. Não podemos comparar (comparare - isto é, tratar sobre uma mesma - pars - base ), já que não existe um sustentáculo externo para poder fazê-lo. Somente podemos imparare, isto é, aprender do outro abrindo-nos desde nosso ponto de vista a um diálogo dialógico que não pretenda vencer ou convencer, senão buscar juntos desde nossas diferentes posições ${ }^{1295}$.

\subsection{0 diálogo, uma necessidade vital}

Para Panikkar, "o encontro entre as religiões é tão vital que, de fato, mais ou menos, todas as grandes religiões atuais são fruto destes encontros"1296. Ele nos

\footnotetext{
1293 PANIKKAR, Raimon. La nueva inocência, p. 333.

${ }^{1294}$ Id., El diálogo interno, p. 252.

1295 Id., Sobre el dialogo intercultural, p. 136.

${ }^{1296}$ Id., O diálogo indispensável, p. 39.
} 
apresenta, em seu livro $O$ diálogo indispensável, três níveis que apontam para essa necessidade vital ${ }^{1297}$ :

a) Nível pessoal - o ser humano se constitui como pessoa nas relações. E estas necessitam de diálogo. Sem vida dialógica, o ser humano não chega a sua humanidade plena. Ele é um animal loquens. Essa comunicação não trata apenas de sua relação exterior, mas, sobretudo, de seu interior. O homem é um ser dialógico. O diálogo é uma necessidade para o ser humano, e no aspecto religioso será difícil sem uma autêntica vida litúrgica.

b) Das tradições religiosas - o diálogo é imprescindível às religiões. Não dialogando entre si, degeneram-se e dão lugar a reações fanáticas de todo tipo, é realmente uma necessidade vital.

c) O nível histórico - O homem é um componente essencial do cosmos. E estes não podem viver sem religião. O destino da humanidade depende de que a religiosidade genuína reúna (religat) os homens entre si e a realidade na sua totalidade e, ao mesmo tempo, salvaguarde a sua liberdade (ontonomía). Faz-se necessário um verdadeiro encontro religioso entre o ser humano e a Terra, ou será aniquilada a vida sobre a mesma. "O diálogo das religiões não é só um tema acadêmico ou uma questão eclesiástica ou oficialmente "religiosa" [...] é o campo no qual se pode jogar de forma pacífica o destino histórico da humanidade"1298.

Panikkar, aprofundando a necessidade vital do diálogo, nos apresenta oito pontos que, segundo ele, revelam com deve ser o diálogo entre as religiões ${ }^{1299}$ :

a) Esse diálogo precisa como parte essencial, ser aberto. E não apenas o ser humano participa deste diálogo, mas também toda ideologia, visão de mundo e a filosofia. Ninguém tem o monopólio sobre a religião. Não deve ser confundido o encontro ou diálogo entre as religiões com qualquer outra atividade. Trata-se de um diálogo aberto entre pessoas às quais preocupam as perguntas fundamentais da realidade ${ }^{1300}$.

${ }^{1297}$ Cf. PANIKKAR, Raimon. O diálogo indispensável pp. 41-46. Abordaremos, a partir deste livro, a reflexão que Panikkar realize sobre o diálogo entre as religiões; $\mathrm{O}$ ecumenismo-ecumênico a partir do diálogo intra-religioso torna-se para Panikkar em verdadeira atitude teológica e existencial de toda sua teologia, conferir em seu livro: El nueva inocencia, pp. 327-332.

${ }^{1298}$ Id., O diálogo indispensável, p. 46.

${ }^{1299}$ Cf. Ibid., pp. 49-107. Cf. Id., Il dialogo intrareligioso, pp. 94-113.

${ }^{1300}$ Cf. Id., O diálogo indispensável, p.52. 
Não tem como objetivo uniformizar o mundo ou criar uma única religião mundial. "A verdade não pode reduzir-se nem à unidade nem à multiplicidade [...] A verdade é sempre relação, comunicação, e não lhe convém nem singularidade nem pluralidade"1301. O diálogo é uma expressão desta polaridade inerente ao homem e à realidade enquanto tal. O diálogo é fruto da experiência da nossa contingência. Nem sequer toda a humanidade viva pode encarnar a medida absoluta da verdade. Contingência significa que tocamos (tangere) os nossos limites e que o ilimitado nos toca (cum-tangere) tangencialmente ${ }^{1302}$.

b) O diálogo deve acontecer a partir do interior. Procede de uma fonte mais profunda e mais interna, que pode ser chamada "silêncio", ou talvez "a sede de verdade humana". Ele deve emergir da dimensão mais profunda do ser humano. Logo, o diálogo intrarreligioso é um fundamento necessário do diálogo interreligioso. O diálogo começa com uma pergunta interior. "O diálogo surge sempre da dimensão mais profunda do nosso 'si mesmo' [...] Não é surpreendente que o diálogo se apresente como caminho de salvação, transfiguração, iluminação"1303, pois toca a parte mais recôndita do coração dos dialogantes. O autêntico diálogo religioso só se instaura quando um dos participantes se sente implicado, ameaçado, alentado, estimulado.

Panikkar destaque:

Se falamos de tradições religiosas ou de religiões em geral, não devemos ficar na superfície da experiência humana religiosa. Devemos começar vivendo, conhecendo e experimentando nossa própria tradição, ou subtradição particular, tão intensa e profundamente como nos seja possível ${ }^{1304}$.

Deve ser precedido por um clima de silêncio. Nesta atmosfera, os pensamentos têm a sua origem onde as palavras extraem o seu poder, onde é possível encontrar-se com outro como realmente é. E tem lugar no coração da realidade. O diálogo tem um núcleo místico não visível na superfície das relações humanas. Algo acontece no coração de cada dialogante e no núcleo mais interno do mundo. O diálogo alcança o coração místico da realidade ${ }^{1305}$.

\footnotetext{
${ }^{1301}$ PANIKKAR, Raimon. O diálogo indispensável, p.52.

1302 Cf. Ibid., pp. 49-55.

${ }^{1303}$ Ibid., p. 57.

${ }^{1304}$ Id., Sobre el dialogo intercultural, p. 131.

${ }^{1305}$ Cf. Id., O diálogo indispensável, p. 58-59.
} 
c) O diálogo é uma atividade do logos humano. O homem é homo loquens, sua linguagem é um dom e falar é a sua missão. Mas as palavras humanas são algo mais que simples sinais do seu sentir ou signos para expressar os seus conceitos. No diálogo, a pessoa envolvida, de forma mais ou menos consciente, é o veículo de uma tradição 1306.

O diálogo é duálogo, ou seja, requer o encontro. Duálogo não quer dizer dois monólogos, mas sim confiar ao outro, ideias, pensamentos, intuições, experiências, vidas que realmente se encontram, apesar de procederem de fontes distintas. E assim o diálogo deve desenvolver-se em duas direções: intercultural e inter-religioso. Fala-se em duálogo e não "plurilogo", porque um duálogo é possível quando se pode estabelecer um campo comum no qual a discussão tem sentido1307. Deve ser bilíngue: "um diálogo autêntico não só requer que todo dialogante se expresse a si mesmo, mas sim que cada um fale na sua própria língua"1308. O diálogo tem lugar entre pessoas. A hermenêutica dos textos não é suficiente; devem-se compreender as pessoas.

d) O diálogo religioso é também político. É necessário não reconhecer o status quo político como algo absolutamente intocável. A religião como dimensão antropológica não pode separar-se da política. "Todo encontro inter-religioso entra em contato com problemáticas humanas que influenciam a vida da polis"1309. O diálogo entre as religiões não está encerrado nos recintos das instituições "religiosas". Está presente no cotidiano das pessoas. O diálogo é indispensável, a sua negação leva à inumanidade. Negar o diálogo equivale a negar a humanidade do adversário ${ }^{1310}$. E mais ainda, diante da busca pela paz:

A transformação da vontade não se consegue com a força nem da política nem da ameaça velada chamada "intimidação". É necessária uma verdadeira conversão, a metanóia. Esta conversão requer muito mais que uma simples convicção racional; requer uma verdadeira mudança de coração que a violência não pode gerar. Pensar que a religião não tem nada a compartilhar com a política ou que a justiça seja simplesmente racionalidade não levará nunca a paz. Intelligenti pauca!1311.

\footnotetext{
${ }^{1306}$ Cf. PANIKKAR, Raimon. O diálogo indispensável, p. 61.

${ }^{1307}$ Cf. Ibid., pp. 64-65.

${ }^{1308}$ Ibid., p. 65.

${ }^{1309}$ Ibid., p. 68

${ }^{1310}$ Cf. Ibid., p. 74.

${ }^{1311}$ Id., Paz e interculturalidad, p.135.
} 
e) Dia-logos significa também abrir caminho atravessando o logos (dia ton logon, "atravessando o logos") para chegar ao mythos"1312. Logo, o diálogo das religiões, se é verdadeiramente vivo, não pode deixar o mythos de fora do diálogo. No diálogo dialógico os participantes são conscientes de que os conceitos utilizados brotam de uma fonte mais profunda. Neste diálogo a pessoa envolvida chega a conhecer melhor o seu próprio mythos a partir das críticas e as descobertas do seu interlocutor.

Para compreender uma religião é preciso conhecer o seu 'credo'. Por isso, "o diálogo entre as religiões deve ser um diálogo de fé"1313. A fé-crença ${ }^{1314}$ que se manifesta no pisteuma do crente, é o que ele assume como verdadeira na sua experiência. No diálogo para alcançar o pisteuma do outro é necessário assumir de alguma forma esse pisteuma como verdadeiro. A fé do crente que se expressa na sua crença pertence essencialmente àquilo em que o crente acredita.

f) O diálogo é em si mesmo um ato religioso, pois requer certa conversão interior. “O diálogo tem em si mesmo um espírito religioso. O diálogo em si é uma autêntica manifestação de religiosidade"1315. O diálogo liberta as espiritualidades, antes marcadas por uma inflexibilidade, para uma experiência além das fronteiras.

Quando tratamos de compreender o fenômeno religioso do gênero humano, não podemos rejeitar nossa própria dimensão religiosa desenvolvida com mais ou menos esforço, desde uma tradição particular. De outra forma, distorceríamos a visão espontânea e com um sentido instintivo (o que os escolásticos, seguindo Platão e Aristóteles, chamavam per connaturalitatem) as fontes viventes de sua tradição, a discussão se daria em simples formulações e se tornará algo rígido. Não terá lugar nem o diálogo nem o encontro ${ }^{1316 .}$

O diálogo surge do reconhecimento de não possuir a verdade absoluta, e de que a religião do outro se converte numa questão pessoal. Salvação, libertação, felicidade, realização, iluminação, redenção, assim como justiça, paz, plenitude

\footnotetext{
${ }^{1312}$ PANIKKAR, Raimon. Paz e interculturalidad, p. 77.

${ }^{1313}$ Ibid., p. 82.

${ }^{1314}$ Segundo Panikkar "a distinção entre fé a crença é fundamental. A crença pode expressar-se em formulações dogmáticas. A fé manifesta-se na vida. A fé é uma dimensão humana constitutiva. A crença expressada num credo é uma formulação concreta dessa fé. Neste sentido, o fato de que a "gente" possa expressar honestamente a sua fé em formulações diferentes de credo não é mais que a manifestação natural da diversidade de culturas e religiões. A fé não está nos enunciados, disse S. Tomás de Aquino." Ibid., p. 84.

${ }_{1315}$ Ibid., p. 84.

${ }^{1316}$ Id., Sobre el dialogo intercultural, p. 134.
} 
humana, não são apenas problemas individuais. "Realizamo-nos na medida em que participamos ativamente no destino de todo o cosmos"1317.

Se os participantes adquirem uma abertura interior de sua própria tradição seriam capazes de dar-se conta do que Panikkar chamou de efecto pars pro toto. A visão que uma pessoa tem da realidade é através da perspectiva que oferece sua própria janela. Ela pode até acreditar que a sua janela é a melhor, e que a perspectiva que dela se obtém não está distorcida. Pode também estabelecer uma ponderação sobre as visões que se obtém de outra janela, mas não pode ocultar o fato de que através da sua janela vê todo o panorama - o totum. Ou seja, ninguém fica satisfeito com a parcialidade ${ }^{1318}$.

É necessário ser consciente de que, a partir de sua janela se vê apenas o totum per partem, o todo através da parte. É um totum, porém per partem, limitada à visão que oferece uma janela, a sua. Vê o totum, porém não totaliter, poderíamos dizer (já que não vê através de outra janela, e assim descrevê-lo de maneira diferente, porém ambos vêm o totum, apesar dos que vêem in toto porém per partem ${ }^{1319}$.

Assim, o diálogo constantemente renovado abre a possibilidade de encontro; aplana os caminhos e constrói pontes entre as distintas tradições, sem desenraizarse do solo de suas tradições; tece uma rede de relações e transforma a realidade das religiões. Esta dinâmica é própria do espírito religioso. E ajuda a acreditar que não é o único que procura a verdade. "A busca da verdade não consiste em persegui-la como um objeto, consiste em deixar-se possuir pela verdade e, até onde é possível, partilhar o destino de todos os demais. Esta é sem dúvida uma atividade religiosa" 1320 .

g) O diálogo possui uma dimensão integral, pois “a práxis do diálogo é um modo de ser religioso, uma atividade religiosa, e isso vale também para as reflexões teóricas sobre o diálogo"1321. O diálogo é uma aproximação holística, pertence à própria vida religiosa. É o homem inteiro que está comprometido.

O caráter dialógico do ser é um traço constitutivo da realidade. Acordo significa convergência de corações e não somente aglutinação de mentes. Sempre existe

\footnotetext{
${ }^{1317}$ PANIKKAR, Raimon. O diálogo indispensável, p. 89.

${ }^{1318}$ Cf. Id., Sobre el dialogo intercultural, p. 134.

${ }^{1319}$ Cf. Ibid., p. 135.

${ }^{1320}$ Id., O diálogo indispensável, p. 92.

${ }^{1321}$ Ibid., p. 95.
} 
espaço para a diversidade de opiniões e a multiplicidade de esquemas mentais de inteligibilidade ${ }^{1322}$.

Amar verdadeiramente o próximo exige conhecê-lo verdadeiramente e expressar as suas convicções mais profundas e tentar adaptá-las à visão do mundo do outro para fazer-se compreender e superar o seu solipsismo. O diálogo compromete o homem na sua totalidade ${ }^{1323}$. Panikkar destaca que:

Uma teoria próxima de uma religião particular hoje em dia, tem que tratar com outras religiões. Não podemos ignorar as outras por mais tempo. As religiões dos demais - nossos vizinhos - são uma questão religiosa para nós, para nossa religião ${ }^{1324}$.

h) Tem também uma natureza litúrgica, "liturgia propriamente falando significa 'obra (ergon) do povo (laos)', onde esta obra está inspirada pelo Espírito. É uma sinergia que reúne os "três mundos"- cósmico, humano e divino"1325. Cada religião pode acreditar que representa a verdade e que interpreta o papel principal, mas deve estar disposta a ouvir a outra. Enfrentam-se os riscos porque há confiança.

Ou seja, "o diálogo é uma communicatio in sacris, uma sagrada comunhão, sem a qual não pode subsistir verdadeiramente nenhuma comunidade humana"1326. Desempenha um papel cósmico: as religiões encontram-se uma com a outra como formas históricas cósmicas, tornando-se um ato cósmico. O encontro pertence essencialmente à religião.

i) $\mathrm{O}$ encontro entre as religiões deve ser permanente. Seu objetivo não é chegar à completa unanimidade ou misturar todas as religiões, mas, sobretudo, comunicação, complementaridade entre polos. Diálogo é um processo permanente: ele nunca se completa, nunca se acaba. "O diálogo é contínuo. Permanece sempre inconclusivo e, no entanto, todo o diálogo está em si mesmo autenticamente completo - é um em si mesmo"1327.

Estas relações, diálogos e estudos mútuos, mudam tanto a opinião dos participantes como a interpretação do outro. As religiões mudam através destes contatos; tomam emprestados do outro, e inclusive reforçam seus pontos de vistas, porém com menos superficialidade. Este diálogo não somente representa um esforço religioso para os participantes no mesmo, senão que é um lócus theologicus genuíno, para

\footnotetext{
1322 PANIKKAR, Raimon. Sobre el dialogo intercultural, p. 138.

${ }^{1323}$ Cf. Id., O diálogo indispensável, pp. 96-97.

${ }^{1324}$ Id., Sobre el dialogo intercultural, p. 137.

${ }^{1325}$ Id., O diálogo indispensável, p. 97.

1326 Ibid., p. 98.

1327 Ibid., p. 102.
} 
dizer na linguagem escolástica cristã, uma fonte, em si mesma, de compreensão religiosa (teológica) ${ }^{1328}$.

É uma experiência trinitária. A relação permanece constitutivamente aberta, manifestando uma estrutura triádica. Sempre existe algo que faz surgir o diálogo. Este "algo" subjaz à capacidade de cada participante. Poder-se-ia dizer que ambos os participantes são transcendidos por um terceiro, chamado por "Deus", "Verdade", "Logos", "Karman", "providência", "compaixão" ou de qualquer outra forma ${ }^{1329}$. Este "terceiro", em torno do qual o diálogo acontece, impede toda a manipulação e estará sempre presente. É o Espírito que sopra, onde, quando e como quer ${ }^{1330}$. O diálogo dialógico pertence à própria vida do homem.

O diálogo é indispensável e não se trata apenas de um imperativo social é um dever histórico.

A constituição humana é dialógica. A polaridade pertence à essência do homem e também à da realidade. $\mathrm{O}$ diálogo religioso faz emergir a nossa mais profunda humanidade [...] Nela participamos tão profundamente do Logos do espírito que chegamos a beber da mesma fonte de onde bebe o Logos: o Silêncio ${ }^{1331}$.

O verdadeiro diálogo entre as religiões é em si mesmo religioso. Ele se realiza no coração de quem o busca. E assim, quando o diálogo é intrarreligioso se converte em um ato religioso pessoal em busca da verdade. Pois este se inicia em:

um diálogo interno dentro do próprio eu, um encontro no profundo da religiosidade própria e pessoal do eu, quando este se depara com outra experiência religiosa nesse nível íntimo... Um diálogo intrarreligioso que tenho que começar eu mesmo, perguntando-me sobre a relatividade das minhas crenças, aceitando o desafio de uma conversão e o risco de mudar meus enfoques tradicionais ${ }^{1332}$.

Quem participa neste diálogo não somente olhando para a realidade transcendente ou para a tradição original, mas também horizontalmente, para o mundo de seus semelhantes, tem encontrado caminhos que conduzem a realização do destino humano. A busca chega a ser então uma oração aberta em todas as direções ${ }^{1333}$.

Para o diálogo inter-religioso, requer:

\footnotetext{
${ }^{1328}$ PANIKKAR, Raimon. Sobre el dialogo intercultural, p. 137.

${ }^{1329}$ Cf. Ibid., p. 103.

${ }^{1330}$ Cf. Ibid., p. 104

${ }^{1331}$ Ibid., pp. 105-107.

${ }^{1332}$ Id., El dialogo interno: la insuficiência de la llamada 'epoche' fenomenologia en el encuentro religioso. Salmanticensis, 1975.

${ }^{1333}$ Cf. Id., Religión. Diálogo intrarreligioso. In: Casiano FLORISTAN \& Juan Jose TAMAYO. Conceptos fundamentales del cristianismo. Madrid: Trotta, 1993, p. 1146.
} 
uma atitude de busca profunda, uma convicção de que estamos caminhando sobre um solo sagrado, de que arriscamos nossa vida. Não se trata de uma atitude de curiosidade intelectual nem de uma bagatela, mas de uma aventura arriscada e exigente. Faz parte daquela peregrinação pessoal para a plenitude de nós mesmos, que se obtém ultrapassando as fronteiras de nossa tradição ${ }^{1334}$.

\subsection{Pluralismo não significa pluralidade}

O relativismo se destrói a si mesmo quando afirma que tudo é relativo. A relatividade, por outro lado, afirma que qualquer afirmação humana, e, portanto qualquer verdade é essencialmente relacional. Qualquer verdade se relaciona com um entendimento. $\mathrm{O}$ conceito de verdade absoluta tem que se relacionar com um entendimento infinito ${ }^{1335}$.

O pluralismo da verdade vai mais longe. Declara que a verdade mesma é pluralista, e por tanto não é uma; tampouco muitas. Pluralismo não quer dizer pluralidade. Afirmar que a verdade mesma é pluralista é declarar que não existe uma única verdade totalizante ou absoluta ${ }^{1336}$.

Esta afirmativa está baseada em dois pressupostos fundamentais: a primeira é antropológica; a segunda teológica ou filosófica. O primeiro pressuposto é o de que cada pessoa é uma fonte de entendimento e também inclui coletividades e, especialmente, culturas como entidades históricas.

Se cada ser humano, enquanto humano, está provido de autocompreensão, cada cultura, enquanto possui uma visão própria da realidade, possui também certo mito como horizonte dentro do qual as coisas e os acontecimentos são discernidos ${ }^{1337}$.

A pessoa envolvida não será capaz de compreender os demais sem compartilhar a autocompreensão de quem está implicada no diálogo. E se forem mais além, terá que compartilhar verdades comuns, sem fazer projeção da sua verdade sobre a outra. A segunda é teológica, ou ainda, metafísica. Desafia uma das crenças mais extensas tanto no oriente como no ocidente. Desafia a última crença de cada monismo idealista. Ou seja, que existe um Ser ou uma Realidade que abarca tudo o que é, e que esta realidade é pura consciência, absolutamente autointeligível, porque tudo é transparente à luz do intelecto, tudo está

\footnotetext{
${ }^{1334}$ FLORISTAN \& Juan Jose TAMAYO. Conceptos fundamentales del cristianismo, p. 1149.

${ }^{1335}$ Cf. PANIKKAR, Raimon. Sobre el dialogo intercultural, p. 112.

${ }^{1336} \mathrm{Ibid}$.

${ }^{1337}$ Ibid., p. 114.
} 
impregnado por cit, nous pela mente. O que se afirma é que o Ser não é totalmente redutível ao mesmo ${ }^{1338}$.

Uma das implicações filosóficas desta perspectiva, é que não existe nada absolutamente idêntico a si mesmo. Cada ser, sem excluir um possível Ser Supremo, apresenta um resquício opaco, um aspecto misterioso que desafia a transparência. Este é precisamente o lugar da liberdade, e a base do pluralismo ${ }^{1339}$.

Qualquer teoria universal nega o pluralismo. E nenhuma teoria pode ser absolutamente universal, a contemplação da verdade não é uma contemplação universal, como tampouco é uma "verdade" (teórica) de tudo o que existe na realidade. Ele diz que não se trata de apresentar uma contra-teoria, senão uma nova inocência ${ }^{1340}$.

Panikkar acredita que

se existe alguma solução para a situação presente, não provém de uma única visão religiosa ou tradição, senão que terá que avançar na colaboração das diversas tradições do mundo. Nenhuma tradição humana ou religiosa é hoje em dia autossuficiente e capaz de resgatar a humanidade da situação atual. Já não podemos dizer por mais tempo que "isto é teu problema". O hinduísmo não sobreviverá se não confronta a modernidade 1341 .

Necessita-se de outros símbolos. Ele elege a 'concórdia', que como tal desafia a quantificação. Nem a multiplicidade como tal nem a total unidade leva, nem inclusive permite, a harmonia. A harmonia implica uma polaridade constitutiva que não pode ser substituída dialeticamente. A 'concórdia' "não é nem unicidade nem pluralidade. É o dinamismo do Múltiplo para o Uno sem deixar de ser distinto e sem retornar uno, e sem alcançar uma síntese superior"1342.

Ele nos apresenta a palavra 'simpatia' para expressar o que significa harmonia, que em primeiro lugar, não quer dizer individual, compaixão sentimental, senão o pathos comum entre todos os constituintes da realidade.

A simpatia universal é outro modo de superar a divisão entre os interesses individuais e coletivos, o uno e o múltiplo. E a palavra aqui sugere não somente uma receptividade mais "feminina" em uma cultura predominantemente "masculina", senão uma maior tomada de consciência do mesmo mistério do sofrimento (pathos, dukkha) em uma civilização que evita enfrentar este fator elementar, que nos conscientiza a transcendência e interioridade ${ }^{1343}$.

\footnotetext{
${ }^{1338}$ Cf. PANIKKAR, Raimon. Sobre el dialogo intercultural, p. 116.

${ }^{1339}$ Ibid.

${ }^{1340}$ Cf. Ibid., p. 138

${ }^{1341}$ Ibid., p. 140.

1342 Ibid., p. 145.k

${ }^{1343}$ Ibid., p. 151.
} 
Estes diálogos não pretendem estabelecer grandes teorias universais, senão criar um profundo entendimento mútuo ${ }^{1344}$.

Se tudo repercute no todo e apesar disso os homens e as culturas são diversas, a característica essencial que devem recuperar as culturas, as religiões e as tradições é o pluralismo, base da interculturalidade. A grande tentação seria confundir o pluralismo com pluralidade anárquica, ou cair em um extremo oposto do niilismo. Para evitar esta interpretação poderia reformular-se em sentido inverso o mesmo sūtra dizendo que cada cultura, religião e tradição oferece um caminho de salvação a quem descobre no seu interior o núcleo inefável do homem ${ }^{1345}$.

O momento em que vive a humanidade não requer apenas uma mudança em seu ritmo tecnológico e industrial, mas uma mudança radical, de uma metanóia. É o paradoxo desta civilização, que tendo dominado o mundo e conhecido os seus segredos, deixa a humanidade preparada para dedicar-se ao descobrimento do mistério humano e a uma experiência mais madura do divino.

Por isso, Panikkar insiste na importância do pluralismo. Segundo ele, sem o reconhecimento da interculturalidade, não é possível a paz no mundo. Para ele "a interculturalidade é o fundamento da paz"1346.

As religiões são modos diversos de aproximar-se e alcançar essa paz. No entanto, elas não são (e não pretendem ser) todas iguais. Elas afirmam coisas diferentes e falam línguas distintas. Seu conteúdo último não está desvinculado da forma em que cada tradição o expressa. As palavras fundamentais em quase todas as religiões concordam em reconhecer que seu conteúdo seja a paz do homem e em consequência a de todo o $\operatorname{cosmos}^{1347}$.

Isto supõe um avanço, já que põe a ênfase nos encontros religiosos (em todos os sentidos da palavra) não em problemas doutrinais, senão em uma atitude mais existencial, o qual permite uma cooperação frutífera entre as religiões em nossa situação humana, o nascimento de uma cooperação fecunda entre as distintas religiões ${ }^{1348}$.

A paz é revolucionária. E quando a religião deixa de ser revolucionária, se degenera e não realiza sua função, transforma o que deveria ser uma revolução em uma simples proteção. Ou seja, as religiões poderiam estar mais atentas à transformação do homem do que em soluções para seus problemas internos.

O desafio da interculturalidade consiste em recordar o papel existencial das religiões. No sentido, caberia falar da função revolucionária das religiões que nos

\footnotetext{
${ }^{1344}$ Cf. PANIKKAR, Raimon. Sobre el dialogo intercultural, pp. 136-137.

${ }^{1345}$ Id., Paz e interculturalidad, pp. 160-161.

${ }^{1346}$ Ibid., p. 161.

${ }^{1347}$ Ibid., pp. 163-164.

${ }^{1348}$ Ibid., p. 164.
} 
conduzem a realização. O Corpus hermeticum $(\mathrm{X}, 24)$ diz que o homem é um ser divino mais que um animal terreno, ainda que, 'não deve deixar a terra para ascender às alturas do céu ${ }^{1349}$.

E ainda, o perdão é o grande desafio que recorda o ser humano de sua contribuição única para a harmonia do universo. A inocência perdida exige redenção, liberdade e não um sonho de um paraíso redescoberto. A paz não é restauração. O status quo ante é uma impossibilidade. O único caminho para a paz é o caminho para 'adiante' e não para 'trás'1350.

O perdão é um ato que transcende o dogma básico da modernidade: a vontade. Se o coração não conduz a pessoa ao perdão, este não pode querê-lo. $\mathrm{O}$ ato de perdoar não é um silogismo racional; para perdoar requer uma força do Espírito. 'O perdão é um ato de 'des-criação', anula a culpa; é a superação da causalidade ativa na criação contínua, é a superação de uma causalidade mecanicista graças à força da liberdade"1351.

Panikkar, quando fala da experiência que produz na pessoa uma metanóia, chama-a de 'experiência mística', definindo-a como uma experiência integral da realidade.

Se a realidade se identificar com Deus, será a experiência de Deus; se esta realidade se vê como trinitária, seria a experiência cosmoteândrica; se a vê como vazia, será a experiência da vacuidade... porém, em qualquer caso, é a experiência do 'Todo'. Desaparece assim o estigma de uma mística nas alturas, desencarnada e alheia aos prazeres e as dores do mundo, sem por isso afogar no puro mundanismo ou sufocá-la em ativismos, que experimenta a realidade da condição humana em sua totalidade e, portanto, não perde a serenidade nem a paz e elimina o medo de participar no esforço humano em pro da justiça1352.

Assim, encontramos em Panikkar através de sua experiência cristã de Deus o que ele quer dizer quando afirma que este é o kairós do milênio que se abriu há pouco para todas as religiões, em que ele assegura que continuar com pequenas reformas não tem sentido, mas é necessária uma grande transformação, não violenta, lenta, porém profunda, uma metanóia!

\footnotetext{
${ }^{1349}$ PANIKKAR, Raimon. Paz e interculturalidad,n p. 165.

${ }^{1350}$ Id., Sobre el dialogo intercultural, p. 166.

${ }^{1351}$ Ibid., p. 167.

${ }^{1352}$ Id., De la mística, p. 203.
} 


\section{Conclusão}

Como conclusão parece-nos importante insistir na necessidade de uma maturidade cristã, porque tanto como Merton como Panikkar põem em evidencia uma realidade que vai além do próprio projeto espiritual. Ambos os testemunhos são uma confissão de solidariedade e talvez de humildade, de impotência e de solidão, porém também de enorme maturidade espiritual arraigada no cristianismo. Diante da experiência de fé destes dois místicos, acreditamos que o caminho para o diálogo inter-religioso deve ser perpassado pela experiência de Deus.

Merton, um monge contemplativo, recolhido ao diálogo silencioso da oração e da meditação, não se furtou ao diálogo com o mundo, abrindo sua alma e coração com rara franqueza e honestidade. Como mestre espiritual que foi, tornou-se uma referência incontornável nos estudos da espiritualidade cristã e da experiência religiosa num sentido mais geral. Pode-se mesmo afirmar que sua decisiva contribuição para o cristianismo contemporâneo foi promover uma renovação e redimensionamento da vida contemplativa.

Merton nos apresenta a contemplação como sinal de maturidade cristã. Essa experiência permite ao crente alcançar a comunhão com o Deus vivo, colocando-o em uma constante metanóia. Pois é certo que Cristo habita seu eu mais profundo. O ser humano pode, enfim, descobrir-se como ser infinitamente maior: filho de Deus, descobrindo a si mesmo e os outros por meio da caridade. Torna-se necessário reconhecer que o conhecimento de Deus está inseparável da experiência de amor.

Essa experiência é no mais elevado sentido, comunhão. Em que a própria realidade do crente está unida à Deus. E nessa união o crente torna-se livre, capaz de encontrar Deus nas outras pessoas. A presença de Deus na profundidade do ser da pessoa, desperto para a consciência espiritual, marca sua vida por uma mudança: abandonar a vida exterior para uma vida interior.

Logo, a contemplação tem uma significativa contribuição para o diálogo inter-religioso, quando o crente torna-se um discípulo de Cristo. E tem nele aperfeiçoada a imagem divina, enchendo-se de vida e liberdade. Torna-se possível um diálogo mais profundo, no conhecimento mais pessoal de Deus. 
Quando em contato com o eu mais profundo, o crente descobre-se inseparável do amor de Deus e de sua verdade, de sua profundeza surge todo bem para o outro. Sem essa experiência interior, a imagem permanece apenas uma semelhança em potencial. No entanto, quando tocada pela inefável misericórdia de Deus, identifica-se com Aquele que é amor.

Torna-se necessário para a vida contemplativa um espaço para a liberdade e o silêncio. De acordo com Merton, deve-se criar uma nova consciência de tempo, um et temps vierge. Um tempo para as novas escolhas, para si mesmo, para a compaixão. E esse tempo, que não significa um espaço vazio, pode se transformar, para o diálogo inter-religioso, uma oportunidade para o encontro, desde que não se perca a identidade mais profunda de cada tradição religiosa. Isso, porque o ser humano tem a capacidade de ser mais plenamente e humanamente vivo, quando faz uso consciente de sua liberdade.

Como vimos, Merton foi um peregrino essencialmente humano que realiza o desejo de viajar e conhecer experiencialmente a Ásia, mas que afirmava aos amigos “(...) nossa verdadeira viagem na vida é interior: é uma questão de crescimento, de aprofundamento e de uma entrega sempre maior à ação criadora do amor e da graça em nossos corações" ${ }^{\text {1353 }}$.

No mesmo caminho, encontramos Panikkar, que nos apresenta 'a harmonia invisível', de todas as religiões, como condição para alcançar a verdade total, que se encontra parcialmente em todas elas. A harmonia invisível se relaciona com o que ele denominou "efecto pars pro toto". Ou seja, o que se consegue ver da realidade, a partir de um lugar particular, é apenas parcial. O que se conhece é apenas em parte. A partir dessa experiência não é mais possível tentar reduzir tudo a um denominador comum, mas em estar aberto para acolher a experiência do outro.

Para Panikkar a Realidade é relacional, é advaitica (a-dual), onde se encontram o Cosmos, o ser Humano e Deus intimamente relacionados. Surge o que ele denominou de Perspectiva Cosmoteândrica ou Trindade Radical, com o interesse de superar toda a fragmentação do conhecimento por meio da interrelação. Cada parte tem seu valor, cada experiência tem sua importância para revelar o todo. O desafio é reconhecer a relatividade radical de toda a Realidade,

${ }^{1353}$ MERTON, Thomas. O diário da Ásia, p. 232. 
onde tudo está relacionado com tudo. Torna-se claro para Panikkar que Deus é pura relação. E assim vimos se constituir o alicerce de sua concepção trinitária.

Torna-se importante respeitar cada pessoa para que a rede das relações humanas não se rompa. E assim Panikkar nos fala do terceiro olho contemplativo, místico. E da oração como silêncio e lugar do encontro com o que cada um é. Nesse respeito e acolhida, nos deparamos com um ecumenismo que ultrapassa às confissões cristãs, para um ecumenismo inter-religioso, o que ele denominou de ecumenismo-ecumênico. Tal conceito significa a harmonia de corações despertos, com o objetivo de compreender sem diluir a herança ou prejudicar as diferenças entre as religiões e que se reconheça a alteridade de comunhão. Ou seja, em dar-se contra de que as diferenças que as separa pode complementar a experiência do outro, em sua própria identidade.

Panikkar está convicto de que a imagem da perichôrêsis trinitária divina deve servir de inspiração para a relação entre as mais diversas religiões, pois estas não existem sem que estejam uma relacionada a outra. Ele, indo além do diálogo inter-religioso, nos apresenta o diálogo intrarreligioso. Diálogo que se dá no interior da vida religiosa da pessoa, construindo a partir de um caminho profundamente espiritual. Em um mergulho no que lhe é mais íntimo e profundo, na descoberta de si e dos outros a sua volta. Surge aqui, o diálogo a partir da fé.

O diálogo é uma necessidade vital. Em que perpassa o nível pessoal, religioso e histórico. O diálogo constantemente renovado favorece o encontro, destrói barreiras sem desenraizar-se do terreno de suas tradições. Constituindo-se uma dinâmica própria do ser religioso, pertence à própria vida religiosa. O verdadeiro diálogo inter-religioso é em si mesmo religioso. O diálogo intrarreligioso torna-se um ato religioso pessoal em busca da verdade. E quando essa experiência produz na pessoa uma metanóia, Panikkar a define como experiência mística, com experiência integral da realidade.

Em Panikkar vemos um homem que, na profundidade de sua experiência de Deus, longe de um mosteiro, acredita que toda caminhada espiritual em que o homem procura com todo o seu ser o encontro com Deus, a Realidade Última, se encontra um monge ainda desconhecido. E em Merton encontramos um místico consciente do valor da solidão para seu crescimento espiritual e da necessidade de comunicar-se com as outras pessoas. À medida que crescia sua experiência de Deus, sentia uma maior responsabilidade pelo bem do outro e de toda a sociedade. 
Diante destas experiências, vislumbramos as pegadas da presença de Deus em nossas vidas. E, assim, tomamos consciência do pressuposto radical de toda possível experiência de Deus, ativa e inconfundível no centro do ser de cada ser humano.

Assim, vimos que as experiências de Merton e de Panikkar apresentam meios para a descoberta de uma mística inter-religiosa através de uma profunda experiência de Deus no interior do Cristianismo e, de tal modo, reconhecemos que qualquer pessoa religiosa também pode realizar seu percurso de intimidade com Deus, e através desta, pode exercer a humildade na acolhida às demais religiões, em uma rica e madura mística inter-religiosa. 


\section{Considerações finais}

\section{Perspectivas para uma maturidade cristã e uma mística inter- religiosa - Caminhos apontados por Thomas Merton e Raimon Panikkar.}

Diante do contexto ricamente plural em que nos encontramos, deparamo-nos com um forte pluralismo religioso que desafia as diferentes tradições. No entanto, como demonstramos, acreditamos ser este momento uma oportunidade para que as tradições religiosas possam chegar a uma maior profundidade, assumindo sua real vocação: a de ser caminho para que o ser humano, no mais íntimo de si, entre em contato com a Realidade Última, Deus.

Os estudos da religião levam à convicção de que o cultivo da verdadeira religião, longe de limitá-la, amplia as possibilidades da razão humana; longe de inibir a liberdade, possibilita e favorece o seu exercício, dentro do marco insubstituível da finitude que lhe é consubstancial, do mesmo modo que, longe de ser estrutura repressiva, é fonte de felicidade.

Procuramos, para isto, ampliar a concepção de Deus presente nas tradições religiosas, permitindo contemplar com mais profundidade seu mistério, que se revela maieuticamente na História e que nem sempre é percebido. Indicamos que esta Presença pode ser melhor percebida por meio de uma experiência religiosa, e que o sujeito religioso vive das mais diferentes tradições religiosas, nas mais variadas formas. Experiência esta que conduz o ser humano ao encontro com Deus, e ao mesmo tempo a voltar-se à Humanidade e a auxiliar os que estão em busca de tal caminho.

Refletindo sobre o homem e Deus, percebemos que o problema não é a religião, mas a dificuldade de vivê-la à altura que exige. $\mathrm{O}$ problema não é dizer 'Deus', mas dizê-lo sabendo o que se diz. Por isso, acreditamos que o malentendido adquirido na consciência moderna, entre o homem e Deus, somente será respondido quando essa palavra surgir de uma consciência que tenha entrado em contato real com Ele, quando for a expressão de uma vontade que reconheceu a presença misteriosa que nela habita; quando, portanto, os religiosos dizem 'Deus', não o fazem por ouvir dizer, mas pela experiência realizada no mais íntimo de si, uma experiência pessoal de transcendência, de consentimento a sua presença amorosa, da experiência única que supõe haver 'sucumbido' a Deus. 
Por consequência, procuramos propor, diante das insuficientes respostas dos mais diversos paradigmas apresentados, que o diálogo inter-religioso não aconteça propriamente no nível religioso, mas em um nível mais profundo, em uma comunhão para além das palavras e de todos os conceitos, na experiência mais profunda de todo ser religioso. Em um lugar que, liberto de todo o medo da perda de identidade, possa entrar em comunhão com o diferente, com o inefável, com o Absoluto.

Em Velasco, encontramos na mística a possibilidade para que as religiões se descubram através de seus místicos junto com outros crentes e não crentes, o sinal da presença e condição da permanência da fé. Para ele, deve evitar-se no diálogo inter-religioso o dogmatismo e a indiferença. Acreditamos, após nossa reflexão sobre o tema, que nenhum sujeito religioso está mais bem preparado contra esses perigos que o sujeito místico, por se encontrar na união com Deus. Experiência que o religioso vive na mais pura fé, na mais absoluta confiança.

Essa nossa compreensão dá-se também pelas provocações que Queiruga nos faz quando diz que todas as religiões são verdadeiras, refletindo por meio de duas ideias: da revelação que se dá maieuticamente na criação e da 'eleição' como necessidade histórica. Para ele, a revelação constitui uma presença real de Deus no coração de toda a História humana, e a 'eleição' constitui uma necessidade histórica, que consiste em 'intensificar' a uns para chegar melhor a todos, eliminando o esquema: cristianismo, como revelação e outras religiões como não revelação. Essa ideia elimina também o privilégio das religiões de se acharem de alguma forma as únicas verdadeiras.

Por ser então a revelação um dado constitutivo de toda religião - por ter em sua estrutura o homem como seu lugar privilegiado -, e por não existir nenhuma que possua absolutamente a Verdade, nenhuma delas pode, portanto, exaurir a riqueza do Mistério divino. No entanto, como vimos, não deve, por exemplo, o cristianismo diante desta constatação, renunciar à experiência da revelação cristã como manifestação plena e universal de Deus em Jesus Cristo. Mas, ao contrário, deve propagar a experiência cristã como dom a toda a comunidade religiosa.

A revelação que aconteceu de maneira insuperável em Jesus possibilitou o rompimento de toda particularidade. Foi em Jesus que Deus encontrou a oportunidade de entregar-se totalmente a toda a humanidade. A universalidade do cristianismo realiza-se na práxis do cristão, na sua experiência religiosa, porque 
em Jesus Cristo a universalidade dá-se no próprio dinamismo da revelação, no amor com que Deus o amou e o entregou à humanidade. Assim, a autocompreensão do cristão de sua real vocação o abre às demais tradições religiosas.

A experiência de Deus dá-se por meio da experiência de fé. E essa fé impulsiona o sujeito à acolhida, à aceitação e ao seu reconhecimento com consciência de que esse contato o coloca diante de uma Presença 'sempre já aí'. A experiência mística assim acontece por ser consequência da revelação e da fé que move o sujeito.

Deus que não cessa de querer revelar-se, nunca deixa de insinuar-se à humanidade por desejar a libertação e a felicidade do ser humano. E esta é a maior expressão do seu amor: o fato de se dar a conhecer. O sujeito, quando acolhe essa Presença, passa a ser construído desde a sua profundidade, e realiza-se como pessoa. Apenas nesta relação é possível aos homens compreender esse amor de Deus como possibilidade de ser a sua autêntica realização.

Diante do desejo de Deus em querer revelar-se e ser para o ser humano a possibilidade de sua realização, entendemos que para um sadio pluralismo religioso, impõe-se às religiões superar suas tendências à exclusão recíproca, e que isso seja a oportunidade para o exercício da compaixão e da hospitalidade inter-religiosa.

Reafirmamos que mesmo que o diálogo inter-religioso tenha se chocado permanentemente com o dogmatismo e com o relativismo indiferente, o cultivo da dimensão mística pode eficazmente ajudar a evitar esses obstáculos, pois o exercício da experiência mística permite captar o íntimo parentesco de todas as religiões ao pôr em contato quem a vive com a raiz de onde todas elas procedem.

Podemos dizer que a mística assume o melhor lugar para o encontro e diálogo inter-religioso, pois, nas atuais circunstâncias, sendo indispensável esse diálogo para a paz mundial, superará as diferenças quando os fiéis das várias religiões fizerem intervir neles as experiências que as sustentam e a preocupação pela melhoria e pelo progresso da humanidade que as anima. Ou seja, quando se desenvolverem os elementos místicos que todas elas compartilham.

Como vimos, o Concílio Vaticano II, deu um grande salto com relação às outras religiões. Seu ensino sobre as religiões se caracterizou por uma atitude positiva diante das demais, iniciando uma abertura sem precedentes nos 
posicionamentos oficiais da Igreja em sua relação com os não cristãos. Em seguida, grandes avanços foram feitos; no entanto, todos os paradigmas apresentados mostraram-se insuficientes para resolver o duplo desafio da relação do cristianismo com as outras religiões. Diante de tantos modelos que procuraram preservar a identidade cristã, sem se fechar à novidade proposta por outras tradições religiosas, reconhecendo-as em sua alteridade, estamos convictos de que uma madura experiência cristã de Deus pode ser para os cristãos a possibilidade de encontro com religiosos de outras religiões.

É certo que, mesmo que a pretensão de unicidade e universalidade da salvação cristã apresente dificuldades para o diálogo inter-religioso, não podem ser desprezadas as afirmações do Novo Testamento e de toda a tradição de experiências cristãs sobre a revelação divina decisiva e definitiva em Jesus Cristo.

As experiências de místicos como Merton e Panikkar são testemunhos que se caracterizam pelo esforço em aprofundar no reconhecimento da especificidade e singularidade, sua própria experiência cristã de Deus, a partir de sua fé, no diálogo com outras tradições religiosas. Assim, diante do pluralismo religioso, nos é sugerido mergulhar nas raízes da profundidade do próprio Mistério divino pelo qual nos tornamos capazes de encontrar em nós mesmo, não somente a nós mesmos, mas a Deus.

Estudando como Merton e Panikkar apresentam meios para uma mística inter-religiosa, através de uma profunda experiência de Deus, poderemos vislumbrar possíveis caminhos para que, no interior do Cristianismo, a pessoa religiosa possa também realizar seu percurso de intimidade com Deus, e através desta, poder exercer a humildade na acolhida às demais religiões, em uma rica e madura experiência cristã de Deus.

Nosso percurso se deu por considerarmos que não há possibilidade de se fazer teologia a não ser a partir de uma fé específica. O que não significa dizer que a experiência do sagrado não possa ser feita fora do Cristianismo, pois, como já pudemos ver através das experiências de nossos autores, a experiência religiosa faz parte da experiência humana. Segundo Panikkar, a experiência de Deus "não só é possível, como também necessária para que todo ser humano chegue à consciência de sua própria identidade" ${ }^{1354}$.

${ }^{1354}$ PANIKKAR, Raimon. Iconos del mistério. La experiência de Dios. Barcelona: Península, 1998. 
O que, então, queremos dizer quando falamos de maturidade cristã e de uma mística inter-religiosa? Acreditamos que na experiência cristã de intimidade com Deus, ocorre no interior do religioso o desvelamento da verdadeira imagem de Deus em que foi criado. De um Deus que é amor. E nessa experiência torna-se para os demais religiosos de outras tradições uma manifestação desse amor.

Assim, vimos nos passos para o diálogo inter-religioso, apontados nas experiências vividas por Merton e Panikkar, tornarem-se visíveis a importância do desenvolvimento da dimensão espiritual e a experiência interior na vida dos cristãos. E aqui está a importância para o melhor desenvolvimento do diálogo entre as religiões para o cristão: aprofundar, por meio da fé, a experiência de encontro com Deus; descobrir-se e assumir no encontro com outros religiosos como imagem de Deus, ou seja, que está destinado a viver em harmonia com Deus.

Por conseguinte, para o diálogo inter-religioso, em que se deve evitar o dogmatismo e o indiferentismo, a experiência de intimidade com Deus tem um lugar excepcional. A experiência do Mistério como centro pode valorizar a vida religiosa, seja qual for o lugar em que ela floresça, superando a tentação de absolutista e exclusivista, bem como o perigo do indiferentismo.

Diante do que nos foi dito pelos místicos estudados, acreditamos que o caminho para o diálogo inter-religioso deve ser perpassado pela experiência de Deus. No contexto de pluralismo religioso em que vivemos, se a experiência do cristão estiver enraizada na intimidade com Deus, essa situação de pluralismo pode, na medida em que for assumida e interpretada, tornar-se uma oportunidade para uma rica experiência religiosa.

Logo, partindo da presença de Deus no 'eu' interior, no exercício de sua capacidade de amar, o ser humano torna-se capaz de encontrar Deus nos outros, encontrando a Cristo no lugar antes ocupado por sua individualidade. Tornamonos plenamente humanos quando nos damos um ao outro no amor. Pois o ser humano procura a unidade porque ele é a imagem de Deus Uno e assim viver em comunhão com os outros é necessário para que o ser humano permaneça humano, pois em união com os demais é possível estabelecer a unidade interior.

Para isso, faz-se necessário nos desfazer de toda falsa imagem de Deus, a romper com um tipo de experiência de Deus que em muitos momentos comprova uma deficiência, como nos lembra o livro de Jó: “eu te conhecia só de ouvir. 
Agora, porém, os meus olhos te veem"1355. Livrando-se de todo tipo de formalismo mecânico e compulsivo, para poder despertar o fervor interior e espontâneo do coração. E assim restaurar a orientação profundamente interior de atividade religiosa, almejando a renovação e a purificação da vida interior, de se deixar surpreender pela ação do Espírito. A partir de uma experiência de profundidade no 'eu' mais profundo que quando desperta encontra-se na presença de quem é imagem, Deus.

Então nesta experiência de mergulho, o cristão torna-se capaz de interiorizar e de contemplar, de entrar em si, orar e reconhecer em seu interior a presença silenciosa e amorosa de Deus; capaz de deter-se diante da natureza e do cosmos e descobrir neles a presença do Deus vivo, de reconhecer na história, nos seres humanos a manifestação de Deus; capaz de viver e experimentar que, quanto mais unido a Ele, mais seu semelhante pode ser.

Percebemos que o contexto de pluralismo religioso indica onde são necessárias as transformações: nas formas de prática religiosa, procurando viver em profundidade, recuperando a dimensão da experiência íntima do mistério de Deus e da experiência da unidade com ela. Entre os níveis de encontro com suas respectivas formas de diálogo que o cristianismo tem buscado concretizar, acreditamos que a experiência de Deus é o que alcança o nível mais profundo. Deve-se estar convicto de que a presença de Deus não é algo exterior à pessoa, que Ele não está fora, mas no próprio interior, na própria vida.

De acordo com Merton, o auge da vida interior é a contemplação; a experiência de Deus em profundidade, a mística. Faz-se necessário o despertar do cristão para a vida ao entrar em contato com Deus pela fé, em uma profunda participação na vida de Cristo. É importante para a experiência cristã não apenas a consciência do eu interior, mas também, pela fé, uma apreensão exterior de Deus, na medida em que ele se faz presente em nosso eu interior. O contemplativo deve caminhar na presença de Deus.

Para Panikkar, a Realidade é totalmente relacional. E o ser humano não é um ser isolado, seu vínculo com o corporal e o divino lhe é constitutivo. A mística é uma experiência humana em sua plenitude, permitindo com que o ser humano faça a experiência do seu último fundamento, do que realmente é. É uma 
experiência necessária para que todo ser humano chegue à consciência de sua própria identidade.

O requisito indispensável para acolher a experiência de Deus é a integração do interior humano. E assim o ser humano deve estar em harmonia consigo mesmo e com o universo. Harmonia entre ele e a sua "casa", entre Deus e os homens, entre contemplação e ação, entre tudo o que vive e tudo o que morre, entre a renúncia e a conquista de si mesmo.

Por ser esta experiência uma experiência de profundidade, o ser humano descobre em si mesmo e nos outros seres a dimensão de profundidade, de infinito que existe em tudo. Esta experiência concede humildade, e ao mesmo tempo liberdade.

É imprescindível que os cristãos se conscientizem de que a mística não distrai o ser humano do cotidiano. Pelo contrário, o coloca em atenção diante dos desafios e necessidades de seu tempo. A experiência mística não separa o amor de Deus do amor ao próximo. O amor a Deus e ao próximo são um só amor. É o amor que se faz humano através de Deus que leva o ser humano à sua plenitude, tornando-o filho de Deus. É certo que o mistério do ser humano se revela através do mistério de Cristo. E assim, se descobre o Cristo vivo de hoje, ontem e sempre.

Por isso, a contemplação é sinal de vida cristã madura, por ser uma experiência que torna o ser humano amigo de Deus, retirando-o de toda e qualquer alienação e submissão de suas falsas imagens. A maturidade cristã atingida pela contemplação permite ao crente alcançar a comunhão com o Deus vivo. O ser humano conhece a si mesmo pelo testemunho de seu eu mais profundo, de seu espírito; também Deus se revela a si mesmo no amor de seu Espírito. O ser humano foi criado à imagem e semelhança de Deus, e não há outro meio de descobrir quem é senão descobrindo em si mesmo a imagem de Deus.

Torna-se necessária uma experiência de Deus inseparável de uma experiência de amor. A recuperação da imagem divina em nossa alma, na medida em que é experimentado por todos nós, é a experiência de um modo de ser inteiramente novo. Tornamo-nos "homens novos" em Cristo. O ser humano que alcança a integração do seu ser, não mais se encontra limitado pela cultura em que está inserido. Aceita a humanidade toda. Quem se abre a essa experiência transcende as divisões para alcançar uma unidade por cima de qualquer divisão. 
Diante do nosso desejo de encontrar um possível caminho para uma maturidade cristã e uma mística inter-religiosa, não podemos esquecer que o centro da fé cristã não se vive no projeto de divinização do ser humano, senão em sua radical humanização. Não porque a vida divina não seja importante, senão porque não pode haver vida divina onde a vida humana se vê ameaçada, limitada, humilhada ou deteriorada da maneira que for.

Estamos certos de que, para o cristão, o mergulho em sua profunda intimidade é o caminho no discipulado de Jesus. No Evangelho, encontramos a causa de Deus se confundindo com a causa da vida, a tal ponto que a pregação de Jesus e seu comportamento nos dizem o seguinte: nos seres humanos encontramos a Deus na medida, e somente na medida, em que defendemos a vida, respeitamos a vida e dignificamos a vida.

Podemos dizer que a experiência mística presente no Evangelho não é uma experiência centrada no sujeito, em sua própria perfeição, em sua santificação pessoal, na aquisição de determinadas virtudes. A mística presente no Evangelho é de uma experiência centrada nos outros, orientada para os demais, com a intenção de aliviar o sofrimento alheio, ou mais exatamente, trata-se de uma experiência centrada na defesa da vida, o respeito à vida e a luta por dignidade da vida. Por fim, consiste exatamente em que se confunda a causa de Deus com a causa da vida humana.

Para finalizarmos, não querendo aqui dar por concluída nossa pesquisa, mas apenas em termos apresentado como possível conclusão um caminho espiritual radicado no profundo encontro com Deus, como possibilidade para uma madura experiência cristã e uma mística inter-religiosa, citamos o trecho do pronunciamento do Papa Francisco, nas comemorações do $50^{\circ}$ aniversário da Fundação do Pontifício Conselho para o Diálogo Inter-religioso, em que ele afirma:

Como Cristo a caminho de Emaús, a Igreja deseja tornar-se próxima e companheira de viagem de todos os homens. Esta disponibilidade em caminhar juntos é necessária, sobretudo, no nosso tempo marcado por profundas e nunca antes conhecidas interações entre os povos e culturas diversas. Neste contexto, a Igreja estará cada vez mais comprometida a percorrer o caminho do diálogo e a intensificar a cooperação, já frutuosa, com todos aqueles que, pertencentes a diferentes tradições religiosas, partilham a vontade de construir relações de amizade e participam nas numerosas iniciativas de diálogo ${ }^{1356}$.

1356 Essa mensagem foi dirigida ao Cardeal Jean-Louis Tauran e aos participantes de uma conferência por ocasião das comemorações do $50^{\circ}$ aniversário da Fundação do Pontifício Conselho 
Esta declaração nos permite ver que a cooperação inter-religiosa na construção de um mundo novo é o único modo de ir adiante. Compreendemos que no mundo de hoje, ser religioso é ser inter-religioso. No entanto, faz-se necessário manter e aprofundar o compromisso religioso único que nos é próprio, recuperando a experiência de profundo encontro com Deus para um sincero e fecundo diálogo inter-religioso.

para o Diálogo Inter-religioso, em 19 de maio de 2014. Cf., em: http://m2.vatican.va/content/francescomobile/pt/messages/pont-messages/2014/documents/papafrancesco_20140519_messaggio-50-dialogo-interreligioso.html. 


\title{
Referências Bibliográficas
}

\author{
Bibliografia de Thomas Merton
}

MERTON, Thomas. Ascensão para a verdade. Belo Horizonte: Itatiaia, 1999.

Na liberdade da solidão. Petrópolis. Rio de Janeiro: Vozes, 2001.

Bread in the widerness. Collegeville, MN: Liturgical Press, 1986. [Ed. bras.: O pão no deserto. Petrópolis: Vozes, 1958.]

Conjectures of a guilty bystander. New York: Doubleday, 1966. [Ed. bras.: Reflexões de um espectador culpado. Petrópolis, RJ: Vozes, 1970.]

Contemplation in a world os action. New York: Doubleday, 1971. [Ed. bras.: Contemplação num mundo de ação. Petrópolis: Vozes, 1995.]

Disputed questions. San Diego: Harcout Brace, 1985. [Ed. bras.: Humanismo cristiano. Cuestones disputadas. Barcelona: Editorial Kairós, 2000.] 1962.

Espiritualidade, contemplação e paz. Belo Horizonte: Ed. Itatiaia,

Incursiones en lo Indecible, Sal da Terrae: Santander, 2004.

La experiencia interna. Notas sobre la contemplación, In. Cistercium 212 (1998).

La vida silenciosa. Desclée de Brouwer: Bilbao, 2009.

Love and living. San Diego: Harcourt Brace Jovanovich, 1985. [Ed. bras.: Amor e vida. São Paulo: Martins Fontes, 2004.]

Mystics and Zen Masters. New York: Farrar, Strauss and Giroux, 1976. [Ed. bras.: Místicos e mestres Zen. São Paulo: Martins Fontes, 2006.]

News seeds of contemplation. [Ed. bra.: Novas sementes de contemplação. Rio de Janeiro: Fissus, 2001.]

No man is an Island. New York: Phoenix Press, 1986. [Ed. bras.: Homem algum é uma ilha. Campinas, SP: Verus Editora, 2003.]

O homem novo. Rio de Janeiro: Agir editora, 1966. 
Reflexiones sobre Oriente. Barcelona: Ediciones Oniro, 1997.

Sabedoria do deserto. São Paulo: Martins Fontes, 2004.

Seeds of contemplation. New York: New directions, 1986. [Ed. bra.: Sementes de contemplação. Porto: Tavares Martins, 1956.]

Seeds of destruction. New York: Farrar, Strauss and Giroux, 1996. [Ed. bras.: Sementes de destruição. Petrópolis: Vozes, 1966.]

The Asian Journal of Thomas Merton. New York: New Directions, 1973. [Ed. bras.: O diário da Ásia. Belo Horizonte: Ed. Vega, 1978.]

The inner experience: notes on contemplation. [Ed. bras.: A experiência interior: notas sobre a contemplação. São Paulo: Martins Fontes, 2007.]

The sign of Jonas. New York: Octagon Books, 1983. [Ed. bras.: O signo de Jonas. São Paulo: Ed. Mérito, 1954.]

The way of Chuang Tzu. Boston: Shambhala Publications, 1980. [Ed. bras.: Via de Chuang Tzu. Petrópolis: Vozes, 2003.]

Vida y santidad. Sal Terrae: Santander, 2006.

Vivir con sabeduria. Madri: PPC, 1997.

Zen and the birds of appetite. London: Shambhala, 1968. [Ed. bras.: Zen e as aves de rapina. Rio de Janeiro: Civilização brasileira, 1972.]

The seven storey mountain. San Diego: Harcourt Brace Jovanovich, 1990. [Ed. bras.: A montanha dos sete patamares. Petrópolis: Vozes. 2005.]

\section{Bibliografia de Raimon Panikkar}

PANIKKAR, Raimon. Autobiografía intelectual. La filosofía como estilo de vida. Anthropos, 1985.

A Self-Critical Dialogue. En The intercultural Challenge of Raimon Panikkar editado por Joseph Prabhu, 227-291. Maryknoll, NY: Orbis, 1996.

Cometas. Fragmentos de un diario espiritual de la postguerra. Madrid: Suramérica, 1972. 
Culto y secularización. Madrid: Marova, 1979.

Herber, 2005.

De la mística. Experiencia plena de la Vida. Barcelona: Editorial 1994

Ecosofía. Para una espiritualidad de la tierra. Madrid: San Pablo,

El concepto de natureza. Análisis histórico y metafísico de un concepto, CSIC, Madri, 1972.

El Cristo desconocido del hinduismo. Madrid: Grupo Libro 88, 1994.

El dialogo interno: la insuficiencia de la llamada 'époché' fenomenologica en el encontro religioso. Salmanticensis, XXII/2 , 1975. 1999.

El espíritu de la política. Homo politicus. Barcelona: Península,

El mundanal silencio. Barcelona: Martínez Roca, 1999.

El silencio del Buddha. Una introducción al ateísmo religioso. Madrid: Siruela, 1996.

El toque contemplativo. En El árbol de la vida editado por Chantal Maillard et al., Barcelona: Kairós, 2001.

Elogio de la sencillez. Navarra: Verbo Divino, 2000.

Entre Dieu et le cosmos. Entrevista com Gwendoline Jarczyk, Albin Michel: Paris, 1998.

Experiencia de Dios. Madrid: PPC, 1994.

Humanismo e cruz. Rialp, Madrid, 1963.

2007.

Icones do místério. A experiência de Deus. São Paulo: Paulinas,

Il diálogo intrareligioso. Cittadella: Assisi, 1988.

Invitación a la sabiduría. Espasa: Madrid, 1999.

Jesús en el diálogo interreligioso. En Diez palabras clave sobre Jesús de Nazareth, compilado por Juan José Tamayo, 453-488. Navarra: Verbo Divino, 1999.

La experiência filosófica de la Índia. Madri: Trotta, 1997.

La intuición cosmoteándrica. Las tres dimensiones de la realidad. Madrid: Editora Trotta, 1999. 
La nueva inocencia. Pamplona: Verbo Divino, 1999.

La plenitud del hombre. Una cristofanía. Madrid: Siruela, 1999. 1992.

La transformación de la misión cristiana en diálogo. Madrid,

La Trinidad. Una experiencia humana primordial. Siruela, Madrid, 1998.

La vision cosmoteandrica: El sentido religioso emergente del tercer milênio, Qüestions de vida cristiana, 156, 1990. 1985.

La vocación humana es fundamentalmente religiosa. Anthropos,

Mistica comparada? Em VV AA, La mistica en el siglo XXI. Trota: Madrid, 2002.

Mito, fe y hermenéutica. Barcelona: Herder, 2007.

Ontonomía de la ciencia. Sobre el sentido de la ciencia e sus relaciones con la filosofia, Gredos: Madris, 1961.

El conflicto de eclesiologías: hacia un concilio de Jerusalén II, Tiempo de Hablar, 1993.

Paz e interculturalidad. Una reflexión filosófica. Barcelona: Herder, 2006.

Paz y desarme cultural. Santander: Sal Terrae, 1993.

Pensamiento científico y pensamiento cristiano. MaliañoMadrid: Sal Terrae-Fe y secularidad, 1994. 1986.

Presentación de La montée au fond du coeur. OEIL, Paris,

Sobre el diálogo intercultural. Salamanca: San Esteban, 1990.

Reflexiones sobre religión y Europa. Alandar, Madrid, 1997.

Religión. Diálogo intrarreligioso. In: Casiano FLORISTAN \& Juan Jose TAMAYO. Conceptos fundamentales del cristianismo. Madrid: Trotta, 1993.

Salvation in Christ: Concreteness anda Universalitty. The Supername, Tantur, Jerusalem, 1972. 
The Cosmoteandric Experience. Maryknoll, NY: Orbis, 1993.

Bibliografia de Juan Martin Velasco

VELASCO, J. Martin. El fenómeno místico. Estudio comparado. Madri: Trotta, 1999.

Experiência cristã de Deus. São Paulo: Paulinas, 2001.

(org.). La experiencia mística. Estudio Interdisciplinar. Madri: Trotta, 2004. 1993.

El malestar religioso de nuestra cultura. $2^{\mathrm{a}}$ Ed. Madrid: Paulinas,

Introducion a la fenomenologia de la religión. Madri: Trotta, 2006.

Bibliografia de Andrés Torres Queiruga

QUEIRUGA, A. Torres. A revelação de Deus na realização humana. São Paulo: Paulus, 1995.

Autocompreensão cristã: diálogo das religiões. São Paulo: Paulus, 2007.

O diálogo das religiões. São Paulo: Paulus, 1997.

Um Dios para hoy. Santander, Sal Térrea, 1997.

Recuperar a criação. Por uma religião humanizadora. São Paulo: 1999.

Recuperar a salvação. Por uma interpretação libertadora da experiência humana. São Paulo: 1999.

El dialogo de las religiones en el mundo actual. El Vaticano III. Barcelona, Herber-El Ciervo, 2001.

O fim do cristianismo pré-moderno: desafios para um novo horizonte. São Paulo: Paulus. 2003.

Repensar a ressurreição. A diferença cristã na continuidade das religiões e da cultura. São Paulo: Paulinas, 2004. 
Cristianismo y religiones: 'inreligionación' y cristianismo assimétrico. In: Estúdios Sal Térrea 84, n. 1 p. 3-19, 1997.

¿Qué significa afirmar que Dios habla? In: Selecciones de Teologia 34, n. 134, p. 102-108, 1995.

Inculturación de la fé. In: FLORISTAN, C. (org.). Conceptos fundamentales de pastoral. Madrid: Cristiandad. 1983. pp. 471-480.

Repensar o pluralismo: da inculturação à inreligionação. In: Concilium. Petrópolis: Vozes, n. 319, 2007.

\section{Bibliografia geral}

Documentos, livros, revistas, entrevistas e artigos de diversos autores pesquisados para a elaboração da tese.

\section{Documentos da Igreja}

CONCÍLIO VATICANO II. Constituição dogmática Lumen Gentium. Petrópolis: Vozes, 1969.

Constituição dogmática Dei Verbum. Petrópolis: Vozes, 1969.

Constituição pastoral Gaudium et Spes. Petrópolis: Vozes, 1969.

Decreto Ad Gentes. Petrópolis: Vozes, 1969.

Decreto Unitatis Redintegratio. Petrópolis: Vozes, 1969.

Declaração Nostra aetate. Petrópolis: Vozes, 1969.

Declaração Dignitatis Humanae. Petrópolis: Vozes, 1969.

CNBB, Guia para o diálogo inter-religioso. (Estudos n. 52) São Paulo: Paulus, 1997.

A Igreja Católica diante do pluralismo religioso III (Estudos $n$. 62). São Paulo: Paulus, 1991.

A Igreja Católica diante do pluralismo religioso III (Estudos $\mathrm{n}$. 69). São Paulo: Paulus, 1993.

A Igreja Católica diante do pluralismo religioso III (Estudos $\mathrm{n}$. 70). São Paulo: Paulus, 1994. 
CONGREGAÇÃO PARA A DOUTRINA DA FÉ. Declaração "Dominus lesus" Sobre a unicidade e universalidade salvífica de Jesus Cristo e da Igreja. São Paulo: Loyola, 2000.

JOÃO PAULO II. Encíclica Redemptoris Hominis. Petrópolis: Vozes, 1980.

Encíclica Redemptoris Missio. Petrópolis: Vozes, 1991.

PONTIFÍCIO CONSELHO PARA O DIÁLOGO INTER-RELIGIOSO. Diálogo e Anuncio. São Paulo: Paulinas, 1996.

SECRETARIADO para os Não-Cristãos. A igreja e as outras religiões. São Paulo: Paulinas, 2001 (Documento Diálogo e Missão).

Livros e artigos

ABUMALHAM, Montserrat. Conversación con Raimon Panikkar. In. Revista de Ciencias de las Religiones. Samâdhânam. Anejo VI (2001): pp.7-26.

AMALADOSS, M. Pela estrada da vida. Prática do diálogo inter-religioso. São Paulo: Paulinas, 1996.

O pluralismo das religiões e significado de Cristo. In: TEIXEIRA, Faustino. Diálogo de pássaros. Nos caminhos do diálogo inter-religioso. São Paulo: Paulinas, 1993. pp. 89-109.

Religiões: violência ou diálogo? In: Perspectiva teológica. v. 34, n. 93, 2002. pp. 179-196.

ANCILLI, E. Mística non Cristiana. In: ANCILLI, E. (org.). Dizionario Enciclopédico di Spiritualità. v. 02. Roma: Città Nuova Editrice, 1900.

AGUILAR, Emilio Galindo. Musulmanes y cristianos conducidos por el Espíritu. In: MELLONI, Javier (org.). El no-lugar del encontro religioso. Madri: Trotta, 2008. pp. 169-193.

AZEVEDO, Marcelo de C. Modernidade e cristianismo. São Paulo: Loyola, 1981.

BASSET, Jean-Claude. El diálogo interreligioso. Desclée. Bilbao, 1999.

BERGER, Peter L. O dossel sagrado: elementos para uma teoria sociológica da religião. São Paulo: Paulus, 1985.

BERGSON, $\mathrm{H}$. Las dos fuentes de la moral y de la religion. Madri: Tecnos, 1996. 
BERGERON, Richard. Hors de l'Église plein de salut. Pour une théologie dialogale et une spiritualité interreligieuse. Canadá: Médiaspaul, 2004.

BERTELLI, Getúlio Antônio. Mística e compaixão: a teologia do seguimento de Jesus em Thomas Merton. São Paulo: Paulinas, 2008.

BÍBLIA. Português. Bíblia de Jerusalém. Nova edição revisada. Trad. Soc. Bíblica Católica Internacional e Paulus. São Paulo: Paulus. 1985.

BINGEMER, Maria C. (org.) Violência e religião. Cristianismo, islamismo, Judaísmo. São Paulo: Loyola, 2002.

Loyola, 1992.

(org.) O impacto da modernidade sobre a religião. São Paulo:

Alteridade e vulnerabilidade. Experiência de Deus e pluralismo religioso no moderno em crise. São Paulo: Loyola, 1993.

A sedução do Sagrado. In: CALIMAN, Cleto. (org.) A sedução do Sagrado: o fenômeno religioso na virada do milênio. Vozes: Petrópolis, 1998. 1992.

O impacto da modernidade sobre a religião. São Paulo: Loyola,

O mistério e o mundo. Paixão por Deus em tempos de descrença. Rio de Janeiro: Rocco, 2013.

BOFF, Leonardo. Mestre Eckhart: mística de ser e de não ter. Petrópolis: Vozes, 1983.

BORRIELLO, L. et al. Dicionário de mística. São Paulo: Paulus: Edições Loyola, 2003. pp. 707-709.

BUBER, Martin. Eclipse de Dios. Buenos Aires, Galatea-Nueva Vision, 1970.

BLANK, Renold J. Deus na história: centros temáticos da revelação. São Paulo: Paulinas, 2007.

CATTIN, Yves. A regra cristã da experiência mística. In: Concilium 254, n. 4, 1994.

CASTIÑEIRA, Angel. A experiência de Deus na pós-modernidade. Petrópolis: Vozes, 1997.

CRUZ, S. João da. Obras Completas. Petrópolis: Vozes. Carmelo Descalço do Brasil, 1984. 
Diccionario interdisciplinar de hermenéutica editado por Andrés OrtízOsés y Patxi Lanceros, pp. 650-655. Bilbao: Universidad de Deusto, 1998.

DUPUIS, Jacques. O cristianismo e as religiões. Do desencontro ao encontro. São Paulo: Loyola, 2004.

Le pluralisme religieux dans le plan divin de salut. In: Revue Theologique de Louvain, 29, 1998. pp. 484-505.

Rumo a uma teologia cristã do pluralismo religioso. São Paulo: Paulinas, 1999.

DUQUOC, Christian. El único Cristo. La sinfonia diferida. Sal da Térrea, Cantabria, 2005.

DHAVAMONY, M. Teologia das religiões. In: LATOURELLE, R. FISICHELLA, R. Dicionário de Teologia Fundamental. Petrópolis: Vozes; São Paulo: Santuário, 1994. pp. 806-815.

ELENA, Santiago del Cura. Mística Cristiana: su enraizamiento neotestamentario en perspectiva ecumênica. In: VELASCO. Juan Martin. (org.). La experiencia mística. Estudio Interdisciplinar. Madri: Trotta, 2004. pp. 129-166.

EICHER, Peter. Pluralismo. In: Dicionários de Conceptos teológicos. Vol. II. Barcelona: Herber, 1990, p. 237-242.

Excelência da teologia em conflito com seu pluralismo. In: Concilium 191, n.1, 1980.

ESCOBAR, J.D. Soriano. Revelación, cristianismo y religiones en la obra de Raimundo Panikkar. Universidad Pontificia de Salamanca, 1996.

FORCANO, Benjamin. Entrevista a Raimon Panikkar, Exodo, 65, 2002. pp.10-17.

FORNET-BETANCOURT, Raúl. La mística del diálogo. Jahrbuch für kontextuelle Theologien 93. Frankfurt: IKO, 1994. pp.19-37.

GARCIA RUBIO, A. Unidade na pluralidade: o ser humano à luz da fé e da reflexão cristã. São Paulo: Paulus, 2001.

GUERRA, S. Mística. In: PIKAZA, X., SILANES, N. Diccionario Teologico. El Dios cristiano. Salamanca: Secretariado Trinitario, 1992.

GREFFRÉ, C. O lugar das religiões no plano da salvação. In: TEIXEIRA, Faustino (org). O diálogo inter-religioso como afirmação da vida. São Paulo: Paulinas, 1997. 
HART, Patrick; MONTALDO, Jonathan. Merton na intimidade: sua vida em seus diários. Rio de Janeiro: Fisus, 2001.

HÄRING, S. Superar a violência em nome da religião. In: Concilium 272, 1997. 4, p. 683ss.

HERVIEU-LÉGER, Danièle. O peregrino e o convertido: a religião em movimento. São Paulo: Vozes, 2008.

Representam os surtos emocionais contemporâneos o fim da secularização ou o fim da religião? In: Religião e Sociedade. 18/1, 1997.

JÄGER, W. Adonde nos lleva nuestro anhela. La mística en el siglo XXI. Desclée, Bilbao, 2004.

JAMES, William. Las variedades de la experiencia religiosa. Penisula, Barcelona, 1988.

KÜNG, H. Teologia a caminho. Fundamentação para o diálogo ecumênico. São Paulo: Paulinas, 1999.

Projeto de ética mundial. Uma moral ecumênica em vista da sobrevivência humana. São Paulo: Paulinas, 1992.

Para uma teologia ecumênica das religiões. In: Concilium 161, 19861 , pp. 124-131

KNITTER, Paul. Diálogo inter-religioso e ação missionária: preparai os caminhos. São Paulo: CNBB: COMINA, 1994.

A teologia católica das religiões numa encruzilhada. Concilium 203, n. 1, p.112.

LATOURELLE, R. Revelação. In: Dicionário de Teologia Fundamental. Petrópolis: Vozes; São Paulo: Santuário, 1994.

LIBÂNIO, João B. As lógicas da cidade. O impacto sobre a fé e sob o impacto da fé. São Paulo: Loyola, 2001.

LIPOVETSKY, G. A era do vazio. Lisboa: Relógio d'água, 1989.

LÓPEZ, María Luisa Laguna. Thomas Merton: uma vida com horizontes. Aparecida, SP: Editora Santuário, 2010.

LÓPEZ-GAY. Místique. In: VILLE, M. et al. (Ed.). Dictionnaire de Spiritualitè. v. X. Paris: Beauchesne, 1980.

LÓPEZ-BARALT, L. e L. Piera. El sol a media noche. La experiencia mística: tradición y actualidad. Madri: Trotta, 1996. 
MARDONES, J. Maria. Mística transreligiosa en una sociedade de incertidumbre. In: RODRIGUEZ, Francisco J. S. Mística y sociedad en diálogo. Madri: Trotta, 2006. pp. 89-105.

MARTELLI, Stefano. A religião na sociedade pós-moderna. São Paulo: Paulinas, 1995.

MELLONI, Javier. (org.). El no-lugar del encontro religioso. Madri: Trotta, 2008.

MIRANDA, M. de França. O pluralismo religioso como desafio e chance. REB 55, 1995. Jesus Cristo, um obstáculo ao diálogo inter-religioso? REB 57, 1997. pp. 243-264. $\overline{09-26 .}$

O encontro das religiões. In: Perspectiva Teológica. 68,1994. pp.

Volta do sagrado: numa avaliação teológica. In: Perspectiva teológica, 21, 1989. pp. 71-83.

Um homem perplexo. O cristão na atual sociedade. São Paulo: Loyola, 1989.

O cristianismo em face das religiões. Religiões em diálogo. São Paulo: Loyola, 1998.

MONCADA, Alberto. Historia oral del Opus Dei. Plaza \& Janés: Barcelona, 1987.

MORA, Ferrater. Mayéutica. In: Diccionário de Filosofia. Madrid: Alianza, 1981.

ORO, A. P. - STEIL, C. A. (orgs.). Globalização e Religião. Petrópolis: Vozes, 1997.

OTTO, Rudolf. O sagrado: os aspectos irracionais na noção do divino e sua relação com o racional. São Leopoldo, Sinodal/EST; Petrópolis: Vozes, 2007.

PANASIEWICZ, Roberlei. Diálogo e revelação: rumo ao encontro interreligioso. Belo Horizonte: C/Arte, 1999.

PAIDADATH, Sebastian. Ashms: um movimento de integração espiritual. Concilium 254, n. 4, 1994.

PINGEM, Jordi. El pensament de Raimon Panikkar: Interdependència, pluralisme, interculturalitat. Barcelona: Institut d'Estudis Catalans, 2007. 
PRIETO, Pérez V., Raimon Panikkar. El pensamiento cristiano es trinitario, simbólico e relacional. Encontros con R. Panikkar, Iglesia Viva 223, 2005.

Más allá de la fragmentación de la teología, el saber y la vida: Raimon Panikkar.Valencia: Tirant lo Blanch, 2008.

RAHNER. Karl. Experiencia de la gracia. In: Escritos de teologia. Madri: Taurus, 1961, v.3, pp. 103-107.

Curso fundamental da fé: introdução ao conceito de cristianismo. São Paulo: Paulinas, 1989.

REALE, Giovanni. História da Filosofia Antiga. São Paulo: Paulus, 1990. v. 1.

RODRIGUEZ, Francisco J. S. (org.) Mística y sociedad en diálogo. Madri: Trotta, 2006.

ROSSI, A. Pluralismo e armonía. Introduzione al pensiero di Raimon Panikkar. Roma: L'altrapagina, 1990.

SARTORI, L. Teologia de las religiones no cristianas. In: Diccionario Teológico Interdisciplinar. vol. 4, Salamanca: Sígueme, 1987, p. 423428.

SIGUAN, Miquel. Philosophia pacis. Homenaje a Raimon Panikkar. Madrid: Símbolo, 1989.

SOUZA, Maria Emmanuel e Silva. Thomas Merton: um homem feliz. Petrópolis:Vozes, 2003.

SUDBRACK, Josef. Mística. A busca do sentido e a experiência do absoluto. São Paulo: Loyola, 2007.

SUTTER, A. Mística. In: ANCILLI, E. (org.). Dizionario Enciclopédico di Spiritualità. v. 02. Roma: Città Nuova Editrice, 1900.

SCHILLEBEECKX, E. Religião e violência. Concilium 272, 1997. pp. 744761.

História humana. Revelação de Deus. São Paulo: Paulus, 1994.

STIEL, C. A. O diálogo inter-religioso numa perspectiva antropológica. In: TEIXEIRA, Faustino (org.). 0 Diálogo de pássaros. Nos caminhos do diálogo inter-religioso. São Paulo: Paulinas, 1993. pp. 23-33.

TAMAYO, Juan José. Fundamentalismo y dialogo entre religiones. Madri: Trotta, 2005. 
A mística como superacion del fundamentalismo, p.161. In: RODRIGUEZ, Francisco J. S. (org.) Mística y sociedad en diálogo. Madri: Trotta, 2006. pp. 155-180.

Conceptos fundamentales del cristianismo. Madrid: Trotta, 1993.

TEIXEIRA, Faustino (org.). No limiar do mistério. Mística e religião. São Paulo: Paulinas, 2004.

O diálogo inter-religioso como afirmação da vida. São Paulo: Paulinas, 1997.

Teologia das religiões: uma visão panorâmica. São Paulo: Paulinas, 1995.

Diálogo inter-religioso: o desafio da acolhida da diferença. In: Perspectiva teológica 34, n. 93, 2002. $\overline{591-617}$

Teologia do pluralismo religioso em questão. REB 59, 1999, pp.

TRESMONTANT, Claude. La mística cristiana y el porvenir del hombre. Barcelona: Ed. Herder, 1979.

THEIL, John. Pluralismo na verdade teológica. Concilium 256, n. 6, 1994.

UNDERHILL, Evelyn. La mística. Estudio de la naturaleza y desarrollo de la conciencia espiritual. Madri: Trotta, 2006.

VIGIL, J. Maria. Teologia do pluralismo religioso. Para uma releitura pluralista do cristianismo. São Paulo: Paulus, 2006.

WATT, Ninfa. La fuente de la cordialidad. p. 81. In: RODRIGUEZ, Francisco J. S.(org.). Mística y sociedad en diálogo. Madri: Trotta, 2006. 